Kováts Gergely

\title{
A dékán pozíciója és szerepe az átalakuló felsőoktatásban
}




\author{
Vezetéstudományi Intézet \\ Vezetés és szervezés tanszék
}

Témavezető:

Szabó Katalin, DSc

(C) Kováts Gergely minden jog fenntartva 


\section{Budapesti Corvinus Egyetem \\ Gazdálkodástani Ph.D. program \\ Vezetés és szervezés tanszék}

Kováts Gergely

\section{A dékán pozíciója és szerepe az átalakuló felsőoktatásban}

Ph.D. értekezés

Budapest, 2012. 

„A dékán kötelességei általában ismertebbek, semhogy ehelyütt részletezni kellene."

Ratio Educationis (1777) 



\section{Köszönetnyilvánítás}

A doktori disszertáció befejezése nem csak a kutatói életút fontos pillanatát jelenti számomra, hanem a felsőoktatás világának és önmagam mélyebb megértésének egy állomását is. Bár a dolgozatot lezártam, az utazás nem ért véget.

Sokaknak tartozom hálával, akik ebben az utazásban eddig támogattak.

Köszönet illeti témavezetömet, Szabó Katalint, aki szabadságot adott a munkában, de mindig segítséget nyújtott, ha szükségem volt rá.

Szintén köszönet illeti Dobák Miklóst, a Vezetéstudományi Intézet igazgatóját és az Intézet valamennyi munkatársát, hogy olyan termékeny közeget biztosítottak, amely hozzájárult a dolgozat megszületéséhez. Az Intézet munkatársai közül szeretném külön kiemelni Drótos Györgyöt, aki sok-sok beszélgetéssel járul hozzá az egyetemek müködésének megismeréséhez, Lázár Lászlót és Gelei Andrást, akikkel a szervezetelméletekröl (is) folyó eszmecseréink formálták a gondolkodásomat, Móricz Pétert, Antal Zsuzsát, Hidegh Annát, Révész Évát, Tirnitz Tamást és Csillag Sárát, akik kollégaként támogattak, valamint Bokor Attilát, akitől sokat tanultam arról, hogy mit is jelent kutatónak lenni.

Természetesen sokan mások is támogatták utamat és törekvéseimet. Köszönettel tartozom Hrubos Ildikónak, Temesi Józsefnek, Halász Gábornak és Derényi Andrásnak az inspiráló beszélgetésekért és azokért a lehetőségekért, amelyekkel lehetővé tették, hogy bekapcsolódjak a felsőoktatás-kutatás hallatlanul izgalmas világába.

Külön köszönet illeti mindazokat a dékánokat, egyetemi felsővezetöket és munkatársaikat, akik bizalommal fogadtak, és az interjúk során megosztották velem gondolataikat és közremüködtek a kutatásban. A dolgozatban megfogalmazott állitások és értelmezések természetesen a saját gondolataimat és véleményemet tükrözik, vitathatóságukért én vagyok a felelős.

A kutatás során sok segítséget kaptam Ladencsics Virágtól, aki az interjúk gépelését végezte nagy gondossággal, és Farkas Ildikó, aki nemkülönben alapos volt a disszertáció angol nyelvű forditása során. A kutatás anyagi fedezetét a TÁMOP-4.2.1/B-09/1/KMR-2010-0005 pályázat biztosította.

Végezetül külön köszönet és hála illeti a családomat, Erikát, Tónit és Emmát, akik szeretete, türelme és áldozata nélkül aligha született volna meg ez a dolgozat. Köszönöm Nektek! 


\section{Tartalomjegyzék}

KÖSZÖNETNYILVÁNÍTÁS ............................................................................................................... 1

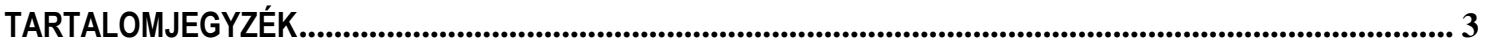

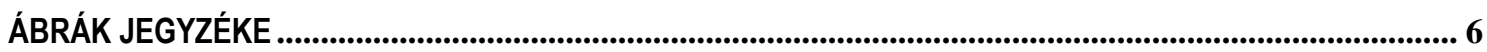

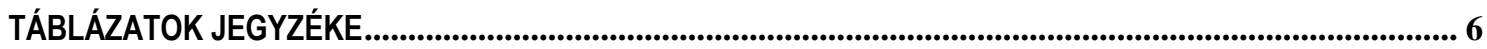

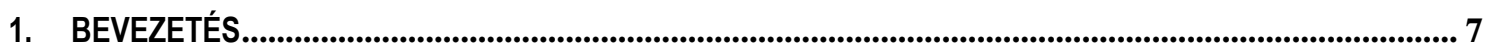

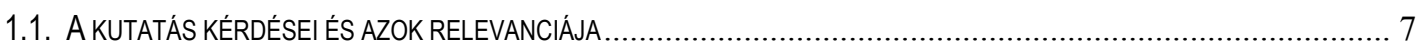

1.2. A DISSZERTÁCIÓ CÉLJA ÉS A SZAKIRODALMI FELDOLGOZÁS FORRÁSAI .................................................... 10

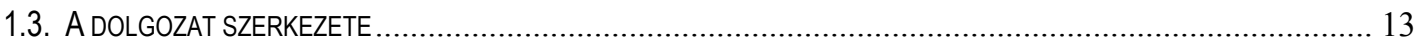

2. SZEREP, SZEMÉLY, SZERVEZET: AZ ELEMZÉSI KERET ........................................................................ 17

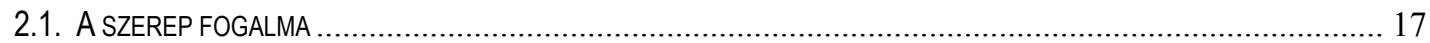

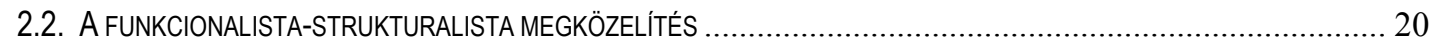

2.3. A SZIMBOLIKUS INTERAKCIONISTA MEGKÖZELÍTÉS ............................................................................... 22

2.4. A KRITIKAI ELMÉLETEK ÉSZREVÉTELEI A SZEREPELMÉLETTEL KAPCSOLATBAN ............................................ 25

2.5. ÖSSZEFOGLALÁS ÉS KÖVETKEZTETÉSEK A DÉKÁN SZEREPÉNEK ELEMZÉSÉRE VONATKOZÓAN........................... 26

3. AZ EGYETEM NARRATÍVÁl A SZAKIRODALOM TÜKRÉBEN .................................................................. 29

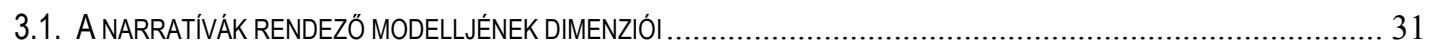

3.1.1. A megvalósítás kontrollja: az egyetem mint szakértői szervezet ........................................ 31

3.1.2. Az egyetemi policy definiálása: az egyetem mint töredezett szervezet ................................. 35

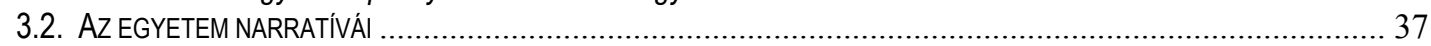

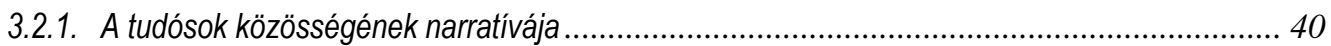

3.2.2. A bürokrácia narratívája .......................................................................................... 42

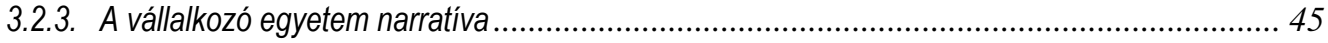

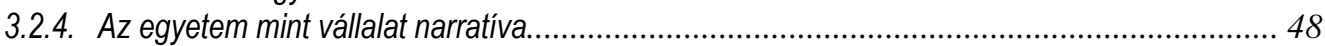

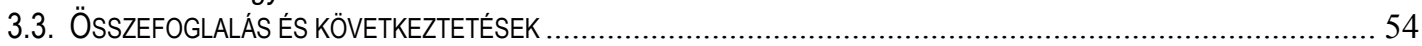

4. A DÉKÁN SZEREPEI A SZAKIRODALOM TÜKRÉBEN ................................................................... 55

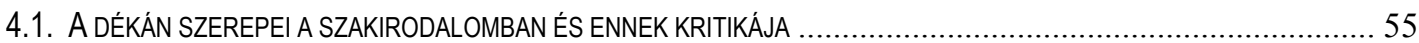

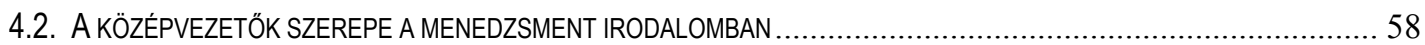

4.2.1. A középvezető mint a felügyeleti rendszer része ............................................................ 58

4.2.2. Az önérdekkövetö és a menedzserista középvezető .......................................................... 59

4.2.3. A középvezető mint a szervezeti bölcsesség közvetítője .................................................. 60

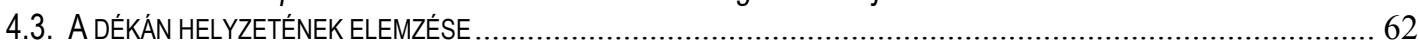

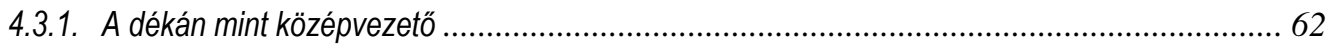

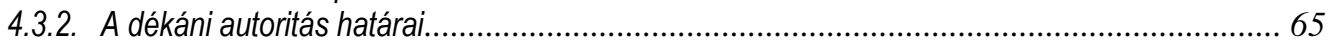

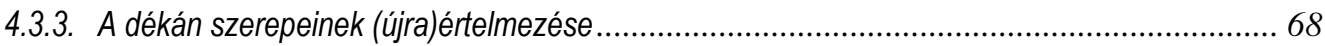

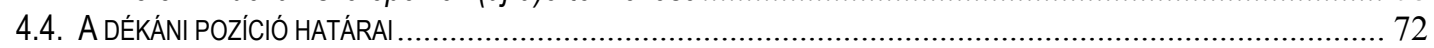

4.4.1. A dékáni karrierút .................................................................................................... 72

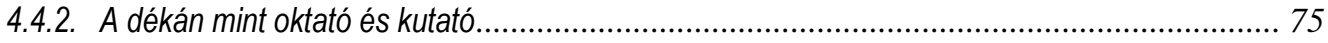

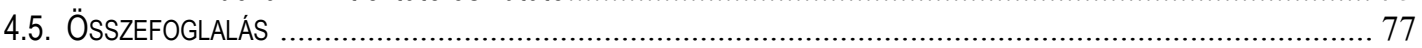

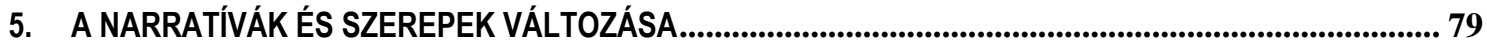

5.1. A NARRATÍVÁK EGYIDEJÜ LÉTEZÉSE ÉS A DOMINÁNS NARRATÍVÁK KIALAKULÁSA ..................................... 79

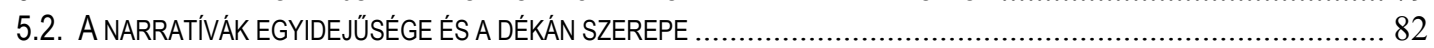


6. DÉKÁNOK A MAGYAR FELSŐOKTATÁSBAN: AZ EMPIRIKUS KUTATÁS BEMUTATÁSA

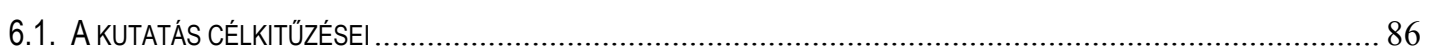

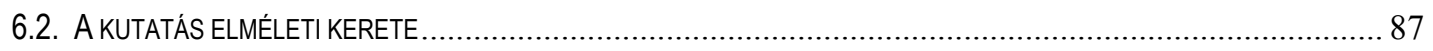

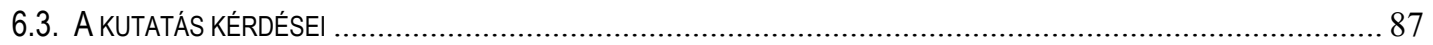

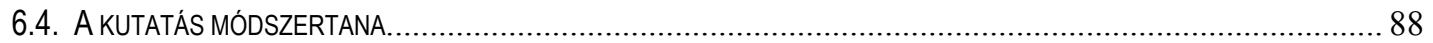

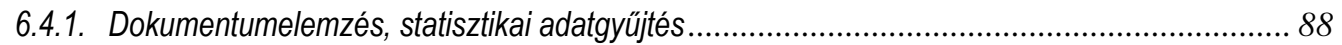

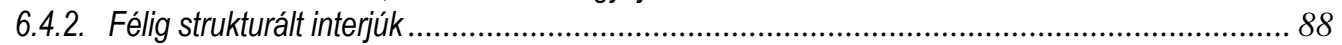

6.4.3. Tervezett, de nem alkalmazott adatgyüjtési módszerek ................................................... 91

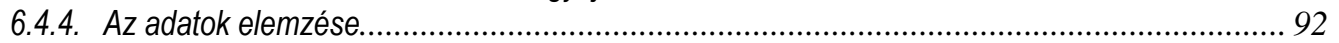

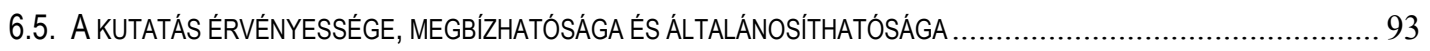

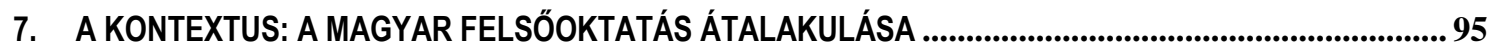

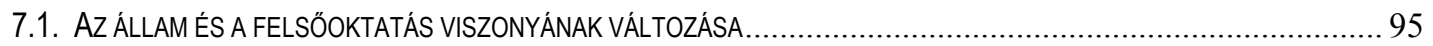

7.2. A FELSŐOKTATÁS EXPANZIÓJA ÉS A KAROKRA GYAKOROLT HATÁSA ............................................................ 99

7.3. AZ INTÉZMÉNYSZZERKEZET ÉS AZ INTÉZMÉNYYKK STRUKTÚRÁJÁNAK VÁLTOZÁSA........................................... 102

7.3.1. A karok számának és néhány jellemzőjének változása..................................................... 102

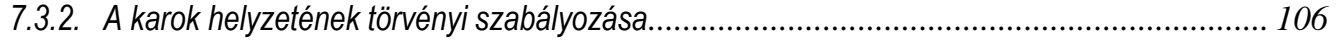

7.3.3. Az intézményi integrációs folyamat............................................................................. 108

7.3.4. Az intézmények irányitásának és belső struktúrájának változása........................................ 109

7.3.5. A karokon belüli szervezeti és irányitási struktúra alakulása................................................. 114

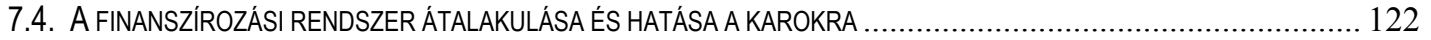

7.4.1. A normatív finanszírozási rendszer.......................................................................... 124

7.4.2. Az államilag finanszírozott alapképzési hallgatói helyek elosztási mechanizmusa .................. 125

7.4.3. A költségtérités (tandij) ................................................................................................. 126

7.4.4. Kutatási és fejlesztési tevékenységböl származó bevételek ................................................ 127

7.4.5. Intézményen belüli forrásallokáció és ezek hatása a karokra............................................... 127

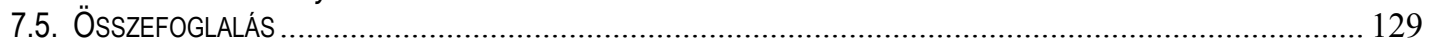

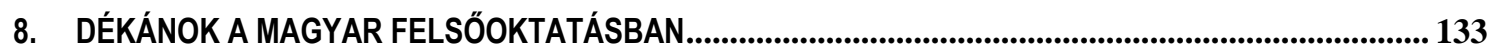

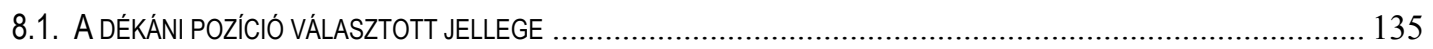

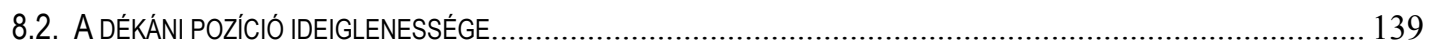

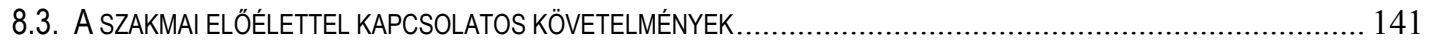

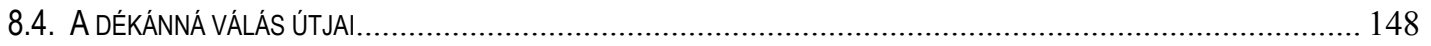

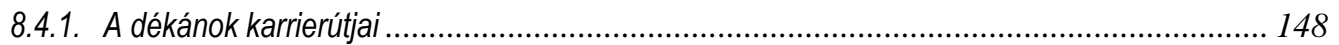

8.4.2. A felsőoktatáson kivüli tapasztalat jelentösége .............................................................. 152

8.4.3. A dékánhelyettesi pozíció jelentősége a dékáni karrierútban ................................................ 153

8.4.4. A tanszékvezetői és intézetvezetöi pozíció jelentősége a dékáni karrierútban........................ 154

8.5. ÖSSZEFOGLALÁS: A DÉKÁNNAL SZEMBENI ELVÁRÁSOK A SZABÁLYOZÁS, A STATISZTIKÁK ÉS AZ INTERJÚK ALAPJÁN 157

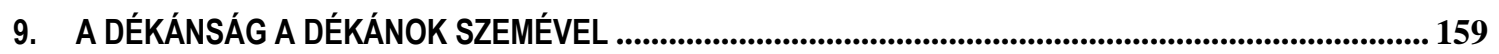

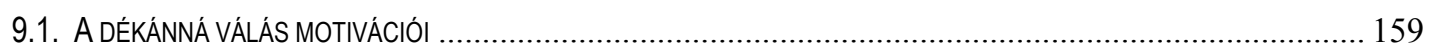

9.1.1. A dékánság mint szolgálat, mint kényszer és mint feladat.................................................... 160

9.1.2. A dékánság mint jutalom és mint az egyéni elönyök forrása.................................................. 162

9.1.3. A dékánság mint (ön)megvalósitás................................................................................... 164

9.2. NYOMÁS ALATT: A DÉKÁNSÁGGAL JÁRÓ HÁTRÁNYOK ÉS AZ ELLENSÚLYOZÁSI STRATÉGIÁK ..............................168

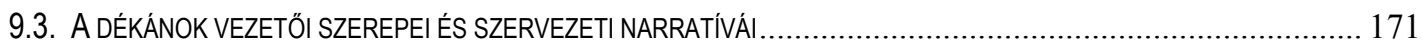

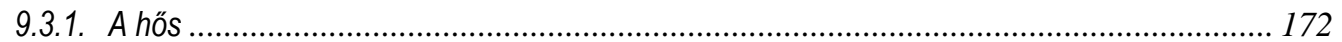

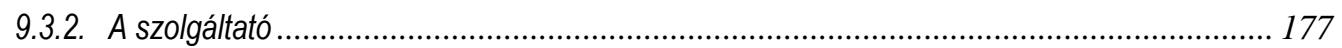

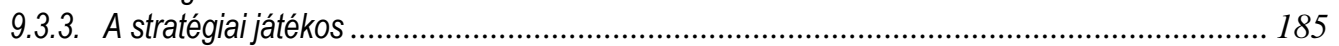

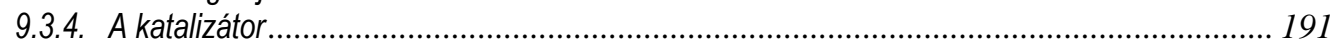

10. ÖSSZEFOGLALÁS ÉS TOVÁBBI NYITOTT KÉRDÉSEK.................................................................... 199

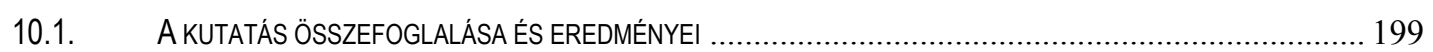

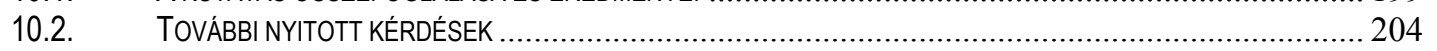

HIVATKOZÁSOK ........................................................................................................................................... 205 
A DÉKÁNOKKAL KÉSZITETT INTERJÚK VÁZLATA..._...... 217

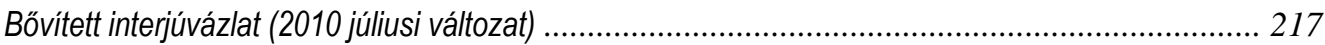

Az egyszerüsített interiúvázlat (2010. november 22-ei változat) ................................................. 219

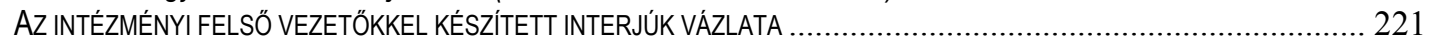

AZ INTERJÚK ELEMZÉSHEZ HASZNÁLT HIERARCHIKUS KÓDSTRUKTÚRA ......................................................... 223

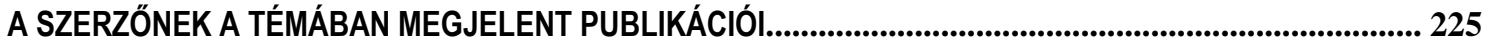




\section{Ábrák jegyzéke}

1. ÁBRA: A KUTATÁSBAN ALKALMAZOTT SZIMBOLIKUS INTERAKCIONISTA MEGKÖZELÍTÉS

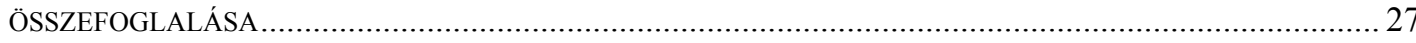

2. ÁBRA: A NARRATÍVÁKBAN FOGLALT KÉRDÉSEKRE ADOTT VÁLASZOK FORRÁSAI............................ 29

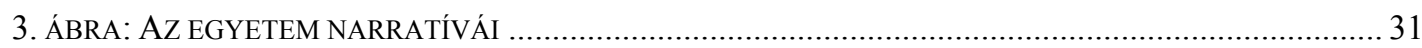

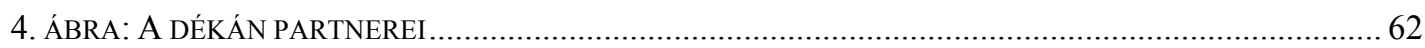

5. ÁBRA: AZ EGYETEM NARRATÍVÁI ÉS A DÉKÁN LEHETSÉGES SZEREPEI ......................................... 70

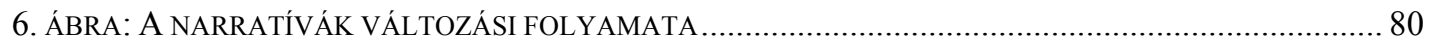

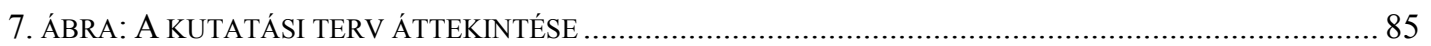

8. ÁBRA: AZ INTERJÚK ALAPJÁN MEGFOGALMAZOTT MÁSODLAGOS SZEREPEK ÉS AZOK VISZONYA A

KIINDULÓ (ELSŐDLEGES) SZEREPÉRTELMEZÉSEKHEZ ................................................................. 172

\section{Táblázatok jegyzéke}

1. TÁBLÁZAT: A STRUKTURALISTA-FUNKCIONALISTA ÉS A SZIMBOLIKUS INTERAKCIONISTA MEGKÖZELITÉS ÖSSZEHASONLITÁSA

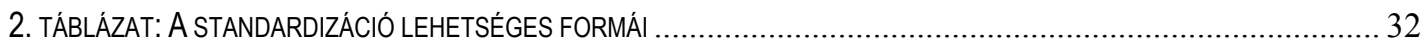

3. TÁBLÁZAT: A TUDOMÁNYTERÜLETEK EPISZTEMOLÓGIAI ÉS KÖZÖSSÉGI JELLEMZÖI ........................................ 36

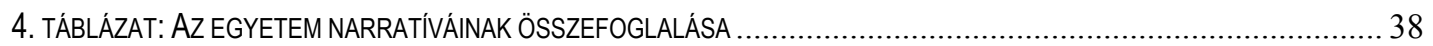

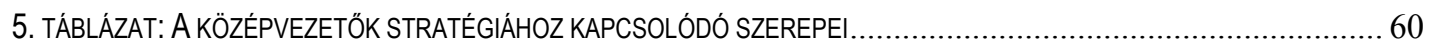

6. TÁBLÁZAT: A KÖZÉPVEZETŐK SZEREPÉRTELMEZÉSÉNEK ÁTALAKULÁSA A MENEDZSMENT IRODALOMBAN .................61

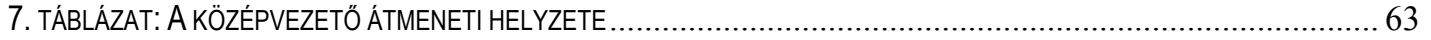

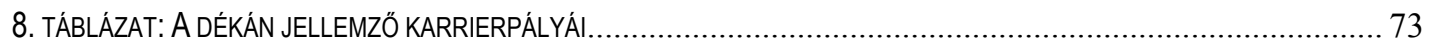

9. TÁBLÁZAT: A DÉKÁNOK KARRIERTERVEI EGY AZ AMERIKAI EGYESÜLt ÁlLAMOKBAN VÉGZETT KUTATÁSBAN (\%) .......74

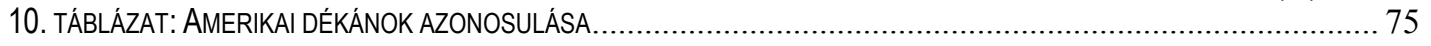

11. TÁBLÁZAT: AZ ÉRVÉNYESSÉG, MEGBíZHATÓSÁG ÉS ÁLTALÁNOSÍTHATÓSÁG ÉRTELMEZÉS ..............................99

12. TÁBLÁZAT: A HALLGATÓI ÉS OKTATÓI LÉTSZÁMOK ALAKULÁSA A MAGYAR FELSŐOKTATÁSBAN 1990 ÉS 2010 KÖZÖTT 100

13. TÁBLÁZAT: A KAROK SZÁMÁNAK ÉS MÉRETÉNEK VÁLTOZÁSA 1987 ÉS 2009 KÖZÖTT. 104

14. TÁBLÁZAT: A SZENÁTUS TAGJAINAK SZÁMA NÉHÁNY FELSÖOKTATÁSI INTÉZMÉNYBEN.................................. 110

15. TÁBLÁZAT: A KÖZPONTI ADMINISZTRÁCIÓ ÁLTAL LEFEDETT TERÜLETEK A MAGYAR FELSŐOKTATÁSI INTÉZMÉNYEKBEN 112

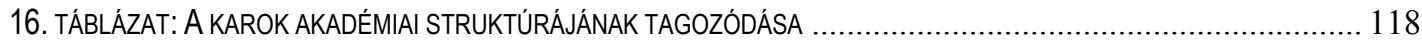

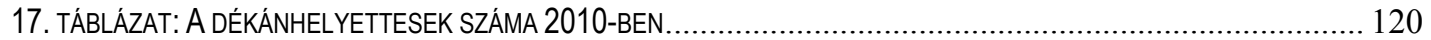

18. TÁBLÁZAT: A dÉKÁNHELYETTESEK ÁlTAL FELÜGYELT TERÜLETEK MEGOSZLÁSA 2010-BEN ............................ 120

19. TÁBLÁZAT: AZ ÁLLAMI TÁMOGATÁS ÉS A „SAJÁT BEVÉTEL” ALAKULÁSA 2000 ÉS 2008 KÖZÖTT ......................... 123

20. TÁBLÁZAT: A NORMATÍVÁK SZÁMÁNAK VÁLTOZÁSA A MAGYAR FELSÖOKTATÁSBAN 1997-2011 KÖZÖTT ............. 124

21. TÁBLÁZAT: A KARI VEZETŐK MEGNEVEZÉSE ÉS KINEVEZÉSI FELTÉTELEI A (FELSÖ)OKTATÁSI TÖRVÉNYEK SZERINT

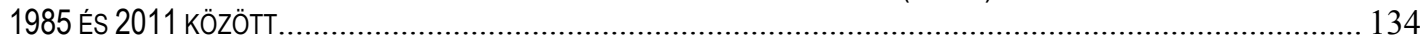

22. TÁBLÁZAT: A 2010-BEN AKTíV DÉKÁNOK HIVATALBAN ELTÖLTÖTT IDEJE A MEGVÁLASZTÁSUK ÓTA ..................... 140

23. TÁBLÁZAT: A DÉKÁNOK MUNKAKÖRE 2010-BEN TUDOMÁNYTERÜLET ÉS INTÉZMÉNYTÍPUS SZERINT ................... 142

24. TÁBLÁZAT: A 2010-BEN AKTIIV DÉKÁNOK ÁTLAGOS ÉLETKORA A KINEVEZÉSÜK IDEJÉN, VALAMINT A POZÍCIÓBAN

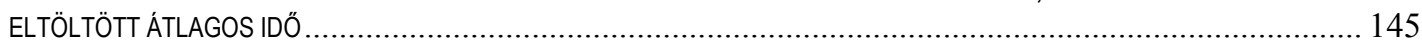

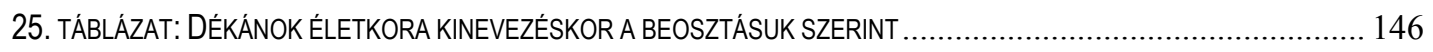

26. TÁBLÁZAT: NŐI DÉKÁNOK ÉS DÉKÁNHELYETTESEK SZÁMA ÉS ARÁNYA 2010-BEN ....................................... 147

27. TÁBLÁZAT: A DÉKÁNOK JELLEMZŐ KARRIERPÁLYÁl AZ EGYESÜLT ÁLLAMOKBAN ÉS MAGYARORSZÁGON ............. 150

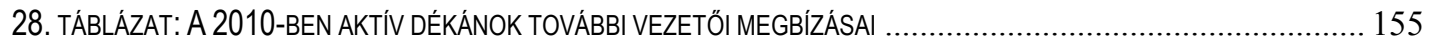

29. TÁBLÁZAT: A TANSZÉKVEZETŐI ÉS INTÉZETVEZETŐI POZÍCIÓVAL KAPCSOLATOS EMLÍTÉSEK ........................... 157 


\section{Bevezetés}

\subsection{A kutatás kérdései és azok relevanciája}

A felsőoktatás-kutatás fóárama szerint a fejlett országok felsőoktatását az elmúlt évtizedekben a tömegesedés, a kutatás intézményrendszerének átalakulása, az állami támogatások csökkenése, az állam szerepének átalakulása és a verseny növekedése határozta meg (Barakonyi [2004b]; OECD [2008]; Halász [2009]). E változások következtében nem csak új szolgáltatások és technológiák jelentek meg az intézményekben (pl. informatikai rendszerek, karrier iroda, diáktanácsadó), hanem az intézmény müködésébe fokozatosan beszivárogtak az üzleti szervezetek irányításához használt technikák is, így például a kontrolling, a $\mathrm{HR}$, a stratégiai tervezés, a minőségmenedzsment és a teljesítményértékelési rendszerek (Sporn [2006]). A felsőoktatási intézmények kormányzása és irányítási rendszerei így jelentős átalakuláson mentek keresztül. Az új szolgáltatások és irányítási technikák müködtetőiként az intézményi menedzsment és az adminisztráció ${ }^{1}$ súlya - a felhasznált erőforrásokat és a létszámokat tekintve - megnőtt (Gornitzka, Kyvik et al. [1998]; Gornitzka - Larsen [2004]), és szerepük jelentős mértékben változott (Teichler [2001]; Barakonyi [2004a]).

E folyamatok bemutatása és elemzése, illetve a szerepek átalakulásának vizsgálata során ugyanakkor az intézményi vezetést többnyire egységesnek és koherensnek tételezik fel (Mignot-Gérard [2003]), és azt kimondva-kimondatlanul a felső vezetéssel azonosítják, azaz hiányzik az intézményi menedzsment differenciáltabb megközelítése. Emiatt jóval kevesebb figyelem irányul a középvezetőkre, azaz a dékánokra és tanszékvezetőkre, miközben ők az átalakulási folyamat kulcsszereplői (Santiago, Carvalho et al. [2006]). Ez az a szint ugyanis, ahol a napi gyakorlatban, konkrét problémák megoldásának kontextusában lehet megvalósítani az új irányítási technikákat, ezen a szinten realizálódik tehát a felsőoktatás irányítási rendszerének átalakulása. Jórészt ugyanis a középvezetőkön múlik, hogy a stratégiai szemléletmód, a kontrolling, a minőségirányítás és a többi technika valóban müködik-e az intézményben, vagy pusztán a külső elvárásoknak való megfelelés szintjén reked meg anélkül, hogy az intézmény

\footnotetext{
1 Ehelyütt célszerünek látom a dolgozatban használt félreérthetőbb fogalmak tisztázását. A „felsőoktatási intézmény” és az „egyetem” fogalmát a dolgozatban szinonímaként használom. Ha az egyetemre mint egy sajátos felsőoktatási intézményre utalok (például megkülönböztetem a föiskolától), akkor azt a szövegben jelzem. Az „academic” kifejezést a magyar gyakorlatnak megfelelően „akadémiai”-nak fordítom, amely alatt az egyetem oktatásitudományos szféráját értem. Ha az „akadémiai” szóval a Magyar Tudományos Akadémiára utalnék, azt a szövegben jelzem.

A „faculty”, illetve „academic staff” kifejezéseket „oktatóként” fordítottam. Az egyetemen dolgozó oktatókra és kutatókra gyakran egységesen „oktató”-ként hivatkozom, függetlenül attól, hogy esetleg kutatói munkát is végeznek. $\mathrm{Az}$ „adminisztráció” (administration) fogalma az egyetem igazgatással foglalkozó, nem oktató és nem kutató munkatársait takarja. Az „akadémiai vezetés” a tanszékvezetőket, dékánokat és rektorokat jelenti.

Végül érdemes megemlíteni, hogy a felsőoktatási intézmények belső struktúrája nagyon sokféle lehet. A sokszinűséget a dolgozatban nem jelenítem meg, ehelyett egységesen három intézményi szintet különítek el: az egyetemi szintet, a kari szintet és a tanszéki szintet (amely magában foglalja az intézeteket és a központokat is).
} 
hétköznapjaira hatást gyakorolna (lásd például Lozeau, Langley et al. [2002]). A középvezetők tehát - Fulton igen kritikus megfogalmazásában - „az újratervezési folyamat frontvonalában harcoló katonák" (Fulton [2003] 162.0.). Szerepük fontosságát és egyben ellentmondásosságát kiemeli, hogy a felsőoktatás - és különösen az irányítási rendszer - átalakulása korántsem mentes a vitáktól és a konfliktusoktól, hiszen azt sok oktató az egyetem küldetésének elárulásaként, mások pedig státuszvesztésként, deprofesszionalizálódásként, sőt: proletarizálódásként éli meg.

Dolgozatomban a dékánok helyzetének vizsgálatára vállalkozom. Azért választottam elsősorban őket (és nem a tanszékvezetőket), mert felelősségüket nagyobbnak, helyzetüket viszont nehezebbnek és szerepkonfliktusokban bővebbnek láttam, mint az egyetem más középvezetőiét, hiszen egyszerre szembesülnek jelentős szervezeti és környezeti komplexitással, döntési kényszerekkel, ellentétes elvárásokkal és korlátozott mozgástérrel. Mindez abból ered, hogy a felsőoktatási rendszer átalakulásából fakadó ellentmondások az ő esetükben különösen élesen jelentkeznek, mert napi szinten nekik kell összehangolniuk az intézmény akadémiai, a gazdasági, az adminisztrációs szféráját, valamint a külső elvárásokat. $A z$ ezek közötti inkonzisztenciák így a dékánoknál válnak kézzelfoghatóvá - elsősorban a velük szemben támasztott elvárások egyre erősebb ellentmondásaiban.

A dékánok azonban korántsem csak passzív elszenvedői a róluk alkotott véleményeknek és a velük szemben támasztott elvárásoknak, hanem maguk is sokat tesznek és tehetnek a dékáni szerep átértelmezéséért (vagy éppen változatlanságáért) és ezen keresztül a felsőoktatás formálódásáért.

Mindebböl a dékánok vizsgálatára vonatkozóan két kérdés adódik:

\section{Milyen szerepe vagy szerepei vannak a dékánoknak az átalakulóban lévő felsőoktatási intézményekben?}

\section{Hogyan élik meg a dékánok a saját dékáni szerepüket és helyzetüket?}

Az első kérdés arra vonatkozik, hogy a dékáni pozícióban lévő személlyel szemben milyen kollektív elvárások érvényesülnek, milyen szerepet vagy szerepeket tulajdonítanak neki, azaz mit is jelent a dékánság intézménye a szervezetben. A második kérdésben azt vizsgálom, hogy a dékánok mint egyének számára mit jelent a dékánság, azaz hogyan dolgozzák fel a kollektív elvárásokat, hogyan viszonyulnak hozzá, milyen saját szerepértelmezéssel és -elvárással rendelkeznek, és mit tesznek a kollektív elvárások rögzülése és a saját értelmezéseik elfogadtatása érdekében.

Az elemzés egysége tehát a dékánság intézménye, a dékáni pozíció. Az első kérdésben ennek a társas struktúrában elfoglalt lehetséges helyét, értelmezéseit vizsgálom, a másodikban pedig azt, hogy hogyan járul hozzá ehhez maga a dékán, és hogyan éli meg azt. $\mathrm{A}$ két kérdés a kutatásban szerves egységet képez, mert a felsőoktatási intézmények változása a dékáni szerep változásával jár, ami pedig az elvárások változásában és az egyéni szinten megélt konfliktusokban, dilemmákban ragadható meg. A logika fordítva is megfogalmazható: az egyéni szinten megélt konfliktusokból az elvárások és a dékáni szerep változására következtethetünk, abból pedig a felsőoktatás intézmények változása vetíthető előre. 
Összességében úgy vélem, hogy a dékánok a felsőoktatás átalakulásának „lakmuszpapírjai”. Magatartási és értelmezési mintáik, észlelt és megélt konfliktusaik, illetve a velük szemben támasztott elvárások és ezek ellentmondásai nemcsak tükrözik, de egyben elöre is vetítik a felsőoktatás átalakulását, mert ezekben láthatóvá válnak mindazok a folyamatban lévő változások, amelyek még nem intézményesültek, és így nem láthatóak a szabályozásban, a szokásokban és a hagyományokban, tehát a felsőoktatási rendszer makrostruktúráiban.

A kutatási kérdések empirikus vizsgálatát a magyar felsőoktatási intézményekben szeretném elvégezni, ezért szeretném röviden megvilágítani azokat a hasonlóságokat és különbségeket, amelyek a dékánok magyarországi vizsgálatát érdekessé, relevánssá teszik.

A magyar felsőoktatás, ha vargabetükkel is, de követi a nemzetközi trendeket (Ladányi [1999]; Fábri [2004]; Derényi [2009]): a rendszerváltás után megkezdődött a tömegesedés, az egy hallgatóra eső állami támogatás radikálisan csökkent, a finanszírozás állandóan napirenden lévő kérdés (Semjén [2004]; Polónyi [2009a]; Polónyi [2012]). Az érettségi/felvételi rendszer átalakításával és a hallgatói létszámok stagnálásával erősödni látszik a verseny is, és a 2005-ös felsőoktatási törvény az állami szerepvállalás átalakításának kísérlete (is) volt.

Mutatkozik azonban néhány lényeges különbség is. A fenti folyamatok nálunk - mint a posztszocialista országok mindegyikében - torlódva, egy időben jelentkeztek, míg NyugatEurópában fokozatosan, egymást követő lépésekben. Az átalakulás miatt képlékenyebb az értékrend, az intézményeken belül az igen különböző felsőoktatási rendszerekben szocializálódott generációk élnek együtt. Az idő rövidsége és a problémák tűzoltásszerű kezelése miatt hiányzik a felsőoktatás szerepéröl, funkciójáról való társadalmi diskurzus, ami nemcsak a tandíj kapcsán, hanem a bolognai képzési rendszerre való áttérés során is világosan megmutatkozott (lásd például Derényi [2008])². A felülről kezdeményezett reformkísérletek, modernizációs törekvések hektikusak, azokat a megszakítottság és a gyakori irányváltás jellemzi. Összességében Magyarországon (és feltehetőleg a posztszocialista országok többségében) a felsőoktatási rendszer egyes elemei közötti inkonzisztencia még nagyobb, mint az átalakulóban lévő nyugat-európai országokban, aminek következtében a felsőoktatási vezetők, beleértve a dékánokat is, egy a nyugat-európainál komplexebb helyzet kezelésére kényszerülnek.

A rendszerváltást követően azonban e folyamatokkal egy időben a karok száma jelentősen megnőtt az intézményeken belül. Ebben közrejátszott a felemásan sikerült integrációs folyamat, a Bolognai képzési rendszer karok elkülönülését elősegítő bevezetése, a kari érdekek tudatosodását elősegítő finanszírozási mechanizmusok és a karok szerepét korábban leértékelő államszocialista múlt túlkompenzálása (Kováts [2009]; Kováts [2012]). A karok megerősödése nem feltétlenül jelenti a dékán pozíciójának megerősödését, de mindenképpen növeli a felelősségüket, és nemcsak magasabbra emeli, de át is alakítja a velük szemben támasztott elvárásokat.

\footnotetext{
2 Ez nem azt jelenti, hogy szakértői körökben ne folyt volna erröl diskurzus. Inkább arra utalok, hogy például a bolognai folyamat kapcsán a koncepcióalkotás helyett csak a megvalósítás időszakában érte el a közvélemény ingerküszöbét az átalakulás, így a társadalmi vita csak elkapkodott és igazi hatás nélküli maradt. Más esetekben a felsőoktatással kapcsolatos kérdések társadalmi szinten rendkívül leegyszerüsített módon és kontextusban jelentek meg (pl. tandíj-vita), és ezért elmaradt az arról való gondolkodás, hogy a felsőoktatásnak milyen társadalmi szerepet kell betöltenie. Ebben nem csak a kérdések átpolitizálódása és az oktatáspolitikai hiányosságok játszottak közre, hanem az akadémiai szféra saját koncepciókeresésének megtorpanása is (lásd például Fábri [2004])
} 


\subsection{A disszertáció célja és a szakirodalmi feldolgozás forrásai}

A disszertáció első felében szeretném bemutatni egyrészt a dékán szerepének vizsgálatához használt elemzési keretet, és az ebböl fakadó kutatási megközelítést. További célom, hogy a szakirodalom összefoglalása, értelmezése és rendszerezése révén olyan kiinduló koncepciókat, témákat, vizsgálati területeket határozzak meg, amelyeket a dolgozat második felében bemutatott feltáró empirikus kutatás során tovább tudok mélyíteni, gazdagítani. Az elméleti keret és a szakirodalmi összefoglaló forrásául az alábbi négy témakör szolgál:

1. A kutatás elméleti keretét a szerep-elmélet (role theory) jelenti, amelynek középpontjában egy adott társadalmi státuszban vagy szervezeti pozícióban lévő személy rendszeresen ismétlődő magatartásmintájának megfigyelése, magyarázata és megértése áll. $A$ szerepelmélet az 1930-as években bontakozott ki. Virágkorát az 1950-es és 1970-es években, a funkcionalista szociológia dominanciája során élte.

A szervezetkutatás (és a felsőoktatás-kutatás) területén a szerepelmélet ebben az időszakban vált népszerűvé, ahol a mérföldkövet Katz és Kahn [1966], illetve Mintzberg (Mintzberg [1971]; Mintzberg [1975]) munkája jelentette. A 90-es évekre - az interpretatív, konstruktivista és különösen a posztmodern elméletek elfogadottságának növekedésével egy időben - a szerepelmélet veszített újdonságerejéből, és az érdeklődés mind a szervezetkutatás, mind a felsőoktatás-kutatás területén fokozatosan az identitás vizsgálata felé tolódott (Martin Wilson [2005]; Simpson - Carroll [2008]).

Ennek ellenére két okból mégis a szerep fogalmát és elméletét választottam elméleti keretnek. Egyrészt olvasmányaim során számos olyan íással találkoztam, amelyben a szerzők a szerep és identitás fogalmát lényegében szinonimaként kezelték, más írásokban pedig a szerepelméletben megjelenő kifejezések (pl. szerepkonfliktus, szerepbizonytalanság, szerepváltozás) már mint magyarázatra nem szoruló fogalmak jelentek meg. Mindkét jelenség arra utal, hogy a szerepelmélet nyelvezete és következtetései, ha nem is tudatos és explicit formában, de a mai napig szerves részét képezik a tudományos diskurzusnak (hasonló álláspontot fejt ki Bailey - Yost [2000] 2425.0.). A fogalmak felcserélhetősége arra is utal, hogy a szerzők egy része csak terminológiát váltott, nem koncepciót, azaz a szerepelmélet elméleti szintű reflexióinak eltủnését (legalábbis szervezetelméleti szinten) én inkább az intellektuális divathullámoknak és nem a szerepelmélet gyengeségének tulajdonítom. Másrészt a szerep koncepcióját az identitásnál alkalmasabbnak találtam arra, hogy mind a dékán egyéni élethelyzetét, mind pedig a társas struktúrában (a szervezetben) elfoglalt helyét tanulmányozni tudjam. (Az identitás és a szerep fogalmának tisztázására a későbbiekben visszatérek.)

2. A dékán helyzetét - különösen egy változó felsőoktatási rendszerben - nehéz megérteni anélkül, hogy ne vizsgálnánk magának a rendszernek, a benne lévő intézményeknek és az erre hatást gyakorló környezetének a változását. Fontosnak tartom, hogy a dékánt ne vákuumban, hanem a felsőoktatási intézmény környezetébe ágyazva láttassam, mert a dékánok helyzetében koronként, országonként és intézményenként jelentős különbségeket és hasonlóságok lehetnek. E különbségek és hasonlóságok feltárása jellemzően a felsőoktatási intézményrendszerek összehasonlító vizsgálatával, országtanulmányokkal történik. Ezek azonban megítélésem szerint túlságosan közvetettek a dékán szűkebb környezetének 
megragadásához, és csak olyan igaz, de nagyon általános következtetésekre alkalmasak, mint például Moses észrevétele, mely szerint

„a dékánoknak az amerikai rendszerben több formális hatalma van, mint a tanszékvezetőknek, míg Európában, az Egyesült Királyságban és Ausztráliában épp az ellentéte volt az igaz. A rendszerek konvergálnak, és a tanszékvezetők és dékánok korlátai hasonlóak és (az intézményen) belüliek: az akadémiai értékek és hagyományok, például a kollegialitás, a kinevezés ideje és a tanszékvezetők státusza." (Moses [1992] 1393.o.)

Az intézményi diverzitás növekedésével (Hrubos [2002]) ráadásul a dékán szempontjából túláltalánositó ország-összehasonlítások jelentősége tovább csökken. $\mathrm{E}$ dolgozatban ezért a dékán környezetét nem a szabályozási, finanszírozási környezet elemzésével vagy a dékánokra vonatkozó rendelkezések (nehezen hozzáférhetö) bemutatásával ragadom meg. Ehelyett egy ennél általánosabb és az elméleti kerethez jobban illeszkedő megközelítést alkalmazok: a dékán környezetét a felsőoktatásra vonatkozó meggyőződések, értelmezési keretek, azaz a narratívák leírásával teszem kézzelfoghatóvá. Az elemzések során nem tárom fel szisztematikusan az érintett országok konkrét intézményi paramétereit (ezek sokszor nem is derülnek ki), hanem a felsőoktatási rendszerek és intézmények céljára, működésére vonatkozó szakirodalom segítségével keresem meg a jellemző gondolkodási mintázatokat. Úgy vélem, hogy az intézményesült struktúrák e meggyőződések következményeiként állnak elő és maradnak fent, a dékán pedig a meggyőződésekhez igazodó szereppel tehet szert legitim és elfogadott müködésre.

A narratívák bemutatása során igen szerteágazó szakirodalomra igyekszem támaszkodni, amely egyaránt érinti az egyetemfilozófiát, a felsőoktatási rendszerek működését és fejlődését, a tudományos intézményrendszer alakulását, valamint a felsőoktatási intézmények kormányzásának és kultúrájának területét. Ebböl az is következik, hogy a dolgozatom szakirodalmat összefoglaló része nem lokalizált, nem köthető konkrét országokhoz vagy intézményekhez. A későbbiekben persze részletesebben is bemutatom a kutatás terepéül szolgáló magyar felsőoktatást, de ezt is már részben a kutatás keretén belül, azaz a dékánok nézőpontjából.

3. A felhasznált források harmadik lényeges csoportját a felsőoktatás-menedzsment és a felsőoktatás-kutatás dékánokra vonatkozó irodalma jelenti. Ez egyszerre tartalmaz empirikus kutatásokat (például Wolverton, Wolverton et al. [1999]), személyes beszámolókat (például Gallos [2002]; Kirk [1997]) és normatív irányultságú menedzsment-kézikönyveket (például Krahenbuhl [2004]).

A dékánok sajátos helyzetére irányuló reflexió bár kezdetben viszonylag alacsony intenzitással, de már lényegében a 60-as évektől jelen van az amerikai felsőoktatás-kutatásban. Európában ugyanakkor - legalábbis az általam elérhető források alapján - még a 90-es évek óta is csak nagyon szórványosan, eseti jelleggel foglalkoznak ezzel a kérdéssel (ehelyett korábban inkább az egyetemtörténeti, mostanában pedig a felsőoktatás-politikai nézőpont dominál). Ennek talán az lehet az oka, hogy a piacosodás és a tömegesedés, amely az egyetem irányításának és így a dékán szerepének változásával jár, az USÁ-ban már a 60-as évekre végbement, míg Európában csak a 80-as és 90-es években kezdődött meg. Jól jellemzi ezt, hogy míg Thorsten Veblen már 1918-ban kritizálja az amerikai egyetemeket azok üzleti szemléletü vezetése miatt (Veblen [1918]), majd Rourke 1964-ben az egyetemek menedzserista forradalomról ír (Rourke - 
Brooks [1964]), addig például az angol felsőoktatásban ezeket a gondolatokat csak az 1985-ben megjelent ún. Jarrett-jelentés emelte a köztudatba, és csak a 90-es években vált mind a felsőoktatás-kutatás (lásd például Trow [1994]), mind a normatív felsőoktatás-menedzsment irodalom központi elemévé. Így a dékán sajátos (vezetői) professzióként való értelmezése - azaz más tevékenységektől, professzióktól való megkülönböztetése - az USÁ-ban viszonylag korán végbement, és így e pozíció betöltői inkább válhattak önálló elemzés tárgyává. Európában ezzel szemben ez a folyamat - rengeteg ellentmondással és belső feszültséggel - jelenleg zajlik ${ }^{3}$ (Amaral, Meek et al. [2003]).

Éppen ez teszi Európában és Magyarországon különösen érdekessé a kutatási kérdések vizsgálatát. Azt a kérdést ugyanis, hogy rövid idő alatt jelentős mértékben átalakuló környezetben mit jelent dékánnak lenni, és milyen konfliktusokkal, feszültségekkel jár, nem lehet megválaszolni a rendelkezésre álló, túlnyomórészt amerikai irodalom alapján, mert az minimális figyelmet szentel annak a kérdésnek, hogy az egyetem szervezeti jellemzői, illetve a felsőoktatás átalakulása milyen módon kapcsolódik össze a dékán helyzetének sajátosságaival és szerepeinek megváltozásával. Így aztán nem is képes reflektálni arra az átmenetre, ami Európában, és különösen Közép- és Kelet-Európa felsőoktatásában ma végbemegy.

4. A dékán pozíciója középvezetői pozícióként is értelmezhető, ami lehetővé teszi az üzleti menedzsment ezzel kapcsolatos szakirodalmának bevonását is az elemzésbe. A menedzsment-irodalom a középvezető fogalmát meglehetősen szabadon definiálja. Uyterhoeven szerint például a középvezető olyan „generalista vezető, aki egy adott üzleti egységért felelős a szervezeti hierarchia középső szintjén" (Uyterhoeven [1989/1972] 136.o.). Mintzberg az operatív mag és a stratégiai csúcs között elhelyezkedő hierarchia-szintet nevezte középvonalnak (Mintzberg [1991] 331.o.), Huy pedig a középvezetőket olyan menedzsereknek definiálta, akik „két szinttel vannak a vezérigazgató alatt és egy szinttel a vonalbeli munkások és szakértők fölött" (Huy [2001] 73.0.)

Az általános definíció megfogalmazását nehezíti, hogy a szervezet(csoport) mérete, komplexitása és az alkalmazott szervezeti struktúra függvényében változhat, hogy mit tekintünk középvezetésnek. A mintzbergi definíció arra is rámutat, hogy önmagában a szervezeti struktúra konceptualizálása is befolyással van arra, hogy kit tekintünk középvezetőnek, hiszen a mintzbergi definícióból az következik például, hogy a technostruktúra (például az egyetemi és kari adminisztráció) vezetői nem középvezetők.

A középvezetés hierarchikusabb vagy komplexebb szervezetekben akár több hierarchia-szintet is magában foglalhat, azaz a középvezetők között is lehet alá-fölérendeltségi viszony. Ezét néha megkülönböztetnek „felső” (upper) és „alsó” (operational) szintű középvezetést (Floyd - Lane [2000]), ami azt is mutatja, hogy a középvezetést a közvetlen felügyelőktől, illetve a felső vezetéstől elválasztó határ meglehetősen bizonytalan. Egyetemi környezetben a fenti definíciók mindegyike illeszkedik a dékánra, dilemma elsősorban az

\footnotetext{
${ }^{3}$ Az ellentmondásosság a legerősebben az jelzi, hogy sokkal erőteljesebben van jelen az európai irodalomban a felsőokatás szervezeti átalakulásának kritikája. Ez a nézőpont tapasztalataim szerint szinte teljesen hiányszik az amerikai irodalomból (különösen a felsőoktatás-kutatásból). Az USÁ-ban elsősorban a felsőoktatás rendszerszintű válságának kérdéseit boncolgatják (lásd pl. Allen Bloom, Bill Readings vagy Derek Bok könyveit), ám azt nem, hogy ez hogyan gyökerezik az intézmény irányításának gyakorlatában, mikropraktikáiban.
} 
intézetvezetőkkel és tanszékvezetőkkel kapcsolatban merülhet fel. Öket a továbbiakban alsó szintü középvezetőknek tekintem.

A definíciók illeszkedése miatt úgy vélem, hogy az üzleti középvezetők sajátosságaival - elsősorban a szerepeikkel, szerepkonfliktusaikkal és a szerepek átalakulásával - foglalkozó elméleti és empirikus források becsatornázása érdekes nézőpontokkal gazdagíthatja a dékánok helyzetének elemzését is. Ezt alátámasztja az is, hogy Jackson a mintzbergi vezetői megfigyelés (Mintzberg [1971]; Mintzberg [1975]) és az amerikai dékánok körében elvégzett hasonló vizsgálat alapján arra mutat rá, hogy „a dékánok vezetői magatartásának mintázatai megegyeznek az üzleti vezetőkéével" (Jackson [2003] 96.o.). Ennek ellenére úgy vélem, ezekkel az elemzésekkel - különösen európai kontextusban - némi óvatossággal kell bánni. Az itt felhalmozott tapasztalatok csak olyan mértékben hasznosíthatóak, amilyen mértékben a felsőoktatási intézményeket azonosítani tudjuk az üzleti szervezetekkel.

A dolgozat korlátját jelenti, hogy a szakirodalmi összefoglalóhoz (a nyelvtudás miatt) csak angol és magyar nyelvű cikkeket és könyveket használtam. Ez óhatatlanul szűkíti az elemzés lehetőségét, mert a német vagy a francia felsőoktatás aktuális kérdései csak közvetítő nyelven, jobbára angolul jutottak el hozzám, miközben történelmi örökségünk folytán e rendszerek lenyomatait közvetve vagy közvetlenül viseljük.

\subsection{A disszertáció szerkezete}

A disszertáció 2. fejezetében bemutatom a szerep fogalmának lehetséges értelmezéseit és kapcsolódását az egyén, illetve a szervezet fogalmához. A szimbolikus interakcionista értelmezésből kiindulva definiálom azt az elemzési keretet, amely meghatározza a későbbi fejezetek struktúráját és az empirikus kutatás során alkalmazott megközelítést is. E fejezet egyik központi üzenete, hogy a dékán szerepe társadalmilag konstruált, azaz a szerep a dékán és a vele kapcsolatba kerülők interakciójában alakul ki és reprodukálódik. Szervezeti közegben ezek az interakciók többnyire strukturáltak, azaz jellemző mintázatot, ismétlődést mutatnak, ami annak köszönhető, hogy az interakciókba lépő felek előzetes (kollektív) meggyőződéssel rendelkeznek a szervezet működésére, a benne szereplők feladatára és magatartására, illetve mindennek magyarázatára vonatkozólag. Ez azt jelenti, hogy e kollektív szervezet-képek (narratívák) és a dékán szerepe között erős kapcsolat van, mert ha változik a narratíva, abból nem csak az egyetem egészének változása következik, hanem a dékánnal szembeni elvárások (azaz a szerep) változása is. És fordítva: a dékánnal kapcsolatos elvárások változása a szervezet egészének változását is tükrözik, elörevetítik. Ebből következően a dékán szerepe és annak változása nem érthető meg a szervezetben fennálló kollektív narratíváknak és azok változásának megértése nélkül.

Ez vezet át a 3. fejezethez, amelyben bemutatom a szakirodalomban - véleményem szerint - leginkább fontosnak tekintett narratívákat: a tudósok közösségét, a bürokráciát, a vállalkozó egyetemet és a vállalat-szerű egyetemet. E narratívák jellemzik tehát az interakcióknak és szerepeknek azt a hálóját, amelybe a dékán szerepének illeszkednie kell. E fejezet nem csak 
a narratívák és kritikájuk bemutatására szolgál, hanem egyben betekintést is ad a dékáni pozíció „kontextusába” - a szakirodalom alapján.

A 4. fejezet a dékánra fókuszál. Célja, hogy a szakirodalom alapján bemutassam a dékán lehetséges szerepértelmezéseit, és ezek alapján a szervezeti narratívákhoz illeszkedő dékáni szerepeket is megfogalmazzam. Négy ilyen szerepértelmezést fejtek ki: a hőst, a szolgáltatót, a katalizátort és a stratégiai játékost. Ezek kibontásához előbb bemutatom a dékán és a középvezetők szerepére vonatkozó szakirodalmat, illetve a dékán sajátos pozíciójából fakadó alapvető dilemmákat, élethelyzeteket is. A fejezet zárásaként rövid kitérőt teszek a dékán mint személy egyéb szerepei felé, és megvizsgálom, hogy e szerepek milyen kapcsolatban vannak a dékánsággal. Elemzem például, hogy milyen kapcsolat (és feszültség) van a dékán oktatói és dékáni szerepe között, illetve hogy hogyan illeszkedik a dékánság a dékánok karrierútjába.

A 3. és 4. fejezetben a szervezet narratíváinak és a dékán ehhez illeszkedő szerepeinek a bemutatására kerül sor. Az 5 . fejezet a szervezetben zajló dinamikáról szól. Kiindulópontja, hogy az egyetemen egy időben több narratíva is érvényes (ezt egy későbbi fejezetben a magyar felsőoktatási rendszer példáján illusztrálom). Ezek egyikének-másikának erősödéséhez, és ezáltal a szervezet átalakulásához, a dékán a saját szerepének megvalósításával járul hozzá, amely azonban felveti a narratívák közti választási vagy a hozzájuk való viszonyulás problémáját.

A 6. fejezetben kerül sor az empirikus kutatás tervének és módszertanának ismertetésére. Az itt felvázolt feltáró, kvalitatív kutatás célja, hogy a magyar felsőoktatási intézményekben gyüjtött empirikus adatok segítségével mélyítsem tovább a dékán szerepéröl és annak változásáról való megértést. $A$ kutatással tehát nem megerősíteni vagy cáfolni kívánom a tervezetben megfogalmazott narratívákat és szerepeket, hanem a korábban mondottakat elmélyíteni, kontextusba helyezni, ezáltal növelni a dékáni szerepekről való megértésünket.

A 7. fejezet célja, hogy részben a szakirodalom, részben az interjúk és más adatgyüjtések segítségével bemutassam a magyar felsőoktatás kontextusát, a karok és dékánok helyzetét befolyásoló legfontosabb tényezőket, trendeket. Itt részletesen kitérek az állam és a felsőoktatás viszonyában bekövetkező változásokra, az intézményrendszer és a karok expanziójára, az intézményszerkezet és az intézmények struktúrájának változási trendjeire, valamint a finanszírozási rendszer alakulására.

A 8. fejezetben a dékánokra vonatkozó szabályozást, ennek következményeit ismertetem három jellemző köré csoportosítva: a választott jelleg, az ideiglenesség és a szakmai és adminisztratív előélettel kapcsolatos elvárások. A szabályzatok vizsgálatát kiegészítem a magyar felsőoktatásban dolgozó dékánok néhány statisztikájának elemzésével, valamint az interjúkból kiolvasható mintázatok elemzésével, például tipikus karrierutak leírásával. A fejezet célja nem csak a dékánok jellemzőinek bemutatására, hanem az is, hogy a gyakori mintázatok alapján következtetéseket vonjak le a dékánokkal kapcsolatos elvárásokra vonatkozóan.

Míg a 8. fejezetben a dékáni pozíciót alapvetően kívülről, külső nézőpontból vizsgáltam, addig a 9. fejezetben a dékánok életét belső nézőpontból próbálom megjeleníteni. Ehhez egyfelől megvizsgálom a dékánná válás motivációit, továbbá a dékánság "túlélésével” kapcsolatos stratégiákat. $A$ fejezet harmadik, legátfogóbb részében a dékánok saját szerepértelmezését és 
szervezetképét veszem górcső alá. E részben kerül sor a 4. fejezetben megfogalmazott kiinduló szerepértelmezési keret elmélyítésére, kontextusba helyezésére és újragondolására is.

A 10. fejezet célja az összegzés: az eredmények kiemelése és a kutatási kérdésekre adott válaszok összefoglalása.

E szerkezetböl nem csak a kutatási megközelítésem, azaz a kétkörös, egyre mélyülő megértési folyamat látható jól, hanem a disszertáció és a disszertáció-tervezet viszonya is. A disszertáció első fele (az 1-5 fejezetek), nagyrészt azonos a disszertáció-tervezettel, és a szakirodalom összefoglalását és a saját reflexióimat, következtetéseimet tartalmazzák. A dolgozat második fele (7-10 fejezet) a korábban megfogalmazott kérdéseket vizsgálja meg a konkrét kontextus és az empirikus adatok fényében. A dolgozat két felében alapvetően ugyanazok a kérdések kerülnek terítékre csak más kontextusban és különböző típusú adatokon keresztül (szakirodalom, majd empirikus adatok).

Kétségtelen hátránya e tárgyalásmódnak, hogy bizonyos témák a dolgozat során ismétlődnek (például a 4. fejezetben megfogalmazott dékáni szerepeket ismét tárgyalom a 9. fejezetben). Bízom azonban abban, hogy az ismételt tárgyalások nem ismétlésként, hanem a megértésünk elmélyüléseként fog hatni.

A téma két körben történő tárgyalása azt is lehetővé teszi, hogy a disszertációtervezetben megfogalmazott kutatási terv, és annak megvalósulása jól nyomonkövethető maradjon. Ennek megfelelően az 2-5 fejezet tartalma döntő részt azonos a disszertáció-tervezet azonos fejezeteivel. E fejezetekben mindössze néhány helyen pontosítottam a szöveget, valamint egy, a magyarországi viszonyokat bemutató illusztráló alfejezetet helyeztem át a magyar viszonyokat részletesen bemutató fejezetbe. 


\section{Szerep, személy, szervezet: az elemzési keret}

A dékán helyzetének sajátosságait, nehézségét és változását a szerep fogalmának segítségével próbálom megragadni, ezért e fejezetben a fogalom értelmezését, illetve a szerepek kialakulásával és változásával kapcsolatos elméleteket járom körbe. Abból adódóan, hogy a szerep összekötő kapocsként szolgál az egyéni szint (az önértelmezés, a self, az identitás) és a társas szint (a szervezet) között, ezért e fogalom értelmezése során szükségszerű az egyén és a szervezet kapcsolatának, illetve a szervezetek működésének a tárgyalása. Így - noha a fókuszban végig a szerep fogalma áll -, a dékán helyzetének elemzési keretét végső soron a személy, a szerep és a szervezet fogalmi hármasa adja.

A szerep fogalmának értelmezése nem csak az elemzés elvi fókuszpontjait, azaz a disszertáció struktúráját jelöli ki, hanem a kutatási módszer megválasztása során is meghatározó jelentőségü.

\subsection{A szerep fogalma}

Az emberi magatartásban szabályszerüség és rendszer figyelhető meg, amelyet a szerepelmélet alapvetően a társas viszonyokra (és nem például az egyéni jellemzőkre) vezet vissza. Ez tükröződik a szerep fogalmában, amely nem más, mint elfogadott magatartásminták, viselkedések és attitűdök olyan összetartozónak vélt repertoárja, amely adott pozícióban, státuszban vagy szituációban lévő egyénnel szemben általánosan elfogadott elvárásként jelentkezik (Bailey - Yost [2000]; Turner [2001] 233.o.). Emellett - különösen a menedzsment irodalomban - a szerep fogalma nem csak a normatív módon előirt (elvárt) magatartást takarhatja (amelyre pontosabb lenne a szerepelvárás vagy a szerepideál kifejezés), hanem a ténylegesen megvalósuló magatartást is (Buda [1997] 80.0.)

A szerepelmélet a szerepekre alapvetően nem a "megjátszás” értelemben tekint. $A$ szerep

„a viselkedésre általában vonatkozik, és elsősorban vonatkozik a spontán, mélyen átélt, énazonosnak érzett magatartásra... [A] szerepfogalom általában olyan kollektív, meghatározott viselkedésformákra vonatkozik, amelyeknek végrehajtása mélyen involválja a személyiség fontosabb összetevőit, érzelmeket, motivációkat mobilizál, attitüdöket kelt, sajátos értékviszonyokat jelenít meg." (Buda [1997] 77-78.0.)

Ehhez hasonlóan Turner is a szerep egyik szükséges összetevőjének látja, hogy olyan átfogó attitüd és magatartásminta legyen, amely valamilyen identitáshoz kötődik (Turner [2001] 234.0.).

A szerepelmélet a szerepek kialakulását az elvárásokra vezeti vissza. Az elvárások amelyek megfogalmazódhatnak formálisan, explicit módon (például egy munkaköri leírásban) és 
érvényesülhetnek informális, implicit módon is (például egy csoportban vagy egy baráti kapcsolatban) - valamilyen társadalmi státuszhoz, (szervezeti) pozícióhoz vagy sajátos szituációhoz kötődnek. Ez alapján megkülönböztethetünk

- alapszerepeket (basic roles), mint például a nemi és életkori szerepek, amelyek jellemzően velünk született szerepek,

- pozíció- és státuszszerepeket (position and status roles), mint például a családi szerepek, illetve egy szervezetben betöltött formális pozícióhoz vagy egy-egy hivatáshoz kapcsolódó szerepek (orvos, ügyvéd), amelyekért az életút során „meg kell harcolni",

- funkcionális csoportszerepeket (functional group roles), amelyek egy-egy szituációban spontán módon kialakuló, jellemzően nem formalizált szerepek (például Belbin csoportszerepei ${ }^{4}$ ), illetve

- érték-alapú szerepek (value roles), amelyek szintén spontán módon alakulnak ki és erősen kötődnek valamely, az adott közösség által elismert értékhez (ilyen például a "hős" vagy a „gonosztevő" szerepe) (Turner [2001]).

A pozíció és státuszszerepeken belül megkülönböztethetőek az általános hatású szerepek, amelyek a szüken vett foglalkozási szférán kivül is meghatározzák a szerep betöltőjének, magatartását, életvitelét, attitüdjét (ilyennek tekinthető például a pedagógus vagy a katona), illetve a korlátozott hatású szerepeket, amelyek a „szociális szervezet-szerveződés a viselkedésnek csak egy körülhatárolható szeletét, vonatkozását tartja kontroll alatt." (Hegedüs [1997] 100.0.)

Fontos hangsúlyozni, hogy a szerepek nem figyelhetőek meg önmagukban, csak társas kapcsolatokon, interakciókon belül, azaz „szerepröl akkor beszélünk, ha az illető viselkedésmód interperszonális jellegü" (Buda [1997] 78.o.). Az interakciókban azonban nem csak az egyik résztvevő, hanem mindkét fél valamilyen szerepben nyilvánul meg. Sok szerep csak a társszerepeivel, komplementer szerepeivel (altering roles, partner roles) együtt értelmezhető, mert a vizsgált szerep tartalma csak így nyer értelmet. Például a vezető szerepe csak a beosztott szerepével együtt válik világossá, az eladóé a vevővel, a tanáré pedig a diákéval.

Egy-egy szervezeti pozícióhoz vagy társadalmi státuszhoz azonban nemcsak egy jellemző viszony (és így magatartásminta) kapcsolódhat, hanem több is. A dékán nem csak az oktatókkal, hanem a rektorral, a hallgatókkal is dékánként beszél, de ez az egyes relációkban más-más magatartásformát jelent. Azaz a dékánság nem egy szerepet, hanem egy szerepkészletet (role-set) jelent (Merton [1968/2002] 453.0.), amely nem egyetlen relációban, hanem az adott szerepre jellemző reláció-halmazban érvényesül5.

\footnotetext{
${ }^{4}$ Belbin híres könyvében megállapitotta, hogy a csoportok tagjai különböző szerepeket töltenek be a csoport müködésében. Ezek alapján olyan szerepeket különböztet meg, mint például a helyzetértékelö, a serkentő, az elnök, a megvalósitó, ötletgyáros, a forrásfeltáró, a csapatjátékos, a megvalósító és a specialista. (lásd például Belbin [2010]).

${ }^{5} \mathrm{~A}$ szerep és a szerepkészlet fogalmának megkülönböztetése a szerepelméletek és a hálózatkutatás érdekes kapcsolatát teszi lehetővé (Polzer [1998]; Biddle [1986]; Biddle [2000]). A továbbiakban az általánosan elterjedt gyakorlatnak megfelelöen a szerep megnevezést használom, kivéve azokban az esetekben, amikor a szerep és szerepkészlet megkülönböztetésének az érvelés szempontjából jelentősége van.
} 
Az eddigiekből az is következik, hogy a szerepelmélet szerint az interakciókban résztvevők nem csak egyénként, hanem az adott társadalmi szerep képviselőjeként is megnyilvánulnak. Ezt tükrözi például az alábbi beszámoló is:

Az egyetemi kultúra olyan adminisztráció és hierarchia és autoritás-ellenes, hogy még egy olyan fegyelmezetlen, spontán és önleleplező személynek, amint amilyen én vagyok, meg kell tanulnia elfogadnia a kari oktatók ragaszkodását ahhoz, hogy amíg az akadémiai ügyek elnökhelyettese vagyok, nem lehetek csak saját magam. A szerep olyan erős elvárásokat hordoz, hogy semennyi jóakarat, hízelgés vagy arra való kísérlet, hogy megtörjem a kereteket, amelybe belekényszerítettek, nem teszi lehetővé, hogy megmeneküljek attól a ragaszkodástól, amelyet egy oktató úgy mondott: amikor veled beszélünk, te nem Allan Cohen vagy, hanem az alelnök." (Cohen (1996), idézi Gallos [2002] 180.0.).

A szerepek vizsgálata tehát lényegében az egyének és a társas rendszerek - például a szervezetek vagy a társadalom - közötti kapcsolat tanulmányozását jelenti, vagyis azt, hogy adott társas rendszer a szerepeken keresztül hogyan gyakorol hatást az egyéni magatartásra (illetve önértelmezésre, identitásra) és fordítva. A szerep fogalma „egységben fejezte ki a viselkedés szabályszerűségeit biztosító egyéni és szociális tényezőket” (Buda [1997] 77.o.), ezért is nevezte Merton a szerepelméleteket „középszintű szociológiai elméleteknek” (Merton [1968/2002]) Az egyéni és kollektív szint összekapcsolódása jelenti a szerepfogalom „interdiszciplináris magvát” (Buda [1997] 78.0.) is, amely révén a fogalom központi magyarázó szerepre tett szert a szociológiában, a szervezetkutatásban, az antropológiában és a szociálpszichológiában egyaránt.

A szerep fogalma az 1930-as évekbeli megjelenését követően szerves részévé vált a szociológia két nagy elméleti irányzatának, a funkcionalista-strukturalista és a szimbolikus interakcionista megközelítésnek is ${ }^{6}$. A szociológia e két alapvető paradigmája azonban alapvetően másként viszonyul a szerepekhez. A különbségeket röviden az 1. táblázat foglalja össze, amelyeket részletesen - elsősorban a szervezeti vonatkozásokra koncentrálva - a következő alfejezetekben bontok ki. Annyit mindenképpen előre kell bocsátani, hogy a szerep értelmezésében mutatkozó eltérések döntő részt a paradigmák közötti ontológiai, episztemológiai és metodológiai különbségekre vezethetők vissza. Ezek részletes bemutatására itt nincsen mód (szervezetelméleti központú tárgyalásaikat lásd például Gelei [2006]; Burrell - Morgan [1979]; Scherer [2008]), ezért a következőkben a paradigma-jellemzőkre csak ott térek ki, ahol ez a szerepek értelmezésének, kialakulásának, működésének és fennmaradásának szempontjából feltétlenül szükséges.

\footnotetext{
${ }^{6}$ Mead az énkép fejlődésének bemutatásával és a szerep fogalmának segítségével fejtette ki társadalomfilozófiáját, Parsons pedig a szerepeket a társadalom építőkövének tartotta.
} 


\section{1. táblázat: A strukturalista-funkcionalista és a szimbolikus interakcionista megközelítés összehasonlítása}

\begin{tabular}{|c|c|c|}
\hline Megnevezés & $\begin{array}{c}\text { Strukturalista-funkcionalista } \\
\text { megközelítés }\end{array}$ & $\begin{array}{c}\text { Szimbolikus interakcionista } \\
\text { megközelítés }\end{array}$ \\
\hline Az elemzés egysége & Státusz / Pozíció & Interakció \\
\hline Alapkérdés & Miért van társadalmi rend? & Hogyan jön létre a jelentéstartalom? \\
\hline A szervezet (a társadalom)... & Objektíven adott elemzési egység & Interakciók hálója, társas konstrukció \\
\hline A szerep... & $\begin{array}{l}\text { Státuszhoz kötődő, társadalmi } \\
\text { konszenzuson alapuló normatív } \\
\text { elvárás, attitüd, azaz „viselkedési } \\
\text { forgatókönyv” (scriptek) }\end{array}$ & $\begin{array}{l}\text { A társas interakciókat strukturáló, de } \\
\text { normatív nyomással nem vagy csak } \\
\text { korlátozottan bíró társas konstrukció }\end{array}$ \\
\hline Az egyén... & $\begin{array}{c}\text { Alapvetően reaktív, passzív, akinek a } \\
\text { helyzetét a társas struktúrák } \\
\text { határozzák meg }\end{array}$ & $\begin{array}{c}\text { Alapvetően aktív és cselekvő, aki a } \\
\text { másokkal folytatott interakciói során } \\
\text { létrehozza és aktívan alakítja a társas } \\
\text { struktúrákat, amelyek azonban } \\
\text { visszahatnak és strukturálják a } \\
\text { későbbi interakciókat }\end{array}$ \\
\hline Központi kategóriák & $\begin{array}{l}\text { Konformitás, szankciók } \\
\text { Szerepkonfliktus } \\
\text { Szerepbizonytalanság } \\
\text { Szereptúlterhelés }\end{array}$ & $\begin{array}{l}\text { Egyeztetett rend (negotiated order) } \\
\text { Szerep-elfogadás (role taking) } \\
\text { Szerepalakítás, szerepformálás (role } \\
\text { making) }\end{array}$ \\
\hline
\end{tabular}

Forrás: saját szerkesztés

\subsection{A funkcionalista-strukturalista megközelítés ${ }^{7}$}

A funkcionalista-strukturalista (vagy röviden: strukturalista) szerepelmélet, amelyet föként Parsons és Merton neve fémjelez, elsősorban arra keresi a választ, hogy hogyan lehetséges a társadalmi rend. Középpontjában annak vizsgálata áll, hogy az egyén hogyan tagozódik be (a szerepek révén) a nagyobb társadalmi struktúrákba, milyen funkciót töltenek be a társadalom, a szervezet vagy a csoport szempontjából és hogyan járulnak hozzá annak teljesítményéhez, fennmaradásához ${ }^{8}$.

A megközelítés központi fogalma a társadalomban elfoglalt hely, a „státusz”, illetve a szervezeti közegben elfoglalt „pozíció”, amelyhez közösen osztott, jellemző és elvárt magatartásformák („szerepek”) társulnak. (Minthogy az elemzés alapvetően a felsőoktatási szervezetekhez kapcsolódik, ezért a továbbiakban egységesen a pozíció kifejezést használom.)

\footnotetext{
7 Néhányan egyszerüen strukturalista szerepelméletként utalnak rá (pl. Stryker [2001]) kihangsúlyozva, hogy középpontjában a társadalmi struktúrák vizsgálata áll. Elismerik ugyanakkor a megközelítés funkcionalista szociológiához való erős kötődését. Én azért használom a strukturalista-funkcionalista megnevezést, mert a szerepelméleteknek elsősorban a szervezeti vonatkozásait vizsgálom, a szervezetelméletek területén pedig ezekre az elméletekre jellemzően funkcionalista elnevezéssel utalnak (pl. Burrell - Morgan [1979]). Vannak egyébként olyan kutatók is (pl. Biddle [1986]), akik megkülönböztetik a funkcionalista és strukturalista szerepelméletet, ez utóbbin olyan irányzatot értve, amely elsősorban matematikai módszerekkel inkább a társas struktúrák és hálózatok leírására helyezi a hangsúlyt, és elhanyagolja a magatartások vizsgálatát.

${ }^{8}$ Épp ezért a funkcionalista-strukturalista megközelítés fő metaforája a színház, amelyben a színészek elöre megírt szerepeket játszanak el. A szerepeket a társas kultúra írja meg, és azok evolúciós alkalmazkodás útján változnak. A szerepek azért elöre megírtak, mert ez biztosítja a darab (a társadalom) koherenciáját, ha valaki improvizálni kezdene. A szerepek kialakítása a darab érdekeinek/a társadalom túlélésének nézőpontjából történik (Biddle [2000]; Turner [2001]).
} 
Az elmélet szerint a szerepek leírását követően egy adott személy pozíciójának ismeretében lehetségessé válik az illető magatartásának megmagyarázása és előrejelzése (Biddle [1986] 70.0.). A pozíciók a szervezeten belüli differenciálódás eredményeként jönnek létre (Turner [2001]).

A strukturalista megközelítés szerint a szerep már a pozíció betöltése előtt adott, mert az a pozíciót korábban betöltők összegyült tapasztalataiból alakult ki evolutív módon, a külső elvárásokhoz alkalmazkodva. A kialakult szerepeket konszenzus övezi. A szerep tartalma a szocializációs folyamaton keresztül hagyományozódik át, amelynek eredményeképpen a szerepelvárások jórészt internalizálódnak, „az egyénbe beépülve belső kényszerekké, részben morális imperatívuszokká, válnak." (Váriné [1994] o.n.). A normakövető magatartást (a rendet) így részben a megerősítő pozitív visszacsatolások, részben pedig a kívülről vagy belülről érkező szankciók (lelkiismeret-furdalás, rosszallás, megvetés stb.), azaz a negatív visszacsatolások biztosítják. A konszenzusos szerepelvárások az adott pozíció betöltőjét egyszerre hatalmazzák fel és korlátozzák magatartásában, hiszen minden szerephez közösen elfogadott jogosítványok és kötelezettségek társulnak. Aki a szerepelvárásokkal összhangban (azokkal konform módon) cselekszik, annak cselekvése nem szorul magyarázatra vagy igazolásra mások előtt (felhatalmazás), sőt, a szerepben való helytállását visszaigazolják, megerősítik. A szereppel inkonzisztens (deviáns) viselkedés azonban vagy magyarázatra szorul, vagy szankciókkal jár (korlátozás) (Turner [2001]). A szerepek tehát a cselekvők konformitásra törekvése révén standardizálják a hasonló pozícióban lévők magatartását, és ezáltal stabilizálják és kiszámíthatóvá teszik a szervezeti viszonyokat. A szerepek az autoritás müködését is lehetővé teszik azáltal, hogy bennük rögzül: adott pozícióban lévő személy mely magatartása legitim és melyik nem (Bess - Dee [2008] 245.0.).

A strukturalista megközelítés empirikus alkalmazásának feltétele, hogy a státuszok jól beazonosíthatóak és egyértelműek legyenek, amely elsősorban az erősen státusz-hierarchizált csoportok és a szervezetek esetében áll fenn (Lopata [1995]) ${ }^{9}$. Nem véletlen, hogy az empirikus vizsgálatok jelentős részét szervezeti közegben hajtották végre, hiszen a szervezeten belüli kapcsolatok többnyire erősen formalizáltak, és így a státuszok a szervezetben elfoglalt pozícióval jól megragadhatóak. A szervezetek különösen termékeny terepnek bizonyultak számos strukturalista szerepelméleti alapkoncepció és összefüggés vizsgálatára. A szerepkonfliktus, a szerepbizonytalanság és a szereptúlterhelés fogalmai például olyan kérdések vizsgálatán keresztül tisztázódtak, mint hogy milyen hatással járnak az ellentmondó, a homályosan megfogalmazott vagy a túlzó szerepelvárások a szervezet/egyén teljesítményére, milyen egyéni és szervezeti tényezők befolyásolják a szerepek egyértelműségét stb.

Ugyanakkor azáltal, hogy a státuszok a formális pozíciók segítségével ilyen kézenfekvő módon ragadhatók meg, sok kutatásban a szerepet leegyszerűsitve értelmezik, és kizárólag a formális felelősségeket és hatásköröket értik alatta (Bess - Dee [2008] 246-247.o.). Ezen irányzat fókuszában az áll, hogy adott szerep milyen funkciót tölt be a szervezet egészének

\footnotetext{
${ }^{9}$ A státusz fogalmi tisztaságát és empirikus megragadhatóságát többen is kritizálták (Lopata [1995]; Jackson [1998]). Ezt a kritikát társadalmi szinten a mai nyugati társadalmakra nézve én is relevánsnak látom, mert ma például a társadalomszerkezet egyre kevésbé írható le egyszerű osztályszerkezetként, az egyéni karrierutak egyre kevésbé tekinthetök lineárisnak. Szervezeti közegben ugyanakkor a strukturalista szerepelméletet (legalábbis ebböl a szempontból) elfogadhatónak látom.
} 
szempontjából, és milyen módon járul hozzá annak müködéséhez. Ez a megközelítés nagyon közel áll a szervezettervezés (Organiation Design, OD) irányzatához ${ }^{10}$ és szerves folytatása a klasszikus bürokráciaelméleti megközelítéseknek. A pozíciókhoz kapcsolódó formális szerepek kizárólagos vizsgálatával azonban figyelmen kívül marad a tényleges magatartás, az ún. rejtett (látens) szerep, és így nem lehetséges megragadni a szervezetben betöltött tényleges szerepet, mert „a formalizáltság, a szerepdefiniálók és szerepgazdák elkülönülése és a szervezeti merevség [...] miatt a szerepgazdák jellemzően kialakítanak egy informálisnak vagy gyakorlatinak nevezhető szerepet, amely jelentősen különbözik a formális szereptöl." (Turner [2001] 243.o.) Ebböl az is következik, hogy a szerepek még szervezeti közegben is jelentős részt a szervezeti kultúrában, és nem kizárólag a formális struktúrában gyökereznek.

A funkcionalista-strukturalista megközelítéssel szemben két alapvető kritika fogalmazható meg (Stryker [2001]; Biddle [1986])11. Egyfelöl az elmélet olyan túlszocializált egyént feltételez, aki a szerepeket csak elfogadni képes, módosítani, megváltoztatni nem, és leegyszerüsítő motivációs feltételezésekkel él, amikor azt állítja, hogy az egyének a szervezeti normákat az önbecsülésének növekedését eredményező pozitív visszacsatolás miatt követi. Másfelöl a strukturalista elmélet azt feltételezi, hogy a szerep a pozícióból fakad, és az „rákényszerítődik” a cselekvőkre. Ez csak akkor elfogadható, ha már a kialakult, stabilan fennálló viszonyokat is feltételezzük. A társas rendszer azonban nem feltétlenül stabil, és a strukturalista elmélet nem képes sem a szerepek kialakulásának megmagyarázására, sem a változás tényleges folyamatának leírására.

\subsection{A szimbolikus interakcionista megközelítés}

A Mead és Blumer munkásságára épülő szimbolikus interakcionizmus olyan általános elméleti keretrendszernek tekinthető, amely mentén többféle elmélet is megfogalmazható, és ezek között nagyon nagy különbségek is találhatóak (a legfontosabb vitapontok és irányzatok bemutatását lásd Stryker - Vryan [2006]). A szimbolikus interakcionista alapokon álló elméletek közös kiindulópontja, hogy az egyének aszerint alakítják a cselekvésüket, ami számukra értelemmel, jelentéssel bír. Ilyen módon a fizikai és a társadalmi környezet is „értelmezett” környezet. Ha az értelmezésük megváltozik, akkor megváltozik a hozzájuk kapcsolódó (rájuk irányuló) magatartás is ${ }^{12}$.

\footnotetext{
${ }^{10}$ Arra is rámutat, hogy a szerepelmélet a szerep fogalmának sajátos értelmezései révén milyen más területekkel áll szoros kapcsolatban.

${ }^{11}$ Biddle [1986] számos kisebb súlyú, nem a koncepció alapjait érintő kritikát is megfogalmaz, például azt, hogy az empirikus adatok nem támasztják alá, hogy a nonkonformitás mindig szankciókkal járna, és az sem bizonyított, hogy a konformitás fenntartásához a szankciókra valóban szükség lenne. További kritika, hogy a strukturalista elmélet számos téves korlátozó feltételezéssel él: nem minden szerep kapcsolódik pozícióhoz/státuszhoz, és nem minden szerepnek van (társadalmi) funkciója. Emellett a normákkal kapcsolatban sem feltétlenül van konszenzus a társadalom egészében, ezt empirikus módon sem igazolták. Az elmélet így nem képes arra sem, hogy értelmezze a normatív szerepelvárások és az aktuális cselekvés, illetve viselkedés közötti viszonyok eltéréseit és változásait (például tartósan fennálló deviáns magatartásokat).

12 Itt nem egyszerüen észlelési különbségröl van szó, hanem arról, hogy egy-egy eseménynek milyen jelentést (következményeket, magyarázatot) tulajdonítunk.
} 
A megközelítés központi kérdése ezért az, hogy hogyan nyer valami értelmet, jelentést valaki számára. Ennek abból a szempontból van jelentősége, hogy a társas együttélés lehetősége azon múlik, képesek vagyunk-e az együttéléssel és a fennmaradással kapcsolatos problémákról kommunikálni, azaz van-e - legalább az interakció idejére átmenetileg elfogadott közös értelmezése a szituációknak, a problémáknak, a megélt környezetnek. Ezek biztosítják a szereplők számára „egymás megértését, koherenciát teremtenek, irányt mutatnak számukra, végső soron lehetővé teszik a koordinált kollektív cselekvést." (Gelei [2006] 85.o.).

A közös értelmezések kialakítása társas interakciókon keresztül szimbólumok (pl. nyelv) segítségével történik. Az interakciók olyan egyeztetési és megegyezési folyamatok, amelyek során a résztvevő felek egymáshoz igazítják elvárásaikat és értelmezéseiket. Stryker megfogalmazásában az interakciók „változó intenzitású küzdelmek arról, hogy kinek a definíciója szervezze az interakciót" (Stryker [2001] 226.0.).

A szélsőséges szimbolikus interakcionista elméletek képviselői úgy vélik, hogy a megegyezési folyamatok minden interakcióban újra és újra lejátszódnak, és így tagadják, hogy az egyén és a nagyobb társas struktúrák (szervezet, társadalom) kapcsolatáról általános megállapítások tehetők. Ezért kerülik a „szerep” fogalmát, mert azt túlságosan statikusnak látják, így az ő esetükben „szerepelméletről” sem lehet igazán beszélni.

A továbbiakban azonban a szimbolikus interakcionista elméletek egy másféle, mérsékeltebbnek tekinthető megközelítéséből indulok ki, amely szerint az interakciók nem „égüres térben” mennek végbe, mert azokat a korábbi interakciók nyomán kialakuló, sokszor szabályokba, tipológiákba, szokásokba (egyszóval: intézményekbe) kódolt közös értelmezések strukturálják, azaz az interakciókban kialakuló közös értelmezés (vissza)hat a cselekvőkre, és befolyásolja a későbbi interakciókat és egyéni értelmezési folyamataikat is. A társadalmi (szervezeti) valóság létrejötte tehát rekurzív folyamat: az egyének az interakciók során társas struktúrákat alakítanak ki (például megállapodnak a szerepekről), amelyek aztán befolyásolják a további interakciókat, amelyek alapján újraalkotják a struktúrákat és így tovább. Így mindkettő feltételezi a másikat, egyik sem tekinthető elsődlegesnek a másikkal szemben (Stryker [2001]; Váriné [1994]). Az interakciók ismétlődésével a közös megegyezések egy része rutinizálódik, fokozatosan szabályokká, normákká, szokásokká kristályosodik ki. A tudatossági küszöb alá süllyedve pedig természetessé, adottá válnak (taken for granted), azaz objektiválódnak és externalizálódnak. Miközben az újratermelődésükben aktívan részt vesznek, a cselekvő egyének ezeket már mint külső, nem befolyásolható valóságot tapasztalják meg (Berger - Luckmann [1998]).

E megközelítésből a szerepek is a társas konstrukciós folyamat eredményei, azaz interakciók során „közös megegyezéssel” alakulnak ki és tisztázódnak. Ez nem feltétlenül tudatos folyamat eredménye, azaz az interakciók többnyire nem a szerepek (újra)definiálására, hanem a hétköznapi cselekvésre és problémamegoldásra irányulnak. Az interakcióban megvalósuló tárgyalási folyamat tehát ritkán szól magukról a szerepekről, az inkább csak az interakció keretét jelenti, a szerepek módosulása pedig az interakció nem tudatos (nem szándékolt?) következményeként áll elő.

Végső soron azonban a szerep inkább tekinthető egy helyi, evolutív jellegű, alulról felépülő (emergent) és megélt (enacted) megegyezéses folyamat eredményének, semmint egy kívülröl a szereplökre erőltetett elváráshalmaznak, miként azt a strukturalista megközelítés 
sugallja. A szerepekben így tükröződnek a „normák, attitüdök, körmyezeti igények, a tárgyalási folyamat, valamint a szituáció alakuló definíciója, ahogyan azt a cselekvők megértik" (Biddle [1986] 71.0.).

Az interakciók ismétlődésével azonban a szerepek jelentéstartalma is rögzül, amelynek során fokozatosan a társas struktúra részévé is válnak. Az imígyen kialakult szerepek azonban nem statikusan léteznek, hanem az interakciókban újra és újra megerősítést nyernek, azaz folyamatosan újratermelődnek, a folyamatos újraalkotás állapotában vannak.

E folyamat lényegi elemét a szerepátvétel (role-taking) ${ }^{13}$ jelenti, azaz amikor a cselekvők az interakciók alatt megpróbálnak belehelyezkedni a másik szerepébe, elképzelik mások helyzetét, cselekvését, és a sajátjukat ehhez igazítják. A szerepátvétel során azonban nem egyszerűen elöre adott forgatókönyvek (scriptek) másolásáról van szó. Az átvett szerepek és az azokra vonatkozó elvárások - a strukturalista megközelítésekkel szemben - nem feltétlenül hatnak normatív nyomásként az interakcióban részt vevőkre, inkább csak tágan vett mintáknak tekinthetőek, amelyek maguk is újraértelmezhetőek, módosíthatóak az interakcióban, azaz a szerepek alakíthatóak (role-making). „Az értelmezés tartalmát és módját [...] a társadalom nem uralja teljes mértékben, az egyéni értelmezésnek is van játéktere. Következésképpen az egyén nemcsak passzív szerepjátszó, hanem társszerzõje is saját szerepének." (Váriné [1994])

A szerepalakításra tett kísérlet nem egyszerűen a kölcsönös megértésnek, a társadalmi integráció erősitésének vagy a hatékony interakciónak a vágyából fakad, hanem abból is, hogy az interakcióban zajló megállapodási folyamat egyben önértelmezési folyamat is. Az én-képzet is - tehát az a képesség, hogy önmagunkat mások nézőpontjából, kívülről, tárgyként szemléljük (reflexivitás) - a más szerepekbe való belehelyezkedés során alakul ki. Ebből adódóan az egyének önmagukat is saját szerepeiken keresztül értelmezik, amelynek során a szerepelvárások egy része internalizálódik, azaz identitássá válik (Stryker [2001]; Bailey - Yost [2000] 2423.o.). Simpson és Carroll ezzel szemben úgy érvelnek, hogy a szerep sohasem válik identitássá, ehelyett a szerepek - mint "határobjektumok” - a jelentéstartalmak közvetítőiként és fordítóiként vesznek részt az identitás kialakításának folyamatában (Simpson - Carroll [2008] 43.o.). Akármelyik értelmezést is fogadjuk el, mindkettőből az következik, hogy adott személy saját szerepértelmezése, énképe és identitása is társas konstrukciós folyamat eredménye, amelyben így a szerepről alkotott kollektív meggyőződések is tükröződnek ${ }^{14}$.

Az interakcionista megközelítés szerint az interakciók kimenetele nem jelezhető előre, és a szerepek tartalma a szerep-alakítás révén újraírható. Ebből azonban nem következik a jelentéstartalmak nagyfokú változékonysága vagy instabilitása, azaz mindezek mellett is lehetséges a szerepek tartalmának megragadása. A szerepek kialakult jelentéstartalma egy fizikából vett példával inkább olyan test állapotára emlékeztet, amelyre bár folyamatosan hatnak erők, mégis nyugalmi állapotban marad. Bár az erők megváltozásával a test mozgásba lendülhet, az állapotváltozás, amely függ a test méretétől, csak fokozatosan következik be. Az analógia szerint tehát minél mélyebben van beágyazódva egy-egy jelentéstartalom a közösség

\footnotetext{
${ }^{13}$ Meadi kifejezéssel élve ez a "nézöpontok kölcsönössége” (reciprocity of perspectives) (idézi Martin - Wilson [2005]).

14 „Minthogy az én-kép tükrözi a társadalmat, ezért az énképek magukba foglalják a társadalom jellemzőit is.” (Stryker - Vryan [2006] 24.0.)
} 
gondolkodásába, az interakciós folyamatok annál nagyobb mértékű átstrukturálása szükséges a változáshoz, amelyhez annál több résztvevőt kell ehhez mozgósítani. A kialakult jelentéstartalmak tehát megragadhatóak, de esetlegesek (kontingesnek) (Wollnik [1995] 367.0.), azaz állandóan fennáll a változás lehetősége, még ha ez nem is feltétlenül következik be.

$A z$ interakciók számosságából és párhuzamosságából, valamint az értelmezési folyamatok nyitottságából az a későbbiekben nagyon fontos szerepet kapó következtetés adódik, hogy egyazon dologra - például a szervezet müködésére vagy a dékánnal kapcsolatos szerepelvárásokra - vonatkozóan a szervezetben egy időben több kollektív értelmezés (narratíva) is létezhet (Wollnik [1995] 370.0.). Erre a későbbiekben még részletesebben visszatérek.

\subsection{A kritikai elméletek észrevételei a szerepelmélettel kapcsolatban}

Az elmúlt évtizedekben mind a szociológiában, mint a szervezetelméletek területén megerősödtek a kritikai elméletek. Ez alatt azokat a megközelítéseket értem, amelyek kiindulópontja, hogy a fennálló társadalmi (szervezeti) rend nem konszenzusra épül, hanem a konfliktusok elnyomására, amely történhet a hatalom nyílt vagy rejtett alkalmazásával, a másként gondolkodás elnyomásával, vagy az ellenérdekek tudatosodásának megakadályozásával (Lukes [1974]). A kritikai megközelítések szerint ezt vagy a társadalom domináns csoportjai generálják, vagy pedig az emberi együttmüködések nem szándékolt következményeiként állnak elö.

A kritikai elméletek a szerepelméletekkel kapcsolatos ellenérveiket is ebből az alapállásból fogalmazzák meg, amikor úgy érvelnek, hogy a szerepelméletek a fennáló társadalmi berendezkedést és az annak alapjául szolgáló társadalmi ideológiát erősítik meg és reprodukálják, tehát alapvetően konzervatív elméletek.

A strukturalista elméletek a tudományosság és annak technikai, látszólag semleges nyelvezetével egyrészt leplezik, hogy a szerepek tartalma mögött valójában társadalmi ideológiák húzódnak meg, másrészt a kialakult szerepek objektív realitásként való feltüntetésével azt az érzetet keltik, hogy azok nem változtathatóak meg. Például a szerepek funkcionális differenciálódásának magyarázatával az elmélet általánosnak, magától értetődőnek és szükségszerünek tünteti fel a kialakult viszonyokat.

A státusz és pozíció kategóriája elleplezi a változatosságot, és homogénnek tünteti fel azt, ami a valóságban nagyon sokszínü (például azt, hogy az egyetemi oktatók nagyon sokfélék nemileg, származásilag, etnikailag, nyelvileg stb.). İgy a státuszhoz kapcsolódó szerep valójában (és szükségszerüen) az uralkodó ideológiára épülő képet teszi meg mércének, azt általánosítja és vetíti ki a társadalom egészére. Aki ezektől a szerepektől eltér, az nem normális, non-konform vagy deviáns.

A szerepkonfliktusok bevezetésével az elméleten belül ugyan megjelenik a konfliktusok magyarázata, ez azonban a konfliktust alapvetően egyéni problémaként kezeli, aminek következtében a megoldás is egyéni szinten történik például olyan technikák (pl. képzés) révén, amelyek segitik az egyéneket abban, hogy az elvárásoknak megfelelő viselkedést tudjanak az 
adott szerepben tanúsítani (Jackson [1998]). A feszültségek forrása a kritikai elméletek szerint azonban nem elsősorban az egyén, ezért írja Biddle, hogy „a szerepkonfliktusok kutatása eltereli a figyelmünket arról, hogy foglalkozzunk a valódi konfliktusokkal, amelyek a társadalmi rendszerekben vannak jelen, vagy azzal a lehetőséggel, hogy az egyén megbirkózhat ezekkel a rendszerek meváltoztatásával." (Biddle [1986] 82.0.)

A kritikai elméletek hasonló kritikát fogalmaznak meg a szimbolikus interakcionista szerepelméletekkel szemben is, amelyek a szerepek kialakulását tárgyalásos folyamatként jellemzik, ám elsiklanak afölött, hogy az alkufolyamatban a résztvevők alkuereje eltérő. Azaz a szerepek társas konstrukciós folyamatában lesznek olyan csoportok, amelyek marginalizálódnak, alárendelődnek és kiszolgáltatottá válnak, mások pedig meghatározó szerepre tesznek szert az uralkodó jelentéstartalom definiálásában. Végső soron azáltal, hogy a szimbolikus interakcionista szerepelméletek konszenzusként tüntetik fel a fennálló helyzetet, legitimálják is azt, és így hozzájárulnak az uralkodó társadalmi (szervezeti) viszonyok és ideológiák újratermelődéséhez (lásd még Bess - Dee [2008]). Hasonló kritikát fogalmaz meg Simpson és Caroll is, amikor azt kifogásolják, hogy „a hagyományos irodalom nem foglalkozik a szerepek diszkurzív, kulturális és politikai konstrukciójával, sem a kontroll és az ellenkezés kérdéseivel. E kritikai megközelítés hiányában a szerepelmélet naívnak, és így korlátozott képességünek tünik abban, hogy a szervezeti élet valóságaival foglalkozzon." (Simpson - Carroll [2008] 31.o.) A kritikai nézőpont azzal gazdagítja a szimbolikus interakcionista keretet, hogy rámutat: a szerepek definiálása a társas konstrukciós folyamatban nem semleges folyamat, hanem egyben a hatalom elosztásának folyamata és következménye is.

\section{5. Összefoglalás és következtetések a dékán szerepének elemzésére vonatkozóan}

A disszertáció további részében a szimbolikus interakcionizmus mérsékeltebb megközelítésének szerep és szervezetképét alkalmazom két okból. Egyrészt a strukturalista megközelítés az egyén és a társas struktúrák közötti viszonyt leegyszerüsitve értelmezi, ezért nem lehet megérteni és elemezni a szerepek kialakulásának, változásának és átalakulásának mikrofolyamatait. Egy radikális átalakulásban lévő felsőoktatásban így a változóban lévő dékáni szerep vizsgálatára e megközelítés kevésbé alkalmas. Másrészt a szimbolikus interakcionizmus magába olvasztja a strukturalista elmélet számos fontos elemét annak az állitásnak az elfogadásával, hogy a kialakult társas struktúrák hatással vannak az egyének helyzetére és a valóságkonstrukciós folyamatra.

A dolgozatban és a kutatásban alkalmazott megközelítésmód kulcskategóriáinak - a szerepnek, a szervezetnek és a személynek - egymáshoz kapcsolódását az 1. ábra mutatja be. 


\section{1. ábra: A kutatásban alkalmazott szimbolikus interakcionista megközelités összefoglalása}

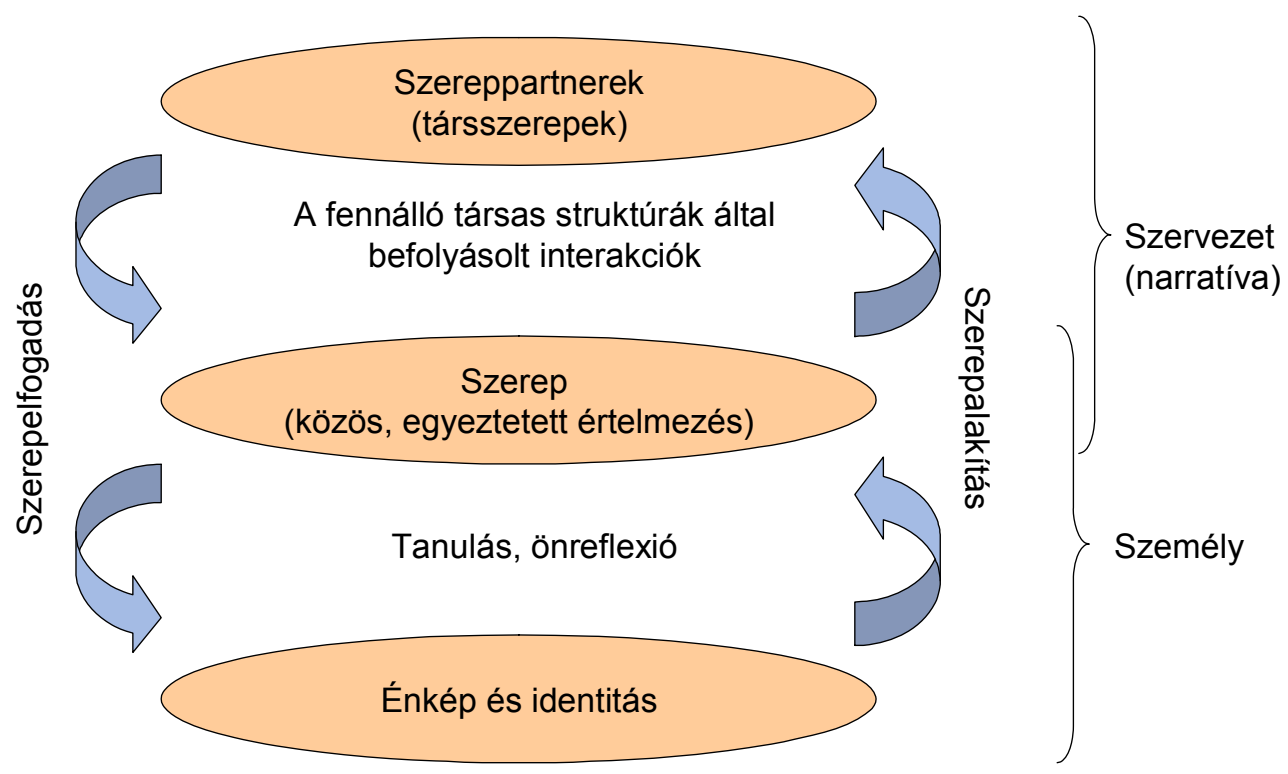

Forrás: saját szerkesztés

Az eddig elmondottak alapján a disszertáció további részére, illetve az empirikus kutatásra vonatkozóan az alábbi következtetéseket vonom le:

1. A szimbolikus interakcionista megközelítés szerint a dékán szerepe társas konstrukció, azaz a szerep tartalma nem a szabályzatok, a felelősségi és hatáskörök megosztása, vagy a történelmi szükségszerüség (a feladatok természetes differenciálódása) miatt változik, hanem azért, mert a dékánnal kapcsolatba kerülö emberek fejében, meggyőződésrendszerében a dékán magatartásáról élő kép megváltozik (Kieser [2008]). A dékán és partnerei az interakciók során e meggyőződésrendszernek megfelelően viselkednek, ezért ezekben az interakciókban a dékán szerepéről alkotott kép folyamatosan rekonstruálódik, újrateremtődik, ami stabilizálja a dékán magatartását is, és ez idővel olyan látható formában is megjelenik, mint például a szabályzatok. A dékán szerepének vizsgálatakor tehát a dékán és partnereinek vallott és követett meggyőződésrendszerét kell vizsgálni, a szerep-változások vizsgálatának középpontjába pedig azokat a konfliktusokat, kihívásokat kell állítani, amelyek a dékán szerepére vonatkozó meggyőződésrendszert érik. Ez a dékáni szerepkonfliktusok egyik forrását is jelenti, hiszen a különböző meggyőződésrendszerekböl különböző elvárások fakadnak.

2. A dékán szerepe nem értelmezhető önmagában, mert a dékán szerepének adott értelmezése implicit módon magában foglalja a szereppartnerek feladatával és tevékenységével kapcsolatos elvárásokat is. Ezek kibontásával és tudatosításával nemcsak a dékán szerepére, hanem az egyetem müködésével kapcsolatos meggyőződésre is pillantás vethető. A szerepek egymáshoz való viszonyának leírása lényegében a szervezet működésének leírást jelenti. Ezért a szerepértelmezés beágyazódik abba a meggyőződésbe, hogy milyen az egyetem és hogyan kell(ene) müködnie (ezt narratívának nevezem a későbbiekben). A logika, úgy gondolom, visszafelé is müködik: a szervezet valós és kívánatos működésére vonatkozó meggyőződés explicit vagy implicit módon tartalmazza, hogy kik a szervezet központi szereplöi és milyen magatartást várnak el velük szemben. Mindebböl az következik, hogy a dékán szerepének 
megértéséhez fel kell tárni a szervezetben uralkodó narratívákat is. A felsőoktatásban uralkodó narratívák feltárására a következő fejezetben fog sor kerülni, az ezekbe ágyazódó dékáni szerepeket pedig a 4. fejezetben részletezem.

3. A szerepek összekapcsolódásából következik, hogy egy-egy szerep változása magával hozza a vele szoros kapcsolatban álló szereppartnerekkel szemben támasztott elvárások változását, azaz a társzerepek tartalmának átrendeződését is (Turner [1990]). Éppen ezért egy-egy központi szereplő szereptartalmának jelentős változása a szervezet egészének változását is tükrözi, hiszen az ilyen szerep változása nyomán számos más szerep is átértelmeződik. A dékán központi, közvetítői szerepénél fogva (amelyet a későbbiekben még alátámasztok) az egyetem ilyen szereplőjének tekinthető, ezért a dékán szerepének változásán keresztül az intézmény egészének változása is megragadható.

4. Ebből következik, hogy egy szervezet jelentős átalakításának szükségszerű részét jelenti a vezetői szerep változása. Sőt, vezetői nézőpontból az intézmény átalakításának szerves részét jelenti a saját szerepüknek, szerepértelmezésüknek a megváltozása és megváltoztatása, illetve ennek az elfogadtatása és a társas struktúrákban való megszilárdítása. (A dékán szerepválasztásának és megvalósításának dilemmáira az 5 . fejezetben térek ki.)

5. A szerep szoros kapcsolatban áll a szerepet betöltő identitásával, énképével, mert a szerep nemcsak a másokkal folytatott interakció, hanem egyben önértelmezési folyamat (azaz az önmagunkkal folytatott interakció, önreflexió) eredménye is. Ezért a dékáni szerep változásának része az is, hogy a vezető az új szerepét megértse, befogadja, és azzal azonosulni tudjon. Így a szervezeti változás a dékán önértelmezésének (szerepértelmezésnek, identitásának) változásában, illetve az ennek kapcsán felmerülő dilemmákban, konfliktusokban is megnyilvánul. E dilemmák egyben a szerepkonfliktusok egy másik forrását is jelentik.

E következtetésekből kiindulva a dolgozat következő fejezetében az egyetemek működésének legnépszerübb narratíváit mutatom be a szakirodalom alapján. $E$ narratívák tükrözik a felsőoktatás főbb szereplőinek meggyőződésrendszerét, felsőoktatás és egyetemértelmezését.

A dékán lehetséges szerepértelmezései beágyazódnak e narratívákba. A 4. fejezet célja ezért egyrészt olyan dékáni szerepértelmezések feltárása, amelyekben tükröződnek az egyes narratívák, másrészt olyan témák, konfliktusok feltérképezése, amelyek a dékáni szerepet jellemzik, és amelyek egyéni megélése az empirikus kutatás során is tanulmányozható lesz.

$A z$ 5. fejezet fókuszában a narratívák változásának folyamata, illetve ehhez kapcsolódóan a szerepek változása és az ehhez köthető egyéni szintű dilemmák állnak. 


\section{Az egyetem narratívái a szakirodalom tükrében}

Az előző fejezet egyik következtetése az volt, hogy a dékánnal szemben támasztott elvárások beágyazódnak az egyetemről alkotott narratívákba. ${ }^{15}$ Narratíva alatt olyan kollektív értelmezési keretet, meggyőződést, magyarázatrendszert értek, amely választ ad arra, hogy

- milyen alapértékre vezethető vissza az egyetem tevékenysége, azaz mitől tekinthető legitimnek az egyetem müködése (és mitől nem),

- hogyan értelmezendő a felsőoktatás viszonya a társadalomhoz és a felsőoktatási rendszer müködése (és hogyan nem), kik a felsőoktatási rendszer domináns csoportjai (és kik nem),

- milyen az egyetem müködésének kívánatos módja (és milyen a nem kívánatos),

- mi az egyetem főbb belső szereplőinek - így az akadémiai vezetőknek, az adminisztrációban dolgozóknak, az oktatóknak és a hallgatóknak - a feladata, szerepe és helyzete (és mi nem).

Természetesen a narratívában foglalt kérdésekre vagy azok egy részére sokféle megközelítésböl próbáltak már korábban választ találni (lásd a 2. ábrát).

\section{2. ábra: A narratívákban foglalt kérdésekre adott válaszok forrásai}

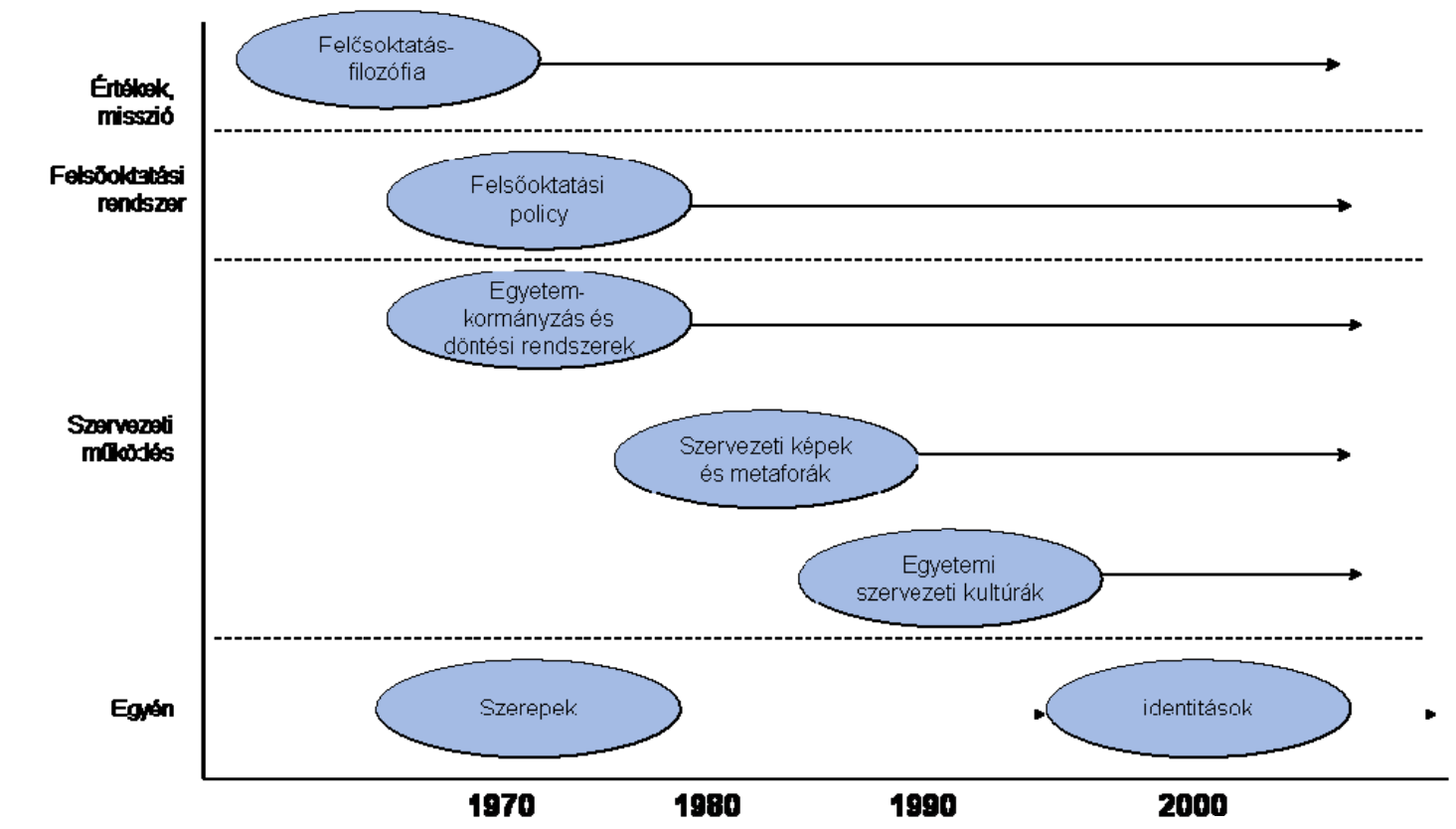

Forrás: saját szerkesztés

${ }^{15}$ A narratíva helyett talán lehetne az ideológia (lásd Barnett [2003]), a diskurzus, esetleg a paradigma kifejezést is használni. 
A felsőoktatás-filozófia (és a történetírás) Kant óta foglalkozik a felsőoktatás társadalmi szerepének kérdésével és annak változásával, ám ezek a megközelítések kevéssé fókuszálnak a szervezet müködésének szintjére és arra, hogy a mindennapi interakciókban hogyan jelenik meg az egyik vagy a másik értelmezés. Mindenesetre ezek a viták ma különösen aktuálisak. Ezt jól mutatja az egyetemek krízisével (például Lyotard [1993]; Readings [1996]), funkcióváltozásával (Tóth [2001]) vagy a társadalmi szerződéssel (Hrubos [2006]; Martin - Etzkowitz [2000]; Neave [2006]) kapcsolatos szakirodalom virágzása, amely pontosan a legitimitási kritériumok változását és a saját önazonosságukat kereső felsőoktatási szervezetek küzdelmét ábrázolja.

Elsősorban a közgazdasági és policy-elemzésekből és a szociológiából bontakozott ki a felsőoktatási rendszer működésének leírása (Clark [1983]), amelynek középpontjában az állam, a piac és a felsőoktatás kapcsolata, illetve ennek szabályozási és finanszírozási kérdései állnak. A felsőoktatási rendszerek folyamatban lévő átalakulása miatt e terület Európában különösen domináns volt az elmúlt évtizedekben.

A szervezeti szint vizsgálata a kezdetektől a domináns menedzsmenttrendeket követte. Az intézményi működés első szisztematikus vizsgálataira a 70 -es években került sor. Ezek eredményeit a különböző egyetemi kormányzási modellek (pl. Walford [1987]; Hardy [1991]; Miller [1995]; OECD [2008] 109-110.0.; Barakonyi [2004a]; Barakonyi [2004b]) és döntési rendszerek (Hardy, Langley et al. [1984]; Hardy [1990]) elemzésében vetették össze. A 80-as években Gareth Morgan Images of Organizations könyvének hatására a szervezeti képek és metaforák szolgáltak a szervezeti kérdések megválaszolásának keretéül (Middlehurst [1993]). A 90-es években a szervezeti kultúra volt az a hívószó, amelynek segítségével megkísérelték leírni a felsőoktatási intézmények müködését (Tierney [1988]; McNay [1995]). Ebben az időszakban jelentek meg a diszciplináris kultúrákat vizsgáló írások is (Becher - Trowler [2001]). Mint arra korábban utaltam már, a szerepek vizsgálata a 70-es évektől kezdődően folyt, amit a 90-es években az identitások vizsgálata váltott fel (Henkel [2000]). Az egyetem leírásának egyes megközelítései a megjelenésüket követően tovább éltek (az új divatok nem „váltották le” őket), azaz ma meglehetősen sok kiindulópontból lehetséges a narratívák megragadására.

A következőkben a narratíva definíciójában foglalt pontokat - a legitimációt, a rendszerre, szervezetre és szerepekre vonatkozó magyarázatot - a fenti források „egybegyúrásából” fogom bemutatni. Kiindulópontként McNay [1995] egyetemi kultúra-modelljét használom, amelyben McNay négyféle intézményi kultúrát különböztet meg (lásd a 3. ábrát): a collegiumot (amelyet én közösségnek vagy tudósok közösségének fordítottam), a bürokráciát, a vállalkozó egyetemet és a vállalat-szerű egyetemet (corporation) ${ }^{16}$.

\footnotetext{
16 Lehetne vállalati egyetemnek is fordítani, de ez a kifejezés magyarul inkább a corporate university-nek, azaz az üzleti vállalkozások által müködtetett egyetemnek a megfelelője (pl. Hamburger University, Microsoft University stb.).
} 


\section{3. ábra: Az egyetem narratívái}

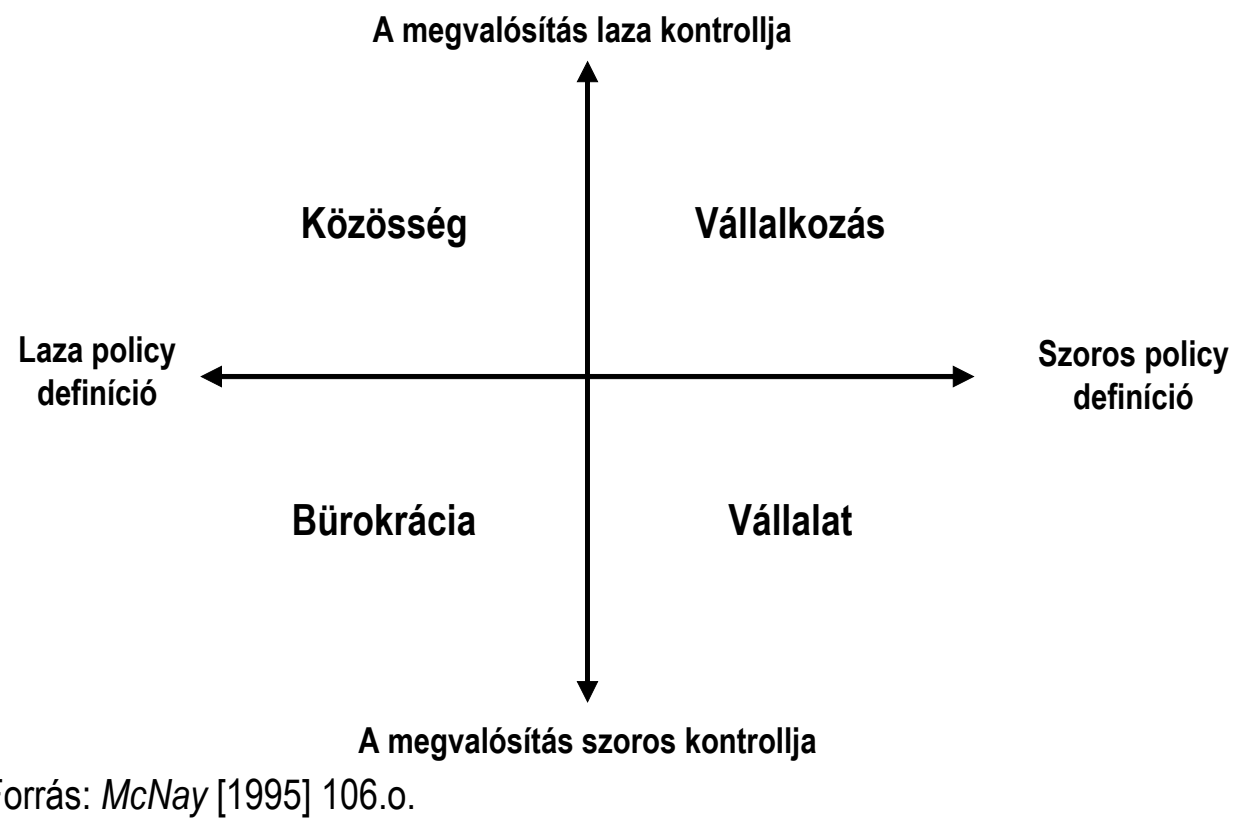

Ezeket a kategóriákat azonban másféle módon és másféle célra használom, mint az az eredeti modellben szerepel. McNay azt sugallja, hogy minden egyes intézmény besorolható a típusok valamelyikébe (és csak az egyikbe), azaz a tipológiáját teljes körünek, univerzálisnak, a kultúrát pedig az intézmény egészére homogén módon jellemzőnek tünteti fel.

Ezzel szemben én a McNay-féle tipológia elemeit általánosabban értelmezem, és olyan tipikus értelmezési kereteknek tekintem, amelyek a szervezetben egyidejüleg létezhetnek. Ez a lista azonban korántsem tekinthető teljesnek, mert ezek mellett további, a helyi interakciótól függő értelmezéseknek is van helye. A narratívák egyidejüleg létező, heterogén egyvelegéböl néhány kiválasztódik, domináns pozícióra tesz szert az egyetemen vagy annak egy-egy részén, és a „saját képére” formálja a szervezet működését, azaz beépül az értékrendbe, a szabályokba. Ennek okaira és következményeire a későbbiekben még részletesen visszatérek.

A narratívák között az alapvető különbségek két dimenzió mentén ragadhatóak meg. Az egyik dimenziót a döntések (a policy) megszületésének módja, a másik dimenziót pedig a döntések megvalósításának szorossága jelenti. A két dimenzió a narratívákat tehát aszerint rendezi, hogy hogyan viszonyulnak az egyetem két meghatározó jellemzőjéhez: a szakértői jelleghez és a töredezettséghez. Éppen ezért előbb röviden áttekintem, hogy milyen válaszra váró dilemmák rejlenek az egyetem e két alapjellemzőjében, majd az egyes narratívákat mutatom be részletesen.

\subsection{A narratívák rendező modelljének dimenziói}

\subsubsection{A megvalósítás kontrollja: az egyetem mint szakértői szervezet}

Az egyetem alaptevékenysége, az oktatás, a kutatás és - narratívától függően - a tanácsadás nagy komplexitású, szakértői típusú feladat. Az egyetem mellett más szakértői feladatot ellátó 
szervezetek is léteznek, például kórházak, tanácsadó cégek, építész és ügyvédi irodák stb. A szakértőként dolgozók közös vonása, hogy más munkavállalókkal (mondjuk egy szakmunkással) ellentétben, kizárólagos autoritásra tartanak igényt nemcsak a munkafeltételekkel kapcsolatban, hanem olyan kérdésekben is, hogy egyáltalán mely kérdések tartoznak a kompetenciájukba és melyek nem, az egyes szituációkban kinek és milyen döntési autoritása van, mely cselekedetek elfogadottak és melyek nem, illetve a nem elfogadott cselekvésekért milyen büntetés, szankció jár (Scott [1995] X.o.). Az orvosok például szakmai kérdésnek tekintik - és ezáltal a saját döntési hatáskörükbe utalják - az otthonszülés kérdését, annak szabályozást, másokat (a laikusokat) pedig ezekből a kérdésekből a hozzá nem értésükre hivatkozva kizárnak. Ugyanígy: a felsőoktatásban dolgozó oktatókra és kutatókra általánosan jellemző, hogy maguk akarnak dönteni olyan kérdésekben, hogy mely problémák tartoznak a saját tudományterületükhöz (és melyek nem), azokat kinek és milyen módon kell/szabad megoldani (és milyen módon nem szabad), hogyan kell ezeket tanítani (és hogyan nem), stb. Magyarország Alaptörvénye például kimondja, hogy „Tudományos igazság kérdésében az állam nem jogosult dönteni, tudományos kutatások értékelésére kizárólag a tudomány mûvelõi jogosultak." 17

A szakértők azonban azáltal, hogy egy jellegzetes és értékes szakértelem egyedüli birtokosai, szervezeti és társadalmi hatalomra is szert tesznek (Clark, Gewirtz et al. [2000] 8.0.), a döntést monopolizálják, a tevékenységük ellenőrzését gátolják. A szakértői autonómia- és autoritásigény alapját az oktatási és kutatási tevékenység nagyfokú komplexitása jelenti, amely korlátozza az oktatás és a kutatás folyamatának, illetve eredményének (outputjának) standardizálhatóságát. Ouchi szerint a standardizáció fókusza lehet

- a tevékenység-láncolat (azaz maga az átalakítási folyamat), amelyre folyamatszabályozás építhető, amennyiben a folyamat jól leírható és elemeire bontható, vagy

- az output, amelyre kimeneti vagy output-szabályozás építhető, amennyiben a tevékenységek eredménye vagy az annak nyomán bekövetkező hozzáadott érték világos szempontok mentén megragadható, illetve

- a magatartás, amelyek alapvetően normakontroll eredményeként állnak elő (lásd az 2. táblázatot).

2. táblázat: A standardizáció lehetséges formái

\begin{tabular}{l|c|c|c}
\hline \multicolumn{2}{c|}{} & \multicolumn{2}{|c}{ A folyamatok standardizálhatósága } \\
\cline { 3 - 4 } & $\begin{array}{c}\text { Jól } \\
\text { standardizálható }\end{array}$ & $\begin{array}{c}\text { Rosszul } \\
\text { standardizálható }\end{array}$ \\
\hline \multirow{2}{*}{$\begin{array}{l}\text { Az outputok } \\
\text { standardizálhatósága }\end{array}$} & $\begin{array}{c}\text { Jól } \\
\text { Output vagy } \\
\text { standardizálhatónatkontroll }\end{array}$ & Output-kontroll \\
\cline { 2 - 4 } & $\begin{array}{c}\text { Rosszul } \\
\text { standardizálható }\end{array}$ & Folyamat-kontroll & Magatartás-kontroll \\
\hline
\end{tabular}

Forrás: Dobák, Antal et al. [1999] 162.o. 11. táblázat

17 X. cikk, 2. bekezdés. Érdemes megjegyezni, hogy a korábban hatályos Alkotmány hasonlóan fogalmaz: „tudományos igazságok kérdésében dönteni, kutatások tudományos értékét megállapítani kizárólag a tudomány müvelői jogosultak." 70/G. § (2) 
Az oktatói munka kapcsán viszonylag könnyü belátni a folyamatszabályozás nehézségét, hiszen az oktatás alapvetően dialogikus folyamat, amelynek a hallgató nem passzív elszenvedője, hanem aktív részese ${ }^{18}$. Ennélfogva az oktatónak az oktatás során számtalan azonnali döntést kell meghoznia, amelyek előzetesen nem rögzíthetőek. Ebből adódik az is, hogy bármiféle folyamatszabályozás legfeljebb a tanítás körülményeinek szabályozására alkalmazható (pl. tárgy meghirdetése, információk adása, a vizsgáztatás feltétele és körülményei), magára a tényleges oktatásra nem ${ }^{19}$.

A folyamat standardizálhatóságának nehézsége a kutatásra is igaz. Noha a tudományos módszerek (amelyek elfogadottsága ismét csak függ a tudományterülettöl, tudományos iskolától) adnak kapaszkodókat, a kutatási folyamat lényegi részei (például a probléma felismerése, az elemzési módszerek megválasztása stb.) csak rendkívül absztrakt szinten általánosíthatók, ami nem teszi lehetővé egy-egy konkrét kutatási folyamat szabályozását.

A folyamatok helyett helyezhetjük a hangsúlyt az output standardizációjára is. Ez azt feltételezi, hogy létezik olyan általánosan elfogadott kritériumrendszer, amely mentén az egyetemek outputja jól jellemezhető. Az output standardizációján alapuló szabályozás ereje abban rejlik, hogy a megvalósításban a végrehajtó szabad kezet kap. Elég az, ha a kívánt végeredményt rögzítjük és ellenőrizzük, így nem szükséges a megvalósítás folyamatos kontrollja.

A felsőoktatásban az output standardizálhatóságának egyik nehézségét az jelenti, hogy sem az oktatás, sem a kutatás outputja nem tekinthető homogénnek. Noha az output mennyiségi szempontból többé-kevésbé leírható (pl. a publikációk vagy a végzett hallgatók számával), ez kevés információt hordoz annak minőségéröl. A minőség mérése, értékelése ugyanakkor meglehetősen nehéz, mert magának a minőségnek a fogalma is összetett és sokrétü, ezért folyamatosan fennálló kérdés, hogy ki és mi alapján ítélheti meg egy képzés vagy kutatás minőségét.

Ez a bizonytalanság mindig magában hordozza a vitathatóságot, az output relativizálhatóságát és állandósítja a teljesítmény újraértelmezésére való törekvést. Ennek természetes következménye, hogy a verseny a felsőoktatásban mindig két szinten zajlik. Az egyik szint az éppen aktuális minőségi kritériumok mentén bemutatott teljesítmény szintjén kialakuló versengés, melynek fö kérdése, hogy adott kritériumok mentén melyik egyetem (kar) a jobb. A másik szint az az értelmezési verseny, amelynek során a felek igyekeznek elfogadtatni az érintettekkel (a többi intézménnyel, a közvéleménnyel, az egyetem többi karával stb.) a számukra kedvező értékelési kritériumokat és azok definícióját például olyan kérdésekben, hogy ki a jó

18 A folyamatszabályozás lényege, hogy minél pontosabban rögzítsük azokat a szabályokat, amelyeket a végrehajtónak meg kell tennie annak érdekében, hogy a kívánt eredményt elérjük. A döntési pontok száma a tevékenység során korlátozott, így a folyamat előre kitalálható és egységesíthető, ezért azokat nem kell állandóan (és személyre szabottan) újra kitalálni. Az eredményesség tehát csak annyiban múlik a végrehajtón, amennyiben a szabályokat betartja.

19 Következmény, hogy az oktatás „minősége” folyamatszabályozáson keresztül nem biztosítható, mert egységes óratervek sem garantálják, hogy a képzésből azonos tudású, képességü, elégedettségü stb. hallgatók kerüljenek ki. Az óratervek egységesítése egyébként nem teljesen elképzelhetetlen, hiszen léteznek olyan business schoolok, ahol minden egyes tanórához igen részletes oktatási útmutatót dolgoznak ki, amelyet - elviekben - kötelező követni. Ez azonban igen költséges folyamat, és úgy vélem, hogy még így is több múlik a megfelelő oktató kiválasztásán. 
oktató/kutató, milyen ismérvekkel írható le a minőségi oktatás, mi jellemzi a kiváló kutatóegyetemet. Az értelmezési verseny terepéül éppúgy szolgálnak a minősítő és akkreditációs szervezetek (pl. MAB), mint a rangsorok, a PR tevékenység, a jogszabályalkotásra gyakorolt befolyás vagy a szenátus és a kari tanács tevékenysége stb. (lásd Barnett [2003]). Vagyis nem csak a teljesítmény, hanem a viszonyítási keretrendszer is vita tárgya (ez összefügg a felsőoktatási szervezet töredezett jellegével, amelyre visszatérek).

Tovább növelik a vitathatóságot a felsőoktatás rendkívül hosszú visszacsatolási ciklusai (Lockwood - Davies [1985]; Varga [1998]), mert a befolyásoló tényezők elkülönítése és a képzés/kutatás tényleges hatásának megjelenítése sok vitára alkalmat adó nehézséggel jár. Például az, hogy megfelelö tananyagot oktatnak-e egy képzési programban, csak akkor derül ki, amikor már a diákok kikerültek a munkaerőpiacra és a munkavállalók jelzik elégedetlenségüket. Ez még a rövid programok esetében is legalább 2-3 év, nem beszélve a hosszabb képzésekről. Ennyi idő után nehéz megítélni, hogy az elégedetlenségben milyen mértékben játszottak közre a diákok gyengébb képességei, a tananyag hiányosságai, az oktatók, oktatási módszerek alkalmatlansága, vagy valamilyen külső körülmény megváltozása (például világgazdasági válság bekövetkezése). Vezetői szempontból e vizsgálatok arra sem adnak egyértelmű visszajelzést, hogy min kell változtatni a jobb eredmények elérése érdekében ${ }^{20}$.

A magatartás és normakontroll lényege, hogy mivel nehéz olyan általános szempontrendszert, indikátorlistát, értékelési eszközt előállítani, amelynek segítségével az adott területen járatlan laikus képes megbízhatóan megítélni az oktatói-kutatói munkát, ezért erre csak más szakértők képesek. Márpedig a felsőoktatási intézmény szervezeti hierarchiájában felfelé haladva fokozatosan csökken a vezető alá rendelt oktatók és kutatók szakértelmének homogenitása és így az irányított szervezeti egység(ek) integritása. Ezzel párhuzamosan a vezető jártassága is csökken az irányítása alá tartozó tudományterületeken. Mindez azt jelenti, hogy az egyetemeken - mint minden szakértői szervezetben - a kontroll jelentős része a szervezet falain túlnyúló szakértői közösség kezébe kerül. Mintzberg megfogalmazásában: „a szervezet lemond a hatalom egy jelentős részéről nem csupán maguknak a szakértőknek, hanem az őket elsősorban kiválasztó és képző egyesületeknek és intézményeknek a javára is." (Mintzberg [1981] 109.o.) Maga a közösség elsősorban a „képességek standardizálásával” (Mintzberg [1981]), azaz hosszú szocializációs eljárások révén biztosítja, hogy az oktatók és kutatók - bizonyos türéshatáron belül - az elfogadott normákat, közösségi gyakorlatot kövessék. Ilyen szabályozó mechanizmusnak tekinthető például a folyóiratcikkek bírálati gyakorlata, a kutatási források elosztása során érvényesített kritériumok, a kinevezéseket megelőző habitusvizsgálatok. A megfelelőség visszaigazolása a szakmai elismerésen keresztül történik. $A$ magatartáskontroll a közösségi normákhoz való állandó igazodási kényszert jelent, ezeken belül

\footnotetext{
20 Ugyanígy nehéz megítélni, hogy az egyetemről kikerülő diák későbbi sikeressége milyen mértékben köszönhető az egyetemnek. Az is lehetséges ugyanis, hogy az adott diák képességei, társadalmi helyzete miatt egyébként is sikerre lett volna „ítélve”. Ez alapján mondhatjuk, hogy a nagy presztízsü egyetemek nem feltétlenül azért sikeresek, mert jól oktatnak vagy kutatnak, hanem azért, mert olyan diákokat tudnak felvenni, olyan kutatókat tudnak alkalmazni, akik más környezetben is kiemelkednének a többiek közül. Ebböl pedig az is következik, hogy az egyetem teljesítménye nem a sokat tudó, végzett diák, hanem az a hozzáadott érték, amelyre a diák az egyetem nélkül nem tett volna szert (azaz a felsőoktatásban az inputok sem tekinthetők homogénnek, hiszen két felvett diák között jelentős különbség is lehet). Nyilvánvaló, hogy ez a teljesítmény-értelmezés még a korábbiaknál is nehezebben megragadható, ami további értelmezési és módszertani vitát generál.
} 
ugyanakkor nagy cselekvési és döntési autonómiával ruházza fel az oktatókat mind az egyetemen belül, mind azon kívül.

A megvalósítás kontrolljának dimenziója végső soron arra keresi a választ, hogy az egyes narratívákban ki, hogyan és mennyire általános érvényűként tudja definiálni a siker, a teljesítmény, a minőség és az output fogalmát. Az egyes narratívák - más-más megfontolásból különböző mértékben fogadják el legitimnek és alkalmazhatónak a kontroll különböző formáit.

\subsubsection{Az egyetemi policy definiálása: az egyetem mint töredezett szervezet}

Minden szervezetet jellemez bizonyos fokú töredezettség például a szervezet differenciálódása vagy a különböző szakmakultúrák kialakulása miatt. A szakértői szervezetek mindegyikében az egyik legnyilvánvalóbb törésvonal a háttértámogatást nyújtó adminisztráció és az alaptevékenységet végző szakértők között van, ami az adminisztráció méretének növekedésével a felsőoktatásban is egyre láthatóbbá válik. $A$ különbségek a célok és folyamatok eltérésére vezethetőek vissza. Az adminisztrációt az üzemszerüség jellemzi, amelyben nem az újszerü feladatmegoldáson, hanem a stabil, megbízható müködésen van a hangsúly. Ehhez jól illeszkedik a folyamatszabályozás, a hierarchikus felépítés, a részfeladatra specializálódó (ún. funkcionális) munkamegosztás, a jól szabályozható felelősségi és hatásköri rendszer. Az adminisztráció tehát működésében és értékrendjében inkább a klasszikus bürokrácia müködésmódját követi, szemben az akadémiai szférával, ahol a munkavégzést inkább a nagyfokú autonómia, a minimális (funkcionális) munkamegosztás, az ellátott feladat egészéért vállalt felelősség és a hierarchikusság alacsonyabb foka jellemzi.

Az egyetemen azonban kulturális különbségek nemcsak az adminisztráció és az akadémiai szféra között vannak, hanem az akadémiai szférán belül is, amely korántsem tekinthető egységesnek vagy homogénnek. Az egyetem abban különbözik más magasan képzett, autonóm szakembereket foglalkoztató szervezettől (például a kórházaktól, a könyvelő cégektől stb.), hogy nem dominálja egy-egy szakmacsoport, és így annak értékrendje nem is hathat integrálóan a müködésére. Ehelyett az egyetemeket - és általában a felsőoktatást - az jellemzi, hogy egy időben számos szakmai csoport létezik egymás mellett, amely az integráció helyett fragmentálja, töredezettebbé teszi az egyetemet (Clark [1983]).

A szakmacsoportok közötti törésvonalakat leggyakrabban a tudományterületek közötti különbségekkel ragadják meg, hiszen a diszciplínák nem pusztán érdeklődési területükben, illetve tudás és valóságképükben különböznek egymástól, hanem társadalmi szerveződésükben is. ${ }^{21}$ (A diszciplínák egy lehetséges felosztására vonatkozóan lásd a 3. táblázatot.) Az egyes diszciplínák tehát egyrészt a tudás sajátos koncepcióját jelenítik meg, irányultságuknak megfelelően értelmezik és vizsgálják a körülöttünk lévő természeti és társadalmi valóságot. Másrészt e diszciplínák az oktatók és kutatók olyan közösségét alkotják, amelynek tagjai sajátos identitással, normákkal, nyelvezettel rendelkeznek, amelyek részben ugyan az ismeretszerzés módjához, részben azonban a tudományos közösség társadalmi státuszának megőrzéséhez, javításához kötődnek (Becher - Trowler [2001]). Mindez strukturálisan a kari/tanszéki

21 Becher hasonlatával: a diszciplínák nem csak a vadászmezők jellemzőit tekintve különböznek, hanem a törzsi szerveződésüket is. 
tagozódásban jelenik meg, hiszen bizonyos fokig minden kar és tanszék adott tudományterület tudományos közösségének helyi (szervezeti) leképeződésének tekinthető.

3. táblázat: A tudományterületek episztemológiai és közösségi jellemzői

\begin{tabular}{|c|c|c|}
\hline & Tiszta & Alkalmazott \\
\hline Kemény & $\begin{array}{l}\text { Tiszta természettudományok (pl. fizika) } \\
\text { A tudás természete } \\
\text { Kumulatív; } \\
\text { Atomisztikus (kristály vagy fa-szerü); } \\
\text { Az általánossal, mérhetővel és az } \\
\text { egyszerüsítéssel foglalkozik; } \\
\text { Eredménye a felfedezés és megmagyarázás. } \\
\text { A közösség jellemzője } \\
\text { Versengő és csoportosuló; } \\
\text { Politikailag jól szervezett; } \\
\text { Magas publikációs ráta; } \\
\text { Cél-orientált. }\end{array}$ & $\begin{array}{l}\text { Müszaki tudományok l alkalmazott } \\
\text { természettudományok (pl. mérnöki tudományok) } \\
\frac{\text { A tudás természete }}{\text { Rendeltetésszerü; }} \\
\text { Pragmatikus (a know-how kemény ismeretek } \\
\text { révén); } \\
\text { A fizikai környezet ellenőrzésére irányul; } \\
\text { Eredménye a termék és műszaki eljárás. } \\
\text { A közösség jellemzője } \\
\text { Vállalkozói és kozmopolita; } \\
\text { Szakmai értékek dominálják; } \\
\text { A szabadalmak helyettesíthetik a publikációkat; } \\
\text { Szerep-orientált. }\end{array}$ \\
\hline Puha & $\begin{array}{l}\text { Humaniórák, szellemtudományok (pl. } \\
\text { történelem) és puha } \\
\text { társadalomtudományok (pl. antropológia) } \\
\text { A tudás természete } \\
\text { Ismétlődő; } \\
\text { Holisztikus (organikus, folyó-szerü); } \\
\text { Az esetivel, a minőséggel és a bonyolítással } \\
\text { foglalkozik; } \\
\text { Eredménye a megértés és az interpretáció. } \\
\text { A közösség jellemzője } \\
\text { Individuális és pluralisztikus; } \\
\text { Lazán strukturált; } \\
\text { Alacsony publikációs ráta; } \\
\text { Személy-orientált. }\end{array}$ & $\begin{array}{l}\text { Alkalmazott társadalomtudományok (pl. } \\
\text { neveléstudomány, üzleti tudományok) } \\
\text { A tudás természete } \\
\text { Funkcionális; } \\
\text { Haszonelvü (a know-how puha ismeretek révén); } \\
\text { A (részben) szakmai gyakorlat fejlesztésével } \\
\text { foglalkozik; } \\
\text { Eredménye protokoll és eljárás. } \\
\text { A közösség jellemzője } \\
\text { Kifelé tekintés; } \\
\text { Státuszában bizonytalan; } \\
\text { Intellektuális divathullámok uralják; } \\
\text { A publikálást a tanácsadás helyettesítheti; } \\
\text { Hatalom-orientált. }\end{array}$ \\
\hline
\end{tabular}

Forrás: Becher [1994] 154.0.

A diszciplináris különbségeket számos vonatkozásban vizsgálták: az oktatás és kutatás szerveződése, céljai, kívánatos magatartásformái mellett (például Smeby [1996]; Smeby [2000]; Becher [1994]; Becher - Trowler [2001]; Neumann, Parry et al. [2002; Hyland [1999]) más területeken is empirikusan mutatták ki a különbségeket. Így például különbségek találhatóak a minőségröl alkotott fogalmakban (Kekäle [2002]; Ylijoki [2000]), a kutatás folyamatának konceptualizálásában (Brew [2001]), a „kutató” (scholar) fogalmának jelentéstartalmában (Neumann [1993]) vagy a tanszékvezetők vezetési (leadership) gyakorlatában (Kekäle [1999]). Ez azt sugallja, hogy az oktatók és kutatók meghatározó igazodási pontjai, munkájuk sikerkritériumai is legalább részben diszciplínafüggőek, és így kötődésük nem kizárólagos (sőt, sok esetben csak másodlagos) az őket foglalkoztató egyetemhez, amely gyakran csak az egyéni törekvéseik hátterét (eszközét?) jelenti. E törekvéseik megvalósítása során azonban sokszor az őket foglalkoztató egyetem érdekével is szembemennek, ami magyarázza egy-egy diszciplína oktatóinak alacsony egyetem-tudatosságát, amely sok vezető számára jelent nehezen megoldható problémát (gondoljunk például a sikeres privát tanácsadói gyakorlatot folytató üzleti oktatókra vagy a tudását szakértőként a saját vállalkozása javára is kamatoztató kutatóra). 
A töredezettségnek érdemes megemlíteni egy másik vonatkozását is, amit az egyetem multipozícionális jellegének nevezhetünk. Ez azt jelenti, hogy az oktatók egy időben egyszerre több pozícióban is lehetnek a szervezeten belül, azaz az azonos tudományterületen dolgozó és formálisan azonos munkakörben lévő oktatók (például két docens) között is jelentős különbségek lehetnek a betöltött további pozíciók függvényében. Ez hatással van a motivációikra, érdekeikre, érdekérvényesitő képességükre, amely miatt az egyes tudományterületeken belöl sem homogenizálhatóak az oktatók. A multipozícionalitásnak elsősorban a párhuzamosan létező tudományos és szervezeti hierarchia jelenti az okát, amelyet a titulusok, címek, egyéb kinevezések rendszere színez tovább. Például ma Magyarországon

„taníthat valaki ingyen, lehet megbízott, részidős és teljes munkaidős; másrészt: lehet tudományos és oktatói státusban; harmadrészt: lehet határozott idejü és véglegesített; negyedrészt: öt lépcsőfokon juthat a tanársegédtől a professzorságig, hat lépcsőfokban a tudományos segédmunkásságtól a kutató professzorságig; ötödrészt: lehet tárgyfelelős, vizsgaelnök, szakdolgozat-vezető, államvizsgáztató. [...] Lehet csoportvezető, tanszékvezetőhelyettes, tanszékvezető, intézetvezető-helyettes, intézetvezető, (többféle) dékánhelyettes, dékán, rektorhelyettes, rektor. Tölthet be fontos bizottságokban tagságokat és elnöki pozíciókat. A doktori iskolákban lehet meghívott tag és alapító (most éppen: törzs-) tag, mindkettőn belül lehet belső és külső, konkrét doktorandusz vezetésére való joggal, vagy anélkül..." (Nagy [2007] 448-449.o.)

A policy definíció dimenzió a narratívákat aszerint vizsgálja, hogy mennyire tekintik kívánatosnak és elfogadhatónak az egyetem töredezett jellegét, és milyen mechanizmusokat alkalmaznak a széttartó érdekek összehangolására.

\subsection{Az egyetem narratívái}

Az imént bemutatott két dimenzió mentén négy egyetemi narratíva bontakozik ki: a közösség, a bürokrácia, a vállalkozói egyetem és a vállalat-szerű egyetem. A 4. táblázatban összefoglalom a narratívák legfontosabb jellemzőit, az egyes alfejezetekben pedig részletesen is bemutatom őket. 
4. táblázat: Az egyetem narratíváinak összefoglalása

\begin{tabular}{|c|c|c|c|c|c|c|}
\hline \multicolumn{2}{|r|}{ Szempont } & Forrás & Közösség & Bürokrácia & Vállalkozás & Vállalat \\
\hline \multirow{2}{*}{ 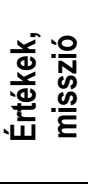 } & Legitimáció forrása & & $\begin{array}{l}\text { Felvilágosodásra nevelés és az } \\
\text { „igazság” érdek nélküli keresése }\end{array}$ & Társadalmi igazságosság & $\begin{array}{l}\text { Fogyasztói igények } \\
\text { kielégítése, hasznosság }\end{array}$ & $\begin{array}{l}\text { Gazdasági megtérülés, } \\
\text { verseny, túlélés }\end{array}$ \\
\hline & Domináns érték & $\begin{array}{l}\text { (McNay [1995]; McNay } \\
\text { [2003]) (Clark [1983]) }\end{array}$ & Szabadság és kiválóság & $\begin{array}{c}\text { (Esély)egyenlöség és } \\
\text { hatékonyság }\end{array}$ & Hozzáértés és megfelelés & Lojalitás és eredményesség \\
\hline \multirow{3}{*}{ 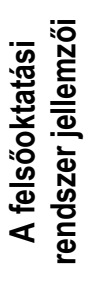 } & $\begin{array}{l}\text { A felsőoktatási } \\
\text { rendszert koordináló } \\
\text { csoport }\end{array}$ & $\begin{array}{c}\text { (McNay [1995]; McNay } \\
\text { [2003]) }\end{array}$ & Akadémiai oligarchia & Állam (mint bürokrácia) & Market policy & Állam (mint policy maker) \\
\hline & Belépési korlát & & Magas & Magas & Alacsony & Alacsony \\
\hline & Teljesítménykontroll & & Alacsony & Magas & Alacsony & Magas \\
\hline \multirow{13}{*}{ 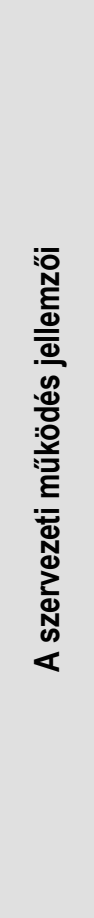 } & $\begin{array}{l}\text { Idealizált szervezeti } \\
\text { forma* }\end{array}$ & $\begin{array}{l}\text { (Mintzberg [1981]; } \\
\text { Mintzberg [1991]) } \\
\text { (Weick [1976]) }\end{array}$ & $\begin{array}{c}\text { Missziós szervezet } \\
\text { Lazán strukturált rendszer (loosely } \\
\text { coupled system) }\end{array}$ & Szakértői bürokrácia & (operatív) adhokrácia & Divizionális szervezet \\
\hline & $\begin{array}{l}\text { Handy kultúra- } \\
\text { megfelelője }\end{array}$ & $\begin{array}{c}\text { (McNay [1995]) } \\
\text { (idézi Bakacsi [1999]) }\end{array}$ & Személy-kultúra & Szerep-kultúra & Feladat-kultúra & Hatalom-kultúra \\
\hline & $\begin{array}{l}\text { Quinn kultúra- } \\
\text { megfelelője }\end{array}$ & (idézi Bakacsi [1999]) & Támogató orientált & Szabályorientált & Innováció orientált & Célorientált \\
\hline & Müködési fókusz & & Belső (szervezet) & Belső (szervezet) & Külső (környezet) & Külső (környezet) \\
\hline & $\begin{array}{l}\text { Domináns szervezeti } \\
\text { egység }\end{array}$ & (McNay [1995]) & Tanszék/egyén & Kar/biztosságok & Alegység/projekt-csapat & Intézmény/felső vezetés \\
\hline & Döntési aréna & (McNay [1995]) & Informális döntési háló & $\begin{array}{c}\text { Bizottságok, adminisztratív } \\
\text { megbeszélések }\end{array}$ & Projektek, teamek & $\begin{array}{l}\text { Munkacsoportok, } \\
\text { felsővezetői csapat }\end{array}$ \\
\hline & Az irányítás stílusa & (McNay [1995]) & Konszenzusos & Formális, racionális & Decentralizált leadership & Politikai, taktikai \\
\hline & A központi autoritás & (McNay [1995]) & Megengedő & Szabályozó & Támogató (ösztönző?) & Utasító \\
\hline & Időtáv & (McNay [1995]) & Hosszú & Közép & Azonnali & Rövid/közép \\
\hline & Környezeti illeszkedés & (McNay [1995]) & Evolúció & Stabilitás & Turbulencia & Válság \\
\hline & Változás természete & (McNay [1995]) & Organikus innováció & Reaktív alkalmazkodás & Taktikai rugalmasság & Proaktív átalakítás \\
\hline & \begin{tabular}{|l} 
A változás \\
kezdeményezői
\end{tabular} & & Professzorok & Adminisztráció & Vásárlók & Felső vezetés \\
\hline & Külső referenciapont & (McNay [1995]) & Láthatatlan kollégium & $\begin{array}{c}\text { Minisztérium, szabályozó } \\
\text { testületek, }\end{array}$ & Vásárlók, szponzorok & $\begin{array}{c}\text { Policy maker-ek mint } \\
\text { véleményvezetők }\end{array}$ \\
\hline
\end{tabular}


4. táblázat: Az egyetem narratíváinak összefoglalása

\begin{tabular}{|c|c|c|c|c|c|c|}
\hline \multicolumn{2}{|r|}{ Szempont } & Forrás & Közösség & Bürokrácia & Vállalkozás & Vállalat \\
\hline & Belső referenciapont & (McNay [1995]) & A tudományterület & Szabályok & Piaci erősségek, hallgatók & Tervek, tervszámok \\
\hline & Az értékelés alapja & (McNay [1995]) & Peer review & Audit eljárások & Ismétlődő megbízások & Teljesítmény-indikátorok \\
\hline \multirow{6}{*}{ 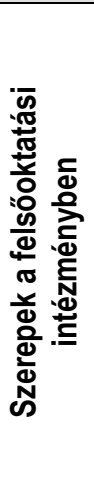 } & A vezetők & & Primus inter pares & Racionális tervezők & Vizionáló leaderek & Kontrolláló menedzserek \\
\hline & $\begin{array}{l}\text { A vezetői autoritás } \\
\text { forrása }\end{array}$ & & Tudományos kiválóság & Formális pozíció & $\begin{array}{c}\text { Meggyőző vízió, } \\
\text { szakértelem }\end{array}$ & Erőforrás-kontroll \\
\hline & A hallgatók & (McNay [1995]) & Tanítványok & Ügyfelek* & Vásárlók & Erőforrás-egységek \\
\hline & Az oktatók & & A tudományos közösség tagjai & Szakértők & $\begin{array}{l}\text { "államilag támogatott } \\
\text { vállalkozók" }\end{array}$ & "tudásmunkások" \\
\hline & Az adminisztráció & (McNay [1995]) & A közösséget szolgálja & A bizottságot szolgálja & $\begin{array}{l}\text { A külső és belső } \\
\text { klienseket szolgálja }\end{array}$ & A felsővezetőt szolgálja \\
\hline & $\begin{array}{l}\text { Bizottságok, testületek } \\
\text { szerepe }\end{array}$ & & $\begin{array}{l}\text { Közösségi rituálé, közösségi kultúra } \\
\text { fenntartása, információ-megosztás }\end{array}$ & Döntéshozás, koordináció & $\begin{array}{l}\text { Brainstorming, } \\
\text { feladatmegoldás } \\
\text { helyszíne (projekt) }\end{array}$ & $\begin{array}{l}\text { Döntések legitimálása, } \\
\text { illetve előkészítése }\end{array}$ \\
\hline \multicolumn{2}{|c|}{ Kapcsolódó koncepciók } & & $\begin{array}{l}\text { Szervezett anarchia (Cohen - March } \\
\text { [1974]), közjószág rezsim (Slaughter } \\
\text { - Rhoades [2004]) }\end{array}$ & $\begin{array}{l}\text { Puha menedzserializmus } \\
\text { (Trow [1994]), közjószág } \\
\text { rezsim (Slaughter- } \\
\text { Rhoades [2004]) }\end{array}$ & $\begin{array}{l}\text { Puha vállalkozó egyetem } \\
\text { (Barnett [2005]), } \\
\text { akadémiai kapitalizmus } \\
\text { (Slaughter - Rhoades } \\
\text { [2004]) }\end{array}$ & $\begin{array}{l}\text { Kemény menedzserializmus } \\
\text { (Trow [1994]), kemény } \\
\text { vállalkozó egyetem (Barnett } \\
\text { [2005]) } \\
\text { Közmenedzsment rezsim } \\
\text { (Bleiklie [2005]) }\end{array}$ \\
\hline \multicolumn{2}{|c|}{$\begin{array}{l}\text { Más narratívákból } \\
\text { megfogalmazott kritikák }\end{array}$} & & $\begin{array}{c}\text { Nem hatékony, nem elszámoltatható, } \\
\text { nem veszi figyelembe a környezeti, } \\
\text { elvárásokat, igényeket, } \\
\text { (elefántcsonttorony), elitista, } \\
\text { monopolpozícióra törekszik }\end{array}$ & $\begin{array}{c}\text { Kreativitást korlátozza, } \\
\text { lassú, a környezeti igények } \\
\text { változását nem tudja követni }\end{array}$ & Misszió hiánya & $\begin{array}{l}\text { A tudást kommodifikálja, } \\
\text { elnyomó }\end{array}$ \\
\hline
\end{tabular}

* a hivatkozott szerző eredeti javaslatát megváltoztattam 


\subsubsection{A tudósok közösségének narratívája}

A tudósok közösségének narratívája a szabadság fogalmát helyezi a középpontba. Karl Jaspers például így jelöli ki a professzor feladatát Az egyetem eszméje címü írásában: „a professzor [...] szabadon viszonyul lényegi munkájához, csupán arra kötelezett, hogy felelösséget vállaljon saját kutatási tevékenységéért, amelyet - még a kérdés fölvetését is beleértve - teljesen önállóan, mások beleszólása valamint utasitások nélkül folytat." (Jaspers [1961/1991] 244.o.)

A szabadság a tudósok közösségének egy sajátos belső ellentmondását eredményezi: a közösség egyszerre szerveződik a tagok közötti különbségen és azonosságon. Míg az elöbbi relevanciáját a szabadságból eredő sokféleség adja, addig az utóbbit a szabadságot lehetővé tevő közös alapértékek támasztják alá. Míg a különbözőségen alapuló közösség képét inkább Weick lazán strukturált rendszere (Weick [1976]) vagy Cohen és March szervezett anarchiája (Cohen - March [1974]) írja le, addig az utóbbit inkább Mintzberg missziós szervezetével (Mintzberg [1991]), azaz például a monostor metaforájával lehet jellemezni, ahol a tagok csak egy adott értékrenden belül követhetik egyéni céljaikat, érdekeiket.

A közösség tagjainak hasonlóságára épülő megközelités mögöttes feltevése, hogy a tagok bizonyos alapértékeket tekintve hasonló nézeteket vallanak, így például elismerik mások autonómiáját, feltétlen hívei a rációnak és a racionális döntéshozásnak, és érvényesül a közvetlen viszonosságot meghaladó reciprocitás, azaz van egy „általánosított, bár tudat alatt létező hit abban, hogy a rendszer egészének tett jószolgálat végül az egyén javára is válik majd" (Bess [1992] 9.o.). Emellett elfogadják a tudományos közösségeket jellemző mertoni normákat is (univerzalizmus, kommunalizmus, pártatlanság és a szervezett szkepticizmus; Merton [1946/2002]).

A közös értékrendböl adódóan a konfliktusok pusztán az információhiány következményei, amelyeket egyszerüen több információ biztositásával lehet feloldani (Miller [1995]). Ez a nézet könnyen összeegyeztethető az egyetemmel kapcsolatos tipikus elvárásokkal, mert a tudományos gondolkodás egyik központi eleme a racionalitás és az analitikus gondolkodás, amely feltételezi, hogy ugyanazon (és egyben elégséges) információból többen szükségszerüen ugyanazt a következtetést vonják le. E megközelités ezért azt sugallja, hogy a közösség tagjai a Ráció mentén képesek egyéni érdekeiket összehangolni és a közösségi érdekekkel összeegyeztetni. Az érdekek összehangolása egyeztetési folyamatokon keresztül történik, a közösséget így a tagok konszenzus mentén irányitják. Ebböl adódóan a testületek szerepe nem annyira a döntés, mint inkább az egyeztetés elősegitése, így az egyetemi tanács funkciója inkább rituális, amely a már korábban informálisan megszületett döntéseket hagyja jóvá (Lockwood - Davies [1985]). Ha a konfliktusok feloldása gyakran történne a testületekben, az éppen a közösség normáinak hiányát jelentené, hiszen a koordinációt nem a mögöttes értékek, hanem a szenátus (mint hatalmi eszköz) látná el (Bess [1992] 22-23.0.).

$\mathrm{Az}$ egyetem így végső soron - a felvilágosodás eszméje szerint - olyan a mintaközösség, amely a felvilágosodott társadalom előképeként müködik (Readings [1996]). Funkciója nem egyszerüen az igazság felfedése (a kutatás), hanem a felvilágosodás eszményeire való nevelés is (a humboldti logika szerint ezt jelenti az oktatás és kutatás egysége). Az egyetem nem elsősorban az igazságot közvetíti, hanem az igazság keresésére nevel - többek között a példamutatás révén. Ezt nem csak az oktatás és kutatás egységén 
keresztül közvetíti, hanem azáltal is, ahogyan az egyetemi közösség az eltérő véleményeket befogadja (emancipálja), megvitatja, kezeli és konszenzusra törekedve megpróbálja integrálni.

A demokratikusság azonban nem jelenti azt, hogy a tagok minden téren egyenlőek lennének. A közösség teljes jogú tagjává válni csak hosszú, többlépcsős folyamat révén lehet, amelynek során a jelölt teljesítményéről és norma-elfogadó magatartásáról a közösség már meglévő tagjai döntenek. Ennélfogva a szabadságra épülő közösség narratíva alapját nemcsak demokratikus, hanem meritokratikus vonások is meghatározzák.

Az egyetem e narratívájából számos következmény adódik az egyetem szereplőinek helyzetére, pozíciójára, feladatára vonatkozóan. Az egyetemi élet központi szereplői az oktatók és kutatók. Az autonómiának megfelelően ők döntenek az oktatási és kutatási kérdésekről és a gazdasági kérdésekről is. A hallgatókra elsősorban mint az igazság keresésének kultúráját (és módszerét) befogadó tanítványokra tekintenek. A gazdasági és ügyviteli adminisztráció alapvetően alárendelt szerepet játszik, feladatuk pusztán a javaslattétel és a döntések végrehajtása, nem azok megkérdőjelezése vagy befolyásolása. A gazdasági adminisztráció semmiféle önállósodása nem elfogadható.

Az egyetemi vezetők primus inter pares, azaz elsők az egyenlők között. A feladatuk „kevésbé a parancsolás mint inkább a hallgatás, kevésbé a vezetés mint inkább a szakértői ítéletek összegyüjtése, kevésbé a menedzselés mint inkább a támogatás, és kevésbé az utasítás mint inkább a rábeszélés és tárgyalás" (Baldridge, Curtis et al. [1978] 45.0.). Ebben a narratívában a vezetöket a közösség választja, de nem elsősorban a döntések meghozatalára, hanem a döntéshozás támogatására, levezetésére és a protokolláris funkciók ellátására. Ebböl adódóan vezetői készség nem szükséges, hiszen a döntés úgy is a közösség (és az azt szimbolikusan képviselő egyetemi tanács és más választott bizottságok) kezében van.

A választás alapja leginkább a tudományos teljesítmény, az akadémiai kiválóság, azaz e narratíva nemcsak a demokratikusságot, hanem a meritokratikusságot is hangsúlyozza.

Az akadémiai közösség ideája tisztán leginkább azokban a nagy anyagi és szellemi függetlenséget élvező intézményekben valósulhat meg, ahol az egyetem tagjai között erősek a közvetlen kapcsolatok (például kicsi a szervezet mérete). Ha azonban nő a szervezet töredezettsége, és a kapcsolatok felszínesebbé, formálisabbá válnak (például a növekedése miatt), az egységes akadémiai értékrend integráló ereje gyengül, akkor az értékközösséget az érdekközösség váltja fel, akik között kölcsönös függőségi viszony (interdependencia) alakul ki (Weick [1976]) abban az értelemben, hogy egyes célokat csak közösen (mint kar, mint egyetem) tudnak megvalósítani. Az időnként felmerülő együttmüködési kényszereket leszámítva azonban az egyetem inkább az önálló, a saját tudományterületi közösségükhöz kötődő szakértők gyüjtőhelyévé válik, akik között viszonylag kevés kapcsolat van. Miller megfogalmazásában: „az egyetemet olyan egyének és tanszékek alkotják, akiket/amelyeket a parkolással kapcsolatos panaszkodás kapcsol össze" (Miller [1995] 100.o.). Éppen ezért gyakori az a vélemény, hogy "a kollégium ${ }^{22}$ és az akadémiai közösség képe inkább egy forradalmi ideológia és egy utópisztikus kivetítődés semmint egy egyetem valós kormányzási formája" (Baldridge [1971] p.13.).

Barnett a tudósok közösségének narratíváját az erényeinek elismerése mellett inkább ártalmas ideológiának tartja, amelynek kettős célja van:

${ }^{22}$ A szerző itt „kollegiális közösség” értelemben használja a „kollégium” kifejezést (lásd pl. láthatatlan kollégium). 
„az egység szimbólumaként szolgál, amikor az egyetem munkatársainak érdekei a kollegiális egység színlelését kívánják az egyetemen belül vagy az egyetem falain túl, és emellett elfedi, miközben elöre is visz, az oktatók mint egyének közös érdekét. Ez az ideológia egy elmúlóban lévő közösségre utal, talán egy olyan közösségre, amely soha nem is volt, miközben az új individualizmust hirdeti, amely az egyetem oktatóinak közös érdeke." (Barnett [2003] 109110.0., kiemelés az eredetiben).

Másként mondva: az egyének magatartásának határait nem a közösségi érdekek és értékek definiálják, hanem épp fordítva: a közösségi érdek az egyéni érdekek mentén alakul ki. Ez az egyetemi közösség müködésének „politikai” olvasatát sugallja, amelyben a cél az, hogy az egyéni érdekek közös érdekként feltüntetve nyerjenek legitimitást. „Kizárólag a magtartás alapján nehéz megkülönböztetni a kollegialitást a politikától. Sőt, az a magatartás, ami az egyiknek tűnik, néha épp a másiknak bizonyul. Így a sikeres politikához szükséges a kollegiális póz (Pfeffer, 1979). Az önérdeket gyakran a közös jó köpenyével kell álcázni" - fogalmazza Hardy és szerzőtársai (Hardy, Langley et al. [1984] 187.o.).

Minthogy minden egyes karnak, tanszéknek, oktatónak megvannak a saját céljai, elvárásai és érintetti köre, ezért az egyetemen a célok egyeztetése soha le nem záruló folyamat. Az egyetem célstruktúráját „[s]okkal inkább gondolatok laza gyűjteményeként lehet jellemezni, nem pedig koherens struktúraként; sokkal inkább feladatokon keresztül kerülnek a preferenciák a napvilágra, mintsem preferenciák alapján történne a feladatok végrehajtása" (Cohen, March et al. [2005/1972] 103.o.), ezért állandóan jelentős célbizonytalanság (goal ambiguity, Cohen - March [1974]) áll fenn. A hivatalos stratégiák és célkitűzéslisták jobb esetben a tárgyalási folyamat pillanatfelvételének tekinthetőek, rosszabb esetben csak látszólagos - a szereplők által mérvadónak semmiképpen sem tekintett - célok, melyeket a külső elvárásoknak való megfelelés érdekében fogalmaztak meg (Peeke [1994]; Patterson [2001]).

A tudósok közösségének narratívájával szemben más narratívák nézőpontjából néhány további kritika is megfogalmazható. Minthogy a közösség önmagát szabályozza, ezért a tudomány a saját belső dinamikája szerint fejlődik ${ }^{23}$. Ebböl adódóan érzéketlen a társadalmi igényekre és szükségletekre, azok kielégítése csak mellékesen (a kutatási eredmények alkalmazása során) történik. Ez a narratíva ezért implicit módon a társadalomtól való elszigeteltséget, elszigetelődést hangsúlyozza (v.ö. „elefántcsonttorony”). Másrészt azonban azt is láttuk, hogy a közösség nem mindig képes az egyes tagok egyéni szabadságát normatív nyomással korlátozni, ezért lehetőség van arra, hogy az oktatók az egyéni szabadságra való hivatkozással kibújjanak a felelősség alól, és a szabadság helyett szabadosság érvényesüljön (Barakonyi [2004b] 60.0.).

\subsubsection{A bürokrácia narratívája}

A bürokrácia narratívának két központi kategóriája van: az egyenlöség és a hatékonyság. Az egyenlőség a tudás demokratizálásának, széleskörü elterjesztésének eszméjéből fakad, amely így közvetve e narratíva legitimációjának forrása. A narratíva szempontjából meghatározó jelentőségü az expanzió folyamata, azaz a hallgatói létszámok folyamatos növekedése, amely a

${ }^{23}$ Ez azonos azzal, amit Gibbons és társai Mód 1 tudásnak neveztek (lásd Gibbons, Limoges et al. [1994]). 
legtöbb fejlett országban először az 1960-as években kezdődött meg, majd az 1980-as évektől gyorsult fel. A létszámmal együtt nőtt a hallgatók társadalmi összetételének heterogenitása is, ami nem csak a hallgatók igényeinek, hanem a felsőoktatásban alkalmazható pedagógiai és tanulási módszertanoknak a sokféleségét is megnövelte. Mindez egyenesen vezetett a programkínálat növekedéséhez (diverzifikáció) (Hrubos [2002]), az oktatásszervezés bonyolódásához és a különböző oktatásszervezési modellek megjelenéséhez.

Így merült fel az a dilemma, hogy hogyan biztositható az azonos helyzetben lévő egyének számára az eljárások azonossága. Hogyan lehet elérni például, hogy az azonos képzésben részt vevő hallgatók azonos színvonalú oktatásban részesüljenek, és azonos feltételek mellett vizsgázzanak? Hogyan érhető el, hogy adott végzettség azonos tudástartalmat takarjon? Stb.

A tömegesedés vezetett a narratíva másik központi kategóriájának, a müködési hatékonyságnak a felértékelődéséhez, mert a hallgatói létszámok növekedését - nem függetlenül a jóléti államok 70-es években kezdődő gazdasági válságától - nem követte az állami támogatások növekedése. Így a létszám bővülése nem lehetséges az intézmény belső müködési folyamatainak változtatása nélkül.

Az egyenlőség és hatékonyság biztosításának eszköze a nagyobb formalizáltság, a magasabb fokú szabályozottság és standardizáltság, ami a személytelenebb szabályozási mechanizmusokat helyezi előtérbe, és kihangsúlyozza az egyetem rendszer jellegét. A tömegesedés felerősíti az egyetemnek azt a vonását, amit Hardy és kollégái nagyon találóan beskatulyázásnak (pigeonholing) neveztek:

"a beskatulyázási folyamat a szervezet tevékenységeit standard komponensek sorozatára vagy programokra osztja fel, amelyek szintén standardizált, elöre meghatározott szituációkban vagy esetekben alkalmazhatóak... A cél: minden hallgatót egy már létező skatulyába erőltetni." (Hardy, Langley et al. [1984] 175.o.; lásd még Mintzberg [1981]).

A felsőoktatás tömegesedése az igényeket is heterogénebbé teszi, amit csak egy még bonyolultabb skatulyázási rendszerrel és a folyamatok még magasabb fokú standardizálásával (bürokratizálással) lehet kezelni. Ez egyre több, egy-egy részfeladatra specializált adminisztratív szakértő foglalkoztatását teszi szükségessé, így például az oktatásadminisztrációban önálló oktatásinformatikai, órarendkészítő és tanulmányi csoport jön létre, amelyek biztositják az oktatásszervezés gördülékenységét. Ennek ugyanakkor az is feltétele, hogy rögzítsük a folyamatokban részt vevő szereplők pontos hatáskörét és feladatát (beleértve ebbe a testületeket, illetve az oktatókat és kutatókat is).

E folyamatban a hallgató elsősorban ügyfél, aki az adminisztratív és akadémiai szakértők által előre kidolgozott és megtervezett oktatási folyamaton megy keresztül, amely végül jól meghatározott és igazolt ismeretanyaggal ruházza őt fel. Ügyfélként lehetnek ugyan elvárásai és igényei, helyzete mégis alapvetően kiszolgáltatott, hiszen nem lehet annak a képességnek a birtokában, aminek a segítségével a képzés helyénvalóságát meg tudná itélni24. Ezért helyettük

24 Nem egyszerüen információs aszimmetriáról van szó, mert nem az információ hiánya okozza a problémát, hanem az információ értékelésének, értelmezésének még meg nem lévő képessége. $E$ készség épp a képzés révén alakul ki a hallgatóban. 
külső szakmai vagy állami szervezetek lépnek fel és ellenőrzik (akkreditációk és audit eljárások során) az intézmények működését. A kormányzati szféra pedig erőteljes direkt szabályozással igyekszik kikényszeríteni az intézményekből a megfelelő (az egyenlőséget és hatékonyságot támogató) működést.

A bürokrácia narratívában az alaptevékenységek közül különösen az oktatás kerül az előtérbe, nem csak azért, mert a legitimitását a tömegesedés adja, hanem azért is, mert elsősorban az oktatás adminisztrációja és feltételrendszere az intézményen belül a jobban szabályozható és szervezhető területek közé tartozik. Ennek ellenére az egyetemi adminisztrációval szemben a professzionalizmus nem csak e területeken elvárás, hanem általában is, mert a bürokrácia lényege, hogy a jellemzően felmerülő problémákra, folyamatokra standard, célszerű megoldást alakítanak ki.

A bürokrácia narratívában a felsőoktatás továbbra is olyan autonóm szféraként jelenik meg, amelyet alapvetően a saját normái és hagyományai vezérelnek, és az adminisztráció csak e feladatok hatékonyabb, racionálisabb megvalósítását segíti elő. A bürokrácia narratíva idealizált szervezet-képe ezért a mintzbergi szakértői bürokrácia (Mintzberg [1981]): elfogadja az oktatás és kutatás feladatának komplex voltát, szabályozhatóságának nehézségeit, és ebből következően az alaptevékenységet végző oktatók és kutatók helyzetének elsőbbségét. Emellett azonban törekszik minden egyéb folyamat szabályozására. Az adminisztrációt tehát alapvetően értéksemlegesség jellemzi, szerepe az egyetem belsőleg definiált céljának hatékony, szakszerű megvalósítása, az egyenlőséget biztosító szabályok kialakítása, azaz elsősorban megvalósító, szolgáltató, tanácsadó szerepre törekednek.

Ez még akkor is igaz, ha a kormányzat a felsőoktatási intézmények működését jelentős mértékben szabályozni akarja, mert a szabályok alkalmazása, intézményi szintre történő lefordítása továbbra is az intézményi akadémiai közösség ügye marad. Minél erősebb és sokrétübb azonban a külső szabályozás, annál inkább megnő az adminisztratív szakértők szerepe az elvárások értelmezésében és lefordításában, és így az intézmény müködésének közvetett alakításában, azaz jelentős - bár korlátozott - önállóságra tehetnek szert. A bürokráciában két tényező korlátozza az adminisztráció túlzott önállósodását: az akadémiai vezetés és a testületi döntéshozás.

Az egyetemi (akadémiai) vezetők feladata az adminisztráció működtetése és működésének felügyelete, annak biztosítása, hogy az adminisztráció döntés-előkészitési és végrehajtási folyamataiban az akadémiai szempontok valóban érvényesüljenek. A másik feladat a racionális döntéshozás, azaz a professzionális működés biztosítása. Annak szavatolása, hogy a döntéshozás a problémák felismerésével és felmérésével, az alternatívák meghatározásával és a közülük való racionális választással zajlik. Ez a bürokrácia narratívájának abból a feltételezéséből fakad, hogy az egyetem célja(i) világos(ak), a vezetők egyértelmüen meg tudják fogalmazni azokat. Éppen ezért mind a környezet, mind pedig a felmerülő igények elemezhetőek, a sikerességhez szükséges eljárások és folyamatok tervezhetőek. Összességében tehát az egyetemi vezetőkkel szemben elvárás a kimagasló adminisztratív szakértelem és a szakismeret (Baldridge, Curtis et al. [1978]).

A döntéshozás legfontosabb terepe az oktatókat és adminisztratív személyzetet is tömörítő testületek, amelyek idejük jelentős részét a szabályzatok felülvizsgálatával és elfogadásával töltik. A kommunikáció formális csatornáinak nagy a jelentősége. Az eseményeket 
dokumentálni kell: a kérelmeket, jelentkezéseket és panaszokat írásban kell megtenni, a megbeszélésekröl, ülésekröl pedig jegyzőkönyvet kell vezetni (néha még a diákokkal való találkozókról is).

A bürokrácia narratívával szemben több kritika is említhető. Egyrészt e narratíva stabil külső környezetet és belső viszonyokat tételez fel, de mindkettő csak korlátozottan igaz. A célok, amire az egyetemi folyamatokat optimalizálják, rendszeresen módosulnak, felülíródnak vagy a szabályozási környezet változása, vagy a belső egyetemi érdekek módosulása miatt. Minthogy a rendszer alakítása alapvetően reaktív módon történik, ezért a gyorsan változó környezetben a szabályozás soha nem éri utol a változást (Mintzberg [1981]; Middlehurst [1993]). Másrészt a kivételek, egyedi megoldások kezelése a bürokráciában mindig problematikus, ami megöli a kreativitást és mindazt, ami a rendszerlogikába nem illeszthető be, hiszen a standardizáció ellehetetleníti a rendszeridegen megoldásokat (McNay [1995]).

\subsubsection{A vállalkozó egyetem narratíva}

Noha a „vállalkozó egyetem” kifejezés meglepően korán, már 1987-ben megjelent a felsőoktatáskutatás szakirodalmában (Davies [1987]), igazán ismertté 1998-ban vált, amikor megjelent Burton Clark azóta gyakran hivatkozott könyve Creating Entrepreneurial Universities címmel (Clark [1998]). Ennek ellenére az eltelt időszak nem volt elég ahhoz, hogy letisztuljon e kifejezés jelentéstartalma, ezért írja Barnett, hogy „távolról sem tisztázott magának a vállalkozóiságnak a koncepciója, a gyakorlat sokféle módja tekinthető "vállalkozóinak « az egyetemen" (Barnett [2005] 52.o.). Éppen e fogalmi zürzavar miatt tartom fontosnak a vállalkozó egyetem fogalmának tisztázását és megkülönböztetését az általam vállalat-szerü egyetemnek nevezett koncepciótól.

A felsőoktatás-kutatás szakirodalmában a „vállalkozó egyetem” fogalmában legalább két különböző megközelítés mosódik össze. Az egyikben a vállalkozói tevékenység gazdasági megtérülése kiemelt szerepet játszik. Ez a vállalkozó egyetem „kemény” formája, amelyet én vállalat-szerű egyetemnek nevezek. A másik megközelítés a vállalkozó egyetem „puha” formáját jelenti, amelyben szintén fontos szerepet játszik a megtérülése fogalma, ám az nem szükségszerüen pénzügyi-gazdasági vonatkozású (a kemény és puha megközelítést lásd: Barnett [2005] 56.0.).

Az összemosódás oka a vállalkozó egyetem koncepciójának újdonsága mellett az, hogy a két értelmezés közös vonásai - például, hogy az egyetemnek a külső környezet felé nyitnia és ahhoz alkalmazkodnia kell - sok szerző számára (különösen, akik a tudósok közösségének nézőpontjából érvelnek) fontosabbnak tűnnek, mint a különbségek. Az is szerepet játszhat, hogy a hétköznapokban a vállalkozások egyben vállalatok is, azaz a müködési és irányítási formájuk, tevékenységük, eszközrendszerük és retorikájuk alapján azonosnak tekintjük őket. A különbségek nem elsősorban az alkalmazott irányítási eszközökben figyelhetők meg, hanem abban, ahogyan azokat használják, azaz inkább a vezetők és dolgozók gondolkodásmódjában, a hozzáállásában és végső soron a létállapotukban, identitásukban.

A továbbiakban vállalkozó egyetem alatt a puha vállalkozói egyetemet értem, a kemény vállalkozói egyetem, azaz a vállalat-szerű egyetem narratívájának bemutatására a következő alfejezetben kerül majd sor.

A vállalkozó egyetem legitimitása a hasznosságában gyökerezik: csak annak van létjogosultsága, aminek társadalmi-gazdasági funkciója, értéke van. Az egyetemet tehát 
szolgáltatóként definiáljuk újra, ahol „az egyetem egyszerre aláveti magát a társadalomnak és kísérletet tesz a társadalom szükségleteinek átalakítására. Vállalkozóvá válik, aki a portékáját erős reklámkampánnyal adja el.” (Bókay [2006] 245.o.) Az egyetem így a (létezni vélt) „tiszta racionalitás helyett [...] a társadalmi vágyak, átélés-hátterek felkeltésének és kielégítésének megfelelő retorikájú, meggyőző prezentációjára törekszik." (Bókay [2006] 245.o.) Sikeressége attól függ, milyen mértékben képes innovációra, azaz az új igények felismerésére vagy megteremtésére, és azok kielégítésére. ${ }^{25}$

Az innovációs potenciál elsősorban a kutatásban van jelen, így a vállalkozóvá válás szükségszerüsége is a kutatási intézményrendszer átalakulására vezethető vissza. Ennek kiváltó oka a tömegesedés, amelynek hatására egyre több a kutatások végzésére alkalmas emberek száma. Amellett, hogy ez közvetlen módon csökkenti az egyetemek és professzoraik exkluzivitását, társadalmi státuszát, ahhoz is hozzájárul, hogy kutatók egyre nagyobb arányban helyezkednek el a felsőoktatási szférán kívül olyan szervezeteknél, amelyek üzleti vagy egyéb megfontolásból összetett problémák megoldásával (is) foglalkoznak (például tanácsadó cégek, alapítványok, kutatóintézetek, kormányzati szervek, NGO stb.). Az új szereplők megjelenése nem csak az ismeretek mennyiségét növeli meg, hanem felszámolja az egyetemek kutatásban korábban élvezett monopóliumát és jelentősen átalakítja az országok kutatási intézményrendszerét, amelynek eredményeképpen

„egy többmilliárd dolláros tudásipar fejlődött ki a már létező felsőoktatási intézmények körén kívül, amely sokkal közvetlenebbül és többnyire sokkal hatékonyabb módon reagál az ipar és a munkaerőpiac igényeire. Ennek következtében erodálódik az egyetemek monopóliuma, melyet a képzések nyújtásában, illetve az olcsó végzettségek magánszektor számára történő kibocsátásában élveztek." (Gibbons, Limoges et al. [1994] 76.0.).

Így az egyetemek „többé sem tudományosan, sem gazdaságilag, sem politikailag nincsenek elég erős pozícióban ahhoz, hogy meghatározzák, mi számít kiválónak az oktatásban vagy a kutatásban." (Gibbons, Limoges et al. [1994] 85.0.).

Ennek következtében nemcsak az ismeretek mennyisége növekszik, hanem kibővül a tudás fogalma is, tartalma pedig relativizálódik (Barnett [2000]). Új tudások és tudásolvasatok jelennek meg, amelyek kívül állnak az egyetem tradicionális (ún. Mód 1) ${ }^{26}$ olvasatán. Ennek a

\footnotetext{
${ }^{25}$ Clark maga is dilemmázik azon, hogy inkább innovatív egyetemnek nevezze-e el (Clark [1998] 4.o.).

${ }^{26}$ A Gibbons és társai (lásd Gibbons, Limoges et al. [1994]) által hagyományosnak tekintett „Mód 1" tudástermelés jellemzöje, hogy a kutatás a mertoni normák alapján müködő, alacsony diverzitású, nagy homogenitású és jól körülhatárolható intézményrendszerben (leginkább az egyetemek és az akadémiai kutatóintézetek által alkotott felsőoktatásban) zajilik, amelyeknek szerveződési alapja a diszciplína. A megoldandó tudományos problémákat és az eredmények minőségét a diszciplináris közösség határozza meg. A termelés és alkalmazás lineáris folyamat, az alapkutatás és az eredmények konkrét helyzetben történő alkalmazása egymást követő, egymástól elváló lépések. A kutatás eredményei közjószágok, ahhoz bárki szabadon hozzáférhet.

A Mód 2 tudástermelés-szervezésben a kutatási probléma definiálása nem kizárólag a tudományos közösség kompetenciája, hanem egy adott problémában érintett közösségé. A problémák az alkalmazás kontextusában („in the context of application") definiálódnak. Az alap- és alkalmazott kutatás megkülönböztetése tehát a Mód 2-ben értelmetlenné válik (pl. gyógyszeripar). A kutatási eredmények hasznosíthatóságára, következményeire és hatásaira kezdettől fogva figyelemmel kell lenni. Az elszámoltathatóság már a problémadefiníciót és a kutatási prioritások meghatározását is áthatja. A minőségkontroll a folyamatban érintett szereplők gyakorolják a kutatás egésze felett az alapján, hogy tudott-e megbízható, releváns ismereteket nyújtani a problémát definiáló közeg számára. A kutatásszerveződésnek alapja nem az állandó kutatócsoport, hanem a változékony, eseti összetételü kutatási projekt (Laki - Palló [2001]).
} 
kutatás mellett az oktatásra is messzemenő hatása van, mert az elvárt tudástartalom egyre nehezebben definiálható, ezért a hangsúly egyre inkább a végzettek társadalmilag használható képességeire (skilljeire) kerül, azaz „az egyetem igazságtartalmakra épülő oktatásának súlypontját az igazságtartalmak megalapozásának retorikai-hermeneutikai folyamataira kell áttenni." (Bókay [2006] 245.o.).

Az új tudásolvasatok megjelenése ahhoz is hozzájárul, hogy a felsőoktatási és akadémiai intézmények mellett más szereplők is legitim módon tartozzanak a „tudományos" tudást előállító szervezetek közé, amit a tudomány és áltudomány felerősödő definíciós vitája is mutat 27 .

Noha vélhetnénk úgy, hogy a tudás meghatározásában meglévő monopolpozíciók elveszítése miatt az egyetemek szerepe marginalizálódik, ennek ellentmondó tendenciák is mutatkoznak. Az új tudástermelök ugyanis termelési folyamataikban kevésbé rugalmasak, mert kutatói személyi állományuk statikus. A tanácsadók, tudásbrókerek, think tankek stb. ezért előbbutóbb a megoldások értékesítésében, és nem a problémák megoldásában lesznek érdekeltek, és standardizálni kezdik a szolgáltatásaikat. Az egyetemek ugyanakkor - ahol a senior hallgatók jelentős mértékben hozzájárulhatnak a kutatáshoz - a hallgatók állandó cseréje miatt rendkívül rugalmasak a kutatások végzésében (Leydesdorff - Etzkowitz [2001]).

Emellett a tudományterületek számának növekedésével a tudomány egyre töredezettebbé, fragmentáltabbá válik, a létrejövő ismeretek komplexitása fokozódik, így egyre nehezebbé válik annak áttekintése, rendszerezése (Nyíri [2005]), az újszerű, releváns kutatási eredmények elérése tehát egyre növekvő specializációt tesz szükségessé (Clark [1997]; Clark [1998]). Az egyre speciálisabb szaktudást ezért egyre költségesebb „házon belül” tartania bármely üzleti vállalkozásnak, azaz jobban megéri „bérbe venni” őket. Mindezek eredője, hogy „...az egyetemi kutatók a közszféra alkalmazásában állnak, ám egyszersmind egyre inkább függetlenednek is töle. Olyan kutatók ők, akik kapitalistaként viselkednek a közszektoron belül, azaz államilag támogatott vállalkozók." (Slaughter - Leslie [1997] 9. o.).

A vállalkozó egyetem szervezeti müködését Mintzberg adhokrácia modellje írja le nagyon találóan, amelynek alapjellemzője, hogy a döntéseket a megrendelőhöz a lehető legközelebb hozzák, mert ez biztosítja a megrendelő igényeihez való rugalmas alkalmazkodást. A vállalkozó egyetem legfontosabb egységévé ezért a projekt válik (Laki - Palló [2001]). A vezetők maguk is szakértők, és így részt vesznek a projektmunkákban. Legfontosabb feladataik közé az új igényekre, lehetséges piacokra vonatkozó, alulról érkező javaslatok összehangolása és kidolgozása tartozik, illetve az ötletelési folyamat stimulálása a különböző projektek és teamek

\footnotetext{
${ }^{27}$ Ha egy ismeretre „tudományos” módon tettek szert, akkor ahhoz alapvetően racionális, értéksemleges konnotáció társul. A tudományos tudás tehát annak révén tesz szert legitimitásra, hogy a közvetlen társadalmi viszonyoktól, a kutató észlelésétöl és érdekétöl stb. függetlennek tünteti fel magát. Az értéksemleges ismeret ennélfogva értéktelítetté is válik, hiszen így a tudományos ismerethez társadalmi érték kapcsolódik. Éppen ezért jelentős „harc” folyik azért, hogy mindenféle kutatás, ismeret „tudományosnak” tüntesse fel magát, amire az ad lehetőséget, hogy nem lehet definiálni, mit is értünk „tudományos” megismerési folyamaton, azaz nem definiálhatóak jól a „demarkációs kritériumok". Ugyanakkor a „társadalmi-gyakorlati dimenzióban a kérdés valójában nem az, hogy hol húzódnak a tudomány határai, hanem hogy hol találhatjuk azokat a határokat, amelyek a megbízható tudást, a döntéseink alapjául szolgáló tudást elválasztják a megbízhatatlan vélekedéstől" (Kutrovácz, Láng et al. [2008] 354 o.). Márpedig megbízható, hiteles ismerethez nem-tudományosnak tekinthető módszerekkel is hozzá lehet jutni, ami fokozatosan kiterjeszti és relativizálja a tudás fogalmát.
} 
összekapcsolása révén. Ennek eszközéül részben a testületek, részben pedig olyan strukturális eszközök bevezetése és müködtetése szolgál, mint a mátrix-megoldások (Dobák, Antal et al. [1999]; Drótos [2003]; Drótos [2009]). Természetesen maguk a vezetők kiemelkedően fontos forrásai azoknak a vízióknak, amelyek a hallgatók, a vállalatok, a társadalom jövőbeli igényeire vonatkoznak. Összességében tehát a vezetők alapvető szerepe az „egyetemet átható vállalkozói kultúra” és az „erős és stimulált akadémiai hátország” megteremtése (Clark [1998]) ${ }^{28}$.

A vállalkozó egyetem innovativitása elsősorban a kutatás változásából és projektszerüségéből fakad. Az oktatási programoknál erősebb a standardizációs hajlam, és ezért a bürokratikus megoldások felé való irányultság. Ez azonban nem jelenti azt, hogy ne lehetne innovációra törekedni az oktatásban, különösen a nagy hozzáadott értékü oktatási programok, a rövid programok, a vállalati képzések területén, vagy például a választható tárgyak körében. $\mathrm{Az}$ innovációnak azonban feltétele, hogy legyen rájuk fogadókész kereslet, a képzési programok tartalmát ezért elsősorban a hallgatói igények formálják. A vállalkozó egyetem narratívában tehát a hallgatók alapvetően vásárlók, akik tudják, hogy mit akarnak, és választásaikért felelősséget is viselnek.

A vállalkozó egyetemmel szemben számos fundamentális kritikát fogalmazott meg Barnett [2003]. Nem önmagában a vállalkozóiságban van a probléma, hanem annak transzformatív jellegében. A vállalkozó egyetemben a piac nem egyszerüen hat az egyetemre, hanem az egyetem (és az oktatói) a piacon keresztül definiálják önmagukat. Ezáltal az egyetem elveszíti integritását, valamint a párbeszédre való képességét, mert többé nem a párbeszédben, hanem a sikerben lesz érdekelt.

\subsubsection{Az egyetem mint vállalat narratíva}

Az egyetem mint vállalat narratíva sok szerzőnél szintén a vállalkozó egyetem köntösbe bújva jelenik meg. Amiben az előző, „puha” vállalkozói megközelítéstől különbözik, az a gazdasági megtérülés hangsúlyozása, amely a korábbitól eltérő ösztönzési struktúrát eredményez (Barnett [2005]). Különösen a kritikai szerzőknél jellemző, hogy e koncepcióra a pejoratív felhangú „kemény” vagy „új” menedzserista megközelítésként hivatkoznak (Trow [1994]; Trowler [1998]). Míg a puha menedzserista narratíva (amit én a korábbiakban bürokráciaként mutattam be) a hatékonyságot a felsőoktatás autonómiájának és sajátos, önirányító természetének tiszteletben tartása mellett kívánja javítani, addig a kemény menedzserializmus képviselőinek

„nincsen bizalmuk az egyetemi közösség bölcsességében, és e közösség tevékenységét a finanszírozási képletek és olyan elszámoltatási mechanizmusok révén kívánják átalakítani és újraformálni, melyeket kívülröl erőszakolnak rá a közösségre, és amely mechanizmusokat oly módon hozták létre és alakították ki, hogy a nagy üzleti vállalkozásokra legyenek alkalmazhatóak" (Trow [1994] 11.o.).

\footnotetext{
${ }^{28}$ Clark a már emlitett könyvében a vállalkozó egyetem öt alapvető feltételét, jellemzöjét sorolja fel: 1) Erős és professzionális menedzsment, 2) fejlesztő perifériák létrehozása, 3) diverzifikált finanszírozás, 4) erős és stimulált akadémiai hátország kialakitása és 5) egyetemet átható vállalkozói kultúra megteremtése. A puha vállalkozói egyetemben megitélésem szerint a hangsúly egyértelmüen az utóbbi kettőre esik, az első három feltétel inkább csak a vállalkozói kultúra kialakitásának lehetséges eszközeit jelenti. (Clark [1998])
} 
E narratíva a legitimációját két, egymással erőteljes kapcsolatban álló érvrendszerből eredezteti. Az egyik a tudás kapitalizálódásának folyamata:

„Amint a tudományos tudást jövedelemtermelésre használják fel, a tudomány maga átalakul a társadalmi többletet felhasználó kulturális folyamatból olyan termelőerővé, amely kulturális értelmen túl is új jövedelmet generál. Amint egy dolgot, legyen bár látható vagy láthatatlan, gazdasági érték létrehozásának szándékával használunk fel, fogyasztás helyett »tőkévé« válik [...] A kultúra, beleértve a tudományt is, tőkévé válik, amint jövedelemáramlást generál." (Etzkowitz [1997] 143. 0.)

A kapitalizálódási folyamat lehetővé és egyben kötelességévé is teszi az egyetemek számára a társadalom gazdasági fejlődéséhez való közvetlen hozzájárulást azáltal, hogy az egyetem közvetlenül vesz részt a piaci tranzakciókban, „saját jogán válik gazdasági aktorrá” (Etzkowitz [1998] 833. 0.). Etzkowitz ezt második akadémiai forradalomnak ${ }^{29}$ nevezi (Etzkowitz [1997]; Martin - Etzkowitz [2000] 14. 0.), amelyben az egyetem nem csak létrehozza és közvetíti az új ismereteket, hanem maga próbálkozik meg azok gazdasági kiaknázásával. „Dióhéjban: az új vállalkozói szellem egyenlő a régivel plusz a profit-érdekeltséggel.” (Etzkowitz [1998] 828.0.)

A másik kategória, amelyre a vállalati egyetem legitimitása épül a verseny. Amint a tudás tőke-természete nyilvánvalóvá válik, úgy megszűnik az egyetemek és az üzleti világ közötti különbség, ami versenyt eredményez. A verseny megfigyelhető mind az oktatás, mind a kutatás területén.

Az oktatásban a tömegesedéssel növekvő képzési piac vonzó célpont az üzleti vállalkozások (pl. for-profit egyetemek) számára, azaz újabb szereplők lépnek be a felsőoktatás piacára. Ez többnyire egybeesik a forráshiánnyal küzdő, és ezért a versenyt erősíteni kivánó oktatáspolitikai törekvésekkel is (lásd később). A versenyt a speciális képzési igények kielégítésére érzéketlen vagy alkalmatlan felsőoktatási intézményrendszer is fokozza, amely arra ösztönzi a vállalkozásokat, hogy saját képző helyeket (vállalati egyetemeket) hozzanak létre, amelyek sok esetben nem csak belső képzéseket nyújtanak, hanem bárki számára nyitottak. $\mathrm{A}$ versenyt az expanziót követő stagnáló és csökkenő hallgatói létszám is fokozza.

A kutatás területén a felsőoktatás tömegesedése inherens módon vezetett a hagyományos kutatási mező (egyetemek, akadémiai hálózat, szakmai szervezetek) bővüléséhez, hiszen a végzett hallgatók egyre inkább a felsőoktatáson kívül képesek használni az elsajátított ismereteket. Emellett a multinacionális cégek tőkefelhalmozása is lehetővé teszi olyan céges kutatási infrastruktúra kialakítását, amely korábban - annak eszközigényessége miatt - többnyire csak állami forrásokkal volt lehetséges. Mindezek következtében ma már valódi „tudástermelőként” lépnek fel a vállalati kutatóhelyek, a tanácsadók, a kormányzati kutatóközpontok, a think tankek stb.

A határvonalak feloldódásának igazi katalizátora azonban az állami szerepvállalás változása. A 70-es évek gazdasági nehézségei véget vetettek a második világháborút követő prosperáló időszaknak. A jóléti államok kormányai számára a folyamatosan növekedő közkiadások kordában tartása vált a fő kérdéssé. A hallgatói létszámok növekedéséből adódó

${ }^{29}$ Az első akadémiai forradalom a XIX. században volt, amikor az egyetemek célrendszerébe az oktatás mellé a kutatás is beépült. Ez egészül most ki egy harmadik céllal. 
egyre nagyobb költségvetési támogatás pedig a felsőoktatást óhatatlanul az átalakítandó területek közé emelte, amely a felsőoktatás irányítási és finanszírozási rendszereinek változásához vezetett. A reformok a szabályozott verseny kialakítását, a magánszféra bevonását és a felsőoktatási intézmények gazdálkodási és irányítási mozgásterének növelését célozták (Johnston [1998]; Eurydice [2000]). Ezekkel együtt azonban az állam szerepe is átalakult: közvetlen szolgáltatásnyújtó és -szervező szerepből a reformok során egyre inkább szabályozói, megrendelői, és az állampolgárok nevében fellépő ellenőri szerepbe kerül. A bürokratikus modellel szemben, ahol az állam tevékenysége a szolgáltatások inputja és a szolgáltatók müködési folyamatainak kontrolljára irányul, egyre inkább a szolgáltatások outputjának kontrolljára helyeződik a hangsúly (Goedegebuure, Kaiser et al. [1994] 330.0.), például különböző teljesítményindikátorok bevezetése és összehasonlítása révén. Korántsem az állam szerepének csökkenéséről van tehát szó (lásd Teichler [2003]), ami különösen nyilvánvaló azokban az országokban, ahol állami irányítással hoztak létre erősen szabályozott, felsőoktatási kvázipiacokat (pl. Anglia). Ezekben az országokban az állam szerepe még növekedett is ${ }^{30}$.

Csökkenő állami támogatás és a növekvő verseny mellett nem megengedhető a felsőoktatási intézményeket általánosságban jellemző (leginkább a tudósok közösségéhez és a bürokratikus működésmódhoz kapcsolódó) működésmód, azaz a stratégiai tervezés hiánya, az egyéni és csoportos felelősségvállalás (accountability) alacsony szintje, az individualizmus és az intézmény iránti alacsony elkötelezettség, a konfliktuskerülés és a problémák szőnyeg alá söprése, a célok bizonytalan megfogalmazása és a célok eléréséhez szükséges eszközök meghatározásának hiánya, valamint tisztázatlan hatáskörökből és a testületek túlzott szerepéből adóan a döntéshozás rendkívüli időigényessége (Davies [2001]).

A versenyben történő helytállás az erőforrás-felhasználás hatékonyságának javitásával, az erőforrások megszerzésére vonatkozó intézményi erőfeszítések összehangolásával, a megfelelő ösztönző rendszerek kiépítésével és az intézményi prioritások, fókuszpontok kijelölésével, azaz a hosszabb távú, stratégiai szemlélet érvényesitésével biztositható. Ennek feltételét az állami felügyelet közvetetté válása, azaz az intézmény döntési autonómiájának kiszélesedése, eszközrendszerét pedig olyan, az erőforrás-felhasználás tudatosságát középpontba állító módszerek bevezetése és adaptálása jelenti, amelyeket az üzleti szférában már régóta alkalmaznak ${ }^{31}$. Ezek közé tartozik például a controlling, a HR, a stratégiai tervezés, a minőség-menedzsment és teljesítményértékelési rendszerek bevezetése (Sporn [2006]), továbbá az intellektuális tőkét, a tudásvagyont menedzselő és kiaknázó technikák is, így a fejlesztő perifériák, spin-off vállalkozások létrehozása (Clark [1998]), illetve technológia-transzfer központok, a szabadalmak menedzsmentjével foglalkozó központok kiépítése.

\footnotetext{
30 Bleiklie ([2005] 52.0.; 2007]) ezeket „közmenedzsment rezsimeknek” (public managerialist regime) nevezi, kiegészitve Slaughter és Rhoades [2004] népszerü elméletét, mely szerint a tudás közjószágból tőkévé válik, azaz a felsőoktatás közjószág-rezsimből (public good knowledge/learning regime) az akadémiai kapitalizmus rezsimjébe (academic capitalism knowledge regime) alakul át.

31 Érdemes megemlíteni, hogy az irányításban bekövetkező ilyen irányú változások nem csak a felsőoktatásban következtek be, hanem általában a közszolgáltatások szervezésében is. Ennek eszmei-ideológiai keretét az Új Közszolgálati Menedzsment (New Public Management) irányzat jelentette és jelenti ma is (Hajnal [2004]; Thom Ritz [2005]; Horváth [2006]). Ennek az értelmezési dimenziónak a bemutatásától és elemzésétől azonban most eltekintek.
} 
Mindez együtt jár a szervezeti struktúra jelentős átalakitására is, amely mögött részben a költségek csökkentése, részben pedig a tiszta pénzügyi felelösségi és hatásköri viszonyok kialakítása áll. A karok és tanszékek összevonása mögött például jellemzően mérethatékonysági megfontolások és az interdiszciplinaritást erősíteni kívánó szándékok állnak (Taylor [2006]), a karokon belül kialakított mátrix struktúra középpontjában pedig (a vállalkozói modellel ellentétben) nem elsősorban a koordináció, hanem a megfelelő pénzügyi ösztönzési rendszer kialakítása áll (Drótos [2009]).

A struktúra átalakításának fontos része az intézményi és kari szint közötti viszony tisztázása is. Ebben a kérdésben - és a működési modellben általában - a divizionális struktúra jelenti a szervezeti ideált, ahol a karok (mint diviziók) jelentős önállóságot kapnak az oktatás és kutatás megszervezéséért, a kar pozícionálásáért, és ehhez jelentős (bár korlátozott) döntési autonómia és pénzügyi felelősség társul. Az intézményi szintű menedzsment dönt ugyanakkor az intézmény portfoliójáról (jellemzően az új karok és képzési programok alapításáról), valamint a karok közötti redisztribúcióról. Ez utóbbi alapjául a karok teljesítménye, fejlődési potenciálja és a kar által lefedett piacok vonzereje szolgál. Ennek megfelelően intézményi szinten összpontosulnak a teljesítmények mérését és összehasonlíthatóságát biztosító elszámolási rendszerek (minőségügy, kontrolling, HR), illetve az átfogó stratégiai és kapacitástervezési rendszerek is ( $H R$, vagyongazdálkodás, IT, spin-off cégek irányítása stb.). Intézményi szintre kerülnek a jelentős standardizálást igénylő tevékenységek és - mérethatékonysági okból számos szolgáltatás is (Mintzberg [1981]; Dobák, Antal et al. [1999]) ${ }^{32}$.

Nemcsak a szervezeti egységek, hanem a különböző szereplök között is határozott munkamegosztás érvényesül. A korábbi narratívák adminisztráció-fogalma értelmét veszti, mert az akadémiai vezetés és az adminisztráció egybemosódik az „intézményi menedzsment”-ben (Clegg - McAuley [2005]), amely önálló szakmaként intézményesül a szervezeten belül. A menedzsment fő feladatának

„az akadémiai vonalat fenyegető kockázat csökkentését tekinthetjük. [...] Az egyetemi menedzsment felelös tehát egyrészt az oktatás és kutatás minőségéért, [...] másrészt [...] az egyetemi müködéshez szükséges eszközök mennyiségéért és minőségéért [...], harmadrészt az egyetem müködésére fordított pénzeszközök hatékony felhasználásáért..." (Barakonyi [2004b] 179.0., kiemelés az eredetiben).

A menedzsment tevékenysége így a környezeti függőség (kockázatok) csökkentésére, a kapacitástervezésre, a monitorozásra és szükség esetén a beavatkozásra irányul. Az oktatók feladata kizárólag az oktatás és a kutatás végrehajtása (ennek minőségéért már a menedzsmenté a felelősség), illetve az ahhoz közvetlenül kapcsolódó adminisztratív tevékenységek. Az oktatók között is elkülönülés jön létre részben az oktatás és kutatás szétválasztásával (van csak oktató és csak kutató személyzet), részben pedig az átmeneti

\footnotetext{
32 Intézményi szinten célszerủ megvalósítani az egyetem egészét érintő beruházási és szolgáltatási tevékenységeket (például ingatlangazdálkodás, IT rendszerek), és azokat a szolgáltatásokat is, amelyek ugyan kari szinten is megvalósithatóak lennének, de a központositásuk csekély minőségromlás mellett olcsóbb (például pénzügyi és számvitel, könyvtár, tanulmányi ügyintézés, hallgatói szolgáltatások). Szintén az intézményi szintre érdemes telepíteni azokat a szolgáltatásokat, amelyeket a karok csak időnként vesznek igénybe, ezért kari szintű fenntartásuk indokolatlan (például jogi ügyintézés).
} 
kapacitás-kiegyenlítés érdekében felvett óraadó oktatók, valamint a részidős és a teljes idős oktatók közötti határvonal erősödésével.

McNay szerint a vállalati modell alapvetően krízis-modell, azaz erős az centralizáltság és túlélési kényszerből elfogadott működési modell hosszú időn keresztül nem tartható fenn (McNay [1995]). Ugyanakkor a versenyhelyzet állandó hangsúlyozásával lehetséges a permanens krízis állapotának érzékeltetése, amellyel tartósan legitimálható a vállalati egyetem narratívája és működési modellje. Ebben épp a fenti munkamegosztás ad lehetőséget, mert a menedzsment kezében összpontosulnak a környezet értelmezéséhez szükséges információk. Azaz a menedzsment a komplex környezetben pufferként szolgál (Gumport - Sporn [1999]), és szüri, értelmezi, csoportosítja és az oktatók számára közvetíti a komplex környezetből érkező információkat, amelyet saját helyzetének legitimálására is fordíthat. Reed ezt a változás stratégiai narratívájának nevezi (narrative of strategic change), amelyben a változás általánosságának és elkerülhetetlenségének érzetét keltve leplezik el a hatalom újraosztási folyamatát. Ennek során a menedzsment érdekeit egyetemes szervezeti érdekként tüntetik fel (Reed [2001]; lásd még Fulton [2003]). Ezzel rá is térünk az egyetem mint vállalati narratívája kritikájára.

A kritikai szerzők különböző mélységgel és különböző ideológiai alapállásból kérdőjelezik meg a narratíva alapfeltevéseit, és mutatják be annak nem szándékolt vagy elleplezett következményeit. Érdemes megemlíteni, hogy a vállalati narratíva bizonyos jellemzők mentén hasonlóságot mutat a bürokrácia és a vállalkozás narratívával, ezért helyenként a vállalati megközelítéssel szemben megfogalmazott kritika e két megközelítésre is vonatkozik. $A z$ alábbiakban a gazdag kritikai irodalomnak csak néhány fontosabbnak vélt megállapítását mutatom be.

Amit Etzkowitz a tudás kapitalizálódásának nevez, az a kritikai nézőpontból a tudás „Személyes jellegének” (Polányi) háttérbe szorulásának és kommodifikációjának folyamata. Ahogy Lyotard fogalmaz a Posztmodern állapot címủ nagyhatású írásában:

„Ettől kezdve várható, hogy a megismerési folyamat bármely pontján helyezkedjen is el a "tudó«, a tudás teljesen külsővé válik. Egyre inkább romba döl az a régi alapelv, hogy a tudás elsajátitása elválaszthatatlan az elmének és magának a személynek a kiművelésétől (Bildung). A tudás elóállítóinak és használóinak viszonya az általuk előállított, illetve használt tudáshoz egyre inkább olyan formát ölt, mint amilyet az árutermelök és a fogyasztók viszonya az általuk termelt és fogyasztott javakhoz már magára öltött - azaz értékformát. Az ismeretek eladásra termelik ma is és a jövőben is, és azért használják fel, hogy új termelésben értékesüljön: mindkét esetben a csere a cél. A tudás célja immár nem önmaga, elveszíti »használati értékét»". (Lyotard [1993] 15.0.)

E narratívában a tudásra vonatkozó előfeltevés, hogy a tudás „atomizált, állandó, kumulatív, kontextus-független és áru-szerü (kommodifikált)" (Trowler [2001] 188.0.), a tanulás pedig ennek megfelelően a tudáselemek egymást követő megszerzésének (elsajátításának) racionális és mechanikus természetű folyamata (Trowler [2001]), amiből következik a tanulás és a tudás, azaz az egyéni és szervezeti teljesitmény mérhetőségének a tézise.

A teljesítménykritériumok meghatározásának és mérésének számos nem szándékolt következménye van. Az egyik, hogy a nem mért tényezők elveszítik jelentőségüket legyenek mégoly hasznosak is. Maga Mintzberg is kifejezetten alkalmatlannak találja a divízionális struktúrát az egyetemek irányítására: 
„Az irányítás eszközeként a teljesitmény számbavételére helyezve a hangsúlyt, egyoldalúság keletkezik a könnyen operacionalizálható divizionális célok javára, amelyek zömmel gazdaságiak, s nem társadalmiak. [...] Az üzleti szférán kívül azonban a célok gyakran társadalmi jellegűek és nem számszerüsíthetők. A teljesítményellenőrzés eredménye ekkor az, hogy a társadalmi célokat helytelen módon kiszorítják a gazdaságiak." (Mintzberg [1981] 111.0.)

Amit Mintzberg a szervezeti szintre vonatkozóan fogalmazott meg, az igaz az egyéni teljesítménymérési eljárások során is. A teljesítmény mérése mind szervezeti (pl. auditálás, akkreditáció stb.), mind egyéni szinten többnyire bürokratikus, improduktív és bizalmatlanságot keltő eljárás. Abból adódóan, hogy a mért teljesítmény alapján történik az erőforrások elosztása, mindenki érdekeltté válik a látszatteljesítmények felmutatásában, amelyet a teljesítmény mérése során le kell leplezni, ami növeli a bizalmatlanságot a szervezeten belül. Hozzájárul ehhez az is, hogy az erőforrások elosztására alkalmazott piaci logika a szervezeten belül is a versenyt helyezi a középpontba az együttmüködés helyett (ez vezetői szinten lehetővé teszi az „oszd meg és uralkodj" stratégia érvényesítését is, lásd (Chandler, Barry et al. [2002]). A mérés érdekében tett egyre nagyobb erőfeszítés azonban fordítható lenne oktatásra és kutatásra is, tehát a mérés által keltett bizalmatlanság a produktivitás csökkenéséhez vezet. Jól illusztrálják ezt a rangsorok intézményre és dékánokra gyakorolt ellentmondásos hatásai. Több empirikus elemzés is bemutatja, hogy a rangsorok miként torzítják az intézményi célrendszert, és miként kényszerítik a dékánokat a teljesítmények látszatának felmutatására, a kutatástól és oktatástól már teljesen elszakadó tevékenységek (pl. PR, marketing) erősítésére (lásd pl. Sauder - Espland [2007]; Espland - Sauder [2009]).

A látszatteljesítmények miatt nem csak az adminisztrációs, hanem az oktatási és kutatási folyamatok részletesebb szabályozása is szükségessé válik, ami az egyetemek „McDonaldizálódását”, „McUniversity”-vé válását eredményezi (Ritzer [2002]; Prichard - Willmott [1997]).

A célmeghatározás $\rightarrow$ mérés $\rightarrow$ összevetés $\rightarrow$ beavatkozás logikát a középpontba állító menedzsment-technikák alkalmazása végső soron nem tekinthető másnak, mint olyan kísérletnek, amely a taylori munkaszervezési elveket kívánja a felsőoktatásba átültetni. Ez nem csak a menedzsmentet pozícionálja át a folyamatokat a kontrollja alatt tartó vezetőkké, hanem gyökeres hatással van az oktatók helyzetére is, akik az irányitásban bekövetkező változásokat deprofesszionalizálódásként, proletarizálódásként, a menedzsmentnek történő alárendelődési folyamataként élik meg (Parker - Jary [1995]; Fulton [2003]; Reed [2001]; Prichard - Willmott [1997]; Hayes - Wynyard [2002]), amelyben az oktató az „intellektuális futószalag” melletti „tudás-munkássá” (knowledge-worker) változik. Növekszik a vezetők és nem a vezetők közötti távolság és konfliktus is, ahogy a korábbi horizontális kapcsolatokat vertikális kapcsolatok váltják fel, ami ellenállást szül.

Röviden összefoglalva: amint az egyetem a vállalkozásokat és az üzleti vállalatokat tekinti müködési példaképének, és a „globális tudáspiacba” való bekapcsolódást tűzi ki célul, nem lehet majd megkülönböztetni más vállalkozásoktól, mert a működési logikáját, érdekeit tekintve azonossá válik velük. Az egyetem mint fogalom kiüresedik, elveszíti megkülönböztető jellegét, és az oktatási és kutatás szolgáltatásokat nyújtó vállalkozás fogalmával válik szinonimmá. $A$ felsőoktatás vállalativá válása így az a folyamat, melyben - habermasi fogalmakkal - az üzletigazdasági logika „gyarmatosítja” a felsőoktatás „életvilágát”. 


\section{3. Összefoglalás és következtetések}

A narratívák áttekintését követően felmerülhet az a kérdés, hogy hogyan köthetők a felsőoktatási intézmények és a felsőoktatási rendszerek az egyes narratívákhoz, és mindez időben hogyan változik. Noha e dinamika vizsgálata fontos kérdés, erre csak az 5. fejezetben kerül majd sor. Ezt megelőzően azonban a dékánok szerepét és helyzetét szeretném tisztázni, amelyhez két, a narratívákkal kapcsolatos szembetűnő dologra szeretném felhívni a figyelmet.

Egyrészt a narratívák az egyetem igen különböző, egymást részben kizáró arcait festik meg, ám mindegyikük kimondva-kimondatlanul a tudósok közösségét tekinti viszonyítási pontnak, és ahhoz képest határozza meg magát. Ez azt jelenti, hogy a rendszerező modellnek megfelelően mindegyik értelmezés a laza döntéshozásból és a laza megvalósításból indul ki, azaz az intézmény müködésével kapcsolatban két alapkérdésre keresik a választ. Egyrészt arra, hogy hogyan lehetséges a nagy szakértelemmel és autonómiával rendelkező oktatók, azaz szakértők (professionals) körében a döntéseket megvalósítani. Másrészt arra, hogy hogyan lehetséges a célokat és érdekeket összehangolni az alapvetően a saját egyéni céljaikat követő szakértők, valamint az egyetem más érdekcsoportjai között, azaz egy rendkívül töredezett szervezetben. E vonások az egyes narratívákban különböző mértékben jutnak érvényre.

Másrészt az egyes narratívák a vezetők helyzete kapcsán vagy a legfelső vezetőre (rektorra, alkancellárra, elnökre) utalnak implicit, esetleg explicit módon, vagy pedig csak általánosságban hivatkoznak a vezetőkre. Az egyes olvasatokból tehát hiányzik a dékán lehetséges szerepére vagy szerepeire vonatkozó értelmezés, amely illeszkedik a dékán szervezeti pozíciójából eredő sajátosságokhoz. A következő fejezetben ezért erre a kérdésre koncentrálok. 


\section{A dékán szerepei a szakirodalom tükrében}

E fejezet fő fókuszát és struktúráját az a kutatási kérdés adja, amely a dékán szervezetben betöltött szerepére vonatkozik. A fejezet elsődleges célja, hogy a szakirodalom, illetve a dékán helyzetének elemzése alapján olyan lehetséges szerepeket mutassak be, amelyek az előző fejezetben megfogalmazott szervezeti narratívákhoz illeszkednek. Ehhez előbb áttekintem a dékán és a középvezető szerepével kapcsolatos irodalmat, majd részletesen elemzem az egyetem töredezettségének és szakértői jellegének a következményeit, és a dékán pozícióira gyakorolt hatását. Ezek alapján egy, az egyetem narratíváihoz illeszkedő szerepmodellt javaslok.

A fejezet másik célja a második kutatási kérdéshez kötődik, amely arra vonatkozik, hogy a dékán hogyan éli meg a saját szerepét. Ehhez kapcsolódóan olyan tipikus dilemmák, szituációk, élethelyzetek beazonosítása a cél, amelyekkel a dékánok munkájuk során szembesülhetnek, és amelyek ezért az empirikus kutatás kiinduló bázisául szolgálhatnak. $E$ jellemzők a dékáni autoritás korlátozottságához, illetve a köztes, középvezetői helyzethez kötődnek.

\subsection{A dékán szerepei a szakirodalomban és ennek kritikája}

A felsőoktatás-kutatásban, miként a menedzsment irodalomban, számos szerepmodell látott napvilágot például az intézményvezetőkre (Cote [1984]; Cote [1985]; Engwall, Levay et al. [1999]; Middlehurst [1993]; Neumann - Bensimon [1990]), az akadémiai ügyekért felelős felsővezetöre (chief academic officer, Mech [1997]) vagy a tanszékvezetőre (Middlehurst [1993]; Larsen [2003]) vonatkozóan. A dékánok szerepéről szintén több tipológia érhető el.

Wolverton és Gmech [2002] szerint a dékánok szerepei közé az erőforrásmenedzselés, a kar (belső) hatékonyságának javítása, az oktatói és kutatói állománnyal kapcsolatos HR kérdések kezelése, a vezetés (leadership), a külső és politikai kapcsolatok kezelése, valamint a saját oktatói-tudományos munka folytatása tartozik. Az egyes szerepek tartalma azonban meglehetősen különböző tevékenységeket takar. Például az erőforrások menedzselésébe beletartozik a nem oktatói személyzet irányítása, a nyilvántartások pontosságának biztosítása, a kar pénzügyi és fizikai erőforrásainak kezelése, a technikai fejlődéssel való lépéstartás és az akkreditációs irányelvekkel való összhang biztosítása. A vezetés (leadership) szerepbe a külső partnerek és alapítók tájékoztatása, a velük való együttmüködések koordinálása, a „leadership team meetingek” megtervezése és vezetése, a tanszékvezetők és a kari igazgatók feladatainak kiadása, valamint a kar fejlesztésére vonatkozó javaslatokra bátorítás tartozik.

Ehhez hasonló Maghroori és Powers [2004] alábbi öt szerepe is:

- pénz- és erőforrásszerző (provider), tehát minden lehetséges módon (vállalkozási tevékenységek kezdeményezése, fund-raising, másokkal való versengés stb.); 
- promóter (promoter), kampányol, sajtót és PR-t szervez;

- próféta (prophet), vizionáló vezetöként ösztönzi a munkatársakat;

- pandúr (police officer), aki őrködik afölött, hogy a kari munkatársak betartsák az egyetem írott és íratlan szabályait;

- politikus (politician), döntési során egyensúlyoz a különböző frakciók és érdekcsoportok között.

Krahenbuhl [2004] a dékánoknak szóló kézikönyvében még hosszabb listát ad a dékán szerepeiröl, amelyek közé az alábbiakat sorolja:

- az adminisztratív ügyek felelőse: „a kar (college) ügyeinek és annak különböző dimenzióinak felelőse, beleértve a személyi kérdéseket, a költségvetést, a képzési programokat, az ingatlan és helyiséggazdálkodást, a hallgatói ügyeket és a fejlesztést" (Krahenbuhl [2004] 20.0.);

- a fejlesztési ügyek felelőse, ami a fund-raisingért való felelősséget jelenti;

- az akadémiai ügyek felelőse: a felsőoktatási standardok és szellemiség őrzője;

- vezető mentor: ha a karon valaki hibázik, akkor a dékánnak kell diszkréten és kedvesen szóvá tenni, és elmagyarázni, hogy miért és hogyan kellett volna az adott problémát másként megoldani;

- hangulatfelelős: a dékán határozza meg a karon folyó diskurzusok hangnemét, amellyel kapcsolatban Krahenbuhl megjegyzi: „A dékánnak optimistának kell lennie a jövőt illetően annak érdekében, hogy hatásosan tudjon vezetni" (Krahenbuhl [2004] 22.0.);

- kommunikációs felelős: vízióalkotó és a kar közéletét tematizáló személy;

- ceremóniamester a kar fontos eseményein;

- fögondnok: összességében a dékáné a végső felelösség a kar ügyeit illetően, így felelőssége kiterjed „a pénzügyi, intellektuális, operatív, funkcionális, szervezeti és jogi dimenziókra";

- döntőbíró: a karon belüli konfliktusokban döntő és közvetítő személy.

Népszerü, gyakran idézett háromelemű tipizálást ad Bryan és Tucker (idézi például Wolverton, Wolverton et al. [1999]), akik szerint a dékánoknak három föbb szerepe van: békegalambként (dove) kibékítik az ellenséges csoportokat és frakciókat, diplomataként (diplomat) vezetik és bátorítják a karon dolgozó oktatókat és kutatókat, míg sárkányként (dragon) tartják távol a kartól a külső és belső veszedelmeket.

Az eddig idézett szerzők a dékán szerepeit intuitív módon határozták meg, amelyet aztán felhasználtak magyarázataikhoz vagy (kvantitatív) empirikus vizsgálataikhoz. Martin kutatóegyetemi környezetben folytatott kvalitatív vizsgálata azonban maguknak a szerepeknek a feltárására irányult (Martin [1993]). A szerző az egyetemi közösség által eredményesnek tartott dékánokról készített környezettanulmányokat, amelynek eredményeképpen öt szerepet különített el.

A kutatási ideál megtestesitőjeként és a kultúra megszemélyesitőjeként fontos, hogy a dékán valóban elkötelezett legyen a kar tudományterületéért, a kar és az egyetem ügyéért, és a személyes értékrendje egyezzen a kutatóegyetem ideáljával. 
Kommunikátorként a dékán képes megszervezni az információk megosztásának formális módjait (tanácsadó testületek, bizottságok), de emellett elég időt tölt a karon, és nem csak megosztja az információt, hanem képes meghallgatni is másokat.

Menedzserként képes a feladatok ellátását megszervezni, képes azokat delegálni, hogy több időt tudjon a kar és az egyetem tágabb, filozofikusabb kérdéseinek szentelni. Mestere a költségvetések tervezésének, és annak, hogy a kar pénzügyi helyzetét érthető módon mutassa be, a központnál pedig támogatásért lobbizzon. A dékánok a menedzser szerepben pontosan érzik, hogy meddig terjed a rájuk ruházott hatáskör, és tudják, hogy „mikor és hol kell önálló döntést hozniuk, mikor közös vagy konzultatív döntést, és mikor nem kell hozni döntést egyáltalán." (Martin [1993] 24.0.)

Tervezőként és elemzőként képes közös víziót építeni és az oda vezető utat képes felvázolni. A kar helyzetét tudja holisztikusan szemlélni, meglátja a látszólag nem összefüggő dolgok között a kapcsolatot, és jó érzékkel szét tudja választani a fontos és a kevésbé fontos tényezőket, ügyeket.

Szószólóként a dékán mások számára is láthatóvá teszi a kart. Erős kapcsolatot épít ki más karokkal, és fundraising révén külső forrásokat biztosít a kar működéséhez, fejlesztéséhez. Ezek a tevékenységek a dékán idejének legalább 50\%-át teszik ki.

Martin úgy látja, hogy a „szerepek nem statikusak, és nem forgatókönyv-szerüen müködnek, amelyet könnyen követni lehetne. Ehelyett a személyiség integráns részei, amelyek a vezetett kar értékeivel összhangban vannak." (Martin [1993] 17.o.) Emellett mind az öt szerep egyaránt fontos a jó teljesítmény elérése érdekében. Martin elemzésében egyébként feltűnő az autoriter vonások teljes hiánya. Ez megfelel annak az általános képnek, hogy a dékán meglehetősen gyenge hatalmi helyzetben van a karon. („A dékán csak javasol” - foglalja ezt össze egyetlen mondatban Gallos ([2002] 179.0.).

Az egyes szerepmodellek között jelentős átfedések tapasztalhatóak, ami azt jelenti, hogy a szerepek a dékánokkal szembeni valós (vagy legalábbis hihetö) elvárásokat takarják. Ugyanakkor figyelemreméltó különbség is található. A legtöbb modellben szerepet kap az az elvárás, hogy a dékán testesítse meg a kar ideálját, ám mindössze egy sorolta az oktatást, a kutatást és a személyes tudományos munka tényleges folytatását a dékáni szerepkészlet elemei közé. Ez azt sugallja, hogy narratíva-függő, hogy e tevékenység elvárás-e a dékánnal szemben. A dékán oktatói és vezetői szerepének kapcsolatára a későbbiekben még részletesen visszatérek.

Az eddig említett modellekkel kapcsolatban több kritika is megfogalmazható. Egyrészt érdemes tudatosítani, hogy az összes modell az USA felsőoktatási rendszerének kontextusában készült, amelyben - nagy általánosságban - az intézmények nagyobb gazdálkodási és működési önállósággal rendelkeznek, mint az európai intézmények. Az amerikai felsőoktatási rendszer alapjai régóta stabilizálódtak, és a rendszer jóval kisebb mértékủ változásokon megy keresztül, mint például a sokáig állami védettséget élvező vagy állami kontroll alatt álló európai rendszerek. Ebből egyrészt az következik, hogy az egyes modellek inkább azokat az elvárásokat tükrözik, amelyek az amerikai felsőoktatási környezetben alakultak ki.

Például ezek a szerepmodellek a dékánokat mint önálló vezetőket elemzik, és egyáltalán nem reflektálnak arra, hogy a dékán középvezetőként valamiféle köztes helyzetben van az egyetem és a kar között, tevékenysége így nem csak a kartól, hanem az egyetemi szinttől 
is függ. A megfogalmazott szerepek többsége egy rektorra vagy egy általános vezetőre is ráilleszthetőek lennének, így a „szendvics helyzet” - bár az irodalom alapján kétségkívül jelen van - mégsem érvényesül specifikusan a szerepekben.

Ennek megfelelően a szerepmodellek nem segítenek a dékáni szerepváltozásából eredő konfliktusok megértésében sem, mert nem látható, hogy az egyes szerepek között milyen belső ellentmondások húzódnak meg. Ez részben abból fakad, hogy a szerepeket nem a dékán interperszonális kapcsolatainak tükrében látjuk, azaz hiányzik a dékán szervezeti beágyazása. $A$ kontextus-érzékenység hiánya azt is megnehezíti, hogy e modelleken keresztül tanulmányozzuk a szerepek változását.

A kritikák ellenére mindenképpen hasznos e szerepmodellek áttekintése, mert ha nem is túl mély, de mégis elég átfogó képet adnak a dékán által ellátott feladatokról.

\subsection{A középvezetök szerepe a menedzsment irodalomban}

Clegg és McAuley [2005] másféle megközelítést javasol a felsőoktatási középvezetők, köztük a dékán szerepeinek megragadására. Ök az üzleti menedzsment irodalmában szereplő középvezetői-értelmezéseket vetítették ki a felsőoktatási középvezetőkre. Az üzleti irodalomban négy szerepértelmezést különítettek el, ám ebböl az egyiket kevéssé tekintették relevánsnak a felsőoktatás szempontjából. A következőkben az ő logikájuk mentén, és azt kiegészítve mutatom be a lehetséges értelmezéseket.

\subsubsection{A középvezető mint a felügyeleti rendszer része}

A 80-as éveket megelőző időszakban uralkodó nézet szerint a középvezető a felső vezetés meghosszabbított keze, akinek alapvető feladata a felsővezetői szándék kommunikálása, implementálása és megvalósítása elsősorban a belső vállalati felügyeleti rendszerek működtetése révén. $A$ középvezetés tehát nem más, mint a „szervezet kontroll-rendszerének része" (Floyd - Wooldridge [1994] 48.o.), amely felelős a stratégia megvalósításának megfelelő taktika és költségvetés kidolgozásáért, az egyéni és csoport-szintű teljesítmény monitorozásáért, valamint az elvárásoknak megfelelő magatartás kikényszerítéséért. A középvezetők tehát elsősorban „puffer” (Clegg - McAuley [2005]) vagy „relé” szerepet töltöttek be, „a gyenge, fókuszálatlan jelek emberi felerősitői" voltak (Drucker [1988] 46.o.). A döntésvégrehajtói szerep bizonyos narratívákban releváns lehet a dékán számára is, ám Clegg és McAuley ezt nem tartotta igazán releváns dékáni szerepértelmezésnek.

Felhívták ugyanakkor arra is a figyelmet, hogy a középvezetők a felügyeleti rendszer müködtetése mellett egy másik, rejtett szerepet is betöltöttek. Mivel általában az alsóbb hierarchia-szintről emelkedtek középvezetővé, ezért ők voltak a vállalati értékek, a vállalati szokások és helyismeret legfontosabb ismerői és közvetítői is. Ez felsőoktatási közegben Clegg és McAuley értelmezésében az akadémiai értékek közvetítésével azonos (Clegg - McAuley [2005]). 


\subsubsection{Az önérdekkövető és a menedzserista középvezető}

A középvezetés helyzetével, szerepével és funkciójával kapcsolatos irodalom a 80-as években futott fel igazán. A gazdasági növekedés lassulásának reflexiójaként ebben a korszakban váltak népszerűvé azok a menedzsment divatok - a decentralizáció, a lean management, az empowerment és a BPR -, amelyek a középvezetők számának radikális csökkentését irányozták elő. Peter Drucker egyik jövőt felvázoló cikkében egyenesen azt írja, hogy „a nagy és sikeres információ-alapú szervezetekben egyáltalán nincs középvezetés" (Drucker [1988] 48.0.). E törekvés mögött az a meggyőződés állt, amely - megfordítva az előző időszak érvrendszerét - a középvezetőket nem a vállalati értékrend képviselöiként, hanem alapvetően konzervatív, a szokásokhoz mereven ragaszkodó és a gyors, rugalmas cselekvést gátló szereplőkként ábrázolta, akik a pozíciójukból és technikai szakértelmükből fakadó információs előnyüket a saját egyéni helyzetük védelmezésére és erősitésére fordítják. Mintzberg például a középvezetők alapvető vonásának balkanizációs - hatalommegosztási, nagy autonómiával rendelkező egységekre osztó - hajlamukat nevezte (Mintzberg [1981]). E gondolkodás kialakulásához számos tényező járult hozzá.

A 80-as évek gazdasági lassulása a szervezetek növekedését is lassította, ami a sok hierarchiaszinttel rendelkező szervezetekben a karrierpályák bedugulását eredményezte. A válsággal (és a fogyasztói orientáció erősödésével) újult erőre kapott a divízionális jellegü szervezetek térnyerése, amelyek elsősorban generalista szemléletü középvezetőket kerestek. Mindez erodálta a funkcionális területen müködő középvezetők korábban technikai szakértelemre épülő identitását. Végül a középvezetés leépítése mellett szóló érvként hangzott el nagyon gyakran, hogy a középvezetés operatív felügyeleti és adatszolgáltatási funkcióját könnyen be lehet majd tölteni a korszerü IT megoldások alkalmazásával, amelyek segítségével a felső vezetés irányítási feszttávja és felügyeleti ereje is jelentősen növelhetö. $E$ trendek és az ezek nyomán bekövetkező leépítések csökkentették a középvezetők motivációját, ami megerősítette a kiindulásul szolgáló meggyőződést (Dopson - Stewart [1990], Dopson - Stewart [1994], Dopson, Risk et al. [1990]).

Slaughter és Leslie Academic Capitalism című könyvükben felvetik annak lehetőségét, hogy az erőforrások csökkenése miatt a középvezetői pozíciók idővel marginalizálódnak a nagy kutatóegyetemeknél, ám később a dékánok egyre erősödő szerepét látva elvetik ennek realitását (Slaughter - Leslie [1997] 231-232.0.). Clegg és McAuley sem tartotta a bővülő felsőoktatás szempontjából relevásnak a középvezetők számának csökkenésére vonatkozó trendet (Clegg McAuley [2005]). Noha empirikus adatok nem állnak rendelkezésre, mindkét szerzőpárosnak igaza lehet abban, hogy a középvezetők száma a felsőoktatásban nem csökkent. Ezen az alapon azonban - úgy vélem - nem lehet az „önérdekkövető vezető” szerepértelmezést kizárni a felsőoktatásban is érvényes lehetőségek közül. A későbbiekben erre még visszatérek.

A leépítési („donwsizing”) és a vezetési szintek számát csökkentő („delayering”) mozgalom nemcsak a felsőoktatásban nem következett be, de az üzleti szférában is kisebb volt a hatása, mint azt sokan láttatták. Ennek ellenére mégis jelentős mértékben átalakította a középvezetést, mert noha a középvezetök száma csak kevéssel csökkent, hatáskörük és felelősségük - összhangban az ekkor felfutó empowerment és job-enrichment mozgalmakkal jelentős mértékben bővült (Dopson - Stewart [1990], Dopson - Stewart [1994], Dopson, Risk et al. [1990]). Ez a bővülés a munkájuk jellegét is jelentősen átrendezte: csökkent a technikai 
szakértelmet igénylő operatív felügyelet szerepe (amely a közvetlen felügyelök hatáskörébe került át), nőtt ugyanakkor generalista szemléletet igénylő, a szervezeti egység egészének teljesítményéért való felelősség (beleértve például a szervezeti egység munkáltatói és pénzügyi jogositványainak gyakorlását is) (Hales [2006]). Ezzel az átrendezéssel együtt ugyanakkor a munkaterhelés is jelentős mértékben megnőtt. Vouzas, Burgoyne és Livian (1997) (idézi Thomas - Dunkerley [1999] 158.o.) erre utalva a 80-as évek menedzsment-hullámait egyszerűen a „munkaintenzitás növelésének retorikai igazolásának” nevezte.

Clegg és McAuley e generalista középvezetői réteget a menedzserista ethosz felsőoktatási megnyilvánulásaként interpretálta (Clegg - McAuley [2005]), amelyben a középvezetők olyan „szervezeti bürokraták” (corporates bureaucrats), akik a szakmai-irányítási feladatok helyett a tervezési, müködtetési, ellenőrzési és végrehajtási folyamatokban működnek közre.

\subsubsection{A középvezető mint a szervezeti bölcsesség közvetítője}

A 90-es évek elején a megelőző időszak ellenhullámaként kibontakozó irányzat kiindulópontjai azok az empirikus kutatások voltak, amelyek azt igyekeztek igazolni, hogy az információtechnológia térnyerése nem váltotta ki a középvezetők szerepét, mert a felsővezetők már csak a piaci változékonyság miatt sem akarnak, illetve tudnak operatív kontrollt gyakorolni. Sőt, az információ-technológia térnyerése újabb, speciális szakértelemmel rendelkező szereplőket emel fontos szervezeti pozícióba. Ez a szervezet belső komplexitását növelte tovább.

Így a középvezetők operatív felügyeleti szerepének és technikai specializációjának csökkenéséből nem a középvezetői szint megszűnésére, hanem a középvezetés tartalmának átalakulására, azaz stratégiai szerepük erősödésére következtettek. Mindez nagyon letisztult módon jelent meg Floyd és Wooldridge írásaiban, akik modelljükkel (5. ábra) számos, a középvezetők stratégiaalkotásban játszott szerepét vizsgáló kutatást inspiráltak (lásd például Floyd - Wooldridge [1994]; Floyd - Lane [2000]; Floyd - Wooldridge [1992]; Mantere [2008]; Westley [1990]; Currie [1999]; Currie [2000]; Currie - Procter [2005]).

5. táblázat: A középvezetők stratégiához kapcsolódó szerepei

\begin{tabular}{|l|l|c|c|}
\hline \multicolumn{2}{|l|}{} & \multicolumn{2}{c|}{ Magatartási tevékenység } \\
\cline { 3 - 4 } & \multirow{2}{*}{$\begin{array}{l}\text { Kognitív } \\
\text { befolyás }\end{array}$} & Felfelé gyakorolt befolyás & Lefelé gyakorolt befolyás \\
\cline { 2 - 4 } & Integráló & $\begin{array}{c}\text { Stratégiai alternatívák } \\
\text { képviselete }\end{array}$ & $\begin{array}{c}\text { Alkalmazkodóképesség } \\
\text { támogatása }\end{array}$ \\
\hline
\end{tabular}

Forrás: Floyd - Wooldridge [1994] 50.0.

Floyd és Wooldridge [1994] a korábbi évek torzító középvezetői értelmezésével vitába szállva úgy érveltek, hogy amikor a középvezetők a felső vezetői elképzeléseket figyelmen kívül hagyják, azt nem a felső vezetőkkel szemben teszik, hanem éppenséggel értük. A középvezető ugyanis sokkal inkább tisztában van a helyi viszonyokkal, mint a stratégiát kitaláló felső vezető, 
ami ugyan eredményezheti az implementálás során az attól való eltérést, ugyanakkor megvalósíthatóságát is javítja.

Leegyszerüsítésnek vélték azt a megközelítést is, hogy a középvezetők szerepe kizárólag a központi érdekek helyi megvalósítására (implementáció) vagy a központi döntéshozáshoz szükséges helyi információk összegyüjtésére, szintetizálására és továbbítására korlátozódik. A középvezetők szerepe tehát nem csak a már kialakított gondolkodási kereteken belül képzelhető el, hanem sikerrel képviselhetnek olyan stratégiai alternatívákat is, amelyek lehetőségeire helyismeret hiányában a felső vezetés nem gondolhat. A középvezető ezáltal a stratégia alakításának aktív szereplője, akinek helyismerete segíthet abban, hogy a központi stratégiát - annak „szellemét” szem előtt tartva - a helyi viszonyokra adaptálja (rugalmas alkalmazkodás), és így a változás ellenzőjéből (change resister) éppen változásvezetővé (change master) váljon.

A középvezetök helyi kezdeményezései növelik a szervezeten belüli variációk számát, ami kifejezetten elönyös lehet egy kiismerhetetlenül változó dinamikus környezetben. A középvezetők végső soron olyan „vállalati vállalkozók” (corporate entrepreneurials), akik központi szerepet töltenek be a vállalat stratégiai megújulásában, az új szervezeti kompetenciák és készségek elsajátításában.

A szervezeti bölcsesség közvetítőjének szerepét Clegg és McAuley teljes mértékben relevánsnak vélte a felsőoktatási környezetben is. Olyan „mesteremberként” definiálják a középvezetőt, aki a szakmai és a menedzsment ismereteket egyszerre birtokolja. Kulcskérdésük, hogy a szakmai hálózatok kiváló ismerete és a humanisztikus gondolkodásmód, amely e megközelítés része, vajon lehetővé teszi-e a felsőoktatás kevésbé konfrontatív átalakítását (Clegg - McAuley [2005]). Hasonló gondolatokat fogalmazott meg Kallenberg [2007] is. (A középvezetés üzleti menedzsment alkalmazott megközelítéseit a 6. táblázat tartalmazza.)

\section{6. táblázat: A középvezetők szerepértelmezésének átalakulása a menedzsment irodalomban}

\begin{tabular}{|c|c|c|c|}
\hline & 70-es évek & 80-as évek & 90-es évek \\
\hline $\begin{array}{l}\text { Az üzleti középvezetés } \\
\text { jellemzői és szerepük } \\
\text { értelmezése }\end{array}$ & $\begin{array}{l}\text { Operatív szerep: implementáló } \\
\text { A szervezeti értékek képviselete } \\
\text { Funkcionális szakértelem } \\
\text { Átmeneti pozíció a felsővezetői } \\
\text { poszt felé } \\
\text { Puffer szerep }\end{array}$ & $\begin{array}{l}\text { Önérdekkövető } \\
\text { Balkanizáló }\end{array}$ & $\begin{array}{l}\text { Stratégiai szerep } \\
\text { Vállalati vállalkozó } \\
\text { és innovátor }\end{array}$ \\
\hline $\begin{array}{l}\text { Uralkodó menedzsment- } \\
\text { divatok }\end{array}$ & $\begin{array}{l}\text { Rendszerelmélet } \\
\text { Kontingencia-elmélet } \\
\text { Divizionális és mátrix szervezet }\end{array}$ & $\begin{array}{l}\text { Empowerment } \\
\text { Lean management } \\
\text { TQM } \\
\text { BPR }\end{array}$ & Szervezeti tanulás \\
\hline $\begin{array}{l}\text { A középvezetéssel } \\
\text { foglalkozó menedzsment } \\
\text { irodalom által vizsgált } \\
\text { kiemelt problémák }\end{array}$ & Szerepkonfliktus & $\begin{array}{l}\text { Empowerment és elbocsátások } \\
\text { összehangolása } \\
\text { Leépítése kezelése } \\
\text { Túlélő szindróma kezelése }\end{array}$ & $\begin{array}{l}\text { Stratégiaalkotásba } \\
\text { való bevonás } \\
\text { Szerepkonfliktus } \\
\text { Identitáskonfliktus }\end{array}$ \\
\hline $\begin{array}{l}\text { Társadalmi-gazdasági } \\
\text { kontextus }\end{array}$ & $\begin{array}{l}\text { Gazdasági növekedés } \\
\text { Sok hierarchia-szinttel } \\
\text { rendelkező (funkcionális) } \\
\text { szervezetek }\end{array}$ & $\begin{array}{l}\text { Lassuló növekedés } \\
\text { Demográfiai ciklus csúcspontja (?) } \\
\text { Divizionális szervezetek térnyerése } \\
\text { Erősödő fogyasztó-orientáció } \\
\text { IT térnyerése }\end{array}$ & $\begin{array}{l}\text { Gazdasági } \\
\text { növekedés }\end{array}$ \\
\hline $\begin{array}{l}\text { A felsőoktatási } \\
\text { középvezetők lehetséges } \\
\text { értelmezése }\end{array}$ & $\begin{array}{l}\text { Az akadémiai értékek } \\
\text { képviselete }\end{array}$ & Menedzserista középvezető & $\begin{array}{l}\text { Mesterember } \\
\text { (master } \\
\text { craftsmen) }\end{array}$ \\
\hline
\end{tabular}




\subsection{A dékán helyzetének elemzése}

A dékán lehetséges szerepeinek bemutatásához először a narratívákat rendező dimenziókat, és az általuk felvetett kérdéseket értelmezem a dékán szintjén. A cél olyan dilemmák, élethelyzetek megragadása, amelyek az empirikus kutatásban is vizsgálható témákat vetnek fel, és amelyek mentén az egyetem különböző narratíváiba illeszkedő szerepek is meghatározhatóak.

\subsubsection{A dékán mint középvezető}

Az első rendező dimenzió a célok egyeztetésének, közössé tételének lehetőségére, kívánatosságára vonatkozik, amely az egyetem töredezettsége miatt lehet a narratívákat meghatározó dimenzió. Már Merton utal arra, hogy egy adott szerephez tartozó szereppartnerek eltérő érdekekkel és értékekkel rendelkeznek, eltérő elvárásokat fogalmaznak meg, éppen azért mert a társadalmi vagy szervezeti struktúrában eltérő helyzetben, pozícióban vannak (Merton [1968/2002]). Minél töredezettebb a szervezet, annál szövevényesebb az az elvárásrendszer, amelyben a dékánnak utat kell találnia. A dékán jellemző partnereit mutatja a 4. ábra. Természetesen az interakciók a különböző partnerekkel nem egyforma intenzitásúak és gyakoriságúak, vannak a dékán szempontjából meghatározóbb partnerek, akik a dékán szerepét elvárásaikkal jobban formálják, mások kevésbé.

\section{4. ábra: A dékán partnerei}

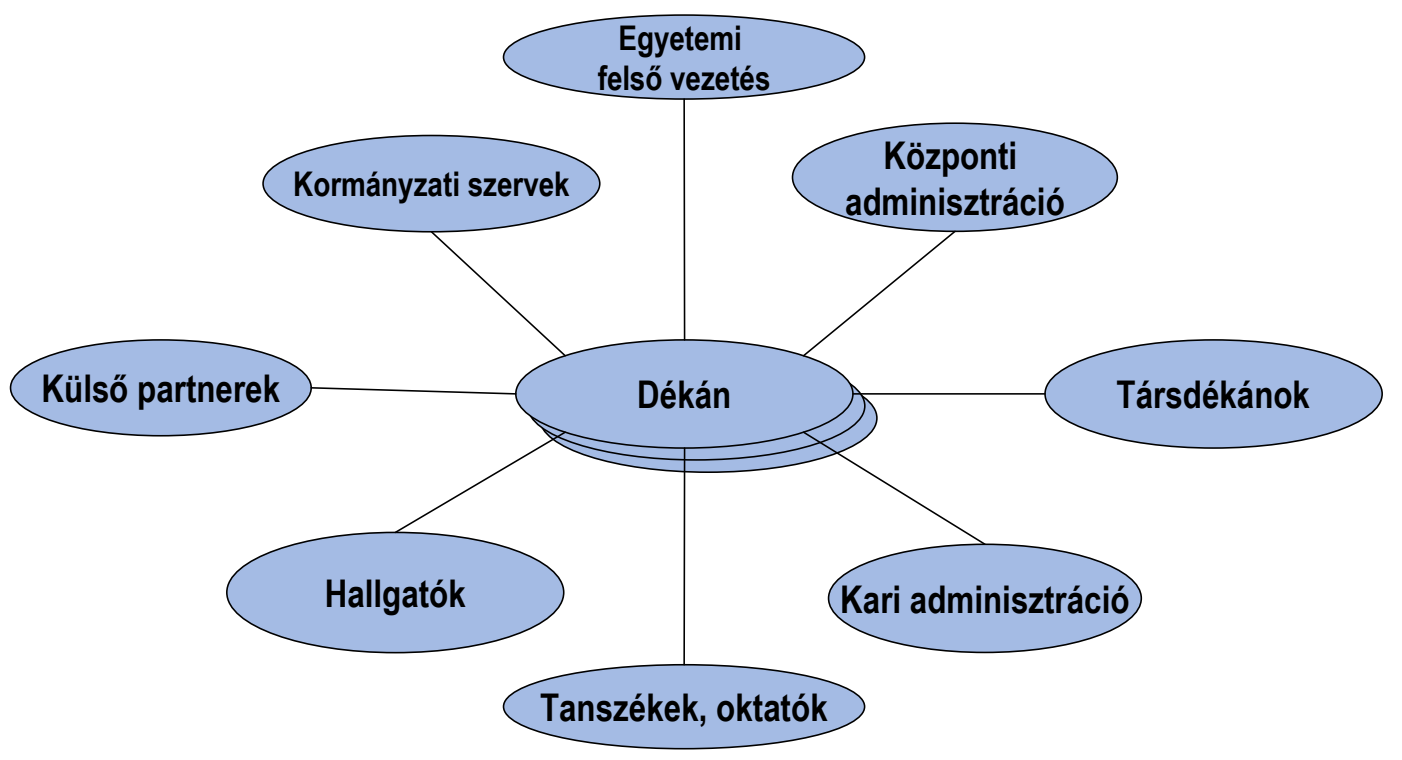

A dékáni pozíció egyik sajátossága talán éppen az, hogy az érdemi partnereinek száma nagyon magas. Középvezetőként a dékán legszorosabb partnerei közé - úgy vélem - a tanszékvezetők, az oktatók és a kari adminisztráció, illetve az egyetemi akadémiai és adminisztrációs felső vezetés tartozik (Jackson [2003]). Ők azok, akik a leginkább formálják a dékán szerepének tartalmát. 
A 7. táblázat a tanszékvezetők és az akadémiai felső vezetés pozíciójának néhány lényeges különbségét foglalja össze, és illusztrálja, hogy a dékán mint középvezető átmeneti helyzetekkel szembesül.

\section{7. táblázat: A középvezető átmeneti helyzete}

\begin{tabular}{|l|l|l|l|}
\hline & $\begin{array}{c}\text { Tanszék- és } \\
\text { intézetvezetők } \\
\text { (Operatív vezetés) }\end{array}$ & $\begin{array}{c}\text { Dékán, } \\
\text { dékánhelyettesek } \\
\text { (Középvezetés) }\end{array}$ & $\begin{array}{c}\text { Rektor, } \\
\text { rektorhelyettesek } \\
\text { (Felső vezetés) }\end{array}$ \\
\hline $\begin{array}{l}\text { Az alárendeltek készségeinek, } \\
\text { státuszának homogenitása, az } \\
\text { irányított szervezeti egység(ek) } \\
\text { integritása }\end{array}$ & $\begin{array}{l}\text { Nagy homogenitás, } \\
\text { magas integritás }\end{array}$ & $\begin{array}{l}\text { Alacsony } \\
\text { homogenitás, } \\
\text { alacsony integritás }\end{array}$ \\
\hline $\begin{array}{l}\text { Az irányítása alá tartozó } \\
\text { tudományterület(ek)ben való } \\
\text { jártassága }\end{array}$ & $\begin{array}{l}\text { Magas szakértelem, } \\
\text { specialista }\end{array}$ & $\begin{array}{l}\text { Korlátozott, } \\
\text { generalista }\end{array}$ \\
\hline Operatív/stratégiai orientáció & $\begin{array}{l}\text { Operatív müködés } \\
\text { Tanszékhez tartozó } \\
\text { szak, tárgy, oktatás } \\
\text { megszervezése és } \\
\text { menedzselése, } \\
\text { a tanszéki kollégák } \\
\text { menedzselése }\end{array}$ & $\begin{array}{l}\text { Az egyetem } \\
\text { finanszírozási } \\
\text { pozícióinak, képzési } \\
\text { portfóliójának } \\
\text { menedzselése, } \\
\text { vagyongazdálkodás, } \\
\text { infrastruktúra kezelés }\end{array}$ \\
\hline $\begin{array}{l}\text { Gondolkodási spektrum és } \\
\text { időtáv }\end{array}$ & $\begin{array}{l}\text { Rövid táv (féléves- } \\
\text { éves) } \\
\text { Parciális szemlélet }\end{array}$ & $\begin{array}{l}\text { Belső müködési } \\
\text { orientáció }\end{array}$ & $\begin{array}{l}\text { Hosszú táv } \\
\text { Globális szemlélet }\end{array}$ \\
\hline Külső/belső orientáció & Jelentős, face-to-face & $\begin{array}{l}\text { Külső kapcsolati } \\
\text { orientáció }\end{array}$ \\
\hline $\begin{array}{l}\text { Oktatókkal, hallgatókkal való } \\
\text { interakció gyakorisága, formája }\end{array}$ & $\begin{array}{l}\text { Alacsony intenzitású, } \\
\text { esetleges, gyakran } \\
\text { formális }\end{array}$ \\
\hline
\end{tabular}

A pozíciók különbségéből adódik, hogy a tanszékvezetők és az egyetemi vezetők egy időben eltérő elvárásokat fogalmaznak meg a dékánnal szemben, azaz szerepkonfliktus áll elő. Gallos szerint például a karon többnyire a minimális beavatkozás, a maximális támogatás, az autonómia és a sokszínűség tiszteletben tartása, az informális és nem-hierarchikus kapcsolat az elvárás egy dékánnal szemben. Az egyetemi szintről nézve azonban a megítélés fő szempontja, hogy milyen mértékben képes a kar megfelelni a minőség, a kiegyensúlyozott költségvetés, a külső támogatás nagysága, a kreativitás, a produktivitás és az együttmüködési hajlandóság szempontjainak (Gallos [2002]). Míg a kar oktatói és dolgozói többnyire a kari érdekek egyetemi szintü képviseletét várják el a dékántól, addig az egyetemi vezetők az egyetemi érdekek kari érvényesítését kérik számon.

Az eltérő (ellentétes) elvárásoknak való megfelelési kényszert hol dékáni „présnek” (Gallos [2002]), hol „szendvics-helyzetnek” nevezik (Baldridge [1971]). Mások szerint a dékán olyan „Janus arcú vezető” (Gmelch [2003]), aki „egyszerre szolgál két mesternek” (Rosser, Johnsrud et al. [2003]; Wolverton, Gmelch et al. [2001]). Huy megfogalmazásában pedig a középvezetők „kötéltáncosok”, akik különböző érdekek között egyensúlyozva próbálják meg megteremteni a kontinuitást a változás és a stabilitás között (Huy [2001]).

A dékán nem csak a kar-egyetem viszonylatban áll középen, de határszerepet (boundary spanning position) tölt be a külső partnerek (cégek, hatóságok stb.) és a kar 
kapcsolatában is, akik többnyire kevéssé értik az egyetem sajátos belső viszonyait, és a dékánt olyan vezetőnek tekintik, aki a pozíciójából fakadóan rendelkezik azzal az autoritással, amellyel szavatolhatja a megállapodások betartását. A dékánnak tehát egyszerre kell tiszteletben tartania a kari oktatók autonómia-igényét és a „megrendelő” elvárásait az ügyeik gyors, pontos és zökkenőmentes intézésével kapcsolatban. Az előbbiek megsértésével a belső konfliktusokat kockáztatja, az utóbbiakkal viszont azt, hogy alkalmatlan és gyenge vezetőnek tünik (Gallos [2002]).

Az ellentétes elvárások nem csak időben eltolódva, hanem sokszor egyidejüleg is jelentkeznek. Például egy tanácskozáson egyszerre vannak jelen a hallgatók, az oktatók és felső vezetők, hozzájuk a dékán mind egyszerre szól. Sokszor nem csak azzal kell óvatosnak lennie tehát, hogy mit mond, hanem azzal, is, hogy azt milyen közegben mondja.

A határszerep a belöle fakadó konfliktusok miatt hathat bénítólag a dékánra, különösen ha ezt a formális döntési lehetőségek relatív gyengeségének fényében mérlegeljük. Érdemes azonban azt is észrevenni, hogy a dékáni pozíciónak megvannak a maga erényei is, amelyek pontosan ugyanabból fakadnak, amiből a nehézségek. Éppen középvezetői helyzeténél fogva a dékán olyan, mint a „játékos edző” (Uyterhoeven [1989/1972]). Az egyetemi felső vezetéssel szemben még testközelből ismerheti a kar mindennapjait, részt vesz annak operatív működtetésében, de - ellentétben a tanszéki vezetéssel - már rálátása és ráhatása van a hosszú távú, egyetem-stratégiai ügyekre is (Martin [1993]). Ebből adódóan a dékán olyan információs helyzetben van, amely az egyetemi stratégia kialakításában és megvalósításában, sőt, a stratégiáról való gondolkodási keretek formálásban is fontos szerepet biztosithat neki (Floyd Wooldridge [1994]). Másrészt persze ez a szituáció ismét csak ellentétes elvárások közé feszíti a dékánt, például érzékenynek kell lennie az egyedi problémákra, de mindennek a rendszerszintű következményeivel is tisztában kell lennie. Vagy: támogatnia és ösztönöznie kell a kreativitást, az egyéni törekvéseket, de a kar integritását is meg kell őriznie.A kar belső és külső világa közötti közvetítés „kétnyelvűséget” igényel (Uyterhoeven [1989/1972]), azt a képességet, hogy a dékán egyformán jól mozogjon az egyetemi szint bürokratikus, adminisztratív (politikus?) kultúrájában és a kar szakmai-tudományos kultúrájában is. A kétnyelvűség szükségessége még egyértelműbb azokban a helyzetekben, amikor a dékán a kar, valamint az akadémiai kultúrától idegenebb szereplők (külső megrendelők, adminisztráció) között tolmácsol (English [1997]). Mindez persze azt is szükségessé teszi, hogy - figyelembe véve a dékánok fragmentált napirendjét - tudjon gyorsan váltani a szerepkészletének elemei és a különböző relációk sajátos nyelvi játékai között (az egyik pillanatban még felettesként beszél, néhány perccel később már alárendelt helyzetben van stb.).

Az eddigiekben olyan helyzeteket vázoltam fel, amikor a dékán két különböző szereplő ellentétes elvárásaival szembesült. Érdemes azonban megemlíteni, hogy a szerepkonfliktusnak előfordulhatnak olyan, első látásra talán meglepő esetei is, amikor ugyanazon személy fogalmaz meg ellentétes elvárásokat a dékánnal szemben. Ennek többféle oka is lehet.

Az egyik okot jól szemlélteti egy tanszékvezető megnyilatkozása, aki egy amerikai egyetemen folytatott kutatásban vett részt: „Időnként azt szeretném, ha a dékán valóban vezetne. A dékán számára viszont ez egy 22-es csapdája. Ha a dékán valóban irányít, akkor ellenállásba fog ütközni. Ha nem, akkor az emberek azt szeretnék, bárcsak irányítana. Nem tudom, megoldhatja-e bárki ezt a helyzetet." (idézi McCarty - Reyes [1985] 15.0.) Gallos is azt 
hangsúlyozza, hogy a karon dolgozó oktatók, kutatók és tanszékvezetők gyakran egyszerre érdekeltek az erőskezű és a gyengekezü dékánban (Gallos [2002] 180.0.).

Egy másik lehetséges ok az egyetemnek arra a sajátosságára vezethető vissza, hogy egy-egy személy a szervezeten belül egyszerre több különböző pozícióban is lehet. Ezekből esetenként más-más elvárást fogalmaz meg, és az ellentmondásnak ő maga sincsen feltétlenül tudatában. Ugyanilyen konfliktushoz vezet az is, amikor a hivatalos és az informális elvárások egymással szembekerülnek (Turner [2001]).

\subsubsection{A dékáni autoritás határai}

A narratívákat rendező modell másik dimenziója a megvalósítás kontrolljára vonatkozott, amely azt a kérdést veti fel a dékánok számára, hogy hogyan lehetséges egy szakértői szervezetben a döntések megvalósulását biztosítani és a teljesülésüket ellenőrizni (függetlenül attól, hogy a döntéseket egy testület, egy felettes vagy maga a dékán hozta). Milyen eszközei és lehetőségei vannak a dékánnak ehhez, és milyen dilemmákkal, nehézségekkel szembesül a döntések megvalósítása során? Végső soron mi a dékán autoritásának alapja?

$\mathrm{Az}$ alábbiakban az autoritás három forrását vizsgálom meg: a szakértelmet, a kulcsfontosságú erőforrások kontrollját és ehhez kötődően a büntetés és jutalmazás lehetőségét, illetve a bizonytalanságnak és az információknak a kontrollját (lásd még Bakacsi [1999]).

A dékán szakértelme meghatározó szerepet játszik abban, hogy képes-e megítélni a döntések mögött meghúzódó oktatási-pedagógiai és kutatási-tudománypolitikai érveket, azok valódiságát, súlyát és következményét. Az oktatás és kutatás azonban nagy komplexitású feladat, és a felsőoktatási intézmény szervezeti hierarchiájában felfelé haladva fokozatosan csökken a vezető alá rendelt oktatók és kutatók szakértelmének homogenitása, így a vezető jártassága is csökken az irányítása alá tartozó tudományterületekben. Bár a karon folyó tevékenységek minőségéért többnyire formálisan a dékán a felelős, tényleges kontrollt tartalmi kérdésekben már csak korlátozottan gyakorolhat. Elég csak arra gondolni, hogy milyen nehézséget jelent az, ha egy vezetőnek bizonyítania kell egy oktató vagy kutató alkalmatlanságát.

A dékán tehát jellemzően generalista vezető, azaz olyan területek felügyeletéért és összehangolásáért felelős, amelyekhez kevésbé ért, mint a hozzá tartozó specialisták. Minél inkább heterogén az irányított kar, a dékán annál inkább rászorul a döntéshozáshoz szükséges információkban az adott terület belső és külső szakértőire (például professzorokra) és a tanszékvezetőkre, noha formálisan az irányítási hierarchiában felettük áll. Természetesen a kar mérete és tudományterületi homogenitása, a tudományterület konszenzusossága és a specializálódás foka is befolyásolja, hogy a dékán tudományterületi jártassága milyen mértékü szakmai felügyeletet tesz egyáltalán lehetővé, azaz a generalista jelleg mértékét. 33

\footnotetext{
${ }^{33}$ Más nézőpontból nézve azonban a dékán generalista megítélése megfordulhat. Mert míg a karon belülről nézve a dékán pusztán a tudományterület egy részéhez (jól) értő, adminisztratív feladatokat ellátó személy, akinek ereje így a kar jóakaratán (is) múlik, addig felülről (és kívülröl) nézve a dékán az adott tudományterület egészének specialistája és képviselője, akinek szakértelmét, autoritását a betöltött pozíciója erősíti meg (Gallos [2002]; Jackson [2003]).
} 
A belső szakértőkre és tanszékvezetőkre való támaszkodást az oktatás és kutatás alapvetően individualista jellege is indokolttá teszi, mert többnyire nem csak a dékán hozzáértése korlátozott, hanem a kar széttagolt tevékenységének felügyeletéhez szükséges erőforrások is hiányoznak. Az oktatás és kutatás komplex volta megnehezíti, hogy e tevékenysége néhány mérőszám segítségével mechanikus módon megragadhatóak legyenek. Kreatív technikákkal és felügyeleti rendszerekkel persze lehet ezen változtatni. Például nem kell az oktatókat ténylegesen ellenőrizni, elég az ellenőrzés reális lehetőségét fenntartani. Ha például minden előadást rögzítenek abból a célból, hogy az a diákok és a szélesebb közvélemény számára később is hozzáférhető legyen (az egyetemi előadások végső soron nyitottak), az megszünteti az előadás egyszeriségét, mert magában hordozza annak a lehetőségét, hogy azt később bárki (beleértve a kollégákat, pályatársakat, vezetőket, akkreditációs képviselőket) visszanézze. Ebben az esetben tehát a nyilvánosság, az ellenőrzés és a szankcionálhatóság lehetősége vezet növekvő (ön)kontrollhoz.

A dékán generalista szerepe a saját pénzügyi-gazdálkodási vagy informatikai apparátusával szemben is fennállhat. A dékán ugyanis - hacsak maga nem rendelkezik ilyen jellegü szakértelemmel - nemcsak felügyelője/irányítója, hanem kiszolgáltatottja is a saját adminisztrációjának, amelyre gazdasági vagy informatikai kérdésekben hagyatkoznia kell. ${ }^{34}$ Különösen így van ez akkor, ha az adminisztráció állandó, a dékán pedig időre-időre cserélődik (például mást neveznek vagy választanak ki). llyenkor az ügyek egy részének folytonosságát az adminisztráció biztosítja. (A kiszolgáltatottságot, az adminisztráció uralmát persze jelentősen befolyásolja, hogy a dékán milyen hosszú időt tölthet el a pozícióban.)

A dékán pozícióját meghatározza, hogy az oktatók és kutatók szakértői tudása diszciplínánként különböző mértékben - átváltható gazdasági, kapcsolati vagy társadalmi tőkévé (privát tanácsadás, vállalatvezetés, szerkesztőbizottsági tagság, kormányzati felelősség). Sok esetben a valódi, naprakész ismeret feltételezi, hogy az oktató vagy kutató megfelelő kapcsolatrendszerrel rendelkezzen (például beágyazódjon a megfelelő szakmai közösségbe).

Ennek két következménye van: egyrészt az oktatók és kutatók alkupozíciója erősödik az intézménnyel szemben, és csökken az intézménytől való közvetlen függésük, hiszen például jövedelmük jelentős részéhez az intézményen kívüli forrásokból juthatnak hozzá35. Így a dékán az erőforrások kontrollján (jutalmazáson, büntetésen) keresztül csak akkor tud befolyást gyakorolni a döntések megvalósulására, ha azok olyan erőforrások (például drága kutatási eszközpark), amelyekhez az oktatók másként nem tudnak hozzáférni. Ez természetesen diszciplináris adottság kérdése is.

Másrészt az oktatók olyan, az egyetem vagy kar számára is kritikus erőforrásokhoz férnek hozzá, amelyek jelentősen megnövelik az intézményen belüli érdekérvényesítő képességüket (Pfeffer - Salancik [1974]). Az ilyen oktatók a kar arculatát, müködését és lehetőségeit alapvetően meghatározó „primadonnákká” (Bakacsi [2008]), „sztárokká” válnak, akik

\footnotetext{
${ }^{34}$ Ez ma a magyar felsőoktatásban egyébként sürün megfigyelhető jelenség magasabb hierarchiaszinteken, például a rektor-gazdasági föigazgató viszonyában is.

35 Nagy Péter Tibor 1997-es jövedelmi adatokat elemezve megállapítja, hogy átlagosan az oktatók összes jövedelmüknek $76 \%$-a a föállásuk után járó bérjövedelem, 24\%-a pedig kiegészitő jövedelem. Ugyanakkor nagyok a szórások: MTA tagként, társadalomtudományi vagy müszaki területen dolgozóként a kiegészítő források aránya lényegesen nagyobb (Nagy [2003] 213-215.0.).
} 
a dékántól kiemelt figyelmet vagy szabadságot igényelnek. Például az akkreditációhoz szükséges egyetemi és MTA kvalifikációk birtokosaként, a hallgatóságot vonzó híres előadóként, vagy egyegy nagyobb vállalat befolyásos igazgatótanácsi tagjaként az intézményen belül komolyabb formális pozíciók nélkül is olyan befolyásra lehet szert tenni, amely meghaladja a szervezeti hierarchiában egyébként feljebb álló vezetők érdekérvényesitő képességét. Ez az érdekérvényesítő képesség felhasználható a formális egyetemi pozíciók megszerzésére is, de ez nem szükségszerü.

A kulcsszerepet játszó erőforrásokat ugyanakkor maga a dékán is biztosithatja a kar számára. Így a számos szerző által említett forrásszerző, network-építő szerep (Wolverton Gmelch [2002]; Krahenbuhl [2004]; Maghroori - Powers [2004]) a dékánnak nem csak a feladatát, hanem egyben a karon belüli érdekérvényesitő képességének alapját is jelenti.

A tartalmi felügyeletnél és az erőforrások kontrolljánál közvetettebb irányítást tesz lehetővé az információk és a bizonytalanság kontrollja. Minél komplexebbnek érzékelik az oktatók az intézmények külső környezetét és belső működését, annál erősebb bennük a bizonytalanságérzés, hiszen a felsőoktatásban végbemenő folyamatok átlátása, megértése egyre nehezebb, egyre több időt és egyre nagyobb erőfeszítést kíván. A dékán - egyfajta „pufferként” (Gumport Sporn [1999]) - jelentős szerepet játszhat a bizonytalanság csökkentésében azáltal, hogy narratívákat, értelmezési kereteket nyújt, amelyek a komplex valóság leegyszerűsitése és magyarázása révén segítik az oktatókat az eligazodásban (Gioia - Chittipeddi [1991]). Ezzel a cselekvésük iránya is befolyásolható. $A$ bizonytalanság kontrollja részben a dékán személyes adottságain - meggyőzőerején, karizmáján, hitelességén -, részben pedig az oktatók és a dékán között információs aszimmetria nagyságán múlik.

Ez utóbbit számos tényező befolyásolja. Így például az, hogy az oktatók mennyire beágyazottak más külső (szakmai és szakmapolitikai) közösségekbe, ahonnan számos a tudományterület, vagy az intézmény szempontjából releváns információhoz férnek hozzá. Ahol ez a beágyazottság mély, ott ez egyszerre segíti a kart abban, hogy a kritikus információkhoz időben hozzájusson, ugyanakkor egyben gyengíti is a dékán információs előnyét.

Fontos szerepet játszik a felsőoktatáson belüli mobilitás is. Ha ez alacsony, akkor a leköszönő dékánok „egyszerü” oktatókként visszatérhetnek a tanszékükre, ám megőrzik információikat, befolyásukat, kapcsolatrendszerüket és beágyazottságukat ${ }^{36}$, s ezáltal befolyásolják az utódjuk mozgásterét, viselkedését is. (Kontrasztként képzeljük el azt az üzleti szervezetet, amelyben az elmúlt évtizedek leváltott igazgatói továbbra is szakértőként dolgoznak.) Ezt néhány helyen például úgy próbálják meg kivédeni, hogy a ciklusát lezáró dékán egyéves kutatói szabadságot kap. Az alacsony mobilitás további következménye, hogy a karon belül viszonylag rövid idő alatt a viszonyulásoknak, a személyes kapcsolatok történetének és az érdekpozícióknak olyan sürü szövete jön létre, amely minden egyes interakciót sokrétü, külső szemmel szinte kibogozhatatlan jelentéstartalommal képes megtölteni. A dékán „politikusi”

\footnotetext{
${ }^{36}$ Mindez nem minden szférában van így: a magyar közoktatásban például az iskolaigazgatói posztról nagyon ritka a visszatérés egyszerü tanári státuszba - azt valóban bukásként élik meg sokan (Bauer - Kováts [2006]). Ennek többek között az lehet az oka, hogy a felsőoktatásban - a kutatás miatt - a szakmai karrierút sokkal nagyobb önkiteljesítési lehetőséget rejt magában, mint a közoktatás tanári pályája. Emiatt a közoktatásban sokkal erőteljesebb a karrier szervezeti hierarchia mentén történő értelmezése. Úgy vélem, ugyanez igaz az egészségügyi karrierutakra is.
} 
szerepe (Wolverton - Gmelch [2002]; Maghroori - Powers [2004]) éppen az erre való érzékenységet hangsúlyozza, amely feltétele annak, hogy értsük, mi miért történik a karon. Egy kívülröl érkező dékán egyik legnagyobb hátránya (és egyben legnagyobb előnye is) az, hogy ezeken a viszonyokon kívül áll. Egy belülről választott dékán számára is hordozhat azonban veszélyeket a helyismeret: esetleg túlságosan is foglyává válik a helyi viszonyoknak.

Látható tehát, hogy az oktatók nemcsak a dékánon keresztül, hanem számos más forrásból is hozzáférhetnek az információkhoz. Ez a tény azonban még nem jelenti azt, hogy ténylegesen rá is szánják az ehhez szükséges időt és erőfeszitést. A dékán formális pozíciójának jelentősége azonban éppen abban áll, hogy ennek révén a dékán számára dedikált idő és erőforrás áll rendelkezésre ahhoz, hogy a különböző bizottságokban részt vegyen, információt gyüjtsön, és a döntéseket befolyásolja.

Összefoglalva a fejezetben elhangzottakat: a döntések megvalósításának kontrollja azt a kérdést veti fel a dékán számára, hogy hogyan lehetséges egy nagy autonómia-igényü szakértőkből álló szervezet működését befolyásolni, a döntések megvalósulását ellenőrizni. Attól függően, hogy a szakértelem, az erőforrások és az információk feletti kontroll hogyan oszlik meg az intézmény vagy kar szereplői között, sokféle konstellációja alakulhat ki a dékán, az adminisztráció és az oktatók kapcsolatának. Létrejöhet egy erős dékáni pozíció, ám éppúgy reális esély van olyan helyzetek kialakulására is, amelyben a dékán egyidejűleg van alacsonyabb és magasabb státuszban más személyekhez képest. Ilyen helyzet az, amikor például egy adott tanszék docensét nevezik ki dékánnak, aki így egyszerre felettese és alárendeltje a tanszékvezető egyetemi tanárának (Nagy [2007]). Ha az egyetem vagy kar müködésében gyakoriak és meghatározóak az ilyen státuszinkonzisztenciás helyzetek, akkor az egyetemen nem alakulhatnak ki tiszta, világos hierarchiák, és nem lesz egyértelmű, hogy ki kinek a főnöke, és az sem, hogy „főnöknek lenni” pontosan mit is jelent (Nagy [2007]). Mindez végső soron vezetői szerepbizonytalanságot idéz elő. A dékáni (és minden más) vezetői szerep valódi határait csak próbálkozások révén lehet kitapogatni. További következmény a szereptúlterhelés (Bess Dee [2008]), az a szituáció, amikor a dékán olyan magatartási elvárásokkal szembesül, amelyek teljesítése a lehetőségeit (a rendelkezésre álló idejét, erőforrásait) túllépik. Ez olyan helyzetekben ölt leggyakrabban testet, mint amikor egy-egy probléma megoldását mindenki a dékántól várja el, miközben a dékán úgy érzi, kevés ráhatása van a problémát előidéző vagy orvosolni tudó karon belüli (és kívüli) tényezőkre.

\subsubsection{A dékán szerepeinek (újra)értelmezése}

A narratívák elrendezésére szolgáló két dimenzió, a célok összehangolásának módja és a döntések megvalósításának kontrollja a dékán számára két általános dilemmát eredményez.

A célok összehangolásának módja egy töredezett egyetemi szervezetben alapvetően azt a kérdést veti fel a dékán számára, hogy mint középvezető hogyan egyensúlyozzon és hogyan közvetítsen a kar és az egyetem, illetve a kar és a diákok/megrendelök elvárásai között. Másként fogalmazva: a kari müködés javítására tett dékáni erőfeszítéseket milyen mértékben lehet a kar saját belső érdekei és dinamikája szerint alakítani, és milyen mértékben kell figyelembe venni külső igazodási pontokat, elsősorban az egyetemet és a még tágabb környezetet? Az egyes narratívákból ezekre a kérdésekre különböző válaszok következnek. Míg a tudósok közössége és a bürokrácia-narratíva alapvetően a kar belső müködését és annak 
konzisztenciáját hangsúlyozza, addig a vállalati és vállakozói egyetem narratíva a külső környezethez való illeszkedésre, a külső tényezőktől való függésre és az ezekből levezethető válaszkényszerekre helyezi a hangsúlyt.

A döntések megvalósulásának kontrollja azt a kérdést veti fel, hogy a dékán mint generalista vezető milyen eszközökre támaszkodjon a döntések megvalósításának érdekében egy szakértőkkel teli karon. Az egyik lehetőséget a munkavégzést befolyásoló folyamatok és rendszerek jelentik, mint például az oktatás-adminisztráció, tervezés, költségvetés, ösztönzésbérezés, teljesítményértékelés, hallgatói tájékoztatás. Ezek alakítása révén biztositható a standardizáltság, az összemérhetőség, az erőforrások nyomonkövethetősége, ami átláthatóbbá és ezáltal felügyelhetöbbé teszik a kar müködését. A rendszerek és folyamatok alakítása a dékán pozíciójához köthető hatalomforrásokra épül, különösen azért, mert az adminisztrációban dolgozók erőteljes közremüködését igényli. Ennélfogva viszonylag jelentős a formális kommunikáció súlya.

A másik lehetőség az oktatók (döntéshozók) motivációinak, gondolkodásmódjának, gondolkodási mintáinak befolyásolása, amely a döntéseknek egy lazább, ám rugalmasabb megvalósítását teszi lehetővé. $E z$ az eszköz főként a dékán személyéhez kötődő hatalomforrásokra épít, mert müködését olyan tényezők befolyásolják, mint a vezető hitelessége, szakértelme és karizmája, amelyek elsősorban akkor hatnak, ha a dékán sok emberrel folytat közvetlen, informális kommunikációt. A dékán formális pozíciójának jelentőségét inkább az információkhoz való jobb hozzáférés lehetősége jelenti.

A döntések megvalósításának kontrolljára vonatkozóan az egyes narratívákból másmás fókusz következik a dékán számára: a vállalkozás és a tudósok közössége inkább a rugalmasságot, a hasonló gondolkodásmód és értékrend kialakítását helyezi a középpontba, míg a bürokrácia és a vállalat-szerü egyetem narratívája inkább a szabályok, folyamatok és a rendszer alakítását hangsúlyozza.

A célok összehangolásából és a döntések kontrolljából következő dilemmák mentén négy, az egyetem narratíváihoz illeszkedő dékáni szerep írható le, amelyeket metaforikusan neveztem el: a közösségi narratíva idealizált dékánja a hős, a bürokrácia dékánja a szolgáltató, a vállalakozó egyetemen a dékán katalizátorként müködik, míg a vállalat-szerü egyetemen a dékán alapvető szerepe a stratégiai játékos (lásd az 5. ábrát). Ezek a szerepek magukba foglalják a dékán korábban ismertetett szerepmodelljeinek egyes elemeit, és részben átfednek az üzleti középvezetők korábban bemutatott szerepértelmezéseivel is (Clegg - McAuley [2005]), ám ezeket a dékán helyzetének elemzése alapján több ponton átértelmeztem. ${ }^{37}$

37 E szerepeket saját magam definiáltam a szervezeti narratívák és a dékánokról olvasottak alapján. A disszertációtervezetem 2009-es megírása óta azonban máshol is megjelentek az itt bemutatotthoz hasonló tipológiák (lásd például de Boer et al [2010]). Ezek azonban a dékánt többnyire mint a kar vezetőjét tekintik, és fogyelmen kívül hagyják a dékáni pozíció középvezetői, köztes jellegét. 


\section{5. ábra: Az egyetem narratívái és a dékán lehetséges szerepei}

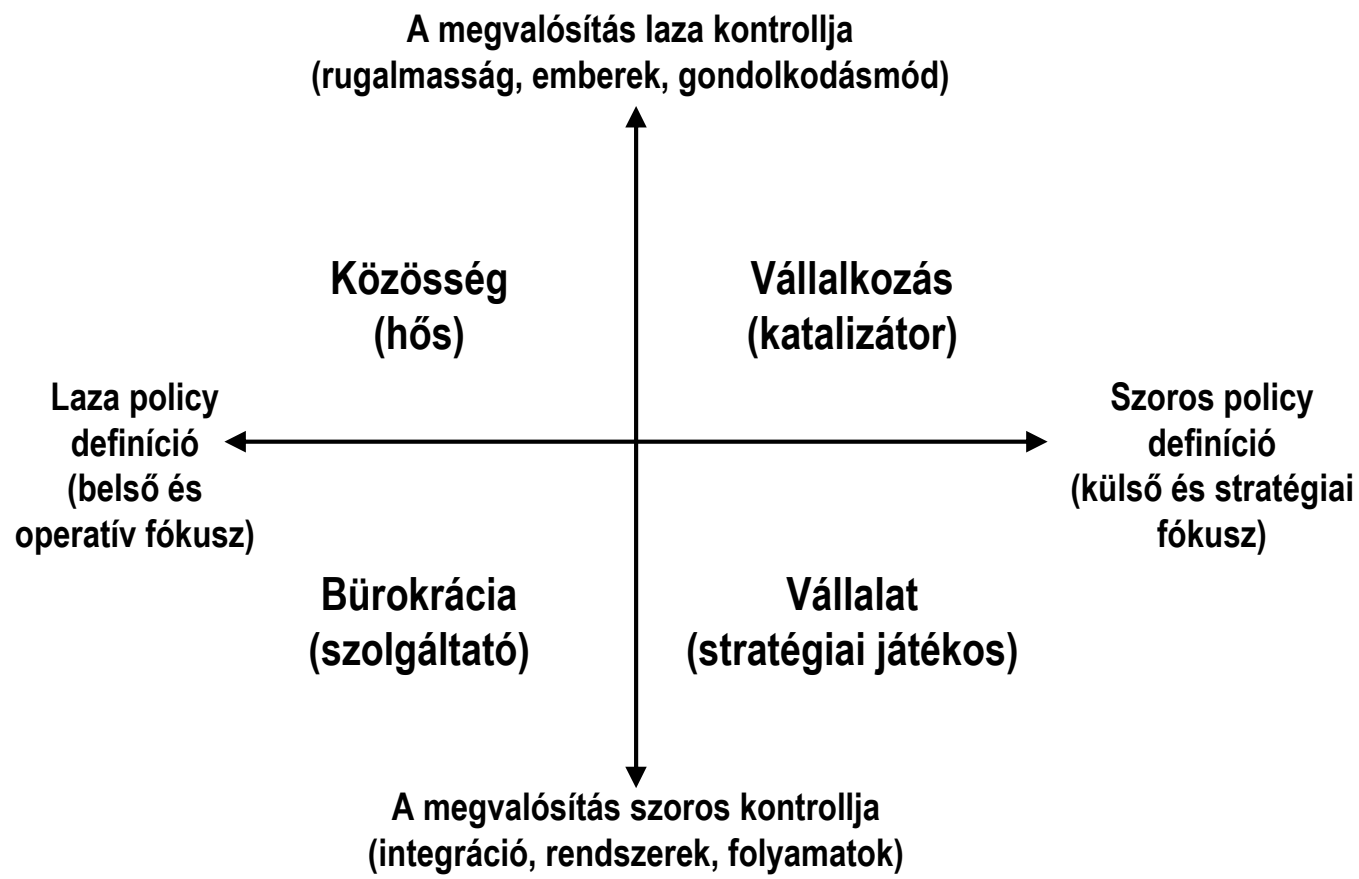

A hős olyan dékán, aki az adott közösségben érvényes értékrend szerint rendkívül sikeres, és így dékánná válva nem csak megtestesíti, hanem meg is erősíti a közösség értékeit, meggyőződéseit, sőt, követendő példává is válik (ezért a példakép elnevezés is indokolt lenne). Ez jellemzően azt jelenti, hogy a dékán mögött nagyon sikeres tudományos múlt áll. Ez azonban nem jelenti feltétlenül azt, hogy szakmai téren még aktív. Inkább a közösség megbecsült, bölcs tagja, aki ismeri a tudományos szakma fortélyait és egyben a kar történetét, múltját. A dékán emiatt nem a közösségen kívül álló személy, és önmagára is mint az oktatói közösség részére tekint.

A hős feladata nem a változtatás, hanem a fennálló értékrend, a gondolkodási minták megerösítése és szimbolikus közvetítése mind a karon belüli kommunikációban (ceremóniamester, testületek vezetése), mind pedig a kar és a külvilág kapcsolatában (szóvivő). A karon belül aktívan segíti a közösség többi tagját a fennálló értékrend elsajátításában (mentor), és felhívja a figyelmet az ezzel ellentétes trendekre. A karon kívül a dékán a közösség felhatalmazásával jár el. Lencseként gyüjti össze, szintetizálja és fókuszálja a karon felmerülő véleményeket, és ennek segítségével lobbizik a kari álláspont érvényre jutásáért.

A szolgáltató dékán feladatát a felmerülő igények és szükségletek hatékony kielégítésében látja. Ez a karon belül az oktatáshoz, a kutatáshoz és a tanuláshoz szükséges adminisztratív feltételek biztositását jelenti. Ennek során a kari oktatók és hallgatók adminisztrációs terheit igyekszik csökkenteni például a kari szintü adminisztráció racionalizálásával és hatékony megszervezésével, az egyetemi szintről érkező adminisztrációs feladatok központositott ellátásával, vagy az ilyen jellegű feladatokhoz nyújtott támogatással, továbbá az egyetemi szinten müködtetett rendszerek alakitására tett javaslatokkal. Tevékenysége így vonatkozik a tájékoztatás és a kommunikáció megszervezésére, az értékelések, akkreditációk és előléptetések hatékony lebonyolítására, a bizottságok és testületek működési feltételeinek megteremtésére, a gazdasági-pénzügyi és oktatás-adminisztrációs 
feladatok ellátására, a kari adminisztrációs személyzet irányitására, a nyilvántartások pontos vezetésére stb.

A dékánt hasonló szolgáltató attitüd jellemzi a központtal kapcsolatban is, amelyek adatkéréseit, rendelkezéseit, pontosan, gyorsan teljesíti. A szintek közötti információáramoltatásban a szerepe elsősorban hírvivő, tehát az üzenetek pontos továbbítására törekszik (ezért lehetne rá az erősítő vagy relé metaforát is használni).

Konfliktus esetén a mércét a szabályzatok és a testületi állásfoglalások jelentik. Ezek alapján a tevékenységének részét képezi a rend fenntartása és a szabályok betartatása is. $A$ dékán önmagára elsősorban mint a kari apparátus professzionális müködtetőjére, és nem mint az oktatói közösség részére tekint.

A dékán a katalizátor szerepben az egyetemen és a karon folyó változási folyamatok erősítésére, támogatására törekszik. A dékán középvezetői pozíciója lehetővé teszi az ötletek és lehetőségek áramoltatását, szakértelme pedig az új ötletek generálását és azok kreatív összekapcsolását. Az alulról érkező kezdeményezéseket és a felülről érkező víziókat tehát nem egyszerűen továbbadja, mint a szolgáltató vagy a hős, hanem felhasználja és alakítja azokat (lásd Floyd - Wooldridge [1994]). Olyan ötletek között is megtalálja a kapcsolatot, amelyet mások nem vesznek részre.

A dékán tehát a kar és az egyetem, illetve a kar és a külvilág közötti kapcsolatban nem semleges, közvetítő, hanem aktív, gazdagító szerepet játszik. Például képes a felülröl érkező víziókat a kar nyelvére lefordítani, az egyetemi stratégia szellemiségét a kar helyzetére pozitív módon adaptálni, és a vízió egészét így vonzóvá tenni. Az alulról érkező javaslatokat ösztönzi, azokat felkarolja, gazdagítja, színezi, és képes kreatívan becsatornázni más, alulról vagy felülről érkező kezdeményezésekbe.

Természetesen a dékán maga is forrása új vízióknak, amelyek alapján nem csak az oktatók és egyetemvezetők fennálló gondolkodási mintáinak és orientációjának a megváltoztatása a célja, hanem új kiaknázható lehetőségek feltárása is. ${ }^{38} E$ víziók forrása elsősorban a folyamatosan változó környezet, amellyel a dékán állandó kapcsolatban áll. Ezt segíti, hogy a dékán szakmailag (tudományosan) is aktív marad, amelynek révén nem csak ismereteit tudja naprakészen tartani, hanem képes a kapcsolatrendszerét is bővíteni, és a karon belül hitelességét megőrizni.

A katalizátor dékán tevékenysége elsősorban kifelé, azaz új piaci vagy társadalmi igények felismerésére és kielégítésére, illetve új szakmai, pályázati ötletek kitalálására és megvalósítására irányul. Ennek révén azonban központi szerepet tölt be új szervezeti (és nem csak kari) kompetenciák és készségek kialakításában is, így hatással van az egyetem belső viszonyainak megújulására. A katalizátor dékán nem csak „entrepreneur”, hanem „intrapreneur” is egyben - és ebben több, mint egy innovatív dékán. A katalizátor dékán ugyanis nem csak innovatív, hanem másokat inspirálva képes a kar egészének innovációs képességét fokozni, katalizálni. Ez indokolja e szerep elnevezését.

A stratégiai játékos magatartását az a felismerés jellemzi, hogy a kar függő helyzetben van a környezetétöl (beleértve az egyetemi szintet és a tágabb környezetet is), mert a környezet biztositja a működése szempontjából fontos erőforrásokat (pénzügyi erőforrások, presztízs,

${ }^{38} \mathrm{~A}$ vízionáló vezető szerepéről, jellemzőiről részletesen lásd: Barakonyi [2004b] 
legitimáció, lobbi erő, kapcsolatrendszer, hallgatókhoz és kutatási pénzekhez való hozzáférés stb.). Tevékenységének fókuszában e függő helyzet csökkentése áll, amelyet részben az erőforrás-igény csökkentésével (azaz a belső müködési hatékonyság javitásával), részben pedig az erőforrások feletti kontroll növelésével és a kockázat csökkentésével biztosít. A dékán így főként a tervezésre, a környezet (a termékek és piacok) értékelésére, az oktatók és tanszékek teljesítményének értékelésére, és az ezt elősegítő objektív rendszerek kiépitésére (vagy az ezt szolgáló egyetemi rendszerek bevezetésére) koncentrál. A környezettől való függőség csökkentése egyben a dékán karon belüli pozíciójának a megerősödésével is jár.

Stratégiai játékosként a dékánt kalkulatív szemléletmód és tranzakciós logika jellemzi: mindent és mindenkit aszerint értékel, hogy milyen erőforrásokat igényel és biztosit, illetve milyen mértékben járul hozzá a kulcs-erőforrások feletti kontroll növeléséhez, és ezáltal a függőség csökkentéséhez. A kart egyszerre szemléli az egyetem részeként és attól függetlenül, azaz az egyetemhez füződő viszonya ambivalens, és attól függ, hogy a kar az egyetemtől milyen mértékű függőségben van. Kis mértékü függőség esetén érvényesülhet a középvezetés „balkanizációs hajlama” (Mintzberg [1981]), azaz teret nyer az „egyetem van a karokért” nézet ${ }^{39}$. Erőteljes függőség esetén azonban a dékán betagozódik az egyetem rendszerébe, és nem önálló vezetőként, hanem valódi középvezetőként viselkedik $A$ dékán önmagára inkább mint menedzserre és kevésbé mint az oktató közösség tagjára tekint.

\subsection{A dékáni pozíció határai}

A dékánság a dékáni pozíciót betöltő személy életének csak egy kisebb vagy nagyobb jelentőségü szeletét jelenti. Noha a vizsgálat fókuszában a dékánság intézménye áll, érdemes pillantást vetni azokra a határterületekre („határszerepekre”), amelyeket a dékán a dékánság mellett még betölt. E kitérőt az indokolja, hogy e szerepek is hatással vannak arra, hogy a dékán a dékáni pozícióban hogyan viselkedik, és milyen szerepet tud a magáénak vallani. Ebben az alfejezetben a dékáni karrierúttal és a dékánok oktatói és kutatói szerepével kapcsolatos viszonylag csekély számú irodalmat foglalom össze. A kitekintés szempontjából további lényeges területet jelentene a dékánság magánéletre gyakorolt hatásának, illetve a munka és magánélet egyensúlyának bemutatása, ezt azonban mellőzöm, egyrészt a források minimális száma miatt, másrészt pedig azért, mert úgy vélem, hogy az e területen született írások (például Wolverton, Wolverton et al. [1999]; Jackson [2003] 94.o.) kevés, a hétköznapi tapasztalatot meghaladó belátást nyújtanak.

\subsubsection{A dékáni karrierút}

A dékáni karrierút vizsgálatát az indokolja, hogy sok esetben a dékán oktatói-tudományos, adminisztratív és más, az intézményben betöltött pozíciói nem függetleníthetők egymástól. Abból

\footnotetext{
39 Emiatt vélem úgy, hogy a menedzsment irodalomban megjelenő önérdekkövető középvezető értelmezés igenis érvényes a felsőoktatásban is.
} 
adódóan, hogy a felsőoktatásban a szakmai és az adminisztratív hierarchia egymással párhuzamosan áll fenn, a karrier fogalma jóval összetettebb, mint az üzleti szférában (lásd például Gilliot, Overlaet et al. [2002]). Ez megnehezíti az intézményen belül valamilyen egységes státusz-hierarchia érvényesitését. Sajnos a dékánok karrierútjával foglalkozó igen kisszámú empirikus vizsgálat nem ilyen összetett módon vizsgálja a dékánok pályáját, hanem szinte csak az adminisztratív (vezetői) pályafutás vizsgálatát értik alatta. A következőkben röviden bemutatom néhány felmérés eredményét.

Moore [1983] mintegy 1200 amerikai dékánra vonatkozó elemzésében két tényezőt vizsgál: egyrészt azt, hogy milyen pozícióból lesz valakiből dékán, másrészt azt, hogy kívülröl vagy belülröl érkezik-e valaki a dékáni pozícióba. A leggyakoribb feltételezés - a normának tekintett modell - a belső (intézményen belüli) lineáris karrierpálya: oktató $\rightarrow$ tanszékvezető $\rightarrow$ dékánhelyettes $\rightarrow$ dékán. Ezt az ideális utat azonban Moore kutatásai nem igazolták. Moore az empirikus adatok alapján hat jellemző dékáni karrierpályát különböztetett meg (8. táblázat).

\section{8. táblázat: A dékán jellemző karrierpályái}

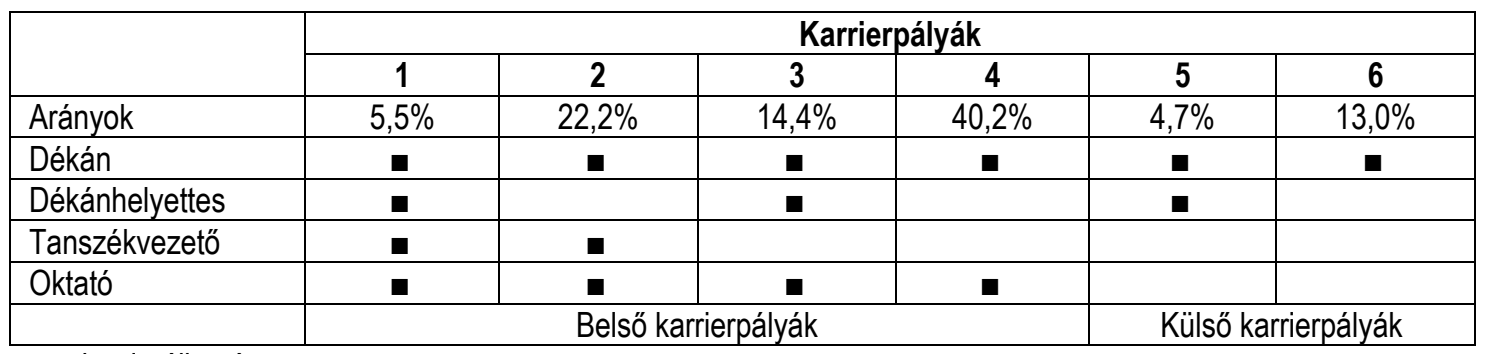

- karrierállomás

Forrás: Moore [1983] adatai alapján ${ }^{40}$

Az adatok azt tükrözik, hogy sem a tanszékvezetöi, sem a dékánhelyettesi poszt nem elengedhetetlen a dékánsághoz. Előbbi az esetek 27,7\%-ban, utóbb csak 24,6\%-ban játszott szerepet. Érdemes arra is felhívni a figyelmet, hogy a dékánokat döntő részben az intézményen belülről nevezték ki, ugyanakkor 17,7\%-uk külsősként töltötte be a tisztséget, elsősorban azokon a területeken, amelyeknek erős kapcsolódása volt valamely gyakorlati szférához (pl. jog). Összességében a dékánok karrierpályája igen változatos képet mutatott, ami alapján az „ideális” pálya csak nagy általánosságokban tekinthető igaznak. A valóságban „öbb egyén igazodik a »normák« variációhoz, mint magukhoz a »normákhoz«" (Moore, Salimbene et al. [1983] 514.0.).

A későbbi felmérések némileg változó tendenciákra engednek következtetni. Wolverton és kutatótársai egy 1996-ban zajlott nagymintás felmérés adatai alapján kijelentik, hogy a dékánok több mint 60\%-ának tanszékvezetői, 40\%-uknak dékánhelyettesi, 18\%-uknak egyetemen kívüli, 30\%-uknak pedig korábbi dékáni tapasztalatai vannak. Ugyanakkor ők is megerősítik azt, hogy az USÁ-ban a dékánokat továbbra is jellemzően belülről nevezik ki, és azt, hogy a dékáni karrierpálya „hierarchikus lineáris modellje” továbbra sem rajzolódik ki (Wolverton - Gonzales [2000]; Wolverton - Gmelch [2002]).

40 Moore egy másik tanulmányában (Moore [1983]) kisebb mintán más arányokat közöl, de az eltérések okai nem derülnek ki. 
A magyarországi dékánok jellemző karrierútja tekintetében csak hozzávetőleges adatok állnak rendelkezésre. Forgó Melinda elemzése szerint a 2006-ban dékáni pozíciót betöltő személyek 64,4\%-ának volt valamilyen előzetes (dékánhelyettesi, tanszékvezetői vagy esetleg a rektori, rektorhelyettesi tapasztalata) (Forgó [2008]). Ez megegyezni látszik az 1996-os amerikai felmérés adataival, de itt sem derül fény a karrierpályák jellemző mintázataira.

A dékánok karrierútjával kapcsolatos képet az tenné teljessé, ha a dékánság után betöltött pozíciók vizsgálatára is sor kerülne. Ebböl arra is fény derülne, hogy a dékáni pozíció mennyiben tekinthető önmagában is értékes, vonzó pozíciónak, és mennyiben csak ugródeszkának valamilyen más pozíció elnyeréséhez. Sajnos erre vonatkozólag is csak hozzávetőleges adatok állnak rendelkezésre az 1996-os amerikai felmérés alapján, amelyben a dékánokat jövőbeli szándékaikról is faggatták (lásd a 9. táblázatot). Magyar vagy európai felmérésről nincsen tudomásom.

\section{9. táblázat: A dékánok karriertervei egy az Amerikai Egyesült Államokban végzett kutatásban (\%)}

\begin{tabular}{|l|c|c|c|c|}
\hline & $\begin{array}{c}\text { Bölcsész- } \\
\text { tudományok }\end{array}$ & $\begin{array}{c}\text { Üzleti } \\
\text { tudományok }\end{array}$ & $\begin{array}{c}\text { Nevelés- } \\
\text { tudomány }\end{array}$ & Nővérképzés \\
\hline Visszatér oktatónak & 27 & 24 & 27 & 18 \\
\hline Dékán egy hasonló intézményben & 4 & 2 & 7 & 3 \\
\hline $\begin{array}{l}\text { Dékán egy nagyobb presztízsü } \\
\text { intézményben }\end{array}$ & 8 & 12 & 8 & 11 \\
\hline $\begin{array}{l}\text { Dékán marad a jelenlegi } \\
\text { intézményben }\end{array}$ & 15 & 14 & 17 & 19 \\
\hline $\begin{array}{l}\text { Magasabb akadémiai vezetői } \\
\text { beosztás }\end{array}$ & 35 & 26 & 22 & 21 \\
\hline $\begin{array}{l}\text { Vezetői beosztás a felsőoktatási } \\
\text { szférán kívül }\end{array}$ & 0 & 7 & 2 & 5 \\
\hline Nyugdíjba megy & 12 & 16 & 17 & 23 \\
\hline
\end{tabular}

Forrás: Wolverton - Gmelch [2002] 106.0.

A felmérés eredményei azt mutatják, hogy - a nővérképző karok kivételével - a felsőoktatásban maradó dékánok körülbelül 1/3-a tér vissza oktatónak, 1/3 képzeli el jövőjét továbbra is dékánként (a saját intézményében vagy valamely más intézményben), és körülbelül 1/3 azoknak az aránya is, akik magasabb vezetői beosztásba szeretnének kerülni. Mindez elég magas „pályaelhagyást” sejtet. Ezt látszik alátámasztani több szerzőnek is azon véleménye, hogy egyre rövidül a dékánok szolgálati ideje és egyre magasabb körükben a fluktuáció különösen olyan területeken, mint például a gazdaságtudomány (Twombly [1992]; Gmelch, Wolverton et al. [1999]). Gmelch mindezt elsősorban a pozícióval járó nagyfokú stresszel, bizonytalansággal és konfliktusokkal magyarázza, ami miatt a dékánt „veszélyeztetett fajként” jellemzi (Gmelch, Wolverton et al. [1999]).

McCarty és Reyes tanszékvezetők körében végzett kismintás, kvalitatív vizsgálatában arra (is) kereste a választ, hogy a tanszékvezetők miért (nem) akarnak dékánok lenni. $A z$ ellenérvek között szerepelt például, hogy kevesebb idő jut az oktatásra és kutatásra, az adminisztrációval járó papírmunka és tárgyalások nem vonzóak, a pozíció túl stresszes, a 
döntések túlságosan nehezek, a dékán vezetési lehetőségei túlságosan korlátozottak, és a pozíció túlságosan sok politikával jár (McCarty - Reyes [1985] 13.0., 1. és 2. táblázat).

\subsubsection{A dékán mint oktató és kutató}

A dékánok azonosulását, identitását vizsgálva több felmérés is arra mutat, hogy a legtöbb dékán önmagát legalább részben továbbra is oktatónak látja. Ausztráliában például „a dékánok elsöprő többségben oktatóként, vagy az oktató és vezető keverékeként gondolnak magukra" (Gmelch, Wolverton et al. [1999] 733.o.). Az USÁ-ban a dékánok 2/3-a definiálja önmagát oktatóként vagy valamilyen keverékszerepben. Ez a felmérés azt is mutatja, hogy a tanszékvezetökhöz képest növekszik a vegyes identitású dékánok aránya (lásd a 10. táblázatot) (Gmelch [1999]). Angliában pedig Henkel arra a megállapításra jut, hogy minél hagyományosabb egy egyetem, annál kisebb valószínüséggel azonosítják az egyének önmagukat menedzsernek, még akkor is, ha egyébként elismerik, hogy ilyen jellegü tevékenységet végeznek (Henkel [2000]).

\section{0. táblázat: Amerikai dékánok azonosulása}

\begin{tabular}{|l|c|c|}
\hline & Dékánok & Tanszékvezetők \\
\hline Oktató & 6 & 44 \\
\hline Vezető & 32 & 4 \\
\hline Oktató és vezető & 62 & 52 \\
\hline
\end{tabular}

Forrás: Gmelch [1999] 1. és 2. ábra

Az oktatói és dékáni szerep illeszkedéséről érdekes tanulságokkal szolgál a szakirodalom tanulmányozása is. Sokan a dékáni és oktatói szerepek szinergikusságát hangsúlyozzák. Akik például a dékán példakép (role model) szerepét fontosnak látják, azok az oktatást és a kutatást a dékáni munka szerves részének tekintik (lásd például Newsome [1997]). Mások arra mutatnak rá, hogy az oktatók és kutatók csak azt a dékánt veszik komolyan, aki folyamatos értékelhető oktatói és kutatói tevékenységet mutat fel. Az oktatói és kutatói munka tehát nem szerves része a dékán szerepének, de nagyban hozzájárul a karon belüli legitimációjának megerősödéséhez (Gallos [2002]). Ez a megközelítés illeszkedik ahhoz a képhez is, hogy a szakértői szervezetben a szakértők elvárják, hogy a vezetőjük elfogadható módon értsen az adott területhez, és ezt alkalomadtán demonstrálja is.

Ezzel szemben a dékáni szereppel foglalkozó szerzők többsége nem említi az oktatói és kutatói tevékenységet a dékáni szerepkészlet elemei között. A dékánok személyes beszámolói, amelyben tapasztalataikat és tevékenységeiket összefoglalják, szinte szót sem ejtenek a vezetői időszak alatti kutatási és oktatási tevékenységéről. Ezt látszik megerősíteni Harman is, aki elemzésében kimutatja, hogy az ausztrál dékánok és tanszékvezetők kutatási aktivitása az egyetem többi szereplőjéhez képest 1977 és 1997 között jelentősen visszaesett (Harman [2002]). Kirk [1997] pedig azt hangsúlyozza, hogy a kutatás és az oktatás olyan tevékenység, amelyek segítenek kiszakadni a dékán napi adminisztratív rutinjából, és hozzájárulnak a pihenéshez, kikapcsolódáshoz, azaz inkább az egyénhez, és kevésbé a dékán szervezeti szerepéhez kötődik.

Az oktatói és dékáni pozícióból fakadó elvárásoknak való egyidejű megfelelés sajátos (ún. szerepközi, inter-role) konfliktusok forrása lehet. Ez nem csak az időbeli 
összeegyeztethetőség nehézségeire vezethető vissza, hanem az oktatói és dékáni tevékenység jellegében mutatkozó különbségekre is, amely Gmelch [2000] ellentétpárjainak kiegészítésével az alábbiakban foglalható össze:

- Magányosság helyett társasági szereplő: az oktatók munkájuk jelentős részét egyedül, önállóan végzik, a dékánok munkavégzésének legföbb terepe a társaság: megbeszélések, bizottsági ülések, előkészítő tárgyalások. Az oktatónak tehát egyéni cselekvőből egy kapcsolathálózat müködtetőjévé és fenntartójává kell válnia. Ez azzal is jár, hogy a dékán - az oktatóval szemben - ritkán vesz részt a feladatok tényleges kivitelezésében, és sokkal nagyobb a delegálás szerepe.

- Autonómia helyett elszámoltathatóság: az oktatók munkáját a nagyfokú autonómia, a döntési szabadság igénye és a saját döntésekért vállalt felelősség jellemzi. A dékánok munkájában a kar egészének működéséért való felelősség válik dominánssá. Ezt érdemes azzal is kiegészíteni, hogy az oktató jelentős kontrollt gyakorolhat a tevékenység lefolyása, körülményei és eredménye fölött. Ezzel szemben a dékán csak korlátozottan képes befolyásolni azokat a tényezőket, amely a kar müködését meghatározzák. Tevékenységének jelentős részét emiatt a nem kontrollálható tényezőkben bekövetkező változásra adott reakció teszi ki. Mindez azt is jelenti, hogy bár vezetőként a dékán a saját munkafeltételeit jelentős mértékben képes befolyásolni, mégis a szerep szabadságfoka az oktatói autonómiához képest csökken. ${ }^{41}$

- Fókuszált munkavégzés helyett fragmentált munkavégzés: az oktatók hosszú ideig, megszakítások nélkül, elmélyülten foglalkoznak egy-egy dologgal, míg a dékánok munkavégzését a gyakori megszakítás, munkaidejüket a töredezettség jellemzi (Jackson [2003]). Mint a vezetők többsége (Mintzberg [1971]), úgy a dékánok sem maguk kontrollálják a saját munkaidejüket.

- Kéziratok helyett emlékeztetők: az oktatók az alapos, gondosan kimunkált kéziratokkal, laza határidőkkel dolgoznak, a dékánoknak azonban a tömör, kifejező írást kell megtanulniuk, és szigorú határidőket kell betartaniuk.

- Magánszféra helyett közszféra: míg az oktatók korlátozzák a nyilvános idejüket (elérhetőségüket), addig a dékánoknak lehetőleg mindig elérhetőnek kell lenniük. $A$ dékán közéleti szerepe, láthatósága fontos eleme a dékán szerepkészletének.

- Szakmai munka helyett rábeszélés: az oktató a tudományterület építésével, a dékán a konszenzus építésével foglalkozik fő feladatként.

- Stabilitás helyett mobilitás: az oktató a saját szakterületében mélyed el, ami a stabilitás, a kiszámíthatóság, az ismertség érzetét nyújtja számára. A dékánnak azonban - mint a kar képviselőjének - mindenhez hozzá kell szólnia, sokszor olyan kérdésekben is véleményt kell megfogalmaznia, amely nem a szakterülete. Így mindenhez értenie is kell egy keveset.

\footnotetext{
${ }^{41}$ Egy szerep szabadságfokán azt értem, hogy a szerep betölöje milyen mértékben képes a szerephez kapcsolódó tevékenységek, célok, elvárások jellemzőit befolyásolni. (Nicholson [1984])
} 
- Ügyfél helyett felügyelö: az oktatók elvárják a munkájuknak megfelelő feltételeket, a kiszolgálást, azaz ügyfélként viselkednek, míg a dékán az erőforrások elosztását és felhasználását felügyeli.

Összességében tehát az oktatói-kutatói és a dékáni munka a korábban már említett specialista-generalista ellentéttel írható le azzal a kiegészítéssel, hogy a dékánok oktatói-kutató szerepükben olyan területen mélyednek el az esetek döntő többségében, amely csak közvetve járul hozzá a dékáni tevékenységük sikeréhez (pl. a részecskefizika területén szerzett új ismeretek kevéssé alkalmazhatóak a dékán mindennapjaiban). Fontos tapasztalat az is, hogy az oktatói-kutatói pályán szerzett szocializáció csak korlátozottan készít fel a dékán minennapos élethelyzeteire.

\section{5. Összefoglalás}

A fejezetben áttekintettem a dékán és az üzleti menedzsment középvezetök szerepeire vonatkozó szakirodalmát, valamint összefoglaltam a dékán pozíciójának sajátosságait taglaló szakirodalmat is. Ezek alapján definiáltam a dékán négy, a korábban már megfogalmazott narratívákba illeszkedő szerepét: a hőst, a szolgáltatót, a stratégiai játékost és a katalizátort. Emellett olyan, az empirikus kutatás során is vizsgálható témák merültek fel, mint az ellentmondó elvárások, a kétnyelvűség, a kiszolgáltatottság, a felelösség és kontroll problémája, az oktatói szerephez füződő viszony vagy a dékáni pozíció elhelyezkedése az életútban. 


\section{A narratívák és szerepek változása}

Az előző két fejezet a szervezeti narratívákat, illetve a narratívákhoz illeszkedő dékáni szerepeket mutatta be. A fejezet célja e kettő összekapcsolása, és a változási folyamatok értelmezése, azaz a modell dinamizálása.

\subsection{A narratívák egyidejü létezése és a domináns narratívák kialakulása}

Az egyetem töredezettségének és szakértői jellegének természetes következménye, hogy az egyetemröl a szervezeten belül egyazon időpontban számos narratíva létezik. A szakértői jelleg miatt az oktatók a feladatellátás egésze fölött nagyfokú kontrollal rendelkeznek, ami csökkenti az együttműködési kényszereket. A különböző tanszékek és karok oktatói között így nincsen szükség gyakori interakciókra. Ennek következtében az oktatói-kutató csoportok elszigetelődnek egymástól, és egyben lehetővé válik az is, hogy a jobban együttmüködő csoportok többékevésbé független szubkultúraként müködjenek (Weick [1976]), aminek része, hogy saját narratívát alakítsanak ki az egyetem működéséről. Emellett az oktatók a tudományterületi közösségük mellett - különösen a nyitottabb tudományterületek esetében - több más, az egyetemen kívüli szakmai közösségnek (community of practice) is részesei, ami újabb narratívák forrása lehet.

A szakértői jelleg, az egyetem töredezettsége és az interakciók ritkasága így a narratívák sokféleségét eredményezi, és ahhoz vezet, hogy az egyetemen egyetlen narratíva sem tehet szert általános érvényre, mert állandóan új és új értelmezések jelennek meg, amelyek ellenpontozzák a dominanciára törekvő narratíva alapfeltevéseit. Trowler úgy fogalmaz, hogy az egyetemek „dialogikus képződmények”, amelyeket „a többféle jelentéssel bíró diskurzusok sokfélesége hoz létre" (Trowler [2001] 191.0.), azaz az egyetemeken egy időben mindig többféle narrativa is érvényesül.

A narratívák egyidejü létezése a szervezetben azonban nem jelenti azt, hogy egyes narratívák átmenetileg ne tehetnének szert fölényre. Ennek mechanizmusát Simsek és Louis [1994] mutatják be, akik az uralkodó narratíva változását Kuhn paradigmaváltási folyamataival állítják párhuzamba (lásd a 6 . ábrát). 


\section{6. ábra: A narratívák változási folyamata}

Anomáliák sokkok, kiváltó Megkérdőjeleződés Iparági minták, események

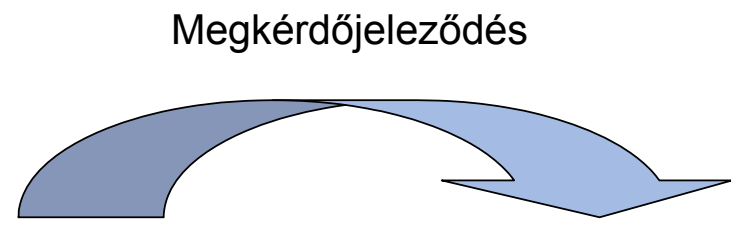
megoldások
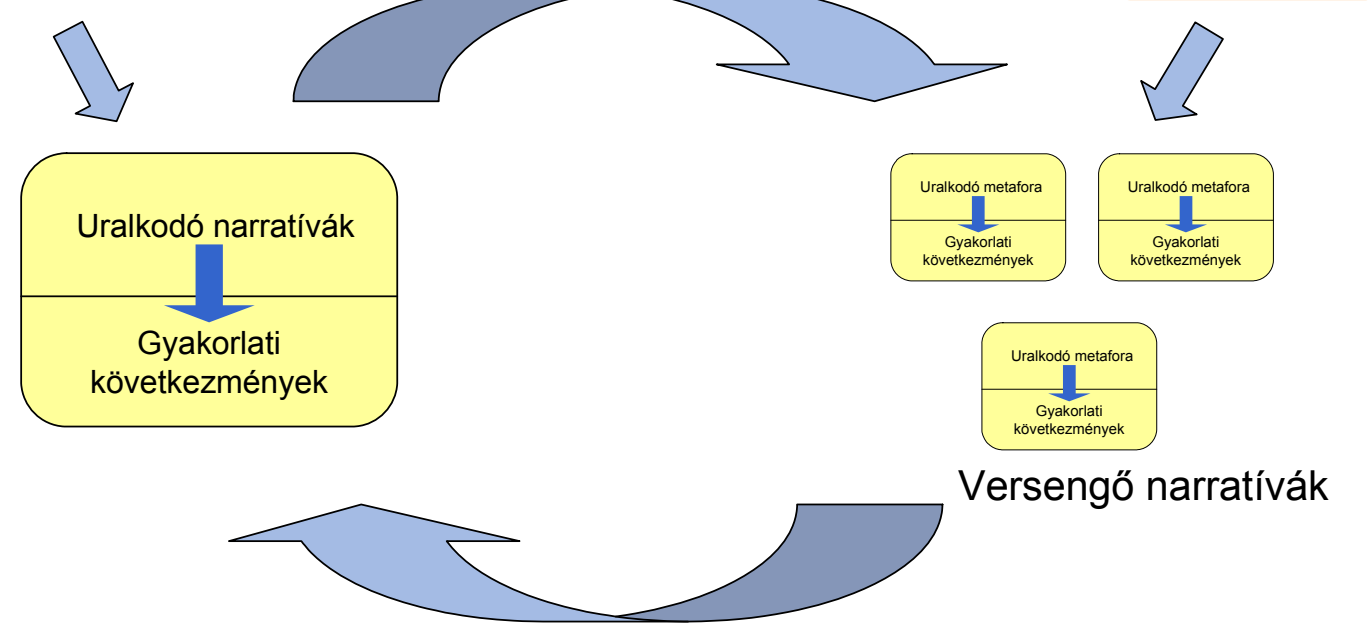

Kiválasztódás

Forrás: Simsek - Louis [1994] 675.0. alapján

Szerintük az uralkodó narratívák időről-időre anomáliákkal szembesülnek, azaz az egyetem tagjai olyan társadalmi, gazdasági és szervezeti folyamatokat észlelnek és minősitenek kollektív módon jelentősnek, amelyre vonatkozóan az uralkodó narratíva keretei között nem tudnak megfelelő szervezeti választ elképzelni (ilyen dilemma például a tömegesedés, a verseny, az erőforrások csökkenése). Így fokozatosan megnyilik a tér az alternatív narratívák támogatói előtt. A változás az egyes narratívák képviselőinek háttérbe szorulásával következik be. Amint az alternatív narratívák támogatóinak száma elér egy kritikus szintet, a szervezetben uralkodó domináns értelmezési keretben hirtelen változás következik be, amelyet a jól látható intézményesült megoldások (a szervezeti struktúra, a pozíciók, az értékrend, a szokások, a szerepek stb.) fokozatos átrendeződése követ. A változás oka tehát nem valamiféle „valódi” szervezeti probléma felismerése, hanem az értelmezési rendszer változása, az elégséges befolyással rendelkezők meggyőződése arról, hogy a változás szükséges (Kieser [2008]). Ezt természetesen gyakran befolyásolják az éppen aktuális felsőoktatási menedzsment divatok (Birnbaum [2001]) és a felsőoktatási rendszer peremterületén folyó társadalom diskurzusok is. llyennek tekinthető például az állam szerepének és a közszolgáltatások szervezésének újragondolását kitűző Új Közszolgálati Menedzsment (New Public Management) mozgalom is (lásd például Hajnal [2004], Thom - Ritz [2005], Horváth [2006]).

A dominánssá váló narratívák azonban nem érvénytelenítik egy csapásra a többi narratívát, azok az egyetem „hátterében” továbbra is léteznek, sőt a szervezet kevésbé központi struktúráiban és mechanizmusaiban (például egy kar vagy egy tanszék gyakorlatában) továbbra is meghatározó szerepben maradhatnak. A folyamat, noha van benne egy hirtelen, sokkszerü 
lépés, összességében mégis inkább változásként, hangsúlyeltolódásként értékelhető, semmint sokkszerű váltásként42.

A narratív sokszínűség így szervezeti szinten egyszerre eredményezi az egyetemek rugalmasságát és rugalmatlanságát, hiszen a sokszínűség egyfelől állandósítja a vitákat, félreértéseket és megnehezíti az egyetem szereplőinek együttmüködését, ám ugyanakkor az egyetem - az új és háttérben maradó narratívák révén - mindig magában hordozza a megújulás lehetőségét is, és ez éppen a viták állandóságában gyökerezik. A felsőoktatási intézmények sokféleségének, diverzitásának az egyetem narratív sokszínűsége az oka.

$\mathrm{Az}$ uralkodó narratívák bemutatott folyamatából következik, hogy a változásnak többnyire nincsen elöre megjósolható iránya, mert legalább olyan mértékben függ az intézmény belső dinamikájától (az egyes nézeteket támogató erők egyensúlyától és alkupozíciójától), mint a külső (észlelt) tényezőktől.

Az előrejelezhetőség korlátozottsága azonban nem zárja ki a domináns narratívák változásának utólagos rekonstruálását. Ez szolgál alapjául felsőoktatási intézmények és rendszerek evolúciós, fejlődési magyarázatának is. Eszerint például kezdetben voltak az elit egyetemek (közösségi modell), amelyek a tömegesedés hatására bürokratizálódtak, majd a finanszírozási nehézségek a vállalkozói/vállalati kultúra meghonosodásához vezettek (lásd például Hrubos [2004b]; Hrubos [2009]).

E nagyon általánosító logika finomítható oly módon, ha feltételezzük, hogy a különböző típusú és diszciplináris összetételü felsőoktatási intézményekben más-más narratíva válik dominánssá: Hrubos Ildikó például utal arra, hogy a nagyobb presztízsű, tradicionális intézmények jobban ellent tudnak állni a vállalkozói vagy vállalati kultúra „bevezetésének” (Hrubos [2004c]). Hasonlóan különbségeket tételezhetünk fel az oktatás-dominálta főiskolák és a kutatással komolyabban foglalkozó egyetemek között is. Feltételezhető az is, hogy azok az egyetemek, amelyekben túlsúlyban vannak az alkalmazott - gyakorlatban gyökerező tudományterületek (müszaki tudományok, közgazdaságtudomány, menedzsmenttudomány, jog stb.), nyitottabbak a vállalkozói kultúrára, mint a bölcsészettudományi és természettudományi karokkal rendelkező intézmények stb.

Az evolúciós logika a felsőoktatási rendszerek fejlődésére is értelmezhető: McNay például a cikk írásának idején (1995-ben) Angliát az akadémiai oligarchia és a direkt állami felügyelet felöl a közvetett állami felügyelettel müködtetett kvázipiacok felé látta mozogni, amelyek szervezeti megfelelői közé a kollegiális-bürokratikus, illetve a vállalati-vállalkozói kultúra tartozik. A rendszerváltó országok ugyanakkor - legalábbis szerinte - egy bürokratikus-vállalati kultúrát elösegítő rendszer felöl egy kollegiális-vállalkozói kultúrát erősítő rendszer irányába mozogtak (McNay [1995] 111-112.0.).

E magyarázatok a külső tényezők szükségszerü következményeiként láttatják a kialakuló állapotot, így éppúgy teremtik (legitimálják), mint ahogy magyarázzák a fennálló uralkodó narratívát. Az evolúciós magyarázatok ugyan jó heurisztikául szolgálnak a komplex események megragadhatóságához, a rendszerben meglévő narratív sokszínűséget és annak belső dinamikááát azonban óhatatlanul (és szükségszerüen) elfedik és homogenizálják.

${ }^{42} \mathrm{~A}$ rendszerváltás közgazdaságtanának transformation vs. transition vitája ez szervezeti szinten. 


\subsection{A narratívák egyidejüsége és a dékán szerepe}

Milyen következményei vannak a narratívák sokszinüségének a dékán helyzetére nézve? Hogyan kapcsolódik egymáshoz a dékán magatartása, szerepe és a narrativák? E kérdések megválaszolásához a narrativák összemérhetőségét, illetve a dékán narratívák megvalósulásában játszott szerepét kell megvizsgálni.

A narratívák összemérhetőségével kapcsolatban abból indulok ki, hogy a narratíva egy szituáció észlelésének és értelmezésének adott, meghatározott módját jelenti (például a 3. fejezetben felsorolt narratívák a felsőoktatás változásának értelmezései). Ebből következően a különböző narratívák mentén a szituációból más következtetések adódnak és így más döntések is születnek. A kari autonómia pártolása például értelmezhető úgy, mint a saját befolyás megörzésére való törekvés vagy a központi kontrolltól és teljesítményértékeléstöl való menekülés (vállalat-szerủ egyetem narratívája), a rugalmasság és alkalmazkodóképesség megörzésének racionális megoldása (vállalkozó egyetem narratíva), az oktatási és kutatási szabadság, illetve az értéksemlegesség fenntartásának alapja (tudósok közösségének narratívája), vagy mint olyan szabályozási és hatáskör-megosztási megoldás, amelyet a szervezet célja alapján kell értékelni (bürokratikus narratíva). Egy másik példán keresztül: egy kis szak fenntartása jelentheti a nemzeti tudomány védelmezését és az akadémiai szabadság melletti kiállást (tudósok közössége nézőpont), a tanszéki vagy kari érdek sikeres védelmezését (vállalat-szerủ egyetem narratíva), bizalmat abban, hogy a szak hozzájárul az egyetem hosszú távú akadémiai és gazdasági érvényesüléséhez (vállalkozói egyetem narratíva), vagy egyszerủen csak az akkreditációs elöírásoknak való megfelelést (bürokratikus narratíva).

Noha a narratívák alapvetöen különböznek egymástól, ez nem jelenti annak szükségszerüségét, hogy az egyes narratívák mentén minden esetben ellenkező következtetésre kell jutni. Éppúgy elöfordulhat, hogy a különböző narrativák más logika mentén ugyan, de mégis azonos következtetésre jutnak egy adott kérdésre vonatkozóan (például a mátrix struktúrát mind a vállalkozó, mind a vállalati egyetem használja, de más-más megfontolás áll mögötte). Ez az eltérő elöfeltevések, azaz a narratív sokszinüség fennállása esetén is lehetővé teszi a közös cselekvést. Ugyanakkor el is leplezi az egyetem narratív sokszinüségét, mert az interakciók többsége jellemző módon a következmények mérlegeléséről (azaz döntésről, a problémák megoldásáról) és nem az előfeltevések különbözőségéről szól. Ez utóbbi tisztázására inkább csak a tartós egyet nem értés (és fennálló kompromisszumkényszer) vagy nagyfokú nyitottság és reflektív képesség esetén szokott sor kerülni.

A narratívák nem a cselekvőktöl függetlenül léteznek, hanem épp a cselekvésekben nyilvánulnak meg. Amikor tehát a dékán dönt vagy cselekszik, akkor az interakcióban megvalósít egy szerepet, de ezzel nem csak az adott szerepértelmezés, hanem egyben egy adott narrativa reprodukálódásához, megerősödéséhez is hozzájárul. Például döntésével, megnyilvánulásaival és érveivel jelentőséget ad egyes témáknak (másoknak viszont nem). Ezzel egyben megerősíti az adott jelenség bizonyos értelmezési módját is. Jelentősége azonban nem csak annak van, hogy a dékán milyen témákat tart fontosnak (és milyeneket nem), illetve hogy milyen álláspontot foglal el az adott kérdésben (és milyeneket nem), hanem annak is, hogy mindez folyamatában hogyan zajlik ( $\mathrm{pl}$. a dékán kezdeményez vagy csak reagál, konzultál, javasol vagy dönt stb.). Megnyilvánulásai tehát befolyással vannak arra, hogy az egyetemen milyen témákkal, miért és 
hogyan kell foglalkozni (mi a narratíva), csakúgy mint arra, hogy a dékánnak milyen témákkal, miért és hogyan kell foglalkoznia (mi a dékán szerepe).

Kétségtelen, hogy egy adott jelenség többféle értelmezésének a dékán is tudatában lehet, azaz a narratív sokszínűség felismerhető. A döntés azonban (amely lehet akár a nem döntés, a döntés elhalasztása vagy másra háritása is) már egy bizonyos értelmezés mentén fog megtörténni, azaz a dékánok az egyes szerepek megvalósítása révén és során hozzájárulnak valamely narratíva megerősödéséhez is. Itt válik a szerep igazán személyes kérdéssé: milyen gondolkodási minták, értelmezési keretek megerősödéséhez, és ezzel milyen egyetem megvalósulásához járul hozzá a dékán a döntéseivel? Milyen egyetemet szeretne ő maga? És vajon lehetséges-e másként dönteni, másféle szerepet megvalósítani és ezzel másféle egyetemet létrehozni?

A narratívák összemérhetetlensége és a döntési kényszer nem egyszerüen komplex, hanem állandóan fennálló és válaszra váró szuperkomplex helyzetet eredményez a dékán számára:

„A komplexitás a dolgok olyan állapota, amelyben a kereslet meghaladja a kielégítésükhöz szükséges erőforrásokat. Következésképpen az adatokkal, dolgokkal és ügyfelekkel való túlterheléssel szembesülünk. Az ilyen helyzet valódi kihívást, sőt stresszt, eredményez, de alapjában véve kezelhetö lenne, ha több erőforrással rendelkeznénk. A szuperkomplexitás ezzel szemben fogalmi túlterheltség során keletkezik. Röviden: a szuperkomplexitás a keretrendszerek sokaságának eredménye. [...] Amint egy adott kereten belül vagyunk, a szabályok többé-kevésbé világossá válnak. A modern világban a nehézséget az jelenti, hogy többé nem lehetünk bizonyosak abban, hogy mely keretrendszert kell belakni." (Barnett [2000] 415.0.)

A narratívák közötti választás nehézségét az jelenti, hogy a racionalitási kritériumok maguk is az értelmezési keretrendszerek részei, ezért a maga módján mindegyik narratíva legitim és racionális. Nincs olyan univerzális, mindenkor érvényes racionalitási kritérium, amely alapján választani lehetne közöttük.

Alternatív lehetőségként kínálkozik valamilyen kompromisszum keresése. A dékán helyzetére lefordítva ez azt jelenti, hogy a dékán szerepei között nem „vagy-vagy”, hanem „és” logika érvényesül. A sikeres dékánnak nem az egyik szerepbe helyezkedve kell jól teljesítenie, hanem egyszerre kell(ene) hősként, stratégiai játékosként, szolgáltatóként, katalizátorként és szervezetben kialakuló többi szerepekben is helyt állnia. A dékánnak tehát egyszerre kell tudnia az egyetem és a kar, az emberek és a rendszerek nézőpontjából gondolkodnia.

E feladat nehézsége abból fakad, hogy a szerepek révén a dékán narratívákat is közvetít, azaz a szerepek összehangolása az egymáshoz nem illeszkedő narratívák összehangolását, hiteles közvetítését is megköveteli. Reed például az angol felsőoktatás átalakulását elemezve megállapítja, hogy

„a mi menedzser-oktatóink mindent összevetve nagyon »kelletlen menedzserek«, akik nagyon vonakodónak tünnek abban, hogy beteljesítsék az új menedzserializmus ideológiája és gyakorlata által rájuk rótt történelmi küldetésüket. Ahelyett, hogy a menedzserista forradalom »rohamkatonáiként» elsöpörnék az idejét múlt és nem hatékony szervezeti gyakorlatot és az ellenszegülö szakértői-termelöi monopóliumot, abban az irigylésre nem méltó pozícióban találják magukat, amelyben a súlyosan sérült, de még nem halott 'ancient regime' és a még csak félig kialakult modernizációs ideológia alapjában véve nem kompatibilis imperatívuszait próbálják meg összetartani." (Reed [2001] 175.0.) 
E kelletlen és vonakodó magatartás abból fakad, hogy az egyes dékáni szerepek - mint az a szerep fogalmából adódik - énazonos magatartást tételeznek fel. Azaz a kompromisszum mint logika azt kívánja meg, hogy a dékán egyszerre legyen saját maga (a saját szerepében) és valami más (egy másik szerepben). De vajon lehetséges-e ez?

A döntési folyamatokat természetesen befolyásolja az éppen domináns narratíva, amelyik egyik vagy másik szerep felé orientálhatja a dékánt. Ha létezik erős, domináns narratíva, az mindenképpen megkönnyíti a dékán választását, függetlenül attól, hogy a saját szerepértelmezése illeszkedik e domináns narratíva szerepfelfogásához. Ha illeszkedik, akkor a dékán konform a várakozásokkal. Ha viszont nem illeszkedik egymáshoz a kettő, akkor sem a választás jelenti a problémát, hanem az új szerep kivitelezése és elfogadtatása. Választási probléma akkor adódik, ha több, egyformán legitim narrativa is fennáll. Ebben az esetben a dékán valóban szuperkomplex választási helyzettel szembesül. Ennek a helyzetnek, úgy vélem, a posztszocialista országokban nagyobb az esélye éppen az átmenetiség állapota miatt. 


\section{Dékánok a magyar felsőoktatásban: az empirikus kutatás bemutatása}

E fejezet célja az empirikus vizsgálat alapjául szolgáló kutatási terv bemutatása. Ehhez Maxwell „interaktív kutatástervezési modelljére” támaszkodom, amely a kutatási tervet nem összetevők lineáris sorozataként, hanem egymással kölcsönös kapcsolatban álló, és ezért egymásra felelgető elemek halmazaként értelmezi (Maxwell [1996] 5.o.). Az alábbi ábra a kutatási terv összefoglalását tartalmazza. Az ábra egyes pontjainak kifejtésére az alfejezetekben kerül sor.

\section{7. ábra: A kutatási terv áttekintése}

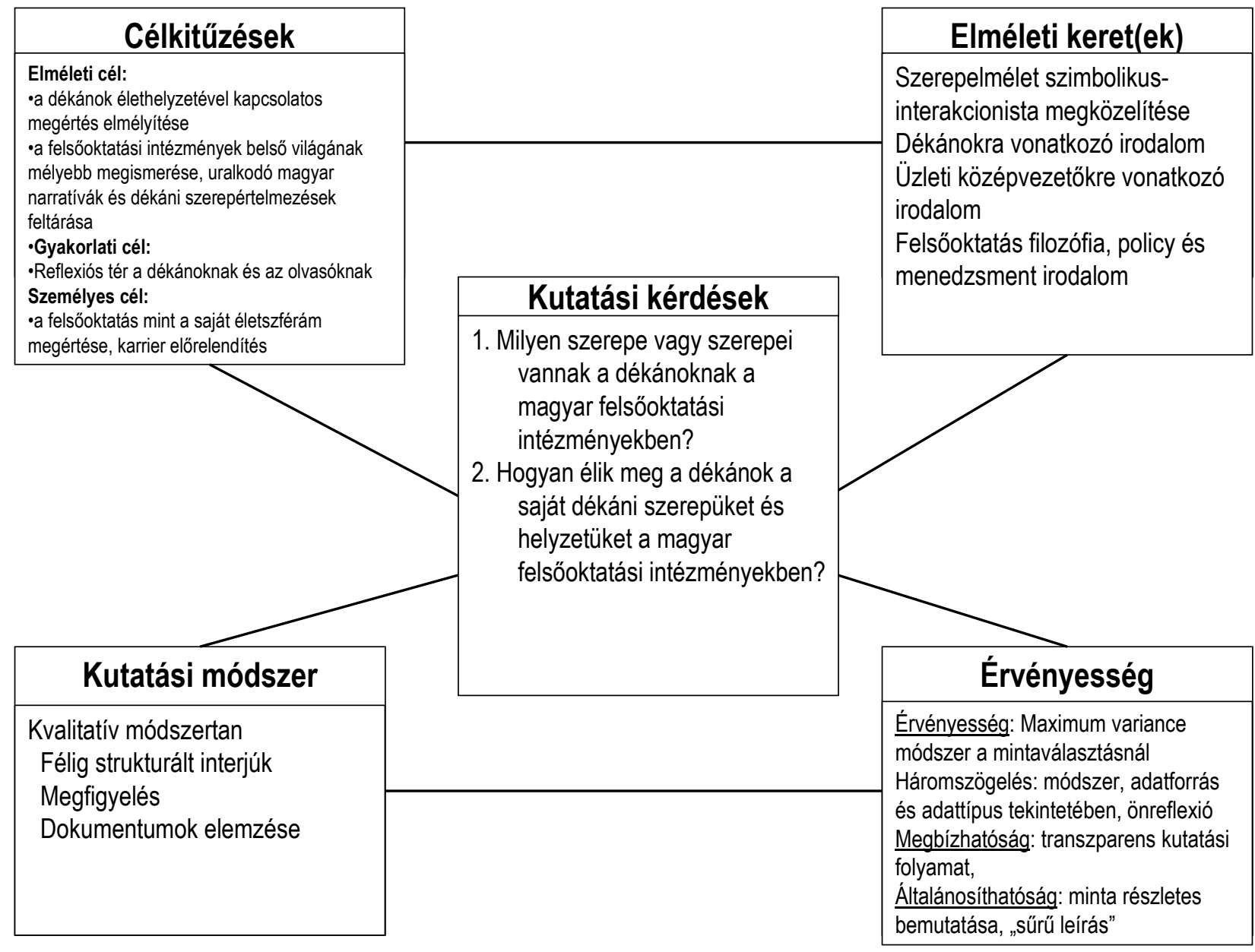

Forrás: Maxwell [1996] 5.o. adaptálásával 


\subsection{A kutatás célkitüzései}

Maxwell háromféle cél tisztázását javasolja: a kutatási célokét, a gyakorlati célokét és a személyes célokét (Maxwell [1996] 15.0.).

A kutatási vagy teoretikus célok valaminek a megértésére irányulnak, ezért az elméleti, koncepcióbeli újdonságra helyezik a hangsúlyt. Milyen újszerü ismeretre szeretnék tehát szert tenni a kutatás révén?

A kutatás teoretikus célja, hogy a dékán vizsgálatán keresztül bepillantást nyerjünk a magyar felsőoktatási intézmények belső világába, müködésébe, dilemmáiba és jellemző narratíváiba, mert a rendszerváltás utáni magyar felsőoktatás-kutatásból, úgy vélem, jobbára hiányoznak a tényleges intézményi gyakorlatot feltáró mikroszociológiai empirikus kutatások (kivételként emlithető például Hrubos [2004a]). Ez a cél e kutatásban a dékán sajátos pozíciójának, élethelyzetének, konfliktusainak megértése révén teljesithető.

A kutatás a dékáni szerepek megragadására irányul. A kutatás célja, hogy az interjúk révén az elméleti összefoglalóban megfogalmazott szerepeket, narrativákat megtöltsem élő tartalommal, és ezáltal mélyebb értelmezését adjam a pusztán a szakirodalomból levezetett absztrakt koncepcióknak. Ennek révén a kutatás keretében azt is megvizsgálom, hogy a szakirodalomból levezetett szerepértelmezésekhez képest - legalábbis a magyar felsőoktatásban készülő interjúk alapján - hol vannak eltérések, értelmezési nehézségek, pontatlanságok, dilemmák, azaz lehetővé válik az eredeti szerepértelmezések pontositása, elmélyitése, szükség esetén úiraértelmezése.

A kutatásnak nem célja a statisztikai reprezentativitás. Ehelyett inkább olyan mintázatok feltárására, megragadására törekszem, amely jól jellemzi egyfelöl a pozíció sokféleségét, másfelöl azokat a kérdéseket, dilemmákat, amelyek e pozícióban jellemzően felmerülnek. Éppúgy keresem tehát a tipikus mintázatokat, mint az atipikusakat.

A kutatás gyakorlati céljául olyan célok szolgálnak, amelyeket a kutatás segítségével el szeretnénk érni. Úgy vélem, hogy Magyarországon hiányoznak azok az intézményesített mechanizmusok, amelyek a tapasztalatok átadását, a dékánok tanulását és önreflexióját segítenék elö. Ennek következtében „minden vezetőnek nulláról kell magát felépítenie”, ahogy Setényi János fogalmazott egy konferencián (Setényi [2008]). Ennek okát nem csak a dékánokat tömöritő szervezetek és a formalizált képzések, hanem a rájuk vonatkozó kutatások hiányában is látom. A kutatás ezt kívánja a lehetőségekhez képest ellensúlyozni két módon. Egyrészt az eredményei révén hozzáférhetővé és megélhetővé teszi a dékáni tapasztalatokat mások számára is. Másrészt a kutatási folyamat maga is olyan alkalom, amelyben a dékánok saját tevékenységükre, müködésükre reflektálhatnak. A dékánok fejlesztése azonban nem célja a kutatásnak, tehát nem akciókutatásról van szó. Ennek rögzitése elsősorban a saját kutatói szerepem tisztázása szempontjából lényeges (lásd később.)

A kutatás személyes célját jól világítja meg Kozma Tamás egy észrevétele, mely szerint „a felsőoktatás kutatása olyan »tudomány«, amelyet föleg azok müvelnek, akikről szól.” (Kozma [2004] 13.o.). A kutatás személyes célját tehát az adja, hogy az rólam is szól, mert a felsőoktatás világa nem csak egy távoli kutatási tér a számomra, hanem a mindennapi életterem is. Ebböl adódóan a kutatás során olyan megértésre törekszem, amely a saját személyes életemben is segitségemre van. 


\subsection{A kutatás elméleti kerete}

A kutatás elméleti keretét a szerepelmélet szimbolikus interakcionista megközelítése jelenti, amelyet a 2. fejezetben részleteztem. A tartalmi csomópontokat a disszertáció 3-5. fejezetei tartalmazzák.

\subsection{A kutatás kérdései}

A tézis bevezetőjében már ismertettem a kutatás két kérdését, amelyek így hangoztak: Milyen szerepe vagy szerepei vannak a dékánoknak a felsőoktatási intézményekben? Hogyan élik meg a dékánok a saját dékáni szerepüket és helyzetüket a felsőoktatási intézményekben? $\mathrm{E}$ kérdések empirikus vizsgálatára a magyar felsőoktatási intézményekben kerül sor, ezért az empirikus kutatás fő kérdései a következőképpen hangoznak:

1. Milyen szerepe vagy szerepei vannak a dékánoknak a magyar felsőoktatási intézményekben?

2. Hogyan élik meg a dékánok a saját dékáni szerepüket és helyzetüket a magyar felsőoktatási intézményekben?

A dékánok szerepére és tapasztalataira vonatkozó empirikus források hiánya miatt a kutatás feltáró kutatás, amelynek célja a „dékánság” megértése, és a dékán szerepére vonatkozó koncepció mélyítése. Ez egybevág a "grounded theory” logikájával, amelyben az elmélet (a dékánok szerepei, azok szervezeti beágyazódása és változása) az empirikus adatgyűjtéssel együtt fejlődik (Glaser-Strauss [1967], idézi Maxwell [1996] 33.o.). Ebből adódóan hipotézisek megfogalmazására a kutatás során sem került sor. Ehelyett az alábbiakban a kutatási kérdéseket megpróbálom részletezni, „operacionalizálni”, azaz olyan témakörökre lebontani, amelyek révén a kiinduló kutatási kérdések a hétköznapi élet szintjén megragadhatóak. A kutatás kérdéseire tehát az alábbi kérdések megválaszolásán keresztül próbálok majd választ találni:

- Milyen (szerep)elvárások érvényesülnek a dékánokkal szemben a magyar felsőoktatásban?

- Kiket választanak dékánná? Milyen formális és informális kritériumoknak kell a dékánoknak megfelelniük a kiválasztási eljárás során?

- Milyen elvárásokat támasztanak a különböző szereplők a dékánokkal szemben?

- Melyek a dékánok saját szerepértelmezései? Mit jelent dékánnak lenni?

- Miért és hogyan lesz valaki dékán? Milyen előnyök és hátrányok fogalmazódnak meg a dékánsággal szemben? Milyen alkalmazkodási stratégiák vannak?

- Milyen a dékánok vezetői önképe? Milyen témákról beszélnek sokat, és milyenekről nem? Kik a lényeges szereplők számukra (Kikről 
beszélnek sokat), és kik nem? Milyen konfliktusokat észlelnek (egyáltalán: mit tekintenek konfliktusnak)? Hogyan élik meg szerepüket mint középvezetők?

- Milyen szervezeti narratívái vannak a dékánoknak? Milyen metaforákat fogalmaznak meg?

\subsection{A kutatás módszertana}

A kutatás feltáró jellege és az elméleti keretül választott szimbolikus-interakcionista megközelítés is elsősorban kvalitatív kutatási technikák és adatgyüjtési eljárások alkalmazását indokolja. Ennek megfelelően az elsődleges adatgyüjtési módszerem a félig strukturált interjú. Az ezek alapján megfogalmazott következtetések érvényességét és megbízhatóságát azonban kiegészitő információk gyüjtésével célszerű árnyalni (trianguláció), amelyet jelen kutatásban a dokumentumelemzés, a megfigyelés, valamint a statisztikai adatgyüjtés jelenti.

\subsubsection{Dokumentumelemzés, statisztikai adatgyüjtés}

A kutatás fentebb vázolt kérdéseire egyfelől a dékánokra és karokra vonatkozó általános adatgyüjtésből kerestem választ. A dékánok formális pozíciójának és a karok helyzetének megértéséhez megvizsgáltam a rendszerváltás óta érvényes felsőoktatási törvényeket és fontosabb rendeleteket, valamint 2011-ben és 2012-ben áttekintettem az összes állami intézmény SZMSZ-ét és helyenként a foglalkoztatási szabályzatokat, illetve tanulmányoztam az intézményi honlapokat. További adatgyüjtésre 2010 augusztusában került sor, amelynek során rendszereztem a Magyarországon működő 150 karra és dékánra vonatkozó legfontosabb statisztikákat, áttekintettem a karok honlapjait és megvizsgáltam a dékánok önéletrajzát. 43

A dokumentumelemzés és a statisztikai adatok gyüjtése nem csak kiegészítő módszertanként volt lényeges, hanem azért is, mert az az interjúkkal végzett adatgyüjtés fontos előkészületét jelentették.

\subsubsection{Félig strukturált interjúk}

A kutatásban az elemzés egységét a dékánság intézménye, azaz a dékáni pozíció, az ahhoz kapcsolódó elvárások (azaz a szerepek) és azok megélése jelenti. Az erre vonatkozó adatok adatgyüjtésének alapvető eszköze a félig strukturált interjú (Kvale [2005]), amely jó eszköz a jellemző szerepértelmezéseknek, a szerep megélésének és az érvényes egyetemi narratíváknak

${ }^{43}$ A karokon dolgozó oktatók és hallgatók létszámára vonatkozó adatok forrása az OKM (NEFMI) 2008-as felsőoktatási adatbázisa volt (az adatfeldolgozás során - 2010 augusztusa - ezek voltak a legfrissebb elérhető adatok). Ezeket az egyes karok honlapján, illetve az ott elérhető dokumentumokban fellelhető adatokkal egészítettem ki. A dékánokról részben a kari és a tanszéki oldalakon szereplö adatokat, önéletrajzokat használtam fel, részben pedig más nyilvános adatbázisban elérhető önéletrajzi adatokat (például a születési dátumokat a www.doktori.hu oldal adataiból egészítettem ki).

A karokra vonatkozóan egy további adatgyüjtésre is sor került, melynek során a karok SZMSZ-eit és organogramjait gyüjtöttük össze (ebben köszönöm a segítséget Horváth Ákosnak). 
a megragadására. Az interjúk elemzése a vallott értékek mellett lehetővé teszi a kevésbé tudatos, követett értékek feltárását, valamint a mögöttes jelentések megfigyelését is.

Az adatok elsődleges forrásául maguk a dékánok szolgálhatnak, ezért a mintaválasztás kérdését a velük készülő interjúk szmepontjából fogalmaztam meg. A kvantitatív kutatástól eltérően a kvalitatív kutatásban célszerü (és nem véletlenszerü) mintaválasztás történik annak érdekében, hogy a kutató olyan eseteket tudjon tanulmányozni, amely a vizsgálat tárgya szempontjából információban gazdag (Jones, Torres et al. [2006] 66.0.). A kvalitatív mintavétel így a következőképpen jellemezhető (Miles - Huberman [1994] 27.o.; Gelei [2002] 169-170.0.):

- kis minta és kontextusba való beágyazottság (szemben a nagy mintával és a kontextus figyelmen kívül hagyásával);

- szándékosan, célirányosan megválasztott minta (szemben a véletlen mintavétellel);

- az elmélet alapján megválasztott minta (szemben a reprezentativitással);

- folyamatosan, lépésről lépésre kialakuló minta (szemben az előre definiált mintával).

A magyar felsőoktatásban az interjús kutatás kezdetén (2010 júniusában) 150 dékán volt. A mintaválasztás során elsősorban a maximális különbözőség (maximum variance) biztosítására törekedtem (Miles - Huberman [1994] 28.o.), mert úgy gondoltam, hogy a nagyon különböző élethelyzetben lévő dékánok vizsgálata lehetővé teszi a szerepek és tapasztalatok variációjának dokumentálását, ugyanakkor a közös mintázatok azonosítását is. Emellett azonban praktikus (kényelmi) szempontokat is szem előtt tartottam, azaz csak néhány, jól megválasztott intézmény dékánját kerestem meg, hogy az interjúkat lehetőleg koncentráltan tudjam elkészíteni.

A különbözőség érvényesítése érdekében a mintaválasztás során törekedtem az alábbi szempontok figyelembe vételére:

- lehetőleg sokféle diszciplináris háttérü kart képviseljenek (lásd Becher - Trowler [2001], illetve a töredezettség fejezetben írtakat),

- mind az egyetemekről, mind a főiskolákról kerüljenek ki interjúalanyok (intézmény típusa), a fővárosból éppúgy, mint vidékröl (intézmény helyszíne),

- állami, egyházi és magánintézményi fenntartó által működtetett intézmény dékánjait is megkérdezzem (fenntartó),

- figyelembe vegyem a kar múltját, azaz új alapítású, intézményi integráción áteső karok, illetve történelmi karok dékánjai is bekerüljenek a mintába,

- minthogy a felsőoktatás a nők szempontjából meglehetősen zárt pálya, éppen ezért törekedtem minél több női dékán megkérdezésére (nem),

- a fiatal és idős dékánok esetenként másként szocializálódhattak, más motivációs profillal rendelkezhettek, ezért törekedtem arra, hogy fiatal és idős dékánok is bekerüljenek a profilba, és végül

- törekedtem arra, hogy a pozíciót régóta betöltő és oda újonnan került vezető is bekerüljön a mintába (vezetőként eltöltött idő).

A kiválasztott intézményekben az aktív dékánok mellett a megkerestem olyan volt dékánokat is, akik a megkeresést megelőző évben fejezték be a dékánságot, és akik egy másféle, már reflektáltabb pozícióból tudták megfogalmazni véleményüket. A dékáni szerep konstruálásában a dékánok szereppartnerei is részt vesznek, akik közül az intézményi 
felsővezetőket vontam be a kutatásba. Velük elsősorban az intézményi kontextus és a dékánokkal szembeni elvárások jobb megértése érdekében készítettem interjúkat.

Végül összesen 12 intézmény dékánja és felsővezetője közül 58 főt keresetem meg levélben, amelyhez mellékeltem a kutatás témájának és céljainak rövid, háromoldalas összefoglalását. Közülük hét felsőoktatási intézmény 30 (hivatalban lévő, éppen leköszönő vagy leendő) dékánjával és 8 felsővezetőjével készítettem interjút. A felsővezetők egy része korábban dékánként szolgált, őket elsősorban felsővezetői szerepükben szólítottam meg. Az interjúkra két kivétellel az interjúalanyok munkahelyén került sor, a fennmaradó két esetben pedig a Budapesti Corvinus Egyetemen.

Az interjúkat három körben készítettem el: 2010 júliusában, 2010 novemberében és decemberében, valamint 2011 áprilisa és májusa között. Az interjúalanyok megoszlása röviden az alábbi volt:

- A dékánok megoszlása: 25 fő aktív dékán, 3 fő volt dékán, 1 fő megbízott dékán (dékánhelyettes), 1 fő leendő dékán. 21 interjúalanyom férfi, 9 interjúalanyom nő volt.

- Az aktív dékánok megoszlása életkor szerint (az interjú időpontjában vett életkor): 9 fő 60 év fölött, 10 fö 51 és 60 év között, 5 fö 50 év vagy az alatt (1 föröl nincs információ). A hivatalban eltöltött idő szerint: 6 fö 0-3 év, 13 fő 4-6 év, 6 fő 6 évnél több.

- Az elsősorban felsővezetői minőségükben megkérdezett interjúalanyok megoszlása a következő volt: 1 rektor, 1 volt rektor, 2 stratégiai rektorhelyettes, 2 gazdasági főigazgató, 1 gazdasági főigazgató-helyettes, 1 főtitkár. A 8 felsővezető közül egy volt nő.

- Az interjúalanyok hét intézményben dolgoztak, ebböl 4 egyetem, 3 pedig föiskola volt. Az interjúalanyok közül 25 fő egyetemen dolgozott, 13 fő föiskolán.

- 9 interjú budapesti, 29 interjú vidéki intézményben készült. Érdekességképpen megemlíthető, hogy a budapesti interjúalanyok körülbelül kétharmada elutasította a megkeresésemet, a vidéki interjúalanyok ugyanakkor 90\%-ban pozitívan reagáltak az interjúra való felkérésre.

- Minden vizsgálatba bevont intézmény állami intézmény volt. 1-1 egyházi és alapítványi fenntartású intézmény vezetőit is megkerestem, de egyetlen interjúalany sem vállalkozott a beszélgetésre.

- A 30 dékán által képviselt kar tudományterületi megoszlása a következő volt: 8 kar gazdálkodástudomány/társadalomtudomány, 5 kar műszaki/informatika, 2 kar agrártudomány, 2 kar természettudomány, 5 kar pedagógia, 3 kar bölcsésztudomány, 2 kar jog, 3 kar egészségügyi terület.

Röviden az interjúk menetéről. Az interjúk előtt áttekintettem az intézmény és a kar honlapját, intézményfejlesztési tervét, akkreditációs anyagait, legfontosabb statisztikáit, a kari tanácsok napirendjeit és a kari hírleveleket (ha elérhetőek voltak), valamint a dékánról elérhető információkat (önéletrajz, publikációs jegyzék). Ennek célja az volt, hogy képet kapjak a kar múltjáról, intézményen belüli súlyáról és helyzetéről, a kart érintő tendenciákról, valamint az aktuális kérdésekről. A legfontosabb jellemzőket és kérdéseket karonként egy-egy adatlapon 
foglaltam össze. Az interjúk alatt és után jegyzeteket készítettem, amelyben rögzítettem az interjú körülményeit, a helyszínnel és az interjúval kapcsolatos megfigyeléseimet és benyomásaimat.

$A z$ interjúkhoz előzetes interjúvázlatot készítettem (ezt az első interjúkör után átdolgoztam, az átdolgozott interjúvázlatot lásd a mellékletben), amely alapján az interjúkat 90 100 percre terveztem. A dékánok ennél jellemzően kevesebb időt tudtak a beszélgetésre szánni. Az interjúk átlagosan 60-75 percig tartottak. A legrövidebb interjú 35 percig tartott, a leghosszabb három óráig. A rövidebb idő következtében végül bizonyos eredetileg tervezett témák vagy háttérbe szorultak, vagy nem minden beszélgetésben kerültek elő. Az interjúk során nem az interjúvázlat „lekérdezésére” törekedtem, hanem arra, hogy a legfontosabb területekröl mindenképpen beszéljen az interjúalany. Az interjú elején egy-két általánosabb kérdést feltéve igyekeztem minél többet beszélni hagyni az interjúalanyokat, majd az általa elmondottakból építkezve, azokra visszakérdezve igyekeztem továbbvinni a beszélgetést.

Az interjúalanyok túlnyomó többsége nagy kedvvel válaszolt a kérdéseimre, s úgy tünt, örömmel beszélnek dékáni tapasztalataikról. Többen megjegyezték, hogy még sohasem kérdezték erről őket. A beszélgetések jó hangulatúak voltak, és számos esetben fordult elő, hogy az interjú elején rögzített időkeretet jelentősen túlléptük, vagy az interjúalany az interjú fomális lezárását követően még hosszan mesélt élményeiröl.

$\mathrm{Az}$ interjús kutatások esetében különösen fontos szerepe van a bizalom megteremtésének. Ennek érdekében a következő lépéseket tettem:

- Az interjúalanyoknak a felkéréssel együtt elküldtem egy a kutatás célját és hátterét összefoglaló háromoldalas dokumentumot, amelyet többen el is olvastak.

- A felkéréssel egyidejüleg jeleztem a kutatás anonim jellegét, azaz azt, hogy az interjúkat csak olyan módon használom fel, hogy abból ne lehessen következtetni az intézményre, karra vagy az interjúalany személyére.

- A kutatás céljáról, az eredmények felhasználásáról az interjú elején ismételten tájékoztattam minden interjúalanyt.

- Noha az összes interjút - előzetes engedélykérés után - diktafonnal rögzítettem, a kényesebbnek gondolt témáknál mindig felajánlottam a diktafon lekapcsolását, amellyel többen éltek is.

- Az interjúalanyoknak felajánlottam a kutatás eredményeinek (magának a disszertációnak) a megosztását.

- Egyetlen esetben kérésként felmerült a felhasznált interjúrészletek előzetes véleményeztetése, ennek oka azonban nem a bizalmatlanság volt, hanem inkább az interjús módszer idegensége.

\subsubsection{Tervezett, de nem alkalmazott adatgyüjtési módszerek}

Noha előzetesen terveztem, a kutatásban végül nem került sor kérdőíves vizsgálatra, és a felsővezetőkön kívül más érintetteket sem kérdeztem meg a dékán szereppartnerei közül. Ezek elmaradásának egyik oka az volt, hogy az összegyüjtött adatok mennyiségét nem akartam újabb interjúkkal, kérdőívekkel tovább növelni, mert kellő mélységben az újabb adatokat már nem tudtam volna feldolgozni. További ok volt, hogy a kutatás célja a meglévő modell magyarországi kontextusban történő mélyítése és pontositása volt, ehhez pedig elégségesnek éreztem a megkérdezett kört. 
Lehetőségként szintén szóba került esettanulmányok készítése is. Erről végül azért tettem le, mert fontosabbnak tartottam, hogy több különböző intézményben dolgozó, vagy különböző helyzetben lévő dékánt is megkérdezzek (a maximális különbözőség elérése miatt), mint azt, hogy egy vagy két intézményben járjam alaposabban körül a dékáni szerepeket. Ez indokolta végül azt is, hogy az eredetileg tervezett 12-15 interjú helyett 30 dékáni interjú készüljön, mert csak ennyi interjú révén volt biztosítható az interjúalanyok sokszínűsége (és ekkor értem el a szaturációs pontot44). Ebből az is következik, hogy a kutatási módszertan miatt a hangsúly a dékánok saját szerep- és szervezetértelmezésére, annak tartalmára helyeződött, s nem a többi szereplő elvárásaira. Ezt a dékánságot szabályozó intézmények és gyakorlatok részletesebb elemzésével, illetve a felsővezetői interjúkkal igyekeztem ellensúlyozni.

\subsubsection{Az adatok elemzése}

A mintegy 44 órányi beszélgetésből szó szerinti átirat készült, amelynek terjedelme 700 oldalt (körülbelül 2 millió karaktert) tett ki ${ }^{45}$. Az átírás során a helyzet minél pontosabb visszaadása érdekében rögzítettük az interjúalany hosszabb szüneteit, érzelmi megnyilvánulásait (pl. nevetés), a kitöltő hangokat (pl. ööö-zés).

Az interjúk feldolgozása Nvivo szoftverrel, több körben történt. Az első körben 4-5 interjút kódoltam nyillt kódolási módszerrel (Strauss - Corbin [1990]), ez alapján, valamint az eredeti interjúkérdések és a kiinduló szerepmodellek alapján hoztam létre egy előre rögzített, hierarchikus kódrendszert (ez megtekinthető a mellékletben). Ennek segítségével kódoltam az összes interjút. Ezt követően a tapasztalatok fényében felülvizsgáltam a kódrendszert és szükség szerint újrakódoltam az interjúkat. Az elemzéseket az újrakódolt interjúk alapján végeztem el.

Az elemzés során igyekeztem azonosítani azokat a témaköröket, amelyek több interjúalanynák is megfigyelhetőek voltak, és ezek alapján próbáltam új dilemmákat és tipológiákat megfogalmazni. Emellett megkíséreltem minden interjúalany viszonyát meghatározni a 4.3.3-as fejezetben bemutatott kiinduló szerepmodellhez, azaz olyan megnyilatkozásokat kerestem az interjúkban, amelyek az adott dékán a hős, a szolgáltató, a katalizátor és a stratégiai játékos szerepekhez kötik. Ennek segítségével nemmcsak kontextusba helyeztem a szakirodalom áttekintésével létrehozott modellt, hanem bizonyos elemeit újra is tudtam fogalmazni.

A kutatás hitelességének növelése érdekében az eredmények bemutatása során a felmerült értelmezéseket, mintázatokat az interjúalanyok saját szavaival fogom alátámasztani, illusztrálni. $A z$ idézett interjúrészleteket egyrészt a könnyebb olvashatóság, másrészt az anonimitás ígérete miatt szerkesztettem. Ennek során az anonimitást sértő részeket kihagytam vagy megváltoztattam, és az élőbeszéd nyelvi pongyolaságait, ismétléseit pedig elhagytam. Minden esetben ügyeltem arra, hogy az interjúk jelentéstartalma a szerkesztés folyamán ne változzon.

\footnotetext{
${ }^{44}$ Az elméleti szaturációs pont olyan mintaválasztási stratégiát takar, amelyben addig keresnek újabb és újabb alanyokat, amíg már nem merül fel új, lényeges információ, és a minták ismétlődnek (Strauss 1987, idézi Maxwell [1996] 133.0.).

${ }^{45} \mathrm{E}$ helyütt szeretnék köszönetet mondani Ladencsics Virágnak, aki interjúk gépelését végezte.
} 
Az interjúalanyoknak anonimitást ígértem, ezért az idézett interjúrészleteknél nem tüntetem fel sem az intézmény, sem pedig az interjúalany azon jellemzőit, amely alapján beazonosíthatóak lennének. Az interjúalanyokat kódokkal szerepeltetem, a dékánoktól származó idézeteket „D”, a felsővezetői idézeteket „F” kódjellel és azonosító számmal láttam el.

\subsection{A kutatás érvényessége, megbízhatósága és \\ általánosíthatósága}

Mint minden kutatásnál, így a kvalitatív kutatásnál is szükséges tisztázni a kutatás „jóságát” meghatározó kritériumokat. A hagyományos, pozitivista orientáltságú kutatások az érvényesség, megbízhatóság és az általánosíthatóság kategóriával ragadják meg és biztosítják a kutatás eredményeinek tudományosságát. A szimbolikus-interakcionista (interpretatív) értelmezés azonban a saját módszertanának megfelelően értelmezi újra e fogalmakat (lásd a 11. táblázatot).

11. táblázat: Az érvényesség, megbízhatóság és általánosíthatóság értelmezés

\begin{tabular}{|l|l|l|}
\hline & $\begin{array}{l}\text { Hagyományos / pozitivista } \\
\text { Felfogás }\end{array}$ & $\begin{array}{l}\text { Interpretatív / kvalitatív } \\
\text { Felfogás }\end{array}$ \\
\hline Érvényesség & $\begin{array}{l}\text { A mérőeszköz azt méri, amit mérnie } \\
\text { kell? }\end{array}$ & $\begin{array}{l}\text { A kutató a lehető legalaposabban } \\
\text { feltárta és megismerte a helyi tudást és } \\
\text { jelentéseket? }\end{array}$ \\
\hline Megbízhatóság & $\begin{array}{l}\text { A mérés ugyanezeket az } \\
\text { eredményeket biztosítaná más } \\
\text { alkalmakkor is (feltételezve a mérés } \\
\text { „tárgyának” változatlanságát)? }\end{array}$ & $\begin{array}{l}\text { Más kutatók más alkalmakkor hasonló } \\
\text { megfigyeléseket tennének? }\end{array}$ \\
\hline $\begin{array}{l}\text { Általánosítha- } \\
\text { tóság }\end{array}$ & $\begin{array}{l}\text { Mi a (statisztikai) valószínüsége } \\
\text { annak, hogy a minta azonosított } \\
\text { jellemzői a tágabb populációban is } \\
\text { érvényesülnek? }\end{array}$ & $\begin{array}{l}\text { Mennyire valószínű, hogy az adott } \\
\text { kontextusból eredő felismerések és } \\
\text { elméletek alkalmazhatók más } \\
\text { kontextusokra is? }\end{array}$ \\
\hline
\end{tabular}

Forrás: Easterby-Smith et al., [1993], idézi Gelei [2002] 189.0.

Az érvényesség - amelyet autentikusságnak, hitelességnek és belső általánosíthatóságnak is lehet nevezni (lásd Miles - Huberman [1994]) - alapvetően „egy leírás, következtetés, magyarázat, értelmezés vagy másféle beszámoló helyességét vagy hihetőségét" (Maxwell [1996]) takarja. Ennek érvényesülését két tényező nehezíti: egyrészt a kutató torzító, reflektálatlan szubjektivitása, másrészt pedig a kutató terepre gyakorolt nem tudatosított, nem szándékolt hatása (például megfelelési szándékot vált ki az interjúalanyból). A kutató előfeltevései és terepre gyakorolt hatása azonban minden kutatási folyamat része, éppen ezért ezek kiküszöbölése nem lehetséges. Ehelyett a tudatosításukra van szükség, ami folyamatos kutatói önreflexiót igényel (Gelei [2002]). Fontos megemlíteni, hogy az empirikus kutatás olyan terepen zajlik, amely oktatóként, kutatóként, gyakorlati szakemberként is része a mindennapi életemnek. Ez egyfelől előny, hiszen mélyebb ismeretem van a magyar felsőoktatásról, mintha idegen kutatási terepen kellene dolgoznom. Ugyanakkor az is valószínü, hogy számos rejtett, nem tudatos előfeltevésem van a felsőoktatási rendszer müködésével kapcsolatban, amely az 
adatok értelmezését és így a kutatás érvényességét befolyásolja. A torzitó szubjektivitás kiküszöbölésére szükséges valamilyen önreflexiót elősegítő technika alkalmazása, amely lehetővé teszi, hogy a kutatás előtt és alatt saját előfeltevéseimet feltárjam és tudatosítsam. Erre a kutatási napló (Gelei [2002]) írását végeztem, azaz folyamatosan rögzítettem reflexióimat az interjúzás és az adatok elemzése során is.

A torzító hatások további módszerek segítségével is kiküszöbölhetőek, amelyek közül törekedtem (Maxwell [1996]; lásd még Miles - Huberman [1994] 266.o.)

- az ellentmondó adatok és esetek tudatos keresésére, amellyel csökkenthető a megalapozatlan, következtetések levonásának esélye, valamint a

- triangulációra, azaz egy-egy jelenségre vonatkozóan többféle módon, többféle forrásból, többféle fajta adatot is gyüjtöttem (statisztikai adatok, dokumentumelemzés, interjú, illetve dékáni/felsővezetői megnyilatkozások).

Maxwell további validitást erősítő módszerként említi még a gazdag adatok gyűjtését és elemzését, így azt, hogy ne csak jegyzeteljünk, hanem interjúátiratokkal dolgozzunk (így tettem), illetve „kvázi-statisztikák” készítését, amelyek segítségével vizsgálható az események, megfigyelt jelenségek előfordulási gyakorisága (ezekre később még utalni fogok). Ez szintén elősegítheti az érvényes következtetések levonását.

A megbizhatóság arra utal, hogy a kutatás folyamata mennyire konzisztens és stabil időben és a kutatók között (ugyanazt találják-e a később vagy a velünk egyidejüleg vizsgálódó kutatók). A megbízhatóságot elősegíti a transzparens és (elviekben) megismételhető kutatási folyamat, illetve ennek szükségszerü kellékei, így a világossá tett kutatói szerep és státusz, az alkalmazott eszközök és paradigmák egyértelműsége, a kutatási kérdés világossága. Emellett a széleskörű adatgyüjtés is segithet (Miles - Huberman [1994] 278.o.; Bokor [2000]; Gelei [2002]). Fontos jelezni, hogy az általam végzett kutatás megbízhatóságát gyengíti a transzparencia részleges hiánya, amely az anonimitás biztosításának következménye.

Az általánosíthatóság arra keresi a választ, hogy a kutatásban megszerzett tapasztalat mennyire mutat túl a vizsgálat közvetlen kontextusán. Az általánosíthatóság vonatkozhat a vizsgálati csoporton belülre (belső általánosíthatóság), vagy ennél általánosabb populációra (külső általánosíthatóság). A kvalitatív kutatások elsősorban az előbbire fókuszálnak (Maxwell [1996]). E kutatás során a maximális különbözőség mintaválasztási módszer érvényesítésével törekedtem arra, hogy az eredmények a magyar felsőoktatáson belül jól általánosithatók legyenek. Úgy gondolom, hogy az eredmények korlátozottan a középvezetőkre vonatkozóan is általánosithatóak.

Emellett az általánosíthatóságot igyekeztem elősegíteni a minta jellemzőinek részletes bemutatásával (lásd később a statisztikai adatok elemzését) annak érdekében, hogy más vizsgálatok mintáival összevethetők legyenek. Az általánosíthatóságot fokozó további eszközként a dékáni szerepértelmezéseket, dilemmákat és konfliktusokat olyan részletes, „sürü leírásokkal” is igyekszem alátámasztani, amelyek révén az olvasó azonosithatja a saját helyzetével egyező feltételeket. Ez amúgy elengedhetetlen feltétele a kutatás praktikus céljának is, azaz annak, hogy a kutatás elősegítse a dékánok és más felsőoktatási szereplők önreflexióját is. $A z$ általánosithatóság lehetőségéhez járul hozzá a folyamatok és azok eredményeinek általános leírása, valamint az általánosítható elmélet(ek) explicitté tétele is (Miles - Huberman [1994]; Bokor [2000]). 


\section{A kontextus: a magyar felsőoktatás átalakulása}

E fejezetben nagy vonalakban áttekintem a magyar felsőoktatás rendszerváltozás utáni alakulását elsősorban a karok és a dékánok nézőpontjából. Noha egy teljes egészében interpretatív kutatás esetében a kontextus bemutatása is kizárólag belső nézőpontból (azaz az interjúalanyok megfogalmazásában és szemszögéböl) történne, én mégis domináns módon külső nézőpontból, azaz a szakirodalom, statisztikai adatgyüjtések és más interjúk alapján elemzem a lényegesnek tartott tényezöket. Ennek oka, hogy a kutatás interjúkra épülö része nem elsősorban a tágabb kontextus vizsgálatára irányult, ezért az ebböl nyert nézőpontok csak igen töredékesek. Annak érdekében azonban, hogy egyrészt átfogóbb képünk legyen a dékánok müködésének környezetéröl, másrészt meg tudjuk ítélni a magyar felsőoktatásra vonatkozó kutatási kérdések relevanciáját, szükségesnek láttam, hogy megismerjük a karok helyzetét meghatározó tágabb (rendszer szintü) és szükebb (intézményi szintü) kontextuális elemeket, valamint a karokat jellemző trendeket. Az elemzés az 1985 és 2011 közötti időszakra vonatkozik, különös tekintettel az interjúk készitésének időpontjában - azaz 2010-ben és 2011-ben - érvényes helyzetre. Az elemzésben csak érintőlegesen térek ki a 2011 utáni időszakra. A változásokat az alábbi négy témakör mentén mutatom be: az állam és a felsőoktatási rendszer közötti kapcsolat ellentmondásai, a tömegesedés, az intézményszerkezet és az intézményi struktúra változása, valamint a gazdálkodási és finanszírozás kérdéseinek alakulása.

\subsection{Az állam és a felsőoktatás viszonyának változása}

Az interjúkban a felsőoktatás kontextusát a dékánok és felsővezetők egyöntetủ véleménye szerint a szabályozás képlékenysége és kiszámíthatatlansága jellemezte.

„A felsőoktatást ugye most már 20 éve reformálják. Szerintem egy picit magára kéne hagyni, de ez az én gondolatom. (interjúalany mosolyog) Lehet, hogy több haszonnal bírna a társadalom számára, mint hogy állandóan mesterségesen átformáljuk. De most újra, ami át fogja rajzolni megint a versenynek a térképét, ott meg észnél kell lennünk." (D26)

„És még rosszabb az, hogy nem elég, hogy változik, hanem bizonyos értelemben jogbizonytalanság állott elő azzal, hogy a törvények még visszamenőleg is kezdenek érvényessé válni. Tehát ez évek óta így van. Ami számomra döbbenetes volt: az első olyan jelzés, hogy hü, itt komoly problémák is fölmerülhetnek, amikor az éven belül az adózási törvényt, az adózási szabályokat megváltoztattuk, vagy megváltoztatták kormányzati szinten. Egy éven belül. Tehát máshogy kezdtem el adózni az év elején, mint ahogy el kellett számolni az év végén. Ennél szörnyübb dolgot én nem tudok elképzelni, meg kell hogy mondjam. Szóval ez a jogbiztonságba vetett hitét ássa alá az embereknek." (D15)

„Nem könnyü, mert gyakorlatilag a '90-es évek óta ez a folyamatos változás... tehát mindig egy versenyfutás az idővel. [...] az a fajta (kis szünet) stabilitás kellene, hogy most, most olyan 4 
évig tudjuk, hogy mi fog történni. Tehát nekem lehet, hogy túl sok volt a változás, és ezért van bennem ez a fajta igény." (D5)

„A másik az, hogy követhetetlen a makro környezet. Tehát a játékszabályok állandó változása. Az egész egyszerüen nem csak, hogy nagyon fárasztó követni, hanem abszolút, hát nem fair. Ugye? Nézd, hát akkor az ember azt mondja, hogy akkor miért vegyek részt egy olyan játékban, ami nem fair? Hát... Úgyhogy ez mondjuk nagyon-nagyon unalmas, amikor ilyen folyamatos alkalmazkodási kényszerbe hajszolják az embert. Aminek hát vagy megfelel, vagy nem felel meg. A legjobb tudása szerint próbál megfelelni. De hát nehéz, na, nehéz megfelelni." (D10)

„Most rettegünk persze, hogy mi lesz felsőoktatási törvény ugye, hogy most akkor mit mondanak ott a nagyfönökök. Ugye, hogy mit csinál velünk ott. Most összevon, szétvon, szétszed, beszed, leszed, hát óriási károkat tesz, hogy ha például ehhez hozzányúl. Dehát a világ persze ilyen, hogy folyamatosan változik. Hát egyszer úgy kéne persze ebbe egy nyugvás. Tehát egy 10 év nyugalom. Ugye?" (F7)

E nézőpont dominanciája persze nem meglepő, ha figyelembe vesszük, hogy az interjúk 2010-ben és 2011-ben készültek, amikor éppen az új oktatási kormányzat hivatalba lépése és felsőoktatási koncepcióival kapcsolatos ötletelés zajlott. Ugyanakkor persze az is igaz, hogy például 1990 és 2011 között az országnak négy, egymástól jelentősen különböző felsőoktatási törvénye volt, amit számtalan törvénymódositás és különböző kormányrendelet is tovább cizellált.

A folyamatos változás egyik lehetséges oka a közép- és kelet-európai régió egyik meghatározó sajátossága: a torlódás. A rendszerváltást követően mindazok a folyamatok, amelyek a fejlett nyugati országokban 30-40 év alatt fokozatosan zajlottak le, a posztszocialista országokban egy időben indultak meg. Magyarországon is jól megfigyelhető, hogy egyszerre zajlott a felsőoktatás tömegesedése, a finanszírozás és az irányítás átalakítására tett kísérletek, a képzési szerkezet átalakítása stb. (Fábri [2004]; Semjén [2004]; Derényi [2009]; Polónyi [2009a]) E folyamatokra a társadalmi-gazdasági rendszerváltás meglehetősen képlékeny jogi és normatív keretei között került sor, amelynek következtében nem volt igazán lehetőség kiérlelt felsőoktatási koncepciók következetes megvalósítására. Így bár a szabályozási környezetben a változások hamar bekövetkeztek (és gyakran módosultak), a tényleges gyakorlatban sokszor a már megszokott megoldások bizonyulnak iránymutatónak. A felsőoktatási rendszer különböző elemeinek és szintjeinek összecsiszolódása még nem történt meg.

Ennek következtében a közbeszédben számos felsőoktatási narratíva létezik egy időben. Ezek egyike a humboldti eszmék széleskörü újraéledése (amely a közösségi narratívának feleltethető meg). Erre utalva jegyezte meg találóan Scott, hogy „a kommunizmus még akkor is elősegítette a homogenizálódást, miután megszűnt létezni” (Scott [2006] 430.0.) Bár a régió országainak felsőoktatása különböző (részben német, részben francia) gyökerekkel rendelkezik, a szovjet befolyás 40 éve jelentős homogenizációs erőnek bizonyult, amelynek örökségeként a régió országaiban a rendszerváltást követően is jelentős együttmozgás figyelhető meg (Reisz [2003]).

A humboldti eszme középpontjában az oktatás és kutatás szabadsága (és egysége) áll, amelyet az állam a felsőoktatási intézmények autonómiájának és akadémiai szabadságának garantálásával biztosít. Minthogy a kommunista időszakban ezeket - különösen a társadalomtudományi területen - jelentős mértékben korlátozták, ezért a humboldti eszme 
beteljesítése a szovjet modell meghaladását, és sok országban - Magyarországon is - a nemzeti modellhez való visszatérést jelentette.

A humboldti modell legitimitása azonban nem csak e két tényezőböl fakad, hanem abból is, hogy többnyire e modellel azonosították a nyugat-európai egyetemeket is. Ebben gyökerezik az a meggyőződés, hogy az egyetemi autonómia és szabadság intézményesítése szavatolja a közép-európai felsőoktatás modernizációját és felzárkózását a nyugati felsőoktatáshoz (Neave [2003] 25.0.)46. Eközben azonban megfeledkeznek arról, hogy - mint láttuk - az akadémiai szabadság nyugaton is egyre inkább feltételes, azaz nem garantált, hanem újra és újra ki kell harcolni (Henkel [2007] 96.0.). A humboldti modellhez való viszony ezért egészen más a nyugati felsőoktatásban, mint Közép- és Kelet-Európa felsőoktatásában: „Ugyanabban a pillanatban, amikor Közép-Európában a felsőoktatás sikerrel fordul von Humboldt szelleméhez, hogy kiüzze a Párt és a Nómenklatúra démonait, a nyugati kollégáikat összehívják, hogy megszabadítsák őket ugyanezen úriember szellemétől annak érdekében, hogy a felsőoktatásba jobban be tudják fogadni a vállalkozói kultúrát, a menedzserizmust és a pénzvilágot." (Neave [2003] 30.o.) Másként megfogalmazva: a posztszocialista államok egy idealizált, észlelt modell felé törekednek (Reisz [2003]). Nem véletlenül írja Scott, hogy „a humboldti egyetem tisztább formában létezik az Elbától keletre" (Scott [2006] 438.0.).

Eközben a gazdaságban és a társadalom más szféráiban a (neo)liberális gondolkodásmód erőteljesen érvényesült, amelyben átértékelődött az állam szerepe, és nagyobb hangsúly helyeződött az öngondoskodásra és a piaci mechanizmusok szerepének növekedésére. Ez a tendencia retorikailag (pl. a vállalkozó egyetem fogalma révén) és a szabályozásban a felsőoktatásban is megjelent (pl. tandij bevezetési kísérletei, az irányítási rendszer reformja, az alternatív finanszírozási koncepciók megjelenése), noha domináns pozícióra, úgy vélem, nem igazán tudott szert tenni.

Sajátos ambivalens viszony alakul ki tehát az állam felsőoktatásban betöltött szerepével kapcsolatos meggyőződésekben: a posztszovjet örökségből az intézményi autonómia kívánása és az állami beavatkozást elutasítása következik. Az intézményi autonómia ${ }^{47}$ azonban a piaci viszonyok kiszolgáltatottságától való védelmet is kivánja, amelynek épp az állami szabályozás a biztositéka. A magyar felsőoktatásban tehát egyszerre van jelen a gondoskodó állam (és az állami szabályozás) igénye és elutasítása ${ }^{48}$. A humboldti idea paradox módon egyszerre válik „haladó” és a „haladást gátló” eszmévé, mert egyszerre tekinthető a túlcentralizált szovjet modell korrekciójának, de egyben a Nyugat-Európában zajló (egyébként ellentmondásos megítélésű), az intézmények nagyobb társadalmi szerepvállalását elősegítő változási folyamatok akadályának is.

Első megközelítésből tehát rendszerszinten a magyar felsőoktatásban négy nagyobb narratíva látszik kibontakozni:

\footnotetext{
46 Itt most nem érintem az imitáció kérdését, azt a magatartást, amikor formailag átveszünk intézményrendszereket, intézményi megoldásokat (például legitimációs okból), ám azokat ténylegesen nem használjuk.

${ }^{47} \mathrm{Az}$ intézményi autonómia maga is igen sokrétü fogalom, amely az egyes narratívákban másféle értelmet nyer. Ennek dekonstruálására itt nem vállalkozom. Az autonómia kérdéséről részletesen lásd például Barakonyi [2004b] vagy Henkel [2007] írását.

$48 \mathrm{Az}$ állam felsőoktatásban betöltött szerepe Nyugat-Európában is változik, de ott a folyamat nem az állammal szembeni bizalmatlanságban gyökerezik, mint az a közép-európai posztszocialista országokra jellemzö.
} 
- egy modernizálódó-idealizáló-tradícionalista humboldti narratíva, amely a korábban bemutatott közösségi narratíva megfelelöje. Ezt például jól tükrözi az Alkotmánybíróság azon indokolása, amelyet a 2005-ös felsőoktatási törvény irányítótanácsot ${ }^{49}$ felállító passzusainak alkotmányellenessége kapcsán fejtett ki. E szerint az oktatás és kutatás szabadságával ellentétes az, ha egy ilyen testület dönthet az intézmény stratégiájáról, és az csak kizárólag önkormányzati úton, az intézmény tagjaiból választott testület révén biztositható. ${ }^{50}$

- egy állam-ellenes, pragmatikus humboldti (posztszocialista) narratíva, amely az antibürokratizmusban gyökerező, közösségi logikának felel meg. Ez arra irányul, hogy az állam bürokratikus úton nem tud olyan jó döntéseket hozni, mint a döntések következményeit megélő intézmény.

- egy a piacellenességben gyökerező állampárti narratíva, amely a piacot (kockázatot, felelösséget) elutasító, az állam védelmező, szabályozó és irányitó szerepében hivő logikát jelent (bürokratikus narratíva). Ezt példázza az a kutatás, melyben a felsőoktatási intézmények stratégiai tervezési folyamatait vizsgálták a stratégiaalkotásért felelős vezetökkel készült interjúk alapján. A kutatás egyik kérdéseként azt vizsgálták, hogy a stratégiaalkotás folyamatán mit kellene változtatni. A válaszadók egy csoportja szerint „központilag kellene kialakitani egy stratégiai rendszert, illetve annak ellenörzését is. Ez alapján az intézmények jelentős segitséget kapnának, valamint nem csak önmaguk elvárásaihoz tudnának viszonyítani, hanem másik intézményekhez képest is sokkal jobban látnák negativumaikat, illetve sikereiket, erősségeiket." (Lévai [2011] 99.o.).

- egy piacpárti logika, amely az intézmények "nagykorúsitását", felelösségvállalását és cselekvési, gazdálkodási terének bővítését szorgalmazza (vállalati-vállalkozói logika).

A modellek és eszmék egymás mellett élése, egymásba ágyazódása a gyakorlatban olyan hibrid megoldásokat eredményez, mint például a „szuperprofesszorátus” intézménye. A felsőoktatásban uralkodó fokozatok és címek rendszerében egy egyetemi tanári kinevezéshez ma egyszerre kell PhD-val, habilitációval és gyakorlatilag kötelezően MTA doktora címmel rendelkezni (Polónyi [2006]). E tekintetben tehát Magyarországon egyszerre érvényesül az angolszász (PhD), a német (habilitációs) és a szovjet-francia (központi minősités, MTA dominancia) modell azok minden mögöttes cél és jelentéstartalmával együtt (Reszkető - Váradi [2002]; Nagy [2007]).

Fontos probléma, hogy hiányzik a felsőoktatás társadalmi szerepéröl, funkciójáról való többé-kevésbé konszenzusos vízió, $s$ így hiányoznak a felsőoktatással szemben megfogalmazható, és a kormányzat által képviselhető, számon kérhető tartalmi elvárások is. Kétségtelen, a korábbi rendszer ideológiai kontrollja mellett a kormányzat kontrollja és

\footnotetext{
${ }^{49} \mathrm{Az}$ irányítótanács tagjai az egyetemmel munkaviszonyban nem álló tagok, akiket az egyetem, a hallgatók és az oktatási kormányzat delegál oly módon, hogy az oktatási kormányzat által delegált tagok vannak kisebbségben. (Tag még a rektor is.)

50 39/2006. (IX. 27.) AB határozat. Részletes kritikáját lásd Barakonyi [2009a], Barakonyi [2009b]
} 
beavatkozásai igen kényes kérdéssé válnak, talán nem véletlen egyfajta passzivitás is e téren. Maga a felsőoktatás sem tett azonban sokat ezek megfogalmazására, kommunikálására és társadalmi megvitatására (Fábri [2011]). A konszenzusos, kormányokon átívelő és a felsőoktatási rendszer szereplőivel közösen elfogadott meggyőződések hiányában a kormányzat tevékenysége jobbára kétféle magatartásban merül ki: a kormányzati irányítás vagy mikromenedzseléssé válik, vagy pedig az operatív feladatokban nyer teret és értelmet, amelynek során a beszámoltatás bürokratikussá válik, és nincs stratégiai kontroll. Ez utóbbi esetben a kormányzat inkább passzív, operatív müködtetésre és a feltételrendszerre koncentráló policy-t folytatott, azaz az intézmények akár saját stratégiát is követhettek. Ez ugyanakkor nem annyira kényszer, mint inkább lehetőség volt: sem a környezet, sem a szabályozás nem tette szükségszerűvé. A lehetőség kihasználása nagymértékben múlt magukon az intézményeken.

\subsection{A felsőoktatás expanziója és a karokra gyakorolt hatása}

A rendszerváltást követően a magyar felsőoktatás egyik meghatározó történése a hallgatói tömeg növekedése, és ezzel együtt az igények és a képzési programok kínálatának heterogénebbé válása volt.

A magyar felsőoktatásban 1990 óta a hallgatói létszámok megnégyszereződtek, ami elsősorban az „atipikus” (főként az estis és levelezős) képzési forma felfutásának, és kisebb mértékben a nappali képzésben végbemenő növekedésnek köszönhető. A költségtérítéses finanszírozási forma megjelenését követően a költségtérítéses hallgatók száma is fokozatosan növekedett, és a 2000-es évek derekára a hallgatói létszám felét már ők tették ki. A 2004-2006os trendfordulót követően azonban nem csak a költségtérítéses hallgatók aránya indult csökkenésnek, hanem a felsőoktatásba beiratkozott hallgatók száma is, amely a demográfikai hullámvölgy miatt a következő években várhatóan tovább fog csökkenni.

Ugyanakkor sajátos pedagógiai-módszertani és kapacitás-jellegű kihívást jelentett az intézmények és karok számára, hogy a kereslet felfutását az oktatói kapacitások változása csak kis mértékben követte, amit jól mutat, hogy az oktatói állomány alig 30\%-kal növekedett ebben az időszakban (az is főként a részidős oktatói gárdában ment végbe), és az egy hallgatóra eső kiadás is jelentősen csökkent (OECD [2011]). ${ }^{51}$ Az egyik dékán megfogalmazásában:

„És a tetejébe az elit képzési oktatási módszertanok 700 főnél megbuknak. Már 250-nél tapasztaltuk, nem egyszerre lett 700 fö, hanem fokozatosan. 750 főnél már világos volt, hogy így nem lehet, ahogy korábban, azokat a módszereket el kell felejteni, a tömegoktatás módszertanát kellene kidolgozni. Azt kell mondjam, hogy a tömegoktatás módszertana még ma sincs meg. De hát ez nem máról holnapra születik meg. Éppen ezért nagyon erősen kritikával kell fogadni azt a döntést, hogy egy tollvonással egyik évröl a másikra átálttunk országosan [ti. a Bologna képzési rendszerre]. Nagyon sok baj ebböl származik, nem csak a mi

\footnotetext{
51 Árnyalja a képet, hogy a statisztikák figyelmen kivül hagyják a „bedolgozó oktatókat”, tehát a diákmunkaerőt, a demonstrátorokat és a PhD hallgatókat, valamint a rendszeresen meghívott, vagy külsősként részt vevő oktatókat, akik pedig néhány tudományterületen és intézményben igen jelentös szerepet játszottak az átmenetileg szükséges oktatói kapacitások biztositásában. Mindez azt sugallja, hogy az oktatói állomány heterogenitása is növekedett a vizsgált időszakban.
} 
szakterületünkön. A többi szakterületen is, hogy az oktatóknak nem hagytak lehetőséget arra, hogy hozzáigazítsák a módszereiket, ehhez a helyzethez. És ez vezetői szinten is igen komoly feladatokat, meg problémákat generált. Nem csak dékáni szinten, egész egyetemi szinten." (D15)

\section{2. táblázat: A hallgatói és oktatói létszámok alakulása a magyar felsőoktatásban 1990 és 2010 között}

\begin{tabular}{|c|c|c|c|c|}
\hline Tanév & $\begin{array}{c}\text { Hallgatói létszám összesen } \\
\text { (ezer fö) }\end{array}$ & $\begin{array}{c}\text { Ebböl: költségtérítéses } \\
\text { hallgatók száma (ezer fö) }\end{array}$ & $\begin{array}{c}\text { Költségtéritéses } \\
\text { hallgatók aránya (\%) }\end{array}$ & $\begin{array}{c}\text { Oktatók száma } \\
\text { (ezer fö) }\end{array}$ \\
\hline $1990-1991$ & 108,7 & & & 17,3 \\
\hline $1991-1992$ & 119,3 & & & 17,5 \\
\hline $1992-1993$ & 136,0 & & & 17,7 \\
\hline $1993-1994$ & 157,4 & & & 18,7 \\
\hline $1994-1995$ & 179,5 & & & 19,1 \\
\hline $1995-1996$ & 198,9 & 27,9 & $14,0 \%$ & 18,1 \\
\hline $1996-1997$ & 233,7 & 37,4 & $16,0 \%$ & 19,3 \\
\hline $1997-1998$ & 258,1 & 49,9 & $19,3 \%$ & 19,7 \\
\hline $1998-1999$ & 278,6 & 60,9 & $21,9 \%$ & 21,3 \\
\hline $1999-2000$ & 294,0 & 79,4 & $27,0 \%$ & 21,2 \\
\hline $2000-2001$ & 327,3 & 136,5 & $41,7 \%$ & 22,9 \\
\hline $2001-2002$ & 349,3 & 157,1 & $45,0 \%$ & 22,9 \\
\hline $2002-2003$ & 381,6 & 184,0 & $48,2 \%$ & 23,2 \\
\hline $2003-2004$ & 409,1 & 202,8 & $49,6 \%$ & 23,3 \\
\hline $2004-2005$ & 421,5 & 211,4 & $50,1 \%$ & 23,8 \\
\hline $2005-2006$ & 424,2 & 207,7 & $49,0 \%$ & 23,2 \\
\hline $2006-2007$ & 416,3 & 197,6 & $47,5 \%$ & 22,1 \\
\hline $2007-2008$ & 397,7 & 185,3 & $46,6 \%$ & 22,4 \\
\hline $2008-2009$ & 381,0 & 169,3 & $44,4 \%$ & 22,5 \\
\hline $2009-2010$ & 370,3 & 156,3 & $42,2 \%$ & 21,9 \\
\hline
\end{tabular}

Forrás: NEFMI-statisztika, Polónyi [2009b]

A felsőoktatásba belépő hallgatók arányának növekedése azt is eredményezte, hogy képességeik, felkészültségük, illetve származásuk tekintetében is sokkal heterogénebbé vált a hallgatói populáció. Különösen a hosszú oktatói és vezetői pályafutást maguk mögött tudó interjúalanyok utaltak arra, hogy jelentősen megváltoztak a hallgatói motivációk is.

„Szóval idővel egyszerűen eltűntek ezek [ti. épitőtáborok], meg a kirándulások, a minden félévben kötelező kirándulások, hogy, hogy az iskolától autóbuszt kaptunk, meg kellett a programot szervezni, volt benne egy kötelező üzemlátogatás, ami persze egyébként, ha jó volt megszervezve, akkor még hasznos is volt. De annak a másik két napnak is közösségteremtő ereje volt. És ez nincsen. Tehát egyfelöl megváltozott az intézményi környezet és talán, hogy ezzel összefügg-e vagy különben is, mert, mert hogy a társadalmi környezet is más. Megváltozott az a légkör, ami ezeket a viszonyokat jellemzi, hogy tanár diák, hogy egy idő után kijelentették a hallgatók, hogy ők nem kérnek ebböl a megaláztatásból, hogy nevelötanár. Mert őket nem kell nevelni. Dehogy nem kell. Mert, hogy felnőttek, hát persze, igen, jogilag felnőttek. Meg is látszik." (D12)

„(...) annak idején, hát egy hallgató, hogyha bekerült, akkor egyszerüen úgy érezhette magát, hogy vegye megtiszteltetésnek, hogy bekerült ebbe az intézménybe. (...) most az van, hogy a hallgató, természetes módon megvan a joga ahhoz, hogy őneki ilyen-olyan-amolyan szolgáltatás, hogy ilyen-olyan amolyan színvonal és így tovább. És, hogyha, ha netalántán nem tetszik, akkor nyilván fordulhat bírósághoz (...) tehát ez egy teljesen más helyzet, olyan, mint 
hogyha ugye egy szolgáltatást igénybe venne, és ebböl adódóan őneki nyilván jogai vannak. Tehát össze nem hasonlítható énszerintem a két időszak." (D28)

A kereslet növekedésével a képzési kínálat is jelentős mértékben átalakult. Az új hallgatók föként a társadalomtudományi és üzleti képzések javára rendezték át a képzési területek súlyát, amiben az játszott szerepet, hogy egyre több intézmény kezdett képzéseket kínálni ezeken a területeken. 2009-ben például 29 intézmény hirdette meg valamilyen formában a gazdálkodás és menedzsment alapszakot, és 8 intézmény az osztatlan jogász képzést 52 . Növekedett a képzési programok sokszínűsége is. Egyfelöl új képzési formák jelentek meg, így például a felsőfokú szakképzések, a szakirányú továbbképzések, valamint a doktori képzés, másfelöl az egyes szinten elérhető különböző képzési programok száma is növekedett, ami az ezredfordulón a „programburjánzásról” szóló rendszeresen visszatérő aggodalmakhoz vezetett.

A hallgatói létszám és a képzési kínálat növekedése elösegítette a karok számának növekedését. Az egyik felsővezetői interjúalany például így indokolta az új karok létrehozását:

„Az egyik az, hogy növekvő hallgatói létszám egy intézményben nehezen teszi kezelhetővé akár a müködtetést, akár az akadémiai folyamatokat. A másik pedig az, hogy a profil erőteljesen elkezdett differenciálódni, mert olyan képzések kerültek be intézménybe, amelyek azelőtt nem voltak." (F3)

A képzési programok burjánzását a Bologna-rendszer 2005-ös bevezetése során ${ }^{53}$ az alapszakok számának adminisztratív korlátozásával és a képzési programok standardizálásával igyekeztek visszaszorítani (lásd például Oktatási Minisztérium [2003] 22.0.), ami azonban a mesterképzések terén azonban ismét megjelenni látszik (lásd Derényi [2009]). A standardizálási törekvés ugyanakkor sajátos módon rendezte át az intézményen belüli kari együttmüködéseket, mert az új képzési programok tartalmának kialakítására képzési területi konzorciumokban került sor, amelyek döntése az adott képzést indítani akaró intézmények számára kötelező volt. Az intézményekben egy-egy tudományterület vagy képzési program képviselete többnyire egy-egy karhoz kötődött, így a megegyezési folyamatban a hasonló profilú karok keresték az érdekeiknek megfelelő kompromisszumokat. A folyamatban nem sok lehetőség mutatkozott arra, hogy egyegy intézményen belül kialakuló egyedi (más intézményekben nem jellemző) karközi együttmüködés a képzési programban általánosan érvényes (és kötelező) szintre emelkedjen. Azaz a konzorciális döntéshozási folyamat nem segítette elö, hogy olyan tárgyak váljanak a képzési program szerves részévé, amelyek a konzorcium tagjainak tudományterületi határain túlnyúlnak - egész egyszerüen azért, mert ezt nem lehet olyan intézményekben érvényesíteni, amelyekben az adott tárgyat nem képesek oktatni. Ennek következtében az intézményeken belüli karközi együttmüködések gyengültek. Ezt tovább erősítette az interdiszciplináris képzések akkreditációjával szemben támasztott szigorúbb feltételrendszer is, nevezetesen az, hogy az interdiszciplináris képzéseknek a - jórészt felsőoktatási intézmények képviselőiből álló - Magyar Akkreditációs Bizottság két tudományterületi bizottságának jóváhagyását is el kellett nyerniük, így

${ }^{52}$ www.felvi.hu adatok alapján

${ }^{53} \mathrm{~A}$ folyamat során a hároméves föiskolai és ötéves egyetemi képzésekböl álló duális képzési rendszert egymásra épülő, ún többciklusú képzési rendszerré alakították, amelyben a hároméves alapképzésre egy kétéves mesterképzés épült (ez további képzésekkel, így a felsőfokú szakképzéssel és a doktori képzéssel egészült ki). 
a képzés által okozott potenciális érdeksérelem (tehát az elutasitás esélye) is magasabb volt. Mindez szintén erősítette a karok önellátásra való berendezkedésének attitüdjét, és azt a meggyőződést, hogy a képzést a kar, és nem az intézmény nyújtja.

A Bologna folyamat bevezetésének másik, az interjúkban gyakran emlegetett hatása az volt, hogy jelentős mértékben növekedett az oktatásszervezés komplexitása. Ez a duális és többciklusú képzések együttélése és adminisztratív kezelésének nehézségeiböl adódott ${ }^{54}$, amint arra például az egyik interjúalany is utal:

„És nagyon sok átmenetet cipelünk. $A$ régi képzésböl még visszük ki a hallgatókat, már itt vannak az újak, és lehet, hogy 2 év múlva ez, ez újraindul ez az egész. [...] És ez sok felesleges energiát [elvisz]." (D5)

A Bologna folyamat a verseny növekedését is elősegítette, mert a többciklusú képzési rendszerre való átállás lehetővé tette, hogy a főiskolák belépjenek a mester- és doktori képzések területére, amellyel számos föiskola is élt (főként a tanárképzés, a gazdálkodástudomány és a társadalomtudomány területein). Ezzel lényegében megszűnt a főiskolák és egyetemek közötti adminisztratív megkülönböztetés, és megnyílt az út a főiskolák egyetemmé válása előtt.

Az intézmények közötti versenyt a képzési programok standardizálásával egy időben felfutó rangsorok is elősegítették. Számos hetilap készítette el a maga rangsorát55, amelyek intézményekre, karokra vagy képzési programokra/területekre állapítanak meg rangsorokat. Ezek közös jellemzője, hogy többnyire input-változókat (például a minősített oktatók száma) és szubjektív változókat (pl. hallgatói vélemények) szerepeltetnek, és kis súlyt helyeznek a kimeneti változókra (pl. elhelyezkedési adatok). A rangsorok jelentősége a dékáni interjúk alapján azonban korlátozott - alig néhány interjúban merültek fel viszonyítási pontként, sikerkritériumként.

\subsection{Az intézményszerkezet és az intézmények struktúrájának változása}

\subsubsection{A karok számának és néhány jellemzőjének változása}

A felsőoktatás hallgatói létszámának növekedésével együtt átalakult az intézményrendszer is. $A z$ intézmények száma fokozatosan növekedett köszönhetően annak, hogy a 90-es évektől lehetővé vált a magán- és egyházi intézmények alapitása (ezek többsége kis méretü, önálló intézmény, amelyek nem kari struktúrában müködnek). A nem állami intézmények elsősorban az üzleti, jogi és társadalomtudományi képzési területeken támasztottak versenyt az állami intézmények számára. Ennek ellenére a nem állami felsőoktatásban tanuló hallgatók száma meglehetősen

\footnotetext{
${ }^{54}$ Ezt az idegen nyelvü képzések néhány intézményben tapasztalható növekvő aránya is fokozza. Elég csak arra gondolni, hogy az idegen nyelvü programok felügyelete és adminisztrációja jellemzően nem tagolódik be az intézmény magyar nyelvü képzéseinek oktatásirányítási folyamataiba, hanem azokkal párhuzamosan új vezetők és szervezeti egységek állnak fel.

${ }^{55}$ HVG, Népszabadság, Heti Válasz, valamint a felvi is
} 
alacsony maradt (12-13\% körül mozgott). Az állami fenntartású intézmények száma ugyanakkor az 1999-es integrációs folyamatnak köszönhetően jelentősen csökkent.

Változások mutatkoztak a kari struktúrában is. Az egyik jól megfigyelhető trend a karok számának növekedése, amit jól mutat, hogy 1987 és 2009 között a karok és karként funkcionáló intézetek száma jelentős mértékben emelkedett (66-ról 135-re). A növekedés egyik oka nyilvánvalóan az intézményintegrációs folyamat (lásd később részletesen), amely során az addig önálló intézményeket karként olvasztották be más intézményekbe. Ugyanakkor jelentős a karok számának spontán növekedése is, ami abból látható, hogy 1987-ben a karok, a karként müködő intézetek és egy integrációs folyamatban potenciális karként figyelembe vehető önálló egyetemek és főiskolák együttes száma 96 volt, míg 2009-ben 144 (kizárólag az állami fenntartású intézményeket figyelembe véve). Jelentős volt tehát a karok számának spontán (nem integráció miatt bekövetkezett) növekedése is. Új karok alapításában különösen aktív volt a Debreceni Egyetem, az Eötvös Loránd Tudományegyetem, a Szent István Egyetem, a Kaposvári Egyetem és néhány főiskola (Berzsenyi Dániel Főiskola, Eszterházy Károly Főiskola, Károly Róbert Főiskola). Az új karok sokszor a nagyobb karokból történő kiválással jöttek létre, de esetenként voltak „zöldmezős beruházások” is. A karok megszűnése nagyon ritka, de erre is van példa (Zrínyi Miklós Nemzetvédelmi Egyetem).

Az integrációs folyamat mellett a karok alapítását ösztönző tényezők közé tartozik a karalapítás feltételeinek egyszerüsödése, az irányíthatóság fenntartása a növekvő hallgatói létszámok és képzési programok mellett, stratégiai megfontolások (belépés új képzési területekre, márkaépítési megfontolások, karriermenedzsment szempontok), továbbá fajsúlyos oktatók egyéni ambíciói is.

Noha tapasztalataim szerint a nyugati felsőoktatási intézményekben is dominál a kari szerveződés, a kevés számú empirikus vizsgálat azt mutatja, hogy a trend éppen ellentétes a magyarországival: inkább a koncentrálódás, a kisebb számú, diszciplinárisan átfogóbb karok létrehozása a gyakori (lásd például Taylor [2006]). ${ }^{56}$

A karokat illető másik lényeges trend a karok méretének változása. A karokra és önálló intézetekre eső hallgatói létszám 866 főről 2245 főre emelkedett, azaz 2009-ben egy-egy kar majdnem háromszor akkora hallgatói tömeg gondozásáért, adminisztrációjáért felelt, mint 1987ben. Ez természetesen összefüggésben van a felsőoktatás hallgatói létszámának korábban ismertetett expanziójával. Az oktatói, kutatói létszámok ugyanakkor alig 30\%-kal emelkedtek ebben az időszakban, így a karok az oktatói létszámot tekintve elaprózottabbak lettek: míg 1987ben egy-egy karon vagy karként müködő intézetben 175 oktató dolgozott, addig 2009-ben csak 127 fő. (Az oktatók számának operacionalizálását lásd a 13. táblázat megjegyzésében.)

Összességében a karok száma jelentős mértékben megnőtt a rendszerváltást követő években, és növekedett a kari struktúrában müködő intézmények száma is. A következőkben ennek okait elemzem részletesebben: a karok müködésének törvényi szabályozását, az intézményi integrációs folyamat következményeit, a finanszírozási rendszer hatásait és a Bologna folyamat következményeit.

56 Itt most nem térek ki arra, hogy a karok funkciója is változhat. Például a kar-tanszék alapvető tagozódást helyenként felválthatják a mátrix típusú intézet-projekt típusú szerveződések, amelyekben ugyan a kari szint megtalálható, de szerepe más tartalommal telitődik, például a programok tartalmi felügyelete és szabályozása alapvetően nem a kari vezetés hatásköre (lásd részletesebben Drótos 2009). 
13. táblázat: A karok számának és méretének változása 1987 és 2009 között

\begin{tabular}{|c|c|c|c|c|c|c|c|c|c|c|c|c|c|c|c|c|c|c|c|c|c|}
\hline & \multirow{2}{*}{\multicolumn{3}{|c|}{$\begin{array}{c}1987 \\
\text { állami fenntartó }\end{array}$}} & \multicolumn{9}{|c|}{1997} & \multicolumn{9}{|c|}{2009} \\
\hline & & & & \multicolumn{3}{|c|}{ állami fenntartó } & \multicolumn{3}{|c|}{ egyházi fenntartó } & \multicolumn{3}{|c|}{ alapítványi fenntartó } & \multicolumn{3}{|c|}{ állami fenntartó } & \multicolumn{3}{|c|}{ egyházi fenntartó } & \multicolumn{3}{|c|}{ alapítványi fenntartó } \\
\hline & $\mathrm{db}$ & $\begin{array}{l}\text { átl. } \\
\text { hallg. } \\
\text { (fö) }\end{array}$ & $\begin{array}{l}\text { átl. } \\
\text { okt. } \\
\text { (fö) }\end{array}$ & $\mathrm{db}$ & $\begin{array}{l}\text { átl. } \\
\text { hallg. } \\
\text { (fö) }\end{array}$ & $\begin{array}{l}\text { átl. } \\
\text { okt. } \\
\text { (fö) }\end{array}$ & $\mathrm{Db}$ & $\begin{array}{l}\text { átl. } \\
\text { hallg. } \\
\text { (fö) }\end{array}$ & $\begin{array}{l}\text { átl. okt. } \\
\text { (fö) }\end{array}$ & $\mathrm{db}$ & $\begin{array}{l}\text { átl. } \\
\text { hallg. } \\
\text { (fö) }\end{array}$ & $\begin{array}{l}\text { átl. } \\
\text { okt. } \\
\text { (fö) }\end{array}$ & $\mathrm{db}$ & $\begin{array}{l}\text { átl. } \\
\text { hallg. } \\
\text { (fö) }\end{array}$ & $\begin{array}{l}\text { átl. } \\
\text { okt. } \\
\text { (fö) }\end{array}$ & $\mathrm{db}$ & $\begin{array}{l}\text { átl. } \\
\text { hallg. } \\
\text { (fö) }\end{array}$ & $\begin{array}{l}\text { átl. } \\
\text { okt. } \\
\text { (fö) }\end{array}$ & $\mathrm{db}$ & $\begin{array}{l}\text { átl. } \\
\text { hallg. } \\
\text { (fö) }\end{array}$ & $\begin{array}{l}\text { átl. } \\
\text { okt. } \\
\text { (fö) }\end{array}$ \\
\hline Karok nélküli egyetem & 2 & 603 & 157 & 2 & 1212 & 114 & 3 & 182 & 34 & 0 & & & 4 & 649 & 177 & 3 & 185 & 50 & 2 & 275 & 79 \\
\hline $\begin{array}{l}\text { kari struktúrában müködő } \\
\text { egyetem }\end{array}$ & 17 & & & 19 & & & 2 & & & 0 & & & 14 & & & 2 & & & 0 & & \\
\hline egyetemi karok száma & 42 & 1008 & 229 & 49 & 1985 & 205 & 5 & 1102 & 108 & 0 & & & & & & & & & & & \\
\hline föiskolai karok száma & 10 & 645 & 71 & 22 & 1375 & 108 & 0 & & & 0 & & & 106 & 2229 & 131 & 9 & 1482 & 127 & 0 & & \\
\hline $\begin{array}{l}\text { egyetemekhez, egyetemi } \\
\text { karokhoz kapcsolt } \\
\text { intézetek száma }\end{array}$ & 2 & & & 10 & 1166 & 54 & 0 & & & 0 & & & 7 & 533 & 65 & 0 & & & 0 & & \\
\hline $\begin{array}{l}\text { egyetemek/egyetemi } \\
\text { karok kihelyezett tagozatai }\end{array}$ & 4 & & & 0 & & & 0 & & & 0 & & & 0 & & & 0 & & & 0 & & \\
\hline $\begin{array}{l}\text { Egyetemhez kapcsolóüdó } \\
\text { (önálló szervezeti } \\
\text { egségként feltüntetett) } \\
\text { doktori iskola } \\
\text { egyetemek föiskolai }\end{array}$ & 0 & & & 0 & & & 0 & & & 0 & & & 5 & & & 0 & & & 0 & & \\
\hline $\begin{array}{l}\text { karaihoz kapcsolt } \\
\text { intézetek száma }\end{array}$ & 0 & & & 3 & 292 & 38 & & & & & & & 0 & & & & & & & & \\
\hline $\begin{array}{l}\text { karok nélküli föiskola, önálló } \\
\text { intézet }\end{array}$ & 28 & 1167 & 118 & 33 & 2074 & 124 & 24 & 284 & 34 & 6 & 2891 & 245 & 5 & 2430 & 129 & 20 & 382 & 45 & 13 & 2102 & 126 \\
\hline $\begin{array}{l}\text { föiskolák/főiskolai karok } \\
\text { kihelyezett tagozatai }\end{array}$ & 5 & & & & & & & & & & & & & & & & & & & & \\
\hline $\begin{array}{l}\text { kari vagy intézeti struktúrában } \\
\text { müködő föiskola }\end{array}$ & 7 & 1387 & 190 & 2 & 2660 & 283 & 0 & & & 0 & & & 6 & & & 0 & & & 0 & & \\
\hline karok száma & 0 & & & 0 & 0 & 0 & 0 & & & 0 & & & 22 & 2864 & 90 & 0 & & & 0 & & \\
\hline $\begin{array}{l}\text { föiskolákhoz/föiiskolai } \\
\text { karokhoz kapcsolt } \\
\text { intézetek száma } \\
\text { fpőiskolák/föiskolai karok } \\
\text { kihelyezett tagozatai }\end{array}$ & $\begin{array}{l}12 \\
8 \\
\end{array}$ & 722 & 92 & 8 & 665 & 141 & 0 & & & 0 & & & 0 & & & 0 & & & 0 & & \\
\hline
\end{tabular}




\begin{tabular}{|c|c|c|c|c|c|c|c|c|c|c|c|c|c|c|c|c|c|c|c|c|c|}
\hline & \multirow{2}{*}{\multicolumn{3}{|c|}{$\begin{array}{c}1987 \\
\text { állami fenntartó }\end{array}$}} & \multicolumn{9}{|c|}{1997} & \multicolumn{9}{|c|}{2009} \\
\hline & & & & \multicolumn{3}{|c|}{ állami fenntartó } & \multicolumn{3}{|c|}{ egyházi fenntartó } & \multicolumn{3}{|c|}{ alapítványi fenntartó } & \multicolumn{3}{|c|}{ állami fenntartó } & \multicolumn{3}{|c|}{ egyházi fenntartó } & \multicolumn{3}{|c|}{ alapítványi fenntartó } \\
\hline & $\mathrm{db}$ & $\begin{array}{l}\text { átl. } \\
\text { hallg. } \\
\text { (fö) }\end{array}$ & $\begin{array}{l}\text { átl. } \\
\text { okt. } \\
\text { (fö) }\end{array}$ & $\mathrm{db}$ & $\begin{array}{l}\text { átl. } \\
\text { hallg. } \\
\text { (fö) }\end{array}$ & $\begin{array}{l}\text { átl. } \\
\text { okt. } \\
\text { (fö) }\end{array}$ & $\mathrm{Db}$ & $\begin{array}{l}\text { átl. } \\
\text { hallg. } \\
\text { (fö) }\end{array}$ & $\begin{array}{l}\text { átl. okt. } \\
\text { (fö) }\end{array}$ & $\mathrm{db}$ & $\begin{array}{l}\text { átl. } \\
\text { hallg. } \\
\text { (fö) }\end{array}$ & $\begin{array}{l}\text { átl. } \\
\text { okt. } \\
\text { (fö) }\end{array}$ & $\mathrm{db}$ & $\begin{array}{l}\text { átl. } \\
\text { hallg. } \\
\text { (fö) }\end{array}$ & $\begin{array}{l}\text { átl. } \\
\text { okt. } \\
\text { (fö) }\end{array}$ & $\mathrm{db}$ & $\begin{array}{l}\text { átl. } \\
\text { hallg. } \\
\text { (fö) }\end{array}$ & $\begin{array}{l}\text { átl. } \\
\text { okt. } \\
\text { (fö) }\end{array}$ & $\mathrm{db}$ & $\begin{array}{l}\text { átl. } \\
\text { hallg. } \\
\text { (fö) }\end{array}$ & $\begin{array}{l}\text { átl. } \\
\text { okt. } \\
\text { (fö) }\end{array}$ \\
\hline intézmények száma összesen & 54 & 1834 & 283 & 56 & 3638 & 300 & 29 & 226 & 49 & 6 & 2891 & 245 & 29 & 11066 & 619 & 25 & 861 & 88 & 15 & 1859 & 119 \\
\hline $\begin{array}{l}\text { Karok nélküli } \\
\text { intézmények+karok } \\
\text { száma+önálló intézetek száma } \\
\text { összesen }\end{array}$ & 96 & 1048 & 169 & 124 & 1703 & 151 & 32 & 406 & 46 & 6 & 2891 & 245 & 144 & 2207 & 122 & 32 & 673 & 68 & 15 & 1859 & 119 \\
\hline $\begin{array}{l}\text { Karok és önálló intézetek } \\
\text { száma összesen }\end{array}$ & 66 & 866 & 175 & 92 & 1586 & 166 & 5 & 1102 & 108 & 0 & & & 135 & 2245 & 120 & 9 & 1482 & 127 & 0 & & \\
\hline Karok száma összesen & 52 & 938 & 196 & 71 & 1796 & 183 & 5 & 1102 & 108 & 0 & & & 128 & 2338 & 124 & 9 & 1482 & 127 & 0 & & \\
\hline
\end{tabular}

Megjegyzés: Mind a hallgatói, mind az oktatói létszámok súlyozatlanok (tehát nem az egyenértékes számokkal számoltam). Az oktatói létszámok tartalmazzák a megbízásos oktatókat és a tanárokat is. Forrás: OKM Statisztikai tájékoztató 1987, OKM Statisztikai tájékoztató 1997, OM Statisztikai tájékoztató 2009 alapján saját számítás 


\subsubsection{A karok helyzetének törvényi szabályozása}

A karok számának növekedésében szerepet játszott, hogy az intézmények autonómiája a belső müködési struktúrájuk alakitásában a rendszerváltást követően egyre növekedett. $E$ folyamat részeként a karalapitás feltételei is fokozatosan egyszerüsödtek.

Az 1985-ös oktatási törvény a felsőoktatási intézményeket föiskolákra és egyetemekre tagolta. Az egyetemeken „igazgatási szervezeti egységekként” egyetemi és föiskolai karok voltak szervezhetöek, amelyek létesitése Minisztertanácsi döntéshez volt kötve. A törvény 1990-es módositása a nem állami intézmények karainak alapitását is Minisztertanácsi jóváhagyáshoz kötötte. ${ }^{57}$

Noha a föiskolák nem müködhettek kari struktúrában, a gyakorlatban területi intézetek szervezésével néhány föiskola (például az Ybl Miklós Müszaki Főiskola, a Pénzügyi és Számviteli Főiskola vagy a Liszt Ferenc Zeneművészeti Főiskola) mégis „karosodott”. A későbbiekben a területi intézetek egy része valóban karrá vált (például a Budapesti Gazdasági Főiskola zalaegerszegi Gazdálkodási Kara korábban a PSZF területi intézete volt). Érdemes megemlíteni, hogy az 1985-ös törvény végrehajtási rendelete szerint58 még a tanszékek létesítése is az intézményt felügyelö miniszter jóváhagyásához volt kötve59.

Az 1993-as felsőoktatási törvény ugyan kimondta, hogy „a felsőoktatási intézmények [...] a szervezetüket maguk alakítják ki”'60, és „az intézmény szervezeti tagozódását, a hatáskörök intézményen belüli megoszlását, az intézményhez tartozó szervezeti egységeket" ${ }^{61}$ szabályzatban kell rögzíteniük, ám a törvény azt is meghatározta, hogy „az egyetem karokra, illetöleg más átfogó szervezeti egységekre tagozódik." ${ }^{2} \mathrm{Az}$ állami egyetemeken a karok létesitése továbbra is kormányhatározathoz kötött (az Országos Akkreditációs Bizottság, illetve a Felsőoktatási és Tudományos Tanács előzetes véleményével), a karok felsorolását külön kormányrendelet tartalmazza. A nem-állami intézményeknek pedig bejelentési kötelezettségük volt, amennyiben karokat hoznak létre.

Az 1993-as felsőoktatási törvény továbbra sem tette lehetővé a föiskolák számára, hogy többkarú intézményként müködhessenek. Erre a törvény 1996-os módositása teremtett lehetőséget, amely egyben a karok kormányrendelet szintü rögzitését a magán- és egyházi intézményekre is kiterjesztette.

A kari struktúra szempontjából meghatározó jelentőségü volt az intézményi integrációt előiró 1999-es törvénymódositás, amely a szakföiskolákra és szakegyetemekre tagolt felsőoktatási rendszert egységesítette (erre később visszatérek), és számos addig önálló intézményt olvasztott össze vagy más intézménybe.

A 2005-ös felsőoktatási törvény tovább növelte az intézmények szabadságát belső struktúrájuk alakitására. A törvény a kart mint egy lehetséges oktatási szerveződési formát említi meg63,

\footnotetext{
57 1990. évi XXIII. törvény az oktatásról szóló 1985. évi I. törvény módositásáról.

58 1985. I. törvény. 118. §, ill. Vhr. 8. §

${ }^{59}$ Érdemes megemlíteni, hogy a rendszerváltást megelőző időszakban a felsőoktatási intézmények felügyeletét a megfelelő ágazati miniszter látta el. İgy például az orvosi intézményeket ez egészségügyi miniszter, az agrár intézményeket a földművelésügyért felelős miniszter, stb. A tudományegyetemeket, valamint a tanár- és tanítóképzést folytatói intézményekért az oktatási és kulturális miniszter tartozott felelösséggel.

$6047 . \S(1)$

6151. § (2)

$6248 . \S(1)$

$6330 . \S(2)$, illetve $147 \S$
} 
ám annak részletszabályait - például a kari tanácsok felállitását, vagy a dékán feladatait - a korábbi törvényekkel ellentétben már nem szabályozta. A törvényhez kapcsolódó kormányrendelet ugyanakkor részletezte a karok alapításának minimális feltételeit (meghatározott hallgatói és oktatói létszámot el kell érnie a karnak, illetve legalább két szinten kell képzést nyújtania). Ezek fennállását a Magyar Akkreditációs Bizottság ellenőrizte a törvény szerint64, 2009-től azonban (egy törvénymódosítást követően) megszűnt a karok alapíthatóságának külső ellenőrzése.

Az intézmények egy része élt a müködési struktúra szabad alakithatóságával, és olyan „fakultásokat” és „központokat” hoztak létre, amelyek lényegében karként funkcionáltak még akkor is, ha egyébként hivatalos jogi megerősítést nem is kaptak (lásd például a Szolnoki Főiskola fakultásait). Söt, néhány intézményben olyan karok is létrejöttek, amelyek a kormányrendeletben elöírt feltételeket (például a minimális oktatói létszámot) nem teljesítették, de létrehozásuk valamilyen megfontolásból, például márkanév-épités miatt racionális volt (így jöhettek létre például fogorvostudományi karok).

A 2005-ös törvény további figyelemreméltó eleme, hogy megnyitotta az utat a főiskolák egyetemmé válása előtt, ugyanis az egyetemi státuszt a mesterképzések indításhoz és doktori iskolák alapításához kötötte. A feltételek teljesülése esetén az intézmények kérhették az átminősítésüket egyetemmé. Ezzel párhuzamosan megszűnt az egyetemi és föiskolai karok közötti megkülönböztetés is.

A 2010-es kormányváltással új felsőoktatási koncepció kialakítása vette kezdetét, amelyek az egységesülő felsőoktatás újratagolását, az intézmények közötti különbségek megerősítését szorgalmazta explicit módon. Ez a kari szerveződés megerősítését is jelentette. A nyilvánosságra került felsőoktatási koncepciók és tervezetek az intézmények besorolását (azaz egyetemi vagy főiskolai jellegét) a karok számához kötötte, amelyek típusait (egyetemi vagy főiskolai) és minimális méretét is előírta. Ennek indokául a 2010 őszi koncepció szerint az szolgál, hogy „a karok minimális méretének meghatározásával lehet biztosítani a minőség eléréséhez elengedhetetlenül szükséges kritikus tömeget." A koncepciók visszaállították volna a karok belső működési rendjének központi szabályozását is (pl. a kari tanácsok létesítését), és az 1985-ös törvényhez hasonlóan ismét kormánydöntéshez kötötték volna a karok alapítását. Jellemző, hogy a 2010 őszi koncepció véleményezése során az amerikai minta alapján működő Közép-Európai Egyetem (CEU) amiatt (is) tiltakozott, hogy az elképzelés az intézmény számára is kötelezővé tette volna a kari tagozódást.

Az Országgyülés végül a törvénynek egy olyan változatát fogadta el, amely az egyetemi státuszt többek között legalább három egyetemi kar meglétéhez köti (az egyetemi kar müködése megfelelő létszámhoz, minősítettségi arányhoz és hallgató-oktató arányhoz kötött, kérdés hogy ez valóban biztosítja-e a mérethatékonyságot). Hasonló feltételek érvényesek a főiskolai karok müködésére is. A törvény fenntartja a föiskolák kari müködésének lehetőségét is. A korábbi koncepcióktól eltérően ugyanakkor a törvény nem szabályozza a karok belső müködésének rendjét, sem pedig alapításuk és elismerésük folyamatát.

$6430 \S(6)$, illetve 106. § (2) 


\subsubsection{Az intézményi integrációs folyamat 65}

A karok számának növekedéséhez és a kari szint megerősödéséhez jelentős mértékben hozzájárult az 1999-es törvénymódosítással66 kikényszerített intézmény-integráció is, amelynek során az intézményösszevonásokkal a szakegyetemek és szakfőiskolák miatt kialakult fragmentált felsőoktatási rendszer töredezettségét igyekeztek csökkenteni. A 90-es években - a világbanki program részeként pályázatokkal és az együttmüködések támogatásával igyekeztek az önálló intézményeket integrációra ösztönözni (ilyen egyetemi szövetség jött létre és müködött például Budapesten és Debrecenben), majd ennek sikertelenségét érzékelve döntött a kormányzat a felülröl vezérelt integráció mellett. Ennek során az integrációra kényszerített intézmények az új, integrált intézményben immár karként müködtek tovább, így számukra ez az irányítási szint vált a korábbi önállóságuk megőrzésének terepévé, egyszersmind zálogává. Noha az integrációs folyamat több mint tíz éve ment végbe, megítélése a mai napig meglehetősen ellentmondásos. A téma érzékenységét jelzi, hogy az integrációról a végrehajtás óta nem született nyilvánosan hozzáférhető átfogó értékelés.

$A z$ integráció során három alapvető integrációs megfontolás érvényesült. Ezek sikerességének megítélése nagyon különböző. Az inkább sikeres integrációk közé sorolják a vidéki városokban lévő intézmények integrációját (például Pécs, Szeged, Debrecen), illetve a főváros azonos profilú intézményeinek egybevonását (Budapesti Műszaki Főiskola/Óbudai Egyetem, Budapesti Gazdasági Főiskola). A regionális integrációk azonban, amelynek során az egy-egy régióba tartozó intézményeket vonták egységes irányítás alá (például Szent István Egyetem, Nyugat-Magyarországi Egyetem), csak nagyon laza integrációt tett lehetővé, mert a valóban racionalizálható tevékenységek, oktatási területek (például nyelvi képzés) integrációja nem volt biztositható. Néhány integrált intézménynél pedig fennállt a lehetősége annak, hogy a nagyobb intézmények „lerabolják” a kisebbeket, elvonják az erőforrásokat, gyorsitva ezzel a kisebb intézmények haldoklását. A regionális integrációk fölbomlása, átrendeződése megindult, és jelenleg nincsen igazán sikeresnek tekinthető példa.

Miközben maguk az előzetesen rögzített logikák is eredményeztek ellentmondásokat (például elképzelhető lett volna a Budapesti Müszaki Főiskola BME-be integrálása, a Budapesti Gazdasági Főiskola intézményeinek Budapesti Közgazdaságtudományi Egyetembe integrálása stb.), addig legalább annyira fontos, hogy a konkrét integrációs folyamatot rengeteg helyi és regionális érdek is befolyásolta, amely az előzetes logikák tiszta érvényesítését nem tette lehetővé (például a Győrben lévő intézmények egy része soproni központú Nyugat-Magyarországi Egyetemhez tartozik, a Semmelweis Egyetem és a szombathelyi Berzsenyi Dániel Főiskola meg tudta őrizni önállóságát ${ }^{67}$, az Ybl Miklós Főiskola a Szent István Egyetemhez került a Budapesti Műszaki Főiskola helyett stb.). Sőt, néhány intézmény épp az integrációs folyamat során nyerte el függetlenségét (például a Dunaújvárosi Főiskola ekkor függetlenedett a Miskolci Egyetemtöl).

Az integrációs folyamat beindulása már maga is ösztönözte az újabb karok létrehozását, mert ilyen módon az adott intézmény nagyobb súllyal tudott részt venni az integrációs tárgyalásokon, illetve

\footnotetext{
${ }^{65} \mathrm{Az}$ e részben írottak döntő módon egy olyan kutatásra épülnek, amelyben felsőoktatási szakértőkkel készítettem interjút a magyar felsőoktatás irányítási és gazdálkodási reformjairól. (Részletesen lásd Temesi - Kováts [2010] és Kováts [2012]). 66 1999. évi LII. törvény a felsőoktatási intézményhálózat átalakításáról, továbbá a felsőoktatásról szóló 1993. évi LXXX. törvény módosításáról

${ }^{67}$ Bár azóta a Berzsenyi Dániel Főiskola beolvadt a Nyugat-magyarországi Egyetembe.
} 
később nagyobb befolyásra tehetett szert a Szenátusban/Egyetemi tanácsban (ahol a karok sok esetben azonos súllyal kaptak helyet, függetlenül a méretüktöl).

Az integráció során a korábban független intézmények közötti egyenrangú, együttmüködésre épülő kapcsolat az integrált intézményekben sok helyen versengővé, felszültséggel telivé vált (Derényi [2009]). Az intézményen belüli erőforrásokért való küzdelem felértékelte a karok szerepét, mert az integrációval egy időben az intézményi vezetést nem ruházták fel egyértelmű hatáskörrel, így a rektor továbbra is függő helyzetben maradt a karok képviselőiből álló szenátustól (később pedig az ezen változtatni kívánó gazdasági tanácsok bevezetése nem sikerült). $A z$ intézményen belüli feszültségek többnyire megnehezítették az integrációban rejlő tartalékok intézményi szintü feltárását és kihasználását is (például párhuzamosságok megszüntetése, fejlesztési fókuszok kijelölése). Az integráció alapjául szolgáló elvi megfontolások érvényesülését az is gátolta, hogy az integrációval a campusok, telephelyek, épületek fizikai összerendezése ritkán történt meg (Derényi [2009]).

Összességében ahol a részt vevő felek képesek voltak hosszú távú kompromisszumokat kötni, vagy közösen gondolkodva mindenki számára jó megoldást találni, ott az integrációban komoly fejlödési potenciál jött létre, amely többek között az intézmény érdekérvényesítő és tőkevonzó képességének növekedésében jutott érvényre. Ahol azonban a felek kevésbé voltak kompromisszumkészek, ott az integráció csak formálisan müködött, sőt esetenként kifejezetten kontraproduktívvá vált.

A mintába több olyan intézmény is bekerült, amelynek egy vagy több kara korábban önálló intézmény volt, és ezek között éppúgy volt problémásnak és sikeresnek látott integráció is. Az integráció különösen azokban a beszélgetésekben volt fontos téma, ahol az integrációt az adott dékán (kar) kényszerként élte meg, és ahol a karok közötti együttmüködés emiatt számos problémába ütközött.

\subsubsection{Az intézmények irányításának és belső struktúrájának változása}

Az 1993-ban elfogadott felsőoktatási törvény szerint az intézmény vezetője a rektor (főiskola esetén: főigazgató), ám a legtöbb ügyben (így magának a rektornak/főigazgatónak a megválasztásában) a döntést az oktatók, hallgatók és más érdekképviseletek választott képviselöiböl álló Egyetemi Tanács (Szenátus) hozta. Az intézményekben tehát osztott vezetés érvényesült, ahol a rektor/föigazgató kiszolgáltatott az őt megválasztó testületnek, míg a külső érintettek (így a fenntartó minisztérium) csak közvetett csatornákon keresztül tudták érvényesíteni elképzeléseiket (finanszírozás, bürokratikus beszámoltatási utasítások stb.). A kormányzási rendszer jelentősebb átalakítására 2005-ben ugyan történt kísérlet, amikor a kormányzat „kétkamarás”, board-típusú irányítási rendszer kialakításával próbálkozott, az Alkotmánybírósági vétó hatására azonban a gazdasági, pénzügyi, stratégiai és a rektori kinevezési kérdések továbbra is a választott képviselőkből álló szenátus kezében maradtak ${ }^{6}$. Ezek -

\footnotetext{
${ }^{68}$ A tervezett koncepció szerint a kis létszámú, külső tagokból álló, jelentős stratégiai és felügyeleti hatáskörökkel rendelkező testület (amelyben a kormány képviselői kisebbségben lettek volna) döntött volna számos stratégiai kérdésben (beleértve a rektor személyét), míg az oktatással és kutatással összefüggő kérdések az egyetemi oktatókból és hallgatókból álló Szenátus illetékességi körébe tartoztak volna. Az Alkotmánybíróság ugyanakkor az oktatás és kutatás autonómiájára hivatkozva alkotmányellenesnek találta a 2005. évi felsőoktatási törvény azon részeit, amely a nem intézményi alkalmazásban állókból létrejött gazdasági tanácsot jelentős, az intézmény működését befolyásoló jogositványokkal ruházza fel. Ezt követően egy sokkal gyengébb felhatalmazású testület, a Gazdasági Tanács (GT) jött létre, amelynek inkább a szemléletváltás elősegítésében és a nagy, stratégiai hibák elkövetésének megakadályozásában lehet szerepe. (Az irányítási koncepció átalakításának kísérletét részletesen ismerteti Polónyi [2006]; Barakonyi [2009a]; Barakonyi [2009b]; Polónyi [2009a]).
} 
miként arra Polónyi [2009b] vizsgálata is rámutat - maguk is többnyire nagy létszámú testületek. Aligha alkalmasak tehát a stratégiai dilemmák azonosítására, átbeszélésre, közös értelmezés kialakítására és a döntések következetes érvényesitésére. Ennél árnyaltabb képet adhatna ugyanakkor az intézmények bizottsági rendszerének és müködésének vizsgálata, ezt azonban csak mélyebb, helyszíni vizsgálatokkal lehetne feltárni.

14. táblázat: A szenátus tagjainak száma néhány felsőoktatási intézményben

\begin{tabular}{|c|c|c|c|}
\hline Intézmény neve & Karok száma & $\begin{array}{c}\text { Szenátusban ülő } \\
\text { szavazati joggal } \\
\text { rendelkező tagok száma }\end{array}$ & $\begin{array}{c}\text { Dékánok } \\
\text { automatikusan } \\
\text { szavazó tagok-e? }\end{array}$ \\
\hline Budapesti Corvinus Egyetem & 6 & 36 & Nem \\
\hline Budapesti Gazdasági Főiskola & 3 & 20 & Igen \\
\hline Budapesti Műszaki és Gazdaságtudományi Egyetem & 8 & 33 & Nem \\
\hline Debreceni Egyetem & 15 & 65 & Igen \\
\hline Eötvös Loránd Tudományegyetem & 8 & 33 & Igen \\
\hline Kaposvári Egyetem & 4 & 29 & Nem \\
\hline Károli Gáspár Református Egyetem & 4 & 27 & Nem \\
\hline Károly Róbert Főiskola & 2 & 17 & Nem \\
\hline Miskolci Egyetem & 9 & 36 & Nem \\
\hline Nyíregyházi Főiskola & 5 & 12 & Nem \\
\hline Nyugat-magyarországi Egyetem & 10 & 37 & Nem \\
\hline Óbudai Egyetem & 5 & 20 & Nem \\
\hline Pécsi Tudományegyetem & 10 & 38 & Igen \\
\hline Semmelweis Egyetem & 6 & 36 & Nem \\
\hline Szent István Egyetem & 10 & 47 & Nem \\
\hline Szegedi Tudományegyetem & 12 & 49 & Igen \\
\hline
\end{tabular}

Forrás: intézményi SZMSZ-ek alapján saját összeállítás (2012 februári állapot szerint)

Irányítási szempontból a kormányzási struktúra alakulása mellett az adminisztráció változásának van még jelentősége (erről részletes áttekintést adok, lásd Kováts [2012]). Az integrációs folyamat következményeként olyan méretü intézmények jöttek létre, amelyben központi adminisztráció és szolgáltatások kialakítása irányítási és mérethatékonysági szempontból is ésszerü lehetőségnek tünt. Ezt segítette a szabályozás azon változása is, amely a struktúra belső alakítását egyre inkább intézményi hatáskörbe utalta.

A központi adminisztráció a rendszerváltás óta sok intézményben igen nagymértékben kibővült. Az 1990-es években a hallgatói létszámok, illetve a képzési programok számának növekedése az oktatás-adminisztráció jelentős átalakulását, differenciálódását eredményezte: kialakultak (majd eltűntek) a felvételit menedzselő csoportok, később pedig az órarendet, tanrendet megtervező csoportok, valamint az oktatás-informatikai osztályok is. Az informatikai infrastruktúra (például géppark) jelentős bővülése miatt (annak karbantartására) létrejöttek az informatikai igazgatóságok. Reagálva az ekkor felfutó diákcsere és oktatói mobilitási lehetőségekre, ebben az időszakban jelentek meg a nemzetközi kapcsolatokat, diákcseréket szervező irodák, illetve kibővültek a nemzetközi ügyekkel 
foglalkozó osztályok. A pályázati lehetőségek kiaknázására hozták létre a pályázati és projektirodákat. Az oktatással ellentétben a tudományszervezés sokkal ritkábban jelent meg strukturálisan a központi adminisztrációban, ez inkább részben a doktori iskolákban összpontosult.

A 2000-es évektöl (a hallgatói létszámok stagnálásával egyidejüleg) egyre több helyen jöttek létre az értéknövelt szolgáltatásokat biztosító irodák (tanulási és pszichológiai tanácsadás, karriertámogatás, szakmai gyakorlatok szervezése, alumni szervezetek), a PR-ral és marketinggel foglalkozó osztályok/felelösök. Szórványosan ugyan, de néhány helyen már létrejöttek a vállalati kapcsolatokkal foglalkozó szervezeti egységek is. A müszaki üzemeltetésben széles körben elterjedtté vált a kiszervezés. Csökevényesen ugyan, de a kialakultak a szigorúbb erőforrás-gazdálkodás szervezeti feltételei is. 2012-ben hét intézményben már található stratégiai tervezéssel foglalkozó felelős vagy szervezeti egység, más inézményekben kontrolling irodák alakultak. A HR tevékenység részben vagy egészen a gazdasági igazgatóságok keretében történik ${ }^{69}$. A minőségügyi irodák tevékenysége részben az eröforrások kontrolljához, részben a marketinghez kötődik. Ma már szinte minden intézményben megtalálhatóak e szervezeti egységek, amelyek részben a törvényi elörásoknak való megfelelés, részben az állandósuló, különböző típusú akkreditációs feladatok ellátása, részben pedig pályázati ösztönzések hatására jöttek létre.

Mára tehát az adminisztratív szolgáltatások széles köre épült ki az állami felsőoktatási intézményekben (ezekröl részletes áttekintést ad az alábbi táblázat). Ezek szerveződését tekintve két általános modell rajzolódik ki.

${ }^{69}$ Szervezetileg a HR müködésének két domináns megoldása alakult ki (Poór, László et al. [2009]): az egylábas megoldásban (amelyre 13 intézményben találhatunk ma példát) minden HR tevékenység a gazdasági igazgatóságon zajlik. $\mathrm{Az}$ ún. kétlábas megoldásokban (10 intézmény) a bérszámfejtési feladatok a gazdasági igazgatóságon történnek, az egyéb emberi-erőforrás tevékenységek pedig a rektor/fötitkár alatt müködő szervezeti egységben kapnak helyet. A vizsgált magyar intézmények között egyébként a Közép-európai Egyetemnél arra is találhatunk példát, amikor a HR tevékenység teljes egészében önállósodik: itt a bérszámfejtési feladatok is a gazdasági-pénzügyi területtöl elkülönült HR igazgatóságra tartoznak. Érdemes megjegyezni, hogy a 2000-es években a Budapesti Corvinus Egyetem is kísérletezett ilyen megoldással. 
15. táblázat: A központi adminisztráció által lefedett területek a magyar felsőoktatási intézményekben

\begin{tabular}{|c|c|c|c|c|c|c|c|c|c|c|c|}
\hline & $\begin{array}{l}\text { Stratégial } \\
\text { Intézmény- } \\
\text { fejlesztés }\end{array}$ & $\begin{array}{l}\text { GMI-töl } \\
\text { elkülönülö HR }\end{array}$ & $\begin{array}{l}\text { Minőség- } \\
\text { ügy }\end{array}$ & $\begin{array}{l}\text { Karrier- } \\
\text { szolgáltatások, } \\
\text { pályakövetés }\end{array}$ & $\begin{array}{l}\text { Diáktanács- } \\
\text { adás }\end{array}$ & $\begin{array}{l}\text { Nemzetközi } \\
\text { kapcsolatok }\end{array}$ & $\begin{array}{l}\text { Tudomány- } \\
\text { szervezés }\end{array}$ & $\begin{array}{c}\text { Pályázatok és } \\
\text { Projektek/Innovációl } \\
\text { Technológiatranszfer }\end{array}$ & $\begin{array}{c}\text { Vállalati } \\
\text { kapcsolati }\end{array}$ & $\begin{array}{c}\text { Oktatási } \\
\text { szolgáltatások és } \\
\text { oktatásszervezés }\end{array}$ & $\begin{array}{l}\text { Kommunikációs } \\
\text { tevékenységek }\end{array}$ \\
\hline \multicolumn{12}{|l|}{$\begin{array}{l}\text { Budapesti Gazdasági } \\
\text { Föiskola }\end{array}$} \\
\hline \multicolumn{12}{|l|}{$\begin{array}{l}\text { Budapesti Corvinus } \\
\text { Egyetem }\end{array}$} \\
\hline $\begin{array}{l}\text { Budapesti Müszaki és } \\
\text { Gazdaságtudományi } \\
\text { Egyetem }\end{array}$ & & & & & & & & & & & Kulturális Titkárság \\
\hline \multicolumn{12}{|l|}{ Debreceni Egyetem } \\
\hline \multicolumn{12}{|l|}{ Dunaújvárosi Főiskola } \\
\hline \multicolumn{12}{|l|}{ Eötvös József Főiskola } \\
\hline \multicolumn{12}{|l|}{$\begin{array}{l}\text { Eötvös Loránd } \\
\text { Tudományegyetem }\end{array}$} \\
\hline \multicolumn{12}{|l|}{$\begin{array}{l}\text { Eszterházy Károly } \\
\text { Főiskola }\end{array}$} \\
\hline \multicolumn{12}{|l|}{ Kaposvári Egyetem } \\
\hline \multicolumn{12}{|l|}{ Károly Róbert Főiskola } \\
\hline \multicolumn{12}{|l|}{ Kecskeméti Főiskola } \\
\hline Miskolci Egyetem & & & & & & & & & & & $\begin{array}{c}\text { Marketing és } \\
\text { kommunikációs } \\
\text { csoport }\end{array}$ \\
\hline $\begin{array}{l}\text { Nemzeti Közszolgálati } \\
\text { Egyetem }\end{array}$ & & & & & & & & & & & \\
\hline
\end{tabular}




\begin{tabular}{|c|c|c|c|c|c|c|c|c|c|c|c|}
\hline & $\begin{array}{l}\text { Stratégial } \\
\text { Intézmény- } \\
\text { fejlesztés }\end{array}$ & $\begin{array}{c}\text { GMI-töl } \\
\text { elkülönülö HR }\end{array}$ & $\begin{array}{l}\text { Minőség- } \\
\text { ügy }\end{array}$ & $\begin{array}{c}\text { Karrier- } \\
\text { szolgáltatások, } \\
\text { pályakövetés }\end{array}$ & $\begin{array}{l}\text { Diáktanács- } \\
\text { adás }\end{array}$ & $\begin{array}{l}\text { Nemzetközi } \\
\text { kapcsolatok }\end{array}$ & $\begin{array}{l}\text { Tudomány- } \\
\text { szervezés }\end{array}$ & $\begin{array}{c}\text { Pályázatok és } \\
\text { Projektek/Innovációl } \\
\text { Technológiatranszfer }\end{array}$ & $\begin{array}{c}\text { Vállalati } \\
\text { kapcsolati }\end{array}$ & $\begin{array}{c}\text { Oktatási } \\
\text { szolgáltatások és } \\
\text { oktatásszervezés }\end{array}$ & $\begin{array}{l}\text { Kommunikációs } \\
\text { tevékenységek }\end{array}$ \\
\hline Nyíregyházi Főiskola & & & & & & & & & & & PR Iroda \\
\hline \multicolumn{12}{|l|}{$\begin{array}{l}\text { Nyugat-magyarországi } \\
\text { Egyetem }\end{array}$} \\
\hline \multicolumn{12}{|l|}{ Óbudai Egyetem } \\
\hline Pécsi Tudományegyetem & & & & & & & & & & & Marketing Osztály \\
\hline Semmelweis Egyetem & & & & & & & & & & & $\begin{array}{c}\text { Marketing és } \\
\text { Kommunikációs } \\
\text { Csoport }\end{array}$ \\
\hline \multicolumn{12}{|l|}{ Széchenyi István Egyetem } \\
\hline $\begin{array}{l}\text { Szegedi } \\
\text { Tudományegyetem }\end{array}$ & & & & & & & & & & & $\begin{array}{l}\text { Marketing és } \\
\text { Kommunikációs } \\
\text { lgazgatóság }\end{array}$ \\
\hline \multicolumn{12}{|l|}{ Szent István Egyetem } \\
\hline Szolnoki Főiskola & & & & & & & & & & & $\begin{array}{l}\text { Kommunikációs és } \\
\text { Marketing Iroda }\end{array}$ \\
\hline Pannon Egyetem & (GMI-n belül) & & & & & & & & & & $\begin{array}{l}\text { Külső kapcsolatok } \\
\text { irodája }\end{array}$ \\
\hline Elöfordulási gyakoriság & 7 & 10 & 15 & 12 & 5 & 17 & 6 & 18 & 3 & 19 & $\begin{array}{c}12(6 \\
\text { marketing/PR) }\end{array}$ \\
\hline
\end{tabular}

Megjegyzés: a szürke mező azt jelenti, hogy található az intézményben az adott feladatot ellátó, nevesített szervezeti egység. Ha a rubrikákba név is szerepel, akkor az az adott szervezeti egység nevét mutatja.

Forrás: intézményi SZMSZ-ek és honlapok alapján (2012. februári állapot szerint) saját összeállitás 
A decentralizált modell (Magyarországon föként a Budapesti Műszaki és Gazdaságtudományi Egyetem tekinthető ilyennek) esetében a központban csak néhány funkció kap helyet, a tevékenységek müködtetésének, kivitelezésének nagy része a karokon zajlik. Az összehangolásban fontos szerepet játszanak a szabályzatok, valamint a karok egymásnak nyújtott szolgáltatásainak, illetve közös erőforrás-felhasználásainak pontos elszámolását biztosító rendszerek.

A centralizáltabb intézmények esetében a karok csak bizonyos feladatokat láthatnak el önállóan. A szélsőséges példát olyan organikus fejlődés eredményeképpen kialakult többkarú föiskolák jelentik, amelyekben a karok lényegében csak az oktatás és kutatás szakmai kérdéseivel foglalkoznak, mert mindenféle adminisztratív ügyintézés központosítva történik. ${ }^{70}$ Ezekben az intézményekben sajátos munkamegosztás alakul ki a dékánok és a rektori szint között, amelyet a következőképpen jellemzett egy interjúalany:

\begin{abstract}
„A dékán az szakmai rektor. Tehát ő az akadémiai vezető. [...] Gyakran beszélünk arról is, hogy az egyetem vezetöje, tehát a rektor, az professzionális vezető legyen, vagy az egyetemet legjobban reprezentáló akadémiai ember legyen, vagy mind a kettő. Ebböl kevés van egyébként. Szerintem egy egyetem életében 5 választásból egyszer találnak ilyen figurát. Mert nincs több szerintem bent a rendszerben. Szerintem nagy baj, ha a dékán menedzserré akar válni. Nagy baj. És az is nagy baj, hogy ha a rektor kiválasztásánál az úgynevezett vezetéstudományban vagy menedzsmentben való jártasság kérdését alap gazdálkodásban való előzetes vagy az ilyen típusú kompetenciáit nem mérlegeli az adott intézmény. Tehát [...] abban nincs pardon, hogy a dékánnak szakmailag a leghitelesebb embernek kell lennie. A rektor esetében se baj, de nem gondolom, hogy az perdöntő lenne." (F3)
\end{abstract}

Azaz a dékánnak ilyen intézményekben nincs operatív menedzsment felelőssége (ez a rektori vezetés feladata), hanem elsősorban akadémiai feladatai vannak. A dékánok helyzete ettől értelemszerüen jelentősen különbözik ott, ahol a karon a kari könyvtár felügyeletétől kezdve a tanulmányi osztályon át a kollégiumokkal mindennel foglalkoznia kell. (Az intézmények gazdálkodási rendszereire később még visszatérek.)

\title{
7.3.5. A karokon belüli szervezeti és irányítási struktúra alakulása
}

A dékán helyzetét az adminisztráció szerveződése mellett a saját karának belső akadémiai szerveződése is befolyásolhatja. Irányíthatósági szempontból fontos az a kérdés, hogy mennyire homogén vagy heterogén egy-egy kar összetétele, mennyire széles vagy éppen szük a profilja, és mennyire széttagolt az irányítási rendszere.

A karok akadémiai struktúrájának tagozódását illetően két nagy rendszer alakult ki a történelmi fejlődés során. $A$ főként a német hagyományban megerősödő ún. chair rendszer

\footnotetext{
70 A központi adminisztráció szerveződése is többféle módon történhet. Gyakori megoldás, hogy egyes központi funkciók felügyeletét a rektor/rektorhelyettesek látják el. Fontos kérdés azonban, hogy a rektornak/rektorhelyettesnek be kell-e kapcsolódnia az operatív munkába, vagy pedig erőfeszitéseit kizárólag a stratégiai kérdésekre, ezek egyetemen belüli közvetítésére és a kivitelezés megvalósításának felügyeletére összpontosíthatja. Az utóbbi esetben általában jól képzett, professzionális igazgatóságok jönnek létre. Egy másik gyakori megoldás, hogy a központi funkciók egy része vagy egésze a rektori vagy fötitkári hivatalban összpontosul a fötitkár operatív felügyeletével (pl. Szent István Egyetem, Nyugat-magyarországi Egyetem). Ebben a modellben a főtitkár nem egyszerüen az intézmény szűken vett igazgatási feladatait látja el, hanem tágabb menedzsment-feladatokat is átvesz (például kidolgozza a teljesítményértékelési rendszert, minőségügyi rendszert stb.).
} 
(lehrstühl) lényege az „egy professzor - egy tanszék”. A tanszékvezető professzor egyszerre volt szakmai és adminisztratív vezető, akitől a tanszék tagjai (akik nem lehettek professzorok) függésben is voltak. A chair erős felhatalmazással rendelkezett, ami egyszerre adott jó lehetőséget egy szakmai program megvalósítására, de rendkívüli veszélyt is hordozott magában. Ez a veszély a tanszéki és kari megújulás nehézségéből fakadt, mert a tanszékvezetők lényegében csak kihalással változhattak meg. A felsőoktatás növekedésével a chair rendszer végső soron fenntarthatatlanná vált két okból.

Egyrészt irányítási nehézség lépett fel, ami abból fakadt, hogy minél több chair volt a karon (önálló tanszékkel), annál nagyobbakká váltak az egyeztetési nehézségek és a koordinációs költségek. Másrészt az oktatói állomány bővülésével a chair rendszert sem lehetett a végtelenségig bővíteni, ezért egyre elterjedtebbé vált a kezdetben föként angol-amerikai körökben népszerű department rendszer, ahol a tanszékek mérete nagyobb, a tanszékvezetés inkább szervező-adminisztratív funkció, és a tanszéken több professzor is van, jelentős önállósággal. A department rendszerben a tanszékek átlagos mérete növekszik, a tanszékek száma pedig csökken. A tanszékvezető (head of department) lehet választott vagy kinevezett vezető, amely pozíciót gyakran rotációval töltenek be. A rotáció egyik oka, hogy a tanszékvezetői pozíció vonzereje csökkent, feltehetöleg azért, mert erősödött benne az adminisztratív, nem szakmai feladatok jellege (a szakmai feladatok egy része óhatatlanul az önálló professzorok kezébe került). A tanszékvezetőktől való függés - a tanszéken lévő többi professzor önállósága miatt - jelentősen csökkent.

A magyarországi gyakorlat vegyes képet mutat, amelynek most csak szimptomatikus jeleit sorolom fel:

- A tanszékvezetés még mindig magas státusszal bíró pozíció (gondoljunk, arra, hogy státusz tekintetében gyakran megkülönböztetik a tanszékvezető egyetemi tanárt az egyetemi tanártól).

- A tanszékvezetés formálisan leváltható, gyakran azonban nagyon hosszú ideig betöltött pozíció - sok esetben majdhogynem „élethosszig” (azaz 65 éves korig) tartó.

- Ugyanakkor a tanszékvezetők mellett a tanszéken megjelentek más egyetemi tanárok, az eredeti chair rendszer központosítottsága tehát oldódott.

- A tanszéki rendszer szétaprózottsága már a 70-es évek felsőoktatás-politikájában is kérdés volt, és már akkor szorgalmazták az intézetesedést, vagy tanszékcsoportok létrehozását.

Magyarországon a karok belső tagozódását illetően sok helyen megkülönböztetik az intézeteket (mint nagyobb, tudományterületileg átfogóbb egység) és a tanszékeket (ezek az intézetnél kisebb méretű egységek). A tanszékek létezhetnek az intézeteken belül (ezek gyakran „nem önálló tanszékek” vagy „intézeti tanszékek”), vagy azokkal egy hierarchiaszinten is (ún. „önálló tanszék”). Ami lényeges kérdés, és ez nem feltétlenül derül ki a honlapokon elérhető információkból, hogy mekkora a nem önálló tanszékek vagy intézeti tanszékek önállósága.

A szabályzatokon és a honlapokon elérhető információk alapján a karok kb. felén egyszintű a tagozódás (vagy legalábbis nem látszik a többszintüség), tehát karok vagy intézetek vannak. A karokon a szervezeti egységek száma 2 és 21 között változott, ami azt mutatja, hogy e 
struktúra takarhat koncentrált és széttagolt rendszereket is. Ezt mutatja az egy tanszékre eső oktatók (beleértve ebben a tanárokat is) átlagos száma is, amely 2 és 31 fő között ingadozik. Jellemzően széttagolt módon müködnek a jogi karok, ahol a szervezeti egységek száma magas, az oktatói létszám viszont az átlagnál alacsonyabb. A Károli Gáspár Református Egyetem jogi karán például 19 szervezeti egység működött 73 oktatóval (3,8 oktató/egység), de hasonló mintázatot mutat a Pécsi Tudományegyetem, az Eötvös Loránd Tudományegyetem és a Széchenyi István Egyetem jogi kara is. Egy másik szélsőséges példa a Pannon Egyetem Georgikon Kara, amelyen 11 tanszék és egy idegen nyelvü oktatási központ müködött, amelyre összesen 21 oktató/tanár jutott (1,8/tanszék). Viszonylag nagy tagoltság mutatkozik még a műszaki területen, elsősorban a Budapesti Müszaki és Gazdaságtudományi Egyetem számos kara működik sok tanszékkel, bár ezeken az átlagnál magasabb az oktatói létszám (például a Villamosmérnöki és Informatikai Karon 10 tanszéken 271 oktató és tanár dolgozik).

A másik végletet a Budapesti Müszaki Főiskola (ma: Óbudai Egyetem) és a Budapesti Gazdasági Főiskola képviseli. Például a Kandó Kálmán Villamosmérnöki Főiskolai Karon és a Bánki Donát Gépészmérnöki Főiskolai Karon 2010-ben 5, illetve 3 intézet működött, amelyek átlagos oktatói létszáma 31 és 28 fő volt.

A karok harmadában két- vagy többszintü az oktatási egységek hierarchiája (intézetek, azon belül tanszékek, sőt esetenként ennél mélyebb a bontás, pl. szakcsoport). Ha a vizsgálódást a nagyobb szervezeti egységek mentén végezzük, akkor természetesen az egyszintű megoldásoknál nagyobb koncentrálódásnak lehetünk tanúi: a szervezeti egységek száma karonként 2 és 20 között ingadozik (az átlag 7 szervezeti egység), míg az oktatók száma 8 és 101 között (az átlag 24 oktató/szervezeti egység).

A kétszintü karok között természetesen a legtagoltabbak a bölcsészkarok és a természettudományi karok, ahol sok intézet és tanszék müködik. A legextrémebb példa az Eötvös Loránd Tudományegyetem Bölcsészettudományi Kara, ahol 16 intézetben 67 tanszék működött a vizsgálat időpontjában, továbbá két önálló tanszék és néhány egyéb szervezeti egység - ezzel együtt az egy-egy intézetben dolgozó oktatók száma átlagosan 41 fő volt.

A kétszintű struktúrák esetében természetesen az igazi kérdés az, hogy milyen viszony van az átfogóbb és a specializáltabb egységek között. A kétszintű struktúrák kialakulásának útja lehet például, hogy a kisebb tanszékeket intézetté vonják össze (a korábbi tanszéki struktúra fenntartása mellett), ám ebböl nem lehet automatikusan következtetni a müködésmód változására is, mert ebből nem feltétlenül következik, hogy a szervezés-irányitás terén az intézeti szint súlya drasztikusan növekedne (ami a department-rendszer egyik eleme lenne). Könnyen előfordulhat, hogy az átalakulás ellenére továbbra is a tanszéki szint marad a meghatározó (pl. a pénzügyi elszámolás, a szavazati jogok a tanszékhez kötődnek), ekkor az intézeti szint inkább szimbolikus jelentőségü. Ez a lépés is magában hordja azonban annak potenciálját, hogy a karon idővel valóban az intézetek (departmentek) váljanak lényegi egységgé.

Előfordulhat a másik véglet is, nevezetesen, hogy az intézet további szervezeti egységekre (tanszékekre) bomlik például az oktatásszervezési feladatok operatív lebonyolíása érdekében, vagy esetleg azért, hogy ilyen módon a tanszékvezetők számára társadalmi státuszt juttasson. A két szint fenntartása a struktúraváltás átmenetének szempontjából is fontos, ti. nem kell a tanszékvezetőket megfosztani a tisztségüktől, hanem csak egy újabb vezetési szintet beiktatni. 
Mindenképpen emlitést érdemel, hogy a vizsgált karok között akadt egy olyan kisebb méretű kar is, ${ }^{71}$ amely nem tanszéki struktúrában müködik. A Pázmány Péter Katolikus Egyetem Információs Technológiai Kara magát „department rendszerben” müködő karnak definiálja. „Ennek lényege, hogy a Karon a különböző szakokon a tárgyak tanításában nincs hierarchia, a tanárok [...] önállóan felelnek a tárgyaikért (melyek pedagógiai összehangolása tantárgycsoportokban történik, az akkreditált tanterveknek megfelelően)."72 Nincs tehát tanszéki tagozódás, a fö szervező elvet a tanterv jelenti (amelyért a szakfelelős és az oktatási dékánhelyettes felel).

71 2008-ban 58 oktató/tanár és 611 hallgató volt a karon.

72 http://www.itk.ppke.hu/karunkrol/a_kar_szervezete/ (2012. 02. 19.) 


\section{6. táblázat: A karok akadémiai struktúrájának tagozódása}

\begin{tabular}{|c|c|c|c|c|c|}
\hline A belső struktúra típusa & Karok száma & megoszlás & $\begin{array}{c}\text { Szervezeti } \\
\text { egységek mérete } \\
\text { oktatói létszámhoz } \\
\text { viszonyítva (min- } \\
\text { max, átlag) }\end{array}$ & $\begin{array}{c}\text { Szervezeti } \\
\text { egységek mérete } \\
\text { (hallgatói } \\
\text { létszámhoz } \\
\text { viszonyítva (min- } \\
\text { max, átlag) }\end{array}$ & $\begin{array}{c}\text { Szervezeti } \\
\text { egységek száma } \\
\text { (min-max, átlag) }\end{array}$ \\
\hline Egyszintü (tanszék vagy intézet) & 83 & $55,3 \%$ & $\begin{array}{c}2-31 \mathrm{fő} \\
\text { (átlag: } 12 \text { fö) }\end{array}$ & $\begin{array}{l}19-1537 \text { fő } \\
\text { (átlag: } 282 \text { fő) }\end{array}$ & $\begin{array}{c}2-21 \mathrm{db} \\
\text { (átlag: } 8 \mathrm{db} \text { ) }\end{array}$ \\
\hline $\begin{array}{l}\text { Inkább egyszintü (egy-egy intézet } \\
\text { további tanszékekre tagolódik, de } \\
\text { dominánsan egyszintü belső } \\
\text { tagozódás) }\end{array}$ & 6 & $4,0 \%$ & $\begin{array}{c}18-29 \text { fő } \\
\text { (átlag: } 22 \text { fö) }\end{array}$ & $\begin{array}{l}346-922 \text { fő } \\
\text { (átlag: } 546 \text { fő) }\end{array}$ & $3-12 d b$ \\
\hline $\begin{array}{l}\text { Legalább kétszintü / dominánsan } \\
\text { kétszintű tagozódás. }^{73}\end{array}$ & 49 & $32,7 \%$ & $\begin{array}{c}8-101 \mathrm{fő} \\
\text { (átlag: } 24 \text { fö) }\end{array}$ & $\begin{array}{l}82-3171 \text { fö } \\
\text { (átlag: } 453 \text { fö) }\end{array}$ & $\begin{array}{c}2-20 \mathrm{db} \\
\text { (átlag: } 7 \mathrm{db} \text { ) }\end{array}$ \\
\hline $\begin{array}{l}\text { Egyéb (nem megállapítható, } \\
\text { hiányos adatok, illetve az orvosi } \\
\text { karok többsége a sajátos } \\
\text { struktúra miatt) }\end{array}$ & 12 & $8,0 \%$ & - & - & - \\
\hline Összesen & 150 & $100,0 \%$ & - & - & - \\
\hline Átlag & - & - & 16,4 fö & 351 fö & 7,5 egység \\
\hline
\end{tabular}

Megjegyzés: a kari struktúrára vonatkozó adatokat 2010 augusztusában gyüjtöttem. Ebben az időpontban viszont még csak a 2008 októberi létszámstatisztikák voltak elérhetőek, ezért a számításokat ezekkel a létszámadatokkal végeztem el. Az „oktató” alatt az oktatói és a tanári munkakörben dolgozók összességét értem, ebbe nem számoltam bele ugyanakkor a „kutatói” munkakörben dolgozókat. (az OM/NEFMI statisztikában őket külön tartják nyilván)

Forrás: saját adatgyüjtés alapján

${ }^{73}$ Ez jellemzően intézet-tanszék (+önálló tanszékek), ritkábban tanszékcsoport-tanszék (+önálló tanszék) tagozódást jelent. Esetenként tanszéken belül szakcsoportok, kutatóközpontok is alakulhatnak stb. 
A karok irányitási struktúráját illetően a dékánhelyettesek felelösségi területeit érdemes áttekinteni. A 2010-es adatgyüjtés alapján a dékánhelyettesek átlagos száma 2,1, amely értéknek a szórása 1. Azaz a karok többségén 1-3 dékánhelyettes van. Néhány karon 4, egy karon (PTE Egészségtudományi Kar) pedig 5 dékánhelyettes található. Néhány kisméretű karon nincsenek dékánhelyettesek.

17. táblázat: A dékánhelyettesek száma 2010-ben

\begin{tabular}{|c|c|c|}
\hline $\begin{array}{c}\text { Dékánhelyettesek } \\
\text { száma }\end{array}$ & $\mathrm{db}$ & $\%$ \\
\hline 0 & 11 & 7,3 \\
\hline 1 & 25 & 16,7 \\
\hline 2 & 55 & 36,7 \\
\hline 3 & 45 & 30,0 \\
\hline 4 & 7 & 4,7 \\
\hline 5 & 1 & ,7 \\
\hline Összesen & 144 & 96,0 \\
\hline Nincs információ & 6 & 4,0 \\
\hline
\end{tabular}

A dékánhelyettesek által lefedett területek sokszínű képet mutatnak néhány kiemelkedően gyakori elemmel. A megjelölt területek két vonatkozásban is információként szolgálhatnak: mely területeket tartják olyan fontosnak a karon, hogy ott foglalkozzanak vele, illetve - ha figyelembe vesszük, hogy a dékánhelyettes a dékán nevében jár el - melyek azok a területek, amelyekkel a dékán közvetlenül nem akar foglalkozni.

\section{8. táblázat: A dékánhelyettesek által felügyelt területek megoszlása 2010-ben ${ }^{74}$}

\begin{tabular}{|l|c|c|}
\hline & $\begin{array}{c}\text { Terület megjelenése a } \\
\text { névben }\end{array}$ & Létszámarányos súlyozás \\
\hline Általános dékánhelyettesség & $21,0 \%$ & $15,1 \%$ \\
\hline $\begin{array}{l}\text { Oktatás, beiskolázás, } \\
\text { tanulmányi ügyek tudomány, }\end{array}$ & $41,6 \%$ & $35,6 \%$ \\
\hline $\begin{array}{l}\text { Kutatás, } \\
\text { tudományszervezés }\end{array}$ & $26,7 \%$ & $20,0 \%$ \\
\hline Gazdasági ügyek & $12,6 \%$ & $9,6 \%$ \\
\hline $\begin{array}{l}\text { Nemzetközi, külügyi, kapcsolati, } \\
\text { kommunikációs, közkapcsolati }\end{array}$ & $14,1 \%$ & $9,4 \%$ \\
\hline $\begin{array}{l}\text { A stratégiai, fejlesztési, } \\
\text { pályázati területek }\end{array}$ & 7,2 & $4,2 \%$ \\
\hline Akkreditáció, minőségbiztositás & $2,3 \%$ & $1,3 \%$ \\
\hline Egyéb területek & $7,3 \%$ & $4,8 \%$ \\
\hline
\end{tabular}

Forrás: saját számítások a karok honlapján szereplő adatok alapján

\footnotetext{
${ }^{74}$ Az első oszlop a dékánhelyettesek által lefedett működési területeket mutatják aszerint, hogy az adott terület a dékánhelyettesek mekkora arányánál jelenik meg explicit módon, tehát pl. egy „oktatási és tudományos dékánhelyettes” mindkét területnél megjelenik. Ezért ebben az oszlopban a végösszeg nem teszi ki a 100\%-ot. A második oszlop a létszámot a területekhez arányosítva jeleníti meg (tehát pl. egy „oktatási és tudományos dékánhelyettest" 0,5-0,5 dékánhelyettesnek tekintünk az egyes kategóriákban).
} 
Nem meglepő módon a leggyakrabban előforduló területek között az oktatási, a kutatási, a gazdálkodási és a kapcsolatrendszer gondozása szerepel. Ritkábban jelennek meg a stratégiai, a fejlesztési és pályázati területek. Ennek többféle oka is lehet: nem jelentősek e területek a karon, a feladatok nincsenek nevesitve vagy megoszlanak több vezető között is, esetleg a feladatokat nem dékánhelyettesek, hanem a kari vagy egyetemi szintű adminisztráció látja el. Ezek hiányából úgy vélem nem lehet következtetést levonni, inkább ezek megléte vezethet arra a következtetésre, hogy az érintett karokon e területeket különösen komolyan veszik.

Időnként egy-egy speciálisabb területnek is külön felelöse lesz, így van olyan kar, ahol önálló dékánhelyettes foglalkozik az (a Széchenyi István Egyetem és a Szent István Egyetem igen kreatív az újszerü dékánhelyettesi pozíciók kialakításában):

- idegennyelvü képzésekkel (Budapesti Műszaki és Gazdaságtudományi Egyetem Építészmérnöki Kar),

- az ifjúsági ügyekkel (Ifjúsági és gazdasági dékánhelyettes, Szegedi Tudományegyetem Bölcsészettudományi Kar; Ifjúsági és kommunikációs dékánhelyettes, Juhász Gyula Pedagógusképző Kar; Oktatási és ifjúsági dékánhelyettes Szent István Egyetem Mezőgazdaság- és Környezettudományi Kar),

- a vállalkozási ügyekkel (Vállalkozási és gazdálkodási dékánhelyettes, Szent István Egyetem Ybl Miklós Müszaki Kar),

- az ipari kapcsolatokkal (Ipari kapcsolatok dékánhelyettes, Széchenyi István Egyetem Müszaki Tudományi Kar),

- beiskolázási ügyekkel (Beiskolázási és közkapcsolati dékánhelyettes, Szegedi Tudományegyetem Gyógyszerésztudományi Kar),

- innovációval (Stratégiai és innovációs dékánhelyettes, Szegedi Tudományegyetem Mérnöki Kar).

Szintén érdemes megemlíteni, hogy van olyan kar, ahol külön tanulmányi dékánhelyettes és oktatási dékánhelyettes van (Pázmány Péter Katolikus Egyetem Jog- és Államtudományi Kar).

Érdekes viszonyítási pont lehet Jackson és Gmelch [2003] tanulmánya, amelynek szerzői az 50 legjobb amerikai pedagógiai kar körében végeztek felmérést a dékánhelyettesek számáról és az általuk ellátott felelősségi területekröl. A karok 80\%-ában - a magyar gyakorlathoz hasonlóan - 1-3 dékánhelyettes müködött. A lefedett területek közé az adminisztráció, a kutatás, a hallgatói ügyek, a tanárképzés, a külső kapcsolatok, a mesterképzési szakok, az alapképzési szakok és a gazdálkodás tartoztak.

Noha nincsenek részletes kontextuális adatok (például a karok méretére vonatkozóan), az mindenképpen szembetűnő, hogy az amerikai gyakorlathoz képest a magyar karok egyikén sem találtam programokért felelős dékánhelyettesi pozíciót. Míg a fenti tanulmányban és számos más külföldi intézményben - különösen üzleti iskolákban - is gyakori, hogy egy-egy képzési 
programért vagy képzési szintért önálló dékán(helyettes) felel75, addig ennek a gyakorlatnak Magyarországon nincsen semmilyen nyoma, azaz a képzési program mint elsődleges szervező elv a magyar felsőoktatásban még nem jelent meg.

\subsection{A finanszírozási rendszer átalakulása és hatása a karokra76}

A magyar felsőoktatásban az intézmények kiadásainak GDP-hez viszonyított aránya a rendszerváltást követően $0,8 \%$ és $1,1 \%$ között mozgott, többnyire alulról közelítve az 1\%-os értéket. Figyelembe véve, hogy a GDP a rendszerváltás óta körülbelül a másfélszeresére emelkedett, megállapítható, hogy a felsőoktatás kiadásainak reálértéke is körülbelül ilyen arányban növekedett. Ugyanakkor a hallgatói létszám megnégyszereződött, így az egy hallgatóra eső kiadás nagysága radikálisan csökkent, ami a felsőoktatás költséghatékonyságának javulását és a minőség romlását is jelentheti. OECD összehasonlításban a GDP arányos felsőoktatási kiadások valamivel elmaradnak a hasonló fejlettségű országok (pl. Szlovákia, Szlovénia) kiadásaitól, és jelentős mértékben elmaradnak az OECD 1,5\%-os átlagától. Azaz Magyarország arányaiban kevesebbet költ a felsőoktatási intézmények müködésére, mint a legtöbb fejlett ország.

Az intézményi (kari) mozgástér megítélése szempontjából további lényeges jellemző az intézmények működési és gazdálkodási szabadságának (státuszának) helyzete. Annak ellenére, hogy 1993 óta több próbálkozás is volt az intézmények státuszának újraszabályozására, ezek mind elbuktak (ezekről a kísérletekről áttekintést ad Polónyi [2009b]). Ennek következtében az állami felsőoktatási intézményeknek továbbra is a költségvetésnek megfelelő szemléletben kell müködésüket tervezni (tehát pénzforgalmi szemléletben, költségvetési évenként, igazodva a mindenkori költségvetési törvényhez). A források felhasználásának szabadságát az időről időre változó szigorúságú bürokratikus eljárások korlátozzák (például az előirányzatok közötti átcsoportosítás folyamata, közbeszerzés). Kari szempontból emellett lényeges az is, hogy jogilag és költségvetésileg az intézmény vállal kötelezettségeket, azaz „kifelé” a karok nem látszódnak. A költségvetési szerv státusz emellett számos további kötöttséggel is jár: az intézmény költségvetése év közben is elvonható, a megtakaritási lehetőségek és a vagyongazdálkodás lehetőségei (a 2005-ös felsőoktatási törvény lazításai ellenére) korlátozottak stb. Polónyi István kritikus megfogalmazásában „ma egy nagy egyetem gazdálkodási és vezetési szabályai - kis túlzással - ugyanolyanok, mint például egy kis vidéki színházé vagy - kis túlzással - egy óvodáé." (Polónyi [2009b] 20.0.).

A költségvetési szervként való működés azt is jelenti, hogy az intézményeknek az államháztartás részeként évente kell megtervezniük a kiadásaikat, illetve az ún. saját

\footnotetext{
${ }^{75}$ Ezekre gyakran nem az associate vagy vice-dean of graduate programs elnevezést használják, hanem a dean of graduate programs, dean of undergraduate programs stb. elnevezést. Azaz egy-egy karon különbözö területekért felelős dékánok müködnek, ami szimptomatikus jele a karok intézményen belüli pozíciója átalakulásának.

${ }^{76} \mathrm{Az}$ e részben írottak döntő módon egy olyan kutatásra épülnek, amelyben felsőoktatási szakértőkkel készítettem interjút a magyar felsőoktatás irányítási és gazdálkodási reformjairól. (Részletesen lásd Temesi - Kováts [2010] és Kováts [2012].)
} 
bevételeiket. A kettő különbözete adja a felsőoktatás közvetlen állami támogatását. Ennek aránya a 2000-es években megközelítette a kiadások 50\%-át, 2010-ben pedig meg is haladta azt (Expanzió [2011]). Ugyanakkor azt is érdemes jelezni, hogy a saját bevételek mintegy háromnegyedét az orvosi képzést nyújtó egyetemek egészségügyi ellátása után érkező OEPtámogatás jelenti, és a fennmaradó rész döntő többsége is valamilyen állami forrásból érkező, nem a felsőoktatásnak dedikált, de versenyben elnyert pénz. A saját bevétel kisebbik része tekinthető valódi külső finanszírozásnak, ebből ki kell emelni a költségtérítést, amelynek aránya a saját bevételek 10-20\%-át teszi ki ${ }^{77}$ (Expanzió [2011]; Polónyi [2012]), illetve és a vállalati megrendeléseket (a bevételek 10-15\%; (Engloner [2008]; Polónyi [2012]). Összességében tehát a saját bevételek látszólagosan magas aránya ellenére a hazai felsőoktatás erősen függ az állami finanszírozástól. (Természetesen intézményenként nagyobb eltérések is találhatóak.)

A kiadások szerkezetével kapcsolatban azt érdemes megjegyezni, hogy az intézmények kiadásának körülbelül 70\%-a bérköltség, és a közalkalmazotti státuszból adódó korlátok (bérezés, elbocsátás) gazdálkodási téren jelentősen szükítik az intézményvezetők mozgásterét.

\section{9. táblázat: Az állami támogatás és a „saját bevétel” alakulása 2000 és 2008 között}

\begin{tabular}{|c|c|c|c|c|}
\hline Év & $\begin{array}{c}\text { Felsőoktatási } \\
\text { kiadási elöirányzat } \\
\text { (millió Ft) }\end{array}$ & $\begin{array}{c}\text { Felsőoktatási } \\
\text { bevételi elöirányzat } \\
\text { (millió Ft) }\end{array}$ & $\begin{array}{c}\text { Bevételek arányaaz } \\
\text { intézményi } \\
\text { költségvetésekben (\%) }\end{array}$ & $\begin{array}{c}\text { Állami támogatás } \\
\text { (millió Ft) }\end{array}$ \\
\hline 2001 & 226,4 & 105,6 & $46,6 \%$ & 120,8 \\
\hline 2002 & 239,9 & 109,6 & $45,7 \%$ & 130,3 \\
\hline 2003 & 318,0 & 135,0 & $42,5 \%$ & 182,9 \\
\hline 2004 & 335,0 & 154,5 & $46,1 \%$ & 180,5 \\
\hline 2005 & 353,4 & 169,2 & $47,9 \%$ & 184,2 \\
\hline 2006 & 383,7 & 186,8 & $48,7 \%$ & 196,9 \\
\hline 2007 & 404,2 & 199,5 & $49,4 \%$ & 204,7 \\
\hline 2008 & 416,9 & 200,4 & $48,1 \%$ & 216,4 \\
\hline
\end{tabular}

Forrás: Polónyi [2009b]

A következőkben tekintsük át részletesebben az intézmények néhány bevételi elemét: az állami támogatás elosztási mechanizmusait (ezen belül a normatív finanszírozási rendszert és az államilag finanszírozott hallgatók elosztási rendszerét) ${ }^{78}$, a költségtérítés rendszerét és a kutatási-pályázati bevételek rendszerét. Ezt követően pedig bemutatom a magyar felsőoktatásban előforduló belső forrásallokációs modelleket.

\footnotetext{
${ }^{77}$ A költségtérítési bevételek nagyságáról nincs elérhető publikus statisztika.

78 Itt most helyhiány miatt nem térek ki az állami támogatás 2006 és 2011 között élő egyik lényeges eszközére, az ún. hároméves fenntartói megállapodásokra, amelynek lényege az volt, hogy az intézményektől a három évre garantált támogatásért cserébe indikátorokkal mérhető teljesítményjavulást vártak el, ezek céljait és a haladást mérő indikátorokat azonban maguk az intézmények határozhatták meg bizonyos megkötésekkel. Ebből adódóan számos látszatcél és látszatindikátor kijelölésére került sor. (részletesen lásd FTT [2008] 640.)
} 


\subsubsection{A normatív finanszírozási rendszer}

Az állami támogatások elosztása 1996-ig intézményfinanszírozás keretében történt, azaz olyan, a minisztériummal folytatott alkufolyamat keretében, amely részben bázis alapon (a korábbi évek költségvetésén), részben pedig az intézmény tervezett költségvetésén alapult. Ezt a rendszert váltotta fel 1996-ban az ún. normatív finanszírozási rendszer, amely az intézmény állami támogatását konkrét, jól megragadható, főként inputváltozókhoz kötötte, például a hallgatói létszámhoz vagy az oktatói, kutatói és doktoranduszi létszámokhoz. A rendszert gyakran érte az a kritika, hogy az intézményeket a hallgatói létszámok növelésére és a hallgatók rendszerben tartására ösztönözte.

A normatív rendszer elviekben javította a finanszírozás átláthatóságát és tervezhetőségét, és csökkentette a minisztérium és az egyes intézmények közötti alkuk szerepét, ugyanakkor a normatívák számának, fajtájának és nagyságának gyakori változása ez ellen hatott (részletes áttekintést lásd: Polónyi [2012]). Minthogy 2011-ben és az azt megelőző néhány évben az intézményeknek juttatott közvetlen állami támogatás 50\%-át a képzési normatívák, 25\%-át pedig a tudományos normatíva alapján osztották ki, ezért lényeges kérdés, hogy miért és hogyan változott az elosztás alapjául szolgáló normatívák száma és nagysága.

20. táblázat: A normatívák számának változása a magyar felsőoktatásban 1997-2011 között

\begin{tabular}{|c|c|c|c|c|}
\hline Év & $\begin{array}{c}\text { Képzési normatívák } \\
\text { száma }\end{array}$ & $\begin{array}{c}\text { Tudományos normatíva } \\
\text { elemek száma }\end{array}$ & $\begin{array}{c}\text { Fenntartói normatíva elemek } \\
\text { száma }\end{array}$ & $\begin{array}{c}\text { Összes } \\
\text { elem }\end{array}$ \\
\hline 1997 & 15 & & & 15 \\
\hline 1998 & 7 & & & 7 \\
\hline 1999 & 5 & 1 & 6 & 5 \\
\hline 2000 & 4 & 1 & 6 & 11 \\
\hline 2001 & 4 & 1 & 6 & 11 \\
\hline 2002 & 4 & 1 & 7 & 11 \\
\hline 2003 & 5 & 3 & 5 & 13 \\
\hline 2004 & 7 & 3 & 5 & 15 \\
\hline 2005 & 7 & 4 & 6 & 15 \\
\hline 2006 & 12 & 4 & 8 & 22 \\
\hline 2007 & 12 & 7 & 8 & 24 \\
\hline 2008 & 23 & 7 & 8 & 38 \\
\hline 2009 & 23 & 7 & 8 & 39 \\
\hline 2010 & 24 & 7 & 8 & 39 \\
\hline 2011 & 24 & & & \\
\hline
\end{tabular}

Forrás: Polónyi [2012]

Az állandó változtatás egyik lehetséges magyarázata, hogy a normatívákra az oktatáspolitika nem ösztönző és orientáló eszközként tekintett, amellyel például az intézmények felvételi és képzési politikájára, illetve ezen keresztül a hallgatói jelentkezésekre hatást lehetne gyakorolni. Ehelyett a normatívákat a rendelkezésre álló, a felsőoktatásra fordítható állami

\footnotetext{
79 Nagy vonalakban: a képzési normatíva a képzéssel, a tudományos normatíva a kutatással, míg a fenntartói normatíva az infrastruktúra fenntartásával kapcsolatos költségek fedezetét hivatott biztosítani.
} 
támogatásból számítják vissza. A normatív finanszírozási rendszer hatását ráadásul folyamatosan tompították, azaz sem a kedvező változásokból eredő többlet(finanszírozás), sem a kedvezőtlen változásokból eredő hátrány (elvonás) nem érvényesült tisztán. A normatív rendszer gyakori változtatása és egyre bonyolultabbá válása arra utal, hogy a finanszírozásban továbbra is jelentős az intézményi lobbi és az alkufolyamatok szerepe. Így valójában az alkufolyamatokon alapuló intézményfinanszírozás érvényesül, de ezt a normatívák és egyéb finanszírozási eszközökön keresztül juttatják érvényre, fenntartva az „objektív”, kiszámítható finanszírozási rendszer látszatát. (Erre utalva ír Polónyi „Patyomkin finanszírozásról”; lásd például Polónyi [2009a]). Ez azt jelenti, hogy a normatívák alapján számított támogatás változását más csatornákon (projektfinanszírozás, fenntartói támogatás, fejlesztési pályázatok) ellensúlyozzák, ilyen módon fenntartva egyfajta status quo-t. Polónyi István megfogalmazásában:

„A kialakult képlet szerinti (Patyomkin) finanszírozás és a fenntartói szerződések nyomán kialakult garantált támogatások abba az irányban mozdították el a felsőoktatás támogatási rendszerét, hogy egy a piactól egyre inkább védett, a tényleges teljesitmények helyett részint az intézményi önigazolásnak, részint az oktatáspolitika szubjektivitásának teret engedő rendszer alakult ki. Végeredményként 2010-re egy rendkivül bonyolult, az egyes nagy lobbik érdekeit tükrözö, s több vonatkozásában átláthatatlan finanszírozás jött léte, amelynek eredményeként nagyon sok tekintetben az 1990-es évek elejéhez hasonló, átláthatatlan érdekektől áthatott intézményi kondíciók alakultak ki." (Polónyi [2012])

A finanszírozás e sajátosságai nem feltétlenül válnak nyilvánvalóvá a kari vezetők számára, akik gyakran gondolkodnak továbbra is a normatívák szerint. Ennek lehetséges oka az intézményen belüli forrásallokáció sajátosságaiban keresendő, amelyre később még visszatérek.

\subsubsection{Az államilag finanszírozott alapképzési hallgatói helyek elosztási mechanizmusa}

Minthogy a 2000-es évek végén az állami támogatás körülbelül 50\%-át az államilag finanszírozott hallgatói létszámok alapján allokálták az intézmények között, ezért fontos áttekinteni a finanszírozott hallgatói helyek elosztásának mechanizmusait is. 2005 előtt az államilag finanszírozott helyeket intézmények és szakok szerint a minisztérium osztotta el (amely így természetessé tette az intézmények és a minisztérium közötti alkufolyamatot). A felsőfokú szakképzési és az alapszakos helyek esetében ezt a rendszert 2005-ben váltotta fel a versenyalapú allokáció, melyben az államilag finanszírozott helyeket a minisztérium a képzési területekre vonatkozóan állapította meg, ezen belül pedig alapvetően az érettségin elért eredmény alapján történt a hallgatók rangsorolása. Az államilag finanszírozott hallgatók után az az intézmény kapta a finanszírozást, ahová végül a hallgató felvételt nyert. (A doktori képzésekben a támogatott helyek elosztása meghatározott indikátorokban elért teljesítmény alapján történik, ezt az Országos Doktori Tanács felügyeli80. Ugyanakkor a mesterképzések terén továbbra is kvótarendszer müködik.)

80 Lásd a „Keretelosztás elvei és számítása: 2008- című dokumentumot http://www.doktori.hu/index.php?menuid=351\&cid=24 oldalon. 
A felvételi rendszer reformja alapvetően a nagy presztízsű és/vagy a fővárosi intézményeket hozta kedvezőbb helyzetbe, miközben a vidéki és a kisebb presztízsü intézmények helyzete az államilag finanszírozott hallgatók számának és minőségének csökkenésével romlott. A vidéki intézmények vezetői és dékánjai ezt több alkalommal is szóvá tették az interjúk során. Egy vidéki intézmény felsővezetője szerint például:

\begin{abstract}
...mert nekünk sajnos az a hallgató van, aki jut az új felvételi rendszerben, ami egy nem igazságos elosztás, meggyőződésünk. Azért, mert vannak benne olyan koefficinesek, amelyről nem tehet a budapesti intézmény. Most nem a Corvinusról van szó, hanem egyszerüen a Budapest-centrikus magyarországi gondolkodásról, ami nem csak a felsőoktatásba van a kelleténél nagyobb mértékben beépülve a struktúrákba, az agyi struktúrákba. Tehát úgy tünik, mintha két ország lenne: Budapest és Magyarország." (F3)
\end{abstract}

A rendszer hatását ugyanakkor a minisztérium szabályozási eszközökkel tompította, például a kapacitás-akkreditáció révén igyekezett mérsékelni a nagyobb vonzerejű intézmények előnyét, a nehéz helyzetben lévő intézményeket más csatornákon próbálta támogatni, vagy korlátozta a képzési költségvetés normatív támogatása évenkénti csökkenthetőségének a mértékét81.

Mindennek két további lényeges következménye volt. Egyrészt a hallgatói létszámon alapuló normatív finanszírozási rendszer és a felvételi rendszer a főiskolákat érdekeltté tette abban, hogy mesterképzést és doktori képzést is indítsanak, amit lehetővé tett számukra, hogy az intézmények típusa többé nem kötődött a képzési profilhoz. Másrészt a felsőoktatás fejlesztését ellentmondásossá tette az, hogy miközben az új felvételi rendszer következtében a vidéki intézményekben a hallgatói létszám csökkent, addig a felsőoktatási európai uniós fejlesztési források nagyobb részt a vidéki intézmények számára voltak elérhetőek.

\title{
7.4.3. A költségtérítés (tandij)
}

A normatív finanszírozási rendszer mellett az 1996-os törvénymódosítás másik nagy jelentőségü eleme a költségtérítéses finanszírozási forma bevezetése volt, amely révén az intézmények saját bevételekre tehettek szert. Költségtérítést azoknak kell fizetniük, akiknek nem sikerült államilag finanszírozott képzésre bejutniuk. ${ }^{82} \mathrm{~A}$ tandij általánossá tételére két alkalommal is kísérletet tettek, ezek azonban vagy rövid életűek voltak (a következő kormány eltörölte), vagy népszavazáson megbuktak.

A költségtérítést fizetők köre a bevezetésétől kezdve 2000-es évek közepéig folyamatosan növekedett, és 2004-ben meghaladta az államilag finanszírozott hallgatók arányát. Ezt követően azonban megfordult a trend. A költségtérítéses hallgatók aránya a nappalis képzésekben $20 \%$ körül, a részidős és levelezős képzéseken pedig $80 \%$ körül alakul.

\footnotetext{
81 Lásd: 50/2008. (III. 14.) Korm. Rendelet 3§ 1. bek.

82 A tandífizetésnek főként a posztszocialista régióban létezik e sajátos, duális modellje, amelyben a képzésben résztvevők egy részének nem csak a képzési költségeit fedezi az állam, hanem különböző támogatásokat is nyújt nekik (ösztöndíj, jegyzettámogatás stb.). A költségtérítést (tandíjat) fizetök ugyanakkor semmiféle közvetlen támogatásban nem részesülnek. Ez különösen a magyar közoktatás hátrányokat növelő jellegében tűnik igazságtalan rendszernek. (OECD 2008)
} 
Az intézmények gazdálkodási autonómiáját jelentősen növelte, hogy a költségtérítések nagyságát - a nyugat-európai egyetemekkel szemben - az intézmények maguk határozhatták meg (Estermann - Nokkala [2009] 41.0.). A költségtérítéses képzésekből az intézmények körülbelül 30-35 milliárd forintnyi bevételre tesznek szert, ami a saját bevételek körülbelül 1020\%-át teszi ki, az összes felsőoktatási kiadásnak pedig 6-7\%-át fedezi (lásd még Polónyi [2009b]; Expanzió [2011]; Mészáros [2012]).

Intézményi szempontból a költségtérítési forma megjelenése növeli az intézmények mozgásterét, különösen azért, mert ezen bevételek felhasználásáról az intézmények viszonylag szabadon dönthetnek. Ugyanakkor vannak lényeges korlátok is, leginkább az, hogy az intézmények a piacról szerzett bevételt kénytelenek költségvetési forrásként (azokkal a kötöttségekkel) elkölteni (lásd például a közbeszerzési kötelezettséget), ami a forrásfelhasználás hatékonyságát rontja.

\subsubsection{Kutatási és fejlesztési tevékenységböl származó bevételek}

A kutatási bevételekről 2008-ban készült az utolsó átfogó értékelés (ez 2006-ig vizsgálta a tendenciákat), amely megállapítja, hogy 2005-ben a felsőoktatás kutatásból származó bevétele mintegy 21 milliárd forint volt, amely az összes bevétel 12\%-át, a felsőoktatási kiadásoknak pedig az 5\%-át tette ki (Engloner [2008]; Polónyi [2009c]). Ezekből ugyanakkor az intézmények részesedése nagyon egyenlötlen, mert a bevételek nagy része igen kevés intézményben koncentrálódik (Engloner [2008]). Például a 2003-2005 közötti időszakban mindössze két intézmény (BME, DE), 2006-ban pedig 4 intézmény (BME, DE, SZTE, ELTE) szerezte az összes kutatási bevétel 60-65\%-át. (Polónyi [2009c]) Ez alapján kijelenthető, hogy a kutatás jelentősége az intézmények bevételszerkezetében általánosságban meglehetősen kicsi, ami alól csak néhány intézmény (elsősorban a nagy egyetemek) jelentenek kivételt.

Itt azt is érdemes megjegyezni, hogy a költségvetésen kívüli kutatási bevételek aránya nagyon alacsony: a nemzetközi kutatási pályázati bevételek, illetve a klasszikus vállalati megbízásokból származó bevételek az amúgy is alacsony $K+F$ bevételeknek mindössze 13,4\%, illetve 17,5\%-a volt 2005-ben (Engloner [2008] 21.0.). Ez nem csak a magyar felsőoktatás zártságát mutatja, hanem azt is jelzi, hogy az intézmények $K+F$ bevételei is állami forrásból származnak. Az állami kutatási pályázati források elosztása ugyan versengő, de ezt némileg korlátozza az ország kis méretéből adódó belterjesség (azaz a pályázatok bírálatát nemcsak azok szakmai tartalma, hanem a pályázó kapcsolatai is befolyásolják).

\subsubsection{Intézményen belüli forrásallokáció és ezek hatása a karokra}

Az irányítási modellekhez hasonlóan a gazdálkodást illetően is centralizált és decentralizált modellek alakultak ki, amelyek elsősorban az állami támogatások belső elosztásának mikéntjében különböznek.

A decentralizált modellek a rendszerváltást követő nehéz intézményi finanszírozási helyzetben terjedtek el, amikor az intézményen belüli pénzügyi és finanszírozási döntések felelősségét - gyakran a demokratizmus jegyében - az adminisztráció egy részének (például a tanulmányi ügyintézés, vagy esetenként a gazdálkodás) fenntartási és működtetési kötelezettségével együtt a karokra delegálták. Más intézményekben pedig a gazdálkodás karok, 
tanszékek szintjére történő decentralizálásával igyekeztek ösztönözni a bevételek növelését, és ezzel csökkenteni az intézmény krónikus erőforráshiányát. $A$ decentralizált modell lényegét az egyik nagy egyetem dékánja a következőképpen mutatja be:

„[Az intézményben] kari gazdálkodás folyik, tehát a kari gazdálkodásnak az a szabálya, hogy [...] a karok keresik meg a pénzt, a karok kapják meg a pénzt, és visszafinanszírozzák a központi egységeket. Tehát ez az alapfilozófia. Természetesen kifele egy jogi személy vagyunk, következésképpen az az érdekes, hogy likvid-e az egyetem vagy nem likvid. Papíron persze likvidek vagyunk, mert összeütik az egészet és kiderül, hogy ennyi a nyitott szállitói tartozás. Tehát ezek pluszba vannak, összerakva van három millió forintja az egyetemnek. De ez belül nem így van, belül nagyon pontosan nyilván van tartva, hogy ez mínuszos, ez mínusz, ez meg pluszos. Tehát mi abban a tekintetben majdnem teljesen autonómak vagyunk, hogy az itt keletkezett pénzt mi úgy osztjuk el, ahogy ezt a közösség önmagának elképzeli." (D7)

Jól látható, hogy a decentralizáció és a finanszírozási rendszer (látszólagos) normativitása nagymértékben elösegítette a kari pozíciók intézményen belüli megerősödését, hiszen ilyen módon transzparenssé vált, hogy a karok mennyivel járulnak hozzá az intézményi bevételekhez.

Miközben e modell elviekben takarékos, fenntartható gazdálkodásra szorítja a karokat, számos dilemma is felmerül. Az egyik, hogy az egyes karoknak eltérő a lehetősége az extra jövedelmekre, ami hosszú távon a karok közötti jelentős különbségek kialakulását eredményezheti. A másik probléma abból fakad, hogy a forráselosztás ilyen módja kódolja a karok egymással és a központtal való keresztfinanszírozási konfliktusait, hiszen ettől kezdve bármely vita könnyen a „Te mennyi bevételt hozol az intézménynek” mederbe volt terelhető. Ráadásul az egyes karok többlete (vagy hiánya) csak papíron létezik, hiszen az intézmény a kötelezettségvállaló. Elvben tehát előállhat olyan helyzet, hogy a szenátusi többséget birtokló karok tartósan veszteségesen müködnek, amit a kisebbségben lévő karok nyereségének nem konszenzuson alapuló elvonásával ellensúlyoznak. További fontos konfliktus forrását jelentette a központi szolgáltatások költségeinek karok közötti megosztása, ami különösen az egyre terebélyesedő központi adminisztráció fényében válik fontos kérdéssé.

A normatívák érvényesítése a belső forrásallokálásban egy további dilemmát is eredményezhet. Az intézmény gazdasági pozícióját ugyanis nem egyszerüen a normatívák szerinti teljesítés határozza meg, mert a normatívákhoz kapcsolt mutatókban felmutatott gyengébb teljesítmény ellensúlyozható a normatívák nagyságának manipulálásával (lobbizással), új normatívák bevezetésének kezdeményezésével vagy más állami finanszírozási csatornákon történő bevételszerzéssel. Az állami támogatások belső elosztása azonban mégiscsak a normatívák szerint zajlik, ebböl következően egy dékán számára racionálisnak tűnik azok szerint működtetni a kart. Így például a dékán számára ésszerű a hallgatói létszám folyamatos növelése, mert azt tapasztalhatja, hogy minél nagyobb a hallgatói létszáma, annál nagyobb a támogatása. Ez a logika ugyanakkor nem feltétlenül érvényes az intézmény egészére nézve.

A decentralizált logika e dilemmák miatt nem mindig kívánatos.

„De abszolút nem akarunk odáig jutni, mint az ELTE, vagy a Miskolci Egyetem, hogy ne a helyit mondjam [az interjú a BCE-n készült]. Tehát azt soha nem gondoljuk, hogy úgy kell működni egy intézménynek, hogy például a költségvetési támogatás megérkezik az intézménybe, akkor a mindenkor érvényes finanszírozási kormányrendeletre hivatkozva elosztjuk a pénzt, és akkor elkezd müködni az egyetem, és akkor a karoknak van egyeteme, és nem az egyetemnek 
vannak karai. Tehát ezt, ezt a helyzetet nem akarjuk. Tudniillik nincs valós finanszírozási szisztéma, modell Magyarországon. [...] De amit az államtól kapunk pénzt, az állam nem feladatra adja a pénzt. Az állam alkukból, költségvetési alkuk, nemzetgazdasági, hol bizonyos intézményvezetői lobbik, hol politikai befolyások alapján adja a pénzt, és gyakorlatilag csak csendes köszönőviszonyban van azzal a feladattal, amit az egyetemen ellát. Na most ez karra lebontva meg pláne nem [igaz]." (F3)

Nem szükségszerü azonban, hogy az állami támogatásokat ugyanolyan elvek szerint osszák fel a karok között, mint amilyen elvek szerint ahhoz az intézmény hozzájut, mert - mint korábban utaltam rá - ezek az elvek nem feltétlenül tükrözik az intézmény valós feladatait, teljesítményét. Ez a kiindulópont jelenti az elosztás centralizált modelljének alapját, amelynek logikáját a következőképpen fejti ki egy dékán:

„Tehát valóban centralizált a rendszer. Igen ám, csakhogy az nem mozgástér, hogyha neked van 500 milliód, amiből 499 milliót visszapasszolsz. Na most számos helyen nagyjából ehhez hasonló szituációkat találunk, mert hogy egyébként leosztom a béreket, meg elkezdem kiszámolni a kubatúrát, hogy akkor most mennyi köbméter tartozik rád. És akkor fütési dij, meg az ilyen normatíva, meg az amolyan. Nálunk van egy szemlélet, hogy a pénz addig tart címkézve, amíg megérkezik az egyetemre, onnantól kezdve az egyetemi pénz. Na most ennek következtében a humán erőforrás oldaláról nagyon egyszerü a kérdés, mert évente a dékán leül a rektorral és megbeszélik azt, hogy milyen lehetőségek kínálkoznak az álláslehetöségeket, elöléptetéseket tekintve. Ha megvan az egyezség [...] azzal nekem nem kell foglalkozni, hogy hogy miből fizetem ki az $X$ tanársegédnek a bérét. Ez a rektornak a problematikája. Nem kell foglalkoznom azzal, hogy milyen fütés, hogy mennyit tanitunk itt, hogy mennyit oktatunk át, és nem vitatkozom a másik dékánnal, hogy cseszd meg, neked mennyit oktatunk át, és akkor most ezért mennyi pénzt kellene hogy fizessél. Ezek nincsenek benne a rendszerben." (D13)

A karok mozgásterét a centralizált rendszerekben a központból adott szabadon felhasználható kari keretek biztosítják (ezek nagysága tárgyaláson vagy valamilyen számítási módszer segítségével történhet). Gazdaságilag stabil intézményeknél a centralizált forráselosztási rendszerek dilemmáját az jelenti, hogy hogyan lehet a karok bevételek szerzésére ösztönözni. Ennek eszköze többnyire az, hogy a saját bevételeket, pályázati pénzeket vagy azok egy meghatározott részét a karok megtarthatják, és szabadon felhasználhatják.

A karokon belüli forráselosztás nagyon hasonló logikákat követ, mint a karok közötti gyakorlat. Az interjú során találkoztam olyan intézménnyel, ahol az intézetek/tanszékek közötti forráselosztásról a kari tanács döntött valamilyen logika alapján, és olyannal is, ahol az intézetekhez érkezett a pénz, és abból finanszírozták „vissza” a kari adminisztráció működését.

Fontos dilemmát jelent mind karok, mind az intézetek/tanszékek közötti forráselosztás során, hogy az egyes szervezeti egységeknek különböző lehetőségük van extra bevételekre, fizetők hallgatókra szert tenni.

\section{5. Összefoglalás}

A fejezet elején két célt fogalmaztam meg: a karokra vonatkozó trendek leírását, illetve annak bemutatását, hogy a dékánok tágabb és szűkebb környezete hogyan változott. 
Mit tudtunk meg tehát a karok számának, szerepének változásáról? Egyfelöl kimutatható, hogy növekedett a karok száma és (hallgatói létszám alapján vizsgált) mérete, ami a felsőoktatás szerkezeti átalakításának (például integráció), részben pedig annak a karalapítási láznak köszönhető, amelyet a jogszabályi változások is elősegítettek. Az új karok létrehozását olyan tényezők befolyásolták, mint a méret növekedése, az intézmények irányithatóságának fenntartása, stratégiai szempontok mérlegelése és az egyéni ambíciók.

A dékánok környezetére vonatkozóan a legfontosabb megállapítás, hogy a környezet komplexitása drámai mértékben megnőtt. Ennek csak egyik tényezője a hallgatói létszámok növekedése, a hallgatók és a hallgatói igények sokszínűvé válása és a képzési rendszer bonyolódása. Legalább ilyen fontos tényező, hogy változott a felsőoktatás releváns stakeholdereinek (érintettjeinek) száma, aminek következtében jelentősen bonyolódott az a társadalmi erőtér is, amiben a dékánoknak (és általában a felsőoktatási intézményeknek) mozogniuk kell. A változást jól mutatja például egy vidéki dékán megjegyzése:

„Valamikor egy felsőoktatásnak elég volt, hogyha a tanácsnak, meg a párttitkárnak megfelelt. Most meg az a helyzet, hogy a régióban azért el kell, hogy helyezze magát, és el kell, hogy fogadtassa magát. Tehát nyilván ez is egy teljesen más dolog." (D28)

A viszonyok bonyolultságát jól jellemzi például a többi felsőoktatási intézményhez való viszony, amely az interjúalanyoknál hol a finanszírozásban, lobbiban, hallgatói létszámokban értelmezett „brutális versengésről”, hol pedig együttműködésről vagy együttműködési kényszerekről szólt.

A komplexitás növekedésében jelentős szerepe van a kiszámíthatatlanságot eredményező állandóan zajló felsőoktatási reformoknak is, amelyek különböző felsőoktatási meggyőződések, narratívák mentén zajlanak (amelyek persze különböző társadalomképekbe ágyazódnak be). Ennek következtében különösen a felsőoktatás jogi környezetének a jelentősége nőtt meg, hiszen az időszakosan jelentkező direkt fenntartói utasítások mellett az intézmények és karok cselekvési tere is növekedett, amelynek korlátait viszont a jogszabályok jelölték ki. A reformok nem csak alkalmazkodási kényszereket jelentettek az intézmények számára, hanem lehetőségeket is, amennyiben az intézmények felismerték a lehetőségeket és kezdeményezőkészek voltak. Ez azt jelenti, hogy nemcsak alkalmazkodtak a lassan alakuló viszonyokhoz, hanem maguk is formálóivá váltak azáltal, hogy olyan megoldásokkal is kísérleteztek, amelyeket a szabályozások nem engedélyeztek explicit módon, de nem is tiltottak. Általánosságban úgy is lehet fogalmazni, hogy az állami forrásoktól való nagyfokú függés és a direkt állami felügyelet hiánya inkább a stratégiai orientáció lehetőségét, semmint a kényszerét teremtette meg, amellyel egy-egy intézmény, ha akart, élhetett.

A változások következményeként a dékánok szükebb környezete is komplexebbé vált. Az integráció következtében belső feszültségek és kényes egyensúlyok alakultak ki. A környezeti komplexitást, a gyakori jogszabályváltozásokat a laikus oktatók egyre kevésbé képesek követni, ami elvben felértékeli az intézményi és a kari adminisztráció jelentőségét és intézményen belüli súlyát. Szintén növeli az adminisztráció jelentőségét az egyre terebélyesebbé váló szolgáltatási portfolió is.

E viszonyok között az interjúalanyok körében többé-kevésbé általánosan osztott meggyőződés az volt, hogy ha valaki 
megpróbál ilyen régi, professzor uras stílusban [vezetni], az egy kudarc. Tehát vagy a munkatársak szenvedik meg, mert kénytelenek megcsinálni helyette, ami vezetői feladat lenne, vagy pedig az egész nem fog menni. Tehát ez az első. Tehát ha valaki nem veszi tudomásul, hogy változik a világ. (D20)

Ugyanakkor korántsem világos, hogy „a régi, professzor uras stílus” helyett vajon milyen szerepet is kellene betöltenie egy dékánnak, és valójában milyen szerepet töltenek be? $\mathrm{E}$ változások teszik relevánssá a kutatás kérdéseit, azaz hogy milyen dékáni szerepek bontakoznak ki ilyen környezetben ma Magyarországon? Mi a dékáni szerep tartalma, és mennyire tudnak ezzel azonosulni a dékánok? És végül: mit árul ez el a felsőoktatási rendszer fejlődéséről? 


\section{Dékánok a magyar felsőoktatásban}

Csakúgy, mint az előző fejezetnek, e fejezetnek is kettős célja van. Egyrészt áttekintést kivánok adni a dékánok helyzetét adó szabályozásról, ezek következményeiröl, valamint a dékánok néhány jellemzőjéröl, másrészt megvizsgálom, hogy a szabályozásokból, megfigyelt tipikus mintázatokból milyen direkt és indirekt elvárások olvashatóak ki a dékánokkal szemben. Ehhez a következőkben részletesen bemutatom a dékánok kiválasztására és müködésére vonatkozó szabályozást, különös tekintettel a pozíció ideiglenes és választott jellegére, valamint a választhatóság feltételeire. Az elemzést a 2010-es adatgyüjtésem alapján egészítem ki. A kari vezetők elnevezésének, valamint a választhatóság legfontosabb feltételeinek változását a 20 . számú táblázatban foglalom össze, ezek kibontására a következő alfejezetekben kerül majd sor.

Emellett az interjúk alapján áttekintem a dékánok választásának tipikus helyzeteit, valamint a dékáni karrierút alakulását. Az elemzés során az interjúkat mint tényeket használom fel, célom a felsőoktatási intézményrendszer bemutatása, nem pedig a dékánok gondolkodásmódjának jellemzése. Erre majd a következő fejezetben kerül sor, ahol a dékánok szerepértelmezését veszem górcső alá. 
21. táblázat: A kari vezetők megnevezése és kinevezési feltételei a (felső)oktatási törvények szerint 1985 és 2011 között

\begin{tabular}{|c|c|c|c|c|c|c|c|}
\hline \multirow{3}{*}{$\begin{array}{l}\text { A törvény } \\
\text { vagy a } \\
\text { módosítás } \\
\text { éve }\end{array}$} & \multicolumn{5}{|c|}{ Vezetők megnevezése } & \multirow{2}{*}{\multicolumn{2}{|c|}{ Kari vezetők (magasabb vezetők) kinevezési feltételei }} \\
\hline & \multicolumn{3}{|c|}{ Egyetemeken } & \multicolumn{2}{|c|}{ Főiskolákon } & & \\
\hline & $\begin{array}{l}\text { Egyetem } \\
\text { vezetőjének } \\
\text { megnevezése }\end{array}$ & $\begin{array}{l}\text { Egyetemi kar } \\
\text { vezetőjének } \\
\text { megnevezése }\end{array}$ & $\begin{array}{l}\text { Főiskolai kar } \\
\text { vezetőjének } \\
\text { megnevezés }\end{array}$ & $\begin{array}{l}\text { Főiskola } \\
\text { vezetőjének } \\
\text { megnevezése }\end{array}$ & $\begin{array}{l}\text { (Főiskolai) kar } \\
\text { vezetőjének } \\
\text { megnevezése }\end{array}$ & $\begin{array}{l}\text { Kinevezésének } \\
\text { időtartama }\end{array}$ & Elvárt beosztás \\
\hline 1985 & rektor & dékán & főigazgató & főigazgató & - & 5 évre, max. két ciklus & $\begin{array}{l}\text { Egyetemi kar: egyetemi docens, egyetemi tanár } \\
\text { Főiskolai kar: egyetemi docens, egyetemi tanár, } \\
\text { főiskolai tanár }\end{array}$ \\
\hline 1993 & rektor & dékán & főigazgató & főigazgató & - & 3 évre, max. két ciklus & Nincs szabályozva \\
\hline 1996 & rektor & dékán & főigazgató & főigazgató & igazgató & 4 évre, max. két ciklus & egyetemi tanár, egyetemi docens és főiskolai tanár \\
\hline 1999 & rektor & dékán & főigazgató & $\begin{array}{l}\text { főiskolai } \\
\text { rektor }\end{array}$ & főigazgató & 4 évre, max. két ciklus & $\begin{array}{l}\text { Egyetemi kar: egyetemi docens, egyetemi tanár } \\
\text { Főiskolai kar: egyetemi docens, egyetemi tanár, } \\
\text { főiskolai tanár }\end{array}$ \\
\hline 2005 & rektor & \multicolumn{2}{|c|}{$\begin{array}{c}\text { dékán/ főigazgató (nem } \\
\text { szabályozza)* }\end{array}$} & rektor & $\begin{array}{c}\text { dékán/ főigazgató } \\
\text { (nem szabályozza)* }^{*}\end{array}$ & $\begin{array}{l}\text { 3-5 év, max. két ciklus, } \\
\text { Legfeljebb } 65 \text { éves korig }\end{array}$ & Nincs szabályozva \\
\hline 2009 & rektor & \multicolumn{2}{|c|}{$\begin{array}{c}\text { dékán/ főigazgató (nem } \\
\text { szabályozza)* }\end{array}$} & rektor & $\begin{array}{l}\text { dékán/ főigazgató } \\
\text { (nem szabályozza)* }^{*}\end{array}$ & $\begin{array}{l}\text { 3-5 év, max. három } \\
\text { ciklus** } \\
\text { Legfeljebb } 70 \text { éves korig }\end{array}$ & Nincs szabályozva \\
\hline 2011 & rekor & $\begin{array}{l}\text { dékán/ } \\
\text { föigazgató (nem } \\
\text { szabályozza)* }\end{array}$ & $\begin{array}{l}\text { dékán/ } \\
\text { főigazgató (nem } \\
\text { szabályozza)* }\end{array}$ & rektor & $\begin{array}{c}\text { dékán/ főigazgató } \\
\text { (nem szabályozza)* }^{*}\end{array}$ & $\begin{array}{l}\text { 3-5 év, max. két ciklus } \\
\text { Legfeljebb } 65 \text { éves korig }\end{array}$ & Nincs szabályozva \\
\hline
\end{tabular}

*a törvény csak annyit rögzít, hogy a dékán, illetve föigazgató magasabb vezetői beosztásnak számít.

** a harmadik ciklus megkezdése 2/3-os jóváhagyáshoz kötött. A törvény az életkort is felemelte 65-ről 70 évre. 


\subsection{A dékáni pozíció választott jellege}

Az 1993-as felsőoktatási törvény a dékán megválasztását a kari tanács, kinevezését az intézetvezető hatáskörébe utalta. A 2005-ös törvény ennél több szabadságot engedett az intézményeknek. Eszerint minden dékáni pályázatot nyilvánosan kellett kiírni, akik közül a rektor döntött mérlegelve a szenátus véleményét és rangsorát. $A z$ interjúk alapján kibontakozó tényleges gyakorlat azonban inkább azt mutatja, hogy sok helyen a szenátusi szavazás csak jóváhagyta/megerősítette a kari tanács rangsorát, és rektor többnyire a választás(ok)on első helyen végzett jelöltet bízta meg a vezető feladatok ellátásával.

Magát a választás folyamatát, illetve az azt megelőző teendőket az egyes karok saját szabályai és hagyományai további elemekkel egészithetik ki. Számos karon például a jelölteket nyilvánosan is meghallgatják oktatói összértekezlet keretében, néhányon pedig az oktatók szavaznak is a jelöltekről, amelynek eredménye ugyan nem kötelezi a kari tanácsot, de orientáló hatású lehet, és később plusz legitimációs forrást jelenthet a megválasztott vezető számára, ha itt is támogatást kap. Más karokon a rektor dékánválasztó bizottságokat állít fel (rektorhelyettesi részvétellel), amely menedzseli a választás folyamatát.

A választás mellett van egy másik, ritkábban előforduló dékáni székbe vezető út is: amikor kényszerhelyzet áll elő. Ilyenkor a rektor jogosult átmeneti időre megbízott dékán kinevezésére. A megbízott dékánnak később a formális választási folyamaton is át kell esnie, amennyiben az átmeneti idő után is meg kívánja a pozícióját tartania.

$\mathrm{Az}$ interjúk alapján összesen 22 esetben tudtam tanulmányozni a dékán megválasztásának menetét. 11 esetben nem volt ellenjelölt a választás során, 11 esetben pedig volt legalább egy jelölt (ebből egy esetben a másik jelölt a tényleges választás előtt visszalépett). ${ }^{83}$ Ugyanakkor mindössze egy olyan eset volt, amikor az interjúalany a hivatalban lévő dékánt versenyben váltotta le, azaz a korábbi dékán jelöltette magát ugyan a következő ciklusra, de helyette másik jelöltet választották meg. A többi esetben a korábbi dékán kitöltette a ciklusait, nyugdíjba ment, feljebb lépett, vagy nem akart, esetleg az életkori korlát miatt nem tudott újraindulni a pozícióért. (A több ciklust megélt interjúalanyok is többnyire az első megválasztásukról meséltek, a későbbi választásokat már nem tartották érdemesnek részletezni.) Igazán éles versenyröl nagyon kevesen számoltak be. Azt is érdemes megjegyezni, hogy noha a törvény elviekben nem teszi kötelezővé, hogy a rektor azt nevezze ki, akit a karok választottak, semelyik dékán vagy felsővezető nem utalt arra, hogy a választás ne a kari megerősítés alapján történt volna meg. Mindez igen érdekes kérdést vet fel: ha feltételezzük, hogy egy szervezet (közép)vezetőjévé válni karriernek, előrelépésnek tekinthető, akkor vajon minek köszönhető, hogy csak a karok mintegy felénél volt verseny a dékáni pozícióért, és a többi helyen is viszonylag kevés jelölt közül lehet választani?

Egy magyarázat lehet, hogy a felsőoktatás nem verseny-, hanem konszenzus-orientált, ahol a későbbi dékán személyéről már a választások előtt kialakul valamilyen egyetértés a

83 Hat esetben nem derült ki, hogy volt-e ellenjelölt. 
szokásjogok vagy a különböző érdekcsoportok egyessége alapján, és a választási szituáció csak olyan rítus, olyan színjáték, amit „el kell játszani” (ahogy egy interjúalany megfogalmazza). Ahogy az egyik felsővezető erre utal:

„Hát megmondom őszintén, olyan nagyon nagy tülekedés nem szokott lenni, tehát az a kettős jelölés az elöfordul, de hármas még itt sose fordult elő, de zömében az azért úgy ki van találva, hogy ki lesz a következő dékán." (F8)

Egy másik érv lehet az, hogy nincs elég alkalmas jelölt, mert magasak a jelölttel szemben támasztott formális és informális követelmények. Esetleg az is felmerülhet, hogy a szokásjogok érvényesülése miatt erős öncenzúra érvényesül, azaz az alkalmas jelöltek egy része már eleve nem is pályázik. Például a műszaki területre vonatkozóan jegyezte meg egy felsővezető, hogy

„ha nincs egyetemi tanár [a dékánválasztás során], akkor docensek versenyezhetnek egymással, vagy versenyezhetnének. Ha viszont van egyetemi tanár [a potenciális pályázók között], abban az esetben a docensek nem igen mernek kiállni ellene." (F4)

Ez a szemléletmód érhető tetten egy dékán megnyilatkozásában is:

„Mivel én nem vagyok professzor, én docens vagyok változatlanul, én arre nem is gondoltam, hogy valaha is dékán legyek, mert úgy gondoltam, legyen csak valaki professzor." (D15)

A dékáni pozícióért folyó verseny alacsony intenzitásának az is oka lehet, hogy a dékánság nem túl vonzó pozíció, amire például az alábbi felsővezető is utal:

K: Mennyire vonzó egyébként ez a dékáni pozíció?

$\mathrm{V}$ : Annyira nem.

K: És mi ennek az oka?

V: Hát, mi az oka? Nem... jó kérdés. Jó kérdés. Ööö, (kis szünet) jó kérdés. Nem tudom. Ez jelenleg ennek a megfejtése, ez... Hát én azt látom, hogy inkább személyes ambíciók, egészséges exhibicionizmus az, ami inkább hajjja ebbe az embereket. De tulajdonképpen egy dékán, aki jó professzor, vezet egy tanszéket vagy egy intézetet, semmivel sincsen rosszabb helyzetben, mint hogyha bevállalja azt, hogy a karnak a dékánja." (F3)

Az interjúkból kibontakozó domináns dékánválasztási narratívák sokat elárulhatnak arról, hogy a felsőoktatást (vagy inkább az adott felsőoktatási intézményt) mi jellemzi. Az interjúkban összesen négy (öt) választási történet-típus volt megfigyelhetö:

1. „pályázok és nyerek - akár más jelölt ellenében is” (4 eset): e narratíva képviselői mindig verseny keretében válnak dékánná, azaz több jelölt közül kerültek ki győztesen. Magát a verseny folyamatát alapvetően pozitív jelenségnek látják. A választási folyamatot rendkívül részletesen mutatják be, sokszor még az évekkel korábbi szavazási arányokra is emlékeznek. A verseny hevességét jelzi, hogy az ellenjelölteken többnyire csak néhány szavazattal kerekednek felül. E dékánok hosszan fejtegetik, hogy milyen céljaik, motivációik, és őket alkalmassá tevő adottságaik vannak, tehát a pályázatban elsősorban a belső indíttatásukat hangsúlyozzák, a folyamat többi szereplőjének viszont nem tulajdonítanak jelentőséget abban a döntésükben, hogy pályáznak. E dékánok közül többen gondolkodtak a 
rektori pályázaton vagy már próbálkoztak is vele. A narratíva képviselői olyan karokon váltak dékánokká, amelyek vagy egykor önálló főiskolák voltak, vagy olyan főiskolákon alakultak meg, amelyekben inkább centralizált hagyományok vannak.

„És akkor nyitottá vált a pálya és én akkor úgy gondoltam, hogy eljött az a helyzet, amikor nekem pályázni kell. Én azt is gondoltam magamról, hogy nekem van koncepcióm erre, tekintettel arra, hogy nagyon hosszú [ideje vagyok itt], tehát ide jártam, végig éltem azt, hogy itt egy [...] szakból lett egy kar. [...] Na most azonban én arra olyan nagyon nem számítottam, de volt még egy pályázó. [...] És akkor egyébként nagyon érdekes volt, hogy bejött hozzám ez a kolleganő és elmondta nekem, hogy akkor ő is [pályázik], mert ugye az én pályázásomat mindenki tudta, az övé az egy meglepetés volt, de bejött, elmondta, én mondtam, hogy köszönöm szépen, hát akkor pályázzunk. És akkor pályáztunk, és körülbelül borítékolni lehetett azt az eredményt, hogy nagyjából kik lesznek azok, akik őt fogják támogatni, mert nyilván megvolt a maga köre meg az ő támogatói, és én jöttem ki győztesen nem olyan túl nagy különbséggel, ha akarja meg tudom nézni, tehát ilyen tízen pár fős volt, tehát volt többségem, nem egy elsöprő többségem, de azért volt többségem. [...] Na most én tulajdonképpen, hogyha utólag visszagondolunk, akkor én azt gondolom, hogy én ennek valahol örültem is, mert mondhattam azt, hogy szóval több közül választottunk. De azért mégsem az volt, hogy van egy, és benne van az emberekben az a reflex, hogyha egy van, akkor azt az egyet meg kell választani." (D21)

2. A dékánok egy másik csoportja (3 eset) szintén versenyben vált dékánná, ám a választás egész folyamatról rendkívül szűkszavúan beszélnek, időnként pedig azt teljes mértékben ignorálják. Az ellenjelöltek, a választási folyamat részletei csak külön kérdések kapcsán kerülnek elő. Hasonlóan az előző narratíva képviselőihez, ők is a céljaikat, terveiket, illetve az őket alkalmassá tevő vonásokat (pl. kiterjedt kapcsolatrendszer) említik.

V: Hát nézze, én X éve a felsőoktatásban vagyok és amikor idekerültem, akkor [...] tanszékvezető lettem és a tanszékvezetőség után, [...] az akkori dékán [...] átment rektorhelyettesnek ezzel megüresedett a dékáni szék. Én azt megpályáztam, és a szenátus megválasztott, a rektor úr meg kinevezett.

K: [..]És a választási folyamat, vagy ennek az elökészülete, hogy dékánnak készül, ez hogyan zajlott?

V: Hát annyi, hogy meg lett hirdetve a pályázat, két pályázat beérkezett, aztán ezt követően volt egy nyilvános alkalom, ahol mi jelöltek ismertethettük a koncepciónkat és aztán utána már a procedúra következett. (D13)

3. „frakciók megkeresése” (5 eset): e narratíva szerint azért pályázik az interjúalany dékánnak, mert a kar különböző érdekcsoportjai megkeresik és felkérik, hogy pályázzon. Több dékán is azt emelte ki, hogy a végső lökést az adta számára, amikor a különböző, esetenként ellenérdekelt csoportok is bátorították a pályázatra. Ennek ellenére a választási folyamatban lehetnek ellenjelöltek is, de a hangsúly minden esetben a választást megelőző megegyezésen, konszenzuson van. Sőt, volt olyan dékáni is, aki kifejezetten ragaszkodott ahhoz, hogy ne legyen más jelölt a választás során:

„Tehát én nem akartam úgy elindulni a választáson, hogy mit tudom én, több pályázó [van], vagy hogyha nem érzem a megfelelő támogatottságot." (D11)

Ennek oka nem csak a megfelelő felhatalmazás megszerzése lehet, hanem - ahogy arra egy másik interjúalany utalt $(F 8)$ - a hallgatói beleszólás minimalizálása is. $E$ szempont nem véletlenül merülhet fel, hiszen ez a narratíva többnyire a nagy, széttagolt, heterogén egyetemi 
karok (például bölcsésztudományi kar) dékánjainál, vagy a kicsi, fókuszált, esetenként frissen kivált, fiatal egyetemi karok dékánjainál volt jellemző.

\begin{abstract}
„Amikor fölvetették a kollegák [hogy én legyek a dékán], akkor elöször mondtam nekik, hogy ne hülyéskedjetek, vicceltek velem? En nem szoktam hozzá, hogy velem vicceljetek. És akkor nem hagyták abba, csak jöttek, csak jöttek. Több helyröl jöttek, több irányból. A karon azért van egyfajta feszültség az $\mathrm{X}$ meg az $\mathrm{Y}$ társaság között. És akkor adtam be a derekamat, amikor mind a két oldal megkeresett. Akkor azt mondtam, hogy úgy látszik, hogy valamit akarnak ilyen szempontból. Tehát tudatosan vállaltam, és ilyen módon az, hogy én most szakmai karrieremben nem abban az ütemben haladok, ebböl én magamnak csinálok konfliktust, mert elfogadom ezt a helyzetet, hogy ha én 100\%-ig helyt akarok állni itt ezen a poszton, akkor bizony ennek ára van. Többek között ez, hogy a szakmai karrier, az lassabban halad." (D15)
\end{abstract}

„[Az előző dékán] Az első ciklusa után nem kívánta tovább folytatni, erőteljes rábeszélésre sem a munkát. És akkor vetették föl többen, hogy azt el tudnák képzelni, hogy én csináljam ezt követően. Hát volt számos olyan beszélgetés, ami ennek a szándéknak a komolyságát támasztotta alá. Tehát akkor vállaltam, hogy indulok a dékánválasztáson. Egyébként ehhez ugye az is hozzátartozik, az előkészités folyamatához tartozik hozzá, hogy egy jelölt volt. Tehát volt egy eléggé egyértelmű konszenzus a választás előtt." (D3)

4. Az előző dékán ajánlása ( 3 eset): a dékánná válás folyamatában meghatározó pont az előző, mindig erősnek bemutatott dékán távozása (nyugdij, rektorrá/rektorhelyettessé válás stb.), aki nem csak a kar müködésének, arculatának alakításában játszott fontos szerepet, hanem az új dékán kinevelésében, kiválasztásában is, hiszen az új dékán mindn esetben a régi helyetteseként szolgált. A dékáni interjúkban a választási folyamatról alig esik szó, ellenjelölt többnyire nincs, a választás pusztán formalitás. E narratíva föként nagy egyetemek dékánjainál fordult elö.

„Elötte a karnak a tudományos főigazgató helyettese voltam és a föigazgató úr, aki az egész [intézménynek] a rektora lett, akkor hát rám hagyományozta a kart." (D12)

V: „aztán [meg]alakult ez a kar, mint új kar, és akkor dékán helyettesként kezdtem, általános dékán helyettesként, és a következő ciklusban akkor már alapitó dékán a kora, vagy korkorlátok miatt nem tudta már megpályázni a következő ciklust, és akkor, akkor én kerültem elő.

$\mathrm{K}$ : És ez ilyen magától értetődő volt?

V: Akkor azt gondolom, igen. Igen, azt gondolom, mint általános dékán helyettes, hát valahogy úgy intézte az előző dékán is a dolgokat, hogy úgy körülbelül. Szóval, hogy úgy mindenben bent voltam, és ennek következtében. Bár mondjuk, ami kicsit billegővé tette a dolgot, az az, hogy itt két nagy szakmai terület érintett ezen a karon [...]. Na most az alapító dékán [az egyik szakterület képviselöje] volt, így mondjuk volt egy olyan igény, hogy most a másik szakterületröl legyen valaki, de hát aztán nem. Az az igazság, hogy nem is nagyon ambicionálták mások, úgyhogy így nem volt különösebb verseny." (D19)

5. A rektori vezetés megkeresése (3+4 eset): $E$ történetek sajátossága, hogy a rektor vagy a rektori vezetés a dékán megválasztásában aktív szereplőként jelenik meg. Ennek vagy a kényszer az oka (olyan helyzet áll elő, melyben új dékán megbízása válik azonnal szükségessé), vagy pedig a rektori vezetésnek szilárd elképzelése van az új dékánnal szembeni elvárásokról. Ez utóbbi föként centralizált intézményekben (egykori főiskolákban) jellemző, és esetenként együtt jár atipikus dékáni karrierutakkal is. Míg az előbbi esetben a dékánok maguk is gyakran kényszerüségből vállalják el a pozíciót (ellenjelölt nélkül), addig a 
koncepció mentén kiválasztott dékánok inkább a kihívást és az egyéni lehetőségeket hangsúlyozzák. Ellenjelölt az utóbbi esetben sem nagyon van. A választási folyamat formális.

„És [az előző dékán] augusztus tizenakárhányadikán lemondott. Nagyjából így közölte ezt a rektor úrral, hogy akkor ő most lemond. [...] Tehát elég kellemetlen szituációba hozta itt a rektor urat. Volt benne én szerintem zsarolási dolog. Tehát ő nem gondolta, hogy a rektor úr el fogja ezt fogadni. Csak már akkor megunta a rektor úr ezt a zsarolást, mert nem ez volt az első szituáció. És akkor elfogadta a lemondást és utána hívott föl, most vagy pénteken, vagy szombaton, nem tudom, szóval már nem munkaidőben volt. Hogy hát ez a szituáció és rám gondolt. [...] És gyakorlatilag tényleg nem is volt elképzelésem arról, hogy én most dékán legyek. [...] De gyakorlatilag, tehát én egy olyan szituációba kerültem, hogy megkért a rektor arra, hogy legyek dékán, amit én nem szerettem volna csinálni. Viszont becsülöm annyira a rektort, hogy azt viszont tudomásul vettem, hogy ő milyen kutyaszorítóba került. És ezért [...] mondtam igent tulajdonképpen arra, hogy jó, rendben van, akkor elvállalom." (D1)

E történetek azt mutatják, hogy nincs általában vett domináns választási folyamat, mert az komplex erőtérben megy végbe. Ezt jól mutatja az a sokszínűség, ami a választás menetéröl, a lényeges szereplőkről bontakozott ki az interjúk alapján, azaz a dékáni pozíció választott jellege sokféle dékánt és dékáni szerepolvasatot tesz lehetővé. Erre természetesen hatással lehet a kar adottságai, múltja és mérete.

Természetesen e történetek nem csak a felsőoktatás intézményrendszeréröl árulkodnak, hanem arról is, hogy az ezt elmesélő dékánoknak milyen motivációi, meggyőződései, felsőoktatási narratívái vannak. Kiderül például az, hogy az egyes dékánok kit tekintenek a választási folyamatban fontos (említésre méltó, kiemelt) szereplőknek (és kit nem), milyen szerepet tulajdonítnak maguknak a megválasztásuk folyamatában stb. Itt most azonban a hangsúly a felsőoktatási rendszer jellemzésén van, a dékánok gondolkodásmódjának jellemzésére majd a későbbiekben térek ki.

\subsection{A dékáni pozíció ideiglenessége}

Az elmúlt időszak felsőoktatási törvényei azt is mindenkor szabályozták, hogy a dékáni (magasabb vezetői) beosztás 3-5 évig tölthető be, amely - újabb választással - egyszer meghosszabbítható. Egy dékán így egyhuzamban, megszakitás nélkül legfeljebb 6-10 évet tölthet a pozícióban, utána mindenképpen ki kell hagynia egy ciklust. Ezen általános gyakorlat alól két fontos kivétel akadt. 1999-ben, az integrációs törvénymódosításban úgy rendelkeztek ${ }^{84}$, hogy az integrációban résztvevő intézmény karainak vezetői a megbízatásuk lejártát követően „üres lappal” indulnak, azaz ismét szabadon pályázhatnak, függetlenül attól, hogy korábban hány ciklust töltöttek pozícióban. 2009-ben pedig szintén egy törvénymódosítást ${ }^{55}$ követően lehetővé vált egy harmadik ciklus megkezdése is (akár 65 éves kor felett is), amennyiben az adott dékánt

84 1999. évi LII. Törvény a felsőoktatási intézményhálózat átalakításáról, továbbá a felsőoktatásról szóló 1993. évi LXXX. törvény módositásáról. $7 \S(5) \mathrm{Az} F \mathrm{Ftv} .56$. $§(5)$ bekezdésének vonatkozásában a jogutód intézményben minden intézményi vezetői megbizást új, első megbizásnak kell tekinteni.

85 2009. évi XLIII. Törvény a felsőoktatásról szóló 2005. évi CXXXIX. törvény módositásáról. 
kétharmados többséggel erősítették meg pozíciójában. (Több interjúalanyom is ilyen módon töltötte a harmadik dékáni ciklusát.)

Mindezek következtében elviekben akár az is lehetséges volt, hogy bizonyos feltételek fennállása esetén egy dékán akár 1993 óta megszakítás nélkül hivatalban maradjon. Noha láthatunk példát kivételesen hosszú dékáni karrierekre (egy dékán például 2010-ben már 19. éve volt a kar/főiskola élén), a 2010-ben hivatalban lévő dékánok 90\%-a 8 éve vagy annál rövidebb ideje volt hivatalban.

22. táblázat: A 2010-ben aktív dékánok hivatalban eltöltött ideje a megválasztásuk óta ${ }^{86}$

\begin{tabular}{|c|c|c|}
\hline \multirow{2}{*}{$\begin{array}{c}\text { Hivatalban eltöltött } \\
\text { évek száma }\end{array}$} & \multicolumn{2}{|c|}{ Adott évet eltöltö dékánok } \\
\cline { 2 - 3 } & száma & Aránya (\%) \\
\hline 1 & 9 & 6,0 \\
2 & 13 & 8,7 \\
3 & 16 & 10,7 \\
4 & 14 & 9,3 \\
5 & 20 & 13,3 \\
6 & 14 & 9,3 \\
7 & 8 & 5,3 \\
8 & 4 & 2,7 \\
9 & 5 & 3,3 \\
10 & 1 &, 7 \\
11 & 2 & 1,3 \\
13 & 1 &, 7 \\
14 & 1 &, 7 \\
19 & 1 &, 7 \\
Hiányzó adat & 41 & 27,3 \\
Összesen & 150 & 100,0 \\
\hline
\end{tabular}

Forrás: kari honlapok és dékáni önéletrajzok alapján saját gyüjtés

Összességében mindenképp érdemes azt hangsúlyozni, hogy a szabályozás szerint a dékánság időben korlátozott vezetői megbízás, amit akkor sem lehet tovább folytatni, ha egyébként a vezető maga ambícionálná azt. Ez nyilván befolyásolja a dékáni pozíció professzionalizációjának lehetőségét, a dékánok jövőképét és dékánsággal kapcsolatos motivációit, mert így a dékáni pozíció betöltésével párhuzamosan érdemes fenntartani a már meglévő szakmai pozíciókat is. Ennek számos előnye van, például az, hogy a dékánság igényli a folyamatos szakmai beágyazottságot, ezáltal a dékánság nem válik tisztán adminisztratív pozícióvá. Az időnkénti szükségszerü vezetőcsere pedig nem csak a kar megújulásra ad lehetőséget (az új vezető alatt újragondolhatóak a dolgok), hanem a leköszönő dékánokat sem hagyja elszakadni a szakmától. Az interjúalanyaim közül több dékán is támogatta ezt az

86 Pozícióban folyamatosan eltöltött időnek tekintettem azt is, ha egy adott kar dékánja 1999 előtt önálló főiskola vezetője volt. 
álláspontot (lásd az alábbi idézetet), és alig-alig lehetett olyan véleménnyel találkozni, amely sajnálkozott volna a dékáni poszt kényszerü feladása miatt.

„Én úgy gondolom, hogy az ilyen típusú munkát, az egyetemi vagy kari vezetői munkát, két ciklusig lehet végezni, mondjuk fogalmazzunk úgy, hogy egyszer megújitható. Mivel hogyha csak egyszeri, akkor az olyan rotációt tételez föl, ami gyakorlatilag az adminisztráció uralmát jelenti. Mert mire egy választott vezető belejön abba a munkába, amit csinál, akkora le is telik neki, és ez a végtelenségig is müködik. Semmilyen körülmények között semmiféle kétharmados, meg egyéb trükkökkel nem engedném meg azt, hogy a két cikluson túl csináljon valaki dékánságot vagy rektorságot. A kettő az viszont racionális. Tehát az egyben arra a kérdésére is válasz, az garancia a visszailleszkedésre, a folytatásra, és hogy mindaz, ami ebben tapasztalatként összejött, az szervesüljön." (D3)

Megvannak persze ennek az ideiglenesség hátrányai is: kevésbé éri meg „invesztálni” a dékánságba, erősödhet annak igénye, hogy a dékánságot az egyéni (jövőbeli) szakmai karrier érdekében használják fel. A dékánoknak célszerű fenntartani a korábbi szakmai és adminisztratív pozícióit (kutatásvezetés, tanszékvezetés, szakvezetés stb.), ez viszont elaprózza az idejét, és megnehezíti az erőfeszítések koncentrálását a dékáni feladatokra.

\subsection{A szakmai elöélettel kapcsolatos követelmények}

A 2005-ös felsőoktatási törvényig a mindenkori felsőoktatási törvény szabályozta, hogy a kar vezetőjét az egyetemi docensek, illetve a főiskolai és egyetemi tanárok közül a kari tanácsnak kell megválasztania. (1993 és 1996 között a törvény nem rendelkezett erröl, de az 1996-os módositás egyértelműsítette az 1993 előtt is élő gyakorlatot.) Noha a törvényi megfogalmazások nem egyértelműek, mégis azt sugallják, hogy a kar vezetőjét az adott kar egyetemi docensei és tanárai közül kell választani. A 2005-ös felsőoktatási törvény ugyanakkor - az életkort és ciklusok számát kivéve - semmilyen módon nem korlátozta, hogy ki választható dékánnak, azaz elviekben egy adjunktus vagy egy külsős oktató is lehet kari vezető. A felsőoktatási intézmények SZMSZ-ei, foglalkoztatási szabályzatai, illetve a dékánok tényleges munkakörének vizsgálata azonban arról árulkodik, hogy az intézmények többnyire megőrizték a régi gyakorlatot, és a főiskolai docensnél alacsonyabb munkakörben foglalkoztatott oktató sehol nem válhatott dékánná. (Ez persze nem zárja ki annak a lehetőségét, hogy valakit azért neveznek ki docenssé, hogy dékáni pozíciót is betölthessen. Ez azonban az interjúkban sehol nem merült fel, az önéletrajzok alapján pedig nem vizsgálható.) 


\section{3. táblázat: A dékánok munkaköre 2010-ben tudományterület és intézménytípus szerint}

\begin{tabular}{|c|c|c|c|c|c|c|}
\hline & $\begin{array}{c}\text { Nincs } \\
\text { információ }\end{array}$ & $\begin{array}{l}\text { főiskolai } \\
\text { docens }\end{array}$ & $\begin{array}{l}\text { (egyetemi) } \\
\text { docens }\end{array}$ & $\begin{array}{l}\text { Főiskolai } \\
\text { tanár }\end{array}$ & $\begin{array}{l}\text { Egyetemi } \\
\text { tanár }\end{array}$ & $\begin{array}{c}\text { Egyetemi } \\
\text { tanárok } \\
\text { aránya }\end{array}$ \\
\hline \multicolumn{7}{|c|}{ Tudományterület szerinti beosztás } \\
\hline Agrártudományi karok & 0 & 0 & 3 & 2 & 9 & $64,3 \%$ \\
\hline Bölcsésztudományi karok & 0 & 0 & 7 & 2 & 5 & $35,7 \%$ \\
\hline Egészségügyi és orvosi karok & 0 & 1 & 4 & 4 & 11 & $55,0 \%$ \\
\hline Gazdaságtudományi karok & 1 & 0 & 9 & 4 & 6 & $30,0 \%$ \\
\hline Gazdaság és müszaki karok & 0 & 1 & 0 & 0 & 0 & $0,0 \%$ \\
\hline $\begin{array}{l}\text { Gazdasági és társadalomtudományi } \\
\text { karok }\end{array}$ & 0 & 0 & 1 & 1 & 2 & $50,0 \%$ \\
\hline Informatikai karok & 0 & 0 & 4 & 0 & 3 & $42,9 \%$ \\
\hline Jog és Államigazgatási karok & 0 & 0 & 5 & 1 & 4 & $40,0 \%$ \\
\hline Müszaki karok & 1 & 0 & 5 & 3 & 9 & $50,0 \%$ \\
\hline Müszaki és agrár karok & 0 & 1 & 0 & 1 & 0 & $0,0 \%$ \\
\hline $\begin{array}{l}\text { Müszaki és természettudományi } \\
\text { karok }\end{array}$ & 0 & 0 & 0 & 0 & 4 & $100,0 \%$ \\
\hline Művészeti karok & 2 & 0 & 0 & 4 & 1 & $14,3 \%$ \\
\hline Pedagógiai karok & 1 & 0 & 3 & 10 & 5 & $26,3 \%$ \\
\hline Társadalomtudományi karok & 1 & 0 & 1 & 0 & 1 & $33,3 \%$ \\
\hline Természettudományi karok & 0 & 0 & 1 & 2 & 4 & $57,1 \%$ \\
\hline \multicolumn{7}{|c|}{ Becher-Trowler-féle tudományterületi beosztás szerint* } \\
\hline $\begin{array}{l}\text { Alkalmazott kemény területek } \\
(\mathrm{AH})\end{array}$ & 1 & 2 & 17 & 10 & 33 & $52,4 \%$ \\
\hline Tiszte területek (AH/PH) & 0 & 0 & 0 & 0 & 4 & $100,0 \%$ \\
\hline Alkalmazott puha területek (AS) & 3 & 0 & 17 & 17 & 16 & $30,2 \%$ \\
\hline Alkalmazott területek (AS/AH) & 0 & 1 & 1 & 0 & 1 & $33,3 \%$ \\
\hline Tiszta kemény területek $(\mathrm{PH})$ & 0 & 0 & 1 & 2 & 4 & $57,1 \%$ \\
\hline Tiszta puha területek (PS) & 2 & 0 & 7 & 5 & 6 & $30,0 \%$ \\
\hline \multicolumn{7}{|l|}{ Intézménytípus szerint } \\
\hline Alapítványi egyetem & 2 & 0 & 1 & 0 & 0 & $0,0 \%$ \\
\hline Alapítványi főiskola & 0 & 0 & 0 & 2 & 0 & $0,0 \%$ \\
\hline Állami egyetem & 3 & 1 & 33 & 20 & 58 & $50,4 \%$ \\
\hline Állami főiskola & 0 & 2 & 4 & 11 & 4 & $19,0 \%$ \\
\hline Egyházi egyetem & 1 & 0 & 5 & 1 & 2 & $22,2 \%$ \\
\hline Összesen & 6 & 3 & 43 & 34 & 64 & $42,7 \%$ \\
\hline \multicolumn{7}{|c|}{ Az interjúban részt vevő aktív dékánok megoszlása } \\
\hline & 0 & 0 & 6 & 5 & 14 & $56,0 \%$ \\
\hline
\end{tabular}

* Ennek ismertetését részletesen lásd a 3.1.2-es alfejezetben

Forrás: saját gyüjtés kari vezetők önéletrajza alapján

A megengedőbb törvényi szabályozás miatt azonban az általános trendtöl néhány helyen már eltérés tapasztalható. Néhány intézményben (főként főiskolákban) például lehetővé tették, hogy a főiskolai docenseket is kari vezetővé választhassák. Más intézményben ugyanakkor szigorítottak a feltételeken, és előírták például a habilitáció meglétét is (akár közvetve, például a docensi kinevezéshez kapcsolódva).

A szigorúság (akár a szabályozásban, akár az elvárásokban) nem csak a pozíció presztízsét hivatott jelezni, hanem azt is szavatolhatja, hogy a karok vezetői megfelelő oktatásikutatási tapasztalattal rendelkezzenek. A pozícióból fakadó presztízs és a tapasztalat különösen hierarchizáltabb tudományterületeken jelenti a vezető fontos legitimációs bázisát. Talán nem 
véletlen, hogy főként a kemény (orvosi, műszaki, agrár és természettudományi) területeken dominálnak az egyetemi tanár dékánok, amint az jól tükröződik 23. táblázatban, csakúgy, mint az alábbi dékán beszámolójából is:

„És akkor nekem már elindult az egyetemi tanári kinevezésem, és az lényeges, hogy egy ilyen karon az, hogy a dékán egyetemi tanár legyen, az szerintem majdnem kötelező, de a tudományos dékánhelyettesnek is illik legalább Akadémiai doktorának lenni. [...] Ez csak nálunk hangya. Azért mert olyan a személyi állomány, hogy azt megengedhetjük magunknak. Nyilván ez [ti. a dékánság] azért sok menedzseri képességet is igényel, ami nem feltétlenül van összecsatolva az egyetemi tanári státusszal, sőt meggyőződésem, hogy az egyetemi tanárok, ezt ne írja bele, de meggyőződésem, hogy elhülyülnek, mire oda kerülnek. De a különböző testületekben való tárgyalások, meg az elfogadottság, tehát azért azt egyetemi emberként nyilván érzi, hogy a... Mondjuk nálunk nem is annyira rossz, mint az orvosi egyetemen. De a hierarchia, az mégiscsak hierarchia. És, (kis szünet) tehát van például egy tudományos tanács, aminek tagja minden tanszékcsoportból egy képviselő, egy választott, nem egy delegált képviselö, aki deklaráltan egyetemi tanár kell, hogy legyen és tagja a kar valamennyi akadémikusa. (...) Tehát egy ilyen fórumon [a dékán] könnyen megkaphatja esetleg, hogy egy kis docens ne ugráljon, vagy valami ilyesmi." (D11)

Érdemes azt is hangsúlyozni, hogy minél szigorúbbak a szakmai előmenetel, és ehhez kapcsolódóan a (kari) vezető kinevezési feltételei, annál szűkebb azok köre, akikből a vezető kiválasztható, következésképp csökken az alkalmas vezetők potenciális száma is. Különösen igaz ez azokon a karokon, ahol az egyetemi tanári beosztást várják el feltételként, amely külső szereplő (a MAB) jóváhagyásához kötött, megszerzése ezért néhány tudományterületen nehezebb. A dékáni pályafutásuk végén járó vagy a volt dékánokkal folytatott interjúban számos alkalommal került elő a kari vezető és/vagy az utód megtalálásának nehézsége.

„És én ezen sokat gondolkoztam, hogy lehet, hogy kellene kezdenem nekem valamit ezzel [ti. az utódlással], de most kiböl nevel, kiből néz ki valaki valamit, akiről azt látja, hogy van egy affinitása a dologhoz, és akkor azt mondja, hogy én őt próbálom segíteni, meg nyilván mindent megadok neki, de ehhez kellett volna látni valakit. Na most én látni ilyen értelemben nem láttam senkit, tehát ugye egyrészt kell néznünk, hogy ki felel meg a jogszabályi feltételeknek. Másrészt kell nézni, hogy ugye kinek van affinitása ehhez a dologhoz. Én nem nagyon láttam a kollegáimban ezt az affinitást, tekintettel arra, hogy nekem a tanszékvezetőkkel kellett együtt dolgoznom. (...) És akkor én föladtam ezt a dolgot, mert úgy gondoltam, hogy ezt másnak is akarni kell, azzal együtt, hogy azt is tudtam, hogy a jogszabályi dolgoknak megfelel, és akik pályázók lehetnek, azok közül a legjobb. Na most, hogy így mondjam ezt a történetet. Stimmel? Tehát nem én választottam ki, de az biztos, hogy miután én is egy szavazó voltam, én is rá szavaztam ebben a történetben, mert azt mondtam, hogy... Nézze hát most valljuk be, müködik a kontraszelekció. Valószínüleg én is egy kontraszelektált ember voltam annak idején, most mondjuk ki magunk között, hogy szerintem ő is az, azzal együtt, hogy minden tanulható a matematikán kívül. (mindketten nevetnek) Szerintem." (D21)

„Tehát itt tulajdonképpen nem lett volna gond az utóddal, és nem lett volna gond olyan kollégát elővenni, akire én magam azt mondom, hogy a kari tapasztalata, sok éves kari tapasztalata alapján, meg a karhoz való affinitása alapján, meg aki nem kívülröl jön, meg a belső elfogadottsága alapján, hogy minden tekintetben a legalkalmasabb. De hát ez sajnos nem minden esetben jár együtt azzal, annak a követelménynek a teljesítésével, hogy minősített legyen. És hogyha ott ugye végignéztem azt, hogy kétfélét akarhatok. Akarnék valakit, aki nem minősített és akarhatnék valakit, aki ugyan minősitett, de nem akarom. Nem akarom, mert azt gondolom, hogy nem szívesen látnám. Nem én döntök róla, de mondjuk úgy, ha azt kéne, hogy nevezzek meg utódot, és csak őt tudnám megnevezni, mert egyébként adminisztratíve teljesíti a papíron felsorolt feltételeket, akkor nem nevezném meg, mert egyébként azt gondolom, hogy, hogy Isten őrizz, hogy ő legyen." (D12) 
$E$ részletekben nem csak az olvasható ki, hogy a dékánok aktív szerepet vállalnak az utódlás kérdésében (ami nem magától értetődő), hanem a keresés szempontjai is: „legyen affinitása" a pozícióhoz, ne kívülről jöjjön, legyen belsőleg elfogadott. Mindkettejüknél (és a többi, most nem idézett interjúnál is), a korlátot a minősítettség, illetve a keményebb tudományterületeken az egyetemi tanári cím megszerzésének nehézsége jelentette ${ }^{87}$.

A magyar (és tágabban: a posztszocialista) felsőoktatás egyik sajátossága a hosszú szakmai karrierút (lásd OECD [2008]), ami azt jelenti, hogy a tényleges függetlenséget biztosító egyetemi tanári kinevezés megszerzése többlépcsős, időben igen elnyúló folyamat eredményeképpen szerezhető meg. Ez pedig nem csak erősíti az akadémiai elit kapuőr szerepét (hiszen egyre inkább ők döntenek a jelölt befogadásáról), és így tartósítja a jelöltek tőlük való függőségét, hanem azt is eredményezi, hogy az egyetemi vezetői pozíciókra az oktatók az életpályájuknak jellemzően a második felében vagy az utolsó harmadában válnak formálisan alkalmassá. Így például a 2010-ben hivatalban lévő dékánokat átlagosan 52-53 évesen nevezték ki először (első ciklusban) kari vezetőnek (lásd a 24. számú táblázatot). Ugyanakkor a 25. számú táblázatból látható, hogy nem látszik nagy különbség a docensként, főiskolai és egyetemi tanárként kinevezettek életkora között, pedig az életpálya szerint a docensi kinevezés 35 és 45 éves korban már sok tudományterületen elérhető. Ez azt mutatja, hogy nem elég a megfelelő szakmai előmenetel a kinevezéshez, hanem más tényezők is szerepet játszanak a kinevezés során. Ez lehet önmagában az életkor is (például a jelöltek közül az idősebb dékánok a preferáltak), de lehet olyan tényező is, amely összefüggésben áll a korral (például adminisztratív karrierpálya, vagy életkortól függő készség, például bölcsesség). Ennek - úgy gondolom - a dékánok motivációja, jövőképe, családi helyzete és habitusa szempontjából is következménye van, amelyekre a következő fejezetben majd részletesebben is ki fogok térni.

87 Ennek oka, hogy az egyetemi tanári cím megszerzése nem az intézményen múlik, hanem a Magyar Akkreditációs Bizottság, illetve informálisan az MTA által kontrollált terület (a MAB a nagydoktori címet várja el igen gyakran a kinevezés jóváhagyásához, amelyet viszont az Akadémia ítél meg). 
24. táblázat: A 2010-ben aktív dékánok átlagos életkora a kinevezésük idején, valamint a pozícióban eltöltött átlagos idő

\begin{tabular}{|c|c|c|c|c|c|c|c|c|}
\hline & \multicolumn{4}{|c|}{ Dékán életkora kinevezéskor ${ }^{88}$} & \multicolumn{4}{|c|}{ Pozícióban eltöltött idő 2010-ben ${ }^{89}$} \\
\hline & Átlag & Szórás & $\begin{array}{l}\text { Dékánok } \\
\text { száma } \\
\text { összesen }\end{array}$ & $\begin{array}{c}\text { Dékánok, } \\
\text { akikről } \\
\text { nincsen adat }\end{array}$ & Átlag & Szórás & $\begin{array}{l}\text { Dékánok } \\
\text { száma } \\
\text { összesen }\end{array}$ & $\begin{array}{c}\text { Dékánok, } \\
\text { akikröl } \\
\text { nincsen } \\
\text { adat }\end{array}$ \\
\hline \multicolumn{9}{|c|}{ Tudományterület szerinti beosztás } \\
\hline Agrártudományi karok & 49,0 & 5,4 & 14 & 4 & 6,10 & 3,96 & 14 & 4 \\
\hline Bölcsésztudományi karok & 52,6 & 6,2 & 14 & 5 & 4,18 & 2,44 & 14 & 3 \\
\hline $\begin{array}{l}\text { Egészségügyi és orvosi } \\
\text { karok }\end{array}$ & 53,4 & 7,3 & 20 & 9 & 3,92 & 2,23 & 20 & 8 \\
\hline $\begin{array}{l}\text { Gazdaságtudományi } \\
\text { karok }\end{array}$ & 49,4 & 7,6 & 20 & 9 & 3,93 & 1,79 & 20 & 5 \\
\hline $\begin{array}{l}\text { Gazdaság és müszaki } \\
\text { karok }\end{array}$ & . & . & 1 & 1 & . & . & 1 & 1 \\
\hline $\begin{array}{l}\text { Gazdasági és } \\
\text { társadalomtudományi } \\
\text { karok }\end{array}$ & 51,0 & 12,2 & 4 & 1 & 6,33 & 3,06 & 4 & 1 \\
\hline Informatikai karok & 57,7 & 3,5 & 7 & 0 & 4,71 & 2,63 & 7 & 0 \\
\hline $\begin{array}{l}\text { Jog és Államigazgatási } \\
\text { karok }\end{array}$ & 50,2 & 6,4 & 10 & 1 & 4,10 & 2,73 & 10 & 0 \\
\hline Müszaki karok & 54,5 & 6,1 & 18 & 5 & 4,54 & 2,03 & 18 & 5 \\
\hline Müszaki és agrár karok & 33,0 & . & 2 & 1 & 2,00 & . & 2 & 1 \\
\hline $\begin{array}{l}\text { Müszaki és } \\
\text { természettudományi } \\
\text { karok }\end{array}$ & 57,0 & 2,9 & 4 & 0 & 6,00 & 3,16 & 4 & 0 \\
\hline Művészeti karok & 55,8 & 5,0 & 7 & 3 & 4,25 & 2,22 & 7 & 3 \\
\hline Pedagógiai karok & 53,8 & 4,8 & 19 & 9 & 7,91 & 4,78 & 19 & 8 \\
\hline $\begin{array}{l}\text { Társadalomtudományi } \\
\text { karok }\end{array}$ & 53,0 & . & 3 & 2 & 7,00 & . & 3 & 2 \\
\hline $\begin{array}{l}\text { Természettudományi } \\
\text { karok }\end{array}$ & 52,4 & 4,5 & 7 & 0 & 4,57 & 1,13 & 7 & 0 \\
\hline \multicolumn{9}{|c|}{ Intézményi fenntartó szerint } \\
\hline Alapítványi egyetem & 42,0 & . & 3 & 2 & 2,50 & ,71 & 3 & 1 \\
\hline Alapítványi föiskola & 63,0 & . & 2 & 1 & 1,00 &, 00 & 2 & 0 \\
\hline Állami egyetem & 53,4 & 5,7 & 115 & 38 & 5,01 & 2,64 & 115 & 35 \\
\hline Állami főiskola & 49,5 & 9,2 & 21 & 8 & 4,81 & 2,83 & 21 & 5 \\
\hline Egyházi egyetem & 48,6 & 6,4 & 9 & 1 & 5,44 & 5,27 & 9 & 0 \\
\hline Összesen & 52,5 & 6,6 & 150 & 50 & 4,90 & 2,95 & 150 & 41 \\
\hline \multicolumn{9}{|c|}{ Az interjúban részt vevő aktív dékánok megoszlása } \\
\hline & 52,1 & 5,5 & 24 & 1 & 5,36 & 2.98 & 25 & 0 \\
\hline
\end{tabular}

Forrás: saját gyüjtés kari vezetők önéletrajza alapján

88 Noha nem teljesen azonos a kérdés, de összehasonlításképpen talán érdemes idézni Moore 1293 amerikai dékán körében végzett kérdőíves kutatását, amelyben a lekérdezés időpontjában a dékánok 8,3\%-a 39 évesnél fiatalabb volt, míg a dékánok 36,1\%-a 40 és 49 év között volt. Az 50-59 éves a dékánok 40,2\%-a volt, míg 60 évesnél a dékánok 15,4\%-a volt idősebb. (Moore [1983] 56.0.)

89 Összehasonlításképpen: Moore 1293 amerikai dékán körében végzett kérdőíves kutatásában a lekérdezés időpontjában a dékánok 15,3\%-a 11 évnél hosszabb ideje volt pozícióban, míg 58,3\%-a 5 évnél rövidebb ideje. (Moore [1983] 56 o.)) 
25. táblázat: Dékánok életkora kinevezéskor a beosztásuk szerint

\begin{tabular}{|l|c|c|c|}
\hline Beosztás (2010-ben) & $\begin{array}{c}\text { Adott beosztásban } \\
\text { dolgozó dékánok száma }\end{array}$ & $\begin{array}{c}\text { Dékánok száma, akikröl nem áll } \\
\text { rendelkezésre a szükséges adat }\end{array}$ & $\begin{array}{c}\text { Átlagéletkor } \\
\text { kinevezéskor }\end{array}$ \\
\hline Főiskolai docens & 3 & 2 & 33,0 \\
\hline Egyetemi docens & 43 & 15 & 49,7 \\
\hline Főiskolai tanár & 34 & 18 & 53,8 \\
\hline Egyetemi tanár & 64 & 12 & 54,3 \\
\hline $\begin{array}{l}\text { Nincs információ a } \\
\text { beosztásról }\end{array}$ & 6 & 3 & 47,3 \\
\hline Összesen & 150 & 50 & 52,5 \\
\hline
\end{tabular}

Forrás: saját számítások a kari vezetők önéletrajza alapján

A szenioritás preferálásának egy másik, indirekt hatása, hogy igen alacsony a nők aránya a dékánok között különösen a müszaki és természettudományi területeken (az egészségügyi területek arányát az egészségügyi főiskolai karok javítják, a hagyományos orvosi karok inkább férfi-domináltak). Az általában vett alacsony arány összefügghet azzal is, hogy az oktatói állományban eleve alacsony a nők aránya (2009-ben $37 \%$ volt a NEFMl statisztikái szerint ${ }^{90}$ ), de a docensek és egyetemi tanárok között vélhetően még alacsonyabb. ${ }^{91}$ Mindezek következtében eleve alacsonyabb a formálisan alkalmas női jelöltek száma, mint a férfiaké.

A dékáni pálya elférfiasodásához hozzájárul az is, hogy már az egyik fontos karrierállomás, a dékánhelyettesség is erősen férfi-dominálta pozíció, amint az jól látható az alábbi táblázatból is.

\footnotetext{
90 http://db.nefmi.gov.hu/statisztika/fs09_fm/Default.aspx oldalon a 3.5.2-es táblázat alapján. (elérés dátuma: 2012. március 20.)

91 Sajnos nincsenek átfogó magyarországi statisztikák arról, hogy az egyes oktatói és kutatói munkakörökben hány férfi és nő dolgozik, mert a nők aránya a minisztériumi statisztikákban csak összességében található meg. Nem tekinthető reprezentatívnak, ám mégis érdemes megemlíteni, hogy a Budapesti Corvinus Egyetemen 2004 és 2007 között az oktatók között a nők aránya 37-40\% között mozgott, ugyanakkor az egyes munkakörökben az arány jól megfigyelhető módon csökken: míg tanársegédek között a nők aránya 46-51\% között mozgott és még az adjunktusoknál is elérte a 45-48\%-ot, addig a docenseknél már csak 33-36\% volt, míg az egyetemi tanárok között csak a 13-18\%-ot érte el. (BCE [2009])
} 


\section{6. táblázat: Női dékánok és dékánhelyettesek száma és aránya 2010-ben}

\begin{tabular}{|c|c|c|c|c|c|c|}
\hline & \multicolumn{3}{|c|}{ Dékánok száma } & \multicolumn{3}{|c|}{ dékánhelyettesek száma } \\
\hline & összesen & ebből: nő & $\begin{array}{l}\text { Női dékánok } \\
\text { aránya }\end{array}$ & összesen & ebből: nő & $\begin{array}{l}\text { Női dékán- } \\
\text { helyettesek } \\
\text { aránya }\end{array}$ \\
\hline \multicolumn{7}{|c|}{ Tudományterület szerinti beosztás } \\
\hline Agrártudományi karok & 14 & 1 & $7.1 \%$ & 27 & 4 & $14.8 \%$ \\
\hline Bölcsésztudományi karok & 14 & 4 & $28.6 \%$ & 31 & 13 & $41.9 \%$ \\
\hline $\begin{array}{l}\text { Egészségügyi és orvosi } \\
\text { karok }\end{array}$ & 20 & 4 & $20.0 \%$ & 40 & 10 & $25.0 \%$ \\
\hline Gazdaságtudományi karok & 20 & 6 & $30.0 \%$ & 33 & 10 & $30.3 \%$ \\
\hline Gazdaság és müszaki karok & 1 & 0 & $0.0 \%$ & 0 & 0 & - \\
\hline $\begin{array}{l}\text { Gazdasági és } \\
\text { társadalomtudományi karok }\end{array}$ & 4 & 1 & $25.0 \%$ & 9 & 1 & $11.1 \%$ \\
\hline Informatikai karok & 7 & 1 & $14.3 \%$ & 20 & 2 & $10.0 \%$ \\
\hline Jog és Államigazgatási karok & 10 & 1 & $10.0 \%$ & 23 & 7 & $30.4 \%$ \\
\hline Müszaki karok & 18 & 1 & $5.6 \%$ & 51 & 9 & $17.6 \%$ \\
\hline Müszaki és agrár karok & 2 & 0 & $0.0 \%$ & 3 & 0 & $0.0 \%$ \\
\hline $\begin{array}{l}\text { Müszaki és } \\
\text { természettudományi karok }\end{array}$ & 4 & 0 & $0.0 \%$ & 9 & 0 & $0.0 \%$ \\
\hline Művészeti karok & 7 & 0 & $0.0 \%$ & 5 & 3 & $60.0 \%$ \\
\hline Pedagógiai karok & 19 & 4 & $21.1 \%$ & 32 & 18 & $56.3 \%$ \\
\hline Társadalomtudományi karok & 3 & 1 & $33.3 \%$ & 5 & 1 & $20.0 \%$ \\
\hline Természettudományi karok & 7 & 1 & $14.3 \%$ & 16 & 4 & $25.0 \%$ \\
\hline \multicolumn{7}{|c|}{ Becher-Trowler-féle tudományterületi beosztás szerint* } \\
\hline $\begin{array}{ll}\text { Alkalmazott } & \text { kemény } \\
\text { területek }(\mathrm{AH}) & \\
\end{array}$ & 63 & 7 & $11.1 \%$ & 147 & 27 & $18.4 \%$ \\
\hline Tiszte területek $(\mathrm{AH} / \mathrm{PH})$ & 4 & 0 & $0.0 \%$ & 9 & 0 & $0.0 \%$ \\
\hline $\begin{array}{ll}\text { Alkalmazott } & \text { puha } \\
\text { területek (AS) } & \\
\end{array}$ & 53 & 13 & $24.5 \%$ & 94 & 35 & $37.2 \%$ \\
\hline $\begin{array}{l}\text { Alkalmazott } \quad \text { területek } \\
\text { (AS/AH) }\end{array}$ & 3 & 0 & $0.0 \%$ & 2 & 0 & $0.0 \%$ \\
\hline $\begin{array}{l}\text { Tiszta kemény területek } \\
\text { (PS) }\end{array}$ & 7 & 1 & $14.3 \%$ & 16 & 4 & $25.0 \%$ \\
\hline Tiszta puha területek (PS) & 20 & 4 & $20.0 \%$ & 36 & 16 & $44.4 \%$ \\
\hline \multicolumn{7}{|c|}{ Intézményi fenntartó szerinti megoszlás } \\
\hline Alapítványi egyetem & 3 & 1 & $33.3 \%$ & n.i. & n.i. & - \\
\hline Alapítványi főiskola & 2 & 0 & $0.0 \%$ & 0 & 0 & - \\
\hline Állami egyetem & 115 & 16 & $13.9 \%$ & 260 & 66 & $25.4 \%$ \\
\hline Állami főiskola & 21 & 6 & $28.6 \%$ & 25 & 10 & $40.0 \%$ \\
\hline egyházi egyetem & 9 & 2 & $22.2 \%$ & 19 & 6 & $31.6 \%$ \\
\hline Összesen & 150 & 25 & $16.7 \%$ & 304 & 82 & $27.0 \%$ \\
\hline \multicolumn{7}{|c|}{ Az interjúban részt vevő aktív dékánok megoszlása } \\
\hline & 25 & 7 & $28 \%$ & & & \\
\hline
\end{tabular}

* Ennek ismertetését részletesen lásd a 3.1.2-es alfejezetben

Megjegyzés: 6 kar esetében nem volt információ a dékánhelyettesek számáról és neméről, 5 dékánhelyettes esetében pedig nem volt információ a nemről

Forrás: karok honlapjai alapján saját gyüjtés

A szenioritást preferáló jogi szabályozás tehát inkább az idősebb, férfi dékánok kiválasztásának kedvez, ám ezek az elvárások informálisan is érvényesülnek. Így például a női vezetők időről-idöre kérdések nélkül, önkéntelenül is beszámoltak vezetői elfogadtatásuk nehézségeiről, miközben a férfiak esetében ez a téma - egy kívülről érkező dékán esetét kivéve 
- soha nem merült fel. Az egyik női interjúalany például a dékánná válásának történetére vonatkozó kérdésemre válaszolva tette az alábbi kitérőt:

„És akkor menet közben kialakult, hogy én fölmerültem, mint lehetséges jelölt, akkor történt egy... Tehát én azt kértem, hogy akkor elötte - nem nekem kellett körbejárni, de - járják körül a témát, hogy elfogadnak-e. Én vagyok egyébként az első női dékán [a karon]. Úgyhogy ez... Nem szoktam ennek tulajdonságot, vagy jelentőséget tulajdonítani. Az első újévi fogadást volt, hogy szoknyában követtem el, csak a poén kedvéért, de egyébként nem hiszem, hogy ez gondot okoz." (D11)

Noha az interjúalany az interjú során többször is hangsúlyozta, hogy a nöi mivolta nem okoz semmilyen dilemmát a karon, mégis fontosnak érezte, hogy a témára az interjú során többször is visszatérjen. A nőiség és fiatalság kérdései más, az átlagnál fiatalabban kinevezett dékánoknál is felmerült:

$\mathrm{K}:$ Mennyiben más egy férfi dékánnak a helyzete?

V: Ez egy nehéz kérdés. Azért nehéz kérdés, mert én is ezt... Erröl nagyon sokat gondolkodtam. Az elödöm is nő volt, ezt szeretném hozzátenni. Ő volt az első női föigazgató a karon, mert előtte csak férfi volt. Én meg csak a második vagyok, de a legfiatalabb, hogyha tetszik, mert korban is azt gondolom, hogy nem megszokott, hogy ilyen viszonylag korán kerül valaki dékáni pozícióba. Ezt egy rendhagyó történetnek tartom. Legalábbis állami felsőoktatási intézményben." (D30)

„amikor dékán lettem, akkor se voltam már fiatal. De Miskolcról jön a kollegám vissza, hogy azt mondták, hogy [nálunk] meg egy csitri lett a dékán. Csitri nő. (mindketten nevetnek) Mondom, jól van akkor." (D9)

\subsection{A dékánná válás útjai}

\subsubsection{A dékánok karrierútjai}

Természetesen egy dékánnal szemben nem csak szakmai, életkori és a társadalmi nemet (gendert) illető elvárások érvényesülhetnek, hanem más típusúak is. A dékánokkal készített interjúk első kérdéseként szinte minden esetben azt tettem fel, hogy „hogyan lett Önből dékán”. E kérdésre a válaszadók nagy többsége a korábban betöltött adminisztratív, vezetői pozíciók sorát mutatta be mintegy jelezve ennek az előéletnek a fontosságát. Egy interjúalany már-már szabadkozva úgy kezdte a válaszát, hogy „Hát én nem voltam előtte dékán helyettes”. (D25) (Ellenpontként megemlíthető, hogy a dékánok kis része e kérdés kapcsán a szakmai életútját vázolta, a dékánná választását megelőző kényszerhelyzetekről beszélt vagy a motivációit, a dékánságra őt alkalmassá tevő készségeit, képességeit hangsúlyozta.)

Az előzőekben láthattuk, hogy bizonyos előrehaladás a szakmai (tudományos-oktatói) munkaköri hierarchiában formálisan is elvárás a dékánnal szemben, de az interjúk alapján az adminisztratív-vezetői előélet is szükséges feltételnek tűnik a dékánná választáshoz. Ez jól látható az interjúalanyok előéletéböl, a betöltött adminisztratív-vezetői pozíciókból, illetve az intézményen kívül szerzett tapasztalataikból, amelyek alapján igyekeztem feltérképezni a 
dékánná válás tipikusnak és atipikusnak tekinthető útjait. Összesen 31 dékánná válási esetet elemeztem ${ }^{92}$, amely alapján a tipikus utaknak az alábbiak tekinthetőek:

- Fokozatos karrierút (10 eset): a dékáni kinevezés elött az oktató az adott intézményben előbb tanszékvezetői és/vagy intézetvezetői, majd dékánhelyettesi pozíciót tölt be (gyakran megtartva a tanszékvezetői státuszát is).

- Tanszékvezetőböl dékán (8 eset): e karrierút során a tanszékvezető vagy intézetvezető a dékánhelyettesi pozíció kihagyásával közvetlenül válik dékánná.

- Dékánhelyettesből dékán (6 eset): a dékáni kinevezéshez vezető karrierútból kimarad a tanszékvezetői és az intézetigazgatói pozíció. Ezek a dékánok esetenként (néha kényszerből) a dékáni pályafutás alatt válnak tanszékvezetővé, intézetigazgatóvá. $E$ kategóriába számoltam azt az esetet is, amikor valamely dékán a korábban önálló főiskola föigazgató-helyettese volt.

Megfigyelhető néhány atipikusnak tekinthető karrierút is.

- Központi adminisztrációs kitérővel dékán (3 eset): az intézményen belüli karrierút sajátos esete, amikor a fokozatos karrierutat egy hosszabb-rövidebb ideig tartó, az intézmény központi adminisztrációjában betöltött pozíció (például rektorhelyettesség, főtitkárság) szakítja meg.

- Kívülröl (más felsőoktatási vagy kutatóintézményböl) meghívott dékán (2 eset): a kívülröl, más felsőoktatási intézményböl vagy akadémiai kutatóintézetből meghívott dékán mindkét esetben azzal függött össze, hogy az adott karon vagy intézményben nehéz volt olyan jelöltet találni, aki mind a jogszabályi feltételeknek, mind a dékánnal szemben támasztott kari elvárásoknak megfelelt volna. A dékáni kinevezés jellemzően nem teljesen előzmény nélküli, azt időnként megelőzi egy rövidebb tanszékvezetői, intézetigazgatói periódus vagy esetleg vendégoktatói meghívás, de az intézménybe csábítás már a dékáni kinevezés ígéretével történt. A meghívott dékánoknak más intézményben már volt adminisztratív vezetői tapasztalata, azaz ott valamilyen igazgatói vagy dékánhelyettesi pozíciót már betöltöttek.

- Intézményen kívüli karrier-kitérővel válik dékánná (2 eset): e karrierút során a dékán az egyetemi oktatói vagy adminisztratív karriert megszakitva vagy jelentősen visszaszorítva vállal tartósan külső (például diplomáciai, minisztériumi vagy egyéb intézményen kívüli) feladatot, majd az egyetemre való visszatérést követően válnak - rábeszélés után - dékánná.

Nincs tudomásom európai dékáni vagy felsőoktatási karrierút vizsgálatokról, ezért a 4.4.1. számú alfejezetben idézett amerikai kutatás adataival vetem össze a saját, kis mintaelemszámú kutatásom eredményeit. (Az összehasonlítást a 27. számú táblázat tartalmazza.)

92 Noha 30 hivatalban lévő dékánnal, illetve megbízott, volt vagy leendő dékánnal készítettem interjút ezek nem mindegyike volt használható a karrierút vizsgálata szempontjából. Ugyanakkor az interjúkba bevont felsővezetők egy része szintén töltött be korábban dékáni pozíciót, és életútjuk ismertetése során a legtöbben kitértek dékánná válásuk történetére is. Így végül 31 dékáni életút részletesebb feltérképezésére volt lehetőségem. 


\section{7. táblázat: A dékánok jellemző karrierpályái az Egyesült Államokban és Magyarországon}

\begin{tabular}{|c|c|c|c|c|c|c|}
\hline & \multicolumn{6}{|c|}{ Dékáni karrierpályák } \\
\hline & 1 & 2 & 3 & 4 & 5 & 6 \\
\hline Dékán & $\square$ & - & - & - & - & - \\
\hline Dékánhelyettes & $\square$ & & - & & - & \\
\hline Tanszékvezető & $\square$ & $\mathbf{\square}$ & & & & \\
\hline Oktató & $\square$ & $\square$ & - & $\square$ & & \\
\hline & \multicolumn{4}{|c|}{ Belső karrierpályák* } & \multicolumn{2}{|c|}{ Külső karrierpályák* } \\
\hline Arányok (USA) & $4,8 \%$ & $19,5 \%$ & $12,7 \%$ & $35,4 \%$ & $4,2 \%$ & $11,4 \%$ \\
\hline Arányok (Mo.) & $32,3 \%$ & $29,0 \%$ & $25,8 \%$ & $3,2 \%$ & 0 & 0 \\
\hline
\end{tabular}

- - karrierállomás

* A belső karrierpálya a felsőoktatáson, és nem az intézményen belüli karrierpályát jelenti. A magyar arányokban figyelembe vettem a felsőoktatási intézményváltás miatt korábban atipikusnak tekinthető karrierutakat is. A külső karrierpálya során oktatói tapasztalat nélkül lesz valaki dékán.

Az USA felmérés forrása: Moore [1983]:76 adatai alapján ${ }^{93}$

$\mathrm{Az}$ amerikai felmérés eredményei annyiban hasonlítanak az interjús kutatásból kibontakozó magyar felsőoktatási mintához, hogy az USÁ-ban szintén a felsőoktatási szférán belülről történő kinevezés tekinthető a domináns gyakorlatnak. Jelentős különbség ugyanakkor, hogy a magyar felsőoktatásban nem jellemző a felsőoktatási szférán kívülröl érkező dékánok szerepe. Az amerikai felsőoktatásban a dékánok körülbelül egyhatoda külsősként töltötte be a tisztséget, elsősorban azokon a területeken, amelyeknek erős kapcsolódása volt valamely gyakorlati szférához (pl. jog), ám ez Magyarországon nem fordult elő. Hazánkban nem jellemző az oktatóból közvetlenül dékánná váló karrierút sem, miközben az USÁ-ban ez tekinthető magasan a leggyakoribb pályának. Ennek egyik következménye, hogy Magyarországon egyfelöl nagyobb a szerepe a normának tekintett, általam korábban „fokozatosnak” nevezett karrierútnak, másfelől a dékánná válás szempontjából sokkal nagyobb a jelentősége a tanszékvezetői és a dékánhelyettesi pozíciónak. A magyar kutatásban az előbbi a dékáni karrierutak 61\%-ban, az utóbbi pedig az 58\%-ban játszott szerepet, ami egybevág egy korábbi magyar kutatás adataival, mely szerint a 2006-ban dékáni pozíciót betöltő személyek 64,4\%-ának volt valamilyen előzetes (dékánhelyettesi, tanszékvezetői vagy esetleg a rektori, rektorhelyettesi) tapasztalata (Forgó [2008]). Moore amerikai felsőoktatásra vonatkozó adatai ezzel szemben azt tükrözik, hogy sem a tanszékvezetői, sem a dékánhelyettesi poszt nem elengedhetetlen a dékánsághoz, hiszen az előbbi az esetek 24,3\%-ban, utóbb csak 21,7\%-ban játszott szerepet. (Ugyanakkor azt is meg kell jegyezni, hogy a későbbi amerikai felmérések már nem teljesen igazolták ezeket az adatokat.) Összességében megállapítható, hogy Magyarországon sokkal erősebb a tradicionális (vagy ahhoz nagyon közeli) felsőoktatási karrierutak gyakorisága a dékánná válás során, azaz az interjúalanyok többsége gyakorlatilag „belenőtt” a pozícióba, és a pályafutásának hosszabbrövidebb ideje alatt végigjárta a tanszékvezető, intézetvezető, dékánhelyettes, majd dékán utat. $A$ teljesnek tekinthető karrierút egy-egy állomása könnyen kihagyható, vagy párhuzamosan folytatható, egy-egy esetben pedig az is előfordult, hogy valaki előbb lett dékán, és csak később

93 Moore egy másik tanulmányában (Moore [1983]) kisebb mintán más arányokat közöl, de az eltérések okai nem derülnek ki. 
tanszékvezető. Az adminisztratív hierarchiában való előmenetel esetenként párhuzamosan zajlott az oktatói-kutatói karrierlétra csúcsának megmászásával (azaz az egyetemi/föiskolai tanári kinevezés megszerzésével), de ennél sokkal gyakoribb volt, hogy tanszékvezetővé, dékánhelyettessé már befutott oktatóként váltak az interjúalanyok.

A dékánná válás e fokozatos módja miatt nem meglepő, hogy a dékánok többsége arról számolt be, hogy mikor dékán lett, nem érte őt különösebb meglepetés a feladatokat vagy a szerep tartalmát illetően, hiszen

„amikor a dékánhelyettes voltam, akkor már láttam a feladatokból, még ha (...) nekem az ilyen munkáltatói, gazdasági, egyéb döntésekben nem volt direkt ráhatásom, de láttam.”. (D1)

A dékáni szerep elsajátítása tehát informális szocializáción keresztül zajlott (ez általánosnak tekinthető, amit más felmérések is megerősitettek (del Favero [2006]). Bár többen is megfogalmazták, hogy nem tanult vezetők, a dékánná válás kapcsán senki sem beszélt arról, hogy formális képzésen vett volna részt kifejezetten emiatt, vagy tudatos felkészülésbe fogott volna.

A fokozatosnak tekinthető karrierút dominanciájában bizonyára szerepet játszik a felsőoktatás törvényekkel és belső normákkal körülbástyázott zártsága. A zártság azonban nem egyszerüen a felsőoktatási szféra zártságát jelenti, hanem a felsőoktatási intézmények zártságát is. A tanulmányozott 31 karrierpályából mindössze 7 olyan található, amelyben intézményváltásra került sor, és ebböl is csak 3 volt olyan, amely bevallott módon vezetői (tanszékvezetői, dékáni vagy dékánhelyettesi) kinevezéshez kapcsolódott. $E$ tapasztalatok alapján inkább az tekinthető a magyar felsőoktatás domináns gyakorlatának, hogy az intézmények minden vezetői pozíciót az intézmény oktatói állományából próbálnak meg betölteni, és nem jellemző a külső, már bizonyított oktatók, vezetők elcsábítása.

A domináns gyakorlat tehát az, hogy a dékánok abban az intézményben lesznek kari vezetők, ahol a felsőoktatási pályafutását elkezdték vagy ahol pályafutásuknak jelentős részét eltöltötték. E gyakorlat elterjedtsége arról árulkodik, hogy a dékánság a kari szereplök szempontjából bizalmi poszt, amely igényli a helyi viszonyok nagyfokú ismeretét (és persze következménye a dékánválasztás uralkodó szabályainak - nevezetesen a kari tanácsok támogatásához kötött kinevezéshez). Mindennek kétségtelen előnye, hogy a vezetők a kinevezésükkor megfelelő helyismerettel rendelkeznek, ami egyfelöl biztosítja a kar organikus fejlődését (ritkák a hirtelen irányváltások), másfelöl olyan bizalmi tőkét eredményezhet, amely segítheti a változással járó nehéz döntések elfogadását. Az egyik dékán, aki már hallgatóként is a karon tanult, és (egyedüli jelölt) dékánként szigorú konszolidációs program végrehajtásáért volt felelős, nemcsak arról számolt be, hogy a kari múltja miatt bizalommal voltak iránta a kollégák, hanem arról is, hogy a korábban a rektor által kinevezett külsős egyetemi biztossal szemben jelentős passzív rezisztencia bontakozott ki. Így számol be erről:

„Azt láttam annak idején, hogy ez tulajdonképpen egy passzív rezisztencia (...) És azt láttam, azt a passzív ellenállást akkor oldja meg a biztos, ha ő okosabb ember, akit idehelyeztek, vagy ügyesebb, vagy rátermettebb, akkor oldja meg. Tehát a döntések előkészitésében sem volt jelen, nem kapott jelentős segítséget. Finoman fogalmazok. Tehát ha idehelyezték, csinálja. Tehát ha a kezébe tették, akkor úgyis nála van a döntés, akkor csinálja." (D2) 
Ugyanakkor persze az a gyakorlat egyfajta belterjességet is eredményez, ami éppenhogy csökkenti a karok megújulási képességét, hiszen mire valaki kari vezetővé válik, már túlságosan is foglya lehet a helyi érdekviszonyoknak vagy szemléletmódnak. Hosszú kari múlttal már sokkal nehezebb például hitelesen radikális változtatásokat képviselni, és nagyon erős külső nyomás híján sokkal nehezebb bevállalni a változtatásokkal járó konfliktusokat is. Ennek jelentőségéről egy olyan dékán nyilatkozott, aki a kinevezése előtt nem sokkal került a karra:

„Tehát ott volt egy fél évem, amit oktatóként töltöttem, de ez már akkor szinte nyilvánvaló volt, hogy akkor pályázom, és a dékánságon azon úgy gondolkodtam (kis szünet), hogy ez részben bátorság kérdés-e vagy nem, hogy ráadásul pont egy teljesen másik közeget. De én meg inkább úgy fogtam föl, hogy ez nekem most könnyebb, mert így nincs semmi, ami visszahúzna. Egy csomó személyes kapcsolat, hogy tanítvány volt, vagy mindenféle dolog, ami rengeteg érv, ami hátrányként jelentkezett nekem [a korábbi intézményben]." (D8)

\subsubsection{A felsőoktatáson kívüli tapasztalat jelentősége}

A belterjesség veszélye különösen azoknak az egyébként viszonylag ritka interjúknak a fényében válik érezhetővé, amelyekben az interjúalanyok a más szférában megszerzett tapasztalatok megtermékenyítő erejéröl számoltak be. $E$ tapasztalatukat többnyire olyan fontos viszonyítási pontként értékelik, amelyhez képest képesek értékelni, megitélni a felsőoktatási gyakorlatot, és amely alapján saját vezetői szerepüket is definiálják.

„Mielőtt kimentem volna [külföldre] azelött én készen voltam a kandidátusi dolgozatommal, de
összerúgtam a port itt [az intézményben] valakivel, és aztán utána úgy voltam vele, hogy akkor
engem nem érdekel többet az akadémiai karrier, fogom magam, kimegyek [külföldre], keresek
egy láda pénzt, azt' jól megleszek, azt' kész. Eltelt egy kis idő és aztán hiányzott. Tehát
hiányzott abból a szempontból, hogy, hogy én ezt nagyon értékes dolognak tartom, hogy az
ember csinál egy ekkora cégnek. [... És akkor valahogy úgy voltam vele, hogy engem érdekel
az is, hogy tudok-e még tételeket csinálni, visszajöttem. Visszajöttem Magyarországra, viszont
hoztam magammal egy szemléletet. [...] egy olyan fajta szemléletet, ami a felsőoktatásban nem
okvetlenül létező szemlélet. Tehát én úgy gondolom, hogy ami miatt engem később is itt
nagyon elfogadtak az emberek, az pontosan az, hogy én úgy müködtettem ezt a kart és a mai
napig is úgy müködtetem ezt a kart, mint egy vállalkozást. Tehát az a szemlélet, ami bennem
megragadt kint, és amellett az, hogy a teljes könyvelési rendszert megírtam egy cégnek, és az,
hogy letesznek elém egy fökönyvi kivonatot, én abba tudok tájékozódni, az itt nem volt egy
teljesen tipikus történet." (D7)

„A másik rész az egy ilyen következetes, folyamatos érdeklődés volt az oktatásmodernizálással kapcsolatban. Na most ilyen típusú kihívás manapság akad néhány. Tehát miután itthon és külföldön láttam néhány példát. A franciába alaposan bele kellett dolgoznom magam, amikor a nagykövetségen a felsőoktatás mellett oktatási kapcsolatokkal foglalatoskodtam. Logikus volt, hogy megpróbáljak ezekből a tapasztalatokból valamit áthozni az itteni rendszerbe." (D3)

„(Korábban) Egy akadémiai intézetet vezettem, ott nagyon sok kutatás folyt (...) Egy másik világból jöttem egy másik világba, mert az akadémiai kutatói világ és az akadémiai világ, az teljesen más logika, rendszer szerint müködik, mint egy egyetem. Teljesen más a célok, a mozgástér, a menedzsment, az érdekeltségek, az értékrendek. Tehát ezek nagyon különbözőek. És ezt, hát ezt meg kell mondjam őszintén, nekem azért évek kellettek, amíg ezt megtanultam. (...) Meg itt úgy, és ugye hát hogy szokásos struktúra, kialakultak bizonyos szervezeti modellek, bizonyos pozíciók, emberekbe értékrendek, és hát én hoztam ezt az akadémiai értékrendet ugye, hát mi publikáltunk, írtunk, hát mit tudom én engem ott akkor akadémikusnak jelöltek, satöbbi, tehát nálam ez ugye evidens volt. Hát, itt meg ezek itt ültek, mint a befőtt, semmit nem csináltak (interjúalany és interjúzó nevet)." (F7) 
A felsőoktatáson kivül szerzett munkatapasztalat nem csak mint viszonyitási pont jelenik meg a beszámolókban. Egy másik jellemző narratíva - elsősorban a jól piacosítható területeken - a „,üggetlenség záloga”, amellyel az interjúalanyok az elfoglaltságuk sokféleségét és a dékáni pozíciótól való anyagi függetlenségüket hangsúlyozzák.

„És azt mondtam, ha nem hívtak volna, nyilván nem pályázok, mert elmúlik az én életem anélkül is, hogy dékán legyek, és különös elégedetlenségböl, csalódottsági érzet nem lett volna bennem. Ugyanis én ezen a pályámnál fogva, az oktatói pálya mellett, azért ügyvédkedek is, választott bíró vagyok, tehát van nekem elfoglaltságom is, és a szakmának, ha tetszik, minden hivatásrendi ágát kipróbáltam és majdnem csinálom is. Úgyhogy nem kapaszkodtam volna utána." (D24)

A felsőoktatás melletti munkatapasztalat harmadik típusa a pályakezdőként szerzett munkatapasztalatokat takarja, de a dékánság szempontjából ennek kicsi a jelentősége, az interjúalanyok inkább mint a szakmai pályafutásuk kezdetét jellemzik, és csak egy-egy interjúalany említi úgy, mint aminek fontos szerepe volt a dékáni müködésük vagy szerepfelfogásuk szempontjából.

Maga a külső munkatapasztalat időben háromféleképpen jelenhet meg a dékánok karrierútjában: megelőzheti a felsőoktatási karriert, megszakíthatja a felsőoktatási karriert (ez az intézményen kívüli atipikus karrierút), és tartósan vagy átmenetileg párhuzamosan is haladhat vele.

\subsubsection{A dékánhelyettesi pozíció jelentősége a dékáni karrierútban}

A hosszú adminisztratív karrierút egyszerre ad lehetőséget arra, hogy a kar „tesztelje” az egyes pozícióban lévők alkalmasságát, és arra is, hogy az oktató az adott pozícióban értékelje, képes-e megbirkózni a felmerülő feladatokkal, van-e energiája, kedve foglalkozni azokkal. Különösen a dékánhelyettességnek van a „betanítást” vagy a „beletanulást” elősegítő szerepe, legalábbis életük ezen időszakáról többen is úgy beszéltek, mint valamilyen felkészülési periódusról, gyakornoki időről.

K: És miért lett dékán?

V: Hát azért, mert kiválasztottak dékánhelyettesnek, és ugye az már ilyen betanítási periódusnak számított. (...) Én a dékán helyettesi betanuló periódusomban, az kiderült, mindenkiröl kiderült, hogyha dékánhelyettes lesz, vagy ha hivatalba kerül, hogy bírja-e vagy sem. Akkor az volt a közfelkiáltás, hogy jöjjenek a fiatalok. (...) És hát az a legfontosabb, hogy nem csak arra volt jó tanuló példa, hogy engem teszteltek, hogy bírom-e, hanem én teszteltem magamat, hogy bírom-e, van-e kedvem hozzá. (D4)

[a lehetséges utódot] „egy helyettesi feladatba lehet, hogy már be kéne kapcsolni, hogy ebbe beletanuljon. Tehát vannak utánpótlás jelöltek." (D5)

„(...) abból a szempontból megvolt az én felkészitésem, dékán helyettesként már foglalkoztam gazdasági ügyekkel, tehát nem akkor láttam elöször költségvetést, amikor dékán lettem [...]. Hanem ugye dékánhelyettesként, amikor [az előző] dékán úr engem küldött el például ilyen helyekre, és akkor szépen beletanultam. Tehát ilyen, mondjuk az egy kihívás egy dékánnál, hogy akkor hopp itt van egy négymilliárdos költségvetés vagy ötmilliárdos költségvetés, és akkor mi van ezzel." (D19) 
Az interjúk alapján kijelenthető, hogy szinte bármely dékánhelyettesi vagy főigazgató-helyettesi pozíció szolgálhat ugródeszkául a dékáni poszthoz. Azon dékánok közül azonban, ahol egyértelműen beazonositható volt a dékánhelyettesként ellátott feladat, a legtöbben a tudományos és nemzetközi területért voltak felelősek (6 esetben), ezt az oktatói dékánhelyettesség vagy annak valamilyen speciális vonatkozása (5 említés), majd pedig a hallgatói és az általános dékánhelyettesség követte (2-2 esettel). ${ }^{94}$ Azt is meg kell jegyezni ugyanakkor, hogy a meginterjúvolt dékánok körében csak néhány helyen beszéltek tudatos stratégiaként arról, hogy a potenciális dékánokat előzetesen dékánhelyettesként próbálják ki, vagy azt a pozíciót a dékáni pozícióra való felkészítésként értelmezzék.

\subsubsection{A tanszékvezetői és intézetvezetői pozíció jelentősége a dékáni karrierútban}

A dékánhelyettességgel ellentétben a tanszékvezetöként és intézetigazgatóként eltöltött idő sokkal kevésbé értelmeződött a dékánsághoz vezető út részeként, hiszen a tanszékvezetés soha nem merült fel a „beletanulás” kontextusában. Amikor mégis összekötötték a dékánsággal, akkor a „betanulási” narratíva helyett a saját tanszék vagy intézet inkább egyfajta mintaként merült fel, amit egyfelöl dékánná válva nagyban is érdemes megvalósítani, másfelöl pedig demonstrálja a (leendő) dékán vezetői elképzeléseit és közösségformáló képességét.

„Tehát ha egy tanszéket jól vezet az ember, akkor ha azt átülteti - és ezt próbáltam én megcsinálni a karra -, akkor az is jól fog müködni." (D1)

A tanszékvezetői és dékánhelyettesi múlt értelmezési különbsége azt sugallja, hogy a tanszékvezetői pozíciót az interjúalanyok sokkal kevésbé tartották magyarázatra szorulónak talán azért, mert természetesebben kapcsolódik egy oktató szakmai életútjához, míg a dékánhelyettesség és a dékánság már inkább adminisztratív feladatokat jelent.

Külön érdekes, hogy a tanszékvezetői pozíciót a legtöbben a dékánság alatt is megtartották. A magyar felsőoktatási intézmények dékánjainak mintegy kétharmada tölt be a dékánsággal egyidejüleg valamilyen tanszékvezetői vagy intézetigazgatói pozíciót, és mintegy felük az adott karon belül legmagasabb szintűnek tekinthető szervezeti egység élén áll (például egy intézetekre és azon belül tanszékekre tagolódó karon intézetigazgató, míg egy csak tanszékekböl álló karon tanszékvezetö). Csak a dékánok negyedének nincsen a dékánság mellett egyéb ilyen jellegű vezetői beosztása.

\footnotetext{
${ }^{94}$ Míg az oktatási és tudományos dékánhelyettes általánosan elterjedt posztnak tekinthető, addig a hallgatói és általános dékánhelyettesség ritkábban fordul elő (ezt később részletesen is be fogom mutatni), ezért nem meglepő, hogy kevesebb dékán került ki e posztokról.

Érdemes azt is megemlíteni, hogy néhány interjúalany több dékánhelyettesi ciklust is végigcsinált, vagy több területért is felelös volt. Más interjúalanyoknál nem volt beazonositható, hogy milyen területért voltak felelősek dékánhelyettesként. Egy részük kisebb karokon, föiskolákon töltött be dékánhelyettesi, föigazgató-helyettesi funkciót, ezért feltételezhető, hogy egyetlen helyettesként minden feladatba bevonhatóak voltak.
} 


\section{8. táblázat: A 2010-ben aktív dékánok további vezetői megbízásai}

\begin{tabular}{|c|c|c|c|c|c|c|c|c|}
\hline & \multicolumn{8}{|c|}{ Vezetői beosztások } \\
\hline & \multirow[b]{2}{*}{$\begin{array}{c}\text { nincs } \\
\text { információ }\end{array}$} & \multirow{2}{*}{$\begin{array}{l}\text { nem tölt } \\
\text { be } \\
\text { tisztséget }\end{array}$} & \multicolumn{2}{|c|}{$\begin{array}{l}\text { Egyszintü kari } \\
\text { tagozódás }\end{array}$} & \multicolumn{3}{|c|}{ Kétszintü kari tagozódás } & \multirow[b]{2}{*}{ Egyéb* } \\
\hline & & & $\begin{array}{c}\text { Intézet- } \\
\text { igazgató } \\
\text { (egyszintü) }\end{array}$ & \begin{tabular}{|l} 
Tanszék- \\
vezető \\
(egyszintü)
\end{tabular} & $\begin{array}{l}\text { Intézet- } \\
\text { igazgató } \\
\text { (kétszintű) }\end{array}$ & $\begin{array}{c}\text { intézetigazgató, } \\
\text { tanszékvezető } \\
\text { (kétszintü) }\end{array}$ & \begin{tabular}{|l|} 
Tanszék- \\
vezető \\
(kétszintü) \\
\end{tabular} & \\
\hline \multicolumn{9}{|c|}{ Tudományterület szerinti beosztás } \\
\hline Agrártudományi karok & 0 & 5 & 3 & 3 & 1 & 0 & 1 & 1 \\
\hline Bölcsésztudományi karok & 0 & 5 & 0 & 2 & 1 & 3 & 3 & 0 \\
\hline $\begin{array}{l}\text { Egészségügyi és orvosi } \\
\text { karok }\end{array}$ & 0 & 3 & 3 & 9 & 1 & 1 & 0 & 3 \\
\hline $\begin{array}{l}\text { Gazdaságtudományi } \\
\text { karok }\end{array}$ & 1 & 4 & 4 & 8 & 1 & 0 & 1 & 1 \\
\hline $\begin{array}{l}\text { Gazdaság és müszaki } \\
\text { karok }\end{array}$ & 0 & 0 & 0 & 0 & 0 & 0 & 1 & 0 \\
\hline $\begin{array}{l}\text { Gazdasági és } \\
\text { társadalomtudományi } \\
\text { karok }\end{array}$ & 0 & 2 & 0 & 0 & 1 & 0 & 1 & 0 \\
\hline Informatikai karok & 0 & 2 & 1 & 3 & 1 & 0 & 0 & 0 \\
\hline $\begin{array}{l}\text { Jog és Államigazgatási } \\
\text { karok }\end{array}$ & 1 & 2 & 0 & 6 & 0 & 0 & 1 & 0 \\
\hline Müszaki karok & 3 & 3 & 4 & 5 & 2 & 0 & 0 & 1 \\
\hline Műszaki és agrár karok & 0 & 1 & 0 & 1 & 0 & 0 & 0 & 0 \\
\hline $\begin{array}{l}\text { Müszaki és } \\
\text { természettudományi } \\
\text { karok }\end{array}$ & 0 & 3 & 0 & 0 & 0 & 1 & 0 & 0 \\
\hline Művészeti karok & 0 & 1 & 1 & 4 & 0 & 0 & 1 & 0 \\
\hline Pedagógiai karok & 0 & 7 & 2 & 3 & 1 & 3 & 2 & 1 \\
\hline $\begin{array}{l}\text { Társadalomtudományi } \\
\text { karok }\end{array}$ & 1 & 0 & 1 & 0 & 0 & 0 & 1 & 0 \\
\hline $\begin{array}{l}\text { Természettudományi } \\
\text { karok }\end{array}$ & 0 & 3 & 1 & 0 & 0 & 0 & 3 & 0 \\
\hline \multicolumn{9}{|c|}{ Fenntartó szerinti megoszlás } \\
\hline Alapítványi egyetem & 3 & 0 & 0 & 0 & 0 & 0 & 0 & 0 \\
\hline Alapítványi főiskola & 0 & 0 & 2 & 0 & 0 & 0 & 0 & 0 \\
\hline Állami egyetem & 3 & 30 & 17 & 35 & 8 & 7 & 11 & 4 \\
\hline Állami főiskola & 0 & 7 & 1 & 6 & 1 & 0 & 4 & 2 \\
\hline Egyházi egyetem & 0 & 4 & 0 & 3 & 0 & 1 & 0 & 1 \\
\hline Összesen & 6 & 41 & 20 & 44 & 9 & 8 & 15 & 7 \\
\hline Megoszlás & $4.0 \%$ & $27.3 \%$ & $13.3 \%$ & $29.3 \%$ & $6.0 \%$ & $5.3 \%$ & $10.0 \%$ & $4.7 \%$ \\
\hline \multicolumn{9}{|c|}{ Az interjúban részt vevő aktív dékánok megoszlása } \\
\hline & 0 & 5 & 4 & 7 & 2 & 1 & 4 & 2 \\
\hline & $0,0 \%$ & $20.0 \%$ & $16.0 \%$ & $28.0 \%$ & $8,0 \%$ & $4,0 \%$ & $16,0 \%$ & $8,0 \%$ \\
\hline
\end{tabular}

* rektorhelyettes, nagyprépost, felnőttképzési központ helyettes, szakcsoportvezető, egyéb tanszékvezető

Forrás: kari honlapok és dékáni életrajzok alapján saját adatgyüjtés

Mindez azt sugallja, hogy a tanszékvezetői és/vagy intézetigazgatói pozíció megtartása a dékánság alatt is kifejezetten fontos. Ennek egyik lehetséges oka, hogy a tanszékvezetés további szakmai presztízst és legitimációt ad, és azt is biztosítja, hogy a dékán ne szakadjon el a kar napi valóságától: 
„Tehát amikor én kiadom a tanszékvezetőknek a feladatot, akkor ez azt jelenti, hogy kiadtam magamnak is." (Nevetés.) (D15)

Noha csak említés szintjén került az interjúk során elő, de a tanszékvezetői pozíció megléte segíthet kiküszöbölni a (státusz)hierarchia ellentmondásainak olyan eseteit, amilyennel például az interjúk során találkoztam: egy intézetvezetői pozíció nélküli kari vezető dékánként főnöke, egyetemi docensként ugyanakkor beosztottja az intézetvezetőként dolgozó volt dékánnak.

További fontos érv, hogy míg dékánként csak két vagy három ciklust lehet eltölteni, addig a tanszékvezetői pozíció korlátlan számban ismételhető, a dékán pedig ennek jövőbeli lehetőségéről nem akar lemondani. A tanszékvezetés ugyanakkor nemcsak a jövőbeli lehetőségek mérlegelése és a szakmai munka folytonosságának szempontjából lehet fontos, hanem a dékáni periódus sikerességét közvetlenül is befolyásolhatja azáltal, hogy hátországot, támogatást kínál a dékánnak a karon folyó konfliktusok, döntési helyzetek során.

A dékánság csábító lehetőség arra is, hogy a dékán a saját intézetét kedvezőbb helyzetbe hozza:

„Másfelöl viszont, máshogy tudok akár embereket is, vagy változtatásokat megcsinálni saját intézetben is, dékánként. Bár ebben nem korlátozott mondjuk a [korábbi dékán] különösebben. De nyilván, hogy azért minden ilyen dolog átfutott rajta is, amit én intézetvezetöként döntöttem, és az valamiféle kontroll azért csak volt, most meg ez a fajta kontroll nincs" (D8)

A tanszékvezetői vagy intézetvezetői pozíció megtartásával ugyanakkor állandósulhat is annak gyanúja, hogy a dékán a saját szervezeti egységének kedvez. A szerepek szétválasztásának nehézsége könnyen alááshatja a dékán hitelességét, ezért néhányan a tanszékvezetői, intézetvezetői pozícióról való lemondást tudatosan választották:

K: „De egyébként tulajdonítasz bármiféle jelentőséget (...) annak, hogy nincs mögötted direkt módon intézet, tehát nem te vagy az intézetigazgató (...)?

V: Szerintem könnyebb lesz így nekem. Mert soha nem jelenik meg az, hogy részrehajlás gyanúja merülhetne fel.

K: Mert egyébként azt gondolod, ez mozgatja a szálakat mondjuk más karokon?

V: Van, ahol igen, persze. Még ha szándékosan nem is jelenik meg, de indirekten igen. Nálunk mondjuk nem, és erre mindig is ügyeltek az elödeim. Hogy még a gyanúja se merülhessen fel. És ezért akár, ha kellett, akkor büntették a saját intézetüket. Pontosan azért, hogy ebben nehogy rossz magatartásformát teremtsenek. És ez szerintem így van rendjén. De így nekem könnyebb lesz, mert tényleg még csak a gyanúja sem merülhet fel. (...) Ez egy kicsit talán jobb, mert a kari és az intézeti érdekek jobban össze fognak tudni csapni. Mert kell, mert anélkül nem visz a dolog elöre, és nem lehet egyik intézet érdekét se összemosni a karnak az érdekével." (D26)

Ebben persze az a - nem mindenki által osztott - vélekedés is szerepet játszhat, hogy a tanszékvezetés éppúgy egész embert kívánó feladat, mint a dékánság. Ebből adódóan időnként az az ellenérv is felmerült, hogy nincs idő a dékánság mellett a tanszékkel is foglalkozni, mert a tanszékvezetés is egész embert kívánó feladat. 
29. táblázat: A tanszékvezetői és intézetvezetői pozícióval kapcsolatos említések

\begin{tabular}{|l|l|}
\hline $\begin{array}{l}\text { Tanszékvezetői/Intézetvezetői pozíció } \\
\text { megtartásának előnyei }\end{array}$ & $\begin{array}{l}\text { Tanszékvezetői/Intézetvezetői pozíció } \\
\text { megtartásának hátrányai }\end{array}$ \\
\hline Dékáni hátország & \\
Szakmai presztízs & \\
Hétköznapi valóság megtapasztalása & Szerepek elválasztásának nehézsége \\
A hely, ahová vissza lehet vonulni & Időmenedzsment problémák \\
Szakmai munka folytonosságának biztosítéka \\
$\begin{array}{l}\text { Nincsenek vagy kisebbek a státuszhierarchia- } \\
\text { konfliktusok }\end{array}$
\end{tabular}

Forrás: interjúk alapján saját összegzés

\section{5. Összefoglalás: a dékánnal szembeni elvárások a szabályozás, a statisztikák és az interjúk alapján}

A fejezet alapkérdése az volt, hogy kiket milyen elvárások alapján és hogyan választanak meg dékánnak. A válaszok fontos elemek annak vizsgálatában, hogy mi a dékáni szerepek tartalma, $\mathrm{s}$ ezek hogyan formálódnak.

Első lépésként áttekintettem, hogy milyen szabályozások vonatkoznak ma a dékánokra. Megállapítottam, hogy a dékánság egy meghatározott időszakra megválasztott vezető, de a beszámolók alapján az is világossá vált, hogy a dékán igen komplex erőtérben választódik ki, azaz sokféle szereplő elvárásai befolyásolják a választási folyamatot. Az egyre lazuló szabályozásnak van ugyan orientáló hatása, de az elöírások által formált keretben még nagyon különböző elvárások érvényesítése is lehetséges. Megvizsgáltam ezért, hogy a statisztikák (és az interjúk) alapján mi jellemzi ma a magyar felsőoktatásban dolgozó 150 dékánt. Mik a jellemző mintázatok, és milyen következtetéseket vonhatunk le az elvárásokat, a kiválasztás szempontjait illetően?

A széles körben érvényesített formális választhatósági kritérium az az, hogy a dékán legalább egyetemi docens legyen. Noha erre vonatkozóan kimutatások nincsenek, de a magyar felsőoktatásban úgy vélem, hogy ez a szint 35 és 45 éves kor között már elérhető. Ennek ellenére a dékánok többsége mégis egyetemi tanár, akinek életkora 52-53 év között van, ami a szakmai tekintély és beágyazottság fontosságát mutatja. Ezt erősíti az a tényi is, hogy a dékánok többsége tanszék- és/vagy intézetvezető is, és ezt a pozíciót a többség a dékánság alatt sem adja fel. Azon dékánoktól, akiknek nincsen tanszékvezetői tapasztalata, általában dékánhelyettesi tapasztalatot várnak el.

Eszerint tehát nem csak szakmai, hanem adminisztratív vezetői tapasztalat is elvárás a dékánnal szemben (ennek másik olvasata viszont erős tekintélykultúrát jelez, amely azoknak a dékánjelölteknek kedvez, akik több és magasabb szakmai pozíciót töltenek be). Ez ugyanakkor azt is jelenti, hogy a dékánok többségének karon belüli karriert kell befutnia, és ritkának tekinthető az az eset, ha egy dékán más karról érkezik, vagy ha a dékánnak jelentős felsőoktatáson kívüli tapasztalatra van, és ezt a dékánságát befolyásoló tényezőként tartja 
számon. Összességében az látható, hogy csak egy nagyon erős szakmai és szervezeti (kari) szocializációs folyamat végén válhat valaki dékánná.

Lezárásképpen érdemes megemlíteni, hogy a dékánok 5/6-a férfi, amiben közrejátszik a szakmai előmeneteli pálya nemi szempontból diszkriminatív jellege. 


\section{A dékánság a dékánok szemével}

E fejezet célja annak vizsgálata, hogy milyen gondolkodásmód, szemléletmód jellemzi a dékánokat. A gondolkodásmód nem csak egyéni akarat eredménye, hanem közösségi termék is. Egyrészt a közösség bizonyos gondolkodású embereket választ meg, tart elfogadhatónak: olyanokat, akik nem radikálisan mások, mint a közösség maga. Ahogy egy dékán megfogalmazta:

„Én azt szoktam mondani egyébként, hogy a közösség a hibás azért, hogyha rosszat választ magának. Tehát nem az a hibás egyébként, aki most egészen extrém dolgot mondok, hogy szóval aki torzult jellemmel kerül egy vezetői pozícióba." (D7)

Másfelöl pedig maguk a dékánok is hosszú időn keresztül szocializálódtak a közegben, azaz az a gondolkodásmód, amely a dékánt jellemzi, jellemzi az őt kiválasztó közeget is. Kivéve persze ha nagyon éles konfliktusok alakulnak ki a dékán és a környezete között, ami esetleg arról árulkodik, hogy a külsöleg elvárt és a dékán által képviselt szerepfelfogás különbözik.

A fejezet három nagyobb részre tagolódik. Az első alfejezetben a dékánná válás motivációit mutatom be, a második részben a dékánság hátrányaira, hétköznapi megélésére vonatkozó gondolatokat összegzem, a záró részben pedig a dékánok szerepfelfogását és szervezetképét elemzem.

\subsection{A dékánná válás motivációi}

„Aki azt mondja, hogy rektornak vagy dékánnak készül, az hazudik. Tehát aki felsőoktatásba jön, az tudós akar lenni" - fogalmazta meg a dékánság egyik alapdilemmáját az egyik interjúalany (D7). A tudóssá válás vágyába még könnyen illeszkedik a tanszékvezetői vagy intézetvezetői pozíció, ami inkább tekinthető egy terület szakmai irányításának, mint adminisztratív pozíciónak, de mi visz valakit arra, hogy dékánná váljon, s ezzel - az interjúalanyok döntő többségének véleménye szerint - a szakmai (oktatói-kutatói) munkára fordított idejét jelentősen csökkentse? Miért cseréli fel valaki a szakmai autonómiáját és időbeosztását a tervezhetetlen és kiszámíthatatlan napirenddel, a szabadságot az állandó készenlét kötöttségével és miért vállalja valaki a konfliktusok menedzselésének kényszerét, amikor professzorként továbbra is elkerülhetné az ezzel járó stresszt?95

A kérdés azért is érdekes, mert mint az előző fejezetben láttuk, a dékánokat jellemzően szakmai pályájuk utolsó harmadában választják kari vezetővé, miután már vezető oktatóvá váltak. Ennek következtében igen erős szakmai szelekciós és szocializációs eljáráson vannak túl,

${ }^{95} \mathrm{~A}$ dékánsággal járó lemondásokra később még részletesen visszatérek. 
mire dékánná válnak, ami nem feltétlenül kompatibilis azokkal a feladatokkal, értékekkel, amelyek egy adminisztratív vezetői szereppel járnak. A különbséget érzékletesen ragadta meg az egyik interjúalany:

\begin{abstract}
„A felsőoktatás szereti a tüchtig megoldásokat. Merthogy a kutatásban megszoktuk, hogy precizitásra törekszünk. Megszoktuk, hogy kiváló munkára törekszünk. És aztán most mondok egy példát: itt van egy teljesítményértékelés, aminél tudnánk finomabb méréseket is csinálni, tudnánk jobbakat is csinálni. És nem akarjuk elfogadni, hogy ezt megcsinálhatjuk, csak nem fog müködni. És akkor megcsináljuk, és tényleg nem müködik. (interjúalany nevet) De hát kénytelenek vagyunk müködtetni. És akkor azt mondjuk, hogy szar az egész. Holott a dolog csak abból következik, hogy túllöttünk az elég jón, és kiválóra akartunk törekedni. De kiválót meg nem tudunk működtetni. Mert nincs meg hozzá az infrastruktúránk, nem vagyunk eléggé felkészültek hozzá, nincs meg a folyamatunk hozzá, túl sok mindennek kellene együtt állni. Persze azt a kiválót is tudjuk müködtetni, majd 5 év múlva, ha addig kitartunk mellette, de hát ki az a bolond, aki kitart egy nem müködő rendszer mellett 5 évig?" (D26) ${ }^{96}$
\end{abstract}

A kérdés tehát úgy hangzik, hogy vajon évtizedes szakmai pályafutással a háta mögött miért lesz valaki dékán? Mi a viszonya a szakmai pályafutásnak az adminisztratív pályafutáshoz? Hogyan viszonyul ehhez az a tény, hogy a dékánság ideiglenes vezetői pozíció? És végül: van-e hatása a dékánná válás motivációjának ahhoz, hogy az adott dékán milyen dékáni szerepfelfogást képvisel?

Ebben az alfejezetben az interjúk alapján áttekintem a dékánná válás okainak leggyakrabban előforduló magyarázat-sémáit: a szolgálatot, az egyéni érdeket és az önmegvalósítást. Érdemes megemlíteni, hogy a „miért lettem dékán?” kérdésre adott válasz nem független a „hogyan lettem dékán?” kérdésre adott választól. A dékánok választásával kapcsolatos beszámolók nem csak azt mutatják be, hogy milyen módon lehet valaki dékán a magyar felsőoktatásban, hanem sokat elárulnak magáról a dékánról is: mennyire versengő, mennyire kompromisszumkereső, mennyire tekinti természetesnek azt, hogy a megelőző dékán ráhagyja a pozíciót, hogy a rektori vezetés kiválasztja őt - és vajon ezek fényében beszámol-e bármiféle feszültségröl, konfliktusról. E nézőpontból olvasva a dékánválasztási történetek megmutatják, hogy az aktuális dékán például kit vagy kiket tart meghatározónak, és ennek nyomán milyen szervezeti narratíva él a fejekben.

\title{
9.1.1. A dékánság mint szolgálat, mint kényszer és mint feladat
}

Amikor az interjúalanyoknak feltettem a „miért lett dékán?” kérdést, sokan inkább a hátrányokra reflektáltak, és nehezebben tudták megfogalmazni azokat az előnyöket, amelyekkel a dékáni pozíció járt. A magyarázatot adók közül a legtöbben - miként a dékánválasztási történetek leírásában láthattuk - nem belső okot vagy magyarázatot jelöltek meg, hanem azt hangsúlyozták, hogy nem ők választották a dékánságot, hanem mások - a közösség tagjai, a volt dékán, a rektori vezetés - kérték fel őket erre a pozícióra. Ez egyrészt hízelgett nekik, másrészt pedig a karhoz, egyetemhez lojális emberként a bizalmat nem utasithatják el, a kényszerhelyzetben nem hagyhatják magára a kart, még akkor sem, ha az egyébként a saját pálya „beáldozásával” is jár

${ }^{96} \mathrm{Az}$ oktató és dékán között ehhez hasonló különbségeket mutattam be a 4.4.2-es alfejezetben. 

meg:

„Ezt alapvetően szolgálatként éli meg az ember, ugye ha a mérleg két serpenyőjére raknám az érveket pro és kontra, akkor nagyon billegne. Tehát legalább annyi érv szól ellene, mint amennyi mellette. De van egy olyan érv, amit nem nagyon lehet kikerülni: ez a szolgálat." (D4)

„És akkor adtam be a derekamat, amikor mind a két oldal megkeresett. Akkor azt mondtam, hogy úgy látszik, hogy valamit akarnak ilyen szempontból. Tehát tudatosan vállaltam, és ilyen módon az, hogy én most szakmai karrieremben nem abban az ütemben haladok, ebböl én magamnak csinálok konfliktust, mert elfogadom ezt a helyzetet, hogy ha én 100\%-ig helyt akarok állni itt ezen a poszton, akkor bizony ennek ára van. Többek között ez, hogy a szakmai karrier, az lassabban halad." (D15)

Mások tisztességgel ellátandó feladatként tekintenek rá:

„akkor viszont megcsinálom, tehát az biztos, hogy akkor már úgy vagyok, hogy elvállaltam, kész, ez a feladatom, csinálom." (D9)

„És már nem akkora elánnal, hanem azt mondtam, hogy tisztességgel. Tehát tisztességgel csináljuk végig, és akkor tisztességgel végigcsináltam." (D21)

„Hát én ezt végül úgy fogtam fel magamnak, hogy hát, ha rám esett a sor, akkor ezt meg kell oldani, pont. [...] [az idősebb korosztály] már ezt nem akarják felvállalni még egyszer, mert inkább a tudományos pályájukra szeretnének összpontosítani, mások kiesnek, hát és akkor valakinek el kell vinni a balhét idézőjelben. És aztán végül én elvállaltam, hogy rendben akkor most az elkövetkező három évben én leszek dékán." (D26)

„Mert szóval én úgy vagyok, jön a feladat, akkor feladatot meg kell csinálni, konfliktus van, konfliktust meg kell oldani. És akkor haladunk. (...) Ez ráadásul viszonylag sürü, pillanatnyi sikert jelent." (D11)

Megint mások pedig a szituációból fakadó kényszerként, elvárásként mutatják be a dékánná válásuk okát:

„Hát akkor csináltam következő évben és úgy éreztem, hogy eltelt egy év és nem lett más a helyzet itt. Tehát, hogy ugye most eljátszom megint ezt a kéretem magam ugye széplányként itt illegek-billegek, és akkor itt most könyörögjenek nekem, hát ezt nem. Tehát nem lett más a helyzet, megpályázom még egyszer, hát nem, nem, nem nagyon tudok mást csinálni, megpályázom még egyszer." (D21)

„De hát az volt, hogy korábban még inkább, tehát mondom, hogy most már közel 40 éves tapasztalatom ez, hogy akinek valahogy szakmailag jól ment, akkor attól azt elvárták, hogy vezető legyen, függetlenül attól, hogy nem tudom én ambíciói, vagy esetleges rátermettsége, vagy bármi vizsgálat alá került volna. Tehát ez nem, azt hiszem ez nem volt igazán jó." (D19)

„....nekem nem voltak dékáni ambícióim, tehát én a véletlen dékánok közé tartozom. (...)És akkor lejárt a ciklus a dékánhelyettesi, akkor kéne egy dékán. És akkor így lettem dékán. (interjúalany nevet) Tehát nem, én nem jártam be azt, hogy, hogy én a homokozóban azt mondtam a Zsuzsikának, hogy ha nagy leszek dékán leszek, nem volt ilyen... (interjúalany nevet)" (D9)

„Így egyik napról a másikra, és én mondtam, hogy hát ha muszáj... Meg, tehát. Hogy mondjam? Amikor az embernek a másik oldalon a munkahelye múlik esetleg az adott 
pillanatban rajta, akkor azt kell, hogy mondjam, hogy nem számít. Tehát akkor az ember összeszedni magát, és megpróbálja a lehetetlent is." (D2)

Az idézetek bővelkednek olyan fordulatokban, mint a „kell”, „muszáj”, „valakinek el kell vinni a balhét”, „elvárták”, „rám esett a sor”. Ezek tükrében a dékánság olyan tevékenység, amelyben az egyéni célokat és vágyakat alá kell rendelni a közösség céljainak, a külső kényszereknek. Ennek megfelelően dékánnak lenni e megközelítésben annyit jelent, mint lemondani az egyéni célok és érvényesülési lehetőségek egy részéről. $A$ dékánság tehát áldozattal jár együtt, amely főként a tudományról, a kutatásról és/vagy a családról való lemondást jelenti. A nehézség számukra abban van, hogy e területek között egyensúlyt találjanak, és ennek érdekében a dékáni feladatokat időnként az oktatás (ritkábban a kutatás) teendői alá rendelik. Ennek megfelelően legtöbbük számára a dékánság utáni idő is a szakmához, a kutatáshoz, és az intézetvezetéshez, tanszékvezetéshez való visszatérést jelenti. (Az oktatásban jellemzően amúgy is magas terheléssel dolgoznak a dékánok. Erre később még visszatérek.)

Minthogy e motivációból hiányzik a belső indíttatás, ezért gyakran jár együtt a konszenzusosság igényével és a verseny nélküli dékánválasztással, hiszen ki vállalná önként a lemondást, ha van más, aki örömmel elvállalná a feladatot?

Természetesen a dékánság mint szolgálat narratíva lehet egyszerü taktikázás is, amelynek feladata a saját érdekek és szándékok elleplezése. A közösségre való hivatkozás teremt ugyanis legitimitást a cselekvésre, amely révén az egyéni elönyök is realizálhatóak.

„Én az esetek 90 százalékában nem hiszek abban, hogy azok az emberek azért ragaszkodnak hozzá, mert itt rájöttek arra, hogy hihetetlen dolgokat tudnak a közösségért csinálni, és akkor most ennek... Egy nagy túrót! Arról szól a történet, hogy elesnek egy csomó olyan lehetőségtől, ami egyébként most még jár, de holnapután már nem jár." (D7)

A következőkben ezekröl az előnyökröl lesz szó.

\subsubsection{A dékánság mint jutalom és mint az egyéni előnyök forrása}

E megközelítés lényege azon előnyök előtérbe helyezése, amelyekhez valaki a dékánság révén jut hozzá, és amelyek felhasználhatóak az egyéni érvényesülés és (szakmai) karrier érdekében. Ezek említésére nagyon ritkán, időnként csak közvetve (másokra vonatkoztatva) kerül sor az interjúk során. Az egyéni előnyökről való beszéd (különösen az „áldozathozatal” és „szolgálat” narratíva mellett) mintha illetlenség lenne, amit jól tükröznek az alábbi idézetekben található szabadkozások (lásd a kiemelt részeket):

„Hát azért több előnnyel jár. Tehát akár külföldi kapcsolatok épitése, programok megismerése. Tehát gyakorlatilag több információval rendelkezem, mint esetleg, ha egy tanszéki vezető oktatóként dolgozom. De nem szoktam azért visszaélni ezzel az információs lehetőséggel, hanem átadom a kollegáknak. Tehát, hogy azért ennek van elönye. Presztízsben is." (D5)

„Hát igazából sok jó nincs benne [a dékánságban] alapvetően (nevet). Én magam részéről mondjuk azért vállaltam ezeket, mert hát nagyobb mozgástere van az embernek a területen egyszerüen. Szóval...nálunk még mindig az van, azért, hogy - és ez szerintem egy ilyen, nem tudom én milyen, magyar tradíció -, hogy aki vezető pozícióban van, az az adott szakterületen is hogy mondjam: egyrészt nagyobb elismertséget kap, másrészt pedig ez nem jó, nem jól van igy egyébként. [...] Mert egyébként is, hogyha beosztott lenne, de nem tudom én, számítanak a 
véleményére, meg a munkájára, akkor is részt kell vennie ezekben a bizottságokban, meg mindenféle ilyen, ugye a kar fontosabb kérdéseit tárgyaló értekezleteken. És hát nem mindegy, hogy akkor ki határozza meg, hogy mikor van, hogy van. Szóval ez is egy, ez....De én egyébként, hogy mondjam, ilyen hatalmi vagy egyéb szempontokból, egyáltalán nem preferálom ezt a dolgot." (D19)

„Jó benne az, hogy az embernek bizonyos szintrōl ugye van rálátása. [...] Ez mondjuk jó érzés, mert az ember úgy érzi, hogy nem tudom, hogy magabiztos [...]. Tehát, hogy benne legyen a dolgokban, ugye. Úgy szokták mondani. Tehát hogy ez egy jó érzés, hogy így benne van az ember. És akkor érti, hogy mi miért van és miért van ez a hülyeség és miért van az a hülyeség. Tehát ez az involváltság, vagy nem tudom hogy fejezzem [ki]... Ugye ez az involváltság, ez egy, ez egy, ez egy jó érzés." (D10)

„(...)régen - azt gondolom, hogy - az egy óriási presztizs volt. Ez csökkent, ez szinte biztos, hogy csökkent. Ez nekem nem is esik jól. Tehát én úgy jobban tudnék örülni a szerepemnek is, ha ez... De nem baj, majd ezért küzdök, hogy ez még mindig olyan legyen, mint a presztízs. (mindketten nevetnek)" (D8)

A dékáni pozíció révén nyert plusz erőforrás, rálátás, kapcsolatrendszer és befolyás segítségével a dékán erőforráselosztó és (szakmai) kapuőri feladatokat is ellát, például folyóiratok szerkesztőbizottsági tagja lesz, különböző nemzetközi és akkreditációs testületekbe kap meghívást, amely révén ráhatása lehet mások publikációira, akkreditációjára stb. Ez persze nem választható el teljesen a korábbi szakmai teljesítménytől, de a dékánság tovább emelheti az illető tekintélyét. Az interjúk során például volt olyan dékán, arról mesélt, hogy a tudományos konferenciákon őt dékánként konferálják fel, pedig ő ott kutatóként van jelen, és nem dékáni minőségében.

A befolyás éppúgy felhasználható a kar javára, mint az egyéni előnyök (járadékok) szerzésére vagy éppen az egyéni (szakmai) karrier építésére. Bár a dékánsággal járó feladatok valóban elveszik az időt az aktív kutatói és oktatói munka elöl, a szakmai előmenetelben meglévő hátrány kompenzálható a tudományszervezésben betölthető erősebb pozíciókkal. Emellett Nyugat-Európában és a kisebb országokban az intézményen belüli adminisztratív és vezetői tevékenységet figyelembe veszik a tudományos és szakmai előmenetelröl való döntés során (és fordítva). A nagyobb (és különösen az angolszász) országokban a szakmai értékelés jobban leválasztható az intézményről (Pokol [2004] 206.o., lásd még 224-225.0.), a tudományos közösség a méreténél fogva függetlenebbül tud ítélkezni egy-egy jelölt szakmai kvalitásairól, így ott a pozíciók egymástól való függősége is kisebb.

A pozíciók egymásra hatásából adódóan a szervezeti karrier tudatosan is felhasználhatóvá válik a későbbi szakmai karrier „egyengetése” érdekében. Ahogy erre Nagy Péter Tibor utal:

„Elöfordul, hogy az intézményi karrier éppen arra való, hogy alternatív felemelkedési, pozíciószerzési utat jelentsen, mondjuk egy akadémiai taggá választott vagy nemzetközi meghivásokat kapott nemzedéktárssal szemben. Elöfordul, hogy egy-egy tudományágat domináló professzort vagy akadémikust a következő nemzedék domináns figurája e módon nem letaszít a »trónjáról«, hanem »megkerül«. De elöfordul az is, hogy egy számára fontos tanszék, oktatói csoport relatív helyzetét kivánja erősíteni a tudós, amikor dékáni pozíciót vállal, sokat áldozva személyes szakmai karrierjéböl, idejéböl." (Nagy [2007] 443.0.)

Ugyanez a téma felmerült egy egyetemi felsővezetővel készített interjú során is: 
„Volt itt egy [...] tanszékcsoport, aminek a vezetői sorozatban voltak rektor, dékán, ez, az, amaz. És hát ezt ők arra használták, hogy a tudományos, hát hogy mondjam, eredményeiket jól felhizlalták, fiatal kollégákat vettek föl, tehát a létszám a hallgatói létszámhoz képest óriási nagy volt." (F6)

A dékánság mint feladat és szolgálat felfogás úgy tekintett a dékáni pozícióra, amely miatt fel kell áldozni a szakmai pályát (le kell mondani az oktatásról és a kutatásról). A dékánság mint jutalom és karrier megközelítés azonban azt mutatja, hogy a dékánság nem csak visszavetheti a szakmai karriert, hanem éppenséggel elősegítheti és meg is támogathatja azt. Ebből a szempontból nincsen jelentősége annak, hogy a dékánok jelentős része már szakmailag befutott (egyetemi tanár lett) mire a dékáni pozícióba kerül, hiszen egyfelől maradhatnak még így is elérhető formális címek és pozíciók (pl. akadémikussá válás), és cél lehet a szakmai befolyás kiterjesztése is. Ugyanakkor a dékánság arra is alkalmas, hogy ellensúlyozza - részben épp a dékáni feladatok miatt meglévő - esetlegesen gyengébb szakmai teljesítményt. Másként fogalmazva: egy-egy tudományterületen és életkori periódusban a dékánság nem a szakmai karriertől elkülönülő adminisztratív pozíciót jelent (mint az előző narratívában), hanem a szakmai karrier egy olyan állomását, amely révén a dékán szakmailag emelkedhet ki a többi hasonló beosztásban dolgozó kolléga közül. Egy interjúalany a következőképpen latolgatja a kar mérete, a professzorok száma és motivációja közötti összefüggést:

„Ha a professzorok száma meghaladja az olyan 30-40-et, akkor ott már nem mindegy, hogy ki
[lesz a dékán]. Akkor már többen vannak, aki erre alkalmas lehet. Esetleg presztízs kérdés
lehet a dékánság, ráadásul ott a karrierpályában már egy súly lehet. Egy olyan kar esetében,
ahol a kar súlya az inkább azt mondanám, hogy 30 és 50 év közötti emberekre tevődik és
mondjuk a professzorok száma az előzőtoöl jóval alacsonyabb, ott inkább feladat-orientált lesz a
szervezet, azt gondolom. Merthogy a presztízs... Attól, hogy már valaki professzor egy karon,
az már megadja számára a presztízst, különösebben nem kell továbbmenni ebben a
presztízsben. És akkor már sok szerintem a feladat. És ugye minél fiatalabb egy közeg, ami a
szervezetet alkotja, annál inkább a szervezet akar fejlődni és nem akarja lecövekelni magát. Ez
persze nem azt mondom, hogy az idősebb kollegák nem akarnak fejlődni, csak már azért ilyen
téren más életszakaszban vannak...” (D26)

\subsubsection{A dékánság mint (ön)megvalósítás}

E megközelítés abban különbözik az előzőektől, hogy itt a kar a dékáni cselekvés fókuszában van: vagy az átalakítás tárgya, amelyet a dékán a saját elképzelései szerint szeretne formálni, vagy (ritkábban) a nevelés tárgya, amelynek a fejlődését szeretné a dékán elősegíteni, érettebbé tenni és rávezetni arra, hogy képes legyen megvalósítani a benne lévő potenciált. $E$ narratíva központi szereplője maga a dékán, akinek világos elképzelése van a tennivalókról, és aki révén realizálódik a siker.

„Hát mert én úgy gondoltam, hogy van arra egy koncepció, hogy milyennek kell lennie ennek a karnak és ezt szerettem volna végigcsinálni." (D27)

„Én azt is gondoltam magamról, hogy nekem van koncepcióm erre, tekintettel arra, hogy nagyon hosszú, tehát ide jártam, végig éltem azt, hogy itt egy [...] szakból lett egy kar." (D21) 
„Tehát ezt úgy fogom föl, hogy ha indítok különféle projekteket, hogy elképzelem a kar jövőjét, és amögött van konszenzus és van pozitiv eredmény, akkor csinálom. Tehát számomra fontos egy pozitív visszacsatolás." (D4)

„Az emberben úgy kialakul egyfajta kép, hogy mit kéne csinálni, hogy kéne csinálni, de szívesen tenném. És akkor végül megragadja a lehetőséget, hogyha adódik, hogy akkor most próbáljam meg, hogy, hogyha van egy elgondolásom, akkor kerüljek közelebb a lehetöséghez megvalósítani." (D12)

Ez gyakran jár együtt azzal is, hogy a dékánok a dékánságra nem lemondásként, hanem fejlődésként, önmegvalósításként tekintenek. A pozíció ezért nem teher, hanem kedvükre való dolog, amiért érdemes vállalni akár a versenyben való megmérettetést is. Nem meglepő, hogy e dékánok között nagy számban vannak olyanok, akik magukat jelölték a dékánválasztáson, és ellenjelölttel szemben nyerték el a pozíciót. Sőt, e motivációs háttérrel rendelkezők között találhatjuk meg azokat is, akik még magasabb vezetői beosztásokra is aspiráltak vagy aspirálnak (illetve nem zárják ki ennek lehetőségét).

Noha sokan elismerik, hogy a dékánság nem segíti a szakmai karrierjüket, erre már nem is igen vágynak. Más kihívásokat keresnek, mert úgy érzik, szakmai karrierjük lezárult, további előrelépésre nincs tér vagy igazi szándék, ezért az erről való lemondás nem is tünik valódi áldozatnak. A dékánsággal járó alkotó munka a megújulás, egy másféle kiteljesedés lehetőségeként jelenik meg, amely akár a szakmai munka egy másféle formában történő megélését is jelentheti.

„Nyilvánvaló, hogyha olyan matematikus lettem volna, aki hihetetlen szép karriert fut be matematikusként, kimagaslóan fut karriert, akkor lehet, hogy sose mentem volna el ebbe az [ti. adminisztratív] irányba." (D7)

„Tehát hozzáteszem, hogy ennél többre már ezen a vonalon [a szakmában] nem vágyom, viszont arra, hogy megvalósítsam a terveimet, és pontosan ezzel a rengeteg külföldi kapcsolat, ez a rengeteg vendég, aki jön. Sajnálnám, hogy ettöl elesek." (D25)

Annak ellenére, hogy e dékánok számára a szakmai karrier már nem bír akkora jelentőséggel, nem mondhatnak le az oktatásról és a kutatásról sem. Ez azonban már nem (csak) belső igényként írják le, hanem kényszerként is:

„Hát én ugye meg akarok felelni, mert véletlenül sem akarok semmilyen támadási felületet adni a kollégáknak. Tehát én ugyanannyit tanítok, mint egy rendes föiskolai tanár. Ez most heti 8 óra, hát én a heti 8 órámat, azt megtartom. [...] Gyakorlatilag én ezt megtartom, sőt tegnap TDK verseny volt nálam, van egy TDK-zóm is, tehát igyekszem azt a látszatot kelteni, hogy egyébként egy normális tanár vagyok." (D17)

„(...) vannak még egyéni céljaim, tehát nyilván kis mélyebb tudományos [munka], hogy ha odáig elvergődök. De valójában azt látom, hogy azt is csak azért csinálnám meg, hogy ennek a karnak még ezek a kellékei is még jobbak legyenek. Tehát nem valószínü, hogy én már a következő időben akadémikus leszek, annyira nem is érdekel ez az ügy. De az [foglalkoztat], hogy mondjuk egy akadémiai doktorságig még elvergődni, és pusztán megint csak a példamutatás miatt." (D25)

V: „Hát de muszáj elöre menni, mert ahhoz, hogy az ember teljesítsen egy következőt tehát, hogy egy... 
K: Kell teljesiteni egy következőt?

V: Igen, kell teljesíteni egy következőt, mert benne van az egyetemi szabályzatban, hogy én ugyan föiskolai tanár vagyok, és a felsőoktatási törvény nem írta elö, hogy habilitálni kell, de a mi egyetemi szabályzatunk az előírta, hogy 2012-ig habilitálni kell és akkor én azt mondtam, hogy én nem engedhetem meg magamnak, hogy én ne habilitáljak. (...) Merthogy én azt mondtam, hogy akkor hogy néz az ki, hogy pont az, aki benne van abban a szabályzatelőkészítő bizottságban, amiben ezt mi elöírjuk, azzal együtt, hogy tölem elvileg nem lehet elvenni a föiskolai tanárságomat. (...) maradhatnék itt úgy is [habilitáció nélkül], de én akkor is azt mondom, hogy nekem kell ebben is [elörehaladni], mert nekem attól, hogy én dékán vagyok és azt mondom a kollegáimnak, hogy teljesitsetek dolgokat, és én nem teljesítem, akkor hogy néz ki az a történet?" (D21)

Ezekben a megnyilatkozásokban az tükröződik, hogy az oktatás és kutatás fontosságát - ha vallják is - inkább illendőségből, semmint valós meggyőződésböl teszik. Az oktatás és kutatásban való részvétel kényszere abból a meggyőződésből eredhet, hogy a dékán akkor jó vezetö, ha teljesíti mindazokat a követelményeket (vagy azok egy részét), amelyek a kari professzorokra vonatkoznak, mert csak így várhatja el hitelesen másoktól a hasonló teljesítményt. A dékánok tehát mintaadóként, normameghatározóként definiálják magukat.

K: „Most egyébként tanít vagy kutat Ön? Tehát csinálja még ezt, van még erre...?

$\mathrm{V}$ : Még muszáj, tanítani is, kutatni is.

$\mathrm{K}$ : Muszáj? Miért muszáj?

V: Hát mert egyrészt a[z intézményben] van egy elvárási szint, ami az oktatói tevékenységet is, tehát egy dékánnal heti 6 óra a kötelező óraszáma, ami azért nem kevés. Másrészt meg van egy oktatói pontrendszer, ami a minőségbiztosítási rendszernek egy része, és ott azért minden évben produkálni kell, hogy tudományos konferenciákon, meg különböző szakmai folyóiratokban részt kell venni. Meg hát, nem is igazán lehet lemaradni. Mert ha én nem csinálom, akkor hogy várhatom el a kollegáimtól ezt a fajta tevékenységet?" (D5)

Az oktatásban és a kutatásban való részvétellel egyben azt is üzeni a kari oktatóknak, hogy ő maga is oktató. Az oktatásban való részvételnek abban is fontos szerepe lehet, hogy ilyen módon a vezető fontos információkra tehet szert arról, hogy mi is zajlik a karon, s ezek hasznosithatóak a vezetés során. Egyfelöl visszahúzza őket a földre, szembesüljenek a realitásokkal, ne szakadjanak el az alapfolyamatoktól.

„Vezetöi oldalról [az oktatás és a kutatás] ez nem fontos. Személyes oldalról ez egy fontos kérdés. De vezetôi oldalról ez nem, hát ezt nem használja, nem hasznosítja vezetői munkája során. Hát maximum az impulzusokat, amik ennek kapcsán érik, ez egy fontos kérdés. De ezeket az impulzusokat mondjuk máshogy is meg lehet szerezni. Nekem nagyon nagy elvem, hogy a vezetőnek a fronton kell dolgoznia idézőjelben. Tehát nem lehet egy irodából vezetni valamit." (D26)

„Abban a pillanatban viszont, amikor az ember úgy látja, hogy elszakadóban van a kutatástól, akkor ezt azonnal abba kell hagyni. Mert akkor nem fogja konkrétan érzékelni, hogy milyen problémákkal találkoznak a többiek, és nem fog jól reagálni." (D3)

„Tehát amit mondtam, hogy megtartom az órákat azért, hogy emberléptékű maradjak, és hogy a hallgatókkal elmegyek meginni egy sört, vagy leállok csocsózni. Ez nem tudatos szerep, hanem szeretem őket. De azért ez kell ahhoz, hogy normális maradjál." (D17) 
Ami ezekből az idézetekből látszik, hogy az oktatás és a kutatás nem feltétlenül belső igényből fakad, hanem alárendelődik a vezetői szerepüknek, és eszközzé válik, amely révén eredményesebb vezetők lehetnek.

Nem mindenki tekint azonban úgy a dékánságra, mint ami parkolópályára teszi vagy lezárja a szakmai karriert. Néhány dékán számára a dékánság nem jelenti sem a szakmai karrier feladását a közösség vagy az önmegvalósítás érdekében, sem pedig az egyéni érdekek (szakmai karrier) előtérbe helyezését. Néhány tudományterületen (pl. gazdálkodástudomány), vagy sajátos felsőoktatási érdeklődés esetén ugyanis a dékánság úgy is értelmezhető, mint a teoretikus ismeretek gyakorlatba ültetése - ennélfogva a dékánság nem jelent sem kényszerü kompromisszumot a szakmai érdeklődés és a vezetői feladatok között, sem pedig a szakmai karrier feladását.

„És mondom, mivel vezetéssel, azért azzal foglalkozom eleve, ez abszolút izgalmas. Tehát azért le kell ülni egy-egy emberrel is, hogy ezt a végig játszani ezt a játszmát, vagy valami, én ezt nem nyügként élem meg. Jó, viszi az időt, meg minden, de ez a practice what you preach. Ha már. (...) Nyilvánvaló tudom, hogy ez nem ennyire tiszta és egyértelmü, hogy csak elönye. Biztos, valószínü, hogy ennek lesznek hátrányai, de ez most az én fejemben annyira nem [jelenik meg]." (D8)

"Tehát én végülis egy olyan területen dolgozom, olyan területen lettem professzor, ez a marketing és menedzsment területe, és hát azon belül én mondjuk marketinges vagyok. Ahol szerintem nem elég az, hogyha az ember mondja, de legalább annyira adott esetben csinálnia is kell." (D12)

„Én úgy gondolom, hogy ez olyan szempontból egy érdekes kihívás, engem az oktatás modernizálása, az oktatási struktúrák, külföldiek, itthoniak mindig érdekeltek [...] A másik rész, az egy ilyen következetes, folyamatos érdeklődés volt az oktatásmodernizálással kapcsolatban. [...] Tehát így. Az érdeklödési köröm, illetve az a kihivás, amit megfogalmaztatott, a kettő összetalálkozott, és így vágtam bele." (D3)

Ebböl adódóan e dékánok a pozícióhoz olyan tanulási folyamatként is viszonyulnak, amely hozzájárul személyes fejlődésükhöz (e nézőpont ennyiben köthető az egyéni előnyöket kereső dékáni narratívához is), de amellyel szemben nincs azonnali megtérülési elvárás (ez pedig megkülönbözteti töle). Ez a nézőpont amúgy nagyon ritka volt a dékánok között.

„Tehát szerintem ez is egy tapasztalati szakasz, biztos lesz majd másik szakasz is. Már úgy értem, hogy mikor egész másféle dolgot csinálok. Gyanítom. De hát azt is mondanám, hogy én most ezt élvezem, hát ez egy tanulási folyamat." (D8)

E példa azt is jól mutatja, hogy az egyes motivációk nem feltétlenül zárják ki egymást, egyszerre akár több is érvényesülhet. 


\subsection{Nyomás alatt: a dékánsággal járó hátrányok és az ellensúlyozási stratégiák}

Az interjúkból kibontakozó három motivációs séma közös pontja a szakmai karrierhez, az oktatáshoz és a kutatáshoz való viszony tisztázása. Az nyilvánvaló, hogy szinte minden dékán életének része marad az oktatás (ritkábban emlegetik a kutatást), ennek okai azonban igen sokrétüek. Az egyik emlegetett ok, hogy ezt számukra a törvény, a foglalkoztatási szabályzat írja elő, hiszen a dékánok a vezetői megbizás ideje alatt is docensek, egyetemi tanárok maradnak, akik számára a foglalkoztatási követelményrendszerben elő van írva egy meghatározott oktatási és kutatási terhelés. Dékánokként ezek alól a szabályok alól csak részbeni mentességet kapnak, elsősorban a jobban mérhető és szigorúbban számon kért oktatás területén. ${ }^{97}$ Sokan azonban még ezzel sem élnek, és helyenként meglepő mértékű oktatási terhelésekkel találkoztam az interjúk során. Főként főiskolákon vagy egykori főiskolai karokon előfordulhat heti 14-16-20 órás oktatási terhelés is. Miként az előző részben láthattuk, a további okok között szerepelt az, hogy oktatni (kutatni) azért kell, mert

- ez belsőleg fontos, ez a lényege a felsőoktatásnak,

- a dékánság ideiglenes pozíció, és később vissza kell illeszkedni,

- kikapcsol, regenerál, a vezetői munkával járó stresszt oldja,

- ilyen módon maradhat "ember léptékü" a dékán,

- a „fronton kell dolgozva" szerezheti meg a napi müködés impulzusait,

- így marad hiteles az oktatók előtt,

- példát kell mutatnia az oktatóknak, csak így várhatja el tölük is teljesítést, és

Az a tény, hogy az oktatás (és kutatás) vállaltan, tudatosan képezi a dékánok életének szerves részét, azt sugallja, hogy a dékánok döntő többsége vagy az oktatói közösség részeként tekint magára, vagy igyekszik akként láttatni magát. A dékánok motivációs hátterüktől függetlenül erősítették meg oktatói, kutatói identitásukat, ami azt jelenti, hogy (vallott érték szintjén legalábbis) elfogadják magukra nézve az oktatói közösségre vonatkozó normákat. Azaz dékánként is inkább egy sajátos helyzetben lévő oktatónak értelmezik (láttatják) magukat, semmint olyasvalakinek, aki tevékenységének, feladatainak sajátosságainál fogva az oktatói közösségen kívül áll.

E meggyőződés következménye azonban a „kettős terhelés”: a dékánoknak nem csak a dékánsággal járó adminisztratív feladatokat kell ellátniuk, hanem ezen felül külső kényszer, belső késztetés vagy a jövőre vonatkozó megfontolások miatt még oktatóként és kutatóként is helyt akarnak állni. Ez különösen nehéz annak a fényében, hogy számos kari vezető szerint a

\footnotetext{
97 Amikor áttekintettem a felsőoktatási intézmények foglalkoztatási követelményrendszereit, meglepő szórást tapasztaltam a dékáni kedvezményeket illetően. A 2005-ös felsőoktatási törvény 10-12 órás heti tanítási kötelezettséget ír elő (ez 5-6 75-90 perces tanórát takar). Főként a főiskolákon ennél magasabb az elvárás (például a Károly Róbert Föiskolán 14 óra). A dékánok oktatási terhelése 20\%-tól (Szegedi Tudományegyetem) 75\%-ig (Budapesti Corvinus Egyetem), vagy 2-4 órával csökkenthető, de van, ahol magasabb az általánosan elvárt óraszám, ott a dékánok csökkentett óraterhelése is magasabb.
} 
dékánság egész embert kívánó tevékenység, ami nem végezhető félállásban. Nem csoda, hogy e dékánoknak jellemzően hajnaltól késő estig tartó elfoglaltságokról számoltak be, és így nagyon kevés idejük jut a magánéletükre, családjukra. Mindezt súlyosbítja a dékáni munkával járó tervezhetetlenség és kiszámíthatatlanság.

„Szóval a környezet, a körülmények sem olyanok, ami egy fix stabilitást adna, és nem egyszer van, hogy eltervezem hétvégén, hogy a következö héten mit csinálok, miket, mivel fogunk foglalkozni, hogyan, milyen ütemezésbe tesszük a dolgokat, bejövök ide, és azonnal borul az egész, mert jön egy e-mail, amiben közlik, hogy most azonnal ezt, meg azt, meg amazt. $\mathrm{Na}$, ezek a legrosszabbak." (D15)

„Az biztos, hogy én azt rossz oldalnak éltem meg mindig, hogy én szerettem volna saját magam menedzselni a saját időmet, de ezt soha nem tudtam, tehát ezt nyilván helyettesként különösen nem, mert akkor még ugye ott van egy fönök, aki még inkább beosztja, de dékánként sem, mert akkor is ott van egy fölöttem lévő rendszer, ami nem azt mondja, hogy mert azt én beoszthatom a saját karomon, hogy hogyan müködünk, és akkor azt mondom, hogy csak fogadóórában lehet hozzám bejönni, tehát ott azt tudom. Na de az, hogyha fölhív a rektor, hogy gyere be mert beszélnem kell veled vagy bizottsági ülés van vagy nem tudom én micsoda. Tehát én inkább ezt a... nem saját ura azért, csak nem az ember." (D21)

„Hátránya, hogy nincs, soha nincs vége. Tehát az a fajta érzés, hogy már reggel hajnalban felkelek, akkor a gép mellé ülök, nézem a levelezésemet, és... tehát, hogy soha nincs vége. Tehát ez a...soha nincs az az érzésem, hogy... az a jó érzésem, hogy most valamit megcsináltam és itt vége van. Mert ezek mindig újratermelődnek. Talán ez a nagyon sok adminisztrációból adódó teher, meg ami számomra nagyon nehéz, hogy igazán semmit nem lehet tervezni. Tehát a tervezhetetlenség." (D5)

„Szerintem ritka az a dékán manapság, aki vagy zseniálisan szervez, amit én ezek szerint nem mondhatok el magamról, de 8 órában dolgozik, vagy annál kedvesebben. Ez egy állandó készenléti helyzetet jelent. (...) Tehát ez egy ilyen 24 órás munkakör." (D3)

Mindez nem csak a kiszolgáltatottság érzésével jár együtt, hanem az állandó készenléti kényszer feszültségével is. Az egyik dékán például felidézte, hogy a megválasztása évében égett le a zsámbéki föiskola fóépülete:

„Tehát akkor engem ez kísértett 7 évig. Tehát úgy éreztem, hogy itt bármikor lehet valami olyan, most nem egy feltétlenül leégés - egyébként majdnem lett ezt hadd mondjam el, ez az önteljesítő jóslat -, hogy én állandóan mindent olyan kvázi nem drámának éltem meg, de egy olyan feladatnak, amit meg kell oldani. Minden áron meg kell oldani. És fönn kell tartani egy intézménynek a müködését [...]. És bármelyik épület gyakorlatilag lehet olyan állapotban, hogy leviszi a tetőről a nem tudom én a vihar vagy beázunk, amik ugye nyilván meg is voltak, amit mindent megoldathatok, de tehát én mindig arra jöttem be hétfőn reggel, hogy volt-e valami a hétvégén, aminek most neki kell állni és lehetőleg gyorsan meg kell oldani ezeket a, és én ezeket hordoztam haza. Hordtam haza, és nem tudtam, amikor becsukom az ajtót, befejezni." (D21)

Mindezek miatt az interjúk gyakran visszatérő témája volt a napi munka megszervezése és az időmenedzsment kérdése. Az általános technikák között emlegették az estére és reggelre szorítkozó e-mailezést, a titkárnőkkel kezeltetett időbeosztást. Elengedhetetlennek tartották a csapatmunka jó megszervezését, a delegálás képességét, a munkatársakban való bizalmat.

Az oktatásban való részvételt néhányan sajátos óraszervezési technikákkal oldják meg (mondjuk csak a hétvégi levelezős kurzusban oktatnak). A kutatásban való részvétel valamilyen 
belső munkamegosztással történik (a dékán inkább supervisori tevékenységet végez, ötletemberként müködik közre), mások az alibizést emlegették (a munka kis részét vállalják el). Néhány bölcsész és társadalomtudományi területen, amely jelentős elmélyedést és rengeteg olvasást kíván, a kutatás teljesen háttérbe szorul, vagy késő estére, hétvégékre (azaz a szabadidő és a családi idő rovására) tolódik el.

A dékáni élettel járó terheltség és annak hektikussága különösen azoknál a családos dékánoknál vált ki feszültséget, akik fiatalon válnak vezetővé, mert ott rendszerint még kisebb gyerekek is vannak, ráadásként pedig ebben a korban még inkább érvényesülhetnek a szakmai teljesítménykényszerek is (pl. egyetemi tanári pozíció megszerzése miatt).

K: „És az ebéden kívül miröl kell még lemondania?

V: Ez nagyon aranyos kérdés. Hát, leginkább a barátaimról, meg a családomról. Tehát azok...tehát mondjuk a barátaim, ök rendszeresen írnak olyan e-mailt, hogy köszönik szépen, már most többet már ne írjak. Tehát otthon is a gyerekeim, mondjuk szombat reggel azt mondja a fiam, hogy „apa, ma hova mész”. Vagy vasárnap délután kettőkor, ha fölveszek egy dzsekit, és ki akarok menni, hogy a garázsból beálljak az autóval, akkor megkérdezi, hogy hova megyek. Tehát az, hogy azt látják, hogy én állandóan megyek, megyek, megyek. Tehát ezek, emberi kapcsolataim, azok megsínylik. Tehát én nagyon-nagyon szeretem az embereket, és én ezekről lemondok. Amikor nem mondok le, azok főleg futball, tehát sportokról nem mondok le. Tehát járok sportolni. De azért sok mindenröl igen. Sok mindenröl igen..." (D17)

„Reménykedtem benne, hogy még kevesebb lesz a terhelés, ha majd dékán leszek, de ez ugye, ez nem valósult meg. (kis szünet) Hát igen, sokat kell otthon erről beszélgetnünk. Nagyon sokat kell otthon erröl beszélgetni, hogy az természetessé váljon, hogy, - biztos nem jól csinálom, ezt aláirom - de én vagyok az utolsó, aki elmegy az épületböl, tehát a portaszolgálat már bezárt kapukkal enged engem ki. Este 10 elött gyakorlatilag nem megyek el az épületböl, és azért én reggel 8-kor itt vagyok bent. Van úgy, hogy fél 8-kor. És ezt, ezt azért otthon, ezt nagyon sürün el kell, el kell mondani, el kell beszélgetni. Hogy azért igenis, és otthonra is kell adni egy kicsit az embernek a lelkéből és a családanya szerep, amit ugye mond a társadalom a család szervező rugója, azt ugyanúgy teljesíteni kell. Ez nagyon nehéz. Tehát így szerintem nagyon nehéz. Most nem csak a gondolkodásmód, hanem ez a rész, ez szerintem külön leterhelö." (D30)

Mindezt nagyon nehéz támogató családi háttér nélkül végigcsinálni (az egyik felsővezető interjúalany kifejezett előnyként beszélt arról, hogy a dékánok családi háttere rendezett és konszolidált). Az igazi támaszt, a „stabil zónát” több dékánnál is a szülők jelentették, akik coachként, mentorként, tanácsadóként segitették a dékánt a munkahelyi konfliktusok megoldásában.

„Tehát őt [az édesapát] szoktam kérdezni sok mindenről. Tehát emberi dolgokról. Otthon van a kar összes dolgozójában (interjúzó nevet) és ő szokott abszolút okos dolgokat mondani. Föleg a bölcsesség irányába. Tehát mivel én valószínüleg gondolkodásban idősebb vagyok a koromnál, de nem vagyok azért elég bölcs bizonyos tekintetben, és ő mindig azt az irányt támogatja, amit később én is helyesnek vélek, ami konszenzus, megbeszélés, emberi bánásmód, tehát ami emberré tesz bennünket, abba az irányba terelget, tehát nem dijazza a „kiásom a csatabárdot», és nem is áll nekem jól egyébként." (D17)

„...a másik oldalról meg 82 évesek most már a szüleim, akik engem végig támogattak [...] ők voltak a stabil zóna [...]. A segítő beszélgetés az arról szólt, hogy ők meghallgattak engem és mondták ugye a nagy bölcsességükkel, hogy nem fontosak ezek a dolgok, de én gyakorlatilag olyan terheket tettem rájuk, amit nem szabadott volna rájuk raknom." (D21) 
Az idősebb dékánoknál, ahol a gyerekek már felnőttek, a dékánság csak akkor korlátozó, ha már unokák is vannak, de erről is inkább csak a női dékánok számoltak be. Egyikük például lemondóan úgy nyilatkozott, hogy „vasárnapi nagymama lettem” (D22). A nem családos dékánoknál inkább a párkapcsolatok kialakítása és fenntartása okoz nehézséget, ami a tervezhetetlenségböl, a „24 órás szolgálat”-ból fakad, amit az átmenetiségre való berendezkedéssel igyekeznek „túlélni”.

\subsection{A dékánok vezetői szerepei és szervezeti narratívái}

E fejezetben összefoglalom azokat a szervezeti narratívákat és vezetői szerepfelfogásokat, amelyekkel az interjúk során találkoztam. Minthogy a kutatás célja a szerepeket leíró kiinduló modell (lásd a 4.3.3. fejeztet) mélyítése, gazdagitása, kontextusba helyezése és szükség esetén felülvizsgálata, ezért az interjúk elemzése során kiindulásként az eredeti szerepmodellt használtam fel, azaz az interjúk tapasztalatait megpróbáltam a hős, a szolgáltató, a katalizátor és a stratégiai játékos szerepeken belül értelmezni, majd azokat a dékánok által mondottak révén tovább árnyalni.

Emellett kísérletet tettem arra is, hogy a markáns, rendszeresen visszatérő témák és gondolatok alapján újabb (ún. másodlagos) szerepeket írjak le ${ }^{98}$. Összesen hat másodlagos szerepértelmezést találtam: a koordinátort, a problémamegoldót, a tulajdonost, a taktikust, a szervezetfejlesztőt és a brókert. A másodlagos szerepek indokoltságát az adja, hogy - miként arra az eredeti szerepmodell bemutatásakor már utaltam - a dékánok ritkán fókuszálnak kizárólag egy-egy szerepre, és sokkal gyakoribb a különböző szerepeket vegyítő gondolkodásmód. A másodlagos szerepek pontosan ezt próbálják megjeleníteni azáltal, hogy keresztül nyúlnak a kiinduló szerepértelmezéseken. Emellett azonban mégis segítenek abban, hogy a jól beazonositható gondolkodási minták megragadhatóak legyenek.

Az alábbi ábrán összefoglalom az elsődleges és másodlagos szerepek viszonyát. Az elsődleges szerepek kontextusba helyezésére és a másodlagos szerepek részletes bemutatására az egyes alfejezeteken belül kerül sor.

Fontos hangsúlyozni, hogy az alábbiakban nem az egyes dékánokat elemzem (netalántán értékelem), hanem a visszatérő kollektív gondolkodási sémákat, modelleket próbálom megragadni.

${ }^{98}$ Ez annyiban jelent másodlagos szerepet, hogy az interjúkból kiszürhető szerepeket az eredeti (elsődlegesnek tekintett) szerepek által kifeszitett modelljében próbáltam meg elhelyezni. 
8. ábra: Az interjúk alapján megfogalmazott másodlagos szerepek és azok viszonya a kiinduló (elsődleges) szerepértelmezésekhez

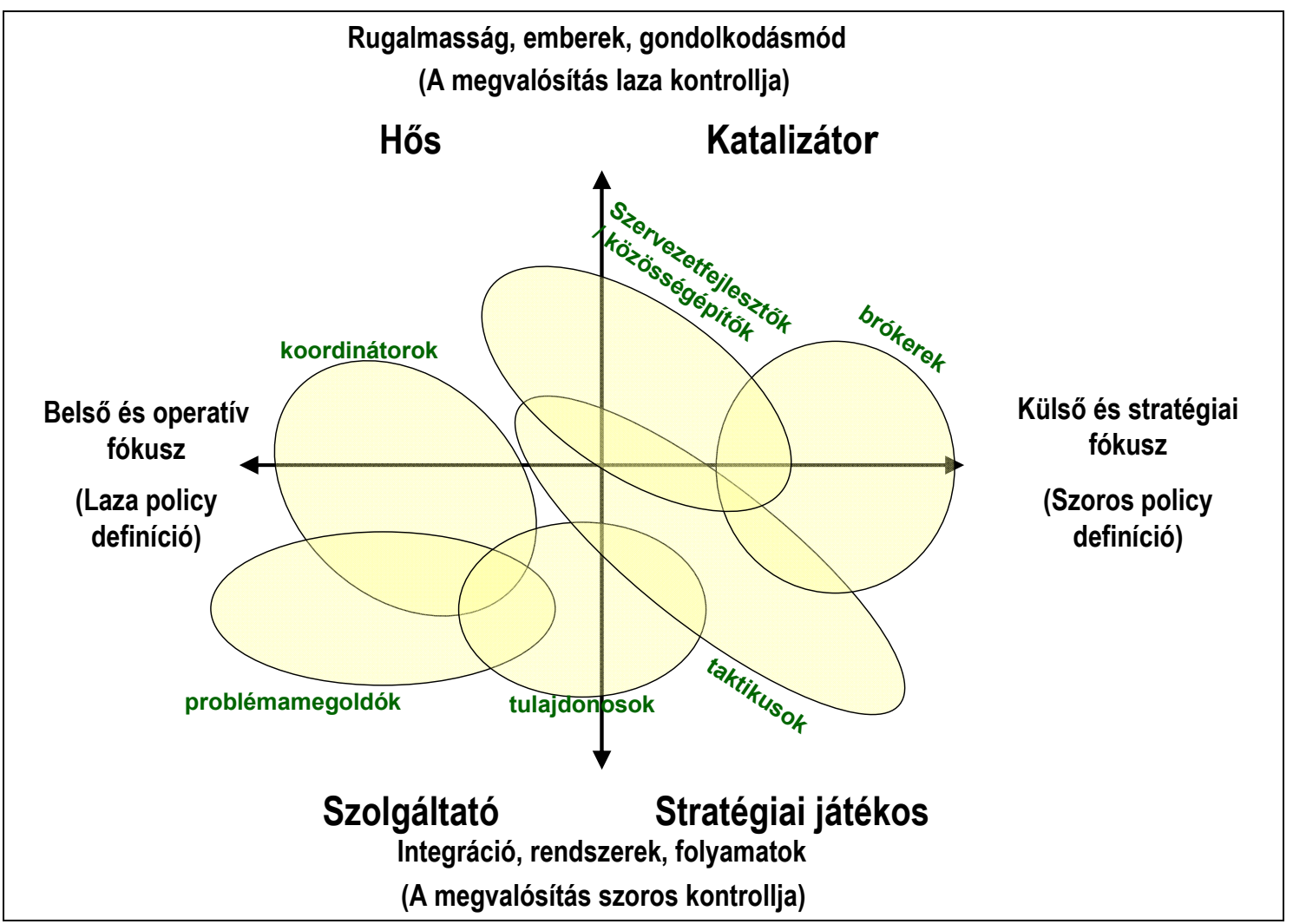

Forrás: saját szerkesztés

\subsubsection{A hős}

„Volt egy érdekes dolog, amikor ott kint dolgoztam. Nem ismertem a rektort, és egyszer csak kaptam egy üzenetet, hogy a rektor vár. Mi? Hát mi közöm van nekem a rektorhoz? Átmentem, és azt mondja, hogy itt van ez a kis szatyor, az anyósa küldte ezt a süteményt Magyarországról. (mindketten nevetnek) Tudniillik konferencián volt, pont egy olyan szakterületen, ahol az apósommal találkozott, (interjúalany nevet) aki odaadta neki a kis szatyrot. Tehát ugye ebből látszik, hogy ő tényleg ment a konferenciákra, és csinálta a dolgokat. Tehát mondjuk ezt a fajta vezetői szerepet tudom én magammal azonosítani, vagy magamat ezzel tudom azonositani, akár dékán, akár rektor, akármi, aki megörzi a professzor voltát, és igyekszik azért alkotni valamit." (D14)

A fenti idézettel jellemzett gondolkodásmód középpontjában olyan dékáni szerepfelfogás áll, amelyben a dékán a vezetői pozíció mellett is törekszik az oktatás és kutatás magas szintű művelésére. Ezáltal a példaképként szolgálhat a kar többi oktatójának, s ezzel segíti a fennálló leggyakrabban a tudományt középpontba állító - normarendszer megerősödését. A magas szintü tudomány ugyanis automatikusan együtt jár a magas szintü oktatással és a magas szintű szolgáltatással, mert ezek alapját is a tudomány jelenti (itt köszön vissza a humboldti alapelv, az oktatás és kutatás egysége). 
„Na most ha valaki jó a tudományban és igényes, akkor az oktatásba ez ugyanúgy átvetítődik. Tehát nem kell azzal a résszel szerintem nagyon erősen foglalkozni, csak akkor, ha baj van, de szerencsére nincsenek bajok." (D6)

„....nyilván az emberben az is benne van, hogy a saját értékrendjét érvényesítse. Én erősen tudománymotivált ember vagyok, tehát az én értékrendemben az messze a legmeghatározóbb. Az én megitélésem szerint az egyetem elsősorban egy tudományos és oktató intézet, és az oktatáshoz is azért kell a tudomány, mert megfelelő tudományos teljesítmény nélkül nagyon nehéz elképzelni, hogy ott egyetemi szintü oktatás folyna. Tehát valójában az én értékrendem egyszerüen megfogalmazható." (D27)

Ebből következően e szerepben a dékán feladata elsősorban a tudományos értékrend képviselete és megtestesítése. Ennek eszköze nem a kényszerítés vagy az ösztönző struktúrák kialakítása (például a tudományos teljesítmények előírása révén), hanem olyan támogató kultúra kialakítása, amely segíti az egyének fejlődését, amely segíti a tudomány szeretetének internalizálását. A dékán elsősorban példamutatással, mentorálással vesz részt e folyamatban.

„....szeretem a nyitottságot, az együttmüködést, sose irigykedem, hogy én egyedül szeretnék egy cikken lenni, sőt! Szeretek utolsó szerző lenni. Én azt szeretem, ha elől egy doktorandusz van, aztán egy olyan fiatalabb kollega, aki segített neki, és a legvégén vagyok én, aki hátulról noszogatom öket a kutatásra. De szeretem azt, hogyha egy cikket megírunk, a végső verzió mindig az én tollam nyomát viseli, tehát én azért még a vesszőket is ki szoktam javítani benne. Tehát nem arról van szó, hogy odaírják a nevemet. Nem engedem, hogy olyan kimenjen, amivel nem értek egyet, mondjuk 95\%-ban vagy 98\%-ban. Ezzel persze nagyon sok idő elmegy, és itt a nagy konfliktus, de úgy érzem, hogy példát kell ezzel mutatni, és mindig mondom, hogy ti is csináljátok ezt, ti is alakítsatok ki ilyen kis iskolákat, és van, ahol ez megy is. Most már több tanszéken müködik: doktoranduszokat összehívják, szemináriumokat tartanak közösen, elkezdenek cikkeket gyártani, közös kutatásokat, tehát végül is elég jól müködik ez a modell." (D14)

Nincs szó tehát beavatkozó, az elvárt magatartást kikényszerítő dékáni müködésről. $A$ dékánnak nincs igénye a közvetlen kontrollra, a teljesítménykényszert maga az internalizált kultúra és az azt képviselő közösség gyakorolja, és nem a dékán által felállított és müködtetett kari vezetési rendszerek (például teljesítményértékelés, büntető/szankcionáló rendszerek müködtetése).

„Decentralizáljuk a pénzeket, és nagyon fontos, hogy a dékán nem szól bele az adott intézetek tudományos teljesítményébe, vezetésébe. Ő csak megjegyzéseket tesz rá, hogyha kevés, vagy ilyesmi, de nem szól bele direktbe." (D6)

A beavatkozás-mentesség valójában persze csak ideál, amely legtisztábban ott érvényesülhet, ahol már kialakult a tudományos teljesítmények fontosságával kapcsolatos konszenzus. Ahol viszont ez hiányzik, ott a dékánnak szükségszerüen közösségformáló szerepet is vállalnia kell, ami a szervezetfejlesztői szerep irányába is tolhatja a dékán szerepét (lásd később a katalizátor dékánt, illetve az innováció kultúrafüggőségére vonatkozó részt). Az e szerepfelfogás mögött meghúzódó uralkodó szervezeti narratíva alapfeltevése tehát, hogy tagok hasonló értékrendje a kívánatos. Az interjúkban jellemzően a tudomány fontossága, szeretete, és az ez iránti elhivatottság jelent meg az értékrend általános tartalmaként, de úgy vélem, bármilyen más elem is alapértékké válhat a közösségben (például az oktatás fontossága). A lényeg az a 
feltételezés, amely ezen értékeket olyan internalizált értékeknek tekinti, amely a tagokat belsőleg teszi motiválttá. 99

A közös értékrend lehetővé teszi, hogy a karon általános meggyőződés alakuljon ki a teljesítmény mibenlétét, tartalmát illetően, így például arról, hogy mi számít teljesítménynek. $\mathrm{E}$ tekintetben egyrészt a keményebb tudományterületek képviselői vannak könnyebb helyzetben, másrészt pedig a hosszabb tudományos és szakmai múlttal rendelkező karok. Talán nem véletlen, hogy az interjúk során főként a szűkebb profilú, inkább a keményebb tudományterületeket művelő egyetemi karokról kerültek ki azok a dékánok, akik a hős szerepfelfogással rokon gondolkodást mutattak. A másik jellemző csoportot azon főiskolák jelentették, ahol a dékánok - hatáskörök hiányában - eleve inkább a tudományosság erősítésére helyezték a hangsúlyt.

A teljesítmény mibenlétét illető konszenzusnak három fonos következményét érdemes kiemelni: az irányítás konszenzusosságát, a szerveztet meritokratikusságát és a tekintély, szenioritás szerepét.

A konszenzusra épülő irányítás (vagy annak vágya) sok interjúban visszatérő elem:

\begin{abstract}
„Még egy fontos dolog, ez lehet, hogy itt számít. Én azt [gondolom] - és sajnálatosan szerintem mindenütt így van, de a mi karunkon is jellemző volt -, hogy azt gondolják, hogy az első számú vezetőnek a véleménye az fontos, és mindenkinek azt csak úgy el kell direktbe fogadnia. De én ezt nem akarom. Tehát én kifejezetten kérem a többieket, hogy tessék szíves lenni kritizálni azt a dolgot, mert nem szeretném azt, hogy énnekem elhangzik a véleményem, és akkor utána csak a folyosón hallok valamit, hogy ezt mégse így kellene. Direktbe szeretem hallani, és egyáltalán nem bánom, hogyha valaki ellent mer mondani, sőt, azt úgy szeretem, hogyha a vélemény, gyakorlatilag a közös vélemény, az egy vitán, vita során alakul, és lehet, hogy amit gondolok, nem az a jó. (interjúalany mosolyog) Nem azt mondom, hogy általában nem jó, mert ez nem igaz. De lehet, hogy nem megfelelö. És akkor én azt nem érzékelem presztízsveszteségnek, hogyha itt nekem a véleményemet vissza kell vonni, vagy pedig azt mondani, hogy... Én direktben meg szoktam mondani, hogy ez jobb egyszerüen, és örülök, hogy ez kijött és kész." (D6)
\end{abstract}

A konszenzus-keresés azonban nem általában érvényes, nem mindenkire vonatkozik, hanem csak egy bizonyos körre: a tanszékvezetőkre, professzorokra, vezető oktatókra, a kiemelkedő teljesítményt nyújtókra. A szervezeti narratíva érvényességének feltételezéséből tehát következik a szervezet meritokratikus jellege is. Az alábbi idézet nem csak a dékán szerepfelfogását és annak konszenzusra irunyultságát tükrözi, hanem a konszenzuskeresésben releváns partnereket is:

„De én hetente tartok tanszékvezetőknek, vezető professzoroknak értekezletet, ez minden kedden délután 14.00-től esetenként, a témától függően a végkimerülésig tart. (Nevetés) Ezt úgy kell érteni, hogy kettőkor elkezdjük, és akkor valamikor 19.00-kor fejezzük be. És akkor csak megszakítottuk a polémiákat. llyen módon minden olyan döntés, ami ilyen irányba, például stratégiát, egyebet érint, azt először elözetesen megbeszéljük a vezetőtársakkal. Én a magam

\footnotetext{
99 E tekintetben különösen fontos lenne az oktatók, kutatók, munkatársak kiválasztásának és szocializálásának gyakorlata is. Ezekre nagyon kevés dékán utalt, ezért itt erre a kérdésre nem térek ki. A feltételezésem ugyanakkor az, hogy a felsőoktatásban az oktatói utánpótlás képzésének és kiválasztásának van egy meglehetősen széles körben bevett és elfogadott gyakorlata (a doktori képzés), amelynek érvényessége magától értetődő, és a dékánok ezt magától értetődőnek tekintik.
} 
részéröl maximálisan a konszenzusos elörehaladásnak híve vagyok. Tehát addig próbálom vinni az ügyeket, amíg a konszenzus, ha fogcsikorgatva is, de elő nem áll. Nagyon ritka az az eset, mikor többségi elv alapján döntünk, mert aki ellenszegül valamilyen ötletnek, annak mindig komoly érvei vannak." (D15)

Az uralkodó teljesítményértelmezés mentén elosztott pozíciók biztosítják az adott teljesítményértelmezés intézményesülését, illetve annak reprodukcióját is, aminek ugyanakkor könnyen lehetnek áthallásai a dékán taktikus, politikus szerepfelfogásával is. A teljesítményre hivatkozva ugyanis a fennálló hatalmi-uralmi status quo is átalakitható, illetve konzerválható.

$\mathrm{K}$ : „Mi kell ahhoz, hogy jó dékán legyen valaki?

V: (...) Megtalálni az emberek között azt a személyes kontaktust és azt a konszenzust, hogy a dolgok egyértelmüen elöre menjenek. (...) Ennek az eszköze végül is azt hiszem az, hogy azok a professzorok, akik meghatározó húzó erők egy karon - márpedig minden karon van szerintem egy hat-nyolc-tíz ilyen - azokat mindenképpen helyzetbe kell hozni. Tehát dékánhelyettesnek, bizottsági elnöknek, hiszen ők azok, akik igazából egyébként is ettöl függetlenül [is húznak]... És velük kell állandó kapcsolatba lenni, és többnyire ezekkel az egyetemen lévő hasonló gondolkodású professzorokkal eléggé hasonló azért a világképe az embernek. Tehát én nem nagyon éreztem azt, hogy »hú, mennyire másként gondolkodna». Nyilván vannak eltérések, nüanszbeli különbségek. De a fö értékrendben azonos, és azért ez már megadja, hogy a dolog az egy felé menjen. Tehát hogy a hajót egy felé kormányozzuk." (D27)

Az utóbbi két idézet azt is tükrözi, hogy a dékán gondolkodási keretét alapvetően a kar (és nem az egyetem), legfontosabb partnereit pedig a kar domináns belső szereplői jelentik. $A$ dékánok többsége vagy nem is említette az egyetemi vezetést (a kar és a dékán tehát autonóm szereplö), vagy pedig mint a dékáni cselekvés korlátozója jelent meg (gyakran a főiskolai eredetű karokon). Ebből adódóan e narratívában - legalábbis az interjúk alapján - a dékánok nem egyetemi középvezetőként, hanem a kar első számú vezetőjeként értelmezik magukat,

A meritokratikusság magára a dékánra is vonatkozik, hiszen őt is a saját tudományos (vagy egyéb, általánosan elfogadott) teljesitménye jogosítja fel a pozíció betöltésére. A dékáni tekintély legfontosabb forrása a dékán kiválósága (az e részben idézett dékánok mindegyike meghatározó szereplője a saját szakterületének).

„...és itt fontos a kor. Nagy tekintély kell, hogy legyen. Most ez hülyén hangzik, hogy én azt mondom magamról, hogy nagy tekintélyü vagyok. Azt gondolom, hogy igen egyébként, tudományos szempontból nem én vagyok az első akadémikusa a karnak. Tehát nyilvánvaló, hogy az általam vezetett intézet a legjobb, hát akárhogy is van, akármilyen mérőszám alapján, biztos, hogy a legjobb intézet. Tehát ez eleve megalapozza, hogyha én valamit mondok, akkor azért annak, annak egy picit nagyobb súlya van... (D6)

Az a tény ugyanakkor, hogy a dékáni pozíció ilyen erősen kötődik a szakmai teljesítményhez, azt is eredményezheti, hogy az oktatás és kutatás a dékáni időszak alatt is szerves része marad a dékán tevékenységeinek (lásd a fejezet nyitó idézetét). Ez nemcsak a példamutatás miatt fontos, hanem demonstrálható vele a tudomány (vagy az uralkodó teljesitménykritériumok) fontossága is, és fenntartható a dékáni autoritás alapjául szolgáló teljesitmény, szakértelem is.

E megközelítés további következménye, hogy a dékánság a szakmai karrier szerves részévé válik. A dékáni pozícióból fakadó tekintélyt kezdetben bizonyára a dékáni pozíciót 
betöltők szakmai teljesítménye adta. Ez a viszony idővel azonban meg is fordulhat, azaz a dékáni pozíció önmagában is presztízshordozóvá válik, amely a pozíció betöltőjét ruházza fel magasabb tekintéllyel. Ennélfogva a hosszabb tudományos és szakmai múlttal rendelkező (tradícionális) karokon a dékáni pozíció könnyen válhat a szakmai karrier szerves részévé, amely viselőjét megkülönbözteti (kiemeli) a hasonló státuszú oktatók közül. (Az érintett karokon többnyire verseny volt a pozícióért.)

A teljesítmény konszenzusossága nem csak meritokratikussá teszi a szervezetet, hanem felértékeli a szenioritás szerepét is. Nemcsak azért, mert egy idősebb oktató tudományos összteljesítménye (és így tekintélye) valószínüleg nagyobb, mint egy fiatalabbé, hanem azért is, mert a mentorálással, konszenzusépitéssel járó feladatok egyfelöl bölcsességet, érzékenységet kívánnak, másfelöl könnyebben elláthatóak a szakmai pályafutás vége felé, amikor már kisebb a bizonyítási és teljesítménykényszer.

„A kor tapasztaltabbá és bölcsebbé tesz. És nyugodtabbá, megfontoltabbá. Ez szerintem nagyon fontos. Ma egy jó vezetőnek ezek fontos ismérvei. Egy fiatalember lehet, hogy sokkal dinamikusabb és valószínű, hogy ugyanolyan szellemi képességek birtokában van, itt nem erröl van szó. Úgy gondolom, hogy egy oktatási intézménynek a vezetése nyugodtságot is kíván, különösen a mai világban, amikor látjuk ezeket a kapkodó, kapkodva történő intézkedéseket. A fiatal politikusaink, akik azt gondolják, hogy ők értik a rendszert, hát nem értik sajnálatosan a rendszert, vagy legalábbis nagyon sok közülük nem érti. De megpróbál beleavatkozni, ezzel többet ártanak általában, mint használnak." (D6)

Milyen következtetéseket, tanulságokat vonhatunk le a kutatás eredményeiből a korábban felvázolt hős szerepértelmezésre vonatkozóan? Úgy vélem, hogy a szakirodalom és a tapasztalat alapján megrajzolt szerep között nincsen éles különbség. Érdemes azonban felhívni a figyelmet arra, hogy a tudományos tekintély és a szenioritás hangsúlyozása összhangban van a dékánok kiválasztására vonatkozó magyar szabályozási rendszerrel, amely - mint láthattuk alapvetően az idősebb, pályájuk második felében járó oktatók dékánná válását támogatja. Azaz az intézményrendszerbe mintha kimondva-kimondatlanul ez a dékáni szerepfelfogás lenne kódolva. Ennek fényében ugyanakkor némileg meglepő, hogy az interjúk során csak elvétve találkoztam olyanokkal, akik e dékáni szerephez hasonló felfogást vallottak volna, de tiszta formájában nem is igen jelent meg az interjúk során, sokkal inkább más szerepfelfogásokat kiegészítve vagy azokkal kombinálódva (lásd később a koordinátor és a szervezetfejlesztő másodlagos szerepértelmezéseket).

Sokkal gyakoribb volt az, hogy a hős szerepe olyan kontrasztként jelent meg, amelynek tükrében próbálták meg az interjúalanyok jellemezni a megváltozott körülményeket, a helyzetük, szerepfelfogásuk sajátosságait. $A$ hős szerep relatív ritka előfordulását ezért a felsőoktatás átalakulásának korábban felvázolt tendenciáinak lehet tulajdonítani.

„...[a dékánság] régen - én azt gondolom - egy óriási presztízs volt. Ez csökkent, szinte biztos, hogy csökkent. Ez nekem nem is esik jól. Tehát én úgy jobban tudnék örülni a szerepemnek is, ha ez... De nem baj, majd ezért küzdök, hogy ez még mindig olyan legyen, mint a presztízs. (mindketten nevetnek) (kis szünet) Meg ahogy ezt azonositották régen, hogy ez egy tudományos és szellemi tekintély is akár, vagy ez kellett, hogy legyen. Ma gyakran ugye van, hogy visszakérdeznek és tényleg volt egész konkrétan énnekem is jó barátom szinte, hogy ez neked kellett? (D8) 
„Tehát nekem van [olyan] régi tanárom, aki azt mondta, hogy hát egy dékán menjen be 10-kor, 11-ig írjon alá, aztán menjen, csináljon tudományt. Ami teljesen jogos történet, de nem egy vidéki föiskolán." (D17)

„Úgyhogy ha valaki ezt nem veszi tudomásul vezetőként, és megpróbál ilyen régi, professzor uras stílusban, az, az egy kudarc. Tehát vagy a munkatársak szenvedik meg, mert kénytelenek megcsinálni helyette, ami vezetői feladat lenne, vagy pedig az egész nem fog menni. Tehát ez az első. Tehát ha valaki nem veszi tudomásul, hogy változik a világ." (D20)

„Tehát én nem hiszek abban, hogyha valaki jól akarja végezni ezt a fajta dékáni vagy rektori munkáját, akkor azt meg lehet úgy csinálni, hogy bejövök 8 órakor, gyorsan aláírok egy kicsit, megkérdezem, hogy van-e valami és negyed tízkor lent vagyok a tanszékemen és oldom a tanszéki feladataimat. Nem. Nekem reggel 8 órától este 5-ig, 6-ig minden alkalommal - azt kell mondjam, hogy - abszolút mértékben el vagyok foglalva." (D7)

Az új körülmények más szerepfelfogásokat tesznek szükségessé. A következőkben az interjúk alapján kibontakozó másféle szerepeket mutatom be.

\subsubsection{A szolgáltató}

A szakirodalom alapján megfogalmazott modellben a szolgáltató dékán szerepe a bürokratikus egyetem szervezeti narratívájában fogalmazódik meg, amelyben a kari célok sok szereplő közötti egyeztetési folyamatokban alakulnak ki, de ezek megvalósitása már szigorúan felügyelt és fókuszált folyamat. Ez a megközelítés sok dékán kiindulópontja:

„Én azt szoktam mondani itt a kollegáimnak, hogy a demokrácia odáig tart, ameddig a döntést meghozzuk, utána viszont azt kőkeményen végre kell hajtani, tehát onnantól nincsenek egyéni érdekek, egyéni vélemények. Hogyha elhatároztuk, hogy valamit végrehajtunk, akkor mindenki azért kell dolgozzon. És onnantól már ne jöjjön, hogy neki miért nem jó, meg hogy hogyan lenne jó. Ha benne volt a véleményalkotásban, benne volt a döntésben, akár a kari tanács szintjén is, vagy vezetői ülések szintjén is, ne akarjon kihúzni már onnantól. Ott volt, odáig volt lehetősége beleszólni, formálni a véleményt." (D1)

"Tehát én azt szoktam mondani, hogy én nagyon kompromisszumkész vagyok, de a kompromisszumom az leginkább a diplomáciai kompromisszumot, tárgyalási kompromisszumot jelenti, és amikor én kezdtem, én csináltam egy, nem tudom 40-50 oldalas elöadmányt. Összehívtam az összes professzor tanszékvezetőt, és azt mondtam, hogy ami rossz húzzuk ki, ami hiányzik, tegyük be, ami jónak ítéltetik, marad, ez lesz az, amit akkor ugye 3 évre terveztem. A következő 3 évben, ilyen tempírozással fogom megcsinálni. De a végrehajtásra nem fogok bizottságokat felkérni, én fogom csinálni, vagy valaki más, hogyha odateszem." (D24)

E kiindulópont látszólag csak a közösen meghozott döntések végrehajtását és a felmerült problémák megoldását teszi a dékán feladatává. Valójában azonban ennél jóval többről van szó, hiszen a dékán feladata a közös döntések kialakulását segítő fórumok, egyeztetési folyamatok koordinálása, valamint általánosságban az oktatói-kutatói müködés (adminisztratív) feltételrendszerének megteremtése is. $E$ feladatok többsége persze nagyrészt operatív természetü, és a dékánok jellemzően a technikai vonatkozásokra koncentrálnak. A stratégiai döntések és a kérdések szakmai vonatkozásai továbbra is az oktatók kezében maradnak. További lényeges jellemző, hogy a dékán által végzett oktatás és kutatás a dékáni feladatok ellátása szempontjából indiferens. 
„Ebbe tisztán elmélyült tudományos elem egy sincsen, hanem ez mind olyan hétköznapi feladat, ami azért különleges, mert az egyetemi szféra önmagában különleges." (D23)

"(...) nem gondolom, hogy egy dékánnak, szakmai területekbe nagyon bele kellene mennie. Onneki alapvetően az a dolga, hogy müködtesse ezt egy egészként. Es egyfelé vigye a dolgot." (D28)

„Tehát nyilván ebből adódik, hogy generálni kell a folyamatokat, hogy valamit neki kell megcsinálni, mert nyilván neki kell megcsinálni, de nem az a küldetése, hogy ő találja ki. Tehát például nálunk óriási viták voltak ebböl, hogy én azt mondtam, hogy nekem nem az a küldetésem, hogy én kitaláljam, hogy milyen képzést csináltok. Ezt a tanszéknek kell kitalálnia. Most az, hogyha ahhoz a képzéshez még kell ember, mert ugye nem tudjuk megcsinálni, akkor az valóban az én dolgom, hogy legyen meg az állás hozzá, meg nem tudom én, gyakorló termet csináltunk, tehát ugye mert itt ez egy nagyon gyakorlatigényes képzés." (D21)

A szerepfelfogás egyik feszültségét persze épp az jelenti, hogy nem mindig lehetséges a szakmai és adminisztratív feladatok szétválasztása, a technikai és szakmai döntések megkülönböztetése. Például az előterjesztések megfogalmazásával, az ügyek tárgyalási sorrendjének meghatározásával a döntések is befolyásolhatóak (erre még később visszatérek). Egy dékán például - az előzőekhez hasonlóan - alapvetően adminisztratív vezetőként definiálta a szerepét, ugyanakkor megfogalmazta ennek dilemmáját is:

„[A dékáni szerep] adminisztratív, mert van egy csomó adminisztratív feladatunk. Na de az adminisztratív feladatok közül gyakorlatilag, hogy ha azt mondom, hogy feladatom a képzésfejlesztés, akkor azt már nem tudom eldönteni, hogy adminisztratív feladat, vagy pedig tudományos. Összemosódik." (D30)

E dilemmák miatt a szerepet nem elsősorban az ellátandó feladatok természetével, hanem a dékáni szerep céljával határozható meg. A szolgáltató dékánok esetében az alapvető feladat nem más, mint a bizonytalanság csökkentése és az alkotáshoz, tanításhoz szükséges stabil környezet kialakítása.

„Ez egy olyan ars poetica, hogy tanár vagyok, iskolát akarok csinálni és az elsődleges törekvés az, hogy egyfelöl a hallgatók számára egy kiszámítható, müködőképes környezetet, biztonságot sugárzó, rendezettséget sugárzó, szervezettséget sugárzó környezetet teremtsek. Másfelöl pedig a kollégáimnak biztosítsam azt, hogy érezzék, hogy egy stabil, állandó elgondolások [vannak], hogy az állandóság nem csak abban van, hogy a mai nap. Hanem hogy ha lépünk, mert hát müködünk elöre, hogy abban is valamilyen, valamilyen nem ötletszerüség, hanem valamilyen megtervezett, látható, valamilyen programszerüség van, amit ki tudnak számítani, amiben nem kell váratlan dolgokra, nem kell nagy átütésekre, nagy robbanásokra számítani." (D12)

„És azt gondolom, hogy az egyetem, az nem az a fajta szisztéma, amit folyamatosan mozgatni kell és a szabályokat folyamatosan változtatni kell. Igazából a komoly, jó egyetemeken a kiszámíthatóság a jellemző. És ezt én nagyon fontosnak tartom, és én itt az intézkedéseimben, a cselekedeteimben ezt próbáltam sugallni. A hosszú távú kiszámíthatóságot." (D6)

Ennek eszközei azonban nagyon sokfélék lehetnek, amelyek mentén az interjúkból különböző másodlagos szerepek bontakoznak ki. A bizonytalanság csökkenthető

- a döntéshozás átláthatóságának biztosításával (koordinátor), 
- a kiszámíthatóság növelésével, ami nem csak a dékán kiszámítható magatartását takarja, hanem a kari rendszerek és folyamatok következetes müködtetését (tulajdonosi szerep),

- valamint a bizonytalanság elnyelésével, azaz a problémák megoldásának lehetőség szerinti átvállalásával (problémamegoldó/puffer szerep),

- vagy ezek valamilyen kombinációjával.

A koordinátor szerep kiindulópontját jellemzően az egyetem vagy a kar sajátosságai, azaz a jól megragadható szervezeti narratívák jelentik:

„(...) a belső szociológiai összetétele egy egyetemi karnak nem hasonlítható össze csak egy közeggel, ez a színház. Tehát ez nagyon érzékeny, értelmes, önbecsülési deficitben nem szenvedő, hogy így mondjam, és sikerre vágyó. A jó szó, mondjuk azt, hogy önmutogató. Talán ez nem azt fejezi ki, amire gondolok, hanem inkább egy jó értelemben vett szereplési vágyat. És ehhez szorosan kapcsolódik egyébként a habitust érintően az érzékenységnek a kérdése. Tehát ugye ebből az következik, hogy utasitásokkal és ukázokkal és egyebekkel kevésbé lehet célt elérni, mint ösztönzésekkel, illetöleg a siker lehetőségének a biztositásával. És adott esetben a sikernek megfelelő publicitásával lehet ezeket inkább elérni." (D23)

„(...) egy egyetem az nem úgy épül fel, hogy vannak a téglatestek, vagy a kockák, vagy valamik és akkor ebböl a szabályos kockákból, téglalap, téglatestekböl építek valamit fel, hanem inkább olyan egy egyetemnek a struktúrája, mint egy puzzle. Tehát ahol minden egyes elem különbözik a másiktól, de hogyha ezeket összetesszük, akkor ez egy képet nyújt kifelé." (D23)

„Ez nem egy részvénytársaság, ez nem egy vállalat, ez nem egy bank, ahol a föosztályvezetönek, mindig igaza van az osztályvezetővel szemben, és hajtsd végre. Hát ez van, szigorú, az egy mandarin rendszer, így kell haladni. Az egyetemen, vagy egy karon belül is gyakorlatilag annyi kicsi kft van, ahány professzor. Az mind külön kicsi világ, és a saját világát akarja megvalósítani. Na most a müvészet szerintem észrevenni, hogy ezek a kicsi világok hogy kapcsolódnak egymáshoz. És úgy megtalálni a fő csapás irányát, hogy saját maga is rá tudja akasztani a saját maga kicsi világát. És hogyha az azért nem teljesen harmonizál azzal, amit én szeretnék, azt úgy kell odavinni, és addig kell elvinni, amíg magától akasztja rá. Tehát eröszakkal hiába teszed, kötöd hozzá, a végletekig fog harcolni azért, hogy eloldja a kötést. És meg fogja csinálni. Mert egy professzor, egy tanszékvezető, az különállóskodik itt. Hát nem arról van szó, hogy az autóba ugyancsak be kell tenni a kereket, mert ha én nem teszem be, hiányozni fog a negyedik. Mindenki saját autót gyárt. Az egyik tanszéken, meg a saját munkájában is." (D24)

„(...) meglehetősen racionálisan gondolkozó emberek gyülekezete, és meg lehet azt tenni, hogy megállapodunk valamiben, és annak mentén haladunk. És hát azt gondolom, hogy akkor lehet igazán elöre haladni, ez ilyen vektor összeadás, meg vektor müvelet, hogyha ellenkező irányba húzunk, akkor nem tudunk annyira elöre haladni, és össze lehet hangolni annyira az állásfoglalásokat, hogy egy irányba húzzunk." (D11)

Mindegyik idézet a kar és az intézmény célstruktúrájának összetettségéröl, a szereplők szándékainak sokszínűségéről és sajátos habitusáról szól. Gondolatban ki lehet egészíteni ezeket a képeket: ha az oktatók jelentik a puzzle darabkáit, akkor a dékán az, aki képes megtalálni azt a képet, amibe illeszkedhetnek. Ha az oktatók különböző irányokba mutató vektorok, akkor a dékán feladata annak az eredőnek a megtalálása, amely leginkább egybeesik a vektorok által kijelölt iránnyal. Ha a kar egyedi kft-k összessége, akkor a dékán az a projektvezető, akinek meg kell találnia azt a projektet, amiben a lehető legtöbben részt tudnak 
venni. Ha a kar egy színház, akkor az az igazgató, aki kitalálja azt a repertoárt, amelyben a színészek leginkább csillogni tudnak, de egyben biztosítja is a színjátszáshoz (a siker biztosításához) szükséges feltételeket is.

Noha egyik-másik metaforában benne rejlik annak lehetősége, hogy a dékán a külső megfelelés kényszerét is hangsúlyozza (pl. nem csak müvészileg magas színvonalú darabokat kell játszani, hanem a pénztáraknál sikeresnek bizonyuló darabokat is), a metaforák mégis azt erősítik, hogy a dékán feladata a meglévő oktatókhoz, kutatókhoz, kompetenciákhoz illeszkedő célok megtalálása. Ezzel nem csak azt sugallják, hogy a célok belülről definiálódnak, hanem azt is, hogy nem a dékán feladata az oktatói állomány, a kari kompetenciakészlet kialakítása. (Az e szerephez kapcsolható dékánok elvétve beszélnek csak például elbocsátásokról vagy az ezekből fakadó konfliktusokról.) Nem arról van tehát szó, hogy hogyan lehet a környezethez jól illeszkedő szervezetet kialakítani, hanem arról, hogy a fennálló feltételekböl hogyan lehet kihozni a legjobbat. $A$ dékán szerepe tehát inkább hatékonysági és nem eredményességi kérdésként fogalmazódik meg.

Az idézetekből jól kibontakozik a koordinátori szerep lényege is: a kar harmonikus működésének elősegítése azáltal, hogy a dékán törekszik mindenkinek megtalálni a helyét a karon. Olyan tevékenységek, célok kialakulását segíti, amelyet mindenki el tud fogadni, és ezzel egyben csökkenthető az alapvető konfliktusok kialakulásának esélye is. Az egyeztetési folyamatokban a dékán tehát elsősorban mediátorként, érdekegyeztetőként működik közre, aki igyekszik a különböző érdekű felek számára kölcsönösen elfogadható javaslatokat tenni. A stratégiai döntés ugyanis a kari és egyetemi képviselők, valamint a karon meghatározó emberek kezében van. Mindez azt igényli, hogy a dékán képes legyen bölcs kompromisszumok kialakítására, rendelkezzen tárgyalási készséggel és megfelelő érzékenységgel.

\begin{abstract}
„Akár óvodai csoportot vezetni, akár Parlamentet vezet az illető, kicsit úgy kell, hogy összerakják, hogy legyen érzéke. Szeme, hogy lássa meg, és legyen füle a hallásra. Az elhallgatott mondatot meghallására is. Tehát az rengeteget jelent, [hogy] körülbelül sejted, hogy az illető merre akar menni. És ezeket meg kell előzni leginkább. Vagy ha nem megy, akkor lehetöleg olybá tompítani, hogy tényleg ne okozzon egy föloldhatatlan ellentmondást. Volt ilyen, de szerintem bölcsességgel oldhatók meg ezek a dolgok. Néha úgy tűnik persze itt, hogy »ohh, ezt most el lehetne dönteni« és nem döntjük el, majd csak a jövő héten. Igen, igen, eldöntöm én most, de akkor egyvalakit leszorítok a szekérröl. Így van? Hát jobb akkor egy héttel később eldönteni úgy, hogy azt mondja, hogy hát igen, igen, igen, jobb lett volna, ha egy sorral elörébb tudok jutni a szekéren, de azt mondták, hogy maradjak a helyemen, vagy éppen egy sorral hátrébb ültettek, de a szekéren vagyok. És nekem is sokat mond, ha tudom, hogy ő még mindig a szekéren marad, minthogyha kilöktük volna, és ő kivülröl kezdené a farönköt lökdösni a kocsikerék alá, hogy álljatok meg. Szóval az nem jó." (D24)
\end{abstract}

A koordinátori szerepfelfogás jól összehangolható a hős szerepfelfogással. A közös pont, hogy a dékán itt is, ott is a rosszul strukturált célkijelölési és döntési folyamat „levezetőjeként” jelenik meg, és a dékán mindkét megközelítésben inkább reaktív szerepet játszik, azaz a dékán inkább a közösségi akarat végrehajtója semmint annak formálója. Különbség azonban, hogy míg a hős esetében inkább az informális egyeztetések és formális bizottságok (konszenzusos vagy kompromisszumos) elnöklésére, levezetésére esik a hangsúly, addig koordinátorként a testületi ülések megfelelő előkészitése és hatékony lebonyolítása a feladat. Jól összehasonlítható ez az alábbi idézeteken: 
„De én hetente tartok tanszékvezetőknek, vezető professzoroknak értekezletet, ez minden kedden délután 14.00-töl esetenként, a témától függően a végkimerülésig tart. (Nevetés) Ezt úgy kell érteni, hogy kettőkor elkezdjük, és akkor valamikor 19.00-kor fejezzük be. És akkor csak megszakítottuk a polémiákat. llyen módon minden olyan döntés, ami ilyen irányba, például stratégiát, egyebet érint, azt először előzetesen megbeszéljük a vezetőtársakkal. Én a magam részéröl maximálisan a konszenzusos elörehaladásnak híve vagyok. Tehát addig próbálom vinni az ügyeket, amíg a konszenzus, ha fogcsikorgatva is, de elö nem áll. Nagyon ritka az az eset, mikor többségi elv alapján döntünk, mert aki ellenszegül valamilyen ötletnek, annak mindig komoly érvei vannak." (D15)

„Amikor a kari titkárságra beküldik az anyagot, akkor ugye kialakítottuk a karon belül, hogy milyen anyagokat ki néz meg. Tehát ha pl. tantervvel kapcsolatos dolog van, akkor van a tanács mellett müködő tantervfejlesztési bizottság, akik először megnézik az anyagot. Ők ugye szakmai szempontból megmondják azt, hogy mi lehetséges, mi nem, ez miért jó, miért nem jó és így tovább, de én magam is mindig megnéztem ezeket az anyagokat, és mindig konzultáltam is ezekkel a tanterv fejlesztő bizottságokkal. [...] És akkor bármiféle ilyen anyag jött, tehát soha nem megy úgy kari tanács elé dolog, hogy mondjuk én magam nem [láttam]. Ha eleve nem tartom jónak, vagy nagyon sok olyan van, hogy úgy adnak be dolgot, ami eleve törvénysértő lenne. Mert nem ismerik a törvényt, a föiskola szabályzatait se, és így tovább. [...] De úgy gondolom, hogy ha ezt rászánja az ember az előkészítésre, akkor amikor kari tanács elé visszük a dolgot, akkor viszont már simán mennek a dolgok és akkor nem kell különösebben ötször visszavinni anyagokat és így tovább." (D28)

A koordinátor mellett a szolgáltató dékán egy másik jellemző megjelenési formája a problémamegoldó. E szerepfelfogással föként a decentralizált intézményekben, illetve a kelletlen dékánok körében találkoztam (akik nem a dékánság pozitívumait, hanem inkább a vele járó kellemetlenségeket, kényszereket hangsúlyozták). A problémamegoldó dékán szemléletmódját jól jellemzi az a példa, amelyben az egyik interjúalany az intézményi szinten bevezetett oktatói teljesítményértékelés kapcsán így beszél:

„»Nem szeretem« feladatok például - ez a többi intézményben is így van - az oktatói pontozás. Mert az előző tanévet le kellett volna pontozni, most, most szóltam, két hónap késéssel. Jó, hát nem nekem kell pontozni, de ugye az dékáni feladat, hogy erre fölhívja a figyelmet, meg hogy ugye ez olyan nem szeretem dolog épp úgy, mint a minőség biztosításnak bizonyos részei is. És akkor van, amiröl megfeledkezik az ember. (...) Ennél fontosabb aktuális feladatok voltak és akkor persze, hogy elfelejtődött az egész." (D29)

Egy másik példa a hároméves fenntartói megállapodások indikátor-jelentéseihez kapcsolódik:

„Hát megint ugye jött, hogy most minden ilyen úgynevezett interjú monitoringban, ugye nem tudom decemberben, most megint minden indikátort nézzünk végig. Mert a végső az január végén vagy február elején lesz. Megnéztük, de minek? Tehát ahhoz, hogy megnézzük azt a szerencsétlen 14 vagy 15 indikátort, ami nálunk van, hihetetlen apparátust kell mozgatni. Ugye mert a különböző szervezeti egységektöl teljes részlétes kimutatás[t kell kérni]. Na most ez nem hiányzik az embernek, amikor tudja, hogy teljesen értelmetlen. Szóval ez abszolút nem fair. (...) Nem mer senki rácsapni [az asztalra], hanem mindenki megjátssza a hülyét, és mindenki ugye ezeket kitölti, és nem tudom micsoda. De mondom hihetetlen apparátus [kell], és rengeteg időt vesz el." (D10)

Mindkét interjúalany a kitüzött célok helyett feladatokról, problémákról, és azok megoldásáról beszél. Az első esetben a dékán feladatként nem a teljesítményértékelést és a visszajelzések megfogalmazását látja, hanem azt, hogy felhívja a figyelmet a lapok kitöltésére. A 
második interjúrészlet ehhez hasonló módon az indikátorok nyomon követését a (formális) megfelelés biztosítása érdekében végzi, és nem azért, hogy például értékelni, fejleszteni vagy priorizálni tudjon. Itt külön érdemes kiemelni, hogy az indikátorokat az intézmény a fenntartói szerződések megkötésekor maga választotta ki, és a célértékeit is maga jelölte meg a fejlődés évenkénti nyomonkövethetösége érdekében. Ennek ellenére a fenti idézetben a dékán a nyomonkövetést a finanszírozás elmaradása miatt nemcsak hogy értelmetlennek mutatta be, hanem az adatok begyüjtését rendkívül nehéznek is találta.

Ami tehát szembetünő, hogy azok az eszközök, amelyek irányitási és a teljesítményt kontrolláló eszközök is lehetnének (például egy stratégiai játékos dékán kezében), itt pusztán a fentről jövő bürokratikus rendszernek való megfelelésre korlátozódnak, amelynek az értelme sem igen látszik. Ez persze számos frusztrációnak is a forrásává válik.

A két eset interpretációja a dékán problémamegoldó szerepfelfogásaként is általánositható. $E$ szerepben a dékán legfontosabb teendője a karon belülről és kívülről érkező feladatok végrehajtásának (a kari oktatók szempontjából) minél fájdalommentesebb megszervezése, valamint a működés során felmerülő problémák megoldása. Az egyik dékán interpretációjában ez a puffer szerep, aki a különböző irányból érkező megkereséseket nem másra hárítja, nem kitér elöle, hanem elnyeli, megoldja:

„Hát a number one nehézség, az a puffer szerep. Ugye végül is egy dékánt azt alulról, fölülröl, elölröl, hátulról mindenhonnan (interjúalany nevet) ütik. És hát végül is vagy az van, hogy az ember ezeket az ütéseket elvállalja, vagy a másik taktika az, [hogy] egész egyszerüen így kibújik alóla, mint, mint egy... Ugye? Tehát ez a két fajta izé van. Na most én nem vagyok kibújós. Tehát akkor, ha már itt vagyok, akkor inkább vállalom. Na most hát ezt azért egy idő után az ember utálja. Hogyha pofozzák jobbról-balról, alulról, fölülröl." (D10)

A puffer szerep egyik oka - és a problémamegoldó dékánok egyik alapvető élménye -, hogy végső soron a karok az alaptevékenység megvalósítói, és így minden reform, adatkérés, vizsgálat végrehajtása rájuk hárul, még akkor is, ha a megkeresés formálisan az intézményi vezetéshez érkezik. Az ugyanis az ilyen esetekben többnyire csak postás, legfeljebb a karokról visszaérkező javaslatok összegzésében vesz részt.

„....de nekem azt, amit legfölsőbb szinten hoznak, majd egy szinttel lejjebb kerül ugye a rektori szintre, nekem ezt aprópénzre kell váltani. Nekem meg kell oldanom, hogy müködőképes legyen és elöre is menjen. És emberekkel kell dolgoznom, és azt kell mondanom, hogy nem kapsz kerkieg-et azért a munkáért, hogy... Tehát ezek konfliktushelyzetek és én vagyok a sor végén." (D30)

„És hát sokszor az van, hogy ez így átcsurog [a rektori vezetésen]. És akkor egyszerübb azt mondani, eggyel lejjebb vinni és azt mondani, hogy »te! Csináljátok meg!«. Na most, hát a »csináljátok meg!», az, nagyon sokszor, hogy mondjam, szinte lehetetlen helyzetekbe sodorja az embert, de megoldjuk. (...) És akkor itt van ez a szint, hogy itt, itt muszáj megoldani. Es akkor meg is oldjuk, általában, mondom, meg is oldjuk. (...)Tehát nem szoktam azt mondani, egy feladatra, hogy ezt mi most nem csináljuk meg, mert annyira hülyeség. Megcsináljuk. Tehát ez lehet, hogy az emberben ugye minisztériumi múlt is, tehát egy ilyen bürokráciás múlt is nagyon segit, mert ott sem kérdezgeti az ember, hogy mit miért, hanem azt, hogy mit hogyan. Ugye? Az a lényeg. Tehát arra koncentrálunk, [hogy] megoldjuk. De nagyon sokszor van, amikor a lelkem mélyén tudom, hogy ez vagy hülyeség, vagy értelmetlen, vagy nem értek vele egyet, vagy nem tudom mi, de teljesítjük." (D10) 
Ez egyben a dékán középvezetői szerepét is definiálja, hiszen a dékán e szerepben végrehajtója a kívülről és felülről érkező kéréseknek, és közvetítője az alulról érkező problémák megoldásának.

A másik ok, ami a dékánt könnyen a problémamegoldó szerep irányába nyomja, azoknak a tevékenységeknek a sokfélesége (különösen decentralizáltabb intézményi modellekben), amelyek a karokra kerültek. Mezey Barna, az ELTE-ÁJK korábbi dékánja (jelenleg az ELTE rektora) például a dékán szerepét olyan „univerzális robotként” írta le, akihez

„....hozzá tartoznak a nemzetközi kapcsolatok, a konferenciaszervezések, de a kiadványok gondozása is. [...] Ha az épület akadálymentesítéséröl van szó, vagy ha a tűzoltóság, az ANTSZ ellenőriz bennünket, akkor is engem keresnek." (Sereg [2008] 55.0.).

Ennélfogva a dékánnak igen sokoldalúnak és igen problémaérzékenynek kell lennie, ahogy azt az alábbi idézetek is tükrözik:

„És érteni minél több dologhoz. De a csavarhúzástól kezdve a festésen át a jogi dolgokon át, az adó dolgokon át, pszichológián át, minden." (D29)

„Kell, hogy legyen egy fajta folyamat szemlélete, itt egy picit bocsánat, nem magam miatt mondom, hanem én azt gondolom, hogy nagyon sok mindennél ott tartunk, hogy van egy adott feladat, vagy mondjuk egy probléma. De a problémának minden egyes fázisát azonnal látni kell. Tehát a végéig kell látni. Hogy mi lesz a csattanója a dolognak." (D30)

A problémamegoldó szerepfelfogás többnyire rövid távú, reaktív gondolkodásmóddal jár együtt.

„És nem tudom, mit mondanak a többi dékánok, de egyre több olyan impulzus ér minket, hogy inkább a napi problémákat oldjuk meg, mert szétforgácsolódunk." (D30)

A szereppel sokszor a kiszolgáltatottság érzése jár együtt, hiszen a dékánoknak saját céljaik megvalósítása helyett mások problémáinak megoldásával kell foglalkozniuk. Könnyen előfordulhat, hogy a sikeres problémamegoldó egyre inkább magára húzza az ilyen jellegü feladatokat. Mások azonban épp az egymást követő feladatok megoldásában találnak visszaigazolást és sikerélményt.

„És egyébként ezért a legnehezebb a dékáni pozíció. Ezt azért szeretném mondani, hogy szinte csak a problémák jelennek meg a napi munkánkban. A sikerek, az egy természetes dolog. De a probléma, az mindig itt landol. És természetesen egy szinttel feljebb is. Ezért fáradnak el a felsővezetők, mert probléma, probléma, probléma. Ha egy beszerzés simán megy, akkor nem jut el [hozzá]. Eljut hozzá az indításnál, meg a végén. De ha problémás, akkor minden fázisban itt van nálam." (D30)

„Tehát, énnekem azt szokták mondani, hogy irigyelnek. Mert szóval én úgy vagyok, jön a feladat, akkor feladatot meg kell csinálni, konfliktus van, konfliktust meg kell oldani. És akkor haladunk. Tehát ez ráadásul viszonylag sürü, pillanatnyi sikert jelent, vannak persze rossz napok is, úgyhogy ez. De hát ezt meg kell tanulni tolerálni." (D11)

A koordinátori és a problémamegoldó szerep elsősorban arról szólt, hogy a dékán hogyan segíti elő a közösségi akarat megnyilvánulását és megvalósulását. Egy harmadik féle 
szerepmegközelítés, a tulajdonosi szerep hangsúlya azonban inkább a korábbi döntések, szabályok és kialakult normák következetes érvényesítésére és betartatására esik. $\mathrm{A}$ dékán a közösség nevében és érdekében lép fel, és igyekszik olyan szemléletmódot közvetíteni, hogy mindenki olyan gondossággal kezelje a kari ügyeket, mintha a saját ügyeit kezelné (innen a szerep elnevezése). ${ }^{100}$

„Tehát végül is megmagyarázták, hogy miért kerül annyiba, de én ezt számon kérem, hogy ha a közösség pénzét költöd, akkor miért költesz ennyit? Saját magadnak is ennyit költöttél volna rá? Ezt a szemléletet próbálom a többieknek a számára is elültetni, hogy amit megspórolunk, az megmarad a közösségnek. Azért telik nekünk sok mindenre, mert sok mindent nem veszünk meg, ami fölösleges." (D7)

„(...) ki volt mondva, hogy - alapvetően ezek, hogy ki van[nak] mondva, ezek úgy beveszik magukat a köztudatba és értékrenddé válnak, követelményrendszerré válnak, meg úgy az intézményi kultúra részévé vállnak -, hogy óratartásban nincs kívánság hangverseny. Kijön egy órarendből, hogy kinek mikor van órája, az órát akkor kell megtartani. És nincs cserélgetés, és nincs alku a hallgatókkal, és mindenkinek ki kell, hogy legyen az órája. És az órát az első percétől az utolsóig meg kell tartani. Most ugye ezek olyan dolgok, amiket alapvetően minden kolléga pontosan tud, hogy ez így van rendben. Úgy a lelke mélyén tudja, hogy ennek hogy kell lennie. De ez úgy az elsö perctöl kezdve azok közé a kérdések közé tartozott, amiknek úgy folyamatosan folyik a lazítgatása. Vagy legalább is törekvés a lazítgatására. Ugye ez egy olyan dolog, hogy egyfelöl kétszemélyes játék. Ök tudják, hogy én tudom, én tudom, hogy ők tudják, és akkor nekem az a dolgom, hogy ezt ne engedjem, és akkor az a dolgom, hogy kitalálódik, hogy minden félév elején az oktatóktól kérjük az óraterhelésnek a kimutatást, meg a tanszékektöl kérjük minden oktató óraterhelésének a kimutatását és az ellenörzését annak, hogy az oktató bent van az órán, és akkor van megtartva. És egy idő után az úgy nem szívesen, de tudomásul vevődik, hogy igen. Meg hát aztán úgyis tudják, hogy ez a rend, szóval még akkor is, ha e mögött mindig van egy ilyen kis feszülö konfliktus." (D12)

„(...) most nagyon vicceset mondok, soha nem engedtettem megvetetni az ágytálmosó készüléket. (mindketten nevetnek) Mert az ápolási tanszékesek állandóan ágytál[lal jönnek], mondtam, hogy azt ne vegyük meg. Menjen ki a gyakorlatba, és nézze meg, de azt a babát, amin azt kell gyakorolni, hogy hogyan kell vénát szúrni, azt bizony vegyük meg. Tehát azért ilyen értelemben próbáltam azért én ennek gátat szabni valami logika alapján. Mert egy csomó dolggal kapcsolatban régebben azt láttuk, hogy beszereztük és semmire nem használtuk, tehát meg kellett indokolni, hogy miért akarja beszerezni, fontossági sorrendet kellett felállítani, ami nélkül nem tud müködni a következő évben, mi az a következő kategória, ha úgy látjuk, hogy lesz rá pénzünk, akkor azt megvesszük, és mi az, amire még vágyunk, mert hát írjuk már le. És nyolcszor kapták vissza ezt a listát. És nem lehet-e.... És ez ment be utána a kari tanácsra, és ennek alapján ott már viszont abban mediálni kellett, amikor [az] egyik tanszéknek volt egy nagyobb beszerzési igénye [...] Tehát ebben viszont kellett, hogy ezt értsék meg, hogy valamikor egyiket, másikat [kell támogatni]." (D21)

A tulajdonosi szerepfelfogásban a dékán aktívabb, kezdeményezőbb szerepet vállal, mint a reaktív problémamegoldó és a kompromisszumokat kereső koordinátori szerepben. $\mathrm{A}$ dékán részvételét a célkijelölési folyamatban nem kimagasló szakmai eredményei teszik indokolttá, hanem az adminisztratív szakértelme, és az a tény, hogy a közösség tagja nem feltétlenül képesek a megvalósíthatóság és fenntarthatóság szempontjait érvényesíteni. A bürokratikus működés alapdilemmáját ugyanis az jelenti, hogy a kari képviselők a gazdasági és

100 Ha csak a közösségi szabályok betartatását tekinteném a szerep fő elemének, akkor a pandúr elnevezés is helyénvaló lenne, de ennél a szerep megítélésem szerint bővebb. 
jogi kérdéseket illetően gyakran felkészületlenek, például hiányoznak az ismeretek akár olyan szakmai folyamatok kapcsán is, mint például szakok akkreditációja. A tágabb jogi környezet ismeretét pedig nehéz is elvárni egy viszonylag gyakran változó közegben. Emellett gyakran hiányzik a hosszabb távú, fenntarthatósági szemlélet is, mert a kari képviselőknek gyakran parciális a szemléletmódja.

„[a kari tanács tagja] nem akar utána nézni, nem akar mögé menni ezeknek a dolgoknak. Tehát hogyha én megkérdezem a véleményét, hogy őneki erről mi a véleménye, akkor azt mondja, hogy az én tanszékemet nem érinti, tehát innentöl ez engem nem érdekel. (...) én azt látom, hogy megkapargat valami felszínt, ami neki elég azért, és nem olvas utána egy csomó dolognak. Nem olvas utána, tehát őneki az elég, amit úgy fölcsipegetett valahol információként." (D21)

"(...) amikor a föiskolai szenátusra vittük dolgokat, akkor is a legkevesebb probléma, hozzászólás és így tovább, mindig az igazán fontos kérdéseknél volt. Az intézmény stratégiáját tekintve és így tovább. A pitiáner, semmi kérdések, az, hogy most az ajtót kicserélik, vagy nem cserélik, azon képesek voltak természetesen fél órát vitatkozni. Na most ebböl adódóan egyszerüen, hogy mondjam, úgy néz ki, hogy minthogyha nem tudom, páran nem akarnánk itt, hogy a másik tanszék mondjuk vigye valamire. És ez, ez egy nagyon kellemetlen dolog, mert hát nyilván egy ilyen helyzetben az ember úgy érzi, hogy mást tenne, hogyha tehetné, de nem biztos, hogy teheti." (D29)

„(...) érdekes módon, vannak nyilván gumicsont témák. Tehát az egyik ilyen gumicsont téma, amiröl végtelenségig el tudnak beszélgetni, az az oktatói munka hallgatói véleményezése. Mert, ahhoz mindenki ért" (D11)

Noha igen kényelmes az a helyzet, amikor a dékán alapvetően a közösségi döntések végrehajtóiként állítják be magukat, ilyen közegben a dékán a problémamegoldó és a koordináló szerepek passzivitásánál jóval aktívabb, kezdeményezőbb szerepet is játszhat, azaz befolyással lehet a döntésre is. Egyfelöl tehát érvényesíthet egyfajta erőforrásszemléletet (ami a stratégiai játékos szerepre is jellemzö), másfelöl biztosithatja, hogy a döntéshozási folyamat összhangban maradjon a korábban hozott szabályokkal és normákkal. Ez értelemszerüen több konfliktus vállalásával is jár (e dékánok többször beszéltek például munkaügyi perekröl).

A tulajdonosi dékáni szerep értelemszerüen jogi és gazdasági felkészültséget igényel. Azok a dékánok, akik közel álltak ehhez a szerepfelfogáshoz, nem csak az ilyen irányú készségeiket, képességeiket hangsúlyozzák, hanem azt is, hogy ezek a kompetenciák nem magától értetődőek az adott karon. Ez nem csak az adminisztratív szakértelmük alapját jelenti, hanem azt is, hogy szakmailag viszont valamennyire kívülállók maradnak.

\subsubsection{A stratégiai játékos}

A szakirodalmi áttekintés alapján a stratégiai játékosok fő jellemzője a függés és a kockázat csökkentése az erőforrások feletti kontroll erősitése révén. $E$ szerepértelmezésben mindez a célok központosított megfogalmazásával és annak kontrollált végrehajtásával biztositható. $A$ kontroll témaköre számos dékánnál került elő az interjúk során:

„Nem az vezérel ma, hogy akkor mit lépjek, hanem, hanem tudja a játék. És a játék az az, hogy egy rendszer úgy kezd el viselkedni, müködni, alakulni, fejlődni, ahogyan én ezt szeretném. Ess ez a része izgat engem. A többi az ilyen szempontból smafu. De az hogy, igen, az ember 
kipróbálhatja magát egy ilyen - hát így mondják az egyetemen, hogy - magasabb vezetői szinten, hogy a kar ezt most tudja-e csinálni, és hogy csinálja, és ez hogyan müködik." (D13)

„Én most nem mondom azt magamról, hogy menedzser vagyok, mert nem reális az önképem nyilván ebböl a szempontból, de hogyha az a menedzserség, hogy az ember kézben tudja tartani, meg tudja oldani, akkor nyilván van bennem egy ilyen motívum, vagy van egy ilyen vonulat, ami alapján engem így is lehet hívni. Nem mondom, hogy eszem ágában sincs, hát én egy tudós embernek tartanám inkább magamat, csak hát..." (D4)

„Át lehet szervezni az egész oktatási struktúrát. Új szakot lehet generálni. Szakot meg lehet szüntetni. Tehát tanszékvezetőként azért ilyenről az ember nem is álmodhat. Itt megvan az a lehetőség, hogy befolyással lehet az ember a menetre. Nemcsak résztvevő, hanem irányító egy adott területen. Tehát ez sokkal nagyobb lehetőség. És ezzel lehet például azt a stratégiát teljesíteni, amit az ember úgy elképzel a későbbiek során. Viszont a bukás is jóval nagyobb."(D1)

A kontroll kérdése természetesen nemcsak a stratégiai játékos dékánoknál került elő, hanem például a szolgáltató (különösen a tulajdonos) szerepfelfogású dékánoknál is. Az egyik különbség jól látható a fenti idézetek és az alábbi idézetek összevetésével:

„...én azt gondolom, hogy tyúkanyó módjára, minden bizottságra, meg minden helyettesre oda kell figyelni. Tehát nagyon jó a csapat, akivel most szerencsém van együtt dolgozni, de azért szeretem naprakészen tudni, hogy ki hol tart, és mit csinálnak, tehát ez, fontos." (D11)

V: „Hát vezetöként, tehát az, hogy mindenhez érteni, nagyon emberségesnek lenni, és mondom föleg az, hogy mindenen rajta tartani a szemét. Igazságos, emberséges, mindenen rajta tartani a szemét. [...]

$\mathrm{K}$ : Mit jelent az, hogy mindenen rajta tartani a szemét?

V: Azt jelenti, hogy az adott egység életében: legfölső, középső, legalsó dolgokig minden. Nem véletlenül mondtam ezt a zármeghúzást, meg a festést, meg egyéb. Tehát az, hogy akkor ha maradunk oktatási intézménynél, tehát a szakmai dolgok, a tantervi, tantárgyi dolgok, akkor ki mit tanit, hogyan tanít, módszertani ellátás, szakmai ellátás, infrastrukturális ellátottság, az egyes embereknek a személyes dolgainak az ismerete, a szakmai dolgainak az ismerete, ilyenek." (D29)

Az idézetek közötti különbség talán az operatív és stratégiai kontroll fogalmával tagadható meg. Míg a szolgáltató dékán föként a részletek kontrollálására fókuszál, addig a stratégiai játékosok fókusza a cél szempontjából lényeges paraméterek kontrollja. A gondolkodási sík az utóbbi esetben sokkal tágabb, és kevésbé ragad le a részleteknél. Még pontosabban: a stratégiai játékos figyelme nem elsősorban a részletekre irányul, de fennáll a lehetősége annak, hogy szükség esetén a részletek is kontrollálhatóvá, ellenőrizhetővé váljanak. Egy felsővezetői interjúalany találóan így ragadja meg a különbséget:

„(...) tehát van, aki stratégiában tud gondolkodni, az a stratégiának rendeli alá a költségeket is. Aki nem tud stratégiában gondolkodni, az lekapcsolgatja a takarítónő után a villanyt akkor is, hogyha fölbukik a takaritónö." (F2)

A másik különbség, hogy a stratégiai játékosok esetében a dékán nem valami általános szabálynak, közösségi akaratnak vagy normának az őrzője (mint például az órák megtartásának ellenőrzéséről szóló idézetben), hanem a saját akaratának a megvalósítója. A dékán itt központi cselekvő szereplő, ami ezen alfejezet első interjúrészletben úgy jelenik meg, hogy „úgy kezd el 
viselkedni, müködni, alakulni, fejlődni, ahogyan én ezt szeretném” (D13). Ebböl következően a stratégiai játékosoknál a közösség gyakran az irányítás tárgyaként, vagy a feladatok végrehajtóként jelenik meg. A dékán központi, cselekvő szerepe a kar fejlődésében más interjúrészletekben is tettenérhető (kiemelések tőlem):

„...egy korábbiakban szintén az általam kidolgozott a piacképes [mesterszak].” (D13)

„....annak idején én indítottam el a [...] föiskolai képzést... Na most hát annak az egész folyamata, az nyilván rajtam múlott." (D13)

„Nézze én semmi olyan pozíciót nem szeretek, amiben nem a saját koncepciómat hajthatom végre." (D13)

„Hát az első és a legfontosabb dolog, hogy olyan kínálatot kellett csinálni, és ez az alap dolog, olyan kínálatot kellett csinálni, amire úgy gondoltam, hogy biztosan lesznek jelentkezők." (D13)

„...éppen most írtam egy új stratégiát, most simítom rajt az utolsókat.” (D4)

„Tehát ezt úgy fogom föl, hogy ha indítok különféle projekteket, hogy elképzelem a kar jövőjét, és amögött van konszenzus és van pozitív eredmény, akkor csinálom." (D4)

„Most azt látjuk: elvonások, stb., stb.. Ennek megfelelően új utakat kell keresnünk, és erre írtam az új stratégiát. „(D4)

„...hogy kézben tudom-e tartani a költségvetést...” (D4)

„Tehát nekem volt egy komolyabb elképzelésem, és azt is, hogy merre fordítanám én, hogyha én lennék a kapitány, ennek a karnak, a hajónak az orrát, vagy egyáltalán milyen sebesség, meg merre tájoljuk." (D25)

„....mert azért ennek az elsőszámú, vagy valamilyen szintủ vezetőnek számomra az egyik legélvezetesebb módja az, amikor az ember úgy érzi, hogy a folyamatokban és a folyamatokért igen komolyan tud tenni is. Úgy éreztem, mint a focista, hogy olyan sokat pattogott már elöttem a labda. Most nem nagyon lehet másra fogni a köröm passzt." (D25)

Az idézetekben két dolog szembetűnő: a nagyon erős célorientáltság, és az, hogy a kar célja sokszor a dékán céljaival azonosítható (szemben például a koordinátor szerepfelfogással, ahol a célok egy dékán által koordinált alkufolyamatban alakulnak ki). Ezek a célok pedig többnyire a versenyben való helytállást, a növekedést jelentik, néhány esetben azonban a fennmaradást és a hiány, veszteség ledolgozását, azaz valóban valamilyen krízishelyzet megoldását.

A célorientáltság egyfelől lehetővé teszi az erőforrások fókuszálását, azok célirányos felhasználását, tehát az erőforrások nagyon tudatos kezelését (ez közös pont a tulajdonosi szerepfelfogású dékánokkal). Az alábbi idézet nem csak ezt az erőforrásokban való gondolkodási logikát tükrözi, hanem egy szerintem e narratívára jellemző vonást is, amely más interjúkban is visszatért (pl. a hajóskapitány metaforában):

„Egy hadvezér kitüz célokat, hogy na akkor hódítunk, vagy elfoglaljuk, vagy megvédjük, stb.. Az első dolga mindig az, hogy megszámolja a seregét, milyen állapotban van. Napóleon tudta, hogy el tudna-e menni Moszkváig a... mert olyan állapotban volt a serege, mert volt felszerelés, volt lőszer, élelmiszer, fegyver, ló, ágyú, stb., most....tehát (gondolkodik) ha így végignézek a kollégáimon, akkor azt látom, hogy túlterheltek, ugye anyagi megbecsültség az minimális, hát 
ha tanársegéd, akkor tudja mennyi a fizetése. (...) De ilyenkor lelkesedéssel lehet pótolni, vagy lelkesítéssel lehet pótolni. Hogyha tudja, hogy amit ő csinál, az egy nagyobb rendszerben elhelyezve, az egy fontos dolog, akkor az (...) jó. (...) Tehát lelkesedéssel egy darabig lehet pótolni mindenféle hiányokat, de ha hadvezér tudja [is] lelkesíteni a seregét, akkor is az a legfontosabb dolga, hogy szerezzen muníciót és szerezzen élelmiszert, meg stb., stb.." (D4)

Ez a hasonlat kijelöli a dékán szerepét is, amennyiben ő az erőforrások szerzője és elosztója a kijelölt célok érdekében. A célorientáltság másik következménye, hogy instrumentális, tranzakciós logikát eredményez, amelyben minden dolog értéke annyi, amennyivel hozzájárul a célok eléréshez.

„....ha az ember megérzi, hogy, hogy az ő tudományterületének, vagy a karának az adottságait, hol lehetne viszonylag kis ráfordítással, de viszonylag nagyot lendíteni az ügyön." (D25)

„Nekem örökké az volt, matematikusként is az volt a filozófiám, hogy az igazán szép matematika, az a matematika, ami a gyakorlati életből szerez egy problémát, erre felállít egy matematikai modellt, azt megoldja, majd visszaadja a gyakorlatba, és akkor azt mondja, hogy ez a megoldása. Tehát engem érdekelt mindig is, hogy bizonyos optimalizálási eljárásokat hogyan lehet alkalmazni, vagy egy optimum számítási problémát, azt hogyan lehet kezelni. Tehát ezek érdekeltek engem." (D7)

„Tehát nem vagyok könyvelö, meg fökönyvelő és a szemléletmód nem is jó (...) De dékánban az a dinamikusabb ember lennék, aki befektet." (D4)

A dékánok egy csoportjánál a hasznosságszemlélet és a tranzakciós logika nem csak a kar és a környezetének viszonyában értelmeződik, hanem a dékán és környezete viszonyában is (ezt a másodlagos szerepet neveztem el taktikusoknak). Ez nem meglepő annak fényében, hogy a kar és a dékán céljai - mint fentebb láttuk - könnyen összemosódnak. Ennek következménye, hogy a dékánságra e dékánok egyfajta játszmaként tekintenek (lásd a fejezet első idézetét), ahol a környezete támogatókra (lojálisakra) és ellenzőkre (nem lojálisakra) lehet osztani, s ahol az egyet nem értés ellenállásként fogalmazódik meg, amelyet le kell győzni. Az e szerepnarratívát képviselő dékánok interjúiban a „kompromisszum” vagy a „konszenzus” szó alig-alig fordult elő.

Természetesen ez nem jelenti azt, hogy ellenállással más dékánok ne találkoztak volna, azonban a magyarázatsémákat illetően érezhető különbségek ragadhatóak meg. Példaként azt a türelmetlenséget és sürgető érzést mutatom be, amellyel a céltudatos dékánok többsége (ők elsősorban a vállalkozók és a stratégiai játékosok között találhatóak) akkor találkozik, amikor a változás nem az elvárt sebességnek megfelelően alakul. Az egyik dékán a következőképpen mutatja be a jelenséget:

„A legnagyobb kudarc? A lassúság. Tehát nem tudok olyan gyorsan haladni, mint szeretnék. Tehát ez kudarc. És ugyanilyen frusztrált a két helyettesem is emiatt. Szóval mindannyian érezzük, hogy ezt gyorsabban kéne csinálni, és nem tudjuk gyorsabban csinálni. (...) Ennek az egyik oka az, hogy a kar dolgozóinak egy része borzalmasan jól érzi magát ebben a langyos vízben. És sütögeti a saját pecsenyéjét máshol. Tehát ez az egyik. A másik, hogy ez nem baj, szóval most ezt nem pejoratíve mondtam. Mert ök azért csinálják így, mert valami miatt itt nem tudják ezt úgy megcsinálni. És ami miatt ezt nem tudják megcsinálni, azokat pedig nem tudom kirúgni, mert meg van kötve a kezem az akkreditáció miatt. Úgyhogy ez a szitu." (D1)

Egy másik dékán (akinek szerepét én alapvetően inkább vállalkozóként, szervezetfejlesztőként láttam) egy hasonló jelenségre másféle magyarázatot adott: 
„Egy dologra nem számítottam: azt nem gondoltam, hogy ami az én fejemben egy fél év, az még négy év alatt sem valósul meg. Tehát mondjuk az, hogy a honlapot használják a kollégák, azt még mindig nem tudtam olyan szinten elérni, mint ahogy én szeretném. Tehát mindig ki kell szelektálni egy-két halottat, vagy egy-két eltávozót, aki nincs itt, mert hogy ez még nem teljesen igény. Tehát azért heroikus a küzdelem." (D17)

Míg tehát az első dékán inkább az ellenérdekeltségre és a megfelelö hatáskörök (hatalom) hiányára vezette vissza a változás lassúságát, addig a másik dékán ezt elsősorban kulturális jelenségnek, a gondolkodásmód, a kultúra, a szervezeti szokások tehetetlenségének tekintette ugyanazt. Ráadásul az első esetben az ellenállás sokkal inkább megszemélyesíthető, így az alkalmazott eszközök is mások lesznek.

A taktikusok esetében az ellenállás kezelésének és célok érvényre juttatásának két nagy eszközrendszere bontakozott ki az interjúk alapján: az erő és a taktikázás. Az erő forrása lehet a dékánsággal formálisan együtt járó felhatalmazások, illetve az erőforrások kontrollja. Az erő logikáját jól szemlélteti az alábbi idézet, amelyben a dékánt arról faggattam, hogy miért tartotta meg a dékánság mellett a tanszékvezetést is:

„NN]em lehet szerintem jó dékán valaki, hogy nincsen mögötte tanszék. Mert a tanszék az, amit te saját magad felépítesz. És az a tanszék adja azt a stabil, biztos szakmai bázist, amely a munkát tudja segíteni. (...) A dékán pozícióját az erősíti, hogy van mögötte egy olyan csoport, nevezzük ezt most tanszéknek, amelyik az ő iskolája. Tehát ami az ő szakmai hátterének az erősitését szolgálja. Tehát a dékán nem lóg a levegöben, és ennek megfelelöen a tanszékvezetök tömegének úgymond a bábja. Hanem igenis szakmailag ott van mögötte az a hátoldal, amit ő felmutatott, és ami hátoldal azokban az emberekben is megtestesül, akik ott azokon a területeken vannak. (...) Tehát az, hogy én mögöttem ott van [számos] [...] védett $\mathrm{PhD}$ hallgató, akiknek én voltam a témavezetője. Akik ennek megfelelően, hát legalábbis reményeim szerint, de hát a tapasztalat is azt mutatja, hogy azért eléggé lojálisan viszonyulnak a személyemhez." (D13 - kiemelés tőlem)

Figyelemreméltó ebben az interjúrészletben, hogy a gondolatmenet tarthatott volna mondjuk a dékán szakmai hitelességének irányába is (ami például a kar közösségi narratívájában könnyen előfordulhatna), de végül a politikai/érdekérvényesítő képesség szempontjából nyert értelmezést. Azaz a saját tanszék a "hátország” támogatása miatt fontos, $s$ hogy a dékán ne legyen a többi tanszékvezető bábja (ami esetleg saját tanszék nélkül előállhatna). A dékán külön fontosnak tartotta kihangsúlyozni a végzett $\mathrm{PhD}$-hallgatók lojalitását is. Az egész gondolatmenet tehát a "mi” vs „ők” dichotómiában értelmeződik.

További fontos erő-eszköz a dékánok kezében a munkáltatói jogositvány, ami különösen a vidéki főiskolákon került elő, ahol nehezebb munkát találni a munkahely elveszítése esetén, illetve a kinevezések kontrollálása. Például egy-egy strukturális átszervezés során lehetővé válik új vezetők kinevezése és megbízása, és

„az, hogy én kinek adom meg az induláskor a tanszékvezetői megbízást, az azért tőlem függ. És az nagyjából el is dönti azt, hogy ki lesz a tanszékvezető hosszabb távon. Hiszen utána kíródik a pályázat, de hát az, aki csinálja, az már egyfajta helyzeti előnyben van ebben a rendszerben és akkor ennek megfelelően nagyobb az esély, a sansz arra, hogy nyer." (D13) 
A vezetői szándékok érvényesítésének másik eszköze a taktikázás és az információk megfelelő kontrollja.

„...a beadás elött, akkor leültünk és akkor megbeszéltük, hogy pályázni fog és mindent megteszünk azért hogy ő legyen a rektor. Viszont az, hogy második helyre mondjuk [a másik kar] jelöltje jusson be, az elképzelhetetlen. Mert az problémát jelentene. Tehát ha őt [ti. az első helyen jelöltet] bármilyen okból esetleg nem nevezné ki a minisztérium, vagy a miniszterelnök, akkor a mögötte levő ember [a karról] legyen." (D1)

„Ennek az állandó konzultációnak két formája van. Az egyik a kar tanácsa, a másik az ún. vezetői ülés, ami azt jelenti, hogy minden egyes részlegről a vezetöket meghívom és kérdezem rendszeres, heti rendszerességgel. Ez azért van, mert sokan sérelmezték azt, hogy a kari tanácsba, nem jutott be mindenki. Nyilván ennek is meg volt az oka, egy idő után, amikor már engem kezdtek támogatni, akkor nyilván az én támogató rétegem került oda be. És nagyon jó dolgozni a kari tanáccsal. Sokkal nehezebb dolog van a vezetői üléseken, mert ott mindenki ott van. De én azt mondom továbbra is, és azt vallom, hogy ezek viszont azok a visszajelzések, amelyek, ha néha fájóak, vagy nehézzé teszik a mindennapi életet, de mindenképpen egy másik aspektusát vetik föl az adott problémakörnek, amit az ember nem mindig fogad meg vakon, de akkor is egy olyan visszajelzés, ami információt tartalmaz, és egy másik nézőpontot tükröz, ami szerintem az egész kar nyugodt vezetésének alapja kell, hogy legyen, mert hogyha nem lennének ezek a megkérdezések, akkor a bizonytalan változásokat hordozná magában. Tehát, ha lenne egy kvázi, egy olyan klikk, aki bár bántó esetleg, de nincs is megkérdezve és mellőzve van, akkor aköré mindig jobban csoportosulnak, mert ugye azok szegény, nincsenek megkérdezve, és akkor el vannak hanyagolva, és... De így erre, nincs lehetöség. Tehát úgy marad izoláltan esetleg ez a vélemény, hogy közben meg is van kérdezve. És egy nagy plénum, nem nekem kell állandóan szembesülni, hanem a közösség dönti el, hogy aztán mi lesz az, amit végül elfogadunk." (D18)

„....amikor konfrontálódni kell, azt jobb egyesével lejátszani, mert nem szabad egyszerre túl sok fronton harcolni, mert akkor, akkor hirtelen kap az ember egy nagy ellenállást. Hogy akkor már mindenkivel bajom van, és én azt hiszem, hogy ez az, ami miatt nincsenek olyan nagy ellenállások, mert egyesével könnyebben meggyőzhető a csapat, a másik oldalról meg most már a konszolidált helyzet miatt egy picit nyugodtabbak, és nekem onnan szoktak lenni problémáim, hogy néha egy kicsit túl nyugodtak." (D2)

Milyen következtetéseket, tanulságokat vonhatunk le a kutatás eredményeiből a korábban felvázolt stratégiai játékos szerepértelmezésről?

Először is: az interjúk alapján e szerepnarratívában a dékán külső orientációja nem tünik erősebbnek, mint más narratívákban. A külső környezet szerepe főként megfejtésre váró képzési igényekként jelennek meg, vagy az önkormányzattal, a várossal való protokolláris és együttműködési kapcsolatok említésére terjed ki. Egy-egy kivételtől eltekintve tehát nem a környezeti kihívások, az azokhoz való alkalmazkodás kényszere az, ami igazolja a dékán szerepértelmezését, ebből következően e modell aligha tekinthető válságmodellnek. (Természetesen dékánságuk tartóssága nehezen ítélhető meg, mert a többi érintett elégedettségével kapcsolatban nem gyüjtöttem adatot.)

A külső kényszerek hangsúlyozása helyett sokkal erősebb a dékánok célorientált viselkedése, a sikeréhségük, tennivágyásuk. A célok tehát inkább belülről, és nem kivülröl adottak, azaz nem annyira külső, mint inkább stratégiai vagy célorientációról érdemes beszélni.

Másodszor: a szakirodalom alapján a stratégiai játékos dékánt az jellemzi, hogy vezetési rendszereket épít ki, amelyek biztosítják a kulcserőforrások feletti kontrollt és a többi szereplő megfelelő ösztönzését. Ugyanakkor ilyesféle vezetési rendszerek csak egy-egy 
dékánnál merülnek fel említés szintjén, és csak elvétve találkozni olyan eszközökkel, mint egyéni és szervezeti szintű teljesítményértékelés, tudatos emberierőforrás-menedzsment, kontrolling rendszer, vezetői információs rendszer, másokkal való szisztematikus összehasonlítás (benchmarking), portfóliószemlélet, toborzási stratégia stb. Ezt az is tükrözi, hogy a kétnyelvűség, azaz az akadémiai és menedzsment nyelvezet keveredése az interjúk során nemigen volt jellemző. Egy-egy (esetenként menedzsmenttel foglalkozó) dékánnál fordul csak elő, hogy rendszeresen használt olyan kifejezéseket, mint „stratégia”, „taktika”, „extenzív és intenzív növekedés”, „portfólió”, „pozíció”, „vízió”, „csapatépítő tréning”, „projekt”. Elképzelhető persze például kisebb karokon, hogy e tapasztalatok ellenére mégis müködnek vezetési rendszerek, csak azok nem formalizáltak. Az is lehetséges, hogy a dékán nem tartotta fontosnak ezek említését. A narratíva szempontjából azonban mindez azt jelenti, hogy a dékán nem ezeken az eszközökön keresztül értelmezi saját szerepét, helyzetét, ami azt is jelenti, hogy a vezetési és irányítási rendszerek nem intézményesültek, hanem erősen személyfüggőek (maradtak?), ami magyarázatot ad arra, hogy az empirikus tapasztalatok alapján e narratívában miért olyan erős a politikai-függési értelmezési séma. Ez indokolja a taktikus másodlagos szerep létjogosultságát is.

\subsubsection{A katalizátor}

A szakirodalom elemzése alapján a katalizátor a vállalkozó egyetemen belül megfogalmazódó dékáni szerepnarratíva. A kiinduló értelmezés szerint a katalizátor dékán fókusza a külső igényekre irányul, amelyben a cél azok feltárása és kielégítése. A másik fókuszpontot a humánfókusz jelenti, azaz e dékánoknál a hangsúly a rugalmasságra, az innovativitásra és az ezt megteremtő közösségi kultúrára, gondolkodásmódra esik. Ezt jól tükrözi az a jelmondat, amellyel az egyik interjú helyszínén az újonnan megnyitott épület egyik aulájának falán találkoztam, miközben a dékán büszkén mutatta meg az épületet: "Mindenki tudja, hogy bizonyos dolgokat nem lehet megvalósítani, mígnem jön valaki, aki erröl nem tud, és megvalósitja."

A szerepnarratíva központi fogalma tehát az újszerüség, az innováció, amely nem csak új dolgok kitalálását takarja, hanem - az interjúkban sokkal gyakrabban - a dolgok újszerü alkalmazását, összekapcsolását is. Fontos látni azonban, hogy innovációról nem csak a katalizátor szerepfelfogás kapcsán lehet beszélni, hanem minden szerepnarratívában is. A katalizátor esetében azonban az innovativitás központi szerepet tölt be, amely nem egyszeri esemény, hanem tartósan fenntartható (fenntartandó) állapotot takar. A dékán tehát nem egyszerüen innovál, hanem az egyéni innovációs törekvéseket képes szervezeti képességgé emelni és azt tartósítani. (Ezért indokolt a katalizátor, és nem a innovátor elnevezés.)

Az innováció relatív fogalom: az, hogy mi számít innovációnak, függ az érintett kar fennálló kultúrájától, viszonyaitól, müködésétől is, hiszen az, ami az egyik kar számára rendkívüli újdonság, egy másik karok számára magától értetődően része a mindennapi működésnek. Ennélfogva az e szerepnarratívába tartozó dékánok megítélése is ingadozó lehet, sőt, időben is változhat, emiatt e szerep határai nagyon bizonytalanok. Ezt az is mutatja, hogy az elemzésem szerint a katalizátor szerephez hasonló felfogást mutató dékánok szinte mindegyike „átlóg” másmás narratívába is.

Attól függően, hogy mire is irányul az innováció, két jellegzetes felfogással találkoztam e szerepen belül: az egyik inkább a szervezeti kultúra, a másik pedig a termékportfólió és a kapcsolatrendszer megújítására helyezte a hangsúlyt. Az előbbit ezért belső vállalkozónak 
(intrapreneur), szervezetfejlesztőnek vagy csapatépitőnek lehet nevezni, míg az utóbbi inkább klasszikus vállalkozónak (entrepreneur) tekinthető, akinek a bróker megnevezést adtam.

A szervezetfejlesztő/közösségépitő elnevezés abból adódik, hogy az e felfogást képviselő dékánok gondolkodásának középpontjában a közösség megújitása áll. Ez persze nem jelenti azt, hogy itt ne lenne külső orientáció, de ennek célja a belső viszonyok megújulásának elösegítése. Ezt a szemléletmódot foglalja tömören össze az alábbi idézet:

\begin{abstract}
„A dékán talán fö feladata a közösség kovácsolás. Tehát nem tudomány, nem oktatás, [hanem] közösség kovácsolás. Ha van közösséged, akkor van minden más is. Tehát ha összetartást tudok kovácsolni, akkor be tudom őket irányítani egy irányba. Az más kérdés, hogy olyan nincs, hogy összetartás, és közben nem csinálunk semmit, tehát ezt úgy kell érteni, hogy értelmes célokat kell megfogalmazni, és mögé kell állítani a csapatot. Na most az értelmes célok nyilván sokrétüek. Ez nyilván oktatás és kutatás irányú, de ettől színesebb a dolog, mert, mert egy vidéki főiskola nem lehet elzárva a világtól. Tehát egyfajta nyitást kellett nekem produkálni, mind az iskolák felé, mind a régió felé, mind a vállalatok felé." (D17)
\end{abstract}

Érdemes rögtön arra is utalni, hogy a közösségépítés, a szervezet kultúrájának fejlesztése nem csak e narratíván belül fordulhat elő. Csakhogy ennek értelmezési kerete más narratívákban igen különböző. Például egy leginkább stratégiai játékos narratívával jellemezhető dékán úgy fogalmaz, hogy

„Ugye ezek a közösség építések, ezek nagyon fontosak egy rendszer hatékonysága szempontjából. Mondjuk, ezt látjuk a...csak ott tréningnek nevezik ezt a piacon müködő vállalatoknál, hogy ilyen tréning, olyan tréning, hogy identitást építenek, csapatot építenek, közösségeket alakítanak ki, hogy azzal fokozzák a munka hatékonyságát. Hát nyilván ezt... nem kell tréninget csinálni, nem úgy építjük közösséget, nem ilyen szervezett fonalon. Lehet, hogy az egészet, ha ránéz egy menedzser, azt mondja, hogy hát ez gyakorlatilag csapatépités, amit én csinálok. Csak hát ennek van egy több száz éves hagyománya, és itt inkább közösség formálás, közösségépités." (D4)

Ez a logika nagyon különbözik a korábbi idézet logikájától. Amíg ugyanis az első esetben a feladatok megfogalmazása és a célok kitűzése jelenti az eszközt a közösség építéséhez, addig a másik esetben a közösség fejlesztése jelenti az eszközt a célok megvalósításához. Amíg az első esetben a közösség fejlesztése maga a cél, addig az utóbbi esetben a közösség fejlesztése a munka hatékonyságát fokozó lehetséges eszköz, és nemcsak alárendelődik egy célnak, hanem szükség esetén kiváltható más eszközök alkalmazásával is (pl. több erőforrás rendelkezésre bocsátásával). Ez egybevág azzal a korábbi megállapítással, hogy a stratégia játékosok szemléletmódját instrumentális, azaz eszközelvű szemléletmód uralja.

A másik szerepértelmezésnek a bróker nevet adtam, mert ennek középpontjában a portfólió és a kapcsolatrendszer megújitása áll. A lényeg az újféle termékek és szolgáltatások kitalálása és bevezetése, új igények, partnerek és célcsoportok megtalálása, és újféle kapcsolódások kialakítása a partnerekkel, azaz itt valóban a külső orientáció tekinthető a dominánsnak, és a szervezeti müködés igazodik ehhez. Ezt a szemléletet az alábbi hosszabb beszámoló tükrözi:

„Például az is egyértelmű, hogy a magyar rendszerből mondjuk hiányzik a gyakorlatorientált master, illetve a posztgraduális képzési rendszer, ami számos országban megvan és létezik. Tehát kellett hozni egy olyan szemléletet, ami az egyetemet jobban köti a környezetéhez. A 
régióhoz, városhoz, az euró régióhoz, ha úgy tetszik. Tehát az első olyan programot, ami az $X$ Eurorégió létrehozásához vezetett, azt az $Y$ Intézet kezdeményezte. [...] $\mathrm{Na}$ most ezt a szemléletet érdemes volt megtartani általában véve a fejlesztések esetében. Itt az elmúlt időszakban tudatosan is kerestük azt, hogy milyen innovatív mesterszakokat lehet beindítani és akkreditáltatni. Ehhez a nemzetközi kapcsolatok és a nemzetközi tapasztalatok nyilván érdekesek voltak. [...] Most ezek a mesterszakok eleve föltételeznek egyfajta interdiszciplinaritást, föltételeznek karközi és egyetemközi vagy intézményközi kapcsolatokat, és hát föltételeznek egyfajta nyitottságot a környezet irányába.

Hogy mondjak egy konkrét példát, ugye gyakran elöfordul, hogy különböző emberek, csoportok nem tudnak egymással együtt dolgozni, vagy nem jönnek ki egymással. Ilyenkor a lerendezésnek az egyik klasszikus módja, hogy akkor egy tanszékből csinálnak kettőt, és akkor mindenki nyugodtan müködhet. Na most volt egy ilyen kísérlet nálunk is, én azt mondtam, hogy ez elképzelhető, de ahhoz elötte én a programot szeretném látni. Tehát ha most konkrétan [...] mesterszakról beszélünk, akkor előbb a program és a mesterszak van meg, és utána majd megnézzük, hogy hozzá lehet-e igazítani a szükséges struktúrát. Tehát nem elöbb csinálunk egy [új] tanszéket, és aztán lesz valami, hanem előbb lássuk magát a programot. Ezzel ugye megfordítódott a logika. [...] De ez például azt eredményezte, hogy e mesterszakra [...] ugyanannyian jelentkeztek, mint [az egyik legnépszerübb] szakra. Ami egyrészt mutatja az érdeklödést. Nyilván van benne egy divat elem is, de az kétségtelen, hogy találkozott egyrészt a képzendők érdeklödésével. Másrészt pedig ennek a programnak a kidolgozásakor gondoltunk arra, hogy azok a partnerek - akár színház, akár múzeum, akár filmstúdió, akár rajzfilm stúdió, és egyebek -, amelyek itt a környéken vagy az országban vagy a határon túl [...][vannak], is érdeklődhetnek a képzés iránt. A szakmai gyakorlatra fogadhatnak embereket, potenciális piacot jelentenek, azok integrálva legyenek hozzá." (D3)

Nagyon hasonló beszámolókat más dékánoknál is találhatunk:

„Az oktatásban vannak olyan elképzeléseink, hogy egy picit az agrárterületröl kitörni, vagy nyitni. Akár úgy, hogy az egyetem más karaival, vagy külső szervezetekkel együttmüködve. Es az egyik elgondolás az itt a kerámia területe. Hiszen itt a városban öt porcelán vagy kerámia üzem van, vagy gyár van. Emellett számos kisebb üzem és maszek fazekas, tehát itt a kerámiának, fazekasságnak, porcelánnak itt nagyon nagy hagyománya van [...], és a gyárakkal már van egyezségünk, hogy fölszivják, hogyha... Sőt beiskoláznak, hogyha ilyen jellegü képzést tudnánk indítani." (D2)

„Hát én szerintem alapvetően az [múlik a dékánon], hogy jól kell figyelni a trendeket, hogy mik azok az újabb, hát nem mondanám, hogy társadalmi igények, mert még ilyen szempontból még ezt sem lehet mondani, mert például tök érthetetlen számomra még mindig, hogy az andragógia, az mi a fenétöl olyan vonzó egy 18 éves ember számára. [...] Szóval ez nem is piaci, hát szóval rá kell érezni arra, hogy mi felé mozognak a fiatalok, milyen kérdések, hol, és akkor ezekre különböző szakokat, szakirányokat....tehát a képzési kínálatnak a gazdagodását kell valamilyenmódon állandóan elérni." (D19)

A fenti beszámolókban az a közös, hogy az egyes dékánok a képzési portfólió megújitását a divatok, trendek felismerésével, a hiányosságok és a lehetséges partnerek igényeinek megfigyelésével végzik. Ebben óriási szerepet játszanak a máshol - más intézményben, külföldön - szerzett tapasztalatok, a tájékozottság, amelyek tükrében válnak nyilvánvalóvá a hiányok és a lehetőségek. Maga a megvalósítás is gyakran sokféle szereplő különböző tudományterületek, régiók, intézmények, vállalatok - együttmüködésének keretében zajlik.

Mint az idézetekből látható volt, a dékánok tevékenysége éppúgy felöleli a szemléletmód meghonositását, mint az új megoldásokhoz illeszkedő struktúrák és folyamatok kialakitását (ez indokolja azt, hogy a bróker szerepértelmezés kapcsolódik a stratégiai játékos 
narratívához is). És bár a dékán maga is forrása az új ötleteknek, legfontosabb feladata mégiscsak a közvetítés a különböző szereplök és kontextusok között, és ennek feltételrendszerének kialakítása (networking, tájékozódás). Ez indokolja a bróker elnevezést. $\mathrm{E}$ szerepértelmezésből óhatatlanul következik, hogy az innovációra irányuló kísérletek nem mindig sikeresek. E megközelítés szükséges eleme ezért a próba-szerencse logika is.

„Tehát ismerni kell egy csomó olyan dolgot [amit] lát az ember, amivel egyébként nem találkozik és aminek az átplántálása esetleg megéri. Aztán hogyha van olyan, [hogy] nincs iránta nagyobb receptivitás, akkor ezek elhalnak, de azért az ember ki szokta próbálni, hogy müködike, vagy sem. Ami ilyen volt eddig, az gyakorlatilag szinte minden müködött." (D3)

A szervezetfejlesztő és a bróker megközelítésben közös pont, hogy mindkettő hangsúlyozza a szemléletmód, a közösségi kultúra jelentőségét (mégha esetleg különböző mértékben is). $\mathrm{E}$ tekintetben a katalizátor felfogás szoros rokonságot mutat a hős szerepnarratívával, amelyben a dékán szintén a közösségi kultúrát, normarendszert helyezi a középpontba. Ami mégis megkülönbözteti töle, az az, hogy a katalizátor (és különösen a szervezetfejlesztő) dékán nemcsak megőrizni akarja a fennálló kultúrát, hanem aktívan alakítani is, azaz szilárd elképzelései vannak a kivánatos müködési módról. A stratégiai játékossal ellentétben azonban az átalakítási kísérleteket nem konkrét célok, hanem távoli víziók, „álmok” vezérlik.

„És hát ugye azt mondják, hogy aki fölkészült, és sok mindent akar, azt az angyalok, meg a Jóisten segíti. Tehát mi megnyertünk egy TÁMOP pályázatot [...]. És ezt a Jóisten pont úgy adta nekünk, hogy azokat a dolgokat kell fejleszteni, ami nekem a vesszőparipám volt. Tehát gyakorlatilag, hát kaptam 140 milliót azért, hogy megvalósítsam az álmaimat." (D17)

„Tehát az, amit mi tudunk, vagy ismerünk, vagy ami jó, azt meg kellett, illetve meg kell tudni álmodni és szerkeszteni más-más müfajokban." (D3)

A kontraszt kedvéért érdemes utalni egy olyan volt dékán megjegyzésére, aki leginkább a szolgáltató szerepböl fogalmazta meg álláspontját. A beszélgetés során különbséget tett a „praktikusan fontos” és az „elegánsan fontos” célok között. Amikor arra kértem, hogy fejtse ki bővebben az elegánsan fontos célok tartalmát, a következőt felelte:

\footnotetext{
„Mostanában azoknak a vágyálmoknak a kergetése, ami abszolút általánosan jelentkezik. Futunk a külföld után. Tehát futunk a külföldi intézmények kegyei után, akik olyan nagyon kegyesnek nem látszanak. Hogy milyen képzéseket csinál, mit lehet onnan idehozni, hogy müködjenek együtt velünk, meg a közös joint degree mesterképzések, doktori képzések, nem tudom micsoda. Annyi minden van, amit földhözragadtan rendbe kell tenni, és ami, ami... szóval ami a léthez fontos, azt kell megcsinálni. Majd akkor gondolkodhatunk arról, hogy nem tudom milyen joint degree-ket szervezzünk nem tudom milyen neves egyetemekkel." (D12)
}

Annak, hogy a katalizátor dékánnál a célok és feladatok helyett víziók és álmok határozzák meg a működést, az a jelentősége, hogy ez lehetővé, sőt, elkerülhetetlenné teszi azt, hogy az ahhoz vezető út kimunkálásába mások is szerepet vállaljanak. A közremüködés nem csak kreativitást kiván meg másoktól is, hanem egyben partnerré is teszi őket. Ebből az is következik, hogy e narratívában nem támogatók és szövetségesek, vagy az egyéni érdekeiket követő, de a realitásokat felismerő, kompromisszumkész emberek vannak, hanem partnerek és 
közös gondolkodók. Annak ellenére, hogy a dékánnak markáns meggyőződései (álmai) vannak a jövőre vonatkozóan, maga a vízió nincsen kőbe vésve. Ennek formálásában, alakításba a közösség tagjai éppúgy beleszólhatnak, mint a dékán. A dékán feladata éppen az, hogy felvetéseivel, javaslataival vitát provokáljon, és megteremtse az alkalmat és a lehetőséget a párbeszédre, amelynek keretében mindenkiben tudatossá válnak az előfeltevések, a jövőképek, a meggyőződések, és ez szolgál alapjául annak, hogy a vízióhoz mások is hozzájárulhassanak. Csak az állandó dialógus révén válhat a kar müködése közös vállalkozássá. Ebbe a dialógusba természetesen a dékán is beleviheti a maga meggyőződéseit, de ez nem feltétlenül azonos a közös meggyőződéssel.

„Én mindig abból indulok ki, hogy nem az a kérdés, hogy mit gondol a dékán. A dékán sok mindent gondolhat magánemberként. Az a kérdés, hogy miben tud megállapodni a karral. Ebben persze a dékán gondolata egy lesz a többiekéböl, még akkor is, hogyha a szituációból fakadóan lehet, hogy kicsit fajsúlyosabb gondolat. De ez nem jelenti azt, hogy teljesen az ellenkezőjéről biztos, hogy meg tudja győzni a karát. Ezért én azt, ha ez ilyen téren arc poeticát nézünk, akkor az én ars poeticám az inkább az, hogy látok kulcsterületeket, amikben az a feladatom, hogy kompromisszumokra rávegyem a kollégáimat, döntsünk, mert én a legrosszabbnak azt találom, amikor nincs döntés. [...] Ugyanakkor ne az legyen, amit a dékán akar, hanem azt a kar akarja, és az tudatos legyen, mert ha csak a dékán akarja, akkor ez három év múlva nem lesz. Tehát az organikus fejlődést csak egy szervezeti akarattal lehet elérni, ez számomra egy lényeges kérdés." (D26)

Ebböl következően a dékán nem vindikál magának kiemelt szerepet, és nem akar mindent a saját meggyőződései szerint kontrollálni sem, ellentétben például a stratégiai partner narratívában (ugyanakkor hasonlóvá téve a hős narratívához).

„És olykor a [dékánság] legnagyobb titka, hogy hagyom az embereket dolgozni. De hát az egy nagyon fontos vezetői attitüd, hogy nem akarok mindent kitalálni. Tehát nagyapám azt mondta, hogy nincs az a hülye ember, aki néha okosat ne tudna mondani, és én ezt maximálisan müködtetem. Nyilván nincsenek hülye emberek, de hogy maximálisan bízok abban, hogy nem én vagyok a legokosabb. Nem csak bízok, tudom is. Itt van egy csomó okos ember, és hagyom öket dolgozni, megteremtek mindent, kilobbizok mindent, konfliktust vállalok értük, tehát ha kell, akkor a rektorral szemben is, cserébe azt várom el, hogy ötleteljenek." (D17)

„És erre mondom azt, hogy olyan kollegákkal kell, viszont ilyenkor körbevegye magát, akikre számíthat, mert ez nem egyszemélyes cirkusz. [...] nem nekem kell gazdasági téren a legokosabbnak lenni. Nem nekem kell az oktatás területén a legokosabbnak lenni, hogy a felsőoktatás változásait, rezdüléseit érezni minden pillanatban, hanem igazából, valahol ez ilyen karmester funkció. Én ezt tudnám inkább mondani. Tehát nem biztos, hogy a karmester a legjobb zenész a zenekarban. Csak ő tudja, hogy kinek hogy kell szólni." (D2)

A párbeszédet állandóan fenntartani és mindenkit bevonni rendkívül időigényes folyamat, amely a dékán számára igen megterhelö.

„Tehát hogy nagyon-nagyon sokat beszélgetek, tehát nagyon sokat vagyok az embereim között. [...] Tehát ez nekem eszméletlen sok idő, tehát ez nekem napi 10-12-14-16 óra, mikor mennyi. Nagyon-nagyon sokat dolgozok, ami nem effektíve...van, amikor hazamegyek, és azt mondom, hogy nem is dolgoztam. Tehát nem csináltam semmit ma, mert én ezeket a demokratikus lépéseket megpróbálom lejátszani. Tehát elmegyek az intézetbe, leülök velük, megbeszélem, itt ülnek, ahol te ülsz. Panaszkodnak, meghallgatom, gondolkozok, rakosgatom, pszichológusként müködök. Próbálom bíztatni őket, ha kell odaállni.” (D17) 
„Rengeteg időt visz el az emberekkel való beszélgetés, amit viszont tudom, hogy mekkora értéke van, az én helyzetemben pláne, hogy kell is, hogy megismerjenek. Mondom, valamennyire úgy integrálódtam, mert elfogadtak, és nem csak a többi vezető oktató, hanem például a dolgozók is. Tudom, mert kapom, hát nyilván a jó visszajelzéseket kapom, nem a negatívat." (D8)

A katalizátor szerepfelfogás esetén az innováció igyekszik a közösségböl táplálkozni, ezért organikus fejlődéssel jár, amely építkezik a múltból, azaz például a meglévő készségek, képességek újszerű felhasználását, újrakombinálását jelenti, vagy pedig a meglévő gondolkodási minták átalakulását. Ezzel szemben például a stratégiai játékos megközelítésben inkább diszruptív innovációk találhatók, ahol a dékán jelöli ki, vezeti be a működés új módját, ahogy például azt az alábbi idézet is mutatja:

„Aztán értek itt meglepetések, mert itt ugye voltak szokásjogok, voltak ugye, ahogy szokták volt mondani, csontvázak. [...] És amikor jöttek, hogy de hát ezt régen így csináltuk, meg ez így szokás, akkor mondtam, hogy rendben van. Idáig ez így volt, én holnaptól így szeretném. Tehát viszonylag kulturáltan és elég határozottan én elmondtam, hogy én hogy szeretném." (D25)

Ezzel szemben - ahogy láttuk - a katalizátor szerepfelfogásban a dékán inkább új irányokat jelöl ki, vagy apropókat teremt, amelyben az új irányok kijelölődnek, és ezeket azután a közösség közösen tölti meg konkrét tartalommal.

Az eddigiekben a katalizátor szerep tartalmát főként a kar és a dékán viszonyában mutattam be. A kar vezetője ugyanakkor középvezető is, ami az innovativitás egy az eddigiektől eltérő kibontakozását is lehetővé teszi. Az innováció ugyanis nem csak a termékekre és kapcsolatokra érvényes, hanem a szervezeti megoldásokra és a belső működésre is, továbbá nem csak a kar és a külvilág vonatkozásában jelenhet meg, hanem az intézményen belül is, például a kar és a központ kapcsolatában is. Ez - legalábbis az interjúk alapján - meghatározó a dékán középvezetői szerepértelmezésében is.

„....ök [a rektorátus] együttmüködnek minden olyan ötletben, ami egyébként nem ellentétes az egyetemi döntésekkel és alapelvekkel, megfelel a szabályzatnak, de hogyha esetleg egy kis kreativitást igényel, ezt... Hogy fogalmazzak? Ez egy olyan kölcsönös munka, vagy együttmüködés, játék, akárminek lehet ezt nevezni, amikor a mi feladatunk ebben azt hiszem az, hogy a problémáinkat... Nem a problémáinkat kell rátolni a rektorátusra, hogy milyen bajaink vannak, hanem nekünk a megoldási javaslatainkat kell odatolni, hogy könnyen dönthessenek. Mert ha csak a problémát toljuk, akkor is könnyen döntenek, csak az nekünk nem olyan jó. Tehát nekünk mindig azon kell egy lépéssel elörébb kell gondolkodni, amikor megkapunk egy olyan utasítást, hogy azt esetleg hogyan lehet úgy végrehajtani, hogy a mi karunkon már ne sújtson nagyobbat, mint amit kéne. Ez viszont nyilvánvaló, hogy a saját szakembereink részéről igényel egy olyan gondolkodásmódot, és hála Istennek, ezzel azért meg vagyunk áldva, mert nagyon sokan átlátják, akik benne vannak ebben a döntési, vezetöi körben, átlátják ezeket a helyzeteket, és nagyon igyekeznek azon, hogy a kar a lehető legkevésbé csorbuljon bármilyen negatív döntés hatására is." (D2)

Mi az, amit a kiinduló modellhez képest megtudtunk? A vállalkozói szervezetfelfogás és a katalizátor szerepnarratíva számos eleme köszönt vissza annál a néhány interjúalanynál, akik a legtöbb hasonlóságot mutatták e megközelítéshez. Ennek ellenére vannak hangsúlyeltolódások, különbségek is. 
Egyrészt a katalizátor szerepnarratíván belül elég világosan szétváltak a szervezetfejlesztő/csapatépítő és a bróker másodlagos szerep képviselői, illetve ezen másodlagos szerepek tartalma is.

Másrészt az interjúk alapján innovációkról kizárólag szervezeti-müködési és oktatási vonatkozásokban volt szó. A kutatást illetően a téma fel sem merült, ami nem meglepő azon adatok fényében, melyek szerint a magyar felsőoktatási intézmények nagy többségének minimális vállalati megbízása van. Általában véve inkább a reménybeli klienseknek (például leendő hallgatóknak, potenciális munkáltatóknak) való megfelelés a domináns müködési logika, és nem nagyon esik szó konkrét megrendelőkröl.

Harmadrészt e megközelítésben a legitimáció forrását a szakirodalom szerint a fogyasztói igények kielégítése és hasznosság jelenti. Azok a dékánok, akiknél ez a megközelítés viszonylag tisztán érvényesült, szinte mind valamilyen kényszerhelyzetröl számoltak be. Ebbe beletartozott a csökkenő hallgatói létszám, illetve egyes bölcsésztudományi karoknál a gyengülő társadalmi legitimáció (mire is jó ezeket a tudományokat tanulni). Egy intézményben az innovativitás a dékáni hatáskörök korlátozottságából, azaz a centralizált intézményi vezetés és a dékán cselekvési vágya, ambíciói közötti feszültségböl táplálkozott. Bizonyos értelemben tehát minden dékán kényszervállalkozóként csöppent bele ebbe a narratívába, és nem csak saját vízióinak megvalósítása miatt.

Negyedrészt, a dékáni beszámolók alapján szó sincs arról, hogy az oktatók „államilag támogatott vállalkozók" lennének. Elvétve kerültek szóba olyan innovációk, szolgáltatások, amelyeket a vállalkozóiság szellemében az oktatók maguk kezdeményeztek és hajtottak volna végre. Egyáltalán nem volt szó az ilyen teljesítmények kapcsán felmerülő problémákról (például arról, hogy a kari erőforrásokkal megvalósított projekt után mi is jár az oktatónak és mi a karnak). Ezek helyett a beszámolókban az volt gyakori, hogy az oktatók közös ötletelés során felvetett javaslatai kari szintű projektté váltak. 


\section{0. Összefoglalás és további nyitott kérdések}

\subsection{A kutatás összefoglalása és eredményei}

Disszertációmban két kérdésre kerestem a választ. Egyrészt arra, hogy milyen szerepe vagy szerepei vannak a dékánoknak a magyar felsőoktatási intézményekben, másrészt arra, hogy hogyan élik meg a dékánok a saját dékáni szerepüket és helyzetüket.

E kérdések központi fogalma a szerep. A szerep nem más, mint elfogadott magatartásminták, viselkedések és attitüdök olyan összetartozónak vélt repertoárja, amely adott pozícióban, státuszban vagy szituációban lévő egyénnel szemben általánosan elfogadott elvárásként jelentkezik (Bailey - Yost [2000]; Turner [2001] 233.0.), és a kutatás célja ezen szerepek tartalmának feltárása volt (kevésbé fókuszáltam a szerepek konstruálódásának folyamatára, ez a választott módszertan keretében nehezen is lett volna feltárható.)

A szerepek tartalmának leírása részben a szakirodalom feltárásával, részben empirikus kutatás segítségével történt.

A disszertáció egyik eredményének tekinthető az a szakirodalom alapján megfogalmazott szerepmodell, amelyet dékán sajátos helyzetének elemzése és a középvezetőkre vonatkozó szakirodalom alapján vezettem le és ágyaztam be a felsőoktatási intézményekre vonatkozó narratívákba (úgymint tudósok közössége, bürokrácia, vállalkozás és az egyetem mint vállalat).

A dolgozat további újdonsága, hogy a dékánok helyzetét nem önmagukban vizsgáltam, hanem igyekeztem reflektálni azok középvezetői szerepére is.

A kiinduló elemzés eredménye négy jól körülírható és narratívákba jól beágyazott szerep megfogalmazása volt, amelyeknek metaforikus neveket adtam (hős, szolgáltató, katalizátor, stratégiai játékos).

Az empirikus kutatás célja ezen szerepek kontextusba helyezése, elmélyítése, szükség esetén újragondolása volt, tehát olyan sürü tartalommal történő felöltése, amellyel érthetöbbé, megragadhatóbbá válnak.

A kutatás egyik pillérét olyan intézményesült struktúrák vizsgálatára jelentette (szabályozás, karrierutak, kiválasztási mechanizmusok), amelyekből a gyakori minták tartalmára tudunk következtetéseket levonni. Ezekböl megállapítható volt, hogy a dékán igen komplex erőtérben választódik ki, azaz sokféle szereplő elvárásai befolyásolják a választási folyamatot, ám az is kijelenthető, hogy a megengedő szabályozás ellenére jellemzően csak egy nagyon erős szakmai és szervezeti (kari) szocializációs folyamat végén válhat valaki dékánná. Ezt támasztják alá a dékáni pozíció választott, ideiglenes jellegére vonatkozó intézményesült elemek és statisztikák, továbbá a dékánok szakmai előéletével és karrierpályájával kapcsolatos elemzések is.

A kutatás másik pillérét az interjúk jelentették. Ezek révén igyekeztem (újra)értelmezni a korábban már megfogalmazott szerepeket, és a visszatérő témák alapján új szerepeket megfogalmazni. Ezeket végül elhelyeztem a kiinduló szerepmodellben is. 
A hős szerepfelfogás középpontjában az áll, hogy az oktatás és kutatás magas szintű művelésével példaképként szolgáljanak a kar többi oktatója számára, s ezzel segítsék a fennálló - elsősorban a tudományt középpontba állító - normarendszer megerősödését. Ebből következően e szerepben a dékán feladata a tudományos értékrend képviselete és megtestesitése. Ennek eszköze nem a kényszerítés vagy az ösztönző struktúrák kialakítása pl. a tudományos teljesítmények előirása révén, hanem olyan támogató kultúra kialakítása, amely segíti az egyének fejlődését, amely segíti a tudomány szeretetének internalizálását. $A$ dékán elsősorban példamutatással, mentorálással vesz részt e folyamatban. Nincs szó tehát beavatkozó, kontrolláló dékáni müködésröl, a teljesítménykényszert maga a kultúra eredményezi, és nem a dékán által felállított és müködtetett kari vezetési rendszerek. Az interjúk alapján azonban látható, hogy a beavatkozás-mentesség csak ideál, amely legtisztábban ott érvényesülhet, ahol már kialakult a tudományos teljesítmények fontosságával kapcsolatos konszenzus. Ahol viszont ez hiányzik, ott a dékánnak szükségszerüen közösségformáló szerepet is vállalnia kell, ami a szervezetfejlesztői irányába is mozdíthatja a dékán szerepét.

A fent megfogalmazott szerepére a dékánt a saját tudományos teljesítménye jogosítja fel. A dékáni tekintély egyik forrása ezért a dékán tudományos kiválósága, ami nem csak meritokratikussá teszi a szervezetet, hanem felértékeli a szenioritás szerepét is. Ez összhangban van a dékánok kiválasztására vonatkozó szabályozási rendszerrel, amely alapvetően az idősebb, pályájuk második felében járó oktatók dékánná válását támogatja. Ennek fényében némileg meglepő, hogy az interjúk során csak elvétve találkoztam olyanokkal, akik e dékáni szerephez hasonló felfogást vallottak volna. Ez a szerep gyakrabban jelent meg olyan kontrasztként, amellyel az interjúalanyok érzékeltetni próbálták a megváltozott körülményeket és a dékán megváltozott feladatait.

A szakirodalom alapján megfogalmazott modellben a szolgáltató dékán szerepe a bürokratikus egyetem szervezeti narratívában fogalmazódik meg, amelyben a kari célok sok szereplő között, lazán strukturált folyamatokban alakulnak ki. Ennek oka, hogy egy-egy kar célstruktúrája a szereplők szándékainak sokszínüségéből és sajátos habitusából adódóan nagyon összetett (ezt az egyik interjúalany a színház és a puzzle kirakós példájával szemléltette). E narratívában a végrehajtás mellett tehát a dékán feladata a „siker lehetőségének biztosítása”, amely a megfelelő háttértámogatás, valamint a munkavégzéshez szükséges környezet megteremtése révén teremthető meg. Ennek elemei közé tartozik bizonytalanság csökkentése, a szabályozottság, a kiszámíthatóság, a stabilitás és a rend biztosítása, a felesleges bürokratikus terhek csökkentése (puffer szerep), valamint a megfelelő munkahelyi légkör megteremtése, az oktatók közötti konfliktusok csökkentése. Ennek megfelelöen három másodlagos szerep bontakozott ki az interjúk alapján. A koordinátor a kar harmonikus müködését azáltal biztosítja, hogy arra törekszik, hogy mindenki megtalálja a helyét a karon. A dékán e szerepben olyan tevékenységek, célok kialakulását segíti, amelyet mindenki el tud fogadni. Ez csökkenti az alapvető konfliktusok kialakulásának esélyét. A dékán a célok kijelölésének folyamatában inkább partnerként vagy javaslattevőként van jelen, a tényleges döntés a kari és egyetemi képviselők, valamint a karon meghatározó emberek kezében van. A problémamegoldó a felmerülő adminisztratív nehézségek elhárítását, megoldását végzi, lehetőség szerint tehermentesitve ezzel az oktatókat. Szerepe döntően reaktív. A tulajdonosok nemcsak közvetítőként vesznek részt a célkijelölési folyamatban (mint a koordinátor), hanem az adminisztratív szakértelmük, a 
megvalósithatóságra és fenntarthatóságra való rálátásuk miatt aktív szereplőként. Biztositanak egyfajta erőforrásszemléletet (ami a stratégiai játékos szerepre is jellemző), másfelöl őrködnek a kialakult szabályok és normák következetes betartásán (pandúr szerep).

A stratégiai játékosok fő jellemzője a szakirodalmi áttekintés alapján a függés, és a kockázat csökkentése az erőforrások feletti kontroll erősítése révén. Ez a célok központosított megfogalmazását és annak kontrollált végrehajtását takarja, ezért a közösség gyakran az irányítás tárgyaként, vagy a feladatok végrehajtóként jelenik meg, a központi cselekvő szereplő e narratívában pedig a dékán (jellemző metaforaként jelenik meg a hajóskapitány, a hadvezér). $A$ narratívát erős célorientáltság jellemzi, valamint az, hogy a kar célja sokszor a dékán céljaival azonositható. Ez egyfelöl lehetővé teszi az erőforrásszemléletet, másfelöl instrumentális logikához vezet, amelyben minden dolog értéke annyi, amennyivel hozzájárul a célok eléréshez.

A dékánok egy csoportjánál a hasznosságszemlélet és a tranzakciós logika nem csak a kar és a környezetének viszonyában értelmeződik, hanem a dékán és környezete viszonyában is (ezt a másodlagos szerepet neveztem el taktikusnak). Ez nem meglepő annak fényében, hogy a kar és a dékán céljai könnyen összemosódnak. Ennek következménye, hogy a dékánságra e dékánok egyfajta játszmaként tekintenek, ahol a környezet támogatókra (lojálisakra) és ellenzőkre (nem lojálisakra) osztható, s ahol az egyet nem értés ellenállásként fogalmazódik meg, amelyet le kell győzni. Az e szerepnarratívát képviselő dékánok interjúiban a „kompromisszum” vagy a „konszenzus” szó alig-alig fordult elö.

A taktikusok esetében az ellenállás kezelésének és célok érvényre juttatásának két nagy eszközrendszere bontakozott ki az interjúk alapján: az erő és a taktikázás. Az erő forrása lehet a dékánsággal formálisan együtt járó felhatalmazások, illetve az erőforrások kontrollja. További fontos erő-eszköz a dékánok kezében a munkáltatói jogosítvány, illetve a kinevezések bizonyos fokú kontrollálása. A vezetői szándékok érvényesítésének másik eszköze a taktikázás és az információk megfelelő kontrollja, tálalása.

$\mathrm{Az}$ interjúk alapján a kiinduló feltevésekhez képest fontos tapasztalat, hogy e szerepnarratívában a dékán külső orientációja nem tünik erősebbnek, mint más narratívákban. Egy-egy kivételtől eltekintve tehát nem a környezeti kihívások, az azokhoz való alkalmazkodás kényszere az, ami igazolja a dékán szerepértelmezését, ebből következően e modell aligha tekinthető válságmodellnek. A külső kényszerek hangsúlyozása helyett sokkal erősebb a dékánok célorientált viselkedése, a sikeréhségük, tennivágyásuk.

Másrészt a szakirodalom alapján a stratégiai játékos dékánt az jellemzi, hogy vezetési rendszereket épít ki, amelyek biztosítják a kulcserőforrások feletti kontrollt és a többi szereplő megfelelő ösztönzését. Ugyanakkor ilyesféle vezetési rendszerek csak egy-egy dékánnál merülnek fel emlités szintjén A narratíva szempontjából ez azt jelenti, hogy a dékánok nem ezeken az eszközökön keresztül értelmezik saját szerepüket, helyzetüket, ami azt is jelenti, hogy a vezetési és irányítási rendszerek nem intézményesültek, hanem erősen személyfüggőek (maradtak?), ami magyarázatot ad arra, hogy az empirikus tapasztalatok alapján e narratívában miért olyan erős a politikai-függési értelmezési séma. Ez indokolja a taktikus másodlagos szerep létjogosultságát is.

A szakirodalom elemzése alapján a katalizátor a vállalkozó egyetemen belül megfogalmazódó dékáni szerepnarratíva. A kiinduló értelmezés szerint a katalizátor dékán fókusza a külső igényekre irányul, amelyben a cél azok feltárása és kielégítése. A másik 
fókuszpontot a humán-fókusz jelenti, azaz e dékánoknál a hangsúly a rugalmasságra, az innovativitásra és az ezt megteremtő közösségi kultúrára, gondolkodásmódra esik. Ezt jól tükrözi az a jelmondat, amellyel az egyik interjú helyszínén az új épület egyik aulájának falán találkoztam: "Mindenki tudja, hogy bizonyos dolgokat nem lehet megvalósítani, mígnem jön valaki, aki erről nem tud, és megvalósítja." A szerepnarratíva központi fogalma tehát az újszerüség, az innováció, amely nem csak új dolgok kitalálását takarja, hanem - az interjúkban sokkal gyakrabban - a dolgok újszerű alkalmazását, összekapcsolását is.

Attól függően, hogy mire is irányul az innováció, két jellegzetes felfogással találkoztam e szerepen belül: az egyik inkább a szervezeti kultúra, a másik pedig a termékportfólió és a kapcsolatrendszer megújítására helyezte a hangsúlyt. Az előbbit ezért belső vállalkozónak (intrapreneur), szervezetfejlesztőnek vagy csapatépitőnek lehet nevezni, míg az utóbbi inkább klasszikus vállalkozónak (entrepreneur) tekinthető, akinek a bróker megnevezést adtam.

A katalizátor felfogás szoros rokonságot mutat a hős szerepnarratívával, amelyben a dékán szintén a közösségi kultúrát, normarendszert helyezi a középpontba. Ami mégis megkülönbözteti tőle, az az, hogy a katalizátor (és különösen a szervezetfejlesztő) dékán nemcsak megőrizni (reprodukálni) akarja a fennálló kultúrát, hanem aktívan alakítani is, azaz szilárd elképzelései vannak a kívánatos müködési módról. A stratégiai játékossal ellentétben azonban az átalakítási kísérleteket nem konkrét célok, hanem távoli víziók, „álmok” vezérlik. Annak, hogy katalizátor dékánnál a célok és feladatok helyett víziók és „álmok” határozzák meg a működést, az a jelentősége, hogy ez lehetővé, sőt, elkerülhetetlenné teszi azt, hogy az ahhoz vezető út kimunkálásába mások is szerepet vállaljanak. A dékán feladata, hogy e folyamatba minél többeket bevonjon és katalizálja mind a párbeszédet, mind a megvalósítást. A közreműködés nem csak kreativitást kíván meg másoktól is, hanem egyben partnerré is teszi őket. Ebböl az is következik, hogy e narratívában nem támogatók és szövetségesek, vagy az egyéni érdekeiket követő, de a realitásokat felismerő, kompromisszumkész emberek vannak, hanem partnerek és közös gondolkodók. Ez teszi lehetővé a kar organikus fejlődését.

Az interjúk alapján a kiinduló elképzelésekhez képest megállapítható, hogy innovációkról kizárólag szervezeti-működési és oktatási vonatkozásokban volt szó. A kutatást illetően a téma fel sem merült, ami nem meglepő azon adatok fényében, melyek szerint a magyar felsőoktatási intézmények nagy többségének minimális vállalati megbízása van. Általában véve inkább a reménybeli klienseknek (például leendő hallgatóknak, potenciális munkáltatóknak) való megfelelés a domináns működési logika, és nem nagyon esik szó konkrét megrendelőkről.

E megközelítésben a legitimációs forrását a szakirodalom szerint a fogyasztói igények kielégítése és hasznosság jelenti. Azok a dékánok, akiknél ez a megközelítés viszonylag tisztán érvényesült, szinte mind valamilyen kényszerhelyzetről számoltak be (csökkenő hallgatói létszám, gyengülö társadalmi legitimáció, dékáni hatáskörök korlátozottsága). Bizonyos értelemben tehát minden dékán kényszervállalkozóként csöppent bele ebbe a narratívába, és nem csupán saját vízióinak megvalósítása miatt.

A dékánok szerepének vizsgálata nem csak arra szolgálhat, hogy a dékánoknak, felsőoktatási szakembereknek reflexiós lehetőséget biztosítson és segítsen tisztázni a saját szerepfelfogását, hanem arra is, hogy következtetéseket vonjunk le a felsőoktatási rendszer alakulását illetően. A dékánok domináns szerepfelfogása ugyani az esetek nagy többségében konfliktusok nélküli volt, azaz nem tapasztaltam azt, hogy maguk más szereppel azonosulnának, 
mint amire lehetőségük van. Ez pedig azt jelenti, hogy a dékánok gondolkodásmódja nagyjából tükrözi az ő müködését konstruáló közösség elvárásait. Ez persze nem meglepő, ha figyelembe vesszük, hogy a dékánok szocializációs folyamata milyen jelentős részben épül a kari kultúra elsajátítására.

Mindebből a felsőoktatás alakulására a következő következtetések vonhatóak le. A kiinduló szerepmodell szerinti hős narratíva ugyan előfordult, de csak nagyon-nagyon ritkán és tisztán csak nagyon kis, stabil és/vagy a szük profilú, homogén karoknál, ahol a teljesítmények megítélése viszonylag egyértelmű. Keveredett a szolgáltató dékáni narratívával (jól megfér egymással a példakép szerep és a konszenzusosságot/kompromisszumot kereső koordinátori szerep), a változásvezetővel (ha épp a tudományosság kultúráját akarja kiterjeszteni) és bizonyos fokig a taktikussal is (amikor a közösségi hős narratíva valójában csak álca). Ha valaha volt is tisztán megtalálható hős szerep (az anekdoták szerint volt), az empirikus kutatásban nem találkoztam vele, ami azt jelenti, hogy a „tudósok közössége” narratíva nem tekinthető domináns értelmezési keretnek.

Az interjúk alapján fontos tapasztalat volt, hogy a vállalkozói szemléletmódnak nem csak a fókusza korlátozott, hanem az elterjedtsége is. Az interjúk többségéből úgy tűnt, hogy a vállalkozóiság inkább esetileg, akkor is csak a képzési programokra koncentrálódva jelenik meg (más tevékenységekre vonatkozóan jellemzően nem), és csak elvétve találkoztam olyan interjúalannyal, aki szervezetfejlesztőként, kultúrafejlesztőként viszonyult volna a feladatához.

Nagyon erősnek és elterjedtnek tűnik a szolgáltató szerep. Ezt tükrözi, hogy ott sokféle másodlagos szerep is megfogalmazódott. Ez arra utal, hogy a bürokratikus szervezeti narratívának van validitása, amit a környezetelemzés komplexitásra vonatkozó következtetései is indokolnak. A felsővezetőkkel készített interjúk általános véleménye is az volt, hogy a dékánok rendben tartják a karokat, de hiányzik belölük a stratégiai orientáció és a külső kapcsolati orientáció.

Újdonságnak számít, de mégsem meglepő, hogy a stratégiai játékos szerepe nem annyira vezetési rendszereket, hanem inkább szervezeti politikát takar. Ezt az eredeti modell sem zárja ki. A meglepő nem a szervezeti politika dominanciája, hanem a vezetési rendszerekben, ösztönzési rendszerekben való gondolkodás hiánya. Általánosságban véve is kijelenthető, hogy gyenge a külső orientáció szerepe. Néhány vidéki intézménynél megjelent ugyan a város mint partner, és a kapcsolatépítés fontossága, de ez a szempont messze nem volt domináns az interjúk során.

A hős és a vállalkozói narratívák gyengesége, és a szolgáltató és stratégiai játékos narratívák erőssége azt mutatja, hogy a dékánság értelmezésében sokkal erősebb szerepe van a feladatorientációnak, mint a kapcsolatorientációnak. A pozíció átalakulása során dominánsabbá válnak az adminisztratív feladatok, a rendszerek és a dékánság formális pozíciójából adódó hatalomforrások. Ez nem jelent ugyanakkor teljes elszakadást a vállalkozói vagy hős narratívától, amelyet egyrészt az ezekkel átfedő jelentős számú másodlagos szerep mutat, másrészt az a tény, hogy a dékánok többnyire fontosnak tartják és hangsúlyozzák az oktatói-kutatói identitásukat is.

Mindez egyérszt összhangban van azzal, amit a magyar felsőoktatás kontextusa kapcsán fogalmaztam meg: az elmúlt években jelentős mértékben nőtt a felsőoktatás komplexitása (a képzések és a hallgatók heterogenitása miatt, az érintettek számának 
növekedése miatt, az intézményi integráció miatt), ugyanakkor a stratégiai szemléletmód, a külső orientáció fokozása inkább csak lehetőségként jelent meg, s nem kényszerként. Másrészt összhangban van a felsőoktatás átalakulásának európai tapasztalataival is: a tisztán adminisztratív, menedzserista gondolkodásmód sehol sem tudott egyértelműen domináns pozíciót kivívni (Chandler, Barry et al. [2002]; Fulton [2003]; Carvalho - Santiago [2010]; Trowler [2010]). Még olyan országokban sem, ahol a környezeti nyomás a magyarországinál egyértelmübben és erősebben kényszerítette (volna) az intézményeket ebbe az irányba (pl. UK).

\subsection{További nyitott kérdések}

Noha a kutatás tervezése során figyelembe vettem, az elemzés során - terjedelmi korlátok miatt - már csak érintőlegesen reflektáltam olyan változók hatására, amelyek pedig befolyással lehetnek a szerepek értelmezésére. Ezek közé tartozik például a szervezetek mérete, a tudományterületi különbségek, az intézmény típusa, az integrációk hatása, a dékán életkora, az eltöltött ciklusok száma stb. Kimaradt a vizsgálatból a változások dinamikája is, például hogy változott-e a dékánok felfogása az első és második ciklusban (egy dékánnál egyértelmű volt, hogy az átalakítási hevületet a második ciklusra felváltotta a tisztességgel ellátandó feladat - a motiváció változott, de változott-e ezzel a szemléletmód?). Számos elemzésre méltó témakörre is csak említés szintjén került sor, noha ezek akár az egyes szerepértelmezések szerves részei is lehettek volna: ilyenek közé tartozik például a tipikus konfliktusok vizsgálata, az integrációk hatása, stb. Ezek továbbelemzése gazdagítaná a dékánok helyzetéről, szerepéről való megértésünket.

A mostani kutatás során inkább a nagyobb körre kiterjedő, de kevésbé mély vizsgálatot céloztam meg. Érdemes lenne azonban egy-egy konkrét intézményt esettanulmányszerüen is megvizsgálni, ahol nem csak a szerepek tartalmának dékáni nézőpontból megfogalmazott tanulmányozására nyílna lehetőség, hanem vizsgálható lenne a többi szereppartner elvárása, viszonyulása is (erre a felsővezetői interjúk elemzése most is lehetőséget adott volna, de a terjedelmi korlátok miatt ezek bemutatására nem került sor). Esettanulmány keretében szintén tanulmányozható lenne a szerepek konstruálódásának folyamata is.

Szintén érdekes adalék lenne a nemzetközi gyakorlatokkal való összehasonlítás, ez azonban más országokban is empirikus kutatásokat igényel. llyenekre az elmúlt egy-két évben már került sor, itt azonban már nem volt lehetőség az összehasonlítása. 


\section{Hivatkozások}

Amaral, Alberto - MeEK, V. LynN - LARSEN, IngVILd M. (szerk.) (2003). The higher education managerial revolution. Higher education dynamics. Dordrecht, Boston, London: Kluwer Academic Publishers.

BAILEY, JAMES R. - YOST, JOHN H. (2000). Role theory: Foundations, extensions, and applications. In: BorgattA, Edgar F. - MONTGOMERY, RHONDA J. V. (szerk.) (2000). Encyclopedia of sociology. New York ; London. 2420-2425.0.

BAKACSI, GYULA (1999). Szervezeti magatartás és vezetés. Budapest: KJK Kerszöv.

BAKACSI, GYULA (2008). Stratégiai emberi erőforrás menedzsment az egyetemek fejlesztési és finanszírozási stratégiájának szolgálatában. Előadás a Budapesti Corvinus Egyetem és a Felsőoktatási Gazdasági Szakemberek Egyesületének közös képzésében. 2008. december 12.

BALDRIDGE, J. VICTOR (1971). Power and conflict in the university. Research in the sociology of complex organizations. New York: John Wiley \& Sons.

BAldRIDGe, J. Victor - CuRTIS, DAVID V. - ECKer, George, et al. (1978). Policy making and effective leadership. A national study of academic management. San Francisco: Jossey-Bass Publishers.

BARAKONYI, KÁROLY (2004a). "Egyetemi kormányzás. Merre tart Európa?" Közgazdasági Szemle 51(6): 584-599.

BARAKONYI, KÁROLY (2004b). Rendszerváltás a felsőoktatásban. Bologna-folyamat, modernizáció. Budapest: Akadémia Kiadó.

BARAKONYI, KÁROly (szerk) (2009a). A Bologna "Hungaricum" - Diagnózis és terápia. Budapest: Új Mandátum Könyvkiadó.

BARAKONYI, KÁROLY (2009b). "Megtorpant intézményirányítási reform." Új Pedagógia Szemle(12): $3-42$.

BARNETT, RONALD (2000). "University knowledge in an age of supercomplexity." Higher Education 40: $409-422$.

BARNETT, RONALD (2003). Beyond all reason. Living with the ideology in the university. Buckingham: Society for Research into Higher Education \& Open University Press.

BARNETT, RONALD (2005). "Convergence in higher education: The strange case of entrepreneurialism." Higher Education Management and Policy 17: 43-58.

BAUER, DÁVID - KOVÁTS, GERGELY (2006). The attractiveness of school leaders' role. In: RÉVÉSz, ÉVA (szerk.) (2006). Improving school leadership in Hungary. OECD country report. Paris: OECD 56-72 0.

BCE (2008): Európai Egyetemi Szövetség Intézményértékelési Program - a Budapesti Corvinus Egyetem Önértékelési Jelentése (2007/2008). Budapest: Budapesti Corvinus Egyetem.

BECHER, TONY (1994). "The significance of disciplinary differences." Studies in Higher Education 19(2): 151-161.

Becher, Tony - Trowler, Paul R. (2001). Academic tribes and territories: Intellectual enquiry and the culture of disciplines. Buckingham: Society for Research into Higher Education \& Open UP.

BELBIN, R. MEREDITH (2010). Management Teams. Why they successful or fail. Elsevir.

Berger, Peter L. - LuCKMANn, Thomas (1998). A valóság társadalmi felépitése. Tudásszociológiai értekezés. Budapest: Jószöveg Műhely Kiadó. 
BESS, JAMES L. (1992). Collegiality: Toward a clarification of meaning and function. In: SMART, JoHN C. (szerk.) (1992). Higher education: Handbook of theory and research. Vol. Viii. New York: Agathon Press. VIII.: 1-36 o.

BESS, JAMES L. - DEE, JAY R. (2008). Understanding college and university organization: Theories for effective policy and practice. Sterling, Va.: Stylus.

BIDDLE, BJ (1986). "Recent developments in role theory." Annual Review of Sociology 12: 67-92.

BidDLE, Bruce J. (2000). Role theory. In: Borgatta, Edgar F. - Montgomery, Rhonda J. V. (szerk.) (2000). Encyclopedia of sociology. New York ; London: Macmillan Reference USA 2415-2420 p.

BIRNBAUM, ROBERT (2001). Management fads in higher education: Where they come from, what they do, why they fail. San Francisco, Calif.: Jossey-Bass.

BLEIKLIE, IVAR (2005). "Organizing higher education in a knowledge society." Higher Education 49: 31-59.

BLEIKLIE, IVAR - Kogan, MAURICE (2007). "Organization and governance of universities." Higher Education Policy 20: 477-493.

BÓKAY, ANTAL (2006). "Tanulási eredmények - a felsőoktatás eszméjének átalakulása a tartalmi tervezésben." Társadalom és Gazdaság 28(2): 243-259.

BokOR, ATTILA (2000): Szervezeti kultúra és tudásintegráció: A termékfejlesztés problémája. PhD disszertáció. Budapesti Közgazdaságtudományi és Államigazgtási Egyetem, Vezetési és Szervezési Tanszék.

BREW, ANGelA (2001). "Conceptions of research: A phenomenographic study." Studies in Higher Education 26(3): 271-285.

BUDA, BÉLA (1997). A szerep fogalma a szociálpszichológiában. In: LENGYEL, ZsUZSANNA (szerk.) (1997). Szociálpszichológia (elektronikus változat). Budapest: Osiris Kiadó 75-81 o.

BURRELL, GIBSON - MORGAN, GARETH (1979). Sociological paradigms and organisational analysis: Elements of the sociology of corporate life. London: Heinemann Educational.

Carvalho, Teresa - Santiago, Rul (2010). „Still Academics After All.” Higher Education Policy 23: 397-411.

ChANDLER, JOHN - BARRY, JiM - ClaRK, HEATHER (2002). "Stressing academe: The wear and tear of the new public management." Human Relations 55(9): 1051-1069.

CLARK, BURTON R. (1983). The higher education system. Academic organization in cross-national perspective. Berkeley: University of California Press.

CLARK, BURTON R. (1997). "Common problems and adaptive responses in the universities of the world: Organizing for change." Higher Education Policy 10: 291-295.

CLARK, BURTON R. (1998). Creating entrepreneurial universities. Organizational pathways of transformation. London: IAU Press \& Pergamon.

CLARK, JOHN - GEWIRTZ, SHARON - MCLAUGHLIN, EUGENE (2000). Reinventing the welfare state. In: ClaRK, JOHN - GeWIRTZ, SHARON - MCLAUGHLIN, Eugene (szerk.) (2000). New managerialism, new welfare? London: Sage 1-26 o.

CLEGG, SUE - MCAULEY, JOHN (2005). "Conceptualising middle management in higher education: A multifaceted discourse." Journal of Higher Education Policy \& Management 27(1): 19-34.

COHEN, MiCHAEL D. - MARCH, JAMES G. (1974). Leadership and ambiguity: The american college president. Hightstown: McGraw-Hill.

Cohen, Michael D. - March, James G. - Olsen, Johan P. (2005/1972). A szervezeti választás szemeteskosár-modellje. In: Szervezeti tanulás és döntéshozatal. Budapest: Alinea Kiadó Rajk László Szakkollégium 103-133 o.

COTE, LAWRENCE S. (1984). Presidential roles: A comparative analysis of their relative importance as perceived by college and university presidents and governing board chairpersons. Annual Meeting of the American Educational Research Association. 
Elérhető:http://www.eric.ed.gov/ERICWebPortal/contentdelivery/servlet/ERICServlet? accno=ED244528 (letöltve 2009. augusztus 12.)

COTE, LAWRENCE S. (1985). "The relative importance of presidential roles." The Journal of Higher Education 56(6): 664-676.

CURRIE, GRAEME (1999). "The influence of middle managers in the business planning process: A case study in the UK NHS." British Journal of Management 10: 141-155.

CURRIE, GRAEME (2000). "The role of middle managers in strategic change in the public sector." Public Money \& Management 20: 17.

CuRRIE, Graeme - Procter, Stephen J. (2005). "The antecedents of middle managers' strategic contribution: The case of a professional bureaucracy." Journal of Management Studies 42(7): 1325-1356.

DAVIES, JOHN L. (1987). "The entrepreneurial and adaptative university." Institutional Management in Higher Education II(1).

DAVIES, JOHN L. (2001). "The emergence of entrepreneurial cultures in European universities." Higher Education Management and Policy 13(2).

De Boer, HarRy - GoedegebuURe, Leo - MeEK, V. Lynn (2010): The Changing Nature of Academic Middle Management: A Framework For Analysis. IN: MEEK, V. LYNN GoedegebuURE, Leo - Santiago, RuI - Carvalho, Teresa (szerk.)(2010): The Changing Dynamics of Higher Education Middle Management. Dordrecht: Springer.

Del FAVERO, M. (2006). "Disciplinary variation in preparation for the academic dean role." Higher Education Research \& Development 25: 277-292.

DERÉNYI, ANDRÁS (2008): A bolognai folyamat célkitüzéseinek magyarországi megvalósítása. Áttekintés. Budapest: Kempus Közalapitvány. http://www.tpf.hu/upload/docs/bologna2/bf_jelentes_hu_v03.pdf

DERÉNYI, ANDRÁS (2009). A magyar felsőoktatás átalakulása 1989 és 2008 között. In: DRÓTOS, GYÖRGY - KovÁTS, GERGELY (szerk.) (2009). Felsőoktatás-menedzsment. Budapest: Aula Kiadó 31-62 0.

Dobák, MiKLÓs - ANTAL, ZSUZSANNA - BALATON, KÁROLY, et al. (1999). Szervezeti formák és vezetés. Budapest: Közgazdasági és Jogi Könyvkiadó.

DOPSON, SUE - RISK, ANNE - STEWART, ROSEMARY (1992). "The changing role of the middle manager in the United Kingdom." International Studies of Management \& Organization 22(1): 40-53.

DOPSON, SUE - STEWART, ROSEMARY (1990). "What is happening to middle management?" British Journal of Management 1: 3-16.

DOPSON, SUE - STEWART, ROSEMARY (1994). "What is happening to middle managers in europe? Problems and promises associated with their changing roles and responsibilities." International Executive 36: 55-78.

DRÓTOS, GYÖRGY (2003): Az oktatási programigazgatóság mint a gazdálkodási önállóság, a szakmai felelösség, és a piaci kontroll természetes találkozási pontja. Háttérelemzés a BKÁE működésfejlesztési bizottságának jelentéséhez. Budapest: Budapesti Közgazdaságtudományi és Államigazgatási Egyetem.

DRÓTOS, GYÖRGY (2009). Integrált szakmai és gazdasági felelősség a felsőoktatási intézményekben - az oktatási programigazgatói modell. In: DRÓTOS, GYÖRGY - KOVÁTS, GERGELY (szerk.) (2009). Felsőoktatás-menedzsment. Budapest: Aula kiadó 109-134 o.

DRUCKER, Peter F. (1988). "The coming of the new organization." Harvard Business Review 66(1): 45-53.

ENGLISH, RICHARD A. (1997). "The deanship as a cross-cultural experience." New Directions for Higher Education(98): 21-29. 
ENGLONER, GY. (szerk) (2008). Kutatás, fejlesztés, pályázatok és programok a felsőoktatásban. Az Oktatási Minisztérium Felsőoktatás-fejlesztési és Tudományos Ügyek főosztályának jelentése a 2006 évről. Budapest: Oktatási és Kulturális Minisztérium.

EngWaLL, LARS - LEVAY, CHARLOTTA - LIDMAN, Rufus (1999). "The roles of university and college rectors." Higher Education Management and Policy 11(2).

ESPELAND, W. N. - SAUDER, M. (2007). Rankings and reactivity: How public measures recreate social worlds. American Journal of Sociology, 113: 1-40.

Estermann, T. - NokKalA, T. (2009): University Autonomy in Europe I. Brussels: European University Association.

ETZKOWITZ, HENRY (1997). The entrepreneurial university and the emergence of democratic corporatism. In: ETZKOWITZ, HENRY - LEYDESDORFF, LOET (szerk.) (1997). Universities and the global knowledge economy. The triple helix of university-industry-government relations. London and Washington: Pinter 141-152 o.

ETZKOWITZ, HENRY (1998). "The norms of entrepreneurial science: Cognitive effects of the new university-industry linkages." Research Policy 27(823-833).

EURYDICE (2000): Two decades of reform in higher education in Europe: 1980 onwards. Brussels: European Commission.

EXPANZIÓ (2011). A magyar felsőoktatás szabályozásának stratégiai megalapozása. Az FTT stratégiai ajánlása a felsőoktatás törvényi szabályozásának előkészítéséhez. Budapest: Felsőoktatási és Tudományos Tanács.

FÁBRI, GYÖRGY (2004): Képzetek és akaratok: A magyar felsőoktatás hosszú évtizede, 19882002. Budapest: Universitas Press Felsőoktatás-kutató Mühely. Elérhető: http://www.univpress. hu/2004/data/ea fabri gyorgy.doc (letöltve 2009. augusztus 12.)

FÁBRI, GY. (2011). "Röpirat a magyar egyetem ügyében." HVG 2011(23).

Floyd, SteVEn W. - LANE, Peter J. (2000). "Strategizing throughout the organization: Managing role conflict in strategic renewal." The Academy of Management Review 25(1): 154-177.

FLOYd, SteVEN W. - WoOLDRIDGE, BILL (1992). "Middle management involvement in strategy and its association with strategic type: A research note." Strategic Management Journal 13: 153167.

Floyd, SteWen R. - WooldRIDGe, BILl (1994). "Dinosaurs or dynamos? Recognizing middle management's strategic role." Academy of Management Executive 8(4): 47-57.

FORGÓ, MELINDA (2008). "Felsőoktatási vezetők karrierútja. Vezetési és irányítási tapasztalatok, készségek empirikus szemüvegen keresztül." Felsőoktatási Mühely 2(4): 97-104.

FULTON, OLIVER (2003). Managerialism in UK universities: Unstable hybridity and the complications of implementation. In: AmARAL, ALbERTO - MEEK, V. LYNN - LARSEN, INGVILD M. (szerk.) (2003). The higher education managerial revolution. Dordrecht, Boston, London: Kluwer Academic Publishers 155-178 o.

FTT (2008). Az OKM és az állami felsőoktatási intézmények között létrejött három éves (20072010) fenntartói megállapodásokban szereplő teljesítménymutatók elemzése és értékelése. Budapest: Felsőoktatási és Tudományos Tanács.

GALLOS, JOAN V. (2002). "The dean's squeeze: The myth and realities of academic leadership in the middle." Academy of Management Learning and Executive 1(2): 174-184.

GELEI, ANDRÁs (2002): A szervezeti tanulás interpretatív megközelítése: A szervezetfejlesztés esete. PhD disszertáció. Budapesti Közgazdaságtudományi és Államigazgtási Egyetem, Vezetési és Szervezési Tanszék.

GELEI, ANDRÁS (2006). "A szervezet interpretatív megközelítése." Vezetéstudomány XXXVIII(különszám): 79-97

GiBBONS, M - LIMOGES, L - NowOtNY, H, et al. (1994). The new production of knowledge. The dynamics of science and research in contemporary societies. London: Sage Publication. 
Gilliot, Danielle - OVerlaet, Bert - Verdin, PAul (2002). "Managing academic personnel flow at universities." Tertiary Education and Management 8: 277-295.

GIOIA, DenNIS A. - ChITTIPEDDI, KUMAR (1991). "Sensemaking and sensegiving in strategic change initiation." Strategic Management Journal 12(6): 433-448.

GmelCH, WalteR H. (1999). The education dean's search for balance. Annual Meeting of the American Association of Colleges for Teacher Education. Washington, DC: Elérhető: www.eric.ed.gov

GMELCH, WALTER H. (2000). The new dean: Taking charge and learning the job. Annual Meeting of the American Associaticn of Colleges for Teacher Education. Chicago, IL: Elérhető: Elérhetö: www.eric.ed.gov (letöltve 2009. augusztus 12.)

GMELCH, WALTER H. (szerk.) (2003). Deans' balancing acts: Education leaders and the challenges they face. washington, DC, American Association of Colleges for Teacher Education.

Gmelch, Walter H. - Wolverton, Mimi - Wolverton, MarVin L. , et al. (1999). "The academic dean: An imperiled species searching for balance." Research in Higher Education 40(6): 717740.

Goedegebuure, Leo - Kaiser, Frans - MaAssen, Peter, et al. (1994). International perspectives on trends and issues in higher education policy. In: GOEDEGEBUURE, LEO - KAISER, FRANS MAASSEn, Peteret al (szerk.) (1994). Higher education policy. An international comparative perspective. Oxford: International Association of Universities and Pergamon Press 315-348 0.

GoRNITZKA, Åse - KYVIK, SVEIN - LARSEN, INGVILD M. (1998). "The bureaucratisation of universities." Minerva 36: 21-47.

GORNITZKA, ÅsE - LARSEN, INGVILD M. (2004). "Towards professionalisation? Restructuring of administrative work force in universities." Higher Education 47: 455-471.

GUMPORT, PATRICIA J. - SPORN, BARBARA (1999). Institutional adaptation: Demands for management reform and university administration. In: SMART, JOHN C. - TIERNEY, WILLIAM G. (szerk.) (1999). Higher education: Handbook of theory and research. Vol. Xiv. New York: Agathon Press. XIV.: 103-145 0.

HAJNAL, GYÖRGY (2004): Igazgatási kultúra és New Public Management reformok egy összehasonlító esettanulmány tükrében. $\mathrm{PhD}$ disszertáció. Budapesti Közgazdaságtudományi és Államigazgatási Egyetem, Közszolgálati Tanszék.

HALÁsz, GÁBOR (2009). A felsőoktatás globális trendjei és szakpolitikai válaszok az OECD országokban és az Európai Unióban. In: DRÓTOS, GYÖRGY - KovÁTS, GERGELY (szerk.) (2009). Felsőoktatás-menedzsment. Budapest: Aula Kiadó 13-30 o.

HALES, CoLIN (2006). "Moving down the line? The shifting boundary between middle and first-line management." Journal of General Management 32(2): 31-55.

HARDY, CYNTHIA (1990). "Strategy and context: Retrenchment in Canadian universities." Organization Studies 11(2): 207-237.

HARDY, CYNTHIA (1991). "Configuration and strategy making in universities: Broadening the scope." The Journal of Higher Education 62(4): 363-393.

HaRdy, CYNTHIA - LANGLEY, ANN - MinTZBERG, HenRY, et al. (1984). Strategy formation in the university setting. In: BESS, JAMES L. (szerk.) (1984). College and university organization: Insights from the behavioral sciences. 169-210 o.

HARMAN, GRANT (2002). "Academic leaders or corporate managers: Deans and heads in australian higher education 1977 to 1997." Higher Education Management and Policy 14: 5877.

HAYES, DENNIS - WYNYARD, RoBIN (szerk.) (2002). The McDonaldization of higher education. Westport (Connecticut) and London, Bergin \& Garvey.

HegedŰs, T. AndRÁs (1997). Pszichológia. Fejlődés, nevelés, szocializáció, pedagógusok. Budapest: Aula Kiadó. 
HenKEL, MaRY (2000). Academic identites and policy change in higher education. London and Philadelphia: Jessica Kingsley Publishers.

HENKEL, MARY (2007). "Can academic autonomy survive in the knowledge society? A perspective from britain." Higher Education Research \& Development 26: 87-99.

HoRVÁTH, M. TAMÁs (2006). Közmenedzsment. Debrecen: Dialóg Campus Kiadó.

HRUBOS, ILDIKÓ (2002). "Differenciálódás, diverzifikálódás és homogenizáció a felsőoktatásban." Educatio 11(1): 96-106.

HRUBOS, ILDIKÓ (szerk.) (2004a). A gazdálkodó egyetem. Budapest, Felsőoktatási Kutatóintézet és Új Mandátum Kiadó.

HRUBOS, ILDIKÓ (2004b). Gazdálkodó egyetem, szolgáltató egyetem, vállalkozói egyetem. In: HRUBOS, ILDIKÓ (szerk.) (2004b). A gazdálkodó egyetem. Budapest: Felsőoktatási Kutatóintézet és Új Mandátum Kiadó 14-33 o.

HRUBOS, ILDIKÓ (2004c). A régi-új gazdálkodási filozófia és gyakrolat. In: HRUBOS, ILDIKó (szerk.) (2004c). A gazdálkodó egyetem. Budapest: Felsőoktatási Kutatóintézet és Új Mandátum Kiadó 126-129 o.

HRUBOS, ILDIKÓ (2006). "A 21. Század egyeteme. Új társadalmi szerződés felé." Educatio 15(4): 665-683.

HRUBOS, ILDIKÓ (2009). A felsőoktatási intézmények szervezetének és irányításának dimenziói. In: BugÁR, GYÖRGY - FARKAS, FERENC (szerk.) (2009). Elkötelezettség és sokoldalúság. Tanulmánykötet Barakonyi Károly tiszteletére. Pécs: Pécsi Tudományegyetem, Közgazdaságtudományi Kar 297-301 p.

HuY, QuY NGUYEN (2001). "In praise of middle managers." Harvard Business Review(September): 72-79.

HYLAND, KEN (1999). "Academic attribution: Citacion and the construction of disciplinary knowledge." Applied Linguistics 20(3): 341-367.

JACKSON, JEANNE (1998). "Contemporary criticisms of role theory." Journal of Occupational Science 5: 49-55.

JACKSON, JERLANDO F. L. (2003). Executive behavior patterns of academic deans. In: GMELCH, WALTER H. (szerk.) (2003). Deans' balancing acts: Education leaders and the challenges they face. washington, DC: American Association of Colleges for Teacher Education 89-97 o.

JACKSON, JeRLANDO F. L. ÉS GMELCH, WALTER H. (2003). "How associate deans' positions are designes within the context of the top 50 colleges and School of Education." Peabody Journal of Education 78(2): 88-110.

JASPERS, KARL (1961/1991). Az egyetem eszméje. In: CSEJTEI, DEZSÖ - DÉKÁNY, ANDRÁS SIMON, FERENC (szerk.) (1961/1991). Ész-élet-egzisztencia I. Egyetem, nevelés, értelmiségi lét. Szeged: Társadalomtudományi Kör 177-308 o.

JOHNSTON, BRUCE D. (1998): The financing and management of higher education: A status report on worldwide reforms. Washington: World Bank.

JONES, SUSAN R. - TORRES, VASTI - ARMINIO, JAN L. (2006). Negotiating the complexities of qualitative research in higher education : Fundamental elements and issues. London: Routledge.

KallenBERG, Ton (2007). "Strategic innovation in HE: The roles of academic middle managers." Tertiary Education and Management 13(1): 19 - 33.

KATZ, D. - KAHN, R. (1966). The social psychology of organizations. . New York: Wiley.

KEKÄLE, JOUNI (1999). "'preferred' patterns of academic leadership in different disciplinary (sub)cultures." Higher Education 37: 217-238.

KEKÄLE, JOUNI (2002). "Conceptions of quality in four different disciplines." Tertiary Education and Management 8: 65-80.

KIESER, ALFRED (2008). Konstruktivista elméletek. In: Szervezetelméletek szöveggyüjtemény. Budapest: Budapesti Corvinus Egyetem 
KIRK, STUART A. (1997). "Getting chalk: Distant reflections on deaning." New Directions for Higher Education(98): 75.

KovÁTS, GeRgely (2009). A dékán vezetői szerepei. In: HRUBOS, ILDIKó (szerk.) (2009). Nfkk füzetek 2. Mühelytanulmányok. Budapest: Nemzetközi Felsőoktatási Kutatások Központja 71-93 0.

KozMA, TAMÁs (2004). Kié az egyetem? Budapest: Új Mandátum Kiadó.

KRAHENBUHL, GARY S. (2004). Building the academic deanship: Strategies for success. Westport, Conn. ; [Great Britain]: Praeger.

KUTROVÁCZ, GÁBOR - LÁNG, BENEDEK - ZEMPLÉN, GÁBOR (2008). A tudomány határai. Budapest: Typotex.

Kvale, SteInAR (2005). Az interjú. Bevezetés a kvalitatív kutatás interjútechnikáiba. Budapest: Jószöveg Múhely kiadó.

LADÁNYI, ANDOR (1999). A magyar felsőoktatás a 20. Században. Budapest: Akadémiai Kiadó.

LAKI, JÁNOS - PALLÓ, GÁBOR (2001). Projektvilág és informális hálózat a tudományban. In: NYíRI, KRISTÓF (szerk.) (2001). A tudományos kommunikáció átalakulása. Budapest: MTA Filozófiai Kutatóintézet

LARSEN, INGVILD M. (2003). Departmental leadership in Norwegian universities - in between two models of governance? In: AmARAL, ALBERTO - MEEK, V. LYNN - LARSEN, INGVILD M. (szerk.) (2003). The higher education managerial revolution. Dordrecht, Boston, London: Kluwer Academic Publishers 71-88 o.

LÉVAI, RÓBERT SÁNDOR (2011): A stratégiai gondolkodás helyzete a magyarországi felsőoktatási intézményekben. In: BORSA, M., HORVÁTH, T. és SIMON, I. (szerk.)(2011): Stratégiai gondolkodás a felsőoktatásban. Budapest: Educatio.

LEYDESDORFF, LOET - ETZKOWITZ, HENRY (2001). "The transformation of university-industrygovernment relations." Electronic Journal of Sociology 5(4): 109-123.

LOCKWOOD, GEOFFREY - DAVIES, JOHN (1985). Universities: The management challenge. Windsor: NFER-Nelson.

Lopata, Helena ZnANieCKA (1995). Social roles \& social institutions: Essays in honor of Rose Laub Coser. In: BLAU, JUDITH R. - GOODMAN, NORMAN (szerk.) (1995). Social roles and social institutions. Transaction Publishers

Lozeau, Daniel - Langley, AnN - Denis, Jeann-Louis (2002). "The corruption of managerial techniques by organizations." Human Relations 55(5): 537-564.

LUKES, SteVen (1974). Power. A radical view. London and Basingstoke: The MacMillan Press.

LYOTARD, JEAN-FRANCOIS (1993). A posztmodern állapot. In: BUJALOS, ISTVÁN (szerk.) (1993). A posztmodern állapot. Jürgen habermas, jean-francois lyotard és richard rorty tanulmányi. Budapest: Századvég Kiadó 7-145 o.

MAghrOORI, RAY - POWERS, ChARLES (2004). "How to choose the right dean for your university. Remembering the five p's of deanship." Change(4): 52-54.

MANTERE, SAKU (2008). "Role expectations and middle manager strategic agency." Journal of Management Studies 45: 294-316.

MARTIN, BEn R. - EtZKowitz, HenRy (2000). "The origin and evolution of the university species." VEST 13(3-4): 9-34.

Martin, Daniel D. - Wilson, Janelle L. (2005). Role theory. In: RitZer, George (szerk.) (2005). Encyclopedia of social theory. Calif. ; London: SAGE 651-654 o.

MARTIN, JUDITH L. (1993). Academic deans: An analysis of effective academic leadership at research universities Elérhetö: http://www.eric.ed.gov/ERICWebPortal/contentdelivery/servlet/ERICServlet?accno=ED36207 $\underline{9}$ (letöltve 2009. augusztus 12.)

MAXWELL, JOSEPH AleX (1996). Qualitative research design: An interactive approach. Thousand Oaks, Calif. ; London: Sage. 
McCarty, Donald J. - Reyes, Pedro (1985). Models of institutional governance: Academic deans' decision-making patterns as evidenced by chairpersons. Annual Meeting of the Association for the Study of Higher Education, Chicago, IL.

MCNAY, IAN (1995). From the collegial academy to corporate enterprise: The changing cultures of universities. In: SCHULLER, TOM (szerk.) (1995). The changing university? London: Society for Research into Higher Education 105-115 o.

MCNAY, IAN (2003). The e-factor and organization cultures in british universities. In: WILLIAMS, GARETH (szerk.) (2003). The enterprising university. Reform, excellence and equity. Buckingham: SHRE \& Open university Press 20-28 o.

MECH, TERRENCE (1997). "The managerial roles of chief academic officers." The Journal of Higher Education 68(3): 282-298.

MERTON, ROBERT K. (1946/2002). A tudomány és a demokratikus társadalmi struktúra. In: Társadalomelmélet és társadalmi struktúra. Budapest: Osiris 634-644 o.

MERTON, ROBERT K. (1968/2002). Társadalomelmélet és társadalmi struktúra. Budapest: Osiris Kiadó.

MÉSzÁROS, T. (2012). Gondolatok a magyar felsőoktatásról szóló vitákhoz. In: TEMESI, J. (szerk)(2012): Felsőoktatás-finanszírozás. Nemzetközi trendek és hazai gyakorlat. megjelenés alatt.

MIDDLEHURST, ROBIN (1993). Leading academics. Buckingham: The Societyfor Research into Higher Education \& Open University Press.

MignOT-GÉRARD, StÉPHANIE (2003). "'Leadership" And "Governance" In the analysis of university organisations: Two concepts in need of de-construction." Higher Education Management and Policy 15: 152-183.

Miles, Matthew B. - Huberman, A. Michael (1994). Qualitative data analysis: An expanded sourcebook. Thousand Oaks, Calif. ; London: Sage.

MILlER, HeNRY (1995). The management of change in universities: Universities, state and economy in australia, canada and the united kingdom. Buckingham: The Society for Research into Higher Education and Open University Press.

MinTZBERG, HenRY (1971). "Managerial work: Analysis from observation." Management Science 18(2): B97-B110.

MintZBERG, HenRy (1975). "The manager's job: Folklore and fact." Harvard Business Review(4): 49-61.

MintZBerg, HenRy (1981). "Organizational design, fashion or fit?" Harvard Business Review 59(1): 103-116.

MintzBeRG, HenRY (1991). The structuring of organizations. In: MinTZBERG, HenRY - QuinN, JAMES BRIAN (szerk.) (1991). The strategy process: Concepts, contexts, cases. Prantice Hall 330-350 0.

MOORE, KATHRYN M. (1983): The top-line: A report on presidents', provosts', and deans' careers. Leaders in transition: A national study of higher education administrators. Pennsylvania State University, Center for the Study of Higher Education, University Park, PA. Elérhetö: http://www.eric.ed.gov/ERICWebPortal/contentdelivery/servlet/ERICServlet?accno=ED23130 1 (letöltve 2009. augusztus 12.)

Moore, Kathryn M. - Salimbene, Ann M. - Marlier, Joyce D., et al. (1983). "The structure of presidents' and deans' careers." The Journal of Higher Education 54(5): 500-515.

MOSES, INGRID (1992). Leadership: Deans and heads of departments. In: CLARK, BURTON R. NeAVE, GuY (szerk.) (1992). Encyclopedia of higher education. Oxford: Pergamon Press. 3: 1390-1397 p.

NAGY, PÉTER TIBOR (2003). The academic workplace. Country report: Hungary. In: ENDERS, JÜRGEN - DE WEERT, EgBeRT (szerk.) (2003). The international attractiveness of the 
academic workplace in Europe. Frankfurt/Main: Gewerkschaft Erziehung und Wissenschaft 200-226 o.

NAGY, PÉTER TIBOR (2007). "Négy lehetséges kutatás a felsőoktatókról." Educatio 17(3): 434-452.

NEAVE, GuY (2003). On the return from babylon: A long voyage around history, ideology and systems change. In: FILE, JON - GoedeGeBUURE, LEO (szerk.) (2003). Real-time systems. Reflections on higher education in the czech republic, hungary, poland and slovenia. Enschede: Center for Higher Education Policy Studies, University of Twente 15-37 o.

NeAVE, Guy (2006). "Redefining the social contract. Editorial." Higher Education Policy 19: 269286.

Neumann, Anna - Bensimon, Estela M. (1990). "Constructing the presidency: College presidents' images of their leadership roles, a comparative study." The Journal of Higher Education 61(6): 678-701.

NeUMANN, RUTH (1993). "Research and scholarship: Perceptions of senior academic administrators." Higher Education 25(2): 97-110.

Neumann, Ruth - PARRY, Sharon - Becher, Tony (2002). "Teaching and learning in their disciplinary contexts: A conceptual analysis." Studies in Higher Education 27(4): 405-417.

Newsome, Clarence G. (1997). "What does a dean do?" New Directions for Higher Education: 101.

NiCHOLSON, N (1984). "A theory of work role transitions." Administrative Science Quarterly 29: 172-191.

NYíRI, KRISTÓF (2005). "Szavaktól képekig: A tudomány új egysége." Magyar Filozófiai Szemle 2005(3): 381-410.

OKTATÁSI MINISZTÉRIUM (2003). A magyar felsőoktatás modernizációját, Az Európai Felsőoktatási Térséghez történő csatlakozását célzó felsőoktatás-fejlesztés koncepciója. Vitaanyag. Budapest: Oktatási Minisztérium.

OECD (2008): Thematic review of tertiary education: Synthesis report. Paris: OECD.

PARKER, MARTIN - JARY, DAVID (1995). "The McUniversity: Organization, management and academic subjectivity " Organization 2(2): 319-338.

PATTERSON, GLENYS (2001). "The applicability of institutional goals to the university organisation." Journal of Higher Education Policy \& Management 23(2): 159-169.

PeEke, Graham (1994). Mission and change. Institutional mission and its application to the management of further and higher education. London: Society for Research into Higher Education.

Pfeffer, Jeffrey - Salancik, Gerard R. (1974). "Organizational decision making as a political process: The case of a university budget." Administrative Science Quarterly 19(2): 135-151.

POKOL, BÉLA (2004). A tudomány mint professzionális intézményrendszer. In: (szerk.) (2004). Szociológiaelmélet. Társadalomtudományi trilógia i. Budapest: Századvég Kiadó 200-226 0.

POLÓNYI, ISTVÁN (2009a). A magyar felsőoktatás finanszírozása a korai 2000-es években. In: BERÁCS, JÓzSEF - HRUBOS, ILDIKÓ - TEMESI, JÓzSEF (szerk.) (2009). Magyar felsőoktatás 2008. Konferencia-előadások. Budapest: Budapesti Corvinus Egyetem, Nemzetközi Felsöoktatási Kutatások Központja 88-112 0.

PolóNYI, I. (2009b). "A hazai felsőoktatás gazdasági működése, szerveződése és vezetése a 2000-es évek legelején." Új Pedagógia Szemle(8-9): 3-26.

PolónYI, I. (2009c). Világszínvonalon - mint a magyar futball? A hazai akadémiai szféra nemzetközi összehasonlításban. In: PoLóNYl, I. (szerk)(2009c): Az akadémiai szféra és az innováció. A hazai felsőoktatás és a gazdasági fejlődés. Budapest: Új Mandátum Kiadó. 5579. 0.

PoLÓNYI, I. (2012). Hazai felsőoktatás állami finanszírozásának története 1990-2011. In: TEMESI, J. (szerk)(2012): Felsőoktatás-finanszírozás. Nemzetközi trendek és hazai gyakorlat. megjelenés alatt 
Polzer, Jeffrey T. (1998). Role. In: NiCHOLson, Nigel (szerk.) (1998). The blackwell encyclopedic dictionary of organizational behavior. Cambridge, Mass. ; Oxford: Blackwell Business 495-498 0.

Poór, J., LÁszló, G., BencsiK, A., FekETE, I. És MAJó, Z. (2009). Az egyetemi HR-rendszerek továbbfejlesztésének lehetősége egy empirikus felmérés tapasztalatainak tükrében.In: Drótos, Gy. és Kováts, G. (szerk)(2009): Felsőoktatás-menedzsment. Budapest: Aula. 199229. 0.

Prichard, Craig - Willmott, Hugh (1997). "Just how managed is the McUniversity?" Organization Studies 18(2): 287-316.

READINGS, BILL (1996). The university in ruins. Cambridge (Ma.) and London: Harvard University Press.

REED, MICHAEL I. (2001). New managerialism, professional power and organisational governance in uk universities: A review and assessment. In: AmARAL, AlBerto - JONES, Glen A. KARSETH, BERIT (szerk.) (2001). Governing higher education: National perspectives on instituional governance. Kluwer Academic Publisher 163-185 o.

ReISz, RoBERT D. (2003). "Izomorfizmus, konfliktus és kreativitás. A közép és kelet-európai felsőoktatás az 1990-es években." Educatio 12(1): 19-32.

RITZER, GEORGE (2002). Enchanting mcuniversity: Toward a spectacularly irrational university quotidian. In: HAYES, DENNIS - WYNYARD, ROBIN (szerk.) (2002). The mcdonaldization of higher education. Westport (Connecticut) and London: Bergin \& Garvey 19-32 0.

ROSSER, VICKI J. - JOHNSRUd, LINDA K. - HECK, RONALD H. (2003). "Academic deans and directors: Assessing their effectiveness from individual and institutional perspectives." The Journal of Higher Education 74(1): 1-25.

RouRKe, Francis E. - BROOKS, GlenN E. (1964). "The "Managerial revolution" In higher education." Administrative Science Quarterly 9(2): 154-181.

Santiago, RuI - Carvalho, Teresa - Amaral, Alberto, et al. (2006). "Changing patterns in the middle management of higher education institutions: The case of portugal." Higher Education 52(2): 215-250.

SAUDER, M. - ESPELAND, W. N. (2009). The discipline of rankings: Tight coupling and organizational change. American Sociological Review. 74: 63-82.

SCHERER, ANDREAS GEORG (2008). Szervezetkritika vagy szervezett kritika? - tudományelméleti megjegyzések a szervezetelméletek kritikus alkalmazásához. In: Szervezetelméletek szöveggyüjtemény. Budapest: Budapesti Corvinus Egyetem

SCOTT, PETER (2006). Higher education in central and eastern europe. In: FOREST, JAMES J. F. ALTBACH, PHILIP G. (szerk.) (2006). International handbook of higher education. Dordrecht: Springer. 2: 423-442 0.

SCOTT, W RICHARD (1995). Institutions and organizations. Thousand Oaks (Ca.): Sage Publication.

SEMJÉN, ANDRÁS (2004). Finanszírozási csatornák. Állami támogatások a felsőoktatásban. In: TEMESI, JÓzSEF (szerk.) (2004). Finanszírozás és gazdálkodás a felsőoktatásban Budapest: AULA Kiadó 79-223 o.

SEREg AndRÁs (2008): Interjú Mezey Barnával. In: Habemus Decanum. Interjúk a jogi és igazgatási karok principálisaival. Budapest: De Jure könyvek. 45-57.0.

SETÉNYI, JÁNOS (2008). Hol tart ma a felsőoktatási reform? Előadás a Menedzsmentkultúra a felsőoktatásban III.címá konferencián. Budapest, ELTE PPK. 2008. május.

SIMPSON, BARBARA - CARROLL, BRIGID (2008). "Re-viewing 'role' in processes of identity construction." Organization 15(1): 29-50.

SIMSEK, HASAN - LOUIS, KAREN SEASHORE (1994). "Organizational change as paradigm shift: Analysis of the change process in a large, public university." The Journal of Higher Education 65(6): 670-695. 
Slaughter, Sheila - Leslie, Larry L. (1997). Academic capitalism. Politics, policies and the entrepreneurial university. Baltimore and London: John Hopkins University Press.

SLAUGHTER, SHEILA - RHOADES, GARY (2004). Academic capitalism and the new economy. Baltimore and London: John Hopkins University.

SMEBY, JENS-ChRISTIAN (1996). "Disciplinary differences in university teaching." Studies in Higher Education 21(1): 69-79.

SMEBY, JENS-CHRISTIAN (2000). "Disciplinary differences in norwegian graduate education." Studies in Higher Education 25(1): 53-67.

SPORN, BARBARA (2006). Governance and administration: Organizational and structural trends. In: FOREST, JAMES J. F. - AltBACH, PHILIP G. (szerk.) (2006). International handbook of higher education. Dordrecht: Springer 141-157 0.

Strauss, A.L. - CORBIN, J. (1990): Open coding. In: StRauss, A.L. - CoRBIN, J. (szerk): Basics of qualitative research. London: Sage. 61-74. 0.

STRYKER, SHELDON (2001). Traditional symbolic interactionism, role theory, and structural symbolic interactionism the road to identity theory. In: TURNER, JONATHAN H. (szerk.) (2001). Handbooks of sociology and social research. New York ; London: Kluwer Academic/Plenum Pub 211-231 0.

StRYKER, SHELDON - VRYAN, KeVIn D. (2006). The symbolic interactionist frame. In: DeLAMATER, JoHN D. (szerk.) (2006). Handbook of social psychology. New York, NY: Springer 3-28 o.

TAYLOR, JOHN (2006). "'Big is beautiful." Organisational change in universities in the united kingdom: New models of institutional management and the changing role of academic staff." Higher Education in Europe 31: 251-273.

TEICHLER, ULRICH (2001). "Az európai felsőoktatási reformok főbb kérdései. Egy felsőoktatáskutató véleménye." Educatio: 3-18.

TEICHLER, ULRICH (2003). "The future of higher education and the future of higher education research." Tertiary Education and Management 9: 171-185.

THOM, NORBERT - RITZ, ADRIAN (2005): „Public management: Egy innovatív koncepció az állami szektor vezetésére." Vezetéstudomány. XXXVII(7-8): 21-30.

ThOMAS, RoBYN - Dunkerley, DAVID (1999). "Careering downwards? Middle managers experiences in the downsized organization." British Journal of Management 10: 157-169.

TIERNEY, WILLIAM G. (1988). "Organizational culture in higher education: Defining the essentials." The Journal of Higher Education 59(1): 2-21.

TóтH, TAMÁs (szerk.) (2001). Az európai egyetem funkcióváltozásai: Felsõoktatástörténeti tanulmányok. Budapest, Professzorok Háza.

TROW, MARTIN (1994). "Managerialism and the academic profession: The case of England." Higher Education Policy 7(2): 11-18.

TROWLER, PAUL R. (1998). Academic responding to change. New higher education frameworks and academic cultures. Buckingham: The Society for Research into Higher Education \& Open University Press.

TROWLeR, PAUL R. (2001). "Captured by the discourse? The socially constitutive power of new higher education discourse in the uk." Organization 8: 183-201.

TROWLER, PAUL R. (2010). UK Higher Education: Captured by New Managerialist Ideology? In: Meek, V. L., Goedeggebuure, L., Santiago, R. és Carvalho, T. (szerk)(2010): The Changing Dynamics of Higher Education Middle Management: Springer.

TuRner, RalPH H. (1990). "Role change." Annual Review of Sociology 16: 87-110.

TURNER, RALPH H. (2001). Role theory. In: TURNER, JONATHAN H. (szerk.) (2001). Handbooks of sociology and social research. New York ; London: Kluwer Academic/Plenum Pub 232-254 o.

TwOMBLY, SUSAN B. (1992). "The process of choosing a dean." The Journal of Higher Education 63(6): 653-683. 
UYTERHOEVEn, Hugo (1989/1972). "General managers in the middle." Harvard Business Review 67(5): 136-145.

VARGA, JÚLIA (1998). Oktatás-gazdaságtan. Budapest: Közgazdasági Szemle Alapítvány.

VÁRINÉ, SZILÁGYI IBOLYA (1994). "G. H. Mead eredeti szerepfogalma és késõbbi változásai." Szociológiai Szemle(4): 3-20.

Veblen, ThORSTEN (1918). The higher learning in America: A memorandum on the conduct of universities by business man.

WALFORD, GEOFFREY (1987). Restructuring universities: Politics and power in the management of change. Beckenham: Croom Helm Ltd.

WeICK, KARL E. (1976). "Educational organizations as loosely coupled systems." Administrative Science Quarterly 21(2): 1-19.

WestLeY, Frances R. (1990). "Middle managers and strategy: Microdynamics of inclusion." Strategic Management Journal 11: 337-351.

WolLNIK, MICHAEL (1995). Interpretatív megközelítések a szervezetelméletben. In: KIESER, ALFRED (szerk.) (1995). Szervezetelméletek. Budapest: Aula Kiadó 359-383 o.

Wolverton, Miml - GmelCh, Walter H. - Montez, J. , et al. (2001). The changing nature of the academic deanship. San Francisco: Jossey-Bass.

Wolverton, Mimi - GMelCh, WALTER H. (2002). College deans: Leading from within. Westport, Conn.: Oryx Press.

Wolverton, Miml - GonZAles, MARY Jo (2000). Career paths of academic deans. .rmnual Meeting of the American Educational Research Association. New Orleans, LA: Elérhető: www.eric.ed.gov (letöltve 2009. augusztus 12.)

Wolverton, Mimi - Wolverton, Marvin L. - Gmelch, Walter H. (1999). "The impact of role conflict and ambiguity on academic deans." The Journal of Higher Education 70(1): 80-106.

YLIJOKI, OILI-HELENA (2000). "Disciplinary cultures and the moral order of studying - a case-study of four finnish university departments." Higher Education 39(3): 339-362. 


\section{Mellékletek}

\section{A dékánokkal készített interjúk vázlata}

\section{Bővített interjúvázlat (2010 júliusi változat)}

Az interjúk készítése során a bővített vázlat fedte le az összes érdeklődési területet. Ezt azoknál tudtam alkalmazni, akik hosszabb ideig álltak rendelkezésre.

\section{Az interjú indítása}

- Bemutatkozás

- Az interjú célja, menete és időtartama

- A rögzítés módjának tisztázása (diktafon, jegyzetelés, háttérbeszélgetés), engedélykérés

- anonimitás

\section{Az interjú tartalmi részei}

Háttér, motivációk

- Mióta dolgozik a felsőoktatásban? Miért ezt a pályát választotta?

o Mivel foglalkozott eddig, milyen pozíciókat töltött be?

- Mikor és hogyan lett dékán? Miért lett dékán?

o Mit gondol, melyek voltak azok a jellemzők, tényezők, amelyek miatt Önt választották dékánnak?*

o Milyen volt a választás folyamata?

Szervezeti narratíva feltárása

- Milyen (szervezeti és egyéni) célkitüzései voltak a dékánság kezdetén?

- Milyen jövőképe van a kart illetően? Milyen kart szeretne látni 10 év múlva?

o Milyen kart/egyetemet szeretne látni 10 év múlva? Milyen a kar és egyetem ideális viszonya? Milyen a kar helyzete az egyetemen (más karokhoz képest)? Ön mit gondol arról a vitáról, hogy „az egyetemnek vannak karai, és nem a karoknak van egyeteme?"

Szerepértelmezés, önértelmezés

- A jövőkép és a célok megvalósításában mi múlik Önön (mint dékánon)?

o Ön hogyan értelmezi a saját szerepét a karon és az egyetemen?

- Ezt mások is így gondolják?

o Megitélése szerint az intézmény többi szereplője is így értelmezi az Ön szerepét, vagy másféle elvárásokkal rendelkeznek? Jelent-e nehézséget az Ön számára a szerep-értelmezések különbsége?

- Milyen a jó dékán Ön szerint (ezen a karon)? Van-e, volt-e olyan példakép (minta), amelyet dékánként követ? Mitől volt ő példakép? Hogyan jellemezhető?

- Készült-e a dékánságra a kinevezése elött vagy után? 
- Ön szerint van-e sajátossága, egyedisége dékánnak lenni ezen a karon az intézmény más karaihoz képest? És más intézményekhez hasonló karaihoz képest?

o Mit gondol, férfiként/nőként más lenne dékánként a helyzete, lehetőségei, szerepe?

o Változott-e a dékán szerepe az időben? Ön mit csinál(na) másként, mint a dékán elödei? Miért?

- Mennyiben és miben különbözik a dékáni pozíció azoktól a vezetői pozícióktól, amelyekkel már volt tapasztalata (pl. ha volt tanszékvezetö)?

Történetiség, kritikus események, konfliktusok

- Melyek voltak dékáni pályafutásának csúcspontjai és a mélypontjai? Melyek voltak a kritikus események?

o Milyen tipikus konfliktusok, feszültségeket tapasztal meg dékánként a munkájában? Miből fakadnak ezek?*

o Dékáni pályafutása alatt volt-e olyan döntés, feladat, amelyekkel nehezen tudott azonosulni? Miért?*

o Dékáni pályafutása alatt volt-e olyan szituáció, amikor úgy érezte, hogy jobb lenne bizonyos információkat elhallgatni mások elől? Miért? (Jellemzően kik elöl? Rendszeres-e ez a helyzet?)

o Mi volt az az alkalom, amikor a legkevésbé érezte magát felkészültnek a feladatainak az ellátásra? Miböl fakadt ez? Hogyan kezelte a helyzetet?

Hogyan tud úgy felelősséget vállalni, ha valamihez nem ért eléggé? Mit tesz ez ellen?

Kapcsolat más szereplőkkel, érzékelt elvárások

- Értékelje iskolai osztályzattal, hogy véleménye szerint mennyire elégedett Önnel a rektor/a tanszékvezetők/a központi adminisztráció vezetői/a kari adminisztráció tagjai/az oktatók/a párja, házastársa/önmaga? Miért gondolja így? Mitől függ az egyes szereplők elégedettsége?

o A szereplök közül kinek tartozik felelösséggel, elszámolási kötelezettséggel?*

o Mondható-e, hogy a dékán „fönöke” a tanszékvezetőknek, oktatóknak? Ha nem, miért nem? Ha igen, akkor mit jelent ez? Milyen mértékben képes befolyásolni a tanszékvezetőket? Miből fakad a befolyás (hiánya)?

o Milyen munkamegosztás érvényesül a dékán, a helyettesei és az adminisztráció között? Mennyire kiszolgáltatott nekik a dékán?

o A dékánoknak van rektora vagy a rektor vannak dékánjai?

o Milyen módon befolyásolja a magánéletét a dékáni pozíció? Mire jut ideje és mire nem? Hogyan viszonyul a családja ahhoz, hogy dékán?

o Mennyiben felelt meg a dékánság előzetes elvárásainak? Valóban azt kell csinálni, amire számított? Van-e olyan aspektusa a munkájának, amelyre nem vagy nem így számított?

- Miből tudja, hogy „jó” dékán-e? Kap-e őszinte visszajelzést? Kitől kap? Ki az, akitől nem kap, de szeretne kapni?

o Kiktől kap támogatást abban, hogy a dékánsággal járó feladatokat megfelelő módon lássa el?

o Milyen támogatásra lenne még szüksége Önnek mint dékánnak? Mi az akadálya annak, hogy megkapja ezt a támogatást?

0 Kiben bízik? Fontos kérdés-e a bizalom az intézményben?* 
Hétköznapok, tevékenységek, kapcsolat más szerepekkel/pozíciókkal (szerepértelmezés), jövő

- Létezik-e tipikus munkanapja? Ha igen, miben áll ez?

o Le tudná írni, hogy milyen tipikus feladatokat, tevékenységeket végez?

o Mely feladatokban leli leginkább örömét? És melyekben legkevésbé?

o Milyen mértékben képes befolyásolni az ellátandó feladatokat és a saját napirendjét? Ha van, akkor miböl fakad a kényszer?

- Hogyan befolyásolja a dékánság a szakmai karrierjét a jövőben? Erősíti? Gyengíti? miért?

o Végez-e tudományos munkát? Oktat? Mennyit? Publikál? Mennyit? Szeretne? Miért nem csinálja?

o Mennyiben tekinti magát oktatónak (a közösség része) és mennyiben a közösségen kívülálló vezetőnek?

- A dékánsággal egyidejüleg milyen egyéb pozíciókat tölt be? Hogyan illeszkednek ezek a dékáni pozícióhoz? (Vannak-e szinergiák, érdekkonfliktusok stb.)

o Ha a dékáni pozícióval együtt tanszékvezető is, hogyan befolyásolja a dékáni munka a tanszékvezetőit? Miért csinálja mindkettőt? Mi a kettősség előnye/hátránya? Milyen különbség van tanszékvezetőnek lenni és dékánnak lenni között?

- Milyen tervei vannak a jövőre nézve? mennyiben segíti ezek elérését, hogy dékán volt, és mennyiben hátráltatja? Miért?

\section{Az interjú lezárása}

- van-e kérdése az interjúval kapcsolatban

- későbbi kapcsolatfelvétel

\section{Az egyszerűsített interjúvázlat (2010. november 22-ei változat)}

Az idő rövidsége miatt az interjúk többségénél a rövidített interjúvázlatot használtam, ahol a kérdéseket vezető kérdésekre és alkérdésekre tagoltam. Arra törekedtem, hogy a vezető kérdések által lefedett területeket minden esetben lefedjem az adott interjúalannyal, az alkérdésekre már ritkábban került sor.

1. Mikor és hogyan lett dékán? Miért lett dékán?

o Miért Önt választották meg dékánként? Kiből lesz dékán ezen a karon?

o Mi a dékánság hátránya? Miről kell lemondani? Akkor mégis miért lett dékán?

o Hogyan befolyásolja a dékánság a szakmai karrierjét? Erősíti? Gyengíti? miért? Mekkora az oktatói terhelése, az oktatás fontossága? Miért? Miért éri meg mégis a dékánság?

2. Mit csinál, mi az Ön feladata (dékánként)?

o miben leli örömét, és miben nem?

o mi az, amit csinálna vagy csinálnia kellene, de nem csinál? Miért nem?

o Van-e olyan aspektusa a munkájának, amelyre nem vagy nem így számított?

3. Van-e, volt-e olyan példakép (minta), amelyet dékánként követ? Mitől volt ő példakép? Hogyan jellemezhetö?

o Milyen a jó dékán Ön szerint (ezen a karon)?

o Mit kell tudnia egy dékánnak, milyen kompetenciákkal kell rendelkeznie? Miért?

o Van-e sajátos feladat, vagy szokás, ami az itteni dékánt jellemzi? 
4. Melyek voltak eddigi dékáni pályafutásának csúcspontjai és a mélypontjai? Melyek voltak a kritikus események?

o hogyan szeretné látni akart 5 év múlva? Mikor lenne elégedett a dékánság végével?

o Mi múlik a dékánon ezek elérésében, megvalósításában?

o milyen eszközöket, megoldásokat használ a kar vezetésére? Mi az, amit szeretne használni, de nem használhat? Miért?

5. Milyen tipikus konfliktusok, feszültségeket tapasztal meg dékánként a munkájában? Miböl fakadnak ezek?

o mire vagy kire támaszkodhat a dékán e konfliktusokban?

o mi hiányzik, milyen támogatást hiányol? Miért?

6. Dékáni pályafutása alatt volt-e olyan döntés, feladat, amelyekkel nehezen tudott azonosulni? Miért?

7. Mi volt az az alkalom, amikor a legkevésbé érezte magát felkészültnek a feladatainak az ellátásra? Miből fakadt ez? Kire/mire tudott támaszkodni? Hogyan kezelte a helyzetet?

8. Nőiség/Férfiség: Más lenne a helyzete, mozgástere, szerepe dékánként, ha nő/férfi lenne?

9. Milyen tervei vannak a jövőre nézve? mennyiben segíti ezek elérését, hogy dékán volt, és mennyiben hátráltatja? Miért? 


\section{Az intézményi felső vezetőkkel készített interjúk vázlata}

Az alábbi interjúvázlat a 2011. április 7-ei verziót tartalmazza.

\section{Az interjú indítása}

- Bemutatkozás

- Az interjú célja, menete és időtartama

- A rögzítés módjának tisztázása (diktafon, jegyzetelés, háttérbeszélgetés), engedélykérés

\section{Életút}

- Mióta dolgozik a felsőoktatásban? Mivel foglalkozott eddig, milyen pozíciókat töltött be?

- Volt-e dékán? Dolgozott-e dékánként?

- Miben más dékánnak lenni, mint rektornak?

- Mennyiben és miben különbözik a dékán mint vezető más vezetői szinteken lévő vezetőktől (pl. tanszékvezetőktöl)?

\section{A dékán szerepe, feladata, felelőssége, hatásköre, kompetenciái}

- Miért jöttek létre/hozták létre karokat az intézményben?

- Milyen intézményt szeretne látni 10 év múlva?

- Mi múlik a dékánokon Ön szerint ennek megvalósításáért? Mi a dékánok felelőssége? Mi nem a dékánok felelőssége?

- A dékán kinek tartozik felelösséggel, elszámolási kötelezettséggel?

- Mi korlátozza, akadályozza a dékánokat ennek megvalósításában? Milyen belső, intézményi tényezők? Miért állnak ezek fent?

- (Nem szükséges nevesíteni, de) Ön szerint van-e az intézményben olyan kar, amely müködés, siker szempontjából kiemelkedik a többi kar közül? Miért? Mennyiben múlik ez a dékánon? Miben más a dékán ott, mint a többi karon?

- Ön milyen dékánnal dolgozna együtt szívesen? Miért? llyenek itt a dékánok? Min múlik ez?

- Milyen szempontok szerint értékeli/értékelné a dékánok teljesítményét?

o Pályafutása alatt találkozott olyan dékánnal, akiről úgy gondolta, hogy jó dékán? Milyen volt ő? Mi olyat csinált, amit mások nem?

\section{Férfiség, nőiség}

- Mások-e a férfi dékánok, mint a női dékánok? Miben? 


\begin{tabular}{|l|l|l|}
\hline & $\begin{array}{l}\text { Az intézmény (Ön) } \\
\text { szempontjából } \begin{array}{r}\text { Az intézmény (Ön) } \\
\text { tevékenység, amivel a } \\
\text { dékánnak foglalkoznia } \\
\text { kell(ene) }\end{array}\end{array}$ & $\begin{array}{l}\text { szempontjából nem } \\
\text { fontos tevékenység }\end{array}$ \\
\hline $\begin{array}{l}\text { Dékánok sokat (eleget) } \\
\text { foglalkoznak vele }\end{array}$ & & \\
\hline $\begin{array}{l}\text { Dékánok nem } \\
\text { (sokat/eleget) } \\
\text { foglalkoznak vele }\end{array}$ & & \\
\hline
\end{tabular}

- van-e különbség a dékánok között e tekintetben? Min múlik a különbség?

\section{Támogatás}

- Hogyan lehet segíteni egy dékánnak, hogy jobb vezető legyen? Mit tehet Ön ezért?

\section{A pozíció vonzereje, dékánválasztás}

- Mennyire vonzó pozíció dékánnak lenni az intézményben? Miért?

- Kiböl lesz dékán ebben az intézményben? Miért?

- A feladatra a legalkalmasabb(nak látszó) személyekböl (jelöltekből) lesznek a dékánok? Ha nem, miért nem?

- Hogyan lesz valaki dékán? Mi ennek a menete itt? (El tudná mondani a dékánválasztás menetét?)

\section{Autonómia, függőség és függetlenség, viszony más szereplökkel}

- Volt-e olyan eset, amikor a dékán önállóan akart egy kérdésben dönteni, de nem dönthetett? Miért? Hogyan oldódott ez meg?

- Volt-e olyan eset, amikor a dékán mástól várta a döntést, pedig neki kellett volna cselekednie? Miért? Hogyan oldódott ez meg?

- Előfordult-e, hogy úgy érezi, jobb lenne bizonyos információkat elhallgatni a dékánok elöl? Miért?

- Előfordult-e, hogy a dékánok elhallgatnak Ön elöl olyan információt, amiröl tudnia kellene, vagy bizonyos információkat másként tálalnak (torzítva, szépítve)? Miért?

\section{Konfliktusok}

- Melyek azok a témák, kérdések, problémák, amelyek gyakran fordulnak elő a dékánokkal folytatott megbeszélésein, interakcióin? Milyen témákat vet fel Ön, és milyen témákat vetnek fel Önnek a dékánok?

- Van-e ezek között a témák között olyan, ami rendszeresen feszültséggel, konfliktussal jár?

- Tapasztalatai szerint milyen kérdésekben jellemző, hogy a dékánoknak másokkal konfliktusa van? A dékánok életében mik a tipikus konfliktushelyzetek? 


\section{Az interjúk elemzéshez használt hierarchikus kódstruktúra}

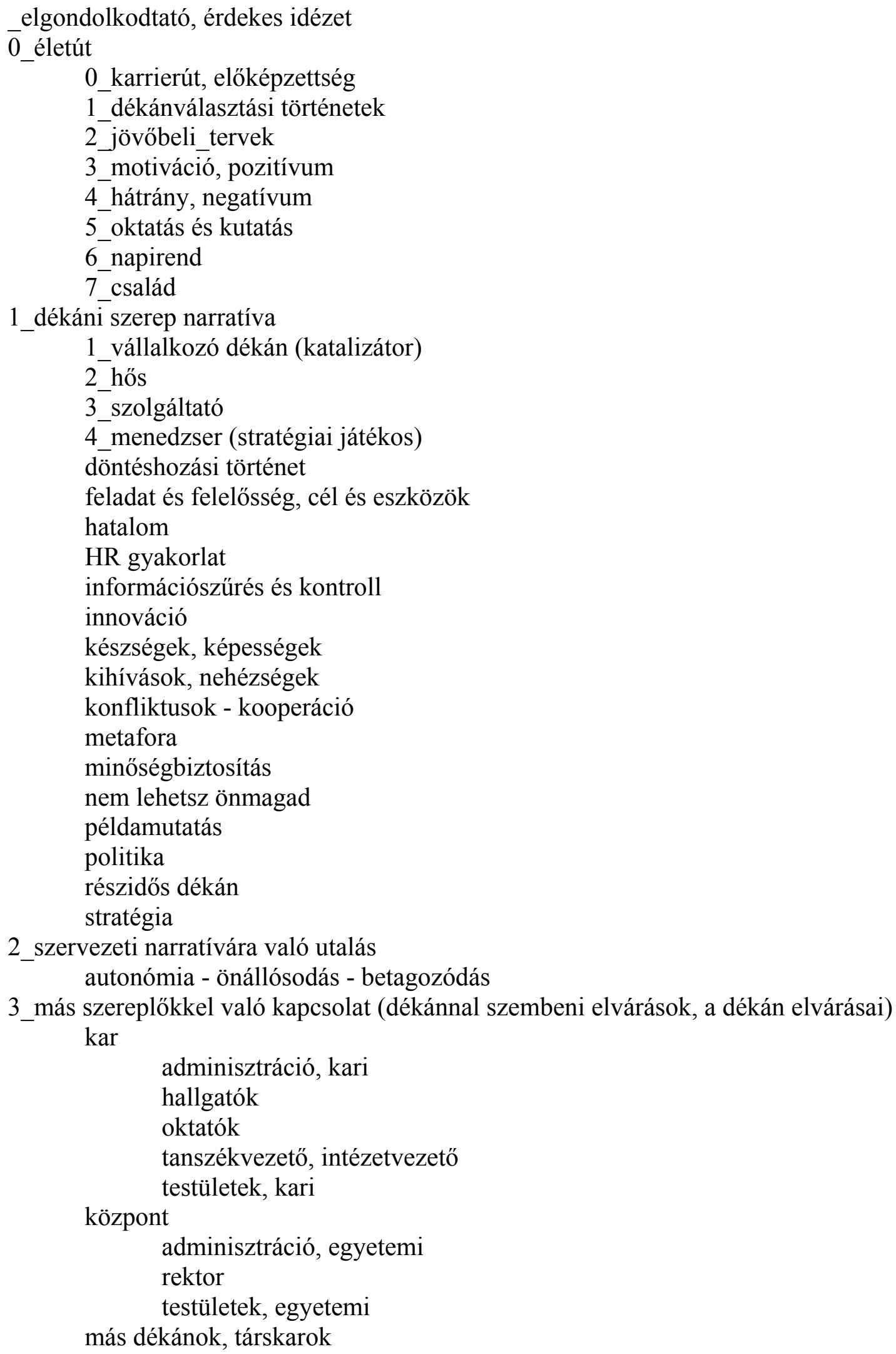


4 kontextus

egyetemen túli

bologna

hallgatói elosztás

hallgatók

integráció

intézményfinanszírozás

karosodás

szabályozási környezet

teljesítményszerződés

verseny

egyetemi

belső forrásallokálás

központi elvonás

önköltségszámítás

kari

transzparencia (hiánya)

5_egyéb_témák

egyéb dékáni pozíciók és ezek szerepe

elöd

idős-fiatal

nőiség - férfiség

tanulás, támogatás (dékánság alatt)

tudományterületi sajátosság

utódlás, kiválasztás

hatáskör

információs aszimmetria

mindenkinek megtalálni a helyét

napirend kontroll

nem egy nyelven beszélünk

oper door policy 


\section{A szerzőnek a témában megjelent publikációi}

\section{Könyvek társszerzőként}

Csóti Dániel - Drótos György - Kaló Réka - Kádár-Csoboth Péter - Kováts Gergely Porubcsánszki Katalin - Tarcsai Anita (2011): Felsőoktatási stratégiai módszertani kézikönyv. Budapest: Oktatáskutató és Fejlesztő Intézet

Antal Zsuzsanna - Drótos György - Kiss Norbert Tamás - Kováts Gergely - Révész Éva Erika Varga Polyák Csilla (2011): Közszolgálati szervezetek vezetése. Aula Kiadó, Budapest. http://www.aula.hu/?id=termekek\&kat_id=4\&art_id=8582\&termek=8582

\section{Könyvek szerkesztőként}

Drótos György - Kováts Gergely (szerk) (2009): Felsőoktatás-menedzsment. Aula Kiadó, Budapest.

\section{Könyvfejezetek}

Kováts, Gergely (2012): The roles of the dean. In: Amann, Wolfgang - Kerretts-Makau, Monica, Fention, Pio - Zackariasson, Peter (2012)(szerk): New perspectives in management education. Excel Publishing

Hidegh, Anna - Csillag, Sára - Kováts, Gergely (2012): 'Breaking the walls'. On teaching Organization Theory and Human Resource Management. A critical pedagogy perspective. In: Amann, Wolfgang - Kerretts-Makau, Monica, Fention, Pio - Zackariasson, Peter (2012)(szerk): New perspectives in management education. Excel Publishing

Kováts, Gergely (2012): Intézményirányítás - a stratégiai szemléletmód esélyei. In: Hrubos, Ildikó (szerk)(2012): Elefántcsonttoronyból kilátótorony. A felsőoktatási intézmények misszióinak bővülése, átalakulása. AULA kiadó, Budapest. 247-294. 0.

Kováts, Gergely (2012): Felsőoktatás-finanszírozás néhány fejlett országban. In: Temesi, József (szerk)(2012): Felsőoktatás-finanszírozás: hazai helyzet és nemzetközi tendenciák. AULA Kiadó, Budapest. 103-64. 0.

Kováts Gergely (2011): A tudományterületi sajátosságok következményei a kutatásban, az oktatásban és a vezetésben. In: Dobák Miklós - Bakacsi Gyula - Kiss Csaba (szerk): Stratégia és menedzsment. Tanulmányok Balaton Károly tiszteletére. Budapesti Corvinus Egyetem, Vezetéstudományi Intézet, Budapest. p. 243-270. 0.

Dobák Mikós - Kováts Gergely (2009): Változásvezetés felsőoktatási intézményekben. In: Török Imre - Hrubos Ildikó (szerk): Intézményi menedzsment a felsőoktatásban. Szemelvények kiemelt témakörökben. Müegyetem kiadó, Budapest.

Kováts Gergely (2009): Az egyetem mint szervezet. In: Drótos György - Kováts Gergely (szerk): Felsőoktatás-menedzsment. Aula Kiadó, Budapest. 63-86 o.

Kováts Gergely (2009): Határon - a doktoranduszok és a doktor képzés Magyarországon. In: Kocsis Miklós - Kucsera Tamás Gergely - Szabó Anita (szerk): A doktori képzés Magyarországon a doktoranduszok szemével. Doktoranduszok Országos Szövetsége, Budapest. 24-56. 0.

Kováts Gergely (2009): Szervezeti és szervezési kérdéskör. In: Horváth Tamás - Kiss László Nyerges Andrea - Roberts Éva (szerk): Diplomás pályakövetés kézikönyv. Educatio Kht, Budapest. 73-86 o.

Kováts Gergely (2005): Változásvezetés az egyetemen. In: Bakacsi Gyula - Balaton Károly Dobák Miklós (szerk): Változás és vezetés. Aula Kiadó, Budapest. 182-199 0. 


\section{Cikkek folyóiratokban}

Kováts Gergely (2012 - megjelenés alatt): A tudományterületi sajátosságok következményei a kutatásban, az oktatásban és a vezetésben. Vezetéstudomány.

Kováts Gergely - Nagy Sándor Gyula - Németh András Olivér (2012 - megjelenés alatt): Felsőoktatás-irányítás és finanszírozás: nemzetközi trendek és hazai gyakorlat. Felsőoktatási Mühely.

Kováts Gergely (2011): Menedzserizmus-kritika az angol felsőoktatásban. Educatio. XX. évf. 4.sz.

Kováts Gergely (2010): Forráselosztás, emberierőforrás-menedzsment és egyéni teljesítményértékelés a London School of Economics-on. Felsőoktatási mühely. No. II, 43-66. 0.

Kováts Gergely (2009): A felsőoktatási intézmények központi adminisztrációjának átalakulása. Felsőoktatási mühely Vol 3. No. 1., 115-124. 0.

Pap Viktória - Kotosz Balázs - Kováts Gergely (2009): A Közgáz gólyái. A 2007-2008-as tanévben a BCE Gazdálkodástudományi, Közgazdaságtudományi és Társadalomtudományi karára felvett alapszakos hallgatók körében végzett felmérés összefoglalása. Köz-gazdaság No.1.71-87.0.

Kováts Gergely (2006): A felsőoktatási intézmények finanszírozási modelljei. Közgazdasági Szemle No. 10, 919-938. 0.

Bíró Kata - Bokor Attila - Kováts Gergely - Takács Sándor - Toarniczky Andrea (2005): Humán tükör - körkép a hazai szervezetekben a HR tevékenységre vonatkozó elvárásokról és annak megítéléséröl I-II. Vezetéstudomány No. 1, 33-47.0. és Vezetéstudomány No. 2 , 16-30. 0.

Bíró Kata - Bokor Attila - Kováts Gergely - Takács Sándor - Toarniczky Andrea (2005): Vezetői elvárások és HR-es önképek I-II. Munkaügyi Szemle No. 2, 19-24. o. és Munkaügyi Szemle No. 3, 15-20.

Kováts Gergely (2003): Új jelenségek a vállalati képzésben: a vállalati egyetem. Vezetéstudomány No. 2, 25-38. 0.

\section{Kutatási jelentések}

Kováts Gergely (2012): Felsőoktatás-irányítás és finanszírozás: nemzetközi trendek és hazai gyakorlat. Kutatási jelentés. In: Felsőoktatás-finanszírozás és minőség célok, vállalkozói források bevonása a felsőoktatásba - nemzetközi gyakorlat adaptálása. Oktatáskutató és Fejlesztő Intézet, Budapest. 6-60. 0.

Kováts Gergely - Csóti Dániel (2011): Stratégiai menedzsment nemzetközi benchmark elemzés. Kutatási jelentés. Oktatáskutató és Fejlesztő Intézet, Budapest. http://femip.hu/web/guest/helyzetelemzesek/lasset_publisher/9qYt/content/strategiaalkotas-afelsooktatasban?redirect $=\% 2 F w e b \% 2 F$ guest $\% 2$ Fhelyzetelemzesek

Kováts Gergely (2009): A dékán vezetői szerepei. In: Hrubos Ildikó (szerk.) Mühelytanulmányok. NFKK Füzetek 2. BCE Nemzetközi Felsőoktatási Kutatások Központja, Budapest. 7193.0.

Temesi József - Kováts Gergely (2010): National system analysis: Hungary, In „Progress in higher education reform across Europe: Governance and Funding Reform,Volume 2: Methodology, performance data, literature survey, national system analyses and case studies". Kutatási jelentés. CHEPS, Twente. http://www.utwente.nl/mb/cheps/publications/ 
Bauer Dávid - Kováts Gergely (2007): The attractiveness of school leaders' role. In: Révész Éva (szerk): Improving School Leadership in Hungary. OECD Country report. OECD, Párizs. 56-72 o. http://www.oecd.org/dataoecd/17/40/38613776.pdf

\section{Oktatási célú esettanulmányok}

Kováts Gergely (2008): A kinevezés. Esettanulmány. BCE Vezetéstudományi Intézet, Budapest.

Kováts Gergely (2006): A vidéki egyetem. Esettanulmány. BCE Vezetéstudományi Intézet, Budapest.

Kováts Gergely (2005): A Doktoranduszok Országos Szövetsége. Esettanulmány. BCE Vezetéstudományi Intézet, Budapest.

\section{Konferenciakiadványban megjelent konferencia-előadások}

Kováts Gergely (2011): The changes int he administration of higher education institutions. In: Come, Thierry - Meskova, Ludmilla (szerk): Universities in Central Europe, 20 years after. Volume 2: Economy and Management. 173-186.o. Bruxelles: Bruylant.

Kováts Gergely (2009): A felsőoktatási intézmények központi adminisztrációjának átalakulása. In: Berács, József - Hrubos, Ildikó - Temesi, József: Magyar Felsőoktatás 2008 konferencia előadások, 2009. január 28., BCE Nemzetközi Felsőoktatási Kutatások Központja, Budapest. 114-126.0.

Bodnár Viktória - Harangozó Tamás - Tirnitz Tamás - Révész Éva - Kováts Gergely (2009): Managing intellectual capital in Hungarian universities - The case of Corvinus University of Budapest. In: Stam, Christiaan - Andriessen, Daan (szerk): Proceedings of the European Conference on Intellectual Capital. INHolland University of Applied Sciences, Haarlem, The Netherlands. 28-29 April 2009. 85-96.o. Elérhető: http://www.academicconferences.org/ecic/ecic2010/ecic10-proceedings.htm

Kováts, Gergely (2007): Dilemmas of career management in contemporary universities. In: Tarrósy, István - Milford, Susan (2007): European higher education in a changing world: a view from the Danube region. Proceedings of the 4th DRC Summer School (22-29 July, 2007). Pécs: Publikon Books. 107-116. 0. Elérhető: http://drcsummerschool.eu/static/designs/drcsummerschool/portlets/portlet. application.DocumentStorage/getFile.jsp?order=getFile\&id=33

\section{Konferenciaelőadások (kiadványok nélkül)}

Kováts Gergely (2012): Nemzetközi jó gyakorlatok adaptációs lehetőségei a hazai felsőoktatási környezet tükrében. Stratégiai menedzsment a felsőoktatásban. 2012. február 7., Budapesti Corvinus Egyetem.

Kováts Gergely (2010): Az oktatói pálya vonzerejének változása és a felsőoktatási intézmények szervezeti válaszai. Általános HR trendek - különös tekintettel az eredményes HR módszerek alkalmazására a magán gazdaságban és a felsőoktatásban (Humán Szakemberek Országos Szövetségének konferenciája). 2010. február 17., Győr, Hotel Famulus.

Bodnár Viktória - Harangozó Tamás - Tirnitz Tamás József - Révész Éva Erika - Kováts Gergely (2010): Managing of intellectual capital in Hungarian universities - The case of Corvinus University of Budapest. The 2nd European Conference of Intellectual Capital. 2010. március 29-30., ICSTE Lisbon University Institute, Lisszabon, Portugália.

Kováts Gergely (2009): A diplomás pályakövetési rendszer néhány szervezeti és szervezési kérdése. Előadás a II. DPR Szakmai napon. 2009. november 18., Budapest. Elérhető: http://www.felvi.hu/images/pub_bin/dload/DPR_SzakmaiNap2_eloadasok/dpr_ea.ppt

Kováts Gergely (2009): A doktori képzés helyzete Magyarországon. Előadás az MTA Közgazdaságtudományi Bizottságának ülésén. 2009. április 23., CEU. 
Bodnár Viktória - Harangozó Tamás - Kováts Gergely - Révész Éva - Tirnitz Tamás (2008): Managing of Intellectual Capital in Hungarian universities. The Case of Corvinus University of Budapest. Elöadás a 4th Workshop on Visualising, Measuring, and Managing Intangibles \& Intellectual Capital címü konferencián. 2008, October 22-24., Hasselt, Hollandia.

Bodnár Viktória - Drótos György - Kiss Norbert - Kováts Gergely - Révész Éva - Dankó Dávid (2006): Performance measurement in a transforming university setting. Workshop on the Process of Reform of University Systems . 2006. május 4-6, Velence.

Bodnár Viktória - Dankó Dávid - Drótos György - Kiss Norbert Tamás - Kováts Gergely Révész Éva (2006): Performance Measurement in a Transforming University Setting. 22nd EGOS Colloquium. 2006. július 6-8., Bergen, Norvégia.

Bodnár Viktória - Dankó Dávid - Drótos György - Kiss Norbert - Kovács László - Kováts Gergely - Révész Éva (2006): The Role of Process Management in Improving the Performance of Higher Education Institutions - The Case of a Hungarian Development Project. PMA 2006 Conference: Performance Measurement and Management - Public and Private - 5th International Conference on Theory and Practice in Performance Measurement . 2006. július 25-28., London.

\section{Egyéb publikációk}

Kováts Gergely (2005): Funding public higher education institutions in Hungary. Szakdolgozat. Institute of Education, University of London.

Kováts Gergely (2002): A vállalti egyetem. Szakdolgozat. Budapesti Közgazdaságtudományi és Államigazgatási Egyetem. 